\title{
WRR
}

WETENSCHAPPELIJKE RAAD VOOR HET REGERINGSBELEID

\section{De staat van de democratie. Democratie voorbij de staat}

E.R. Engelen en M. Sie Dhian Ho (red.) 
De serie 'Verkenningen' omvat studies die in het kader van de werkzaamheden van de WRR tot stand zijn gekomen en naar zijn oordeel van zodanige kwaliteit en betekenis zijn, dat publicatie gewenst is. De verantwoordelijkheid voor de inhoud en de ingenomen standpunten berust bij de auteurs.

Lange Vijverberg 4-5

Postbus 20004

2500 EA 's-Gravenhage

Telefoon 070-356 46 oo

Telefax 070-356 4685

E-mail info@wrr.nl

Website http://www.wrr.nl 


\section{WRR}

WETENSCHAPPELIJKE RAAD VOOR HET REGERINGSBELEID

\section{De staat van de democratie. Democratie voorbij de staat}

E. R. Engelen en M. Sie Dhian Ho (red.) 
ISBN 90-5356-729-1 


\section{VOORWOORD}

Zorgen over het functioneren van onze democratie zijn wijdverbreid. De lage opkomst bij de verkiezingen, de grote schommelingen in kiezersgunst, het geringe aantal leden van politieke partijen kunnen als symptomen daarvan worden opgevat. Hoewel de zorgen ruim worden gedeeld, verschillen de meningen aanzienlijk over de diagnose van de problematiek en dus eveneens over de oplossingen die in aanmerking komen.

De WRR heeft in zijn rapport De toekomst van de nationale rechtsstaat de aandacht geconcentreerd op het rechtsstatelijke element van ons staatsbestel. Maar democratie en rechtsstaat zijn nauw met elkaar verbonden, en beschouwingen over het een kunnen moeilijk zonder het ander. Er was in de huidige omstandigheden daarom alle aanleiding de andere kant van het begrip democratische rechtsstaat tot voorwerp van onderzoek te maken.

Ter voorbereiding van mogelijke verdere studie is een project opgestart, dat bedoeld is als verkenning van de problematiek. Democratie is zo'n vanzelfsprekend begrip, maar kent zoveel verschillende benaderingen en uitwerkingen dat het noodzakelijk is een beeld daarvan te krijgen voordat aan aanbevelingen of zelfs maar aan een goede diagnose valt te denken.

Deze verkenning beoogt dat beeld te bieden. Zij laat allereerst zien hoe veelkleurig de opvattingen zijn. Eenduidige beleidsaanbevelingen worden niet geboden, maar wel wordt het perspectief verruimd. Dat houdt in ieder geval de constatering in - niet toevallig voor degenen die het rapport over de rechtsstaat kennen dat wij ons oog niet alleen op de inrichting van de nationale staat moeten richten wanneer het over democratie gaat. De titel, De staat van de democratie. Democratie voorbij de staat, geeft dan ook iets van een denkrichting aan. Tegelijk blijft de staat, zoals ook bij het rechtsstatelijke element, onmisbaar voor het realiseren van democratische idealen.

De WRR wil met het uitbrengen van deze verkenning een bijdrage leveren tot verdere overdenking van deze voor onze samenleving zo essentiële problematiek.

Prof. mr. M. Scheltema

Voorzitter WRR en voorzitter projectgroep 


\section{INHOUDSOPGAVE}

Voorwoord

Inleiding

M. Scheltema

I Democratische vernieuwing. Luxe of noodzaak?

E.R. Engelen en M. Sie Dhian Ho

$\begin{array}{ll}1.1 & 17\end{array}$

$\begin{array}{ll}1.2 & 19\end{array}$

1.3 Naar vier democratietheoretische perspectieven 28

1.4 Opzet van deze bundel 35

$2 \quad$ Democratie en de buurt $\quad 39$

P. Winsemius, M. Jager-Vreudenhil en N. Boonstra

$\begin{array}{lll}2.1 & & 39\end{array}$

2.2 De buurt als nieuwe locatie voor democratie? 40

2.3 Een systeem van buurtrechten ter revitalisering van de lokale democratie 44

2.4 Een thematische lokale politiek ter revitalisering van de lokale $\begin{array}{ll}\text { democratie } & 47\end{array}$

2.5 Conclusie 51

$3 \quad$ Veranderend politiek burgerschap en democratie 55

I. Verhoeven

$\begin{array}{lll}3.1 & \text { Inleiding } & 55\end{array}$

3.2 Empirische ontwikkelingen in politiek burgerschap 57

3.3 Politiek burgerschap en het politiek-bestuurlijke systeem 68

3.4 Veranderend politiek burgerschap en democratie: een interpretatie $\quad 72$

$4 \quad$ Nabije democratie $\quad 79$

C.A.Hazeu

4.1 Inleiding: de staat van ongenoegen 79

4.2 Het onverminderde belang van het publieke en de rol van de
overheid

4.3 Politiek, democratie en de global/local-paradox 83

$\begin{array}{lll}4.4 & \text { Lacune in de democratie } & 85\end{array}$

4.5 Een antwoord op de democratische lacune: leerprocessen in buurt $\quad 86$

$\begin{array}{lll} & \text { en wijk } & \\ 4.6 & \text { Tot besluit } & 89\end{array}$

$5 \quad$ Naar een mondiale democratie? De rol van 'niet-statelijke 95 actoren'

B.J.M. Arts

5.1 Inleiding 
5.2 Verplaatsing van de politiek $\quad 96$

$\begin{array}{ll}5.3 & \text { Global governance }\end{array}$

5.4 De macht van 'niet-statelijke actoren' 99

5.5 'Democratie' versus 'democratisering' 101

$\begin{array}{lll}5.6 & \text { Nadere positionering } & 104\end{array}$

$\begin{array}{lll}5.7 & \text { Beleidsrelevantie? } & 106\end{array}$

$\begin{array}{lll}5.8 & \text { Conclusie } & 109\end{array}$

6 Publieke verantwoording in de maatschappelijke dienstverlening

H.O. Dijstelbloem en P.L. Meurs

6.1 Heeft de maatschappelijke dienstverlening een legitimiteitsprobleem?

$\begin{array}{lll}6.2 & 114\end{array}$

$\begin{array}{lll}6.3 & \text { Drie vormen van verantwoording } & 117\end{array}$

6.4 De politiek-hiërarchische verantwoordingsstructuur 118

$\begin{array}{ll}6.5 & \text { Toezicht en controle } \\ 6.6 & 120\end{array}$

6.6 Verbreding van de verantwoording 122

7 Dewey en de nieuwe politieke kwesties in de kennissamenleving

H.O. Dijstelbloem, C.J.M. Schuyt en G.H. de Vries

$\begin{array}{ll}\text { 7.1 De confrontatie met unidentified political objects } & 135\end{array}$

7.2 Nieuwe kwesties in de Great Society $\quad 136$

$\begin{array}{ll}7.3 & \text { De uitbraak van aids in Nederland } \\ 7.4 & 140\end{array}$

7.4 Het publiek als gevolg. Deweys idee van democratie 143

7.5 Conclusie: de samenleving als laboratorium? 146

8 Democratisering van de EU: permanente evenwichtskunst $\quad 151$

M. Sie Dhian Ho

$\begin{array}{lll}8.1 & \text { Inleiding } & 151\end{array}$

$\begin{array}{ll}\text { 8.2 Ontwikkeling van de Europese democratie } & 152\end{array}$

$\begin{array}{lll}8.3 & \text { Het integratiedebat } & 161\end{array}$

$\begin{array}{lll}8.4 & \text { Implicaties voor het democratiedebat } & 168\end{array}$

9 Beyond Principal-Agent Governance: Experimentalist Organizations, Learning and Accountability 173

C.F. Sabel

$\begin{array}{lll}9.1 & \text { Introduction } & 173\end{array}$

9.2 Beyond principal-agent governance: experimentalist organizations $\begin{array}{ll}\text { and new public goods } & 177\end{array}$

9.3 Experimentalist service provision and rule making in principle and $\begin{array}{ll}\text { practice: four illustrations } & 182\end{array}$

9.4 But are experimentalist organizations democratizable? $\quad 188$ 
B. Pattyn

10.1 Inleiding

10.2 De gangbare liberale belijdenis

10.3 Identificatie

10.4 Rechtvaardiging

10.5 Vier types groepsidentificatie

10.6 Moderne media en actuele identificatiestijlen

10.7 Discussie en praktische besluiten

II Macht of onmacht van de media? Enkele kanttekeningen bij een actueel debat

D.W.J. Broeders en W.B.H.J. van de Donk

11.1 Inleiding: mediamacht in debat

11.2 Maar: is macht wel het probleem?

11.3 Van toen naar nu, naar later: verschuivende panelen

11.4 A change in the weather or a climate change?

11.5 Een nieuw paneel, een nieuw profiel?

12 Semi-directe consensusdemocratie. Zes voorstellen voor democratische innovatie en verdieping in Nederland

A. Krouwel

12.1 Alles voor het volk, zonder het volk

12.2 Drie democratische problemen: legitimiteit, representatie en controle

12.3 Directe democratie als oplossing voor het democratisch tekort?

12.4 Instituties van de directe democratie: referendum, volksinitiatief en recall

12.5 Institutionele innovaties ter verdieping van de Nederlandse democratie

Democratisering in perspectief. De deliberatieve democratie $\quad 285$ T. Akkerman

13.1 Een tweezijdig probleem 286

13.2 Wat is deliberatieve democratie?

13.3 Omstreden uitgangspunten

14 Associatief-democratische dromen over verplaatste politiek 307 E.R. Engelen

14.1 Inleiding

14.2 Wat is associatieve democratie wel en wat niet?

14.3 Verplaatste politiek? verplaatste democratie! 
15 Problemen van representatieve democratie

B. Tromp

15.1 'Directe' democratie

15.2 Representatieve democratie

342

15.3 Problemen en oplossingsrichtingen

347

15.4 Slot

356

Over de auteurs 


\title{
INLEIDING
}

\author{
M. Scheltema
}

\section{Nadenken over democratie}

Ongerustheid over het functioneren van onze democratie is in de plaats gekomen van gezapige tevredenheid daarover. Toen de communistische dictatuur nog als spiegel kon dienen, was er voor die tevredenheid alle reden. De democratieën van de westerse wereld waren superieur en zagen dat bewezen met de val van de Muur. Maar de stemming is omgeslagen. Kritiek op de politiek, de gedecimeerde aanhang van politieke partijen en het opkomende ressentiment jegens het bureaucratische Europa zijn tekenen van onbehagen. Is er inderdaad reden voor dat onbehagen?

Het project van de Wetenschappelijke Raad voor het Regeringsbeleid (WRR) waarover deze Verkenning verslag doet, is inderdaad uit ongerustheid geboren. Het enkele feit dat er sprake is van een breed gevoel van onbehagen is al voldoende reden om de oorzaak daarvan nader te onderzoeken. Het gaat immers om een centrale waarde van de westerse samenleving. Maar van groter belang is nog dat de vormgeving van ons democratisch stelsel stamt uit een periode waarin de omstandigheden fundamenteel verschilden van de huidige. Ontwikkelingen als internationalisering, kennisintensivering, de verandering van de positie van de media en de verschuivingen in de verhouding tussen publiek en privaat maken onze samenleving tot een andere dan die waarin de democratie gevestigd werd. Dat maakt het onwaarschijnlijk dat de vormgeving van het democratische ideaal nog op dezelfde manier mogelijk is als toen. Die constatering vooral noopt tot een fundamentele bezinning.

Deze bundel is het resultaat van een eerste verkennend project over de problematiek. Er worden vragen gesteld, analyses gemaakt en vanuit een beperkt aantal perspectieven over oplossingen nagedacht. Tot de resultaten van zo'n verkennend project behoort naast een eerste oriëntatie op oplossingsrichtingen ook een ontginning van interessant terrein voor verdere studie. Dat terrein betreft vooral de democratie voorbij de staat.

\section{Het statelijke model van de democratie}

Bij het denken over democratie wordt sinds de opkomst van de nationale staat een centrale plaats ingenomen door de staat. Wanneer de vraag wordt gesteld of iemand in een democratie leeft, betekent dat: is de staat waarin hij leeft een democratie? Zo wordt de wereld verdeeld in democratische en niet-democratische staten.

De staat is ook het voor de hand liggend kristallisatiepunt geweest voor de vormgeving van de democratie. De staat wordt gezien als de organisatie die de beslissingen voor de samenleving neemt, en die daartoe ook de macht heeft. Daarom moeten juist die beslissingen democratisch worden genomen en is de kwaliteit van een democratie af te lezen aan de democratische inrichting van de staat. 
Een logisch gevolg van het denken over democratie in termen van statelijke instituties is dat gebreken die in het functioneren van een democratie worden gesignaleerd, geweten worden aan tekortkomingen in de democratische vormgeving van de staat. Gedachten die dan opkomen richten zich op een andere inrichting van het kiesstelsel, op een andere manier om de kiezers te raadplegen of bestuurders te benoemen. Ook het strakker binden van overheidsinstellingen aan de regie van democratisch gekozen organen is in deze reeks oplossingsrichtingen te plaatsen.

Het is de vraag of deze sterke gerichtheid op de inrichting van de staat niet het zicht beneemt op andere factoren die voor het functioneren van een democratie van belang zijn. Wij weten natuurlijk heel goed dat een land niet van een dictatuur in een democratie verandert enkel door het vastleggen van een democratische grondwet. Bij de hervormingen in Oost-Europa is gebleken dat de ontwikkeling van een democratische samenleving een moeizaam en tijdrovend proces is, waarin niet alleen de staatsinstellingen maar ook de samenleving als geheel de democratie moet dragen. Het belang van de civil society is door die ervaring duidelijker in beeld gekomen. En wij vinden het ronduit naïef wanneer de Amerikanen denken met een nieuwe grondwet en het houden van verkiezingen een democratie in het Midden-Oosten te kunnen vestigen. Wanneer dus een democratie wat meer is dan een democratisch inrichtingspatroon van de staat, dan moet men bij het nadenken over de democratie ook ruimer kijken dan de staatsinrichting. Is men ontevreden, dan kan de oorzaak van die ontevredenheid ook elders liggen.

Men kan het ook sterker zeggen. Het is onwaarschijnlijk dat gebreken in de democratie hun oorzaak voornamelijk vinden in gebreken in de democratische spelregels van de staat. Er zijn sterke argumenten aan te voeren voor de stelling dat de staat - zeker in de huidige tijd - een veel minder centrale positie inneemt bij het verwezenlijken van de democratie dan uit ons vertrouwde denkmodel voortvloeit. Wanneer dat juist is, belemmert de sterke fixatie op de staat als drager van de democratie het zicht op de andere factoren die van belang zijn. Het beperkt ook het antwoord op de uitdagingen die de democratie in de komende tijd te wachten staan, tot constitutionele wijzigingen.

Om die reden voert deze bundel een ruimere verkenning uit. Eenvoudig was dat niet. Wanneer democratie wat anders is dan het democratische staatsmodel dat ons vertrouwd is, wat is het dan wel?

\section{Opzet van het WRR-project}

Om de problematiek in kaart te brengen is voor een brede opzet gekozen. Vier wetenschappers die vier verschillende normatieve benaderingen van democratie vertegenwoordigen, zijn gevraagd hun inzichten over de huidige problematiek naar voren te brengen. Die benaderingen zijn getypeerd als: directe democratie, vertegenwoordigende democratie, deliberatieve democratie en associatieve democratie. De keuze van deze vier benaderingen wordt nader toegelicht in het kaderstellende eerste hoofdstuk Democratische vernieuwing. Luxe of noodzaak? 
van Ewald Engelen en Monika Sie Dhian Ho. Bart Tromp (representatieve democratie), André Krouwel (directe democratie), Tjitske Akkerman (deliberatieve democratie) en Ewald Engelen (associatieve democratie) hebben de rol van protagonisten van de respectieve benaderingen op zich genomen. Gedurende het project zijn zij geconfronteerd met ontwikkelingen en uitdagingen die in de huidige tijd op de democratie afkomen. Voorbeelden daarvan zijn de internationalisering, de overdracht van bevoegdheden naar de Europese Unie (EU), de veranderende opstelling van de burger, de positie van de media. Over deze onderwerpen is een reeks van workshops georganiseerd, waarbij de vier 'vertegenwoordigers' van de democratiebenaderingen met deskundigen ten aanzien van die maatschappelijke ontwikkelingen van gedachten wisselden. Een groot voordeel van deze werkwijze was dat een voorstander van een bepaalde benadering niet kon volstaan met te reageren op uitdagingen waar zijn benadering een oplossing voor biedt, maar ook te maken kreeg met punten waar juist een andere benadering sterker lijkt te zijn.

In deze bundel wordt verslag van deze confrontaties gedaan. Als algemene inleiding daarvoor bepaalt het hoofdstuk van Engelen en Sie Dhian Ho het speelveld van de discussie. Daarna volgen de tien bijdragen van hen die in de workshops problemen en uitdagingen aan de orde hebben gesteld waarmee de hedendaagse democratie zich geconfronteerd ziet. De bundel wordt afgesloten met beschouwingen van Tromp, Krouwel, Akkerman en Engelen, waarin zij vanuit hun benadering van democratie de balans opmaken van de confrontaties die hebben plaatsgevonden.

\section{Enkele voorlopige bevindingen}

Het project beoogt geen eenduidige set van beleidsaanbevelingen te bieden, en die is in deze bundel dan ook niet te vinden. Maar wel blijkt de gekozen werkwijze zinvol voor het verbreden en verdiepen van discussie. Sommige tegenstellingen kunnen worden overbrugd, bepaalde oplossingsrichtingen kunnen als perspectiefrijk worden aangewezen. Hier wordt op enkele van die punten ingegaan.

\section{Vertrekpunt: steun voor de democratie}

Hoezeer we ook horen spreken over crisisverschijnselen in het functioneren van democratische instellingen, er is geen sprake van een afbrokkeling van de democratie als ideaalbeeld voor de inrichting voor de samenleving. De steun daarvoor blijkt onder de bevolking in Nederland groot en stabiel, en neemt de laatste decennia eerder toe dan af. In het rapport Waarden, normen en de last van het gedrag heeft de WRR uitgesproken dat het centraal stellen van de waarde van democratie en rechtsstaat als maatschappelijke waarden ook van essentiële betekenis is voor een vreedzame en rechtvaardige samenleving. Dat standpunt lijkt algemeen te worden gedeeld, en onderstreept het belang van de discussie. Hoewel onder deze overeenstemming nog heel uiteenlopende denkbeelden over democratie kunnen schuilgaan, betekent het wel dat de ermee verbonden waarden als gelijkheid en respect voor de persoon en de meningen van anderen ruim worden onderschreven. Het is van belang dit te kunnen constateren. 


\section{Beperking tot statelijke democratie?}

Hiervoor is al aangegeven dat het denken over democratie zich vaak versmalt tot het denken over de statelijke democratie. Dat ligt in zekere zin voor de hand omdat nationale staten de afgelopen eeuwen de dragers waren van de beslissingsmacht en de beslissingsbevoegdheid over de samenleving. Democratie moet zich dan richten op het democratische gehalte van die beslissingen. De spelregels die daarvoor moeten zorgen zijn in hoofdzaak te beschouwen als de regels van de vertegenwoordigende democratie.

Uit de gehouden discussies en de bijdragen in de deze bundel blijkt dat heel verschillend wordt gedacht over de vraag of vernieuwingen in de democratie, zo die nodig zijn, primair moeten komen van veranderingen in deze constitutionele regels, of juist daarbuiten moeten worden gezocht. Verandering van kiesstelsel of meer directe democratie zijn voorbeelden van de eerste soort veranderingen. Het nadenken over de worteling van de democratie bij burgers en de civil society getuigt van de tweede benadering.

Maar gemeenschappelijk was wel de conclusie dat men nooit kan volstaan met het oog te richten op de statelijke kant alleen. In iedere benadering is het eveneens nodig de burgers en de samenleving, die de dragers van de democratie zijn, in de beschouwing te betrekken. Het meest overtuigende argument daarvoor is dat een democratische staat ook democratisch burgerschap vereist. Dat houdt in ieder geval in dat men inzicht heeft in de manier waarop democratische processen werken, wat de betekenis is van de keuzen die men maakt, en dat men zich moet kunnen neerleggen bij besluiten waarmee men het niet eens is. Het onderschrijven van de met democratie verbonden waarden maakt eveneens deel uit van democratisch burgerschap. Een dergelijk burgerschap is er niet vanzelf. Het moet geleerd en geoefend worden. Hier is een verband te leggen met het WRR-rapport Waarden, normen en de last van het gedrag, waarin de rol van organisaties en maatschappelijke instellingen als werkplaatsen voor de overdracht van waarden, normen en gedrag is benadrukt. Het onderhouden van de waarden van de democratie vergt betrokkenheid van de gehele samenleving. Zo kan men moeilijk democratisch georiënteerde burgers verwachten in een samenleving waarin alle andere organisaties op geheel andere grondslagen zijn gebaseerd. Overheerst daar een autoritaire bestuurscultuur, waarin meningen van anderen niet ernstig worden genomen, maar willekeur de boventoon voert, dan worden democratische spelregels niet aangeleerd. De burger wordt dan ook niet toegerust om gebruik te maken van zijn democratische rechten en om een bijdrage te leveren aan het functioneren van de democratie. De noodzaak ook aan het aspect van het democratische burgerschap aandacht te besteden, komt hierna nog vanuit een ander perspectief aan de orde.

\section{Verplaatsing van de politiek}

Er zijn daarnaast andere argumenten, ontleend aan meer recente ontwikkelingen, die ervoor pleiten de democratie ook in verband te brengen met besluitvorming op andere plaatsen dan binnen statelijke instellingen. Zij worden treffend samengevat onder de noemer 'verplaatsing van de politiek'. Daarmee wordt aangegeven 
dat de staat niet meer de enige organisatie is waar politieke besluiten worden genomen. Politieke besluiten zijn in dit verband besluiten die van invloed zijn op de samenleving en waarbij een afweging van belangen moet plaatsvinden.

Verplaatsing van politiek heeft verschillende gedaanten aangenomen. Een daarvan is de internationalisering: het ontstaan van internationale organisaties waaraan soms vergaande bevoegdheden toekomen om bindende besluiten te nemen. De EU is daarvan het meest pregnante voorbeeld. Dit stelt de vraag naar de democratische legitimatie van deze internationale besluitvorming. Wanneer men de democratie sterk verbindt met het statelijke besluitvormingsmodel, zal men trachten de bovenstatelijke constructies volgens dit beeld te modelleren. Maar het lijkt nauwelijks mogelijk om op dat niveau een met de staat vergelijkbare vormgeving van democratie te bereiken. Voor de EU is een (verdere) ontwikkeling in die richting nog wel denkbaar, al is het ook daar moeilijk voor te stellen hoe een democratie naar nationaal voorbeeld kan functioneren zolang een Europese gemeenschap van burgers niet is ontstaan. Bij andere internationale organisaties Verenigde Naties, Wereldbank, Wereldhandelsorganisatie - is een dergelijk stelsel nog in het geheel niet voorstelbaar. Het enige alternatief vanuit het statelijk perspectief is dan de democratische legitimatie te ontlenen aan de democratische besluitvorming binnen de afzonderlijke staten die bevoegdheden overdragen. Maar deze denkrichting is minder bruikbaar naarmate de internationale besluitvorming sterker eigen spelregels en een eigen karakter krijgt. De gedachte dat de democratische controle op de nationale inbreng in de internationale arena voldoende democratische legitimatie kan verschaffen, verliest dan aan realiteitswaarde.

Verplaatsing van politiek heeft nog een geheel andere gedaante: verplaatsing naar niet-statelijke instellingen en organisaties. Het publieke belang kan niet meer alleen door de staat worden behartigd: ook het besluiten en handelen van private organisaties kan grote gevolgen hebben voor de samenleving. Scholen, ziekenhuizen, beroepsorganisaties, bedrijven en niet-gouvernementele organisaties hebben alle hun eigen doelstellingen, maar raken vaak in aanzienlijke mate aan andere belangen in de samenleving. In het WRR-rapport De toekomst van de nationale rechtsstaat is benadrukt dat ook private organisaties een eigen verantwoordelijkheid dragen voor het publieke belang. Er is daarbij een verband gelegd met de huidige kennissamenleving waarin het eenvoudig niet meer mogelijk is om vanuit een centraal punt te overzien welk optreden in ieder concreet geval het publieke belang het beste dient. Om die reden kan de staat alleen niet meer de verantwoordelijkheid voor het publieke belang dragen, maar moet hij die delen met anderen. In de bijdrage van Dijstelbloem, Schuyt en De Vries, Dewey en de nieuwe politieke kwesties in de kennissamenleving wordt het belang benadrukt van deliberatie, van het mobiliseren van de probleemoplossende kennis van alle betrokkenen bij een maatschappelijk probleem. Gaat het in die bijdrage nog specifiek om complexe maatschappelijke vraagstukken, Sabel veralgemeent deze benadering in zijn bijdrage aan deze bundel, Beyond principal-agent governance: experimentalist organizations, learning and accountability door veel ruimer de 
noodzaak van het gebruik van maatschappelijke kennis in het democratische proces te benadrukken. Democratie kan dan juist een bijdrage leveren aan de oplossingen van problemen doordat kennis wordt gemobiliseerd en gecreëerd.

\section{De staat blijft onmisbaar}

Op de twee zijden van de 'verplaatsing van de politiek' kan verschillend gereageerd worden. Men kan betreuren dat de democratische legitimatie van de statelijke besluitvorming wordt uitgehold, en trachten die uitholling tegen te gaan door de staat zoveel mogelijk sturingsmogelijkheden te laten behouden of terug te geven. Wanneer er dan problemen ten aanzien van de democratie zijn, moeten die worden opgelost door verbeteringen in de vormgeving van de statelijke democratie. Men kan ook de 'verplaatsing' als een gegeven beschouwen en vervolgens gaan nadenken over mogelijkheden om democratische beginselen een plaats te geven in de domeinen waarnaar de politiek is verplaatst. Naar mijn overtuiging moet men beide doen, en het is juist in dit verband dat de vier democratiebenaderingen meer als aanvullend ten opzichte van elkaar moeten worden beschouwd dan als elkaar uitsluitend.

Het leidt geen twijfel dat de staat vooralsnog de beste vormgeving van democratie is. Hoezeer men ook kan trachten democratische beginselen bij het opereren van internationale of private organisaties een plaats te geven, het resultaat zal minder bevredigend blijven dan de vormgeving van de democratie in de nationale staat. Daarom is het verbeteren en aanpassen van de democratische instituties van de staat aan de eisen van de huidige tijd essentieel. De staat zal uiteindelijk ook de spelregels voor het democratische element in de buitenstatelijke besluitvorming moeten verankeren en daardoor de centrale pijler voor de democratie moeten blijven. De vertegenwoordigers van de representatieve en de directe democratie denken in dit spoor.

\section{Het belang van democratische beginselen}

Maar tegelijkertijd lijkt het een illusie te veronderstellen dat hiermee kan worden volstaan. De verplaatsing van de politiek is niet alleen een feit, maar moet onder de huidige omstandigheden in veel gevallen ook als een gewenste en/of onvermijdelijke ontwikkeling worden gezien. Hoe kunnen de democratische beginselen in de nieuwe arena's een plaats krijgen? Op dat punt hebben de deliberatieve en de associatieve democratiebenadering veel te bieden (de deliberatieve democratie richt zich overigens evenzeer op de statelijke democratie).

Zij benadrukken het belang van een brede discussie over de beginselen van de democratie, waarin het niet alleen gaat over het getalsmatige element - meerderheidsbeslissing met bescherming van de minderheid - maar ook over de zelfstandige betekenis van de inhoudelijke kant van de besluitvorming. Daarom zijn het uitwisselen van argumenten, transparantie, openbaarheid van het debat en verantwoording in een democratie zo noodzakelijk. Men zou dus het ene (meerderheids)besluit democratischer kunnen noemen dan het andere indien het beter geschikt is om de voorkeuren van de meerderheid daadwerkelijk te verwezenlijken dan het andere. Besluiten die onvoldoende zijn overwogen, en dus eenvou- 
dig niet geschikt zijn om het beoogde resultaat te bereiken, zijn om die reden ook uit democratisch gezichtspunt verwerpelijk, ook al zijn zij met een grote meerderheid aanvaard.

Zo denkend legt men een aantal beginselen van democratie bloot die niet gebonden zijn aan statelijke instellingen. Daar waar op andere plaatsen over het publieke belang wordt besloten, zouden die beginselen evenzeer een rol moeten spelen. Dat is van groot belang, omdat op die andere plaatsen de vertrouwde uitgangspunten van 'één mens één stem', van verkiezingen en van representatie op veel meer problemen stuiten. Wie heeft een stem, wie mag kiezen en wie moeten gerepresenteerd worden? Het antwoord op die vragen is binnen de statelijke context relatief gemakkelijk te geven, maar daarbuiten veel minder. De andere beginselen van democratie zullen dan een relatief groter gewicht moeten krijgen.

\section{Verder denken over democratie}

Deze verkenning roept meer vragen op dan zij kan beantwoorden. Dat was ook de bedoeling: de democratie is geen rustig bezit van de samenleving meer, maar moet in nieuwe omstandigheden weer opnieuw worden bevochten en vormgegeven. De bedoeling was wel om het perspectief te verbreden: democratie kan vanuit zoveel verschillende invalshoeken worden benaderd. Confrontatie van deze invalshoeken met elkaar en met empirische ontwikkelingen moet richting geven voor verdere reflectie.

Het laat tegelijkertijd zien dat de vraagstukken van democratie nauw verweven zijn met veel andere vraagstukken, sterker dan men vaak vermoedt. Bij de WRR is dat de afgelopen jaren regelmatig gebleken. In de rapporten Nederland als immigratiesamenleving, De toekomst van de nationale rechtsstaat, Ontwikkelingsbeleid en goed bestuur en Waarden, normen en de last van het gedrag kwam steeds naar voren dat het verwezenlijken van de waarden van democratie en rechtsstaat tot de centrale opgaven van de samenleving behoort. Ook in een aantal thans nog lopende projecten wordt dit wederom duidelijk. Om die reden is het niet toevallig dat de bijdragen in deze bundel over nieuwe ontwikkelingen en uitdagingen in belangrijke mate afkomstig zijn van auteurs die binnen de WRR bij deze projecten betrokken zijn.

Graag dank ik de overige leden van de - kleine - projectgroep, Monika Sie Dhian Ho, Ewald Engelen en Floor Dinant, voor het vele werk dat zij in korte tijd hebben verzet om dit project te realiseren. Die dank strekt zich ook uit tot de 'vertegenwoordigers' van de vier benaderingen van democratie: Bart Tromp, André Krouwel, Tjitske Akkerman en wederom Ewald Engelen. Zij hebben een grote inspanning geleverd door hun denkbeelden op papier te zetten, vervolgens aan een intensieve discussie en toetsing in een reeks van workshops te onderwerpen en ten slotte deze te herformuleren ten behoeve van deze bundel. Ook de andere auteurs in deze bundel en deelnemers aan de workshops hebben een belangrijke bijdrage geleverd. Zonder het werk van hen allen had niet in zo korte 
tijd zo veel stof tot verdere overdenking bijeengebracht kunnen worden.

Bovenal wil ik Monika Sie danken. Zij was de bedenker en vormgever van het project en ook degene die alles deed om het project te laten slagen. 


\title{
DEMOCRATISCHE VERNIEUWING. LUXE OF NOODZAAK?
}

\author{
E.R. Engelen en M. Sie Dhian Ho
}

\section{$1.1 \quad$ INLEIDING}

Het heeft er alle schijn van dat Nederland toe is aan democratische zelfreflectie. Onze instituties zijn voornamelijk toegesneden op realisering van democratie binnen het politieke domein van de Nederlandse staat, terwijl een toenemend aantal politieke beslissingen elders wordt genomen. De vraag who gets what, when and how wordt inmiddels in vergaande mate buiten de muren van het Binnenhof bepaald. Ook ten aanzien van de politieke participatie van de burger en de effectiviteit van zijn vertegenwoordiger zijn veronderstellingen besloten in de huidige vormgeving van de Nederlandse democratie die nog maar zeer ten dele geldig zijn. De hedendaagse burger, aldus Van Doorn, 'wil niet meeregeren, maar goed geregeerd worden' (Van Doorn 2002: 10). En de vertegenwoordigende functie van de massapartijen staat al evenzeer onder druk; van massapartijen met een stevige verankering in het electoraat zijn zij verworden tot kaderpartijen die nog slechts fungeren als banenverdelers onder professionele politici (Becker c.s. 2003).

Een reeks van maatschappelijke ontwikkelingen zoals 'verplaatsing van politiek' naar de EU, het lokaal bestuur, de ambtelijke voorportalen, maatschappelijke organisaties, de privé-sfeer en de rechterlijke macht), individualisering (en de afnemende rol van levensbeschouwing, ideologie en sociale positie voor politieke loyaliteiten), de ontwikkeling van een kennissamenleving, de veranderde rol van de media en de internationalisering van de economie lijkt de institutionele vorm te marginaliseren waarin we gewoon zijn over democratie te denken. Zoals de transformatie van de antieke of middeleeuwse democratische stadstaat naar de democratische nationale staat ingrijpende consequenties had voor praktijk, instituties en begrip van democratie (zie Dahl 1971, 1989), zo stellen ook de huidige veranderingen van de context van democratie de manier waarop we gewoon zijn over democratie te denken opnieuw ter sprake.

De vraag naar de kwaliteit van de Nederlandse democratie, die voorheen vooral politicologen, parlementaire historici en staatsrechtgeleerden bezighield, is sinds de politieke aardverschuiving van 15 mei 2002 de gemoederen van velen gaan bezighouden. Met name de enorme winst van de Lijst Pim Fortuyn, waarvan de voorman negen dagen eerder was vermoord, heeft het bestel geschokt. Een electorale verschuiving van deze omvang is in West-Europa alleen eerder vertoond in Italië (1994), Duitsland (1920) en Frankrijk (1906) (Mair 2002: 162). Wetenschappers verschillen van mening over de vraag in hoeverre de radicale omwenteling van 15 mei 2002 een protest was tegen de politiek en het politieke establishment, tegen de democratische instituties als zodanig, dan wel een protest tegen het 
gevoerde beleid. Hoewel de interpretaties van 15 mei 2002 dus sterk uiteenlopen en consensus hierover waarschijnlijk illusoir is, heeft het beeld van 'de Nederlandse democratie in crisis' zich sinds 2002 in de publieke discussie vastgezet.

Ook de reeks bestuurlijke vernieuwingsvoorstellen van minister De Graaf geeft aanleiding tot en is zelf onderdeel van de collectieve democratische zelfreflectie die sinds enige tijd gaande is. De Kabinetsvisie en het Actieprogramma 'Andere Overheid' schetsen de contouren van een 'moderne overheid' (Kabinetsvisie 'Andere Overheid' 2003; Actieprogramma 'Andere Overheid' 2003). De democratische consequenties van de inzet op een 'responsievere en efficiëntere overheid' en een 'meer globaal en op afstand geplaatst sturingsconcept' worden in de notitie slechts aangestipt en vergen nadere doordenking (zie ook Raad voor Maatschappelijke Ontwikkeling 2002). De overige twee hoofdlijnennotities 'Nieuw Kiesstelsel. Naar een sterker Parlement' en 'Direct gekozen burgemeester' (Tweede Kamer der Staten-Generaal 2003a en 2003b) van dezelfde minister zijn door sommigen ontvangen als een welkome invoering van elementen van directe democratie in het Nederlandse democratische stelsel. Anderen zien ze juist als symptoom van wat er schort aan de Nederlandse democratie: een minderheid dreigt via de achterkamers van het coalitieberaad haar wensen door te voeren met vergaande gevolgen voor de Nederlandse democratie zonder daarvoor de weg van de Grondwetsherziening te bewandelen (Tromp 2003). Terwijl voor- en tegenstanders van de democratische vernieuwingsvoorstellen zich roeren en voorheen esoterische politicologische kiesstelseldiscussies ruimschoots aandacht krijgen in krantenkolommen en actualiteitenrubrieken, komt de achterliggende analyse - wat mankeert er aan het democratische bestel, hoe komt dat, waarom zijn deze voorstellen een verbetering ten opzichte van de huidige situatie en zo ze dat niet zijn, wat dan te doen? - er bekaaid af.

Aan die lacune wil deze Verkenning iets doen. Door de publieke en beleidsdiscussie te voeden met empirische inzichten omtrent maatschappelijke veranderingen die van invloed zijn op het democratisch bestel, kan tot een beter gefundeerde diagnose gekomen worden over de aard van het achterstallig onderhoud aan het Nederlandse democratische bestel dan in de lopende discussie het geval is. Bovendien koesteren wij de intuïtie dat de normatieve discussie tussen verschillende democratiebenaderingen - representatief, direct, deliberatief en associatief - constructiever kan worden gevoerd dan tot nog toe gebeurt. Niet de superioriteit van één van deze benaderingen moet inzet van het debat zijn, maar de vraag welke voorstellen onder welke omstandigheden voor welke aspecten van het democratisch bestel een verbetering kunnen betekenen. Ten slotte is onzes inziens, naast een constructiever debat tussen bestaande democratiebenaderingen, een gerichte zoektocht nodig naar nieuwe benaderingen van participatie en verantwoording die voorbij de bestaande institutionele en theoretische kaders liggen.

In het onderhavige presenteren wij eerst een nadere analyse van het democratieconcept in termen van een tweetal kernaspecten van democratie: bestuur (en zijn 
verschillende fasen) en de demos. Vervolgens schetsen wij kort vier democratietheoretische perspectieven die onzes inziens de actuele wetenschappelijke discussie over democratie en democratisering domineren. Dat doen wij door de verschillen tussen deze democratiebenaderingen ten aanzien van de kernaspecten van democratie aan te geven.

\subsection{DEMOCRATIECONCEPT}

De vraag welke institutionele vormgeving van democratie de juiste is mondt al snel uit in heftige discussies en meningsverschillen. Dat geldt niet voor de abstracte betekenis van democratie. Waar voorstanders van welke vorm van democratie ook zich voor hebben ingezet en tegenstanders zich tegen hebben verzet, is herleidbaar tot een aantal nauwelijks controversiële uitgangspunten. Democratie is - minimaal - een politieke besluitvormingsprocedure waarin politieke gelijkheid en politieke vrijheid (procedurele grondrechten en beginselen) zijn gewaarborgd. Bovendien gaat democratische besluitvorming uit van een meerderheidsregel, waarbij de bescherming van de minderheid is verzekerd (zowel door constitutionele maatregelen als door de gezindheid van de bestuurders) (Van der Burg 1991: 59).

De klassieke betekenis van het begrip 'democratie' is uiteraard 'zelfbestuur door het volk', de demos. De vormgeving van democratie in een bepaalde politieke context betreft dus democratische vereisten ten aanzien van twee kernaspecten: (1) het bestuur; en (2) de demos.

Ten aanzien van het bestuur volgen wij hier het uit de bestuurskunde overgewaaide onderscheid tussen input, throughput, output/outcomes en feedback om het bestuurssysteem te analyseren. Elk van deze fasen moet aan bepaalde eisen voldoen om als democratisch legitiem te worden ervaren. In het geval van inputlegitimiteit ligt de nadruk op de steun van de burgers voor gezagsdragers en de heersende spelregels van het systeem; participatie van degenen die worden geraakt door een beslissing; en de representatie van hun belangen en preferenties. In het geval van throughput-legitimiteit, daarentegen, is de billijkheid, redelijkheid en rechtmatigheid van het besluitvormingsproces zelf de voornaamste bron van legitimiteit. In het geval van output-legitimiteit schuilt de legitimiteit van collectieve besluitvorming vooral in de mate waarin die uitkomst overeenkomt met de wensen en preferenties van de beleidsobjecten (responsiviteit van beleid). Het onderscheid tussen output en outcomes duidt aan dat politieke interventies effecten kunnen hebben die niet voorzien waren. Deze kunnen zowel positief als negatief zijn. De democratische legitimiteit van de bestuursstructuur wordt vervolgens in hoge mate bepaald door de wijze waarop verantwoording wordt afgelegd over de uitkomst van het besluitvormingsproces en de kwaliteit van de feedback. Afkeuring dan wel waardering van de uitkomsten van politieke interventies moet liefst zo snel mogelijk weer aan de input-zijde van de democratische besluitvorming worden ingebracht. 
De demos wordt hier omschreven als het publiek dat door een bepaalde beslissing wordt geraakt. Wie hieronder vallen, is dus afhankelijk van de kwestie die in het geding is. Een belangrijke democratische vereiste is dat degenen die worden geraakt door een beslissing (objecten van besluitvorming) ook direct dan wel indirect die beslissing nemen (subjecten van besluitvorming). Behalve de vraag wie tot de demos behoort, is de vraag naar de politieke oriëntaties en opvattingen die in de demos leven - de politieke cultuur - van groot belang voor de democratie. Een bepaald type politieke cultuur - de burgercultuur - wordt geacht bij te dragen aan de stabiliteit van de politieke democratie (bijv. Almond en Verba 1963). Scholing, blootstelling aan massamedia en politiek leiderschap, het functioneren in een beroepsomgeving en lidmaatschap van allerlei verenigingen dragen bij aan de politieke socialisatie in deze burgercultuur.

\subsubsection{DEMOCRATISCH BESTUUR}

\section{Input}

Het democratische credo government by the people stelt bepaalde eisen aan de input-zijde van het besluitvormingssysteem, waaronder (a) steun van de burgers voor gezagsdragers en de heersende spelregels van het systeem; (b) participatie door burgers zelf teneinde hun eisen en verwachtingen ten aanzien van het besluitvormingsproces kenbaar te maken; en (c) representatie van de belangen en preferenties van de burgers (zie tabel 1.1).

Ad (a): Steun van de burgers voor gezagsdragers en de heersende spelregels van het systeem

In de democratische staat zijn verkiezingen de manier bij uitstek geweest om steun te betuigen met besluitvormers en hun besluitvormingsmacht. Instemming met de besluitvormingsstructuur hoeft overigens niet per se actieve steun te impliceren. Vaak wordt ook de afwezigheid van aanzienlijke oppositie of van protestbewegingen in open democratische stelsels gezien als een indicator voor regimesteun (permissive consensus). Of - meer theoretisch - een gunstige uitkomst van het volgende gedachte-experiment: 'stel dat de leden van een gegeven populatie een nieuw besluitvormingssysteem zouden mogen installeren, zouden ze dan iets kiezen dat erg verschillend is van het huidige systeem?' Zo nee, dan wordt ook dat gezien als een indicator van instemming.

Ad (b): Participatie van burgers om hun voorkeuren kenbaar te maken

Naast steun en instemming met het politieke systeem en de gezagsdragers impliceert government by the people dat burgers zelf politiek participeren. Die participatie heeft een instrumentele functie: burgers formuleren hun eisen en verwachtingen ten aanzien van beleid teneinde hun belangen adequaat te beschermen (protective democracy). De achterliggende gedachte is dat betere besluiten worden genomen wanneer ieders belang gelijkelijk wordt meegewogen in de besluitvorming. Daarnaast kennen velen een morele, educatieve waarde toe aan participatie: door te participeren ontwikkelen individuen een voor de gemeenschap en democratische staat cruciale democratische attitude, verantwoordelijk- 
heidszin en sociale en politieke capaciteiten. Participatie heeft in deze interpretatie tevens een belangrijke functie voor het individu (developmental democracy).

Hoe ver participatie moet gaan (bijvoorbeeld om naast goede besluiten ook de bovenbeschreven sociale en psychische effecten te bewerkstelligen) is onderwerp van discussie tussen verschillende democratiebenaderingen. Wat democratie ten minste vereist is een minimale vorm van participatie, zoals het stemmen bij verkiezingen. Het Nederlandse kiesstelsel wordt sinds 1917 gekenmerkt door een lijstenstelsel met evenredige vertegenwoordiging, waarin het hele land één district vormt en de kiesdrempel gelijk is aan de kiesdeler (Andeweg 1985: 85). Het lijstenstelsel houdt in dat de kiezers een stem uitbrengen op een lijst van kandidaten en niet op een individuele kandidaat. Politieke partijen spelen een belangrijke rol in zo'n stelsel, aangezien de kieslijsten door partijen worden ingediend en de volgorde van de kandidaten op de lijsten door partijen wordt vastgesteld. Kiezers kunnen door voorkeurstemmen voor een bepaalde kandidaat overigens wel beïnvloeden wie een zetel gaat bezetten. Nederland kent een van de meest evenredige kiesstelsels ter wereld en een relatief lage kiesdrempel. De evenredige vertegenwoordiging is in Nederland samengegaan met een meerpartijensysteem. Nog nooit is een partij erin geslaagd een absolute meerderheid te winnen in de verkiezingen, als gevolg waarvan Nederland altijd is geregeerd door coalitieregeringen die na de verkiezingen geformeerd moeten worden. Hoewel kiezers dus de volksvertegenwoordiging kiezen, betekent dit niet noodzakelijkerwijs een doorslaggevende stem in de regeringsvorming (de stem voor 'de macht'). Dat Nederland tenslotte één kiesdistrict vormt houdt in dat de zetelverdeling wordt vastgesteld op basis van de landelijke uitslag.

De indirecte aard van het Nederlandse democratische stelsel heeft betekend dat de directe participatiemogelijkheden voor de Nederlandse burger relatief beperkt zijn geweest. Intermediaire organen als de volksvertegenwoordiging, politieke partijen en belangenorganisaties waren veelal actief in zijn plaats.

\section{Ad (c): Representatie}

Gangbaar democratisch uitgangspunt is dat het beleid de preferenties van de demos representeert. Wat representatie betekent is echter betwist. Betekent representatie 'afspiegeling' van wat er in de maatschappij leeft en is de rol van vertegenwoordigers dus beperkt tot handelen op basis van een mandaat, 'standing for' de belangen en wensen van hun achterban? Of impliceert representatie dat vertegenwoordigers in een onafhankelijkere rol en in onderlinge, ongebonden deliberatie op zoek gaan naar het algemeen belang, 'acting for' de gerepresenteerden (bijv. Pitkin 1967; Witteveen 2000)?

In Nederland heeft de Pacificatie van 1917 en de invoering van evenredige vertegenwoordiging een einde gemaakt aan de liberale praktijk van onafhankelijk optreden van de volksvertegenwoordigers in het algemeen belang. In de plaats van dit verlichte elitisme trad de afspiegelingsgedachte, die haar hoogtepunt beleefde tijdens de verzuiling, in welke periode de politieke leiders van de zuilen 
werden geacht de meningen van de leden van de zuil te representeren. Vanaf de ontzuiling en democratisering midden jaren zestig is dit uitgangspunt van 'mimetische vertegenwoordiging' van de opvattingen van de kiezers door de gekozenen steeds meer in twijfel getrokken. Nader beschouwd is de afspiegelingsgedachte inderdaad problematisch. Zo is duidelijk dat het publiek beperkt geïnformeerd is en geen complete en consistente preferenties heeft ten aanzien van alle politieke kwesties. Vertegenwoordigers kunnen dus niet volstaan met het vertolken van de wil van de kiezers maar zullen zich deels moeten laten leiden door hun eigen oordeel. Daarnaast ontbreekt in de mimetische interpretatie een antwoord op de vraag hoe behalve de delen van het volk ook het geheel kan worden gerepresenteerd. In de woorden van Ankersmit (1990: 284-5): “De politieke werkelijkheid is niet iets wat we aantreffen, alsof ze er altijd al geweest was, ze wordt niet 'gevonden', of 'ontdekt', maar 'gemaakt'." Met welke constatering we weer dicht in de buurt komen van de vroegliberale theorie van de volksvertegenwoordiging, aldus Witteveen (Witteveen 200o, hfdst. 3).

\section{Throughput}

Behalve ten aanzien van de input van het systeem stelt democratie eisen aan de wijze waarop beslissingen worden genomen. Deze betreffen: (d) de deelname van burgers aan de besluitvorming; (e) besluitvorming via stemmen dan wel argumenteren; en (f) de bescherming van de minderheid (zie tabel 1.1).

\section{Ad (d): Deelname van burgers aan de besluitvorming}

Democratiebenaderingen verschillen sterk van elkaar in de waarde die zij hechten aan actieve deelname van burgers aan de feitelijke besluitvorming in het systeem. Om de besluitvorming minder top-down te laten verlopen en burgers meer invloed te geven in de beleids- en besluitvorming wordt recentelijk geëxperimenteerd met een scala van interactieve beleidsvormen (zie Van Stokkum 2003; Akkerman 2001, 2003). Deze zijn enerzijds bedoeld om kennis aan te boren waarover ambtelijke professionals niet beschikken en anderzijds om een democratisch draagvlak voor besluitvorming te creëren waar top-down-beleid niet vanzelfsprekend op kan rekenen.

Ad (e): Besluitvorming via stemmen dan wel argumenteren

Democratische besluiten kunnen ofwel genomen worden op basis van aggregatie van preferenties ofwel door argumenteren, het overwegen van elkaars standpunten en bijstelling van meningen. In de eerste benadering worden stemmen geteld, terwijl in de tweede visie de nadruk op democratische beraadslaging en het optreden van collectieve leerprocessen en consensusvorming ligt. De wijze van besluitvorming raakt ook aan de manier waarop met de argumenten, wensen en behoeftes van minderheden wordt omgegaan. Democratie vooronderstelt immers dat ieders belang gelijkelijk wordt meegewogen.

Ad (f): Bescherming van de minderheid

Democratiebenaderingen verschillen in de waarborgen die zij nodig achten tegen de 'tirannie van de meerderheid' (en de bevoegdheden die in dat kader met name 
aan de rechter worden toegekend). Overigens is ook een 'tirannie van de minderheid' denkbaar, namelijk wanneer een kleine minderheid met vetomacht verwezenlijking van de preferenties van de meerderheid langdurig frustreert.

\section{Output en outcomes}

Ook aan de output van het besluitvormingsproces stelt democratie eisen. Als democratie wordt gezien als een manier om collectieve beslissingen te nemen en beleidsproblemen op te lossen, dan dient de vraag zich aan of het totstandgekomen besluit een bijdrage vormt aan het gemeenschappelijk welzijn van de demos. Oftewel, hoe wordt gegarandeerd dat de uitkomst van de besluitvorming voldoet aan de eisen van government for the people?

Democratische vereisten ten aanzien van de output van het systeem betreffen overigens niet in den brede de prestaties van het systeem en de kwaliteit daarvan. De kwaliteit van de democratie en de kwaliteit van de beleidsoutput zijn niet identiek. Een goede kwaliteit van beleid is eerder een positief effect van democratie dan een democratisch vereiste. Verschillende auteurs hebben ervoor gewaarschuwd democratie te vereenzelvigen met een adequate dienstverlening aan burgers in sectoren als de gezondheidszorg, het onderwijs en de volkshuisvesting. Immers: als burgers die dienstverlening als onvoldoende ervaren, zou dit zich kunnen keren tegen de democratische instituties als zodanig en reeds aanwezige antidemocratische tendensen kunnen versterken. Door te veel van democratie te verwachten, wordt het voortbestaan ervan juist ondermijnd (Van Gunsteren en Andeweg 1994: hfdst. 6).

In complexe, meerlagige politieke contexten beschikken lagere uitvoeringsinstanties over ruime discretionaire mogelijkheden om globale en abstracte politieke doelstellingen naar hun eigen hand te zetten. Enerzijds is dit inherent aan het proces van regelgeving - regels kunnen nimmer zodanig worden geformuleerd dat geen interpretatie nodig is bij de toepassing ervan -, anderzijds is dit het effect van lokale machtsposities; actoren hoger in de hiërarchische ladder zullen bij het bewerkstelligen van hun doelen moeten samenwerken met lokale actoren. Omdat in een groot aantal beleidssectoren het politieke systeem een dergelijke mate van complexiteit heeft gekregen, is het zinvol om onderscheid te maken tussen de uitkomsten van het democratische onderhandelings- en deliberatieproces (output) en de reële effecten van het op grond daarvan daadwerkelijk gevoerde beleid (outcomes). Wij kunnen het eens zijn geworden over de noodzaak van meer financiële ruimte voor het basisonderwijs, maar desalniettemin constateren dat deze financiële ruimte door lokale overheden niet effectief wordt gebruikt. Ook indirecte en onbedoelde effecten leiden ertoe dat output en outcomes niet identiek zijn. Zeker voor output-georiënteerde democratieopvattingen is dat een belangrijke constatering, die dwingt tot grotere aandacht voor de werking van eventuele correctiemechanismen in het representatief-democratische stelsel. 
Anders dan goede prestaties in den brede stelt democratie een specifieke eis aan de output en outcomes, te weten: (g) responsiviteit van het beleid (zie tabel 1.1).

Ad (g): Responsiviteit van het beleid

Rond de eis van responsiviteit van beleid (dat wil zeggen de overeenstemming van beleid met de voorkeuren van het publiek) spelen deels dezelfde interpretatiekwesties als rond het representatiebegrip. Democratiebenaderingen verschillen in de wijze waarop ze de responsiviteit willen waarborgen. Wordt semipermanent getracht de waarden en behoeften van de demos te proeven en zijn dus extra toetsingsmomenten noodzakelijk in aanvulling op verkiezingen? Of betekent responsiviteit dat het bestuur wordt overgelaten aan specialisten in wie voor een bepaalde periode vertrouwen wordt gesteld en die - indien zij dat vertrouwen beschamen - kunnen worden ontheven van hun taak?

\section{Feedback}

Verantwoording voor beleidsresultaten en terugkoppeling van publieksoordelen over die resultaten is een centraal aspect van democratie en in zekere zin een voorwaarde voor andere componenten van democratisch bestuur (h) (zie tabel 1.1) (Lord 1998: 80). Het is immers het vooruitzicht van verantwoording dat bestuurders ertoe aanzet om de voorwaarden waaronder is ingestemd met hun machtsuitoefening te eerbiedigen; en het is verantwoording die bestuurders dwingt tot responsiviteit ten aanzien van de bestuurden.

In het politieke domein behelst verantwoording relaties tussen verschillende actoren: administratieve verantwoording (van ambtenaren tegenover politieke leiders); parlementaire verantwoording (van politieke leiders aan democratische gekozen actoren); en electorale verantwoording (van de democratisch gekozen actoren aan het publiek en aan democratische intermediaire organisaties zoals politieke partijen).

Ook wordt wel onderscheiden tussen niveaus van verantwoording. Ten eerste interne verantwoording; de besluitvormer houdt zich zelf aan democratisch vastgestelde normen. Ten tweede verantwoording van verschillende elites of beleidsnetwerken ten opzichte van elkaar. En ten derde publieke verantwoording. Waarbij als vuistregel geldt dat alle vormen van verantwoording die niet kunnen 'escaleren' tot dit niveau van verantwoording, waar besluitvormers door het publiek ontheven kunnen worden uit hun functie, relatief zwak zijn (Lord 1998: 81).

Ad (h): Verantwoording en terugkoppeling In goed functionerende representatieve democratieën bestaan meerdere mechanismen die tezamen zorg dragen voor het democratische vereiste van verantwoording voor beleidsresultaten en terugkoppeling van publieksoordelen hierover $(\mathrm{h})$.

Het eerste mechanisme is dat van de electorale cyclus: kiezers vellen via verkiezingen een periodiek oordeel over het functioneren van hun vertegenwoordigers. Het nadeel van dit mechanisme is zijn traagheid (een keer in de vier of zes jaar) en zijn grofheid (is de vertegenwoordiger wel de auteur van het beleid? Welk poli- 
tiek en bestuurlijk falen heeft de kiezer op het oog met een afwijzende stem? Hoe adequaat kan een multidimensionale beoordeling worden weergegeven via de binaire keuze van een verkiezing?).

Functioneel geredeneerd kan worden betoogd dat politieke partijen in een vertegenwoordigend democratisch stelsel zijn bedoeld om een deel van deze problemen te ondervangen, met name het auteursprobleem. Zij zijn het tweede feedbackmechanisme dat hier wordt onderscheiden. Klassiek hebben politieke partijen verschillende functies: zij werven en selecteren vertegenwoordigers; $z i j$ scholen vertegenwoordigers en politieke leiders; zij formuleren coherente politieke programma's; zij controleren het bestuurlijke apparaat; zij mobiliseren kiezers; en zij bemiddelen tussen leden/kiezers en het staatsbestuur.

Een derde feedbackmechanisme zijn de media. Geschreven pers, radio en televisie, en in toenemende mate ook discussiegroepen op internet, besteden van oudsher veel aandacht aan de politieke deliberatie in de democratische centra van natiestaten (het Binnenhof), alsmede aan de uitvoering en implementatie van daar totstandgekomen besluiten. Klassieke functies van de media zijn diverteren (vermaken), informeren, opiniëren en het kritisch volgen van machtshebbers. De laatste drie taken zijn cruciaal voor een vitale democratische orde waarin burgers actief zijn betrokken bij de besluiten die hun vertegenwoordigers nemen in hun naam en met het oog op het dienen van hun belangen.

Het vierde feedbackmechanisme is bestuurlijk/administratief van aard en betreft het controle- en informatiesysteem dat als het ware intern is aan het (deels) hiërarchisch gestructureerde staatsapparaat. Webers definitie volgend gaat het in een bureaucratie om duidelijk afgebakende taken en verantwoordelijkheden die worden bezet door actoren die centraal worden aangestuurd en die over hun acties verantwoording afleggen aan hogere toezichthouders. Wanneer dit bureaucratische apparaat afdoende functioneert zal de implementatie van centrale democratische besluiten via een proces van stapsgewijze en gecontroleerde concretisering verlopen en derhalve weinig mogelijkheden bieden voor manipulatie en vervorming. Dan zal het centrum bovendien niet alleen op externe actoren (kiezers, politieke partijen, media) zijn aangewezen voor informatie over eventuele afwijkingen tussen outputs en outcomes.

Het vijfde feedbackmechanisme, ten slotte, is dat van de rechterlijke macht. Omdat ons vertegenwoordigend democratisch stelsel is gebouwd op het raamwerk van een constitutionele rechtsstaat bestaat er altijd de mogelijkheid om democratische besluiten (outputs), inclusief hun eventuele ongewenste effecten (outcomes), bij de rechter aan te vechten. Het zal duidelijk zijn dat gezien de antagonistische aard van dit mechanisme, het vooral zal worden gebruikt bij slecht functioneren van de eerdergenoemde feedbackmechanismen, ofwel door het grove en trage karakter ervan (verkiezingen), ofwel door het elitaire, oligarchische karakter ervan (politieke partijen), ofwel door het willekeurige en vertekenende karakter ervan (media). 


\subsubsection{DE DEMOS}

Idealiter zijn in een democratische politieke gemeenschap de objecten van beleid identiek aan de subjecten: de burgers aan de inputzijde zijn (eventueel via mechanismen van vertegenwoordiging) dezelfde als de onderdanen aan de outputzijde (i) (zie tabel 1.1). Wij zijn gewend te denken aan de demos in de context van de nationale staat: de bevolking van een staat beslist over zaken die diezelfde bevolking aangaan. De vraag wie in welke gevallen tot de demos behoort is echter niet altijd even makkelijk te beantwoorden. Door schaalvergroting, verplaatsing van politiek en toenemende maatschappelijke en economische afhankelijkheden moet steeds opnieuw worden besloten wie in specifieke gevallen tot de demos behoren. Dat kunnen Eu-burgers zijn, bewoners van een buurt of regio, of de wereldbevolking. Ook kan een publiek worden gedefinieerd binnen de context van een beleidsinterventie en beleidsdiscours, binnen een functionele in plaats van territoriale context (Hajer 2003). Burgers maken zo beschouwd niet deel uit van één demos, maar juist van meerdere demoï.

Door processen van schaalvergroting en groeiende wederzijdse afhankelijkheden vallen objecten en subjecten van beleid steeds minder samen. Zo treffen milieubeslissingen van de Amerikaanse regering ook burgers in Europa die niet aan die besluitvorming hebben deelgenomen. En raken gedragscodes van multinationale ondernemingen de bevolking van gastlanden waar deze ondernemingen opereren. Deze discrepantie tussen objecten en subjecten van beleid vormt een belangrijke bedreiging van de democratische kwaliteit van de besluitvorming.

Een belangrijke drager van de stabiliteit van democratieën wordt gevormd door de burgerlijke politieke cultuur van de demos (j) (zie tabel 1.1). Geïnspireerd door Almond en Verba's these dat bepaalde politieke oriëntaties van de demos bijdragen aan de stabiliteit van democratieën, heeft verder onderzoek gewezen op drie globale 'culturele voorwaarden voor stabiele democratie' (Daemen 1984: 82):

- Een zekere mate van politieke betrokkenheid. Deze moet voldoende zijn om een bepaald niveau van politieke participatie in stand te houden, dat vereist is voor het behoud van het democratische karakter van het systeem; maar te gering om het systeem bloot te kunnen stellen aan de gevaren van activisme;

- gevoelens van saamhorigheid en verbondenheid met medeburgers, die verhinderen dat het systeem als gevolg van maatschappelijke tegenstellingen uiteenvalt;

- en een gehechtheid aan het systeem die bijdraagt aan de bereidheid collectieve beslissingen te aanvaarden, ook wanneer dit meerderheidsbeslissingen zijn die tegen de belangen van minderheden indruisen of anderszins beslissingen zijn die niet tot de gewenste resultaten leiden.

Hoe ver deze gevoelens van saamhorigheid en gehechtheid aan het systeem moeten gaan en waar zij aan ontleend worden is onderwerp van discussie. Verschillende auteurs menen dat alleen wanneer sprake is van een thick collective identity, voortkomend uit een gedeelde geschiedenis, taal, godsdienst en/of 
cultuur, meerderheidsbeslissingen hun dreigende karakter verliezen. Anderen zien de demos als een veel politieker fenomeen. Het feit dat in de EU over belangrijke politieke zaken wordt beslist, betekent dat hier een politieke arena en een politieke identiteit ontstaan die niet vooraf bestonden. Deze laatste visie is aanzienlijk dynamischer: instituties en de besluiten die daarbinnen worden genomen kunnen op zichzelf bijdragen aan de vorming van een politieke identiteit; doordat mensen participeren in een besluitvormingssysteem verkrijgt dat systeem een legitimiteit die ook afstraalt op de beslissingen van het systeem, en omgekeerd. Daarnaast staat de laatste visie toe dat burgers deel uitmaken van meer dan één demos en verschillende identiteiten kennen, een Rotterdamse, Nederlandse, Europese en wie weet zelfs een kosmopolitische.

\subsubsection{CONCLUSIE}

Hoewel het betrekkelijk eenvoudig is om democratische vereisten ten aanzien van (de verschillende fasen van) bestuur en demos te onderscheiden (zie tabel 1.1), blijkt uit de bovenstaande bespreking al dat hun relatieve belang en hun praktische, institutionele invulling betwist is. Waar radicale democraten de nadruk leggen op institutionele garanties voor inspraak van de burger en dus de inputzijde privilegiëren, zien anderen de outputzijde als voornaamste bron van legitimiteit en leggen zij de nadruk op publieke verantwoording achteraf. In deze discussie weerklinkt overigens een duidelijke echo van het bredere debat tussen de democratische (continentale) en de rechtsstatelijke (Angelsaksische) traditie. De democratische traditie heeft zich door de geschiedenis heen met kernthema's als burgerparticipatie, meerderheidsbesluitvorming, directe dan wel indirecte invloed van de burger op het beleid vooral op de inputzijde van het politieke systeem geconcentreerd. De aanhangers van de rechtsstaatidee daarentegen hebben met kernthema's als binding van overheidsoptreden aan het recht, checks and balances en kwaliteit van de maatschappelijke sturing vooral aandacht gehad voor de outputzijde van het politieke systeem (zie De Jong 1991). Afhankelijk van de normatieve positie zal aan elk van de boven besproken elementen van democratie meer of minder belang worden gehecht en zullen zij in verschillende instituties en praktijken worden vertaald.

Juist in een periode van ingrijpende maatschappelijke verandering is een fundamenteel debat over (de relatie tussen) verschillende kernaspecten van democratische systemen onzes inziens van belang. Impliceren deze veranderingen bijvoorbeeld dat we naar een dynamischere, meer kwestiespecifieke omschrijving van de demos moeten? Leiden zij onvermijdelijk tot een verschuiving in het relatieve belang van inspraak naar verantwoording, of in de hier gehanteerde termen: van democratische input als voornaamste bron van legitimiteit naar output, en welke praktische institutionele vorm moet daar dan aan worden gegeven? Is er als gevolg van maatschappelijke ontwikkelingen sprake van een geleidelijke verschuiving van electorale feedbackmechanismen naar andere mechanismen en wat zijn daarvan de gevolgen? En als dat zo is, hoe moeten wij deze effecten duiden? Iedere duiding vooronderstelt uiteraard een perspectief vanwaaruit geoordeeld 


\begin{tabular}{|l|l|} 
Kernaspect democratie & Democratische vereisten \\
(1) Bestuur & \\
Input & $\begin{array}{l}\text { (a) steun voor gezagsdragers en systeem } \\
\text { (b) participatie om voorkeuren kenbaar te maken }\end{array}$ \\
(c) representatie \\
(d) deelname aan de besluitvorming \\
Output/outcomes & $\begin{array}{l}\text { (e) besluitvorming via stemmen dan wel argumenteren } \\
\text { (f) bescherming van de minderheid }\end{array}$ \\
Feedback & (h) responsiviteit van beleid(suitkomsten) \\
\hline (2) Demos & (i) identiteit van object en subject van besluitvorming \\
& (j) burgerlijke politieke cultuur
\end{tabular}

wordt. Bovendien zullen verschillende perspectieven ook verschillende oplossingsrichtingen suggereren. Om recht te doen aan het controversiële karakter van iedere institutionele vormgeving van het idee van democratie alsmede om de rijkdom te demonstreren van de democratietheoretische traditie, presenteren wij hieronder een viertal democratietheoretische perspectieven die onzes inziens de voornaamste hedendaagse breuklijnen binnen het wetenschappelijke denken over democratie en democratisering belichamen. Dat zijn respectievelijk de vertegenwoordigende democratie, de directe democratie, de deliberatieve democratie en de associatieve democratie.

\subsection{NAAR VIER DEMOCRATIETHEORETISCHE PERSPECTIEVEN}

De geschiedenis van democratische controverses leert dat de tegenstellingen vooral op het vlak van de invulling en inrichting van democratische principes liggen. Wie zich in het huidige politieke klimaat bekent tot enige vorm van aristocratisch bestuur diskwalificeert zichzelf intellectueel. Om Nixon te parafraseren: "We're all democrats now!" Niemand zal serieus willen bestrijden dat een politieke democratie een minimum aan politieke gelijkheid, politieke vrijheid, responsiviteit en participatie vereist.

Veel minder overeenstemming is er echter over de vraag wat dat in organisatorische en institutionele zin betekent. Hoe minderheden tegen meerderheden te beschermen? Is politieke gelijkheid gewaarborgd wanneer iedereen een stem heeft? Of vereist politieke gelijkheid gelijke toegang tot veel verdergaande vormen van participatie? Wie mogen spreken? Hoe te voorkomen dat sociaaleconomische ongelijkheden politieke effecten hebben? Hoe de meningsuitwisseling te beëindigen als er geen consensus is? Hoe de implementatie van besluiten te controleren? Is een democratisch legitieme uitkomst gewaarborgd wanneer de meeste stemmen tellen of is het ook van belang hoe de preferenties die ten grondslag liggen aan die stemmen tot stand zijn gekomen? En, wellicht nog belangrijker, waar is democratie op zijn plaats? Op deze en soortgelijke vragen zijn in de loop der decennia vele verschillende 
antwoorden gegeven. In principe zijn er drie manieren waarop die antwoorden vervolgens theoretisch kunnen worden geordend. De eerste manier is vergelijkend van aard en is afkomstig uit de empirische politieke wetenschap die veel moeite heeft gedaan om de verschillende stelsels van vertegenwoordigende democratie te beschrijven en te ordenen (Lijphart 1994). Kenmerkend voor deze benadering is dat zij vooral oog heeft voor de organisatiekenmerken van de verschillende systemen van politieke representatie.

De tweede manier is historisch van aard en relateert de complexiteit van democratische instituties aan de omvang van de politieke gemeenschap en de complexiteit van de vraagstukken waarop deze gemeenschap antwoord moet vinden (zie Held 1987). Hoewel de aandacht hier tevens uitgaat naar verschillende voorwaarden en verschillende morele legitimeringen, staat ook in deze benadering de formele politieke democratie centraal. In zekere zin, zo kan worden geconstateerd, hebben de meeste contemporaine democratietheorieën zich onvoldoende losgemaakt van de klassieke aristoteliaanse onderzoeksagenda die democratie, naast monarchie en aristocratie, vooral opvatte als een constitutionele grondvorm (Brunner et al. 1972).

In het klassieke politicologische perspectief is democratie een set van instituties die betrekking hebben op de wijze waarop politieke legitimiteitsverwerving op nationaal niveau is georganiseerd. Omdat wij hier het scala aan mogelijke antwoorden op de uitdagingen aan het bestaande statelijke democratische bestel zo groot mogelijk willen houden, willen wij ook het veld aan democratietheoretische perspectieven niet op voorhand inperken. Om die reden kiezen wij voor een invulling van het democratiebegrip, die democratie niet als set van instituties opvat maar juist als een set van principes. Of, om de definitie die wij eerder han-

Tabel 1.2 Typologie van vier burgerschapsstijlen en verschillende rollen van burgers

\begin{tabular}{|c|c|c|c|c|}
\hline & $\begin{array}{l}\text { Vertegenwoor- } \\
\text { digende } \\
\text { democratie }\end{array}$ & $\begin{array}{l}\text { Directe } \\
\text { democratie }\end{array}$ & $\begin{array}{l}\text { Deliberatieve } \\
\text { democratie }\end{array}$ & $\begin{array}{l}\text { Associatieve } \\
\text { democratie }\end{array}$ \\
\hline Input & Burgers & Burgers & $\begin{array}{l}\text { Betrokkenen/ } \\
\text { Geïnteresseerden }\end{array}$ & Betrokkenen \\
\hline Throughput & $\begin{array}{l}\text { Stemmen (burger) } \\
\text { Argumenteren (politicus) }\end{array}$ & Stemmen & Spreken & $\begin{array}{l}\text { Stemmen } \\
\text { Argumenteren }\end{array}$ \\
\hline Output* & Compromissen & $\begin{array}{l}\text { Meerderheids- } \\
\text { besluiten }\end{array}$ & Consensus & $\begin{array}{l}\text { 'Cooperative } \\
\text { problem solving' }\end{array}$ \\
\hline $\begin{array}{l}\text { Feedback } \\
\text { Voornaamste }\end{array}$ & Gefilterde responsiviteit & $\begin{array}{l}\text { Directe - } \\
\text { responsiviteit }\end{array}$ & $\begin{array}{l}\text { Beargumenteerde } \\
\text { responsiviteit }\end{array}$ & $\begin{array}{l}\text { Lokale } \\
\text { responsiviteit } \\
\text { Input }\end{array}$ \\
\hline $\begin{array}{l}\text { bron van } \\
\text { legitimiteit }\end{array}$ & Output & Input & Throughput & Outcomes \\
\hline Demos & Politieke demoï & Politieke demoï & $\begin{array}{l}\text { Vnl. politieke } \\
\text { demoï }\end{array}$ & $\begin{array}{l}\text { Politieke en } \\
\text { functionele demoï }\end{array}$ \\
\hline
\end{tabular}

*) Omdat de mate waarin outcomes en outputs van elkaar verschillen afhankelijk is van de context hebben wij outcomes hier als afzonderlijk kernaspect van democratie weggelaten. 
teerden weer te gebruiken: Democratie is een politieke besluitvormingsprocedure waarin politieke gelijkheid en politieke vrijheid (procedurele grondrechten en beginselen) zijn gewaarborgd. Hoe die procedure vervolgens wordt vormgegeven (direct of getrapt, met een nadruk op spreken of juist op stemmen) en wat als de locatie bij uitstek van democratische besluitvorming wordt gezien (de staat of ook de school, de buurt, het ziekenhuis, de onderneming) is vervolgens onderwerp van discussie. Op deze manier zijn wij in staat om alle onzes inziens relevante breuklijnen binnen de contemporaine democratietheorie een plaats te geven.

Naar onze mening domineren momenteel controverses tussen voorstanders van de vertegenwoordigende (indirecte) en directe democratie, tussen deliberatieve (argumenteren) en aggregatieve (stemmen) democratie en tussen politieke en associatieve democratie. Wij zullen hier eerst de verschillende perspectieven afzonderlijk presenteren, om daarna enige cruciale overeenkomsten en verschillen aan te stippen.

\subsubsection{VERTEGENWOORDIGENDE DEMOCRATIE}

Hoewel vertegenwoordiging de meest voor de hand liggende associatie is bij 'democratie', is historisch gezien de relatie tussen deze twee moeizaam geweest. Hirschman benadrukt dat het universele kiesrecht dat onderdanen tot burgers maakte en deze burgers een indirecte medezeggenschap in het bestuur gaf, meer tegemoetkwam aan de wens van de gegoede burgerij om de inspraakmogelijkheden van de lagere standen beperkt te houden dan aan de roep van de lagere standen om volwaardig zelfbestuur (Hirschman 1982). Dat laatste was namelijk - anders dan de notie van de 'republiek' - in het midden van de negentiende eeuw de dominante invulling van het democratieconcept (Brunner et al. 1978).

Kenmerkend voor het representatieve democratieperspectief is een zekere mate van twijfel aan de rationaliteit van de kiezer. Gebaseerd als het is op het principe van arbeidsdeling (de kiezer stemt, de politicus spreekt, delibereert en oordeelt), geeft het de professionele politicus - geselecteerd, opgeleid en naar voren geschoven door bemiddelende politieke partijen - een cruciale rol bij het achterhalen en interpreteren van de kiezerswens, alsmede bij het aansturen en controleren van het bureaucratische apparaat dat in het leven is geroepen om deze bemiddelde en geïnterpreteerde kiezerswens ten uitvoer te brengen. Zo bezien ligt het zwaartepunt in representatieve democratiebenaderingen aan de outputzijde. De minimale participatiemogelijkheden die representatieve democratische instituties de burger bieden, worden gecompenseerd door een output die, zo is de hoop, meer tegemoetkomt aan wat burgers werkelijk willen - wat niet hetzelfde hoeft te zijn als wat burgers zeggen te willen. Ten aanzien van de demos vooronderstelt de representatieve democratietheorie identiteit van subject en object en een stabiel, duidelijk afgebakend 'volk'. Discussie is er over de mate waarin dat een gedeelde collectieve identiteit impliceert. Minder discussie is er over de aanname van een politiek en bestuurlijk centrum waar de volkssoevereiniteit haar beslag krijgt, terwijl dat in werkelijkheid juist een van de meest discutabele premissen van de representatieve democratietheorie is. 


\subsubsection{DIRECTE DEMOCRATIE}

Directe democratietheorieën zijn er in verschillende soorten en maten. Sommige bepleiten kleinschalige democratische entiteiten waar het democratische ideaal van collectief zelfbestuur zijn beslag zou kunnen krijgen. Andere bepleiten het inzetten van direct democratische elementen zoals direct gekozen functionarissen, het referendum, het volksinitiatief of het gebonden mandaat om de bestaande representatieve democratische instituties responsiever te maken. Weer andere zien in de opkomst van ICT een mogelijkheid om voorbij de bekende democratische beperkingen van tijd, participatielust en expertise nieuwe grensoverschrijdende vormen van participatie te ontwikkelen die meer dan de bestaande representatieve democratische stelsels recht doen aan het democratische ideaal van collectief zelfbestuur.

Wat deze drie varianten delen is een groot vertrouwen in de rationaliteit van de burger. Wie het democratische ideaal serieus neemt, aldus de directe democraat, kan niet anders dan voor (vormen van) directe democratie zijn. Directe democratie geeft de burger instrumenten in handen om zelf te bepalen wat de staat dient te doen. Bezien vanuit het perspectief van de directe democraat vallen input en outputlegitimiteit samen. De uitkomst van de collectieve wilsvorming is legitiem omdat de input dat is. Oftewel, omdat er geen bemiddeling heeft plaatsgevonden is er geen afzonderlijke bron van legitimiteit nodig voor de uitkomsten van het besluitvormingsproces. Om dezelfde reden is ook de notie van throughput-legitimiteit voor de directe democraat minder relevant. Zolang de gehele demos een stem heeft kunnen uitbrengen is deze immers gewaarborgd.

Ten aanzien van de afbakening van de demos wordt door verschillende directe democraten verschillend gedacht. Sommigen bepleiten radicale devolutie en in het voetspoor daarvan functionele kleinschaligheid om stemmen door middel van handopsteken mogelijk te maken. Anderen volgen de demos-opvatting van de vertegenwoordigende democratie en zien zich derhalve voor dezelfde vragen geplaatst. Weer anderen nemen genoegen met vormen van issue-georiënteerde vormen van zelforganisatie zoals op het internet zijn te vinden.

\subsubsection{DELIBERATIEVE DEMOCRATIE}

Ook de zogenaamde 'deliberatieve wending' in de contemporaine democratietheorie moet worden gezien tegen de achtergrond van een groeiend crisisbewustzijn over de houdbaarheid van de vertegenwoordigende democratie. De constatering dat aggregatieve, majoritaire besluitvormingsmodi de standpunten van minderheden structureel negeren, deed de aandacht verschuiven naar vormen van besluitvorming die minder door getalsmatige verhoudingen worden bepaald. Empirische voorbeelden van kleine vergaderingen leerden dat deliberatie minder aan dit soort effecten is blootgesteld. 
Ook onder de voorstanders van deliberatieve democratie kunnen verschillende stromingen worden onderscheiden: meer idealistische en meer realistische; meer politieke en meer functionele; meer representatieve en meer directe. Karakteristiek voor de eersten is de nadruk op de machtsvrije uitwisseling van argumenten die in de plaats zou moeten komen van de belangengeoriënteerde onderhandelingen van politics as usual (Habermas 1996). Daartegenover staan deliberatieve democraten die onderkennen dat belangen en argumenten verweven zijn, net als argumenteren en onderhandelen, en die voor de modus van het spreken/argumenteren vooral een getuigenis afleggende functie zien en om die reden geoormerkte zetels voor minderheden in belangrijke politieke gremia voorstaan (Mansbridge 2000).

Het merendeel van de deliberatieve democraten richt zijn hervormingsaandacht op politieke instituties, maar er zijn er ook die voor deliberatie een plaats willen inruimen in civil society. Omdat de omvang van het delibererende gremium niet te groot mag zijn, bestaat er een zekere Wahlverwandschaft tussen de deliberatieve en de vertegenwoordigende democratie. Desalniettemin zijn er ook deliberatieve democraten die sommige vormen van directe democratie als een middel bij uitstek zien om het deliberatieve gehalte van de politieke besluitvorming te vergroten (Akkerman 2003).

Uiteraard verschillen deze stromingen binnen de deliberatieve democratie ten aanzien van hun waardering van de verschillende bronnen van legitimiteit, zoals ze ook verschillen in hun antwoord op de afbakeningsvraag: wie behoren tot de demos? Wat deliberatieve democraten echter delen is de overtuiging dat input en outputlegitimiteit op zichzelf niet volstaan, maar dat ook throughput-legitimiteit in de beoordeling van de legitimiteit van het democratische proces en product moet worden meegenomen.

\subsubsection{ASSOCIATIEVE DEMOCRATIE}

Kenmerkend voor de associatieve democratie is de nadruk op maatschappelijk zelfbestuur. Als enige van de hier besproken democratieperspectieven neemt associatieve democratie de constatering van de onmogelijkheid van centrale sturing serieus en probeert zij een programma van democratische vernieuwing te combineren met een programma van bestuurlijke vernieuwing. Daarbij weigeren associatieve democraten te kiezen voor ofwel een instrumentele democratieopvatting ofwel een morele. In de ogen van associatieve democraten is maatschappelijk zelfbestuur zowel goed als nuttig. Het is goed omdat zelfbestuur het aantal locaties waar burgers kunnen meebeslissen radicaal vergroot; het is goed omdat het de zelfbeschikkingsmogelijkheden van individuen en collectieven vergroot; het is goed omdat het burgers meer keuzemogelijkheden geeft; en het is nuttig omdat het collectieve oplossingen mogelijk maakt zonder te vervallen in uniformiteit of in vrijheidsberovend paternalisme. 
Ook de associatieve democratie kent meerdere stromingen. De stroming die de nuttigheid ervan benadrukt, laat een instrumentele democratieopvatting meestal prevaleren en schrijft de associaties waarbinnen het zelfbestuur van burgers en gemeenschappen gestalte krijgt weinig interne democratische eisen voor. Deze variant van de associatieve democratie vertoont daarmee veel overeenkomsten met het West-Europese (neo)corporatisme en is niet toevallig in het begin van de jaren negentig door Amerikanen uitgewerkt, die zich hebben laten inspireren door het toenmalige economische succes van regio's als het Duitse Baden-Württemberg (Cohen en Rogers 1995). Uiteraard roept dit vragen op die de bekende nadelen van het (neo)corporatisme betreffen: de geringe representativiteit van associaties; de sterke verstatelijking van associaties; de oligarchisering binnen associaties; en de inertie van associaties.

De stroming die vooral het goede benadrukt, laat de morele democratieopvatting het zwaarste wegen en stelt wel verdergaande intern democratische eisen aan de associaties die het eigenlijke werk moeten doen (Hirst 1994; Bader 2001). Hier zijn de vergeten tradities van het Britse gildesocialisme en het continentale coöperatieve socialisme van de jaren twintig van de vorige eeuw de voornaamste inspiratiebronnen. Van alle hier genoemde democratietheoretische perspectieven lijkt de associatieve democratie de meest flexibele. Omdat zij verschillende besluitvormingsmodi omvat en zich niet vastlegt op een organisatietype, een ideaaltypische demos, noch op een maatschappelijk domein, lijkt zij bij uitstek geschikt om per deelterrein en probleemgebied te kiezen voor verschillende inspraak- en verantwoordingsvormen. Dat laat onverlet dat zij, naast de reeds genoemde problemen, belangrijke coördinatievragen openlaat die het schakelen tussen schalen en lagen betreffen.

\subsubsection{OVEREENKOMSTEN EN VERSCHILLEN}

Uiteraard zijn deze perspectieven niet wederzijds uitsluitend en komen combinaties voor. Gezien de schaal van hedendaagse politieke 'gemeenschappen' gaan directe democratieopvattingen bijvoorbeeld samen met aggregatieve besluitvormingsprocedures, zoals het referendum, terwijl representatie vaak gepaard gaat met deliberatieve besluitvorming binnen het representatieve gremium. Cruciaal voor pleidooien voor directe democratie is het oordeel dat de elitaire besluitvorming waar representatieve democratie schijnbaar vanzelfsprekend in uitmondt, neerkomt op een complot jegens de kiezer die onder democratische condities het laatste woord zou moeten hebben. Oftewel, men verschilt van mening over waar de prioriteit moet liggen: aan de inputzijde (directe democratie) of juist aan de outputzijde (vertegenwoordigende democratie).

Deliberatieve en vertegenwoordigende democraten zijn minder overtuigd van de rationaliteit van de ongefilterde kiezersmening - of anders geformuleerd: angstiger voor de politieke passies van burgers (zie Hirschman 1982) - en bepleiten filters om deze mening van zijn irrationale en gepassioneerde kanten te ontdoen. De eersten zien deliberatie als het middel bij uitstek om kiezers en/of hun repre- 
sentanten te dwingen om hun ongeïnformeerde of egoïstische preferenties te transformeren in geïnformeerde en meer altruïstische preferenties. De tweeden stellen hun vertrouwen in de professionaliteit en rationaliteit van intermediërende partijen en hun elites. Oftewel, in termen van legitimiteit leggen de eersten de nadruk op throughput (de procedure volgens welke het publieke belang wordt vastgesteld), terwijl de laatsten de nadruk leggen op output.

Een belangrijker verschil tussen representatieve en deliberatieve democraten is echter dat de laatsten in beginsel aan iedere burger het deliberatieve vermogen toeschrijven dat volgens representatieve democraten alleen aan de professionele politicus toevalt. De meeste deliberatieve democraten hangen dan ook een breed 'democratie'-begrip aan, min of meer conform de hier gehanteerde institutioneel neutrale democratiedefinitie, en bepleiten een proliferatie van plaatsen waar de burger zijn deliberatieve vaardigheden kan oefenen. De mogelijkheid voor proliferatie van politieke plaatsen wordt door deliberatieve democraten in twee richtingen gezocht. Enerzijds wordt gekeken naar het deliberatieve potentieel van direct democratische instrumenten als het preferendum, d.w.z. het gefaseerde meerkeuzereferendum (Akkerman 2003), anderzijds wordt aansluiting gezocht bij de neo-Tocquevilliaanse theoretici van het maatschappelijk middenveld die wijzen op de positieve externe effecten ('leerscholen der democratie') van deliberatie in de eigen kring van de vrijwillige associatie (De Haan 2003). Karakteristiek voor deze laatste stroming binnen de deliberatieve democratie is de instrumentele zienswijze op deliberatie in de civil society. Deliberatieve participatie in vrijwillige associaties wordt niet als een doel op zichzelf gezien maar staat ten dienste van een versterking van de participatie in de klassieke instituties van de representatieve democratie.

Associatieve democraten delen met deze deliberatieve democraten hun maatschappelijke oriëntatie. Inderdaad is door de 'verplaatsing van de politiek' het aantal politieke plaatsen menigvuldig geworden, en inderdaad biedt dat kansen voor een hernieuwd democratiseringsoffensief, aldus de associatieve democraat. Waarin zij verschillen van deliberatieve democraten is zowel in hun nuchterdere inschatting van het democratische gehalte van vrijwillige associaties als in hun instrumentele benadering van decentrale, functionele democratie.

Niet iedere vrijwillige associatie onderschrijft democratische normen, maar zelfs in het geval van antidemocratische associaties prefereren associatieve democraten zelfbestuur boven centraal staatsbestuur. Dat wil niet zeggen dat zij de vertegenwoordigende democratie op staatsniveau zouden willen vervangen door zelfbestuur op associatief niveau. Zowel de radicale als de gematigde variant van de associatieve democratie staat uiteindelijk een complementaire strategie voor: associatieve democratie betekent uitbreiding van de bestaande democratische instituties door burgers substantiële associatierechten te verlenen en deze associaties een grote mate van vrijheid te geven bij het uitvoeren van publieke taken, reikend van onderwijs tot aan sociale zekerheid.

Deze inzet is zowel ingegeven door de constatering dat het ideaal van autonome 
burgers in toenemende mate op gespannen voet staat met de uniforme oplossingen die traditioneel aangestuurde organisaties leveren als door de constatering dat centrale overheden door de fragmentatie van wensen en eisen en de proliferatie van controlelocaties de 'handen' en 'ogen' missen om effectief te besturen. Vandaar de grote verwevenheid van democratische en bestuurlijke vernieuwing in het associatieve democratieperspectief.

\subsection{OPZET VAN DEZE BUNDEL}

Het vervolg van deze bundel is als volgt gestructureerd. De hoofdstukken twee tot en met elf bieden primair empirische inzichten omtrent maatschappelijke veranderingen die van invloed zijn op het bestuur en de demos en beogen een diagnose over de staat van de democratie. De hoofdstukken twee, vier, vijf, zes en acht bieden analyses van de gevolgen van verplaatsing van politiek naar (en/of politisering van issues binnen) lokale, internationale en maatschappelijke locaties. Winsemius, Jager-Vreugdenhil en Boonstra (hfdst. 2) en Hazeu (hfdst. 4) nemen de lokale politiek voor hun rekening, Arts de mondiale arena, Sie Dhian Ho de overdracht van bevoegdheden naar de EU en Dijstelbloem en Meurs (hfdst. 6) governance in maatschappelijke instellingen. Verhoeven stelt in hoofdstuk drie de vraag op welke wijze de invulling van burgerschap is veranderd en wat de gevolgen zijn voor het democratische bestuur. Dijstelbloem, De Vries en Schuyt (hfdst. 7) en Sabel (hfdst. 9) doordenken de gevolgen van de ontwikkeling van een 'kennissamenleving' voor bestuur en democratie. Pattyn (hfdst. 10) en Broeders en Van de Donk (hfdst. 11) ten slotte analyseren de relatie tussen media en democratie.

In de hoofdstukken twaalf tot en met vijftien komen vervolgens de vier democratiebenaderingen aan het woord, die de behandelde maatschappelijke ontwikkelingen wegen in termen van hun gevolgen voor de democratie, beoordelen waar problemen ontstaan en oplossingsrichtingen schetsen. Krouwel doet dat vanuit het perspectief van de directe democratie (hfdst. 12), Akkerman vanuit de deliberatieve benadering (hfdst. 13), Engelen vanuit de associatieve invalshoek (hfdst. 14), en Tromp vanuit de indirecte democratietheorie (hfdst. 15). 


\section{LITERATUUR}

Actieprogramma 'Andere Overheid' (2003). Brief van de minister voor Bestuurlijke Vernieuwing en Koninkrijksrelaties aan de voorzitter van de Tweede Kamer der Staten-Generaal, Den Haag, 1 december 2003.

Akkerman, T. (2001) 'Urban debates and deliberative democracy', in Acta Politica. International Journal of Political Science, 36 (Spring): 71-88.

Akkerman, T. (2003) 'Talking, Voting and Violence. Divisive Issues and the Limits of Democratic Deliberation', 18. Amsterdam.

Almond, G.A. en S. Verba (1963) The Civic Culture. Political Attitudes and Democracy in Five Nations, Princeton: Princeton University Press.

Andeweg, R.B., A. Hoogerwerf, J.J.A. Thomassen (1985) Politiek in Nederland, Alphen a/d Rijn: Samson H.D. Tjeenk Willink.

Ankersmit, F.R. (1990) De navel van de geschiedenis. Over interpretatie, representatie en historische realiteit, Groningen: Historische Uitgeverij.

Bader, V. (2001) 'Problems and Prospects of Associative Democracy. Cohen and Rogers Revisited', in P. Hirst en V. Bader (red.) Associative Democracy. The Real Third Way, London: Frank Cass.

Becker, F., M. Sie Dhian Ho, W. van Hennekeler en B. Tromp (red.) (2003) Politieke partijen op drift, Het vierentwintigste jaarboek voor het democratisch socialisme, Amsterdam: Wiardi Beckman Stichting/Uitgeverij de Arbeiderspers.

Brunner, O., W. Conze en R. Koselleck (red.) (1972) Geschichtliche Grundbegriffe:historisches Lexikon zur politisch-sozialen Sprache in Deutschland, Stuttgart: Klett, 7 delen.

Burg, W. van der (1991) Het Democratisch Perspectief, Arnhem: Gouda Quint.

Cohen, J. \& J. Rogers (red.) (1995) Associations \& Democracy. Onder redactie van E.O. Wright, vol. 1, Real Utopias Project. London: Verso.

Daemen, H.H.F.M. (1984) Politieke cultuur, in M.P.C.M. van Schendelen (red.), Kernthema's van de politicologie, Meppel en Amsterdam: Boom/Intermediair Bibliotheek: 66-87.

Dahl, R.A. (1971) Polyarchy, New Haven, London: Yale University Press.

Dahl, R.A. (1989) Democracy and its critics, New Haven, London: Yale University Press.

Doorn, J. van (2002) 'Democratie in de overgang. Van collectieve beheersing naar geordende vrijheid', in P.G.C. van Schie (red.), Het democratisch tekort: Interpretaties en remedies, Den Haag: Teldersstichting: 7-56.

Haan, I. de (2003) 'Vertrouwen in Tocqueville'. Krisis, Tijdschrift voor Empirische Filosofie 2003, no. 4: 85-104.

Habermas, J. (1996) Between Facts and Norms. Contributions to a Discourse Theory of Law and Democracy. Cambridge: Polity Press.

Hajer, M. (2003) 'A frame in the fields: policymaking and the reinvention of politics', in M. Hajer en H. Wagenaar, Deliberative policy analysis. Understanding governance in the network society: 88-108, Cambridge: Cambridge University Press.

Held, D. (1987) Models of Democracy, Cambridge: Polity.

Hirschman, A. (1982) Shifting Involvements. Private Interests and Public Action. Princeton: Princeton University Press. 
Hirst, P. (1994) Associative Democracy. New Forms of Social and Economic Governance. Oxford: Polity Press.

Jong, H.M. de (1991) ‘Democratie en rechtsstaat', in J.J.A. Thomassen (red.) (1991), Hedendaagse democratie: 34-51, Alphen aan den Rijn: Samsom H.D. Tjeenk Willink.

Kabinetsvisie 'Andere Overheid' (2003). Brief van de minister voor Bestuurlijke Vernieuwing en Koninkrijksrelaties aan de voorzitter van de Tweede Kamer der Staten-Generaal, Den Haag, 1 december 2003.

Lijphart, A. (1994) Electoral Systems and Party Systems : A Study of Twenty-Seven Democracies, 1945-1990. Oxford: Oxford University Press.

Mair, P. (2002) 'De eigenaardigheden van de Nederlanders. De verkiezingen van 2002 in een vergelijkend perspectief', in Beleid en Maatschappij, 29: 160-163.

Mansbridge, J. (2000) 'What does a Representative do? Descriptive Representation in Communicative Settings of Distrust, Uncrystallized Interests, and Historically Denigrated Status', in W.K.W. Kymlicka en W. Norman (red.) Citizenship in Diverse Situations: 99-123, Oxford: Oxford University Press.

Pitkin, H. F. (1967) The Concept of Representation, Berkeley: University of California Press.

Schie, P.G.C. van (2002) 'Parlementaire democratie op dood spoor?’, in P.G.C. van Schie (red.) Het democratisch tekort: Interpretaties en remedies, Den Haag: Teldersstichting.

Stokkum, B. van (2003) 'Deliberatie zonder democratie', in Beleid en Maatschappij, 30, 3: 153-165.

Tromp, Bart (2003) 'Vernieuwing of verbetering', in Het Parool, 20 november 2003.

Tweede Kamer der Staten-Generaal (2003a) Brief van de minister van Binnenlandse Zaken en Koninkrijksrelaties aan de voorzitter van de Tweede Kamer der StatenGeneraal, Invoering direct gekozen burgemeester, Tweede Kamer, vergaderjaar 2002-2003, 28759, nr. 1.

Tweede Kamer der Staten-Generaal (2003b). Brief van de minister voor Bestuurlijke Vernieuwing en Koninkrijksrelaties aan de voorzitter van de Tweede Kamer der Staten-Generaal, Nieuw kiesstelsel, Tweede Kamer, vergaderjaar 2003-2004, 29 356, nr. 1.

Witteveen, W. (200o) De denkbeeldige staat. Voorstellingen van democratische vernieuwing, Amsterdam: Amsterdam University Press. 


\title{
2 DEMOCRATIE EN DE BUURT
}

\author{
P. Winsemius, M. Jager-Vreugdenhil en N. Boonstra
}

\subsection{INLEIDING}

De burger verandert - en daarmee de verhoudingen tussen burger en instituties.

De 'mondigere en moeilijkere' burger wil meer zelf keuzen kunnen maken (Van den Brink 2002). Hij kan dat ook. Niet langer is het bijvoorbeeld een ambtenaar achter een bureau die bepaalt wanneer wij stilstaan voor een stoplicht, maar wij doen dat op de rotondes zelf op basis van eenvoudige spelregels en in directe wisselwerking met onze medeburgers. Zowel de doorstroming als de verkeersveiligheid bleek gebaat bij de grotere zelfverantwoordelijkheid. Nieuwe vormen van 'rotondedenken' zijn echter ook elders van toenemend belang (Van Asseldonk 1998). Burgers wisten zich uitermate doeltreffend te 'organiseren' als tegenmacht in de productenmarkt om ondernemingen als Nike (kinderarbeid) en Ahold (overmatige beloning toplieden) tot de orde te roepen. De wereldwijde betogingen tegen de oorlog in Irak werden veelal georganiseerd door ad hoccoalities van zeer kleine verbanden. De afrekening van de zittende 'regenten' in vele Europese landen door niet-stemmen of tegen-stemmen op andere of zelfs nieuwe partijen is in die zin illustratief voor de grotere macht van de burger als kiezer.

Deze veranderingen, met inbegrip van de grotere onvoorspelbaarheid daarvan, roepen veel vragen op, ook ten aanzien van het democratische gehalte van de nieuwe verhoudingen. Blijft het in de nieuwe context mogelijk zorgvuldig beleid te formuleren, dat wil zeggen beleid dat voldoet aan de ' $3 \mathrm{E}-$-criteria': Effectiviteit, Efficiëntie en Eerlijkheid? De legitimiteit van de beleidsbepalers (wie heeft hen gekozen of benoemd? Aan wie zijn zij verantwoording verschuldigd?), de rechtsgelijkheid voor allen maar ook de bescherming van zwakkere partijen of individuen, de kwaliteit van informatie voor de burger en de toegankelijkheid daarvan: het zijn maar een paar van de vele vragen die rijzen rond het criterium 'Eerlijkheid'. Daar staat tegenover dat de twee andere E's - die van Effectiviteit en van Efficiëntie - veelal gebaat zijn bij de creativiteit van velen. Wanneer miljoenen mensen denken vanuit een welbegrepen eigenbelang mag je immers verwachten dat meer mensen zich kunnen vinden in de gekozen oplossing dan in het geval dat een klein aantal deskundigen-op-afstand nadenkt over een specifiek maatschappelijk vraagstuk.

De vraag is daarom op welke wijze de grotere betrokkenheid van de burger bij het vinden van de meest passende oplossingen voor eigen problemen het best gestalte kan krijgen. Voorop staat dat de burger alleen betrokken zal willen zijn als aan twee voorwaarden wordt voldaan: het moet gaan om een werkelijk probleem (of het voorkomen daarvan) en hij wil serieus genomen worden. Dat betekent aan de ene kant dat hij niet overal bij betrokken wil zijn. Mensen 'tippelen' niet op een 
betrokkenheid bij onderwerpen die nauwelijks op hun agenda staan en zijn op een gegeven moment ook uitgekeken op sociale activiteiten met een gezelschap dat hen weinig aanspreekt. Ook plichtmatige inspraak - zeven avondjes in het dorpshuis met achteraf een voedzame maaltijd voor het succesvolle begeleidingsteam, dat geen letter aan de voorstellen hoefde te veranderen - heeft in de confrontatie met de mondigere en moeilijkere burger zijn beste tijd gehad. Zij hebben te veel keus en zijn te druk om zich in te zetten als er niet op z'n minst naar hen wordt geluisterd. Aan de andere kant betekent het dat hun betrokkenheid wel degelijk inhoud kan krijgen op alle plaatsen waar burgers voorzien in hun behoeften - wonen, werken, leren, recreëren - en in wisselwerking met alle instanties, die daar een rol spelen. Bij elk van die omgevingen behoort een andere groep mensen die iets met elkaar hebben omdat via de weg van hun gezamenlijkheid 3E-oplossingen kunnen worden gevonden.

Hoe kan de burger worden 'verleid' tot een grotere democratische betrokkenheid? En welke steun in de rug kunnen verschillende overheidslagen, 'sociale spelers', maar ook private partijen daaraan geven? Uitgaande van de burger die zijn keuze al dan niet te participeren laat afhangen van zijn eigen agenda en de mogelijkheden zelf invloed uit te kunnen oefenen, concentreren wij ons op de directe leefomgeving van die burger: 'de buurt'. ${ }^{2}$ In de volgende tekst zullen wij, bouwend op de bevindingen van het onderhanden Buurtproject van de WRR, eerst aannemelijk maken dat de buurt in principe kan voldoen aan de twee gestelde voorwaarden voor een grotere betrokkenheid van de burger. Tegen deze achtergrond formuleren wij vervolgens twee voorstellen tot revitalisering van de lokale democratie, te weten een systeem van buurtrechten en een thematische lokale politiek. Zij verhouden zich als de schering en inslag van de textielweverij: de betrokkenheid van de burger wordt versterkt langs de geografische dimensie buurt, terwijl de (deel)gemeentelijke politiek zorgt voor de evenwichtige afweging van belangen door te kiezen voor een thematische inslag. Zeker in samenhang kunnen zij daardoor naar onze mening leiden tot een doorbraak bij het betrekken van de burger bij 'zijn' democratie.

\subsection{DE BUURT ALS NIEUWE LOCATIE VOOR DEMOCRATIE?}

De buurt doet ertoe. Dat blijkt uit het veldonderzoek dat de WRR verrichtte op 28 locaties in het land. Op ten minste vier wezenlijke terreinen heeft de buurt een meerwaarde voor bewoners en biedt daarom een handvat voor een grotere betrokkenheid van de burger. Indien structuren en processen kunnen worden gedefinieerd om die meerwaarde om te zetten in praktische beleidsmaatregelen, die voldoen aan de $3 \mathrm{E}$-criteria, openen zich nieuwe wegen naar een beter functionerende democratie.

In de eerste plaats betreft dat de kwaliteit van de fysieke inrichting. Op buurtniveau betreft dat aspecten als identiteit, bereikbaarheid en het gebruik van de openbare ruimte. Afstand en fysieke barrières bepalen veelal de contouren van de buurt. Een bijzonder gebouw of een kunstwerk fungeert als herkenningspunt; de 
eigen straat of het eigen parkje versterkt de hechting. En mensen komen in actie als fysieke ingrepen hun buurt bedreigen: zelfs yuppen zijn te 'boeien' door parkeerbeleid, autovrij- of eenrichtingsbeleid, horecaterrasjes en winkelstraten; en grootschalige fysieke ingrepen (bijv. metroaanleg) 'verenigen' buren.

Een buurt wordt niet alleen actief door een dergelijke 'negatieve' aandrijver. Aan de positieve kant bevorderen fysiek levendige buurten cohesie. Voorzieningen zoals een multifunctioneel schoolgebouw, een buurtcentrum, een speeltuin of openbaar groen bieden ruimte voor ontmoeting en ontplooiing. De buurt biedt ook een effectief aangrijpingspunt voor overheidsbeleid op sociaal gebied doordat de fysieke inrichting handvatten biedt voor betrokkenheid (zoals het beheer van openbaar groen) en door de fysieke zichtbaarheid van early wins (kleine, relatief gemakkelijk te realiseren resultaten, zoals het aanbrengen van verkeersdrempels) voor buurtbewoners. Dergelijke kleine interventies hebben een grote signaalfunctie: 'ze' nemen ons serieus.

Ook op het gebied van veiligheid heeft de buurt meerwaarde voor bewoners en overheid. We denken daarbij onder andere aan de aanpak van criminaliteit, overlast en vandalisme, aan 'Justitie in de buurt'3 en particuliere beveiliging. Een adequate verweving via buurtnetwerken vormt een belangrijke bron van een gevoel van veiligheid, meer nog dan blauw op straat of beveiliging per huis. In het kader van meer preventie is het noodzakelijk dat burgers ook hun eigen verantwoordelijkheid (meer) dragen. Politie en overheid kunnen die eigen verantwoordelijkheid in de rug steunen, niet door 'af te schuiven' naar de burger, maar door te laten zien wat ze zelf kunnen doen (dus geen substitutie van verantwoordelijkheid, maar complementariteit). Om hun verantwoordelijkheid te stimuleren en in de praktijk waar te maken moeten burgers ook worden voorzien van goede informatie. Convenanten van overheid, politie en de buurt aan de ene kant met sleutelspelers zoals horeca, winkels, scholen maar ook verzekeraars en particuliere beveiligingsdiensten aan de andere, kunnen bovendien bijdragen aan een daadwerkelijke verbetering van de veiligheid.

Minder voor de hand liggend maar van mogelijk groot belang is de wisselwerking van de buurt met het onderwijs, vooral indien hieronder wordt begrepen de integratie met opvoedingsondersteuning, kinderopvang- en vrijetijdsvoorzieningen in het kader van de zogenaamde 'brede school'. De motivatie van leerlingen en leraren is gediend met een sterkere ouderbetrokkenheid en een betere aansluiting op de samenleving, met inbegrip van andere spelers zoals politie, sportvereniging, enz. Dat betekent: geen gescheiden werelden voor en na school, en daarmee een betere overdracht van waarden en normen en de mogelijkheid tot community learning.

Met name het Vмво is gebaat bij stageplaatsen bij verenigingen, bedrijven, enz. in de buurt; scholen moeten 'voeten in de buurt' hebben en die buurt moet openstaan voor nauwere betrokkenheid bij de school. Ook nu biedt de buurt een aangrijpingspunt voor overheidsbeleid op het gebied van sociale betrokkenheid en integratie. Mensen zijn te motiveren tot samenwerking, de buurt ziet de 
school als de plaats waar 'onze kinderen' worden opgeleid: 'iedereen wil van nature het beste voor zijn kinderen'. Een spannend schoolgebouw (community center met veel voorzieningen) draagt bij aan buurttrots. Speciaal brede scholen bieden bovendien natuurlijke voordelen voor praktische beleidsuitvoering door hun mogelijkheden voor ontmoeting en differentiatie. Voor de ene buurt passen taallessen voor allochtonen of projecten voor tienermoeders goed in het aanbod; bij andere scholen in andere wijken wellicht computercursussen voor senioren, enzovoorts. Hoewel er pas rond de vijfhonderd van dergelijke scholen bestaan (Oberon 2003), zit het brede-schoolconcept steeds beter 'tussen de oren' van het ambtelijk apparaat. Ook buiten het onderwijsveld lopen overheidsprogramma's daarom relatief soepel via dit kanaal: het samenwerkingsverband dat zich rond de scholen gevormd heeft, biedt ook voor beleidsmakers uit andere sectoren handige aanknopingspunten. Omgekeerd bieden scholen, door hun wortels in de buurt, een goede informatiebron voor beleidsmakers. Ten slotte mag niet onvermeld blijven dat schooldirecteuren, die vaak tegelijk ook de oudste 'buurtnetwerkers' zijn, veelal bijzonder waardevol blijken door hun kennis van zaken en grote betrokkenheid.

Een goede buur is niet zonder reden beter dan een verre vriend. Het vierde beleidsterrein, waar de buurt een meerwaarde biedt voor bewoners, betreft daarom dat van de sociale infrastructuur. Hieronder verstaan we onder meer opbouw- en welzijnswerk, vrijwilligerswerk, integratie van migranten, omgaan met kwetsbare groepen en individuen, maar ook de gezelligheid en onderlinge opvang binnen een buurtje. Dagelijks sociaal contact via buurtnetwerken is een voorname bron van sociaal vertrouwen. Bij te hoge doorstroming verdwijnt het cement uit een buurt of komt het niet eens meer tot stand. Een eenzijdig woningbestand, vooral in achterstandsbuurten, maakt dat sociale stijgers, die als rolmodel kunnen functioneren, wegtrekken (bijvoorbeeld naar een Vinex-locatie) als ze daartoe de mogelijkheid krijgen.

Het beleid met betrekking tot de sociale infrastructuur is echter op veel punten onevenwichtig, waardoor het minder effectief is dan stellig mogelijk is. Het is bijvoorbeeld te eenzijdig gericht op achterstandwijken en 'knuffeldorpen' en te veel op de korte termijn, zonder breed gedeelde visie met een positieve boodschap gericht op betere kansen en een record van zichtbare successen. Elk (nieuw) gekozen bestuur neemt nieuwe initiatieven, die nauwelijks de kans krijgen om te beklijven. Die initiatieven lijden bovendien onder een overmatige verkokering en veel kleine en zeer fijngeregelde geldstromen van de rijksoverheid, met name op het terrein van welzijn. Preventief beleid is ook zeldzaam en kwetsbare individuen komen te weinig aan bod. Maar ongeacht deze manco's gebeurt er veel meer dan officieel bekend is door initiatieven van de al dan niet georganiseerde civil society.

De buurt doet ertoe, maar tegelijk is volstrekt duidelijk dat 'de' buurt niet bestaat. Buurten verschillen en een zinvolle aanpak vereist op elk van de genoemde terreinen differentiatie naar buurt, omdat zowel de behoeften van bewoners als 
de optimale wijze van wisselwerking verschillen. Bij de fysieke inrichting van een typische achterstandsbuurt ligt de nadruk veelal op huisvesting, reconstructie van centrale infrastructuur, onderhoud van openbare ruimte, recreatieve voorzieningen. In een middenstandsbuurt (met inbegrip van plattelandsdorpen) daarentegen gaat het meestal om de rust in de buurt en buurteigenheid (buurtcentrum, speeltuin, seniorenhuisvesting) en in een rijke voorstandsbuurt om groenbeheer, parkeerbeleid, terrasjes, winkelen, enz.

Op het punt van veiligheid dient de invulling uit te gaan van de kenmerken van de bewoners. In een achterstandsbuurt gaat het om lik-op-stukbeleid, dominante aanwezigheid van politie en justitie, persoonlijke kwaliteiten, de inzet van rolmodellen (meer allochtonen bij de politie) en afstemming met welzijns- en opbouwwerk en scholen. In middenstandsbuurten en dorpen ligt het accent op uitleggen en onderhandelen en betrokkenheid van ouders en andere opvoeders. Voorstandsbuurten zijn gebaat bij een meer individuele invulling, bijvoorbeeld particuliere buurtpreventie.

Bij het onderwijs moet worden ingespeeld op de behoeften van leerlingen met hun ouders en van buurtbewoners. In achterstandsbuurten gaat het om zaken als het beperken van de kans op schooluitval van kinderen (vooral bij schoolovergangen, onder andere door in te zetten op voorschool en ouderbetrokkenheid), stageplaatsen en taallessen voor allochtonen. In middenstandsbuurten en dorpen kan de school het kloppend hart vormen van de buurt, waar ook de buitenschoolse activiteiten (muziek, sport, computerlessen voor senioren) plaatsvinden. Dat laatste geldt ook in voorstandsbuurten, waar de buitenschoolse opvang echter ook een centralere plaats inneemt als werk- of privé-voorziening voor ouders.

Hoewel de beleidservaring vooral beperkt is tot achterstandsbuurten en dorpen, is de noodzaak tot differentiatie ten opzichte van midden- en voorstandsbuurten ook duidelijk waar het de sociale infrastructuur betreft. De bewoners van achterstandsbuurten hebben een sterke behoefte aan individuele begeleiding, wegwijzers en empowerment (het klassieke welzijns-/opbouwwerk); in dorpen speelt daarentegen vooral de ruimte en ondersteuning voor vrijwilligerswerk.

'Normale' regels, veelal ontworpen voor de grote aantallen burgers in middenstandsbuurten, werken soms niet; allochtonen in achterstandsbuurten zijn bijvoorbeeld veel meer gediend door een op hun eigen netwerken toegespitste aanpak (barefoot recruiting) dan door reguliere arbeidsbureaus en op het platteland gelden idealiter andere spelregels voor kinderopvang dan in de stad.

Het gaat het kader van dit essay te boven om alle - veelal aanmerkelijke - drempels voor verandering in kaart te brengen. Wel willen wij, als gedachte-experiment ter stimulering van het nadenken over de toekomst van onze democratie, een alternatief schetsen dat wellicht beter dan de bestaande benaderingen - meer ' $3 \mathrm{E}$ ' - tegemoetkomt aan de behoeften van de burger in zijn buurt. Op welke wijze kan de betrokkenheid van de burger in zijn buurt, van welke soort dan ook, worden gestimuleerd en verankerd? 


\subsection{EEN SYSTEEM VAN BUURTRECHTEN TER REVITALISERING VAN DE LOKALE DEMOCRATIE}

Voorop staat dat de burger wat te winnen moet hebben bij zijn betrokkenheid en/of wat te verliezen in het omgekeerde geval van niet-betrokkenheid. Als daarom niet het aanbod 'van bovenaf' maar veeleer de vraag 'van onderen af' leidend moet zijn, verdient het aanbeveling te denken in termen van vraagfinanciering zoals die ook in andere sectoren aan de orde is. In het onderwijs wordt bijvoorbeeld geëxperimenteerd met vouchers - vrij vertaald, studierechten die een student en/of zijn ouders de mogelijkheid bieden om een opleiding naar eigen keuze te selecteren. Na inlevering van de voucher kan de school deze vervolgens bij de overheid inwisselen tegen 'hard' geld.

In de gehandicaptenzorg wordt gewerkt met persoonsgebonden budgetten; ook hier gaat het om een recht om eigen invulling te geven aan de zorg. Op andere terreinen werden recentelijk nog verdergaande ideeën geopperd. Leijnse (2001) stelde bijvoorbeeld voor om, voortbouwend op de logica van het huidige pensioensysteem, een nieuw sociaal contract in te voeren, dat zich uitstrekt van loonderving bij inactiviteit en (zorg)verlof tot de financiering van scholing, zorg en vormen van persoonlijke dienstverlening. Dit nieuwe contract kent drie pijlers. De eerste daarvan biedt een minimumdekking; de kosten worden opgebracht door alle verzekerden en de overheid waakt over de - deels private - uitvoering. De tweede pijler gaat uit van collectieve spaarvormen op CAO-niveau, waarin individuele (kapitaal)rechten worden opgebouwd: individueel sparen in een collectief contract dus. Het sociaal contract wordt afgerond met spaar- of verzekeringsvormen die volledig door het individu zelf worden gekozen.

Ons voorstel voor het stimuleren en verankeren van buurtbetrokkenheid sluit aan bij de principes van de drielaagsfinanciering van Leijnse, zoals dat ook in de gezondheidszorgverzekering aan de orde is. We maken daarbij onderscheid tussen (a) een basispakket voorzieningen, (b) een collectief pakket per sector, in ons voorstel betekent dat: per buurt; en (c) een individueel pakket per huishouden. De overheid geeft elke burger een aantal - bij gebrek aan een beter woord buurtrechten. Een deel daarvan wordt - ten behoeve van het basispakket - direct doorgesluisd naar de uitvoeringsinstanties binnen de betrokken (deel)gemeente. Daarbij worden de rechten gewogen afhankelijk van de vigerende problematiek (onveiligheid, werkloosheid, bevolkingssamenstelling, enz.), zoals dat nu al het geval is bijvoorbeeld met de financiering van achterstandsscholen. Een tweede deel van de per persoon beschikbare rechten mag door de burger worden toegewezen ten behoeve van het collectieve pakket van zijn buurt aan dienstenaanbieders in zijn buurt, die de verdiende rechten in contant geld kunnen omzetten bij de overheid. En het laatste deel is vrij beschikbaar voor de burger om te betalen voor die voorzieningen die hij het meest zinvol acht - het individuele pakket.

Laten wij ons idee illustreren aan de hand van de veiligheid binnen een buurt. Het basispakket wordt exclusief aangeboden door de politie en is niet onderhan- 
delbaar. Het collectieve buurtpakket wordt echter vormgegeven door de wisselwerking van 'buren': zij kiezen bij de toewijzing van hun rechten bijvoorbeeld voor extra patrouilles op straat en kopen die dienstverlening in bij de politie of particuliere beveiligingsdiensten, maar kunnen ook besluiten het deels zelf te doen in de vorm van al dan niet betaalde buurtwachten. De individuele rechten kunnen worden besteed aan veiligheidsvoorzieningen in eigen huis, maar desgewenst ook in overleg met buren worden toegewezen aan de collectieve pot. De buurt, en elke burger daarbinnen, moet echter ook afwegingen maken tussen sectoren. Dezelfde buurtrechten kunnen immers ook worden ingezet voor de fysieke inrichting van (bijvoorbeeld aanleg en onderhoud van trapveldjes, speeltuinen, openbaar groen of kunst-op-straat) en het onderwijs en de sociale infrastructuur (bijvoorbeeld opbouwwerk, jeugdhonk of buurtbarbecue) in de buurt. Ook op deze terreinen is sprake van een basispakket, een buurtpot en een individueel besteedbare ruimte.

Naast de overheid zijn ook hoofdrollen weggelegd voor sociale spelers zoals wooncorporaties en zorginstellingen. Het verdient tegen die achtergrond aanbeveling te kiezen voor een tripartiete financiering, waarbij het ontwerp voor een nieuwe Wet basisvoorziening kinderopvang (Wbk) als voorbeeld kan dienen. De regering verwacht een beter passend aanbod van kinderopvang te kunnen realiseren door de financiering volledig via de ouders te laten lopen en beoogt de lasten daarvan te verdelen over drie partijen: ouders, werkgevers en de overheid. Ouders dienen een voor hen overbrugbaar doch aanmerkelijk deel aan de opvang van hun kinderen bij te dragen. Alleen zo kiezen zij zeer bewust voor een bepaalde zorgaanbieder. De ouderbijdrage is daarom inkomensafhankelijk: eenieder moet 'echte' afwegingen maken. Werkgevers dragen op vrijwillige basis een vast bedrag bij voor de opvang van de kinderen van hun werknemers. De hoogte van dit bedrag wordt vastgesteld in het kader van de CAO-onderhandelingen.

Als derde financier fungeert de overheid - in zekere zin als sluitpost. Via bijvoorbeeld de belastingdienst kan het ontbrekende deel worden bijgepast.

Stel dat deze gedachtelijn wordt doorgetrokken naar de buurt en ook wooncorporaties, zorginstellingen en werkgevers investeren in speciaal de collectieve pot. Dat kan gebeuren via directe bijdragen - wooncorporaties hebben bijvoorbeeld een belang bij een veiligere en schonere buurt met goed ontwikkelde sociale banden omdat het de waarde van hun bezit verhoogt; en goede werkgevers weten dat adequate kinderopvang in het kader van brede scholen in hun eigen belang is. Plaatselijke werkgevers sponsoren nu al vaak 'hun' buurtverenigingen. Een hechte band met het bedrijfsleven is echter niet alleen van financieel belang: tegelijkertijd kunnen de collectieve en individuele potten worden gevuld door betalingen voor verleende diensten of bespaarde kosten in de vorm van buurtrechten. Waarom zou de politie niet betalen aan particuliere beveiligingsdiensten of buurtwachten die de uitvoering van een deel van het basispakket - denk bijvoorbeeld aan surveillance - kunnen overnemen? Waarom zouden corporaties niet rechten uitgeven aan bewoners(verenigingen) die zelf een wezenlijk deel van het onderhoud voor hun rekening nemen? In feite doet een aantal corporaties dit 
al met behulp van het uit Engeland overgewaaide Gold Service-puntensysteem, waarmee corporaties inspanningen van bewoners belonen in de vorm van extra service of andere voordelen. Waarom zouden zorginstellingen op het terrein van de thuiszorg niet een vergoeding geven voor de vrijwilligersinzet en waarom betalen verzekeraars niet een extra premie aan buurten die de veiligheid verbeteren of zodanige werk-/privé-voorzieningen tot stand brengen dat het ziekteverzuim van ouders terugloopt? En, nog een slag verder, waarom zouden buren niet elkaar compenseren voor 'klussen'? Ook hier bestaan al voorbeelden van: het concept LETS (Local Exchange Trading Systems): ruilkringen in diverse steden waarbinnen de leden klusjes en diensten onderling uitwisselen via een puntensysteem; en het Friese Te Plak: een organisatie die vanuit het dorpshuis vraag en aanbod van diensten van en voor dorpsbewoners coördineert. Het blijft een curieus fenomeen: oversteek- en voorleesmoeders die zich inzetten ten behoeve van het kroost van meer verdienende free riders.

Het gaat erom dat mensen worden gestimuleerd om - in welke vorm dan ook buurtverbanden te vormen die de sociale samenhang versterken en die daarmee fijnmaziger en dus effectiever en efficiënter een verwerkelijking van de democratische doelstellingen mogelijk maken. Buurtbeleid is immers ook een procesbeleid, erop gericht dat mensen dingen met elkaar doen. Zelfs als die activiteiten geen directe output hebben (het wordt niet meetbaar veiliger of kinderen scoren niet hoger bij de CITO-toets), kunnen ze bijdragen aan een grotere sociale cohesie en - omdat overheden en sociale spelers 'de burger' serieus nemen - een groter politiek vertrouwen. Het proces is in die zin zowel middel als doel.

Vele prikkels zijn denkbaar. De overheid zou het verrichten van vrijwilligerswerk in de informele omgeving kunnen stimuleren. Bijvoorbeeld door een werknemer vijf à zes dagen per jaar de tijd te geven om zich maatschappelijk in te zetten, voor zaken van de gemeenschap, in het buurtcentrum of in de brede school. In de Amerikaanse staat North Carolina wordt een dergelijke inzet zelfs afgedwongen: ouders hebben niet het recht maar de plicht om aanwezig te zijn bij schoolse activiteiten. Een sterke prikkel kan ook worden gegeven door ieder verdiend buurtrecht met een toeslag te verhogen.

Is het allemaal nieuw wat wij voorstellen? Nee, wij wezen reeds op vergelijkbare initiatieven met betrekking tot vraagfinanciering en een tripartiete vulling van fondsen. Veel gemeenten werken ook nu al met wijkbudgetten die de buurt ruimte bieden voor het stellen van eigen prioriteiten. Een aantal koplopers onder de wooncorporaties en zorginstellingen experimenteert binnen de buurt om inhoud te geven aan de reeds nu voorgeschreven sociale taakstellingen. Verzekeraars verlagen al hun premie indien een huis goed is beveiligd en buren wisselen al diensten uit langs min of meer geformaliseerde wegen. Uit ons onderzoek blijkt echter tegelijk dat dergelijke initiatieven vaak klein en kwetsbaar zijn. Zij zijn veelal ook te nauw gericht op de fysieke inrichting en - soms - de sociale infrastructuur; die laatste is echter vrijwel onveranderlijk gehandicapt door een overmatige verkokering en een te geringe continuïteit. Er zijn daarom te weinig 
prikkels om buren structureel tot samenwerking te brengen en op die wijze serieuze problemen daadwerkelijk op te lossen: de buurt doet er weliswaar toe, maar we doen er als maatschappij te weinig mee. De mogelijke voordelen van een grotere betrokkenheid van bewoners bij hun buurt zijn evident, maar de structurele verankering en de democratische vormgeving daarvan roept vragen op. Tegen die achtergrond introduceren we hieronder een beter bij de belevingswereld van de burger aansluitend kiesstelsel voor de lokale democratie.

\subsection{EEN THEMATISCHE LOKALE POLITIEK TER REVITALISERING VAN DE LOKALE DEMOCRATIE}

Politieke en ambtelijke beleidsmakers - in onze definitie de overheid - zijn veelal huiverig ten aanzien van overmatige vrijheden voor de buurt; hun organisaties zijn vaak gericht op het instandhouden van de bestaande orde (ambtelijk apparaat, bewonersorganisaties, sociale spelers, regelgeving). De taakstelling van het voorgestelde buurtbeleid is dan ook complex: het te voeren beleid moet (a) gedifferentieerd, (b) niet-verkokerd, en (c) terughoudend zijn door het bewaren van een gepaste afstand en ruimte te laten voor de burger en zijn buurt. Daarbij speelt terecht de vraag of de 'winst' in termen van Effectiviteit, Efficiëntie en Eerlijkheid voldoende is voor het overhoop halen van de bestaande instituties. Hoe kan bijvoorbeeld een mogelijk ongelijke behandeling van buurten ('koplopers halen de hele kas leeg') worden voorkomen, en wat is de juiste afstand tot de buurt (politiek in of uit de buurt?)?

Juist het formuleren van een passend antwoord op deze laatste twee vraagpunten duidt op mogelijk ingrijpende aanpassingen van de bestuurlijke cultuur van gemeenten waarbij een hoofdrol is weggelegd voor de politiek: colleges van B en $\mathrm{W}$ en de (deel)gemeenteraad. Er moeten immers wezenlijke politieke keuzen worden gemaakt. Welk basispakket is wenselijk? Hoe verschilt dat per buurt? Hoeveel basisrechten en misschien zelfs collectieve en individuele rechten moeten worden verstrekt? Hoe kunnen buurtverbanden scherp worden gehouden? Het heeft immers weinig maatschappelijk voordeel om slapende gezelschappen rijkelijk van geldelijke middelen te voorzien; een vorm van concurrentie is daarom zinvol. Moeten buurtgemeenschappen die er bijvoorbeeld in slagen om de informele zorgvoorzieningen op een hoger niveau te krijgen, meer subsidie ontvangen? De (deel)gemeente beoordeelt dan jaarlijks de kwaliteit en kwantiteit van de geleverde prestaties en geeft de buurt die het beste resultaat en/of de grootste verbetering heeft laten zien, een bonus en de achterblijvers een malus. De antwoorden op dergelijke vragen mogen niet overmatig bepaald worden door cliëntelisme (het eenzijdig voortrekken van de eigen buurt), door koehandel ('als jij mijn buurt steunt op dit punt, steun ik jouw buurt op het andere') of door groot-tegen-klein. De ruimtelijke ordening en de woningbouw - kleine wijzigingen van bestemmings- of streekplannen - leveren bijvoorbeeld te veel illustraties van een te enge belangenbehartiging. 
Het gaat in de buurt om zaken als een veilige, schone leefomgeving met goed onderwijs en waar nodig een effectieve sociale opvang, en dat zijn dan ook de onderwerpen waar de lokale politiek zich mee bezig moet houden. Haagse politiek speelt daarbij in de perceptie van de bewoners een ondergeschikte rol, getuige ook de opkomst van gemeentelijke lijsten de laatste jaren. Er zou daarom een eenduidige spelregel dienen te gelden: in de buurt geen partijpolitiek (zie ook Winsemius en Haverhals 2003). De politiek moet veeleer de afstand bewaren die het overzicht mogelijk maakt om afwegingen te kunnen maken. Zich dus niet laten inzuigen in een buurt maar zorg dragen dat alle buurten, en speciaal die met problemen, op een evenwichtige wijze de vereiste aandacht krijgen. Bewoners krijgen weliswaar meer ruimte om zelf hun buurt in te kleuren, maar de politiek waarborgt dat zwakke belangen worden beschermd of dat maatschappelijke kansen worden benut.

De toewijzing van buurtrechten door de burgers zelf biedt in dit verband een aanmerkelijk voordeel. In ons veldonderzoek bleek steeds weer dat het begrip buurt voor eenieder sterk verschillende betekenis heeft. De buurtbeleving in een traditioneel buurtje met wat oudere bewoners wordt bijvoorbeeld in hoge mate bepaald door de naaste omgeving - zeg een afstand van een paar honderd meter. Jonge, hoogopgeleide mensen definiëren hun buurt echter veelal als een soort netwerk met hun eigen huis als kern en daaromheen op enige afstand sociale knooppunten: kroegen of bistro's, voetbalveldjes in stadsparken, enzovoorts. Hun werk, vaak verder weg, vormt een tweede thuisbasis. Door de allocatie van buurtrechten kan eenieder invulling geven aan de 'eigen' buurt. De overlap daarvan met de top-down-indeling in wijken is daarbij vaak min of meer toevallig. Wijken zijn voor de traditioneel ingestelde burger te groot en voor yuppen juist weer te klein.

Een wijkenstelsel voor de verkiezing van de gemeente(deel)raad, vergelijkbaar met het door minister De Graaf voorgestelde districtenstelsel in de nationale politiek, werkt daarom waarschijnlijk contraproductief. Het risico van een enge belangenbehartiging en een onvoldoende afweging is te groot. Veeleer verdient het aanbeveling te kiezen voor een themastelsel, waarbij politieke partijen zich bij de gemeenteraadsverkiezingen profileren op de voor de inwoners meest belangrijke thema's. Dat zijn bijna onveranderlijk thema's met aangrijpingspunten in de buurt. Politici kunnen dan per thema duidelijk maken welke politieke prioriteiten zij willen stellen bij het maken van hun afwegingen over de inzet van de beschikbare middelen en hoe zij zich voorstellen de afwegingen tussen de verschillende thema's en de verschillende buurten binnen hun (deel)gemeente te maken. Zij dienen daartoe hun visie en uitgangspunten voor de komende jaren te verhelderen door een programma op hoofdpunten te presenteren, maar meer dan tevoren wil de burger actief meebepalen welke richting 'we' uitgaan; wij wezen daar eerder op.

Traditioneel bepalen politieke partijen wat er leeft onder hun potentiële stemmers door middel van enquêtes. Dergelijke opiniepeilingen missen echter vaak 
de verdieping van het maatschappelijk debat. De burger wordt ook niet gedwongen echte prioriteiten te stellen. Niet zonder reden zei een wethouder tegen ons: "Als hondenpoep het grootste probleem is, gaat het natuurlijk prima met een wijk." Het zou een bijzondere stap vooruit zijn indien de kiezer bepaalt welke thema's gedurende een bepaalde periode - zeg: de zittingsduur van een college aan bod moeten komen. Bijvoorbeeld door een stemming een halfjaar voor de 'echte' gemeenteraadsverkiezingen. Politieke partijen en belangengroepen zouden hun onderwerp op een groslijst kunnen plaatsen, waar de burgers er een beperkt aantal - zeg: vijf - uit zouden kunnen selecteren. Zo'n verkiezing van gemeentelijke thema's zou in de grote steden op dit moment stellig het onderwerp multiculturaliteit of integratie hoog op de agenda zetten, terwijl op het platteland wellicht het openbaar vervoer en het behoud van infrastructuur - scholen, winkels, dorpshuizen - naar voren komen. De differentiatie naar gemeente is daarmee een feit.

Een dergelijke aanpak op grond van thema's zou andere rolpatronen vereisen. In de aanloop naar de themaverkiezingen zullen de politieke partijen zich moeten richten op hun beoogde kiezers en die voorlichten over wat nu een christendemocratisch standpunt onderscheidt van een liberale of socialistische keuze. Als de thema's eenmaal gekozen zijn, begint het echter pas. Hun kandidaten moeten zich nu profileren op de prioriteiten die door de burger zijn aangewezen. Hun wordt gevraagd heel concreet aan te geven welke doelstellingen zij in de aanstaande collegeperiode willen realiseren of wat zij op die punten ten hevigste zullen bestrijden. Media en belangenorganisaties zullen de kiezer stellig door vergelijkend onderzoek voorlichten. De debatten spitsen zich, behalve op de personen, ook toe op de inhoud van de thema's. Omdat de burger eerder al betrokken was bij het vaststellen van de thema's, is hij beter in staat en meer geïnteresseerd in het volgen van die debatten.

Na de verkiezingen wordt mede op basis van de gekozen thema's per (deel)gemeente een bestuursakkoord-op-hoofdlijnen opgesteld. We zouden daarbij kunnen opteren voor de traditionele benadering waarbij de beoogde coalitiepartijen dat bestuursakkoord overeenkomen en waarbij daarna het bijbehorende college wordt samengesteld. Daarmee wordt ook het draagvlak in de raad gewaarborgd. Het kan ook anders, bijvoorbeeld door eerst een college samen te stellen dat daarna, uitgaande van de gekozen thema's, een bestuursakkoord overeenkomt waarmee de raad weer moet instemmen. Het - belangrijke - voordeel is duidelijk: voorop staat de formatie van een 'team' van gekwalificeerde mensen die zich verantwoordelijk achten voor hún actieprogramma. Maar we kunnen ons - nog een slag verder - ook voorstellen dat de burgemeester in zijn eentje het voortouw neemt bij het opstellen van een bestuursprogramma en dat ook aan de raad voorlegt. Uit de loop van het debat concludeert hij op welke steun hij daarvoor kan rekenen. Op basis daarvan kan hij dan een college formeren van mensen die zich kunnen vinden in dit programma. Weer moet de raad instemmen met de voorgedragen wethouders. 
Welke keus ook gemaakt wordt, het vervolg zou hetzelfde zijn. Elke wethouder krijgt een thema toegewezen, dat hij concretiseert in een werkprogramma voor de komende vier jaar waarin duidelijk is aangegeven wat de resultaten zijn die hij wil bereiken. De voordelen van zo'n aanpak zijn aanzienlijk. Maatschappelijke en sociale problemen worden integraal en onafhankelijk van ambtelijke kokers aangepakt en opgelost. De politiek heeft ook in de verkiezingstijd spannende onderwerpen - niet alleen 'poppetjes' - om over te praten. Partijen moeten ons als kiezer immers verleiden om hun prioriteiten (in de voorronde) en hun beleidsvoorstellen daarover (bij de 'echte' verkiezingen) de voorkeur te geven. De burger heeft ook een zware stem in de vorming van een bestuursakkoord, dat daarmee uit het schemerduister van de politieke achterkamers wordt getrokken. En ten slotte, omdat het college wordt beoordeeld op de realisatie van het bestuursakkoord, kunnen wethouders concreter op resultaten worden aangesproken.

De politieke aansturing op basis van maatschappelijke thema's werkt ongetwijfeld ook door in de inrichting van het ambtelijk apparaat. Er kan bijvoorbeeld worden gedacht aan het zogenaamde kantelen van de organisatie, zoals dat reeds in een aantal gemeenten vorm krijgt. In plaats van de nu dominerende verticale dimensie van functionele vaardigheden en sectorgerichte afdelingen wordt gekozen voor een horizontale dimensie van beleidsthema's die over verschillende afdelingen heen grijpen. Dat ontwricht veel van de verworvenheden van de huidige ambtelijke organisatie. De geborgenheid van de eigen afdeling vervalt en daarvoor in de plaats komt de onrust van de tijdelijkheid van grote thema's, die immers per collegeperiode kunnen veranderen. Zo'n kanteling veroorzaakt, net als departementale herindelingen in Den Haag, daarom veel onrust.

Hoewel er nadrukkelijke voordelen aan zijn verbonden, zoals ook de prikkelende uitdaging van een themagerichte organisatie voor jong talent, menen wij dat de wenselijke verandering in hoge mate kan worden gerealiseerd via de weg van de geleidelijkheid. Indien de thematische aansturing vanuit het college gedurende een langere periode succesvol inhoud krijgt, ontstaan vanzelf nieuwe ambtelijke samenwerkingsverbanden die doorslaggevender zullen blijken dan de bestaande formele organisatiestructuren. Daarmee - en dat is een wezenlijk voordeel van ons voorstel - wordt op een natuurlijke wijze toe gegroeid naar een minder verkokerde overheid.

Belangrijker echter is de aanpassing van het gemeentelijke kiesstelsel. Het belang van door de burger zelf gekozen thema's zou idealiter ook van invloed zijn op de samenstelling van de (deel)raad, die gebaat is bij inhoudelijk deskundige leden per thema. Net als in het door minister De Graaf voorgestane nationale districtenstelsel zou in een themastelsel daarom sprake kunnen zijn van een mix van traditionele volksvertegenwoordigers en zogenaamde thematische raadsleden, die worden gekozen op basis van hun visie en kennis over de geselecteerde thema's. Bij verkiezingen stemt de burger daartoe op twee kandidaten, een 'algemene' en een thematische. De afstand tussen burger en politiek wordt zo sterk verkleind. 


\subsection{CONCLUSIE}

In het voorgaande hebben we geillustreerd dat de buurt handvatten biedt om de democratische betrokkenheid van de burger te vergroten. Er zijn immers minstens op de vier genoemde terreinen - fysieke infrastructuur, veiligheid, onderwijs en sociale veiligheid - voldoende redenen voor hem om betrokken te willen zijn. Daarmee is voldaan aan de eerste voorwaarde voor betrokkenheid: het systeem van buurtrechten mobiliseert de betrokkenheid van de burger omdat het gaat om voor hem wezenlijke problemen. Het systeem voldoet bovendien aan de tweede voorwaarde: het vergroot de mogelijkheden van de burger om daadwerkelijk invloed uit te oefenen. Het voorgestelde themastelsel maakt vervolgens de vergrote buurtbetrokkenheid te gelde als democratische betrokkenheid op buurtoverstijgend - namelijk gemeentelijk - niveau met als positief neveneffect een minder verkokerd werkende overheid.

Zijn onze voorstellen ook in de praktijk haalbaar? Willen burgers bijvoorbeeld meewerken? Het inzetten van buurtrechten gebeurt immers op basis van vrijwilligheid - een buurtbewoner kan zonder sancties afzien van het inzetten van zijn buurtrechten, maar laat daarmee wel een belangrijke mogelijkheid tot concrete betrokkenheid en invloed liggen. Het systeem van buurtrechten is in zekere zin zelfcorrigerend. Indien namelijk geen samenhangend buurtinitiatief wordt ontwikkeld, ontstaat vanzelf onderuitputting van de collectieve buurtpot. De rechten worden dan wegens wanprestatie gekort. Daardoor is de buurt echter minder toegerust op het oplossen van problemen, dus de waarde van de huizen en het leefplezier van de bewoners is geringer. Dat levert een prikkel om elkaar te zoeken of, als dat niet wil lukken, om te verhuizen. De overgang naar het nieuwe systeem kan bovendien plaatsvinden langs de weg van de geleidelijkheid. De afbouw van het pakket basisvoorzieningen en de gelijktijdige overheveling van bijdragen van overheid en sociale spelers naar de collectieve en individuele potjes kan stap voor stap over een periode van meerdere jaren geschieden. Bij falen van een buurtontwikkeling kan zelfs worden besloten het verplichte basispakket uit te breiden en de financiering via het collectieve potje terug te draaien. Al doende kan dus worden geleerd uit de praktijkervaring en het beleid zo nodig worden bijgesteld.

Desalniettemin heeft het voorstel vele haken en ogen, bijvoorbeeld met betrekking tot de rol van de buurttrekkers die, eenmaal in positie, veelal buitengewoon zetelvast blijken te zijn. Stellig moeten buurtorganisaties gebonden zijn aan een aantal spelregels, die opvolging van bestuurders, toegankelijkheid voor alle bewoners, toezicht op uitvoering en boekhouding, enz. bepalen zoals dat nu al geldt voor gesubsidieerde instellingen. Er is ook goede informatie vereist met betrekking tot de kwaliteit van het dienstenaanbod op het gebied van veiligheid, onderwijs en sociale infrastructuur en over de meting van resultaten. Niet alleen in achterstandsbuurten bestaat bovendien behoefte aan professionele begeleiders - zeg maar: makelaars - die vraag en aanbod bij elkaar kunnen brengen, de noodzakelijke samenwerkingsverbanden kunnen smeden en bovendien de weg weten 
binnen de overheidsburelen. Dat zijn in zekere zin technische problemen: belangrijk maar - dat laat ons buurtonderzoek zien - met goede wil oplosbaar. Het systeem moet daarnaast zo eenvoudig mogelijk blijven, niet alleen om transparant en begrijpbaar te blijven voor de gebruikers, maar ook om niet onnodig in bureaucratie te verzanden. De vrees voor een enorme bureaucratie lijkt overigens ongegrond. De allocatie van buurtrechten kan geschieden met behulp van ICT; geldstromen naar decentrale initiatieven - denk aan een buurtschool of een kinderopvang - moeten ook op dit moment worden verantwoord.

De hamvraag blijft: biedt het voorstel een uitzicht op betere $3 \mathrm{E}-\mathrm{oplossingen?}$ Eerder legden wij een grote nadruk op het door de burger kiezen van prioriteitsthema's. Burgers, actief betrokken door bevlogen politieke voorlieden en voorgelicht door maatschappelijke organisaties en de media, weten zelf immers het beste welke maatschappelijke vraagstukken om een oplossing vragen. Daarbij hoort een grotere rol van maatschappelijke organisaties, dat wil zeggen: die belangengroepen die democratisch gelegitimeerd zijn via andere dan de traditionele wegen. Met de sociale spelers en ook private partijen zoals ondernemingen moeten kaderafspraken worden gemaakt, op basis waarvan zij een veel grotere uitvoerende verantwoordelijkheid kunnen krijgen. Een kleinere overheid concentreert zich op de basisvoorzieningen. Daarboven is bij de besteding van speciaal het collectieve potje het machtsevenwicht verbeterd: een grotere concentratie van vragers is beter dan nu het geval is in staat in de wisselwerking met een kleinere concentratie van aanbieders invulling te geven aan de gedeelde behoeften op buurtniveau.

Voorop staat echter dat de burger - niet alleen de sprekende minderheid van voorlieden in buurten en binnen de kaders van de politieke en maatschappelijke elite - meer rechten verkrijgt en daarmee onlosmakelijk verbonden meer plichten. Hij wordt ook geprikkeld om aan die grotere zelfverantwoordelijkheid inhoud te geven, waarbij de efficiëntie wordt bevorderd doordat er veel te besparen is of vrij te maken door 'zelf doen'. Wij bewegen ons daarmee in de richting van een veel meer participatieve democratie. De gewijzigde rol van de volksvertegenwoordiging is alleszins aanvaardbaar onder voorwaarde dat het bevoegde college verantwoording aflegt voor de kwaliteit van de processen waarbinnen de participatie tot stand komt. Juist die betrokkenheid van velen kan dan bijdragen tot betere $3 \mathrm{E}$-oplossingen voor wezenlijke maatschappelijke vraagstukken. Effectiever door het bredere draagvlak en het denkvermogen van miljoenen burgers. Efficiënter door de financiële prikkels voor zelfverantwoordelijkheid van de burger, evenwichtigere machtsverhoudingen tussen vragers en aanbieders en een resultaatgerichte overheid. En bij een goede uitwerking ook Eerlijker, omdat op basis van afweging door meer inhoudelijk gemotiveerde colleges en meer deskundige (deel)raden evenwichtigere beleidsbeslissingen worden genomen.

En het aardige is dat het voorstel, met uitzondering van dat deel waarvoor een wijziging van het kiesstelsel nodig is, morgen al in de praktijk kan worden gebracht. 


\section{NOTEN}

$1 \quad$ Het begrip 'sociale spelers' zoals in deze tekst gehanteerd, dekt een scala van uitvoeringsinstanties binnen de overheid of met een sterk overheidsaccent (bijvoorbeeld via de financiering), zoals welzijns- en opbouwwerk, politie, scholen en wooncorporaties. Waar wordt gesproken over gemeente of overheid wordt in het algemeen gedoeld op de politieke en ambtelijke beleidsmakers daarbinnen.

2 Het begrip 'buurt' gaat uit van de beleving van burgers. Het gaat om wat mensen op kleinschalige niveaus beweegt om zelf mee te doen aan de aanpak van leefbaarheidsproblemen waarmee ze te maken hebben. Wijken daarentegen zijn in het algemeen administratieve eenheden, vanuit de (gemeentelijke) overheid gedefinieerd. Over de vraag in welke wijk je je bevindt, valt niet te twisten 'buurt' is daarentegen een subjectief begrip.

3 Samenwerking van justitiële organisaties met andere partners op buurt- of wijkniveau. 


\section{LITERATUUR}

Asseldonk, T.G.M. van (1998) Mass Individualisation: Business strategies applying networked order to create economic value in heterogeneous and unpredictable markets, Veldhoven: TVA management bv.

Brink, G. van den (2002) Mondiger of moeilijker? Een studie naar de politieke habitus van hedendaagse burgers, WRR Voorstudies en Achtergronden V115, Den Haag: Sdu Uitgevers.

Leijnse, F. (2001) 'Het nieuwe werken' in P. Winsemius, L. van Driel, F. Leijnse en K. Vuursteen Naar een nieuwe maatschap, Den Haag: Ministerie van Economische Zaken: 94 e.v.

Oberon (2003) Brede Scholen in Nederland, Jaarbericht 2003 (i.o.v. vws, OCw, szw en VNG).

Winsemius, P. en A. Haverhals (red.) (2003) De Publieke Zaak in de r1e eeuw: een zaak van respect en bezieling, Amsterdam: De Publieke Zaak. 


\title{
3 VERANDEREND POLITIEK BURGERSCHAP EN DEMOCRATIE
}

\author{
I. Verhoeven
}

\subsection{INLEIDING ${ }^{1}$}

De moderne democratische orde zoals wij die kennen is gegrondvest op twee centrale instituties: politiek burgerschap en de publieke sfeer of, zo men wil, politieke betrokkenheid en participatie binnen een ruimte voor publieke contestatie (Foweraker en Landman² 1997: 9; Eder 2000: 214). Politiek burgerschap wordt gegarandeerd door politieke rechten die aan burgers de mogelijkheid bieden om als kiezer of via collectieve actie de beleidsvorming en de prestaties in de beleidsuitvoering te beïnvloeden. Alle vormen van beïnvloeding zijn idealiter gesitueerd in de publieke sfeer, die fungeert als een arena voor meningsvorming, interpretatie, betekenisgeving, onderhandeling en contestatie van politiek-bestuurlijke processen (Eder 2000: 214).

De vraag is in hoeverre burgers de mogelijkheden tot beïnvloeding van politiek en bestuur benutten. Anders gezegd, hoe actief betreden burgers de publieke arena om politieke invloed uit te oefenen? Op deze vraag zijn meerdere antwoorden mogelijk die sterk beïnvloed worden door de theoretische focus op wat wel en niet geldt als betekenisvolle vormen van politiek burgerschap. Volgens Ferree et al. (20O2) zijn hierover in democratietheorieën vier posities te onderscheiden:

I De eerste positie omvat klassiek-liberale opvattingen over representatieve democratie, waarbij de aandacht zich vooral richt op de politieke participatie van burgers via verkiezingen. Politiek burgerschap is in deze opvattingen betekenisvol als burgers de strijd tussen de politieke elites in de publieke sfeer volgen en periodiek hun rol als kiezer vervullen. Deze opvattingen kenmerken zich door lage verwachtingen van de politieke betrokkenheid en participatie van burgers.

2 De tweede positie omvat verdergaande liberale opvattingen over participatie waarbij burgers niet alleen als kiezer, maar ook via politieke partijen en vakbonden het politiek-bestuurlijke systeem beïnvloeden. Deze opvattingen vragen meer politieke betrokkenheid en participatie van burgers, maar dan wel indirect via deelname aan de daartoe geëigende organisaties.

3 De derde positie omvat op Habermas geïnspireerde opvattingen van deliberatieve democratie. Vanuit deze positie worden betrokkenheid en participatie via organisaties bij beleidsvorming en -uitvoering als betekenisvolle vormen van politiek burgerschap gezien. Het verschil met liberaal-participatieve opvattingen is dat het hier dient te gaan om grassroots organisaties. Deliberatieve opvattingen vragen niet alleen betrokkenheid en participatie van georganiseerde burgers, maar stellen ook kwaliteitseisen aan betekenisvolle deelname. Argumentatie en consensusvorming staan daarbij centraal. 
4 De vierde positie omvat constructivistische opvattingen van democratie, die de notie van een duidelijk afgebakende publieke sfeer afwijzen. De theoretische claim hierachter is dat politiek als vorm van machtsuitoefening alom aanwezig is. Dit verschaft burgers de mogelijkheid om vanuit hun ervaringskennis de 'verhalen' of discourses van degenen die macht uitoefenen te beïnvloeden. Deze beïnvloeding kan zich zowel richten op de beleidsvorming als op de prestaties in de beleidsuitvoering. Communicatie geldt hierbij als een belangrijk middel voor het bereiken van consensus. Het gaat echter om een onvoorwaardelijke vorm van communicatie, die vrij is van beperkingen op deelname, gelijkheid en rechtvaardigheid. Hierbij dient men het verschil met de standpunten van andere actoren te (h)erkennen, zonder dat men de betekenissen van die standpunten hoeft te delen.

Vooral de liberaal-representatieve en de liberaal-participatieve posities domineren de percepties die wetenschappers en beleidsmakers hebben van betekenisvol politiek burgerschap. Dit kan worden geillustreerd met twee voorbeelden: de populariteit van de metafoor van de 'toeschouwersdemocratie' en de visie van het kabinet-Balkenende II op betekenisvol burgerschap.

Een vrij passieve interpretatie van politiek burgerschap is in Nederland geïntroduceerd door Jos de Beus, die de huidige politieke structuur en cultuur typeert met de term toeschouwersdemocratie. De Beus schetst de veranderende rol van politieke leiders en hun adviseurs, die zich richten op het overtuigen van kiezers en op het bespelen van de media om dat doel te bereiken. In reactie hierop is de burger volgens De Beus een toeschouwer geworden die vanuit een vrij onderkoelde rationele levenshouding de politieke strijd tussen de partijleiders vanaf de zijlijn volgt, die praat over politiek, zijn stem uitbrengt en die periodiek boegeroep, applaus of stilzwijgen voortbrengt (De Beus 2000, 2001, 2002). De combinatie van passiviteit en rationaliteit die De Beus suggereert, doet vermoeden dat moderne burgers vrijwel niet meer voor politieke handelingen uit de leunstoel komen. Hij nuanceert dit beeld overigens door zijdelings te spreken van een actiedemocratie, waarin burgers vrij impulsief via protestgedrag hun onvrede uiten. Volgens De Beus (2001: 27) voegt dit rationeel getinte activisme niet veel toe aan de democratische betrokkenheid van burgers. Het accent blijft daardoor in zijn benadering liggen op de lage verwachtingen van de participatie van burgers, die kenmerkend zijn voor de liberaal-representatieve en in mindere mate voor de liberaal-participatieve opvattingen van betekenisvol politiek burgerschap.

In het regeerakkoord 'Meedoen, meer werk, minder regels' formuleert het kabinetBalkenende II vooral vanuit de term 'meedoen' een aantal verbeteringen van de kwaliteit van de democratie en van de sociale en politieke participatie. Het kabinet wil de vermeende kloof tussen burgers en bestuur (verwoord als 'de afstand tussen kiezer en gekozene') verkleinen door het representatieve element van de democratie te versterken. Hierbij gaat het om de gekozen burgemeester en om de invoering van een districtenstelsel, oftewel de kroonjuwelen van D66. Bovendien gaat het om de versteviging van politieke partijen en om het terugdringen van de 
bureaucratie bij de overheid. Tegelijkertijd wordt er meer accent gelegd op actief burgerschap, waarbij burgers meer eigen verantwoordelijkheid moeten gaan nemen voor hun leven door te werken, door sociale participatie in verenigingen, scholen en buurten en door hun rol als kiezer te vervullen (ministerie van A Z 2003). De kabinetsvoornemens vormen een duidelijk voorbeeld van liberaalrepresentatieve en liberaal-participatieve democratieopvattingen gericht op het (re)vitaliseren van de institutionele structuur, in een richting waarvan men hoopt dat deze burgers in hun rol van kiezer en verenigingslid aanspreekt. Deze opvattingen worden vermengd met communitaristische denkbeelden waarbij vooral een beroep wordt gedaan op economisch en sociaal burgerschap, dat tot uitdrukking moet komen in werk en sociale (gemeenschaps)verbanden buiten de politieke sfeer. Kortom, in de opvattingen van de huidige regering geldt een vrij smalle interpretatie van betekenisvol politiek burgerschap, gecombineerd met een zeer brede interpretatie van betekenisvol economisch en sociaal burgerschap.

De voorbeelden van de toeschouwersdemocratie en van het regeerakkoord roepen de vraag op of er wel voldoende zicht bestaat op de manieren waarop burgers hun mogelijkheden tot beïnvloeding van politiek en bestuur gebruiken. De verwachtingen en interpretaties van de dominante democratieopvattingen lijken onvoldoende rekening te houden met maatschappelijke veranderingen en de gevolgen daarvan voor de invulling van politiek burgerschap. Dit leidt volgens mij tot een onevenwichtig beeld van betekenisvolle vormen van politiek burgerschap. Ter aanvulling van dit beeld probeer ik daarom in deze bijdrage met gebruik van bestaand empirisch materiaal meer licht te werpen op veranderingen in politiek burgerschap. Hierbij zijn de leidende vragen: welke veranderingen zijn er in politiek burgerschap waarneembaar? Wat betekenen deze veranderingen voor het functioneren van het politiek-bestuurlijke systeem? Welke interpretatie kunnen we aan veranderend politiek burgerschap toekennen vanuit de besproken democratieopvattingen?

\subsection{EMPIRISCHE ONTWIKKELINGEN IN POLITIEK BURGERSCHAP}

In deze paragraaf begin ik met het schetsen van een aantal belangrijke veranderingen in de context van het dagelijks leven van burgers in de afgelopen vier decennia. Deze veranderingen zijn kortweg te benoemen als de versoepeling van banden in het privé-leven (subpar. 3.2.1); en het ontstaan van losse banden met organisaties in de publieke sfeer (subpar. 3.2.2). Tegen deze achtergrond beschrijf ik een aantal empirische ontwikkelingen in politieke attitudes en politiek gedrag die in bestaand politicologisch en sociologisch enquêteonderzoek over politiek burgerschap naar voren komen (subpar. 3.2.3). Ik sluit deze empirische exercitie af met de politieke fixatie van burgers op de overheid als belangrijk kenmerk van hedendaags politiek burgerschap (subpar. 3.2.4).

\subsubsection{VERANDERINGEN IN HET PRIVÉ-LEVEN: VERSOEPELING VAN BANDEN}

In de afgelopen veertig jaar zijn in het privé-leven de verhoudingen tussen indi- 
viduen en hun directe omgeving ingrijpend veranderd. Het gaat om een serie maatschappelijke veranderingen die wij doorgaans duiden als het individualiseringsproces. Elders heb ik het individualiseringsproces omschreven als: "een relatieve materiële en morele verzelfstandiging van individuen binnen de marges die geboden worden door de collectieven waarvan men in toenemende mate afhankelijk is" (WRR 2002: 91). Onder invloed van toenemende welvaart, het stijgende opleidingsniveau en de snellere verspreiding van informatie via ICT, zijn mensen in financieel en in cognitief opzicht zelfstandiger geworden ten opzichte van hun directe sociale omgeving. Ze zijn ook fysiek minder sterk aan deze omgeving gebonden, zoals wordt onderstreept door de stijgende mobiliteit gericht op woon-werkverkeer en op vrijetijdsbesteding (WRR 2002: 91-95). In moreel opzicht treedt een verschuiving op die duidt op een relatieve verzelfstandiging van individuen, omdat ze minder sterk zijn blootgesteld aan of zich minder laten beïnvloeden door scheve machtsverhoudingen. Deze verschuiving is waarneembaar in veranderende opvoeding, veranderende levenslopen en in de toenemende secularisering en ontzuiling van het dagelijks leven (Van den Brink 2001, 2002; WRR 2002: 95-98).

De materiële en cognitieve veranderingen en de verschuivingen in morele afhankelijkheden binnen het privé-leven moeten echter niet worden overdreven. Mensen laten zich nog steeds beïnvloeden door hun naasten, maar gaan flexibeler met deze invloeden om. Dat komt doordat ze hun afhankelijkheden sterker hebben gespreid tussen partners, familie, buren, geestelijken en collectieve verbanden zoals werkgevers, studiefinanciering, verzekeraars, uitkeringsinstanties en andere overheidsinstellingen. Volgens Hooghe en Houtman (2003) zijn instituties zowel beperkend als faciliterend. Ze leggen beperkingen op aan de individuele vrijheid via routinisering van gedragspatronen en beperken daarmee de variëteit in gedrag. Ze zijn echter tegelijkertijd faciliterend omdat ze mogelijkheden bieden voor het bereiken van collectieve doelstellingen, waardoor individuen tijd over houden voor andere handelingen. Dit leidt tot een subjectief gevoel van keuzevrijheid en autonomie, dat vaak met individualisering wordt geassocieerd. Objectief gezien is deze vrijheid echter relatief, omdat mensen meer dan voorheen van meer verschillende private en publieke instituties afhankelijk zijn en omdat hun gedrag op subtiele manieren beïnvloed wordt door onder andere de media, reclame, de vrijetijdsindustrie, of gedragsregels op het werk (De Beer 2004).

Het is dus niet zozeer de invloed als wel het sturend vermogen van instituties waarin verschuivingen optreden (vgl. Jansweijer 1987: 9). In het verleden waren de hiërarchische instituties van gezin en kerk de primaire bronnen van beïnvloeding, terwijl dit nu geldt voor de media, commercie en dergelijke. De Belgische socioloog Mark Elchardus (2004) benoemde dit proces recentelijk als 'een verandering in de wijze of modus van sociale controle'. De mechanismen waarmee het gedrag wordt beïnvloed zijn veranderd. De factoren die keuzes bepalen, zoals smaken, opvattingen, vaardigheden, emoties en dergelijke, worden tegenwoordig gevormd door uitvoerige socialisatie en beïnvloeding via andere primaire 
bronnen zoals de media of werkgevers. De spreiding van afhankelijkheden en de veranderende modus van sociale controle betekent in de verhoudingen tussen private instituties en individuen een versoepeling van banden, omdat de nieuwe vormen van socialisatie en beïnvloeding door hun subtiele werking minder hiërarchie veronderstellen. Deze versoepeling van banden vormt het eerste element van het decor waarin veranderingen van het politieke burgerschap optreden. Het tweede element ligt besloten in de losse banden met organisaties in de publieke sfeer.

\subsubsection{LOSSE BANDEN MET ORGANISATIES IN DE PUBLIEKE SFEER}

\section{Empirische aanwijzingen voor losse banden met organisaties in de publieke sfeer}

Uit onderzoek van het Sociaal en Cultureel Planbureau (SCP) blijkt dat Nederlandse burgers over minder tijd beschikken om duurzame banden met organisaties aan te gaan. Als gevolg van de stijgende arbeidsparticipatie van vrouwen en de gelijkblijvende arbeidsparticipatie van mannen, treedt er in het privé-leven een verplaatsing op van huishoudelijke en zorgtaken naar de avonduren en de weekenden. Deze taakverplaatsing resulteert in een afname van de beschikbare vrije tijd (SCP 2003a). Uit een andere SCP-publicatie blijkt dat de beschikbare vrije tijd in afnemende mate besteed wordt aan sociale contacten en aan maatschappelijke participatie. Bovendien blijkt dat in de loop der jaren meer tijd wordt besteed aan een meer divers aantal activiteiten, waaraan men echter niet permanent deelneemt, maar 'wel eens' op ad hoc-basis aan meedoet (SCP 2001: 49, 52-53).

Ondanks het feit dat Nederland na Zweden het land is met het hoogste percentage vrijwilligerswerk en het hoogste percentage lidmaatschappen van verenigingen (zie Dekker en De Hart 2003: 153), verandert de sociale participatie in relatie tot veranderende tijdsbesteding. Deze veranderingen manifesteren zich in de dalende deelname aan vrijwilligerswerk, die zich tussen 1995 en 2000 op alle terreinen en onder alle bevolkingscategorieën begint af te tekenen. Onduidelijk is echter vooralsnog of het gaat om een trend, of dat er sprake is van een tijdelijke dip (SCP 2002: 243). De tijdsdruk die veel mensen ervaren, werkt vooral door in het type lidmaatschap en in de interpretaties van wat lidmaatschap inhoudt. Tussen 1980 en 2000 treedt er een verschuiving op van kerken, politieke partijen en vrouwenorganisaties naar single-issue-organisaties, belangenorganisaties en organisaties gericht op sport en recreatie. De snelst groeiende organisaties zijn single-issue, op de terreinen van abortus en euthanasie, natuur en milieu en internationale solidariteit. Opvallend bij deze organisaties is dat zij hoge percentages passieve leden hebben, in tegenstelling tot de afkalvende organisaties zoals kerken en politieke partijen (SCP 2OO2).

Op basis van de SCP-gegevens is het aannemelijk dat burgers in toenemende mate losse banden aangaan met organisaties in de publieke sfeer. Burgers lijken in ieder geval via hun organisatorische betrekkingen bezig te zijn om hun sociale en politieke betrokkenheid op andere manieren te uiten dan voorheen. Voor de toekomst 
verwacht het SCP dat dit proces zich door zal zetten. Vrijwilligerswerk in de vorm van onbetaalde arbeid zal bloeien omdat korte flexibele bijdragen zoals leesouder zijn op school, of even iemand helpen bij het opstaan en wassen, goed zijn in te passen in drukke agenda's. Tegelijkertijd wordt verwacht dat de steun voor verenigingen die zich kenmerken door duurzame vormen van inzet en betrokkenheid zal dalen en dat als gevolg daarvan vrijwilligerswerk in de vorm van actief lidmaatschap eveneens zal dalen. Ten slotte wordt verwacht dat het moderne verenigingsleven in sportclubs en rond voorzieningen op peil zal blijven, omdat ook daarbij flexibele vormen van betrokkenheid mogelijk zijn (SCP 2002: 243-244).

\section{Zijn losse banden problematisch voor de democratie of niet?}

De groeiende voorkeur van burgers voor single-issue- en belangenorganisaties is volgens Putnam (2000) een van de kernproblemen in de discussie over sociaal kapitaal en politiek burgerschap. Hij vindt het belangrijkste kenmerk van vrijwillige associaties dat persoonlijk contact bijdraagt in het aanleren van de noodzakelijke politieke competenties om als burger actief in een democratie te functioneren. Vanwege hun checkbook-binding met de achterban doen zich in de door Putnam als 'tertiair' geclassificeerde single-issue-organisaties niet de noodzakelijke leereffecten voor die hij toekent aan traditionele vrijwillige associaties (Putnam 1995). Dit wordt voor Nederland bevestigd door SCP-gegevens, waaruit blijkt dat deze organisaties intern ondemocratischer zijn, dat er weinig interactie tussen de leden plaatsvindt (uitzonderingen daargelaten), terwijl ze wel de politieke besluitvorming en de publieke opinie proberen te beïnvloeden (zie SCP 2002).

Critici van Putnam, zoals Selle en Strømsnes (2001), zijn echter van mening dat hij het belang van persoonlijk contact binnen vrijwillige associaties overdrijft. Hun argument is dat mensen in tal van andere persoonlijke netwerken evengoed via leereffecten politieke competenties verwerven. Deze redenatie wordt bevestigd door onderzoeksresultaten van Verba et al. (1995: 335-336) en van Burns et al. (2001), waaruit blijkt dat organisatorische betrokkenheid bijdraagt aan het leren van vaardigheden, maar dat dit zowel op school, op het werk, in de kerk als in non-politieke organisaties à la Putnam gebeurt.

Kortom, het mechanisme van netwerkvorming is wel van belang voor de ontwikkeling van politieke competenties, maar dit mechanisme leunt niet zo exclusief op de door Putnam bewierookte vrijwillige associaties als hij denkt. Zolang mensen inderdaad binnen verschillende netwerken zijn ingebed, zullen ze ook politieke competenties aanleren. Gebrek aan persoonlijk contact binnen verenigingen kan bijvoorbeeld gecompenseerd worden door een baan waarin men wel veel contacten heeft. Compensatie vindt echter niet per se tussen alle elementen van een netwerk plaats. Uit onderzoek van Dekker et al. (2003) blijkt dat scholen meer bijdragen aan de vorming van politieke competenties dan verenigingen. $\mathrm{Op}$ het moment dat scholen tekortschieten, kunnen verenigingen hier slechts marginaal voor compenseren. Ook tussen verenigingen bestaan aanzienlijke verschillen. Volgens Verba et al. (1995: 311) is het waarschijnlijker dat mensen politieke vaardigheden aanleren bij een studentenvereniging dan bij een sportclub. Deze 
redenatie gaat in tegen Putnam, die bijvoorbeeld actief lidmaatschap van een bowlingclub betekenisvoller acht voor de vorming van politieke competenties dan passief lidmaatschap van een single-issue-groep (Putnam 20oo).

De empirische gegevens contra Putnams argumentatie lijken dermate overtuigend, dat we kunnen concluderen dat de democratische betrokkenheid van burgers niet te lijden heeft onder hun toenemende voorkeuren voor single-issue- en belangenorganisaties. Dit geldt zeker voor 'Nederland organisatieland', dat zich in internationaal perspectief kenmerkt door hoge scores op vrijwilligerswerk en een mix van hoge ledenaantallen op zowel traditionele als tertiaire organisaties.

\section{Losse banden en nieuwe publieke rituelen}

De gesignaleerde problemen bij de vormen van organisatorische betrokkenheid blijken bij nader inzien minder groot te zijn dan in pessimistische interpretaties à la Putnam wordt gesteld. Een verschuiving in participatiepatronen naar losse banden met tertiaire organisaties vormt vooralsnog geen bedreiging voor het voortbestaan van de democratie. Deze verschuiving lijkt vooral een aanpassing te zijn op de veranderende democratische vormgeving van de maatschappij. Volgens Eder (2000: 218) zijn er new public rituals ontstaan in het kielzog van de nieuwe sociale bewegingen. Hij ziet hierin nieuwe manieren waarop democratische principes op samenlevingen worden toegepast. Er ontstaan nieuwe institutionele vormen voor politiek, waarbij tertiaire organisaties en belangengroepen voor burgers een belangrijke plaats innemen in de confrontaties met overheden en bedrijfsleven. De locus of control verschuift hierbij van de dichotomie tussen staat en markt naar de trichotomie van staat, markt en civil society. Tussen deze partijen ontstaan tal van dwarsverbanden, die zijn op te vatten als probleemspecifieke en tijdsafhankelijke beleidsdomeinen met hun eigen regels en dynamiek (Eder 200o). Ieder beleidsdomein vormt een politiek platform waarop de politieke actoren elkaar ontmoeten en regelmatig strijd met elkaar leveren. Ook Europese instellingen, lokale besturen, de ambtenarij en de rechterlijke macht spelen binnen beleidsdomeinen een rol naast de nationale overheid, bedrijven en maatschappelijke organisaties. Dit proces is in Nederland geduid als de verplaatsing van de politiek (Bovens et al. 1995; Bovens 2002). Aan deze lijst van actoren kunnen de media inmiddels wel worden toegevoegd. De strijd tussen de actoren wordt niet alleen gevoerd in de onderlinge interacties, maar ook via de media en de gedramatiseerde vormen van publiek debat die zij bieden (vgl. Elchardus 2002).

Als gevolg van het proces van verplaatsing van de politiek en de verkaveling van beleidsdomeinen is een versnipperde publieke sfeer ontstaan, die een beeld oplevert van: "messy, non-generalizable and contingent practices, institutions and discourses" (Cruikshank 1999: 42). Deze politieke context biedt aan burgers echter meer mogelijkheden om hun politieke burgerschap vorm te geven op manieren die passen bij hun persoonlijke omstandigheden. Om hier meer inzicht in te krijgen, zal ik eerst een globale beschrijving geven van de veranderende politieke betrokkenheid en politieke participatie van burgers. 


\subsubsection{DE MEEST OPVALLENDE VERANDERINGEN IN POLITIEKE ATTITUDES EN GEDRAG}

Tegen de achtergrond van de versoepeling van banden in het privé-leven, de groter wordende flexibiliteit van banden met organisaties in de publieke sfeer en de new public rituals, is een aantal opvallende ontwikkelingen in politieke betrokkenheid (attitudes) en participatie (gedrag) van Nederlandse burgers waarneembaar. Deze ontwikkelingen vat ik gezamenlijk op als een macro-indicator voor veranderingen in politiek burgerschap. De belangrijkste bronnen die deze veranderingen sinds jaar en dag in kaart brengen, zijn het onderzoek Culturele Veranderingen in Nederland (CV) van het SCP en het Nationaal Kiezersonderzoek (NKO), dat door wisselende universitaire instellingen wordt verzorgd. In deze onderzoeken wordt een onderscheid gemaakt naar attitudevariabelen en gedragsvariabelen. Voorbeelden van politieke attitudes zijn onder andere: acceptatie van sociaal protest, gevoelens van anomie, politieke interesse en gevoelens van politieke effectiviteit. Voorbeelden van politieke gedragsvariabelen zijn onder andere: stemmen, partijlidmaatschap, deelname aan handtekeningenacties en deelname aan demonstraties.

\section{Veranderingen in politieke attitudes}

- In Nederland is sprake van een groot vertrouwen in de representatieve democratie als politiek systeem. Vooral sinds de jaren negentig schommelt de tevredenheid over de wijze waarop de democratie functioneert rond de 70 procent van de bevolking. Nederland behoort in de steun voor de democratie stelselmatig tot de koplopers in Europa (Dekker 2002: 56).

- Recentelijk daalde de tevredenheid met de regering van 77 procent in 2000 naar 59 procent in 2002. Het percentage Nederlanders dat vindt dat de overheid goed functioneert daalde tussen 2000 en 2002 zelfs van 65 procent tot 35 procent (SCP 2003b). Kortom, de onvrede met de politiek nam toe. De indicatoren voor onvrede zijn echter zeer conjunctuurgevoelig; ze blijken tussen 1975 en 2002 nogal sterk te fluctueren (Dekker et al. 2004). De stormachtige opkomst van de LPF bij de verkiezingen van 2002 en hun ineenstorting bij de verkiezingen van 2003 is een recent voorbeeld van de conjunctuurgevoeligheid van politieke onvrede.

- Volgens Dekker et al. (2004) daalde de politieke onverschilligheid onder de bevolking scherp tussen 1975 en 2002. De verklaring hiervoor ligt volgens hen in het stijgende opleidingsniveau gedurende deze periode. De daling van deze indicator suggereert dat een groot aantal burgers in politiek geïnteresseerd is en dat ze geneigd zijn om politiek in actie te komen als dat nodig is. Beide elementen van deze indicator worden hieronder los van elkaar bekeken.

- De politieke interesse van de bevolking steeg inderdaad tussen 1970 en 2000. In 1970 gaf 35 procent van de bevolking aan sterk of gewoon in politiek geïnteresseerd te zijn, terwijl dit percentage in 2000 was gestegen tot 43 procent (Dekker 2002). Overigens leert een snelle blik op de gegevens uit CV voor 2002 dat de politieke interesse verder steeg tot maar liefst 56 procent van de bevolking (eigen analyse). Bij deze stijging moeten we ons echter afvragen in 
hoeverre er sprake is van een Fortuyn-effect.

- Als de protestgeneigdheid van de bevolking apart wordt beschouwd, dan blijkt dat deze tussen 1975 en 2000 stijgt van 34 procent naar 52 procent (Dekker en Hooghe 2003: 164). Ook dit cijfer steeg verder in 2002 naar 56 procent van de bevolking (eigen analyse Cv). Deze stijging toont volgens Dekker en Hooghe (2003) aan dat steeds meer mensen vinden dat onrechtvaardig optreden door de overheid op minder acceptatie kan rekenen (Dekker 200oa: 89). De vraag uit CV peilt echter of men iets zou doen als de Tweede Kamer bezig was een onrechtvaardige wet aan te nemen. Merk op dat het hier gaat om een actie van de wetgever op nationaal niveau. Ik acht het veel waarschijnlijker dat dit soort attitudes op lokaal niveau een betere voorspeller vormt voor protestgedrag, omdat burgers doorgaans vrij sterk betrokken zijn bij lokale aangelegenheden die directer ingrijpen in hun eigen leefomgeving (zie verderop bij de gedragsvariabelen de stijgende indicator voor lokale acties).

- Naast de toenemende protestgeneigdheid stijgt de steun voor allerlei 'onconventionele' vormen van politieke participatie vrij sterk. Dit blijkt onder andere uit de stijgende instemming met democratische vrijheden zoals demonstraties ( $78 \%$ in 1970 naar $91 \%$ in 2000 ), wilde stakingen (20\% in 1975 naar $43 \%$ in 2000 ), schoolbezettingen ( $35 \%$ in 1975 naar $59 \%$ in 2000 ) en steun voor protest tegen onrechtvaardige wetgeving (38\% in 1975 naar 66\% in 20oo) (Dekker 2002: $57-58)$.

- Uit een eigen analyse van CV blijkt dat burgers meer zelfvertrouwen hebben als het gaat om hun eigen politiek handelen. Een aantal belangrijke indicatoren op de zogenaamde political efficacy-schaal vertoont sinds 1975 een stijgende lijn. Zo is het aandeel onder de bevolking tussen de 18 en 74 jaar dat het oneens is met de stelling dat ze geen invloed hebben op de regering gestegen van 42 procent in 1975 naar 49 procent in 2002. Mensen zijn het ook in toenemende mate oneens met de stelling 'ik denk niet dat ministers en kamerleden veel geven om wat mensen zoals ik denken' ( $45 \%$ oneens in 1975 tegen $51 \%$ in 2002). Ten slotte zijn mensen het in toenemende mate oneens met de stelling dat stemmen de enige manier is waarop ze invloed kunnen uitoefenen op de regering ( $22 \%$ oneens in 1975 tegen $33 \%$ in $1996^{3}$ ).

- Tot slot blijkt uit het POLS-onderzoek van het CBS dat mensen in zeer groten getale willen meebeslissen in de maatschappij. In 2002 lag het percentage mensen dat meebeslissen belangrijk tot heel erg belangrijk vond op 82 procent van de bevolking (CBS-statline).

Samenvattend zien we in een aantal belangrijke politieke attitudes sinds de jaren zeventig de volgende ontwikkelingen: een stelselmatig hoge waardering voor de democratie als politiek systeem; een fluctuerende, vrij conjunctuurgevoelige tevredenheid/onvrede met de regering; een scherpe daling van de politieke onverschilligheid tussen 1975 en 2002; stijgende politieke interesse tussen 1975 en 2000, met zelfs een piek naar 56 procent in 2002; een sterk stijgende protestgeneigdheid tussen 1975 en 2000 ; een vrij sterk stijgende waardering voor allerlei vormen van onconventionele politieke participatie; stijgend politiek zelfvertrouwen; en een grote wil om mee te beslissen in de maatschappij. 


\section{Veranderingen in politiek gedrag}

- Een van de meest opmerkelijke verschuivingen in de politieke participatie is de dalende deelname aan Tweede-Kamerverkiezingen. Deze daalde tussen 1986 en 1998 van 86 procent tot ongeveer 73 procent van het electoraat. Uitzondering op deze trend vormen de verkiezingen van 2002 en 2003, waarbij de opkomst weer steeg naar respectievelijk 79 procent en 8 o procent. Onduidelijk is vooralsnog of hier sprake is van een blijvend herstel van het opkomstcijfer of van een tijdelijke opleving in een vooralsnog dalende trend. De verkiezingen voor andere bestuursorganen zoals gemeenteraden, Provinciale Staten en het Europees Parlement ${ }^{4}$ vertonen sinds het begin van de jaren tachtig allemaal een dalende trend (Dekker en Hooghe 2003).

- Het lidmaatschap van politieke partijen daalde van 10 procent van de bevolking in 1972 naar 4 procent in 1998 (Dekker 20oob). Volgens het CBS (statline) heeft het partijlidmaatschap zich tot 2002 op 4 procent gestabiliseerd. Samenhangend met het dalende partijlidmaatschap is er sprake van dalende deelname aan activiteiten rond verkiezingen zoals het ophangen van raambiljetten, geld geven aan een politieke partij of verkiezingsbijeenkomsten bijwonen. Meer informele activiteiten zoals gesprekken met anderen voeren om hen over te halen op een bepaalde partij te stemmen, liggen op een redelijk hoog niveau (Dekker en Hooghe 2003: 162).

- De deelname aan allerlei vormen van onconventionele politieke participatie steeg systematisch tussen 1977 en 1998. In 1977 deed bijvoorbeeld 39 procent van de bevolking mee aan handtekeningenacties terwijl dit in 199862 procent was. Tien procent van de bevolking deed in 1977 mee aan actiegroepen of demonstraties, tegen 25 procent in 1998. De massamedia werden in 1977 door 5 procent van de bevolking ingeschakeld, tegen 1o procent in 1998. Deze ontwikkelingen doen zich voor in de meeste westerse landen (zie Dekker en Hooghe 2003: 165).

- Gezamenlijke inspanningen van burgers voor kwesties van nationaal of internationaal belang fluctueren vrij sterk. In 1980 deed 12 procent van de bevolking hieraan mee, tegen 14 procent in 2002. In 2000 bereikte deze inspanning echter een historisch dieptepunt, met 9 procent van de bevolking. Een veel consistenter beeld van actieve bijdragen van burgers is tussen 1980 en 2002 waarneembaar bij hun inspanningen voor kwesties van lokaal belang. Uit CV blijkt dat het niveau in 1980 op 26 procent lag, terwijl dit in 2002 was gestegen naar 30 procent van de bevolking. Het laagste niveau in de tussenliggende periode was 21 procent in 1986 (eigen analyse CV).

Samenvattend zien we in het politieke gedrag op de langere termijn de volgende ontwikkelingen: een dalende trend in de deelname aan verkiezingen met wellicht de recente landelijke verkiezingen als trendbreuk; dalend lidmaatschap van politieke partijen en ook dalende deelname aan partijgebonden activiteiten; stijgende deelname aan onconventionele participatievormen; wisselende deelname aan nationale kwesties, maar een vrij consistente deelname aan lokale kwesties. Kortom, deze cijfers suggereren onder de bevolking een toenemende neiging om direct invloed uit te oefenen op politiek-bestuurlijke processen, maar dan vooral op lokaal niveau. 
Veranderingen in politiek burgerschap en opeenvolgende generaties burgers Veel van de hierboven gepresenteerde ontwikkelingen in politieke attitudes en gedrag zijn niet één op één te relateren aan de huidige context van het privéleven, publieke instituties en new public rituals, die eerder werd beschreven. Alleen de meest recente cijfers bieden een representatie van de reacties van burgers op de huidige omstandigheden. De wisselwerking tussen veranderend politiek burgerschap en de maatschappelijke omgeving wordt vooral bepaald door de verschillen in opleiding en inkomen, en door verschillende reacties op de technologische, sociale, culturele en politieke mogelijkheden waarmee men door de tijd heen geconfronteerd wordt. Als gevolg van historische continuïteiten en veranderingen in deze mogelijkheden ontstaan er generatie-effecten in politiek burgerschap. De veronderstelling hierachter is dat iedere generatie burgers binnen haar omgeving een bepaalde politieke socialisatie ondervindt, waarin men zich bepaalde politieke oriëntaties en gedragsvormen eigen maakt. De veranderingen die we waarnemen in politiek burgerschap zijn vanuit deze veronderstelling te interpreteren als uitingen van verschillen in politieke socialisatie tussen opeenvolgende generaties burgers binnen hun maatschappelijke omstandigheden.

Volgens Dekker et al. (2003) hebben de Baby Boom-generatie (geboren tussen 1940 en 1960) en de Baby Bust-generatie (geboren na 1960) meer sociaal vertrouwen en doen ze meer aan politieke participatie. Vooral de Baby Boom-generatie richt zich daarbij op protestgerichte participatievormen zoals boycots en demonstraties, die ze in de nieuwe sociale bewegingen in de jaren zestig, zeventig en tachtig op grote schaal heeft toegepast. Tegelijkertijd doet men echter nog mee met de participatievormen (stemmen) van de oorlogsgeneratie. De Baby Bustgeneratie doet mee aan de participatievormen van beide voorgaande generaties en ontwikkelt bovendien nieuwe vormen van activisme, zoals hacktivism (het massaal zenden van e-mails aan politici), het gebruik van ICT-toepassingen voor gemeenschapsopbouw, participatie in politieke chatgroepen, het verspreiden van politieke informatie via webmagazines en het mobiliseren via internet (zie de anti-globalisten die dit op wereldschaal toepassen) (Vinken en Ester 2002). Zo bezien ontwikkelt iedere generatie burgers nieuwe vormen van politieke oriëntaties en gedrag die naast bestaande vormen worden toegepast. De combinatie van nieuwe en bestaande vormen bepaalt hun burgerschapsrepertoire. De bestaande vormen lijken echter wel wat minder intensief door hen te worden benut, althans dat doen dalend partijlidmaatschap en dalende trends bij verkiezingen vermoeden. De ontwikkelingen van politieke attitudes en gedrag zijn daarom volgens mij op te vatten als een serie moderniseringsgolven van het politieke burgerschap, waarbij iedere generatie iets toevoegt aan een bestaand repertoire van voice-mogelijkheden die binnen de democratie ter beschikking staan (vgl. Vinken 2003).

\subsubsection{DE FIXATIE OP DE OVERHEID ALS MOTOR VOOR POLITIEK BURGERSCHAP}

Losse banden met publieke organisaties, new public rituals en het huidige reper- 
toire aan voice-mogelijkheden bieden aan burgers een grotere diversiteit aan vormen waarlangs ze hun politieke burgerschap op inhoudelijke terreinen kunnen uiten en waardoor ze meerdere ijzers tegelijk in het vuur kunnen hebben. Deze banden en de versnippering van het publieke domein bieden hen echter ook de mogelijkheid om rustig achterover te gaan leunen en anderen de kastanjes uit het vuur te laten halen. Volgens Eder (200o) zijn burgers genoodzaakt om onderwerpen te kiezen waarvoor zij politiek actief willen worden. Ze kiezen daarbij welke rol ze willen spelen in het publieke domein, wanneer ze willen afwachten en wanneer ze willen handelen. Een belangrijke vraag is hoe burgers hiermee omgaan. Wanneer en waarom zijn ze actief en passief? Waardoor laten ze hun politieke gedrag beïnvloeden binnen de hierboven geschetste context van publieke instituties? ${ }^{5}$ Hoewel deze vragen pas beantwoord kunnen worden op basis van verdergaand empirisch onderzoek, kunnen we wel iets zeggen over de richting waarin we moeten zoeken.

Het begin van een antwoord op bovenstaande vragen lijkt mij te liggen in de toenemende fixatie van burgers op de overheid en de legitimiteit van haar optreden. Aanwijzingen hiervoor vinden we onder andere bij Van den Brink (2002: 113-114) die stelt dat er een politieke cultuur is ontstaan waarin overheidsgezag veel meer ter discussie staat. Hij verklaart deze ontwikkeling uit de toenemende gevoelens van eigenwaarde in het privé-leven, die zich bij sommige lagen van de bevolking uiten in een zelfbewuste en assertieve levensstijl. Voorbeelden hiervan zien we al bij de nieuwe sociale bewegingen van de jaren zeventig en de vroege jaren tachtig. Zij creëerden met hun nieuwe politieke participatievormen niches binnen de publieke sfeer waarmee ze zich identificeerden. Ze richtten zich tot de overheid over thema's als milieu, antidiscriminatie, emancipatie en gelijke behandeling (zie voor een uitvoerige beschrijving Tielman 1982; Van der Heijden 1992; Ribberink 1998). De directere politieke participatievormen die de Baby Boom-generatie binnen de nieuwe sociale bewegingen frequent toepaste, zijn inmiddels een geaccepteerd onderdeel van het politieke burgerschapsrepertoire geworden (vgl. de cijfers in paragraaf 3.2.3). Dit repertoire wordt niet alleen meer toegepast om het persoonlijke politiek te maken, maar ook om het overheidsingrijpen in het dagelijks leven te corrigeren en te beïnvloeden.

Burgers hebben in de afgelopen decennia niet alleen het persoonlijke politiek gemaakt, maar zijn zich de politiek ook persoonlijker gaan aantrekken. Volgens Tops en Zouridis (2000: 16) heeft de politiek zich verplaatst naar het individuele niveau. Dat wil zeggen dat politiek voor vrij veel burgers een zaak is geworden van persoonlijke afwegingen. Dit betekent volgens hen dat de overheid minder kan optreden als verzoener van maatschappelijke belangen, zoals in de verzuilde samenleving, maar meer tegenover burgers is komen staan. Op het moment dat de overheid activisme van burgers verwacht, ondervangt zij dit door burgers medeverantwoordelijk te maken als coproducent van beleid (zie WRR 2002: 101103). Probleem is dat het voor de overheid vaak niet te voorzien is welke beleidsvoornemens of uitvoeringspraktijken zullen leiden tot activering van burgers. Dit kan leiden tot soms onverwachte conflicten met burgers die geen genoegen 
nemen met de gemaakte belangenafweging. Naast de door henzelf ontwikkelde burgerschapsrepertoires en het kiesrecht hebben burgers inmiddels de keuze uit een sterk gegroeid arsenaal aan procedurele mogelijkheden om hun ongenoegen tot uitdrukking te brengen. Het gaat onder andere om deelname aan inspraak en interactieve beleidsvorming, mogelijkheden voor bezwaar en beroep binnen het bestuursrecht en ruime mogelijkheden binnen het klachtrecht. Daarnaast kunnen burgers op basis van de Wet openbaarheid van bestuur (Wob) overheidsinformatie inzien. Van deze mogelijkheden wordt ook in toenemende mate gebruik gemaakt (zie WRR 2OO2: $\mathrm{H}_{4}$ en $\mathrm{H} 8$ ).

Er lijkt in de verhoudingen tussen burgers en overheid sprake van een vicieuze cirkel: als gevolg van versterkte politieke competenties ontstaan er bij veel burgers hogere verwachtingen van de overheid en een kritische habitus jegens de publieke omgeving; de overheid reageert hierop met allerlei maatregelen waarbij burgers formeel meer invloed krijgen op beleid; deze reacties versterken de fixatie op de overheid, omdat burgers meer weten over wat de overheid doet en zich bovendien in de rug gesteund weten door de bestuurlijke en juridische maatregelen om in actie te komen; dit proces wordt versterkt door de kritische 'collectieve overtuigingen' over politiek, bestuur en beleid die de media aan burgers voorschotelen. Als gevolg van deze vicieuze cirkel neemt de kans op politieke conflicten tussen burgers en overheid toe. Burgers moeten daarom overtuigd worden van de doeltreffendheid, doelmatigheid, rechtvaardigheid of kwaliteit van het overheidsoptreden, die per geval in wisselende combinaties ter discussie lijken te staan (WRR 2002). Met andere woorden, de loyaliteit van burgers jegens de overheid lijkt niet altijd vanzelfsprekend te zijn. Deze moet worden gegenereerd door hen te overtuigen in het proces van beleidsvorming en beleidsuitvoering. Volgens Hajer et al. (2001: 8) wordt politiek een slag om de geloofwaardigheid van het openbaar bestuur en het vertrouwen van burgers in het bestuur. Het komt erop neer dat de overheid niet langer kan rekenen op de vanzelfsprekendheid van de legitimiteit van haar gezag. Besturen gaat niet langer om het genereren van passief vertrouwen, maar om het steeds opnieuw ontwikkelen van actief vertrouwen. Naast goede prestaties vormen relationele kwaliteitsaspecten en procedures een belangrijke bron van actief institutioneel vertrouwen en legitimiteit (Schuyt en Verhoeven 2003: 14).

De toenemende fixatie van burgers op de overheid is een illustratie van het proces dat de Duitse socioloog Beck omschrijft als 'subpolitiek'. Het gaat om een proces van beïnvloeding van beleid van onderop, waarbij burgers hun burgerschapsrepertoires en hun procedurele mogelijkheden benutten om hun stem te laten horen (Beck et al. 1994). Subpolitiek is volgens mij een belangrijk kenmerk van het hedendaagse politieke burgerschap. $\mathrm{Zij}$ vormt samen met verkiezingen de motor van de politieke betrokkenheid en participatie van burgers. Wat historisch gezien opvalt, is dat de focus van het politieke burgerschap zich verlegt van de culturele en sociale problemen die burgers via de politiek adresseerden in de jaren zeventig en vroege jaren tachtig, naar problematisering van het politiek-bestuurlijke overheidsingrijpen vanaf de jaren tachtig en 
negentig. De culturele inzet van het politieke burgerschap om het persoonlijke politiek te maken is omgeslagen naar een politieke inzet, waarbij de politiek persoonlijk is geworden. Een ander opvallend punt daarbij is dat de vormen van politieke betrokkenheid en participatie zich hebben aangepast aan het discontinue ritme van het privé-leven van burgers en aan de grilligheid van beleidsvoorbereiding en beleidsuitvoering door de overheid. Politiek burgerschap lijkt veel meer dan voorheen een zaak geworden van afwachten en handelen wanneer het nodig is. Van tijd tot tijd bemoeien burgers zich actief met publieke zaken, maar op veel momenten laten ze zich representeren door volksvertegenwoordigers en door single-issue-belangenbehartigers die ze financieel ondersteunen. Uiteraard bestaat op deze punten veel variatie en ongelijkheid tussen burgers, waarop we verderop in zullen gaan.

\subsection{POLITIEK BURGERSCHAP EN HET POLITIEK-BESTUURLIJKE SYSTEEM}

\subsubsection{DE GROEIENDE PARTICIPATIE VAN BURGERS IN DE BELEIDS- VOORBEREIDING EN - UITVOERING}

De empirische ontwikkelingen in politiek burgerschap hangen samen met het functioneren van het politiek-bestuurlijke systeem. Ik zal de meest opvallende samenhangen hieronder bespreken, door de empirische ontwikkelingen van politiek burgerschap te koppelen aan verschillende politieke rollen van burgers.

De legitimiteit van het politiek-bestuurlijke systeem wordt bepaald door de steun van burgers voor de democratie als systeem en door hun inbreng als kiezer, die via het stembiljet de besluitvorming binnen dit systeem beïnvloedt. Uit het empirisch materiaal blijkt dat de steun voor het democratische gehalte van het systeem onverminderd groot is, terwijl er bij nationale verkiezingen - ondanks een dalende trend - nog steeds door driekwart van de bevolking wordt gestemd. De opkomst is echter sterk dalende bij Provinciale-Statenverkiezingen en bij gemeenteraadsverkiezingen. Deze ontwikkelingen bevestigen de diagnose van De Beus dat burgers toeschouwers zijn geworden, die vanaf de zijlijn applaudisseren, boe roepen, of niets van zich laten horen.

De verzwakking van de deelname aan verkiezingen wordt echter vergezeld door een veranderende en groeiende preoccupatie van burgers met de beleidsvorming en beleidsuitvoering. Traditioneel worden deze processen namens burgers bewaakt door volksvertegenwoordigers, politieke partijen en vakbonden. De steun voor politieke partijen is echter sterk teruggelopen, terwijl de ledenaantallen van vakbonden fluctueren (zie CBS-statline). Hier staat echter de sterk gegroeide steun voor allerlei single-issue-organisaties en belangenorganisaties tegenover. Zij gelden in toenemende mate namens burgers als collectieve belangenbehartigers. Via single-issue-organisaties houden burgers op nationaal niveau als het ware verschillende ijzers in het vuur bij de totstandkoming en uitvoering van beleid, maar dan wel op specifieke beleidsdomeinen die hen aanspreken. 
Naast betrokkenheid via tertiaire organisaties treden er ook ad hoc-vormen van betrokkenheid op, die vooral lijken aan te sluiten bij de toenemende fixatie van burgers op de legitimiteit van overheidsoptreden. Burgers volgen politiekbestuurlijke processen steeds nadrukkelijker, gezien hun stijgende politieke interesse en hun grote wil om mee te beslissen in de maatschappij. Bovendien beschikken ze over steeds meer politiek zelfvertrouwen en lijken ze vooral bij lokale kwesties op tal van manieren de besluitvorming te willen beïnvloeden. Deze ad hoc-vormen van politieke betrokkenheid richten zich nadrukkelijk op beleidsinterventies. Zowel materiële als procedurele aspecten van beleidsuitvoering, zoals doeltreffendheid, doelmatigheid, rechtvaardigheid of kwaliteit, kunnen daarbij aan de orde zijn. Beleidsinterventies vormen derhalve in toenemende mate een 'ruimte' voor politiek burgerschap.

Volgens Hajer (2003) stimuleren beleidsinterventies burgers om na te denken over wat ze echt belangrijk vinden en om daarvoor eventueel in actie te komen. Beleid creëert hiermee volgens hem een publieke ruimte waarin mensen hun toekomst, hun onderlinge relaties en hun relaties tot de overheid bepalen. In dit perspectief bestaat er geen notie meer van een collectieve nationale identiteit die het politieke burgerschap stuurt. Actieve beleidsinterventies in hun leefwereld doen mensen pas beseffen waarmee ze zich identificeren. Daardoor kan een beleidsdiscours vormend zijn voor de politieke identiteit van burgers en daarmee vormend voor hun politieke burgerschap. De metafoor die Hajer voor burgers in deze situatie hanteert, is die van burgers op stand by. Dat wil zeggen dat ze doorgaans politiek vrij passief zijn, maar dat ze in reactie op beleidsinterventies als het ware worden uitgedaagd om zich als burger in een gemeenschap van medeburgers te identificeren en actief vorm te geven aan politiek burgerschap. Het beeld dat Hajer schetst, lijkt sterk op de metafoor van de toezichthoudende burgers van Michael Schudson (1998, 1999). Zij zijn niet proactief ingesteld, zoals in veel ideaalbeelden van de 'goede burger' wordt verondersteld, maar ze reageren op het moment dat er naar hun mening iets fout loopt in de totstandkoming en uitvoering van beleid.

Andere vormen van ad hoc-betrokkenheid van burgers bij beleidsprocessen zijn inspraak en interactieve beleidsvorming. Het gaat om overheidsinitiatieven waarbij burgers vooral bij de beleidsvorming medeverantwoordelijk worden gemaakt voor de besluitvorming. Ze worden hierbij in de rol van coproducent van beleid gemanoeuvreerd (zie WRR 2002: 101-103). Een radicalere variant hierop vinden we onder de noemer 'activerend participatief bestuur' in het werk van Wright en Fung (2004). Het accent ligt hierbij op de reorganisatie van elementen van overheidsbestuur op het microniveau van buurten en wijken. Burgers worden verantwoordelijk gemaakt voor het beheer en de vormgeving van voorzieningen in hun leefomgeving. Ook hier gaat het om vormen van ad hoc-betrokkenheid, waarbij het politieke burgerschap zich vooral richt op beheer in plaats van toeschouwen of toezicht houden. 
Als we alles op een rijtje zetten, dan zien we dat de inbreng van burgers als kiezer nog steeds belangrijk is, maar dat daarnaast beleidsvorming en -uitvoering steeds meer aandacht krijgen via single-issue-organisaties en via spontane of georganiseerde ad hoc-vormen van betrokkenheid. In feite vindt als gevolg van deze ontwikkeling een verdichting van de democratische besluitvorming plaats, omdat de langlopende electorale cyclus en korter lopende beleidscycli in toenemende mate verstrengeld raken binnen het politieke burgerschap. Burgers fungeren niet alleen als toeschouwers die periodiek de leunstoel verruilen voor het stemhokje, maar ook als toezichthouders/stand by-burgers die de beleidsvorming en beleidsprestaties van het systeem in de gaten houden en proberen te corrigeren als deze hen niet bevalt. Ten slotte fungeren burgers ook als coproducenten van beleid, of als beheerders van de voorzieningen in hun leefomgeving. De verdichting van de besluitvorming gaat aldus gepaard met de verbreding van de politieke rollen van burgers en omgekeerd. Er vindt hierdoor een herdefiniëringsproces plaats van burgers als politieke agenten en subjecten (vgl. Isin en Turner 2002).

\subsubsection{DE DUBBELE GELAAGDHEID IN POLITIEK BURGERSCHAP}

De verbreding van de politieke rollen van burgers en de bijbehorende uitbreiding van het participatierepertoire gelden niet voor alle niveaus van het politiekbestuurlijke systeem. Sterker nog, de meeste rollen zijn verbonden met verschillende demoï. Althans, zo kunnen we de samenhang in de veranderingen duiden als we - in navolging van Eder (200o) - burgers niet meer zien als het centrale element van een democratie, maar als een van de spelers op het politieke speelveld. Door deze gedachtesprong kunnen we de mate van politieke activiteit relateren aan de institutionele omstandigheden waarin burgers verkeren en waarop ze zich oriënteren. Politiek burgerschap is in deze conceptie niet langer gebonden aan één demos. Er is sprake van een schakering van demoï zoals de EU, de nationale politieke gemeenschap, de gemeente, de buurt, of zelfs een beleidsveld, waarmee op wisselende momenten identificatie plaatsvindt. In de praktijk levert dit een gelaagd beeld op van politiek burgerschap, waarbij op het nationale niveau vooral via het stembiljet invloed wordt uitgeoefend door burgers die verder vooral als toeschouwer fungeren. Verder zien we op specifieke beleidsvelden dat burgers zich bij de beleidsvorming laten representeren door collectieve toezichthouders, zoals single-issue-organisaties. Op het lokale niveau van de gemeente, wijk of buurt bemoeien individuele burgers zich met zowel beleidsvorming als beleidsuitvoering in de rol van toezichthouder/stand by-burger, coproducent of in de rol van burgerbeheerder.

De gelaagdheid van het politieke burgerschap kent echter nog een tweede dimensie die niet zozeer de verschillende demoï aangaat, maar de verschillende reacties van burgers op de veelheid aan keuzes waarmee ze door politieke partijen, bestuursorganen, beleidsnetwerken, single-issue-organisaties, belangenorganisaties en beleidsinterventies worden geconfronteerd. De kwaliteit van het politieke burgerschap lijkt daarbij sterker afhankelijk van hun individuele 
reflexiviteit en van de politieke identificaties, loyaliteiten en verantwoordelijkheidsgevoelens die bepaalde politieke spelers, politieke gemeenschappen, of politieke processen bij hen oproepen. De mate van activiteit en passiviteit in het politieke gedrag kan als gevolg hiervan sterk variëren, evenals de intensiteit van de politieke betrokkenheid. De variatie op beide dimensies kunnen we duiden in termen van vier verschillende politieke burgerschapsstijlen, die ik elders heb omschreven als actief, afwachtend, afhankelijk en afzijdig (WRR 2002: 107-108).

Op basis van een aantal empirische kenmerken, ontleend aan gegevens van Motivaction (2001), kan een duiding worden gegeven van de vier burgerschapsstijlen. Deze stijlen kunnen bovendien op interpretatieve wijze worden gekoppeld aan de verschillende rollen van burgers. Hierdoor krijgt de gelaagdheid van de reacties op politieke omstandigheden meer profiel (zie tabel 3.1).

Tabel 3.1 Typologie van vier burgerschapsstijlen en verschillende rollen van burgers

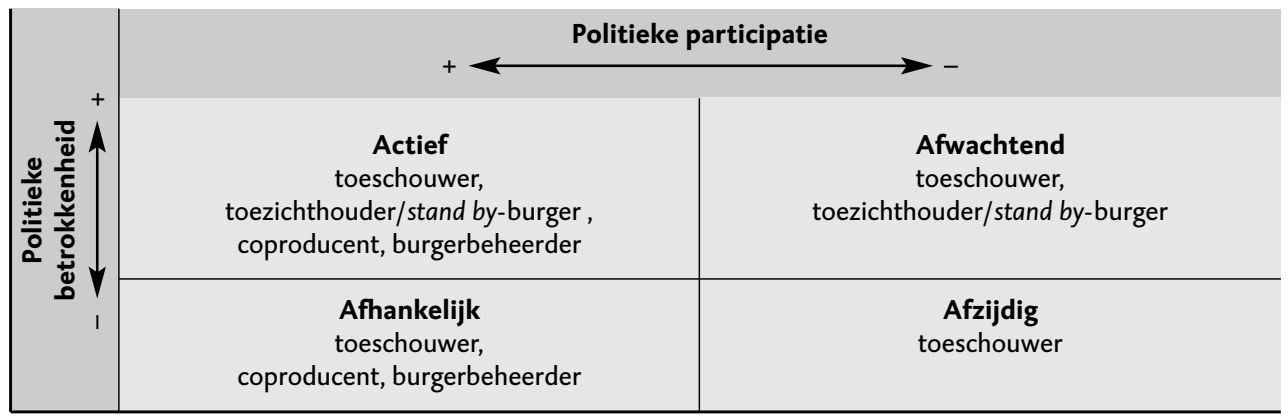

De actieve burgerschapsstijl kenmerkt zich door vertrouwen en een kritische doch welwillende houding jegens de overheid, waarbij interactie en reflectie centraal staan. Bij deze kenmerken passen volgens mij zowel de rollen van toeschouwer, toezichthouder/stand by-burger, als de rollen van coproducent of burgerbeheerder. De afwachtende burgerschapsstijl kenmerkt zich door een veel lagere intensiteit dan de actieve. Kenmerkend voor deze stijl is de behoefte aan informatie en de neiging tot actie als persoonlijke belangen in het geding (lijken te) zijn. Conformisme met politiek op nationaal niveau en een reactieve houding jegens lokale politiek lijken de twee gezichten van burgers te vormen bij deze stijl. Hierbij passen volgens mij de rollen van toeschouwer en van toezichthouder/stand by-burger. De afhankelijke burgerschapsstijl wordt gekenmerkt door afstand tot de nationale overheid, gezagsgetrouw gedrag en betrokkenheid bij de lokale politiek. Hierbij passen volgens mij de rollen van toeschouwer en misschien die van coproducent of burgerbeheerder. De afzijdige burgerschapsstijl, ten slotte, kenmerkt zich door een grote afstand tot overheid en politiek, gekoppeld aan een wantrouwige en intolerante houding jegens gezag. Bij deze stijl kan ik mij vooralsnog alleen de rol van toeschouwer voorstellen. 
Duidelijk is dat de gelaagdheid in de figuur slechts een interpretatie ${ }^{6}$ vormt van verschillende gedragsreacties en verschillende rollen van burgers, die tezamen kenmerkend zijn voor de grote veelzijdigheid van het huidige politieke burgerschap.

\subsection{VERANDEREND POLITIEK BURGERSCHAP EN DEMOCRATIE: EEN INTERPRETATIE}

De samenhang tussen veranderend politiek burgerschap en het functioneren van het politiek-bestuurlijke systeem betekent dat er ook samenhang bestaat met het functioneren van de democratie. In de eerste plaats valt daarbij op dat de gelaagdheid van het politieke burgerschap in termen van gedragsreacties en rollen in feite alle theoretische posities uit de inleiding bestrijkt. De burger als toeschouwer die vooral input biedt op nationaal niveau is in ruime mate aanwezig, hetgeen een bevestiging vormt van de liberale opvattingen over representatieve democratie. In andere demoï zien we een verzwakking van deze positie optreden ten faveure van de andere posities. Nog steeds op het nationale niveau zien we dat ook de liberaal-participatieve positie vertegenwoordigd wordt, maar dan in een nieuw jasje van single-issue-organisaties als collectieve toezichthouders, gericht op specifieke beleidsvelden. De deliberatieve positie zien we vertegenwoordigd in de rol van coproducent of burgerbeheerder, die participeert in en argumenteert over de voorzieningen op lokaal niveau. Ten slotte biedt de rol van burger als toezichthouder/stand by-burger steun aan de constructivistische positie, doordat burgers in deze rol dominante discoursen in de beleidsvorming en -uitvoering proberen te beïnvloeden. De hamvraag is echter hoe we de huidige dubbele rol van politieke burgerschapspraktijken met behulp van deze theoretische posities kunnen waarderen. Wat zijn de mogelijke perverse gevolgen van de huidige ontwikkelingen?

Vanuit de liberaal-representatieve positie is er altijd sprake van lage verwachtingen van de betrokkenheid van burgers. De rol van toeschouwer die bij alle burgerschapsstijlen zit ingebakken is derhalve onproblematisch, zolang burgers maar blijven stemmen. Uiteraard blijft hier de behoefte bestaan aan inspanningen om de betrokkenheid en participatie bij verkiezingen op verschillende niveaus te bevorderen.

Een punt van zorg vanuit het liberaal-participatieve perspectief is de collectieve belangenbehartiging op bepaalde beleidsdomeinen door single-issue-organisaties. Niet iedereen is lid van dergelijke organisaties, waardoor er een potentiële bron van ongelijkheid ontstaat in de representatie van burgers. De omvang van dit probleem is echter minder groot dan het lijkt, omdat ook vroeger bij politieke partijen de omvang van het lidmaatschap niet dekkend was voor de bevolking. Problematisch is echter dat alleen bepaalde issues aan bod komen. Er dreigt als gevolg hiervan een ondervertegenwoordiging van beleidsthema's die burgers niet interessant genoeg vinden, of waarvoor weinig tot geen serieuze collectieve representanten beschikbaar zijn. 
Vanuit de deliberatieve en de constructivistische democratieopvattingen, ten slotte, zijn ook enkele problemen te identificeren. Ten eerste dreigt het gevaar dat de representativiteit van de beleidsvorming of -uitvoering door de overheid wordt ondergraven door de inzet van burgers als beheerders van voorzieningen of als coproducenten bij interactieve beleidsvorming. Het zijn namelijk vaak dezelfde mensen die warmlopen voor dit soort door de overheid georganiseerde vormen van betrokkenheid. Een ander reëel probleem is de neiging tot het 'overvragen' van burgers, omdat - zoals blijkt uit tabel 3.1 - niet alle burgers een burgerschapsstijl hanteren die past bij de rol van coproducent of burgerbeheerder. Het is echter nog te vroeg om hierover een meer definitieve waardering uit te kunnen spreken, omdat de literatuur over onder andere interactieve beleidsvorming nog een overwegend beschrijvend of prescriptief karakter heeft, in plaats van een analytisch of evaluatief karakter (zie Bovens 2003: 51).

Ten tweede dreigt het gevaar van ongelijke representatie bij spontane ad hocvormen van betrokkenheid in reactie op beleidsinterventies. Vaak weten de hardste schreeuwers hun belangen het beste over het voetlicht te brengen. Hierdoor kan een 'democratie van de grote monden' ontstaan, waarbij alleen de zeer mondige burgers hun zaakjes goed voor elkaar hebben. Tegelijkertijd moeten we ervoor waken om hard schreeuwen al te snel negatief te duiden door te verwijzen naar eigenbelang of NIMBY-gedrag. Burgers kunnen ook spontaan hun stem verheffen, als reactie op beleidsinterventies die ook hun medeburgers aangaan. Bovendien kunnen er als gevolg van spontaan protest en participatie leereffecten optreden, waarbij burgers inzien dat er bredere belangen spelen die de moeite van hun betrokkenheid waard zijn. Verdergaand empirisch onderzoek naar beleidsinterventies op lokaal niveau zal moeten uitwijzen welke soorten motivaties burgers bij dit soort ingrepen bewegen en in welke mate er leereffecten optreden. Pas op basis daarvan kunnen we vooral de constructivistische democratieopvattingen verder aanscherpen en een serieuze plek geven binnen de overwegend liberale consensus. 


\section{NOTEN}

1 De auteur wil graag zijn dank uitspreken aan prof. dr. I. de Haan en drs. M. Sie Dhian Ho voor hun nuttige en stimulerende commentaar op deze bijdrage.

2 Verwijzend naar diverse publicaties van de Amerikaanse politicoloog Robert Dahl.

3 Helaas zijn er voor deze indicator geen recentere cijfers beschikbaar, omdat deze vraag sinds 1996 niet meer in het onderzoek is opgenomen.

4 De opkomst in Nederland voor de meest recente verkiezingen voor het Europees Parlement op 1o juni, vertoont voor het eerst sinds lange tijd echter weer een stijgende lijn. De opkomst was nu 39,1\%, hetgeen een stijging betekent van 9,2\% ten opzichte van 1999. Wellicht dat de grotere aandacht voor Europa in de media aan deze stijging heeft bijgedragen.

5 Daarom zijn deze vragen kernvragen in mijn proefschrift in voorbereiding over moderne burgers en veranderend politiek burgerschap in Nederland.

6 Ik hoop deze interpretatie de komende jaren met aanvullend empirisch onderzoek te onderbouwen. 


\section{LITERATUUR}

Beck, U., A. Giddens en S. Lash (1994) Reflexive modernization, politics, tradition and aesthetics in the modern social order, Oxford: Polity Press.

Beer, P. de (2004) 'Individualisering zit tussen de oren', in J.W. Duyvendak en M. Huurenkamp (red.), Kiezen voor de kudde. Lichte gemeenschappen en de nieuwe meerderheid, Amsterdam: Van Gennep: 18-36.

Beus, J. de (2000) 'Veerkracht en misnoegen in de duurzame democratie: de kernstaten sinds 1989', in F. Becker et al. (red.), De toekomst van de democratie; het eenentwintigste jaarboek voor het democratisch socialisme, Amsterdam: De Arbeiderspers/Wiardi Beckman Stichting.

Beus, J. de (2001) Een primaat van politiek, Amsterdam: Vossiuspers UvA.

Beus, J. de (2002) Na de beeldenstorm. Een beschouwing over de werking van de toeschouwersdemocratie in Nederland, Uitgesproken als derde Etty Hilsumlezing, Deventer, 29 november 2003 .

Bovens, M. (2002) 'De permanente verplaatsing van de politiek', in S\&D, 12: 14-20.

Bovens, M. (2003) De digitale republiek, democratie en rechtsstaat in de informatiemaatschappij, Amsterdam: Amsterdam University Press.

Bovens, M., et al. (1995) De verplaatsing van de politiek, Amsterdam: Wiardi Beckman Stichting.

Brink, G. van den (2001) Geweld als uitdaging. De betekenis van agressief gedrag onder hedendaagse jongeren, Utrecht: NIZw.

Brink, G. van den (2002) Mondiger of moeilijker? Een studie naar de politieke habitus van hedendaagse burgers, WRR Voorstudies en achtergronden V115, Den Haag: Sdu.

Burns, N., K. Schlozman en S. Verba (2001) The private roots of public action, Cambridge (Mass.): Harvard University Press.

Cruikshank, B. (1999) The will to empower: democratic citizens and other subjects, Cornell University Press.

Dekker, P. (2000a) 'Politieke participatie', in J. Thomassen, K. Aarts en H. Van der Kolk, Politieke veranderingen in Nederland 1971-1998; kiezers en de smalle marges van de democratie, Den Haag: Sdu.

Dekker, P. (200ob) 'Vijfentwintig jaar politieke betrokkenheid en participatie', in A.E. Bronner, Recente ontwikkelingen in het marktonderzoek, Haarlem: De Vrieseborch.

Dekker, P. (2002) 'Sterkere democraten, zwakkere democratie? Veranderingen in politieke betrokkenheid en participatie 1970-2000', in B en M, themanummer 'Bezige burgers', 29, 2: 55-66.

Dekker, P., P. Ester en H. Vinken (2003) 'Civil society, social trust and democratic involvement', in W. Arts et al., The cultural diversity of European unity: 217-253, Leiden: Brill.

Dekker, P. en J. De Hart (2003) 'Participatie', in De sociale staat van Nederland 2003, Den Haag: SCP: 151-172.

Dekker, P. en M. Hooghe (2003) 'De burger-nachtwaker, naar een informalisering van de politieke participatie van de Nederlandse en Vlaamse bevolking' in Sociologische Gids, 50, 2: 156-202. 
Dekker, P., M. Lampert en F. Spangenberg (2004) 'De politieke onvrede van 2002', in F. Bronner, Jaarboek marktonderzoek 2004, Haarlem: Vrieseborch.

Eder, K. (2000) 'Social movement organizations and the democratic order: reorganizing the social basis of political citizenship in complex societies', in C. Crouch, K. Eder en D. Tambini, Citizenship, markets and the state, Oxford: Oxford University Press: 213-237.

Elchardus, M. (2002) De dramademocratie, Tielt: Lannoo.

Elchardus, M. (2004) 'Autonome volgzaamheid', blz. 205-212 in J.W. Duyvendak en M. Huurenkamp (red.), Kiezen voor de kudde. Lichte gemeenschappen en de nieuwe meerderheid., Amsterdam: Van Gennep.

Ferree, M.M., W.A. Gamson, J. Gerhards en D. Rucht (2002) 'Four models of the public sphere in modern democracies', blz. 289-324 in Theory and society, 31.

Foweraker, J. en T. Landman (1997) Citizenship Rights and Social Movements, Oxford: Oxford University Press.

Hajer, M. (2003) 'A frame in the fields: policymaking and the reinvention of politics', blz. 88-108 in M. Hajer en H. Wagenaar (eds.), Deliberative policy analysis. Understanding governance in the network society, Cambridge: Cambridge University Press.

Hajer, M., T. Akkerman en J. Grin (2001) 'Interactief beleid en deliberatieve democratie. Kansen voor vernieuwing van het democratisch bestuur', in Openbaar Bestuur, 2001, 2: 7-10.

Heijden, H.A. van der (1992) 'Van kleinschalig utopisme naar postgiro-activisme? De milieubeweging 1970-1990’, in J.W. Duyvendak, R. Koopmans, H.A. van der Heijden en L. Wijmans, Tussen verbeelding en macht, 25 jaar nieuwe sociale bewegingen in Nederland, Amsterdam: suA.

Hooghe, M. en D. Houtman (2003) 'Omstreden instituties. Instellingen in een geïndividualiseerde samenleving', in Sociologische Gids, 50, 2: 115-130.

Isin, E.F. en B.S. Turner (2002) 'Citizenship studies: an introduction', blz. 1-1o in E.F. Isin en B.S. Turner (eds.), Handbook of citizenship studies, London: Sage.

Jansweijer, R.M.A. (1987) Private leefvormen, publieke gevolgen, WRR Voorstudies en Achtergronden V57, Den Haag: Sdu uitgevers.

Ministerie van Algemene Zaken (2003) Meedoen, meer werk, minder regels: hoofdlijnenakkoord voor het kabinet CDA, VVD, D66, http://www.minaz.nl/regeringsbeleid/regeerakkoord/docs/regeerakkoord2003.doc (20-5-2003).

Motivaction (2001) Burgerschapsstijlen en overheidscommunicatie, http://www.toekomst-comm.nl/preview/bijlagen/bijlageo5.doc (mei 2001).

Putnam, R.D. (1995) 'Bowling alone: America's declining social capital', in Journal of Democracy, 6, 1: 65-78.

Putnam, R.D. (2000) Bowling alone, the collapse and revival of American community, New York: Simon \& Schuster.

Ribberink, A. (1998) Leidsvrouwen en zaakwaarneemsters, een geschiedenis van de Aktiegroep Man Vrouw Maatschappij (MVM), 1968-1973, Hilversum: Uitgeverij Verloren.

Schudson, M. (1998) The good citizen, a history of American civic life, New York: The free press.

Schudson, M. (1999) Good citizens and bad history: today's political ideals in historical perspective, 'Keynote lecture presented at the conference The transformation of civic life', 13-12-1999, Nashville and Murfreesboro, Tennessee. 
Schuyt, C.J.M. en I. Verhoeven (2003) 'Institutioneel vertrouwen als bron van legitimiteit', in Openbaar Bestuur, 13, 3: 11-14.

Selle, P. en K. Strømsnes (2001) 'Membership and democracy', blz. 134-147 in P. Dekker en E.M. Uslaner (eds.), Social capital and participation in everyday life, London and New York: Routledge.

Sociaal en Cultureel Planbureau (2001) Trends in de tijd. Een schets van recente ontwikkelingen in tijdsbesteding en tijdsordening, Den Haag: SCP.

Sociaal en Cultureel Planbureau (2002) Sociaal en cultureel rapport 2002. De kwaliteit van de kwartaire sector, Den Haag: SCP.

Sociaal en Cultureel Planbureau (2003a) De meerkeuzemaatschappij. Facetten van de temporele organisatie van verplichtingen en voorzieningen, Den Haag: SCP.

Sociaal en Cultureel Planbureau (2003b) De sociale staat van Nederland 2003, Den Haag: SCP.

Tielman, R. (1982) Homoseksualiteit in Nederland, Meppel/Amsterdam: Boom.

Tops, P. en S. Zouridis (200o) Burgers en overheidscommunicatie, http://www.toekomstcomm.nl/preview/bijlagen/bijlageo3.doc (November 200o).

Verba, S., K. Schlozman en H.E. Brady (1995) Voice and equality. Civic voluntarism in American politics., Cambridge (Mass.): Harvard University Press.

Vinken, H. en P. Ester (2002) The culture of engagement. The promise of the internet, 'ISA XV World congress', 7-7-2002, Brisbane, Australië.

Vinken, H. en P. Ester (2003) Civic generations in Europe. A critical assessment of civic involvement of European generations since the 1980s, 'Midwest political science association national conference', 3-4-2003, Palmer house hilton, Chicago.

Wetenschappelijke Raad voor het Regeringsbeleid (2002) De toekomst van de nationale rechtsstaat, Rapporten aan de regering nr. 63, Den Haag: Sdu Uitgevers.

Wright, E.O. en A. Fung (2004) 'Een pleidooi voor actief burgerbestuur', in S\&D, 61, 1/2: $36-43$. 


\title{
4 NABIJE DEMOCRATIE
}

\author{
C.A. Hazeu
}

4.1 INLEIDING: DE STAAT VAN ONGENOEGEN

\section{Democratie onder vuur...}

Op de stand van zaken van de democratie in Nederland zijn verschillende visies mogelijk, die onder andere beïnvloed worden door de tijdspanne van beschouwing. Wanneer we ons vooral richten op de recente jaren dan lijkt de legitimiteit van de vertegenwoordigende democratie onder vuur te liggen. Na de rampen in Enschede en Volendam werd alles wat misging in beleid en politiek - het falende integratiebeleid, wachtlijsten in de zorg, achterstanden in het onderwijs, en met terugwerkende kracht het debacle van Srebrenica - geassocieerd met de (gesloten) politieke cultuur en de depolitisering en verambtelijking van de politiek onder 'paars'. Pim Fortuyn kapitaliseerde dat ongenoegen. En Gerard van Westerloo maakte een scherpe journalistieke analyse in zijn Niet spreken met de bestuurder (2003). Daarin nam hij ook een verslag op van een rondgang langs een aantal vooraanstaande politicologen en bestuurskundigen. Wie dat stuk leest, moet wel concluderen dat de Nederlandse democratie in een ontluisterende staat verkeert.

Die sombere visie kan op abstract niveau in verband worden gebracht met de geleidelijke afkalving van het idee in een maakbare samenleving te leven, en op concreet niveau met de gevolgen die burgers ondervinden van bezuinigingen op collectieve voorzieningen. Dat leidt tot gevoelens van ongemak en ongenoegen; sentimenten die in de tegenwoordige 'dramademocratie' (Elchardus 2003) worden opgespeeld en aangeblazen - wat anderzijds natuurlijk nog geen reden is om ze geheel en al te bagatelliseren!

\section{...of business as usual?}

Maar wanneer we 'meegaan' in die sentimenten en analyses, moeten we toch ook oppassen om niet door te schieten, alsof het verleden (de jaren vijftig? de jaren zestig? de jaren zeventig? of nog elders te situeren in de tijd?) een paradijs vormde, waaruit we $n u$ verjaagd zijn. Ruimte voor de nodige relativering is er ook. Zo laat de oudste reportage - over de Amsterdamse trambestuurders van begin jaren tachtig - uit diezelfde bundel van Van Westerloo (2003) zien dat de 'staat van ongenoegen' niet plotseling in 2002 uitbrak, maar latent steeds, of in ieder geval al veel langer, aanwezig is. Een vermeend 'verloren paradijs' is, met andere woorden, geen dwingend referentiepunt voor de beoordeling van momentaan ongenoegen. In een beschouwing over de staat van de Nederlandse democratie kan ook het - meer historiserende - referentiepunt worden genomen van een gematigde tevredenheid als de 'normale' state of mind in een samenleving. 
En 'gematigde tevredenheid' is dus ook: gematigde onvrede - dat is de andere helft van het glas. Wie die meer historiserende bril opzet en zich wat losmaakt van incidenten, hypes en ander tijdgebonden 'drama', kijkt anders naar diezelfde samenleving, bestuur en democratie. Een longitudinale SCP-studie bijvoorbeeld naar de mate van sociale cohesie in de Nederlandse samenleving die in precies dezelfde tumultueuze periode uitkwam (juni 2002), laat dat perfect zien. Er zijn allerlei ontwikkelingen gaande (individualisering, informatisering, etc.) en toch is er veel business as usual als het gaat om de waardering van bestuur en democratie. Op de overheid wordt gemopperd, zij is er te veel en moet efficiënter, er is een 'kloof' tussen bestuur en burgers, etc., maar strikt genomen is dat niet zo heel anders dan tien, dertig, vijftig of honderd jaar daarvoor, wat ook doet vermoeden dat het over tien, dertig, vijftig of honderd jaar niet wezenlijk anders zal zijn. Er zijn nu eenmaal altijd veel continue lijnen aan te wijzen in de geschiedenis van de maatschappelijke ontwikkeling; een breekpunt van meer radicale discontinuïteit is daarentegen een betrekkelijke zeldzaamheid.

De terminologie verandert natuurlijk wél in de tijd, want dat is nodig om publieke aandacht te blijven genereren - er moet wel een nieuw 'verhaal' zijn. En daarbij hoort ook dat vanuit het nú de beschrijving van het verleden ook vaak het karakter krijgt van een imagined history: een zodanige (her)interpretatie dat de verhalen van nú het gewenste contrast krijgen. Zo is bijvoorbeeld het idee dat de jaren zeventig (1) volledig in het licht stonden van een 'maakbare samenleving', en (2) dat dit beeld algemeen gedeeld werd, en (3) dat het overheidshandelen toen een totaal andere rol speelde in de samenleving (daarom wordt het vaak als contrapunt gekozen), in hoge mate een constructie achteraf!

Ook in het verleden was de politieke democratie voor velen altijd al een 'toeschouwersdemocratie'. Een hoge effectieve participatie van grote groepen burgers blijft in de wereldgeschiedenis zeer uitzonderlijk; het is in ieder geval niet de 'normale' gang der dingen in een democratie. Het is maar zo nu en dan burgerrevolutie, en zelfs dán komen verhoudingsgewijs meestal nog slechts betrekkelijk weinig mensen in beweging. Mensen hebben nu eenmaal nog vele andere - grote en kleine - dingen aan hun hoofd; (te) hoge verwachtingen koesteren van grootscheepse en aanhoudende burgerparticipatie is dus weinig realistisch. Dat geldt voor alle bestuurslagen: Europa, nationaal, de gemeente of de eigen buurt- en wijkdemocratie: het is allemaal best een beetje belangrijk.

Bij sommigen evenwel is een hoge verwachting van aanhoudende, effectieve, directe burgerparticipatie wél onderdeel van hun wereldbeeld, maar dat is vermoedelijk het gevolg van pars pro toto-denken: de kenmerken van de eigen groep (goed opgeleid, etc.) worden gezien als generiek geldend voor de hele samenleving.

Niettemin er is wél een probleem in de legitimatie van het democratische bestel: die werkt onvoldoende meer via de 'oude' mechanismen. Zo konden in de hoogtijdagen van de verzuiling en ideologische tegenstellingen de politieke stromin- 
gen nog een zichtbare achterban mobiliseren. Dat is nu anders. Momenteel is nog maar zo'n vier procent van het electoraat lid van een politieke partij, en dat betreft vooral goedgebekte, hoogopgeleide mensen, die in de politiek al iets 'zijn' of dat willen worden. Vele anderen voelen een grote afstand tot het bestuur, of het nu 'Brussel', 'Den Haag' of de eigen (deel)gemeente is.

Deze bijdrage gaat over de gevolgen van het afnemende belang van ideologische grondpatronen, en het gevaar dat dit leidt tot 'democratische leertekorten' bij burgers. Een van de mogelijke antwoorden op dit probleem is mijns inziens om meer ruimte te geven aan meer en betere vormen van 'democratie van onderop'. Dit betekent dat de overheid moet ophouden om de burger vooral als een (lastige) klant te zien, maar hem meer zou moeten benaderen als een citoyen: iemand die niet alleen consument is van zijn leefomgeving (en klaagt bij of over de overheid als er iets mis is), maar ook medeproducent daarvan. Dit vraagt om het stimuleren van actief burgerschap (vgl. Van Gunsteren 1992), en het creëren van situaties en constellaties waarbij burger en overheid, ieder naar zijn eigen 'maat', zijn steentje bijdraagt aan een grotere leefbaarheid. En dan niet volgens de formule: óf (de overheid) óf (de burger) - wat vooral een redenering is die een verantwoordelijkheid naar de andere partij afschuift, maar volgens een én-én-formule. Dit kan op verschillende manieren en op verschillende niveaus bewerkstelligd worden.

Vanuit het 'Buurtproject' dat momenteel loopt bij de WRR, kijk ik in deze bijdrage of er betere mogelijkheden denkbaar zijn voor nieuwe leerprocessen 'in de buurt' en de doorwerking die dit kan hebben op een revitalisering van de (lokale) democratie. De uitgesproken belangstelling die er momenteel (weer) is voor 'de buurt', 'democratie van onderop', civil community etc. heeft natuurlijk alles te maken met de 'Fortuyn-revolutie' van 2002, waardoor zo pijnlijk kwam vast te staan dat het democratisch bestuur voornamelijk gedragen wordt door een beperkte en op zichzelf en elkaar gerichte bestuurselite, die (te) weinig binding heeft met bredere lagen in de samenleving.

\subsection{HET ONVERMINDERDE BELANG VAN HET PUBLIEKE EN DE ROL VAN DE OVERHEID}

Samenleven is samen-delen met elkaar - van kennis, geld, andere hulpbronnen, ruimte, geluidsoverlast, enzovoorts - en dat gaat regelmatig van 'au'. Economen noemen dat: externe effecten. Om die processen in banen te leiden, zijn vormen van overheidsregulering en -presteren vaak het meest doelmatig. Dat legt inperkingen op aan het gedrag van burgers en bedrijven, en ook dat doet vaak van 'au' alleen weer op een andere manier. We zijn dan wellicht assertiever en individualistischer geworden, en eisen meer autonomie en vrijheid voor ons eigen ik, maar als de overheid die ruimte ook gunt aan 16,3 miljoen medeburgers, is dat toch vaak ook weer niet de bedoeling. Ik wil wel zonder vergunning een dakkapel kunnen bouwen, maar zou toch ook graag de dakkapel van de buurman tegen kunnen houden, en het is nog makkelijker als de overheid dat voor me doet! 
De laatste jaren heeft de overheid zich nogal van streek laten maken door dit opkomende individualisme, de komst van de netwerksamenleving (een optiek waarin er vele - in beginsel gelijkwaardige - 'spelers' zijn, en het publieke element dus geen doorslaggevende rol speelt), de 'deliberatieve democratie', etc. Soms vertonen overheid en ambtenarij zelfs trekjes van zelfhaat: sorry dat ik besta; we zijn ook maar een van de vele spelers. Maar strikt genomen is er weinig aanleiding voor dit gebrek aan zelfvertrouwen. In een samenleving die - door de bank genomen - welvarend, gecompliceerd en 'druk' is, en vele vormen van congestie kent in de onderlinge verhoudingen, gaat individueel handelen (van burgers, bedrijven en andere organisaties) al snel gepaard met onvoorziene en/of onbedoelde en/of ongewenste externe effecten voor anderen. In veel gevallen blijven vormen van overheidshandelen dan onverminderd de meest doelmatige oplossing om het samen-leven in goede banen te leiden.

Soms wordt er wel geponeerd dat meer individualisering en een meer assertieve burgerschapsstijl gepaard zouden (moeten) gaan met minder behoefte aan overheidsoptreden (bijv. Jacobs et al. 2003), maar - hoe paradoxaal dit wellicht ook lijkt - het tegendeel is aanzienlijk waarschijnlijker! Deze trends leiden er met name toe dat de verwachtingen van burgers richting overheid (maar ook ten aanzien van andere instanties) toenemen. In een samenleving waarin veel mogelijk is, verwachten we ook veel; van onszelf, van elkaar én van de (overheids)instanties. Als de politiek onvoldoende reageert op die nieuwe wensen, kan dit leiden tot een verminderd vertrouwen in overheid, politiek en democratie.

Maar ook als de politiek dat juist veel of meer doet, kan de tevredenheid over en het vertrouwen in de overheid afnemen! Een klein lokaal voorbeeld daarvan (geconstateerd in het kader van het Buurtonderzoek van de WRR): als de overheid in buurten - op aangeven van burgers - het hondenpoepprobleem (vaak leefbaarheidsklacht nummer één!) grootscheeps gaat aanpakken, is de voornaamste reactie van diezelfde burgers: "Nu zien we 'ze' eindelijk, maar laten ze vooral probleem $\mathrm{x}, \mathrm{y}$, z eens aanpakken!”

Een vergelijkbaar beeld liet de stadsreiniging in Den Haag onlangs zien: de Dienst Stedelijk Beheer heeft in 2003 de interne lat voor 'schoon' hoger gelegd (van 3 naar 4 op een schaal die loopt van o tot 5). Inmiddels bereikt men een kwaliteit die boven de 4 ligt ("nog schoner kan bijna niet", is daarbij de beleving van de dienstmedewerkers), maar uit de stadsenquêtering naar de waardering van de burgers blijkt dat die het over diezelfde periode juist vuiler vinden geworden! Blijkbaar werkt het zó dat als het schoner wordt op straat, mensen zich ook meer gaan gedragen naar een schonere omgeving en dus ook hun eisen aan die omgeving en aan de schoonmakende dienst opschroeven. ${ }^{2}$

De relatie burger-overheidshandelen, zeker in de informatiesamenleving, wordt blijkbaar gekenmerkt door Linus' law: "given enough eyes, all bugs are shallow," oftewel: hoe meer ogen er kijken, hoe eerder er fouten en tekorten worden gevonden. 


\subsection{POLITIEK, DEMOCRATIE EN DE GLOBAL/LOCAL-PARADOX}

\subsubsection{POLITIEK EN DEMOCRATIE}

In de vorige paragraaf heb ik twee dingen vastgesteld: (1) de overheid is van onverminderd belang in onze samenleving, en (2) de overheid doet het niet snel 'goed'. In dat licht zal ze uit het defensief moeten komen waar ze de afgelopen jaren in is geraakt en haar prestaties ook beter moeten uitdragen. Hoewel het boek The end of democracy al is geschreven (door Guehenno), is het einde van de democratie nog lang niet in zicht - al is het maar omdat een plezant alternatief zich niet aandient: het democratische bestuur moet onverminderd collectieve problemen aanpakken. En dat vergt beleidskeuzes, die ook altijd een distributieve component hebben: het aloude Who gets what, when and how? En via het ontwikkelen en uitdragen van de criteria voor die beleidskeuzes komt democratische legitimering tot stand.

De afgelopen tien à twintig jaar is het idee opgeld gaan doen dat beleidskeuzes ontlopen zouden kunnen worden door overal win-win-situaties na te streven. Dat is echter een misvatting, die nu gelukkig ook over z'n hoogtepunt is (vgl. Hazeu 2003). Ongetwijfeld is 'win-win' zo hier en daar mogelijk, maar streven naar een algemene depolitisering van het politieke keuzeproces leidt vooral tot 'één pot nat' en 'dood in de pot' - wat de geschiedenis van 'paars' wel heeft bewezen.

Beleidskeuzes zijn onverminderd nodig; die moeten gelegitimeerd worden, en politiek en democratie zijn daar de mechanismen voor. Het beleidsproces kent in ideaaltypische zin twee stadia. Eerst binden politici met elkaar de strijd aan - om de gunst van de kiezer, collega-parlementsleden en vertegenwoordigers van maatschappelijke organisaties - over de doelen van beleid aan de input-kant van het politieke proces. Daarna volgt het bestuurlijke vraagstuk van de effectieve uitvoering in termen van output. Met de uitbouw van de verzorgingsstaat heeft er een verschuiving plaatsgevonden van input-gerichte legitimiteit van beleid aan de hand van verzuilde ideologische grondslagen naar output-georiënteerde effectiviteit van beleid als belangrijkste bron van legitimiteit (Hemerijck 2003). En met het afnemend belang van ideologische grondpatronen spitsen actuele politieke discussies zich steeds meer toe op concrete beleidsvraagstukken - en dan met name op beleidsfiasco's - en het 'op de man c.q. vrouw spelen'. ${ }^{3}$

\subsubsection{MEER GLOBAL}

In het huidige tijdsgewricht zien we een aantal ontwikkelingen - schaalvergroting, internationalisering, etc. - die van verstrekkend belang zijn voor de soevereiniteit van de nationale democratie, het bestuur en het parlement. De voortgaande economische internationalisering en Europeanisering van economisch beleid hebben de grenzen verlegd waarbinnen nationaal beleid mogelijk is. Vandaag de dag zijn lidstaten van de EU onderworpen aan een breed scala van Euro- 
pese regelgeving, die enerzijds is ingebed in een institutionele architectuur van de interne markt en de Europese Monetaire Unie (EMU), maar die anderzijds in toenemende mate wordt geschraagd door de sociale dialoog in de Europese arbeidsverhoudingen en het gebruik van 'soft law' en methoden van open coördinatie op terreinen als werk-gelegenheid en pensioenen.

Ondanks processen van internationalisering en Europese economische integratie en sociale maatschappelijke differentiatie zullen politieke processen en aanpassingen in het beleid van de nu semi-soevereine natiestaten van de EU nationaal van karakter blijven, vooral omdat de democratische legitimering van hervormingen om aan de nieuwe eisen van de EU en aan de noden van burgers te voldoen, aan de nationale politiek gebonden blijft (vgl. Dijstelbloem et al. 2004). Nationale regeringen blijven politiek en electoraal verantwoordelijk voor het lot van hun economieën en de prestaties van de overheid in de voorzieningensfeer.

\subsubsection{MAAR OOK MEER LOCAL}

De internationaliseringstendensen gaan tegelijkertijd gepaard met nieuwe impulsen voor het kleinschalige: het 'cocoonen' in club, wijk, buurt. Dat is blijkbaar ook een reactie op die opschalingsprocessen. Die zogenaamde global/localparadox vloeit voort uit de behoefte van mensen om vat te houden op hun leven. Het leidt er per saldo toe dat er een zekere - al eerder geconstateerde (bijv. door Bovens et al. 1995) - 'verplaatsing' van de democratie op natiestaatniveau gaande is naar andere bestuurlijke en democratische lagen - zowel 'naar boven', als 'naar beneden' - en ook 'naar buiten': de school, de werkplek, het ziekenhuis, de kinderopvang, etc. De verplaatsingsthese van Bovens et al. was vooral gebaseerd op de observatie dat dit 'verplaatste beleid' uitmondde in een democratisch tekort. Vandaar dat zij een pleidooi hielden voor een parallelle verplaatsing van democratie. 'Den Haag vandaag' realiseert zich echter (te) weinig en met tegenzin dat hun vat op zaken afneemt, want ziet zichzelf nog graag als het centrum van de wereld. De Haagse representatieve democratie maakt daardoor ook (te) weinig 'verbinding' met de democratische vormen en initiatieven op andere niveaus en lijkt daarmee over steeds minder te gaan. Het 'scharnier' tussen wat burgers krijgen en wat 'Den Haag' vermag, is onverminderd aanwezig, maar verzwakt daardoor wél. ${ }^{4}$

Een tweede verzwakking van de verbinding tussen burgers en 'Den Haag' wordt veroorzaakt door de afnemende werfkracht van ideologische grondpatronen (par. 4.4). Er worden natuurlijk ook antwoorden gezocht, en soms gevonden, op die dreigende democratische lacune. In paragraaf 4.5 ga ik in op één onderdeel van deze problematiek, namelijk de mogelijkheden die 'de buurt' biedt voor het aanpakken van collectieve leefbaarheidsproblemen in de directe leefomgeving, en de leerschool die dat kan zijn voor mensen om zich democratische vaardigheden eigen te maken. Deze toespitsing wil overigens niet zeggen dat andere toespitsingen niet ook mogelijk zijn (de Europese democratie of de democratie op school zijn net zo goed vraagstukken), of dat ze daar op voorhand superieur aan is. 


\subsection{LACUNE IN DE DEMOCRATIE}

\subsubsection{DE PARADOX VAN ONTIDEOLOGISERENDE BURGERS EN REÏDEOLOGISERENDE POLITIEKE PARTIJEN}

Wanneer we naar de opvattingen van 'de mensen in het land' kijken, blijken die in de realiteit van de 21e eeuw vaak een mengelmoesje te zijn. Diepe ideologische overtuigingen worden steeds zeldzamer, en dat maakt het op ideologie gebaseerde partijensysteem steeds meer tot een 'schaatsen op dun ijs'. Je ziet dat onder meer aan de verkiezingsuitslagen die van de ene op de andere keer steeds grotere omslagen laten zien, aan politici die makkelijker overstappen van de ene naar de andere partij of die publiekelijk hun voorkeur uitspreken voor een fusie van partijen (alsof het twee bedrijven zijn in een branche). We 'zweven'!

En juist omdat ideologieën geen grote werfkracht meer hebben, hebben de bestaande politieke partijen soms de neiging om opkomende vraagstukken te ideologiseren. Dusdoende proberen ze het stramien te stutten waarop ze gebaseerd zijn. Thema's als immigratie, integratie, scheiding van kerk en staat etc. zijn bijvoorbeeld onderwerp van reïdeologisering 'van bovenaf'. De tijd zal moeten leren wat deze strijdige tendenties zullen betekenen voor de toekomst van politieke partijen; een eeuw geleden waren ze niet meer dan kieslijsten. Een ander gevolg van de afnemende werfkracht van ideologische patronen is dat nieuwe partijen uit het betrekkelijke 'niets' een grote electorale winst kunnen boeken, zoals de LPF in 2002 en Europa Transparant in 2004 illustreerden. En verder gaat het er steeds meer om of een partij erin slaagt om een aantrekkelijk 'mannetje' of 'vrouwtje' naar voren te schuiven.

De traditionele politieke partijen en verwante zuilenorganisaties hebben dus niet meer de betekenis en slagkracht die ze in het verleden hadden. En de nevenfunctie die ze hadden - het enerzijds overbrengen aan het bestuur van wat er leeft onder mensen en aan de andere kant het bijbrengen aan burgers van enig begrip voor hoe het bestuur moet functioneren en afwegingen maken - wordt ook minder goed vervuld. De 'officiële politiek' is voor de meeste mensen niet veel meer dan een via de media waargenomen schouwspel; vandaar dat wordt gesproken van een 'toeschouwersdemocratie' of een 'dramademocratie' (Elchardus 2003). Samen geven die termen een dubbele problematiek aan: de 'gewone' burger is als regel louter nog toeschouwer bij democratische processen en gebeurtenissen, en zelf geen speler. Maar bovendien is het spel waarvan hij toeschouwer is ook niet naturel, maar is voor hem geselecteerd (door de media) en geregisseerd (door de politici). Ik zou daarom willen spreken van een gemanipuleerde toeschouwersdemocratie.

Deze geleidelijke verwording van het politieke bestuur leidt tot ongenoegen, onbehagen en onvrede. Tussen burger enerzijds en bestuur en politiek anderzijds bestaat nauwelijks nog een 'wij-gevoel'. Soms leidt dit sluimerende ongenoegen tot een uitbarsting, zoals de 'Pim-revolutie' in Nederland of de witte marsen in 
België eind jaren negentig. En als dat ongenoegen tot uitdrukking komt op het niveau van politieke organisatie, zijn het vooral anti-bestelpartijen die opkomen: partijen die vooral sterk zijn om weerstand en weerzin, en soms zelfs uitgesproken ressentiment ('ze', op het gemeentehuis of in 'Den Haag', die er 'een puinhoop van maken'), te organiseren en te verwoorden, en die ver verwijderd zijn van het traditionele bestuur en de traditionele bestuurspartijen. Op nationaal niveau hebben we er inmiddels een regering met het LPF opzitten, maar in het algemeen wordt de lokale politiek nog veel meer door dit fenomeen gekenmerkt dan de nationale.

\subsubsection{EEN LACUNE IN HET DEMOCRATISCH PROCES}

Hoewel 'aan de buitenkant' ons stelsel van ideologische zuilen nog intact lijkt, is een diepe 'worteling' in de hoofden van mensen geleidelijk aan verdwenen. Meer dan veertig jaar nadat Daniel Bell het al aankondigde, lijkt The end of ideology nu veel dichterbij. Daarop gebaseerde politieke partijen, daaraan verwante zuilorganisaties, de gemeenteraad etc. spelen een minder prominente rol dan vroeger. Het gevolg daarvan is dat mensen het proces van democratie zich ook minder eigen maken langs partijpolitieke lijnen en zuilen. Dit mechanisme waarmee mensen inlevingsgevoel kregen van hoe bestuur tot stand komt, werkt tegenwoordig minder goed. Vergeleken met het verleden is er in dit opzicht een democratische lacune te constateren in onze samenleving; geen lacune dus in institutionele vormen, maar een lacune in het leren van democratische processen: hoe leren we dingen met elkaar te doen, met alle geven en nemen dat daarbij hoort, met ook zo nu en dan je verlies moeten nemen en dan toch blijmoedig verder gaan?

\subsection{EEN ANTWOORD OP DE DEMOCRATISCHE LACUNE: LEERPROCESSEN IN BUURT EN WIJK}

\subsubsection{CIVIC SKILLS EN CIVIC COMMUNITY}

Wezenselementen van democratie als mentaliteit zijn dat mensen zich ook in een andere partij en opvatting, en in de uitvoeringsproblematiek kunnen verplaatsen en er begrip voor hebben dat democratisch bestuur ook een afwegingsproces is tussen verschillende keuzemogelijkheden. Daarom blijft het van cruciaal belang dat mensen op het basale niveau van hun directe leefomgeving civic skills ontwikkelen; niet alleen voor de democratie op dat basale niveau zelf, maar ook omdat het kan bijdragen aan enige empathie voor politici en andere beleidsmakers die op hogere niveaus ook moeten werken in dit soort processen (Hazeu 2003a: 118). Want dat is de crux van dit betoog: de ervaringen van burgerinitiatieven vanuit welbegrepen eigenbelang (een schonere wijk, behoud van parkeerplaatsen, etc.) zouden ook een bodem moeten kunnen leggen voor een meer all-round-burgerschap, al is het maar dat door dit soort initiatieven men ook geconfronteerd wordt en kennismaakt met buren, gemeente, instanties, etc., en hún opvattingen en logica's. Het gaat dus om de volgordelijke trits van 'ontmoeting' - inleving - (enig) begrip. 
Tegelijkertijd met het in de vorige paragraaf beschreven betekenisverlies van ideologische structuren zie je tal van initiatieven van burgers om in gezamenlijkheid wat te bereiken, bijvoorbeeld rondom scholen (de 'brede school'), sportverenigingen, de werkplek, veiligheid, enzovoorts. De bloei van de civic community biedt daarmee onverminderd een leerschool om buiten (partij)politieke lijnen vormen van democratie 'mee' te krijgen. (Voor een andere - aanvechtbare en aangevochten - opvatting, zie: Putnam (2000), die ervan overtuigd is dat in de vs de civic community aan ernstige slijtage onderhevig is.) In wezen zijn dit de bekende vormen van politiek en democratie buiten het directe overheidsbestel; de al eerder aangehaalde brochure van Bovens et al. uit 1995 waarin dit neergezet wordt als een 'verplaatsing' van de politiek, is met name op dit punt bekritiseerd: er waren altijd al meer democratische vormen voor wie niet te overheidscentrisch wil kijken. In ieder geval wél betrekkelijk nieuw zijn alle ICT-mogelijkheden die ook nieuwe vormen van kleinschalige democratie mogelijk maken; ook gemeenten experimenteren daarin volop mee met internetpanels, burgertevredenheidsenquêtes, enzovoorts.

\subsubsection{BUURT EN BURGERSCHAP}

Verder zie je dat wijk en buurt de laatste jaren in zekere zin zijn herontdekt, ook als niveaus van democratische leerprocessen (zie bijv. De Boer 2001, Duyvendak en Van der Graaf 2001, Elchardus 2003, Van Kempen 2003, Van der Lans 2003 en Wright en Fung 2004). Als zodanig kun je daar verschillend over denken; op basis van de verschillende stromingen in de literatuur en empirisch onderzoek schetst Van Kempen (2003) in zijn recente oratie drie posities: (1) de buurt is steeds minder, of zelfs niet, van belang, (2) de buurt is een beetje van belang, en

(3) de buurt is van belang. Hij vat zijn conclusies als volgt samen (blz. 11):

"Al met al ontstaat het volgende beeld. In een aantal studies komt naar voren dat de buurt niet zo erg belangrijk is voor degenen die in die buurt wonen. In dergelijke studies wordt meestal op een kwantitatieve wijze onderzocht hoe de invloed van de buurt (op bijvoorbeeld de sociaal-economische positie) zich verhoudt tot de invloed van persoonlijke en huishoudensvariabelen.

Uit andere, vaak meer kwalitatieve, studies wordt duidelijk dat voor specifieke groepen (lage inkomens, allochtonen) de buurt er om verschillende redenen wel degelijk nog toe doet. Het kan daarbij in positieve zin gaan om steun, opvang en sociale contacten en in negatieve zin om de ontwikkeling van 'deviante' waarden en normen, als gevolg van contacten tussen mensen in achterstandsposities."

\subsubsection{WIJKBELEID EN WIJKAANPAKKEN}

Op tal van plaatsen is er de laatste jaren - opnieuw! (voor een beschrijving van twee eerdere naoorlogse 'golven' van wijkbeleid met achterliggende ideeën, zie: De Boer 2001) - wijkbeleid en een wijkaanpak ontwikkeld. Daar zie je hoe 'van onderop' burgers en 'sociale spelers' die in direct contact staan met die burgers (opbouwwerk, scholen, woningcorporaties, politie, etc.), bezig zijn in een bonte 
variatie aan interessante initiatieven en vernieuwingen: het Deventer wijkbeleid, het Opzoomeren in Rotterdam, Justitie in de Buurt, buurt-mediation, tal van invullingen van het Brede School-concept, woningcorporaties die zich intensief met de leefbaarheid in de buurt bezighouden, etc. Soms vinden er ook grootscheepse fysieke herstructureringen plaats (Hoogvliet en de Bijlmer zijn de bekendste voorbeelden) die mede gemotiveerd worden door de wens om de maatschappelijke positie van mensen in achterstandsbuurten te verbeteren. Daarover moeten beleidsmakers (incl. woningcorporaties) zich overigens niet te grote illusies koesteren, zo blijkt onder andere uit onderzoek van Ostendorf et al. (2001). Maar er kan wel voor gezorgd worden dat de fysieke omgeving aantrekkelijker wordt en het leven van de bewoners van die buurten een stuk aangenamer. De slagkracht en slaagkans van kleinschalige initiatieven van onderop nemen toe als lokale en nationale overheid ook de gezindheid hebben om de burger meer directe macht te geven of te laten over zijn onmiddellijke leefomgeving, buurt of wijk (vgl. Elchardus 2003). Als mensen meer invloed kunnen uitoefenen, krijgen hun capaciteiten voor burgerschap meer kansen om te groeien (vgl. Wright en Fung 2004 met hun Empowered Participatory Governance-model en Vos en Van Doorn 2004).

Een belangrijke afgeleide van die kleinschalige aanpakken van leefbaarheidsproblemen is dat het een zelfversterkende werking kan hebben als buurten beter gaan functioneren. Het leidt tot een mobilisatie van (democratische) betrokkenheid en kan cynisme onder en uitsluiting van mensen helpen tegengaan. Ook ontstaan er nieuwe vormen van participatie en betrokkenheid, inclusief nieuwe bestuursvormen, instrumenten en processen. Voorbeelden van een dergelijke 'discursieve beleidsontwikkeling’ (Dekker 2003) zijn: burgerfora, burgerjury’s, wijkmarkten, consensusconferenties, burgerraadplegingen via internet, een politieke markt (zoals in Almere). Steeds meer gemeenten ontdekken inmiddels dat het organiseren van het traditionele avondje inspraak een luie manier van going through the motions is en onvoldoende - en vaak ook onbevredigend voor alle partijen - om burgers bij het beleid te betrekken.

\subsubsection{MEER GRASSROOTS-DEMOCRATIE}

Als ideologische partijen en zuilen er steeds minder in slagen om op een geloofwaardige manier onze democratie te dragen, moeten we dan niet meer gaan investeren in andere en betere mogelijkheden om grassroots-democratie vorm te geven? Zijn er, met andere woorden, geen betere mogelijkheden te creëren om van onderop - ook vanuit wijken en buurten - nieuwe initiatieven, bewegingen en 'clubs' te krijgen die ook positieve doelen en idealen uitdragen, die iets willen bereiken, niet alleen tegen zaken ageren, maar ook dingen mogelijk willen maken en daarvoor verantwoordelijkheid nemen en eventueel ook willen 'doorgroeien' naar het dragen van een verantwoordelijkheid voor het 'gemenebest'?

Het inzicht dat 'Den Haag' ook niet alles kan, laten volgen door een obligaat beroep op 'eigen verantwoordelijkheid' en het 'over de schutting gooien' van 
publieke verantwoordelijkheid, is zowel onbevredigend als onvoldoende. Eerder zal er gewerkt moeten worden aan versterking van vormen van maatschappelijk zelfbestuur in de woonomgeving en bij het beheer van collectieve voorzieningen. Dat moet burgers dwingen tot een afweging van hun belangen en voorkeuren, aanleiding geven tot serieuze discussies over politieke dilemma's, en - naar men mag hopen - enig begrip kweken voor het dagelijks gemodder van politici (vgl. ook Dekker 2003).

Deze instelling kan ook versterkt worden door bijvoorbeeld gemeenteraden anders te gaan samenstellen: bijvoorbeeld door de plaatsen geheel of gedeeltelijk te vullen met wijkvertegenwoordigers - een wijkdistrictendemocratie. Een voordeel daarvan is dat vertegenwoordigers hun eigen constituency hebben bevochten bij de mensen in de buurt en de wijk, en niet langer als 'lijstvolger' in partijlokalen vooral vaardigheden hebben ontwikkeld om op een lijst te komen. Weg met de lijsttrekkersdemocratie dus! Met dit voorstel ligt wellicht meer cliëntelisme op de loer, maar het voordeel ervan is dat er een veel grotere betrokkenheid en directheid tot stand komt. En het resultaat kan zijn dat wijken zo ook een beetje een politieke arena worden en ook een sterkere schakeling krijgen naar het gemeentepolitieke (en mogelijk indirect ook naar het nationale) niveau.

\subsection{TOT BESLUIT}

De populariteit van nieuwe initiatieven in het (sub)lokale beleid is te verklaren uit het feit dat in toenemende mate wordt gekozen voor een mengvorm van '(democratie) leren' en monitoren. Deelnemers worden gestimuleerd om voor elkaar open te staan, terwijl ze elkaar ook in de gaten houden. Cruciaal voor het slagen van dit soort initiatieven is dat de betrokkenen openstaan voor andere wijzen van totstandbrenging van collectieve arrangementen, zich niet opsluiten in dwingende paradigma's, bereid zijn met en van elkaar te leren, en deze relatief precaire processen niet saboteren.

In de kabinetsvisie Andere overheid (Kabinet 2003a) wordt naar voren gebracht dat het rijk medeoverheden voldoende ruimte moet laten ten aanzien van taken die naar aard en schaal tot de competentie van lokale overheden behoren - het aloude subsidiariteitsbeginsel. Daar ben ik het graag mee eens: de regering en de Tweede Kamer moeten de verleiding weerstaan zich lokale zaken toe te eigenen en te nationaliseren.

Maar is naast dit 'laten'-principe ook niet een 'doen'- principe toe te voegen, in de vorm dat regering en parlement meer initiatieven helpen belichten die goed en inspirerend werken? Dit vergt dat het parlement meer werkt als een scharnier, ${ }^{5}$ meer de andere bestuurslagen monitort en interessante experimenten oppikt en onder de publieke aandacht brengt. In die vorm kan er mogelijk van kleinschalige, nieuwe en experimentele vormen van democratie geleerd worden, ook voor de nationale democratie. Een dergelijke benadering wordt vooral begunstigd door democratische ervaringen en een democratische habitus; (veranderingen in) de 
formele democratische instituties - waar Andere overheid zo sterk het accent op legt - zijn er niet voor nodig.

Ook op het lagere bestuursniveau zouden gemeenten zelf initiatieven kunnen nemen, bijvoorbeeld door sterkte/zwakte-analyses van buurten te maken: waar ligt de kracht en macht van een buurt? Waar liggen de problemen? Uit veldonderzoek is al vaker gebleken dat wanneer je nauwkeuriger kijkt (dan beleidsmakers normaliter doen) naar de kleinschalige netwerken en sociale activiteiten in een buurt, er vaak veel meer potentieel is dan van tevoren gedacht, óók in achterstandswijken (zie bijv. Duyvendak en Van der Graaf 2001; Van der Lans 2003). Wat de gemeente vervolgens kan doen met die sterkte/zwakteanalyses is: de sterktes 'aanlichten', niet door ze onmiddellijk in daarop gebaseerde vormen van beleid gemeentebreed 'uit te rollen', maar eenvoudigweg door ze ook aan andere buurten te laten zien (voorbeeldfunctie, rolmodel). En waar er duidelijke zwaktes liggen, kan de gemeente gericht komen met aanvullend beleid voor die specifieke buurt.

Mijn dubbele conclusie is dat er meer sociaal kapitaal onder mensen is dan de Putnams van deze wereld denken en dat bij tekorten daaraan vaak meer te doen is dan adepten van de 'onmachtige overheid' (willen) denken. 


\section{NOTEN}

I In dat project wordt onderzocht hoe wijk en buurt een aangrijpingspunt kunnen bieden voor het zelforganiserend vermogen van mensen en daarmee voor versterking van sociale cohesie en democratische omgangsvormen.

2 Economen zullen dit verschijnsel herkennen als een (extreme variant van) preference drift.

3 Illustraties van dit fenomeen zijn met name ook te vinden in de gemeentepolitiek, waar - aangezet door de recente dualisering - Raad en College op een grotere afstand van elkaar zijn komen te staan.

$4 \quad$ Maar de problematiek van "hebben we nog verbinding?” wordt wél als steeds klemmender ervaren. Vandaar dat Wouter Bos de wijk intrekt, en nu - sinds februari 2004 - ook premier Balkenende wekelijks een dag in z'n agenda probeert vrij te houden voor werkbezoeken aan de basis. Hopelijk beperken al die de wijk intrekkende politici zich niet tot louter 'luisteren', en zeggen ze ook nog eens wat terug over wat ze vanuit de eigen politieke voorkeur wel of niet aan bepaalde problemen willen doen!

5 Over de 'scharnierfunctie' van de nationale overheid, zie bijv. Scheltema 2002: 342-343. 


\section{LITERATUUR}

Boer, N. de (2001) 'De opkomst van de wijkaanpak als dominante strategie in het sociaal beleid', hoofdstuk 2 in J.W. Duyvendak en L. Veldboer (red.) Meeting point Nederland. Over samenlevingsopbouw, multiculturaliteit en sociale cohesie, Amsterdam: Boom.

Bovens, M. et al. (1995) De verplaatsing van de politiek. Een agenda voor democratische vernieuwing, Amsterdam: WBS.

Dekker, P. (2003) 'Afkeer van de politiek?', Christen-Democratische Verkenningen, winter: $30-36$.

Duyvendak, J.W. en P. van der Graaf (2001) Opzoomeren, stille kracht. Een onderzoek naar de kwaliteiten van het opzoomeren in Rotterdam, Utrecht: Verwey-Jonker Instituut Publicaties.

Dijstelbloem, H., C.A. Hazeu en F. den Hond (2004) 'Een zaak van niveau. De schakelfunctie van de nationale overheid in het Europese milieubeleid', Beleidswetenschap, jrg. 18, 2004, nr. 2: 99-117.

Elchardus, M. (2003) De schizofrenie van populaire politiek. Of hoe ernstig te zijn in een dramademocratie, WRR-lecture Den Haag, 27 november 2003.

Gunsteren, H.R. van (1992) Eigentijds burgerschap, WRR-publicatie vervaardigd onder leiding van Van Gunsteren, Den Haag: Sdu Uitgeverij.

Hazeu, C.A. (2003) 'Van milieubeleid naar duurzaamheidsbeleid. Winst voor het milieu?’, Bestuurswetenschappen, jrg. 57, oktober: 427-432.

Hazeu, C.A. (2003a) 'Is sociaal kapitaal een collectief goed?', in A.P. Ros en H.R.J. Vollebergh (red.) Ontwikkeling en overheid. Opstellen aangeboden aan prof. dr. P.A. Cornelisse, Den Haag: Sdu Uitgevers: 115-124.

Hemerijck, A.C. (2003) 'Vier kernvragen van beleid', Beleid en Maatschappij, jrg. 30, nr. 1: 3-19.

Jacobs, B., F. Kalshoven en P. Tang (2003) 'De nieuwe economische agenda van links (1). Noodzakelijk links', Socialisme \& Democratie, jrg. 6o, nr. 10/11: 12-28.

Kabinet (2003a) Kabinetsvisie 'andere overheid', Tweede Kamer nr. 29362 nr. 1, december 2003.

Kempen, R. van (2003) Stad, buurt en beleid. Over verdeelde steden en gedeelde buurten, oratie Universiteit Utrecht.

Lans, J. van der (2003) Het woninkrijk der Bloemstraters. Individualisering en sociaal kapitaal, Amsterdam: Uitgeverij De Balie.

Ostendorf, W., S. Musterd en S. de Vos (2001) 'Social mix and the neighbourhood effect; policy ambitions and empirical evidence', in: Housing Studies, vol. 16, no. 3: 371-380.

Putnam, R.D. (200o) Bowling alone. The collapse and revival of American community, New York: Simon and Schuster.

Scheltema, M. (2002) 'Hoofdstuk 14: Slotbeschouwing', in C.A. Hazeu en G.J. Kronjee (red.) De vitaliteit van de nationale staat in een internationaliserende wereld, Groningen: Wolters-Noordhoff: 337-347.

Sociaal en Cultureel Planbureau (2002) Zekere banden. Sociale cohesie, leefbaarheid en veiligheid, Den Haag: SCP.

Vos, M.L. en K. van Doorn (2004) Empowerment. Over laten en doen, Delft: Eburon. 
Westerloo, G. van (2003) Niet spreken met de bestuurder, Amsterdam: De Bezige Bij.

Wright, E.O. en A. Fung (2004) 'Een pleidooi voor actief burgerbestuur', Socialisme $\mathbb{\&}$ Democratie, jrg. 61, nr. 1/2: 36-43. 


\title{
5 NAAR EEN MONDIALE DEMOCRATIE? DE ROL VAN 'NIET-STATELIJKE ACTOREN'
}

\author{
B.J.M. Arts
}

\subsection{INLEIDING}

De internationale politiek kent een groot democratisch tekort, zo luidt de algemene opvatting. Weliswaar kennen we een Europees parlement (met overigens beperkte bevoegdheden), maar zeker de mondiale politiek - onderwerp van dit essay - ontbeert iedere democratische traditie en institutie. Er is slechts sprake van 'getrapte legitimiteit'. Het zijn regeringen van landen, al dan niet democratisch gekozen, die de internationale besluitvorming bepalen en controleren, niet de burgers van deze wereld. Nationale parlementen hebben slechts een indirecte rol te spelen, in die zin dat zij de door staatshoofden en regeringsleiders ondertekende internationale afspraken dienen te erkennen. Vaak gebeurt dat stilzwijgend. Bovendien zijn veel burgers en parlementen nauwelijks in internationale kwesties geïnteresseerd, terwijl deze toch verstrekkende gevolgen kunnen hebben. De consequentie is dat een kleine doch mondiale elite van ambtenaren en politici de uitkomsten van de internationale besluitvorming bepalen, zonder noemenswaardige administratieve en politieke verantwoording te hoeven afleggen. Keohane en Nye (200o) omschrijven dit als het club model van de internationale politiek.

Echter, dit bolwerk vertoont meer en meer scheuren. Aanleiding daarvoor is het nauwelijks te vertalen fenomeen global governance. Dit begrip beschrijft een dubbele 'verplaatsing van de politiek'. Van de natiestaat naar zogenaamde 'nietstatelijke actoren' (NSA's) enerzijds (horizontale verplaatsing) en van staten naar intergouvernementele organisaties en regimes anderzijds (verticale verplaatsing). De horizontale verplaatsing houdt in dat de rol en macht van bijvoorbeeld pressiegroepen, belangengroepen, wetenschappers en bedrijven in de internationale politiek is toegenomen, waardoor het geschetste club model aan erosie onderhevig is. De verticale verplaatsing, welke meer autoriteit van intergouvernementele organisaties en internationale regelgeving impliceert, versterkt die erosie nog eens. Internationale politiek wordt steeds belangrijker (gevonden), waardoor de legitimiteit van het elitaire clubmodel afneemt.

De vraag is natuurlijk, in het licht van deze bundel, wat de consequenties zijn van deze overgang van intergouvernementele politiek naar global governance voor democratie. Wordt de nationale democratie verder ondermijnd? Of worden de mogelijkheden voor (aanzetten tot) een mondiale democratie juist vergroot? Het openbreken van Keohane en Nye's clubmodel doet vermoeden dat de democratie hier aan de winnende hand is. Immers, meer en meer (private) partijen lijken nu in staat om mee te praten en uitkomsten in besluitvorming mede te bepalen. Tegelijkertijd moeten we beseffen dat een 'pluralisering' van het politieke 
discours en van de besluitvorming op mondiale schaal niet hetzelfde is als de installatie van een wereldparlement. Niettemin zal de conclusie van dit essay luiden dat, ofschoon van een institutionele mondiale democratie geen sprake is, de toenemende rol en invloed van niet-statelijke actoren wel degelijk als een democratiseringsproces kan worden gezien.

De opzet van het essay is als volgt. Allereerst wordt ingegaan op de (niet onomstreden) idee van de 'verplaatsing van de politiek' (par. 5.2). Er kunnen vele 'verplaatsingen' worden onderscheiden, maar het begrip global governance verwijst naar twee in het bijzonder, zoals hierboven reeds uiteengezet (par. 5.3). Vervolgens komen de politieke rol en macht van niet-statelijke actoren op mondiale schaal aan de orde (par. 5.4). Dit verschijnsel roept een aantal vragen op rondom democratie. Vanuit een institutionele en 'nationale analogie'-visie op democratie kan worden betoogd dat (toenemende) private macht en mondiale democratie haaks op elkaar staan. Echter, een meer inhoudelijke en procesgerichte opvatting van democratie leidt tot een diametraal tegengestelde, en bovendien meer genuanceerde, visie (par. 5.5). Vervolgens wordt bekeken hoe overheden, internationale organisaties alsmede NSA's zelf dit mondiale democratiseringsproces kunnen versterken (par. 5.7). Afsluitend volgen de conclusies (par. 5.8).

\subsection{VERPLAATSING VAN DE POLITIEK}

Vele auteurs onderschrijven inmiddels de stelling dat de politiek zich (ten dele) heeft 'verplaatst'. Zo onderscheiden Bovens et al. (1995) zes typen verplaatsingen:

1 van Den Haag naar intergouvernementele organisaties ('internationalisering');

2 van Den Haag naar maatschappelijke organisaties ('technologisering');

3 van Den Haag naar de rechter ('juridisering');

4 van Den Haag naar de ambtenarij ('verambtelijking');

5 van Den Haag naar het lokaal bestuur ('regionalisering'); en

6 van Den Haag naar de privé-sfeer ('individualisering').

Met name de eerste twee verplaatsingen zijn voor dit essay relevant en interessant. Deze uiten zich ook in de dagelijkse politieke praktijk. Zo stamt zo'n tachtig procent van de huidige milieuwetgeving in Nederland uit Brussel, daagt de Europese Commissie Nederland regelmatig voor het Europese Hof van Justitie vanwege gebrekkige implementatie van EU richtlijnen, wordt het nationale klimaatbeleid door internationale kaders bepaald, is het landbouwbeleid een puur Europese aangelegenheid geworden en nagelt de World Trade Organisation (WTO) de EU en de vs regelmatig aan de schandpaal vanwege protectionistische maatregelen. Tegelijkertijd krijgen decentrale overheden meer bevoegdheden, bijvoorbeeld op het gebied van ruimtelijke ordening, milieu en leefbaarheid. Ook de politieke rol van private partijen is groeiende: zo ontwikkelen bedrijven zelf standaarden en gedragscodes om publieke doelen te realiseren (milieuzorg, arbeidsomstandigheden, mensenrechten, enz.), betalen ze zelf mee aan publieke voorzieningen, bijvoorbeeld in de vorm van publiek-private partnerships, worden maatschappelijke organisaties bij beleidsvoering betrokken (interactief bestuur), en voeren private partijen zelf overheidsbeleid uit (bijvoorbeeld in de natuurbescherming). 
De idee van 'de verplaatsing van de politiek' is echter niet onomstreden. Ten eerste kan men de vraag stellen of deze verschuivingen ook empirisch hard te maken zijn. Zo lijken cijfers enerzijds te wijzen op een zich intensiverend proces van politieke en economische globalisering (Castells 1996; Dicken 1998; Higgott et al. 200o). Maar anderzijds kan men evengoed de stelling verdedigen dat er niets nieuws onder de zon is - ook de periode van het begin van de 20 ste eeuw onderscheidde zich door grote internationale openheid -, en aantonen dat al die transnationale ondernemingen of mondiale non-gouvernementele organisaties (NGO's) toch vooral nationaal en regionaal actief zijn (Hirst en Thompson 1996). Ten tweede leiden beschouwingen over de verplaatsing van de politiek niet zelden tot minimalistische en/of pessimistische visies op de rol van de natiestaat. Zo spreekt Strange (1996) van een 'uitholling van de natiestaat' en van een retreat of the state. Eerder dan staten, zijn het tegenwoordig markten die uitkomsten in de mondiale politiek bepalen, met alle mogelijke negatieve gevolgen voor het waarborgen van het publieke belang van dien. Albrow (1996) trekt soortgelijke conclusies over de natiestaat, maar is meer optimistisch over de gevolgen. Hij ziet reeds de contouren van een 'global state' opdoemen, gebaseerd op de opkomst van mondiale actoren enerzijds en kosmopolitische principes en waarden anderzijds. Anderen bestrijden deze visies echter fel, en betogen dat de natiestaat in het licht van globaliserings- en privatiseringsprocessen weliswaar nieuwe taken en verantwoordelijkheden heeft gekregen, maar nauwelijks aan macht en autoriteit heeft ingeboet (Van Kersbergen et al. 1999). Op sommige terreinen is zijn macht en autoriteit de laatste jaren zelfs uitgebreid (bijv. regulering van internet; zie Knill en Lehmkuhl 2002). Op andere terreinen is er bovendien helemaal niets, of nauwelijks iets, verplaatst! Zo speelt de natiestaat nog steeds een cruciale rol op het gebied van orde en recht, oorlog en vrede en publieke dienstverlening (Hirst 200o). Eerder dan van een verplaatsing van de politiek is het wellicht ook beter om te spreken van een (gedeeltelijke) diffusie of herverdeling van politieke macht en autoriteit over verschillende bestuurlijke lagen en over verschillende politieke actoren, (semi-)publiek dan wel privaat.

Ondanks deze bezwaren hanteer ik in dit essay toch de omschrijving van 'de verplaatsing van de politiek', vooral omdat ik het een mooie metafoor vind. Het woord 'verplaatsing' moet echter niet al te letterlijk worden genomen, in de zin van een zero sum game, met andere woorden: dat een toename van macht en autoriteit op het decentrale en internationale niveau per definitie een verlies op het niveau van de natiestaat inhoudt. Want dan zou de stelling van 'de uitholling van de staat' alsnog kloppen.

\section{$5 \cdot 3$ GLOBAL GOVERNANCE}

De afgelopen jaren heeft het concept global governance een grote vlucht genomen in het vakgebied van de internationale betrekkingen (Held en McGrew 2002; Nye en Donahue 200o; Rosenau en Czempiel 1992). Als analytisch concept neemt het afstand van staatscentrische benaderingen, zoals het neorealisme (Waltz 1976). Niet langer is de natiestaat de enige eenheid van analyse, maar 
regionale en internationale systemen van regulering en 'niet-statelijke actoren' zijn dat eveneens. Wat dat betreft bouwt deze literatuur voort op de transnationale literatuur van de afgelopen dertig jaar (Furtak 1997; Keohane en Nye 1971; Risse-Kappen 1995; Strange 1988). Maar ze gaat ook een stapje verder. Waar het klassieke transnationalisme uit de jaren zeventig niet-statelijke actoren vooral beschouwde als 'externe factoren', die weliswaar door pressie van buitenaf invloed konden uitoefenen op intergouvernementele besluitvorming, beschouwt de global governance-literatuur deze spelers als integraal onderdeel van de complexe bestuurlijke lagen en netwerken, die de huidige mondiale politiek constitueren. In de woorden van Keohane en Nye:

"Governance need not necessarily be conducted exclusively by governments and the international organizations to which they delegate authority. Private firms, associations of firms, NGO's and associations of NGO's all engage in it, often in association with governmental bodies, to create governance; sometimes without governmental authority (2000:12).”

In de literatuur komen grofweg twee omschrijvingen van global governance voor: een brede en een strikte. De brede definitie vat governance op als al die coördinatiemechanismen die erop zijn gericht om individuele handelingen en collectieve doelen op elkaar af te stemmen. En of deze mechanismen nu publiek of privaat van karakter zijn, statelijk of niet-statelijk, doet niet ter zake (Knill en Lehmkuhl 2002). Een voorbeeld hiervan is de definitie van de Commission on Global Governance van de Verenigde Naties (vN) (1998:2): "Governance is the sum of the many ways in which individuals and institutions, both private and public, manage their common affaires". De meer strikte interpretatie definieert governance als alleen nieuwe vormen van bestuur, voorbij de natiestaat en intergouvernementele arrangementen. Een voorbeeld hiervan is de opvatting van Scholte (2000) die global governance synoniem acht voor postsoevereine, triangulaire arrangementen tussen staten, internationale organisaties en niet-statelijke actoren. De strikte benadering ziet met andere woorden een verschuiving optreden van government naar governance (of van intergovernmentalism naar global governance in de internationale arena), terwijl de brede opvatting naar alle vormen van sturing verwijst, hetzij publiek, hetzij privaat, hetzij een combinatie van beide. In dit essay wordt van de laatste betekenis uitgegaan (zie ook: Arts 2001, 2003). De idee dat reguleringsmechanismen op wereldschaal aan verandering onderhevig zijn wordt gedeeld, maar dat sluit het voortbestaan van intergouvernementele arrangementen, naast transnationale en private, of in combinatie met deze, niet uit. In sommige beleidsvelden zijn en blijven staten dominant (veiligheid, politie, criminaliteit, belastingen, e.d.). En ook in dergelijke 'klassieke' arrangementen is sprake van governance.

Volgens Held en McGrew (2002) heeft 'de institutionele architectuur van global governance', zoals zij dat noemen, een aantal onderscheidende kenmerken:

1 ze is meerlagig: van het mondiale niveau tot het lokale, met vele niveaus daartussen (regionaal, nationaal, subnationaal); 
2 ze is pluralistisch: er is sprake van een diffusie en fragmentatie van macht en autoriteit over een veelheid van spelers (van staten tot NGO's);

3 ze kent een variabele geometrie: de politieke relevantie en het bestuurlijk vermogen van de verschillende governance-arrangementen verschillen van issue tot issue, afhankelijk van de betrokken lagen en actoren;

4 ze is complex: het gaat om diverse bestuurlijke lagen, regimes en actoren, met verschillende doch elkaar deels overlappende territoriale en functionele autoriteiten, en met verschillende competenties en macht;

5 ze impliceert (nog steeds) een strategische positie voor nationale regeringen: deze blijven belangrijke bouwstenen voor 'global governance' en voor de legitimatie van de nieuwe architectuur.

\subsection{DE MACHT VAN 'NIET-STATELIJKE ACTOREN'}

NSA's kunnen worden gedefinieerd als al die actoren die geen (representanten van) staten of regeringen zijn, maar die niettemin opereren binnen de institutionele architectuur van global governance (gebaseerd op: Arts et al. 2001; Furtak 1997; Higgot et al. 2000; Held en McGrew 2002). In de literatuur worden verschillende categorieën van NSA's onderscheiden: intergouvernementele organisaties (IGO's), internationale niet-gouvernementele organisaties (INGO's), transnationale ondernemingen (TNO's), wetenschappelijke kennisnetwerken, bevrijdingsbewegingen, criminele organisaties en terroristische netwerken. In dit essay wordt echter alleen op INGO's en TNO's ingegaan, en blijven IGO's en andere NSA's buiten beschouwing. Deze afbakening heeft simpelweg met de expertise van de auteur te maken (Arts 1998, 2003).

Een NGO is volgens de VN elke organisatie die niet door een regering of groep van regeringen is opgericht - al mogen zij wel lid van een NGO zijn, zolang zij de onafhankelijkheid van de organisatie maar niet aantasten -, en die bovendien geen geweld gebruikt of predikt, noch een winstoogmerk heeft (Feld and Jordan 1983; Willets 1996a). Voorbeelden zijn Amnesty International, Oxfam International, Greenpeace en de natuurbeschermingsorganisatie International Union for Conservation of Nature and Natural Resources (IUCN) (waar landen overigens ook lid van mogen zijn). Deze omschrijving maakt duidelijk dat een NGO een engere categorie is dan een NSA: zo vallen gewelddadige organisaties en bedrijven buiten de definitie. Tegelijkertijd moet worden beseft dat belangengroepen, die bedrijven vertegenwoordigen, zoals de International Chamber of Commerce of the World Business Council on Sustainable Development, wél als een NGo kunnen worden gezien (iets wat de VN ook doet). Deze hebben, in tegenstelling tot hun leden, geen winstoogmerk, maar zijn uit op politieke invloed. In de literatuur worden die ook wel aangeduid als BINGO's (business NGO's). Individuele TNO's, die overigens meer en meer uit zijn op directe beïnvloeding van politiek en beleid buiten BINGO's om (De Bievre 2002), vallen buiten de categorie van een NGO. Zij zijn echter wel NSA's, en kunnen worden gedefinieerd als grootschalige, commerciële, op winst gerichte organisaties met kantoren en/of productie-eenheden in meerdere landen. Voorbeelden zijn Shell, Unilever, Ford, enzovoorts. 
Volgens vele auteurs zijn NSA's politiek relevante spelers geworden binnen de architectuur van 'global governance'. Morss (1991) onderscheidt vier criteria van politieke relevantie: 1) hun formele erkenning door IGO’s; 2) hun sterk gegroeide aantal in de internationale betrekkingen; 3 ) hun omvangrijke achterban wereldwijd; en 4) hun toegenomen invloed op internationale organisaties en staten. Steeds meer internationale organisaties onderkennen het belang van NSA's, en erkennen hen ook in formele zin. Een goed voorbeeld is de VN. In artikel 71 van het VN-Handvest staat: "The Economic and Social Council may make suitable arrangements for consultation with nongovernmental organizations which are concerned with matters within its competence." Als gevolg van dit artikel kunnen NGO's een 'consultatieve status' bij de VN verkrijgen, die verschillende bevoegdheden garandeert: van het indienen van agendapunten, het laten circuleren van nota's, het hebben van spreektijd tot het kunnen bijwonen van vergaderingen. Vele gespecialiseerde VN-organisaties en -conferenties hebben inmiddels zulke voorzieningen in het leven geroepen. Bovendien zijn de regels voor NGOparticipatie in de VN de afgelopen jaren versoepeld, mede door precedentwerking in de praktijk (Willets 1996b). Zo mogen nu ook nationale en lokale NGO's internationale vN-bijeenkomsten bijwonen.

Wat het aantal internationaal opererende NGO's betreft geven schattingen aan dat er nu meer dan 20.000 zijn, terwijl in de jaren vijftig dat aantal bleef steken op zo'n 1.000 organisaties (Van der Schot en Van Veen 1997). Tegelijkertijd is hun achterban in dezelfde tijd gegroeid van enkele honderdduizenden naar tientallen miljoenen leden en sympathisanten wereldwijd. Het aantal TNO's is nog indrukwekkender en schattingen spreken van zo'n 40.000 (Higgot et al. 200o). Bovendien zou hun aantal in de jaren negentig bijna verdubbeld zijn. Echter, bij TNO's kan niet van 'achterbannen' worden gesproken in de zin van NGO's. Niettemin hebben deze ondernemingen veel werknemers in dienst en bedienen zij miljoenen consumenten wereldwijd. Dergelijke 'achterbannen' spelen wel degelijk een rol als deze spelers invloed proberen uit te oefenen op regeringen.

Het vierde criterium van politieke relevantie sluit bij dit laatste punt aan: politieke macht. Elders heb ik betoogd dat NSA's drie vormen van politieke macht uitoefenen: beslismacht, discursieve macht en regulatieve macht (Arts 2003). De eerste vorm van macht verwijst naar invloed op politieke besluitvorming (Dahl 1961). Voorbeelden van dergelijke machtsuitoefening zijn milieuorganisaties die het Klimaat- en Biodiversiteitsverdrag hebben weten te beïnvloeden (Arts 1998), of TNO's die invloed hebben gehad op aspecten van het wTO-beleid, zoals de bescherming van intellectuele eigendomsrechten in internationale handel (Higgott et al. 20oo). De tweede vorm van macht verwijst naar de invloed van NSA's op het politieke discours. Deze machtsvorm is breder dan de eerste, en betreft de invloed van actoren op de politieke agenda: wat staat er wel op en wat niet, en wat wordt eraan toegevoegd of onttrokken (Bachrach and Baratz 1961)? Met andere woorden: wat wordt er de politiek 'in' en wat wordt er de politiek 'uit' gedefinieerd (Hajer 1995)? Deze processen van in- en uitsluiting verlopen via het politieke discours en zijn vaak minder zichtbaar en meer van een lange-termijn- 
karakter dan politieke besluitvorming en de daaraan gerelateerde beslismacht. Een goed voorbeeld is de wijze waarop 'de universele rechten van de mens' op de internationale politieke agenda zijn terechtgekomen, een proces waarbij mensenrechtenorganisaties - uiteenlopend van oude organisaties zoals de Carnegy Group tot recentere zoals Amnesty International en Human Rights Watch - een doorslaggevende rol hebben gespeeld (Korey 1998).

Een derde vorm ('gezicht') van macht van NSA's is regulatieve macht. Steeds meer blijken deze spelers in staat om zelf internationale regels te ontwerpen en te implementeren, grotendeels buiten regeringen en IGO's om. Goede voorbeelden zijn internationale standaarden op het gebied van interne milieuzorg binnen bedrijven, zoals Responsible Care en ISO 14001 (Gunningham et al. 1998). Deze standaarden zijn (in beginsel) private initiatieven, maar met een duidelijk publiek doel voor ogen (milieukwaliteit), ze kunnen bovendien bindend zijn voor een sector (zoals Responsible Care voor de chemische industrie) of een 'bindend' netwerkeffect hebben (voor toegang tot bepaalde markten en ketens is het dragen van het Iso-keurmerk zeker een pre). Soms zijn deze standaarden een gevolg van behoeften binnen de private sector zelf, bijvoorbeeld om initiatieven in verschillende landen internationaal te harmoniseren, soms een reactie op overheidsfalen. Een voorbeeld van dat laatste is het FSC-keurmerk op gebied van duurzaam hout (Bendel 200o). Omdat overheden faalden om een internationaal bossenverdrag tot stand te brengen, zijn NGO's en (delen van) het bedrijfsleven rond de tafel gaan zitten. Uiteindelijk hebben deze gekozen voor het vaststellen van een internationale standaard van duurzame bosexploitatie. Wanneer bedrijven daaraan voldoen, mogen zij het FSC-keurmerk dragen, en herkennen consumenten de duurzaamheid van het product.

\section{5 'DEMOCRATIE' VERSUS 'DEMOCRATISERING'}

In het voorafgaande is duidelijk geworden dat de opkomst van global governance is samengegaan met een verspreiding van politieke macht, met als gevolg een (zekere mate van) empowerment van NSA's. De vraag is of deze ontwikkeling positief of negatief beoordeeld moet worden vanuit het perspectief van democratie. Verschillende antwoorden zijn denkbaar, gegeven de vele visies op democratie in het algemeen en mondiale democratie in het bijzonder. Een pessimistische visie start met de (terechte) constatering dat er sprake is van een groot democratisch tekort op mondiale schaal. Immers, democratische instituties en tradities, zoals we die kennen binnen (de meeste) natiestaten, ontbreken. Geen verkiezingen, geen parlement, geen grondwet, geen onafhankelijke rechtspraak, geen vrije media, etc. Bovendien is op wereldschaal niet sprake van één demos, zoals op nationale schaal vaak het geval is, maar van verscheidene demoï. Een gezamenlijk kosmopolitisch burgerschap is dan ook moeilijk voorstelbaar. Daarnaast is van politieke verantwoording afleggen in de mondiale politiek nauwelijks sprake. Vertegenwoordigers van staten en regeringen nemen binnen intergouvernementele organisaties (IGO's) besluiten, daarna stemmen nationale parlementen meestal stilzwijgend in, zonder enig politiek debat. 
$\mathrm{Nu}$ wordt de situatie, met meer politieke macht voor niet-statelijke actoren (NSA's), er helaas niet beter op. Immers, er 'lekt' macht weg van nationale regeringen, de enige actoren binnen 'global governance' die tenminste nog enige legitimiteit bezitten, want ze zijn (meestal) door hun eigen burgers gekozen. NSA's kunnen dat laatste niet zeggen. Weliswaar kiezen leden soms hun eigen vertegenwoordigers of bestuurders, maar de gemiddelde burger heeft geen inspraak in het reilen en zeilen van bijvoorbeeld NGO's. Met andere woorden: het democratisch tekort wordt met machtigere NSA's alleen maar groter. Terwijl zij politieke legitimiteit ontberen, bepalen zij wel meer en meer de uitkomsten van global governance. Het antwoord op de hierboven gestelde vraag is dus nadrukkelijk negatief: neen, meer NSA's en machtigere NSA's in global governance leiden niet tot meer mondiale democratie. Integendeel, het democratische tekort wordt alleen maar groter!

Opmerkelijk aan bovenstaande redenering - die enigszins gechargeerd is opgeschreven, maar waarvan elementen zeker herkenbaar zijn in meer pessimistische beschouwingen over mondiale democratie (zie Grugel 2003) - is dat zij uitgaat van een nationale opvatting van democratie (met andere woorden: van een 'nationale analogie'). Men neemt het ideaaltypische model van nationale democratie als uitgangspunt, en gebruikt dat als standaard om de institutionele architectuur van global governance de maat te nemen. Daarbij staat een soort 'productevaluatie' centraal: de vraag is of democratische instituties aanwezig zijn of niet. Mogelijke processen van democratisering worden daarmee uit het oog verloren ('procesevaluatie'). Bovendien hanteert men een eenzijdige opvatting van politieke legitimiteit, namelijk input-legitimiteit. Deze vorm van legitimiteit verwijst naar de manier waarop vertegenwoordigers in het politieke systeem zijn benoemd, via democratische verkiezingen of anderszins. Alleen in het eerste geval is sprake van een hoge politieke legitimiteit (waarmee NSA's dus automatisch laag scoren op deze meetlat).

In het openingshoofdstuk van deze Verkenning laten Engelen en Sie Dhian Ho echter zien dat - naast input-legitimiteit - ook andere vormen van legitimiteit voor democratie en democratisering relevant zijn: namelijk throughput-, outputen feedback-legitimiteit. Throughput-legitimiteit verwijst naar de wijze waarop besluitvorming tot stand komt, of deze gesloten is of open, participatie van burgers toestaat of niet. Met andere woorden: Who decides? (Dahl 1961). Outputlegitimiteit heeft te maken met de vraag of de uitkomsten van politieke besluitvorming ook de wensen van burgers representeren (ook wel 'responsiviteit' genoemd). En feedback-legitimiteit verwijst naar de mate waarin politici en bestuurders verantwoording afleggen, aan elkaar en aan burgers. Ofschoon veel democratietheorieën de nadruk leggen op input-legitimiteit, zijn in een gezonde democratie ook de andere vormen van politieke legitimiteit - participatie, responsiviteit en verantwoording - goed ontwikkeld. Deze bredere visie op politieke legitimiteit maakt het mogelijk om op een andere wijze naar NSA's en mondiale democratie te kijken, iets wat ik hieronder zal doen. Bovendien neem ik daarbij een 'procesperspectief' als uitgangspunt. Ik beoordeel mondiale democra- 
tie dus niet zozeer in termen van 'producten' (democratische instituties), maar in termen van 'processen' (democratisering).

Boven ben ik ingegaan op de drie 'gezichten van macht' van niet-statelijke actoren (NSA's). Deze drie vormen van macht zijn gerelateerd aan de verschillende typen van politieke legitimiteit, die zojuist zijn onderscheiden. Zo bestaat er (in potentie) een link tussen de beslismacht van NSA's enerzijds en (grotere) throughput- en output-legitimiteit van het politieke systeem anderzijds. Immers, beslismacht - zoals in dit essay gedefinieerd - verwijst naar het vermogen van NSA's om intergouvernementele besluitvorming te beïnvloeden. Vaak betekent het uitoefenen van dergelijke macht dat deze organisaties in staat zijn, of in staat worden gesteld, om in de besluitvorming te participeren. Met een toename van de participatie van NSA's wordt het politieke proces meer pluralistisch van karakter, waardoor de throughput-legitimiteit in potentie wordt verhoogd. Bovendien kan daarmee ook de output-legitimiteit worden vergroot, omdat politieke uitkomsten meer de preferenties van NSA's weerspiegelen dan zonder hun beslismacht het geval zou zijn geweest.

Hierbij wordt wel voetstoots aangenomen dat de preferenties van NSA's (deels) overeenkomen met die van 'de' burger, groepen burgers of met het publieke belang. Anders is - met de toename van NSA-macht - alleen sprake van private belangenbehartiging, hetgeen toch moeilijk als 'democratisering' kan worden gezien. Vanuit een rationele-keuzemodel geredeneerd is deze aanname echter moeilijk te verdedigen. In dit model speelt alleen eigenbelang - in termen van nutsmaximalisatie - een rol. Om redenen van empirische adequaatheid ga ik echter liever van een reflexive action-model uit, waarin mixed motives, sociale normen, routines en discursief handelen een rol spelen (Giddens 1984). Binnen dit model is het heel wel mogelijk dat private actoren, naast het behartigen van eigenbelang, publieke zaken dienen: routinematig, onder sociale druk dan wel bewust. Bovendien zijn actoren volgens dit model bereid om van elkaar te leren en in staat om eigen posities aan te passen of los te laten (Van Stokkom 2003).

Discursieve macht - het tweede gezicht van macht - is voornamelijk met inputlegitimiteit verbonden. Via deze vorm van macht bepalen NSA's mede welke thema's en ideeën het politieke proces ingaan, en welke niet. Dat kunnen thema's en ideeën zijn die parlementen, regeringen en/of intergouvernementele organisaties (IGO's) links laten liggen, maar die wel in de samenleving van belang worden geacht. Indien dat het geval is, impliceert discursieve macht van NSA's een verhoging van de input-legitimiteit van het politieke systeem, al verloopt dat niet via de kanalen van formele, democratische verkiezingen en dito vormen van representatie.

Regulatieve macht, ten slotte, heeft vooral met output-legitimiteit van doen. Via deze vorm van macht creëren NSA's zelf politiek relevante uitkomsten, zoals standaarden. Soms is deze zelfregulering een reactie op overheidsfalen. In dat geval leidt zelfregulering zeker tot een verhoging van de output-legitimiteit. 
Immers, daar waar overheden niet kunnen of willen ingaan op wensen uit de samenleving, springen NSA's zelf in dat gat. Maar ook zonder overheidsfalen als achtergrond verhoogt regulatieve macht in potentie de output-legitimiteit. Via de weg van zelfregulering vallen beleidsobject en -subject namelijk samen, hetgeen de kans vergroot dat regelgeving het beste is toegesneden op de eisen en wensen van diegenen die de regels moeten volgen of uitvoeren.

Wanneer nu een toename van macht van NSA's inderdaad samengaat met een toename van de input, throughput en output-legitimiteit van de mondiale politiek, dan is die samenhang mijns inziens als een proces van democratisering op te vatten. Immers, in dat geval weerspiegelen het politieke discours en de politieke agenda meer maatschappelijke preferenties dan voorheen, neemt de inspraak in besluitvorming toe en sluit het resulterende beleid beter aan bij de wensen en eisen vanuit de samenleving.

\subsection{NADERE POSITIONERING}

Het voorgaande put uit en sluit aan bij democratieopvattingen uit de literatuur - algemene opvattingen zowel als specifieke - over mondiale democratie. Om met het laatste te beginnen, Grugel (2003) onderscheidt drie perspectieven op globalisering en democratie: 1) mondiaal kapitalisme en democratisch pessimisme; 2) global governance en democratisch optimisme; en 3) sociaal activisme, tussen hoop en vrees voor de democratie.

Het eerste perspectief hoort thuis in de neo-marxistische traditie en is erg kritisch ten aanzien van de ontwikkeling van het mondiale kapitalisme. Globalisering wordt verstaan als neoliberalisme, een proces dat voornamelijk de rijken ten goede komt en de armen verder marginaliseert. Met andere woorden, de ongelijkheid in de wereld neemt alleen maar verder toe, wat moeilijk als een proces van democratisering te verkopen is. Bovendien ondermijnt de economische globalisering de macht van de natiestaat, het politieke niveau waar de democratie vooralsnog het beste geïnstitutionaliseerd is.

Het tweede (liberale dan wel sociaal-democratische) perspectief is veel optimistischer. Men constateert allereerst dat er zich reeds een mondiaal reguleringssysteem heeft gevestigd (global governance), waarin zich - ten tweede - kansen voordoen om een proces van democratisering in gang te zetten. Een proces dat, volgens dit perspectief, de nationale democratie niet zozeer vervangt als wel aanvult. Er wordt gewezen op de opkomst van kosmopolitische normen en waarden, zoals universele mensenrechten, op (mogelijke) hervormingen van bestaande internationale organisaties, zoals de Wereldbank, en op de (mogelijke) oprichting van nieuwe democratische instituties, zoals een parlement op wereldschaal.

Het derde perspectief, ten slotte, heeft zijn hoop niet zozeer gevestigd op de instituties van global governance, maar op de (wereld)burger zelf, in de vorm van een mondiale civiele samenleving. Sommigen menen dat deze een effectieve 
tegenmacht kan vormen tegen de dominantie van natiestaten en transnationale ondernemingen, en aldus voor een empowerment van de zwakken zorg kan dragen. Anderen geloven daar niet zo in, maar denken wel dat de civiele samenleving aan de basis van de mondiale democratie zou moet staan.

Het moge duidelijk zijn dat ik in beginsel, gegeven mijn analyse tot nu toe, aansluit bij het tweede perspectief. Niettemin besef ik dat de neo-marxisten een punt hebben, namelijk dat de ongelijkheid in de wereld eerder toe- dan afneemt (ofschoon ook hier een nuancering geldt, namelijk dat een aantal ontwikkelingslanden het in sociaal en economisch opzicht steeds beter doet, bijvoorbeeld de Aziatische tijgers, India, China). Maar ik beschouw dat eerder als een sociaaleconomisch vraagstuk dat weliswaar samenhangt met het vraagstuk van politieke democratie, maar daarmee niet samenvalt. Sociaal-economische gelijkheid is denkbaar zonder democratie, sociaal-economische ongelijkheid met democratie. Aan die laatste combinatie zitten overigens wel grenzen, want waarden als vrijheid, gelijkheid en broederschap zijn belangrijke toetsstenen van democratie, en als die waarden te zeer met voeten worden getreden, staat de legitimiteit van ieder democratisch systeem vroeg of laat onder druk. Ook het derde perspectief (sociaal activisme) heeft een punt, namelijk dat een actieve civiele samenleving een basisvoorwaarde is voor democratie. Tegelijkertijd moeten we beseffen dat ieder systeem van mondiale democratie hoe dan ook ver afstaat van de individuele burger. Een directe vorm van democratie acht ik dan ook niet haalbaar op mondiaal niveau. Er zal altijd sprake zijn van een zekere mate van (elitaire) representatie binnen de institutionele architectuur van 'global governance'.

In het bovenstaande heb ik mij voornamelijk gepositioneerd ten aanzien van mondiale democratieopvattingen, en minder ten aanzien van meer algemene opvattingen van democratie. In het openingshoofdstuk onderscheiden Engelen en Sie Dhian Ho vier varianten: de directe, de representatieve, de deliberatieve en de associatieve democratie. Het moge helder zijn dat mijn NSA-gerelateerde opvatting over democratisering niets met directe of representatieve democratie te maken heeft. NSA's zijn geen uitdrukking van een of andere 'volkswil', maar door selectieve gezelschappen opgerichte organisaties - deels op collectieve belangen, deels op eigenbelang gericht -, die (onder meer) specifieke preferenties in politieke uitkomsten uitgedrukt willen zien. En zij doen dat feitelijk ongevraagd. Bovendien kiest 'het volk' hen en hun vertegenwoordigers niet. Hoogstens hebben leden van NSA's invloed op wie de tent runt (in het geval van verenigingen of coöperaties), maar meestal ook niet (in het geval van stichtingen of bedrijfsorganisaties). Met andere woorden, externe (input-)legitimiteit en interne democratie van NSA's zijn in de regel (zeer) beperkt.

Niettemin kan vanuit de andere twee perspectieven - de associatieve en de deliberatieve - worden beredeneerd dat een grotere rol en meer macht van NSA's in potentie iets met democratisering van doen heeft. In deliberatieve opvattingen geldt niet zozeer het tellen van stemmen als onderscheidend criterium voor democratie, maar het gehoord worden van zo veel mogelijk politiek relevante 
meningen, argumenten en visies, of deze nu representatief zijn of niet (Hajer 2000; Van Stokkom 2003). Doel is om op basis van hoor en wederhoor, alsmede op basis van sociaal leren, het publieke belang te definiëren en optimale opties voor beleid te genereren, voorbij het strikte eigenbelang en voorbij slecht gefundeerde emoties. Het is zonneklaar dat NSA's bijdragen aan een grotere politieke deliberatie op mondiale schaal. Zij brengen meningen in, expertise, verhalen, ervaringen, die anders niet zouden worden gehoord, iets wat door regeringsvertegenwoordigers ook zeer wordt gewaardeerd (Arts 1998). Daarnaast neemt de rol van NSA's in de opzet en uitvoering van mondiaal beleid steeds meer toe ('regulatieve macht'). We zien dat binnen de natuurbescherming, ontwikkelingssamenwerking en het mensenrechtenbeleid. Dat past binnen het plaatje van de associatieve democratie, waarin dienstverlening niet zozeer meer een taak is van de ('overvraagde') overheid, of van overheden in internationaal verband, maar van civil society-organisaties (Hirst 2000). Wel dienen die organisaties volgens deze opvatting op democratische leest te worden geschoeid om daadwerkelijk van een associatieve democratie te kunnen spreken. Dat op dit punt NSA's nog veel werk te verzetten hebben moge uit het voorgaande duidelijk zijn geworden (zie ook par. 5.7 hieronder). Kortom, vanuit directe en representatieve democratieopvattingen valt het betoog van dit essay over de relatie tussen NSA's en mondiale democratisering niet te verdedigen. Dat kan echter wel vanuit de twee andere benaderingen, de associatieve en deliberatieve (zonder dat overigens in de huidige praktijk aan alle voorwaarden van die twee democratieopvattingen is voldaan).

\subsection{BELEIDSRELEVANTIE?}

Tot nog toe is een analyse gemaakt van de rol en macht van NSA's in relatie tot het vraagstuk van mondiale democratisering. Zeker vanuit het perspectief van deze WRR-Verkenning is het interessant om deze analyse door te trekken naar een politiek programma van democratische vernieuwing op mondiale schaal. Hieronder wordt daartoe een poging ondernomen. Daarbij formuleer ik enkele 'aanbevelingen' voor statelijke actoren (te denken valt niet alleen aan VN-organisaties, maar bijvoorbeeld ook aan de Nederlandse regering) en vervolgens enkele voor NSA's. Deze aanbevelingen vloeien mijns inziens logisch voort uit de analyse tot nog toe, al worden hier en daar aanvullende overwegingen ter harte genomen:

1 Het is van belang dat overheden en internationale organisatie een responsieve grondhouding ontwikkelen dan wel handhaven ten aanzien van de rol van NSA's, ook al liggen ze soms dwars of kan hun politiek amateurisme zo nu en dan flink irriteren. Dit lijkt een open deur, maar mijn indruk is dat statelijke actoren - na NSA's veel lof te hebben toegezwaaid in de jaren negentig - meer en meer de buik vol hebben van deze organisaties. Tegelijkertijd zijn ze in potentie een van de centra van verdere mondiale democratisering. Een reden temeer, zo dunkt me, om ze juist te koesteren (natuurlijk met de nodige kritische distantie).

2 Onderdeel van een dergelijke responsieve grondhouding zou moeten zijn dat de politieke legitimiteit van NSA's niet louter wordt afgelezen aan de hand van de grootte van de achterban die ze (zeggen te) representeren. Vaak is die ach- 
terban klein, niet duidelijk of zelfs afwezig. Dan nog, zo leert de analyse in het voorgaande ons, kan sprake zijn van legitieme interventies van NSA's, door goede argumenten en zienswijzen aan te leveren (deliberatieve democratie) of door beleid uit te voeren (output-legitimiteit). Een voorbeeld is de nietgouvernementele organisatie GRAIN, die nauwelijks een achterban heeft maar in het biodiversiteitsdebat een grote rol heeft gespeeld, door kennis van zaken op het gebied van biotechnologie en door een bepaalde zienswijze hierop te verspreiden (die veel landen overigens niet deelden; zie Arts 1998).

3 Een responsieve grondhouding van landen en internationale organisaties ten aanzien van NSA's kan natuurlijk ook omgezet worden in stimulerend gedrag: het daadwerkelijk ondersteunen van hun politieke werk. Enerzijds kan men dan denken aan ondersteuning in termen van hulpbronnen, anderzijds in termen van het verruimen van spelregels. Het is al jaren praktijk dat westerse regeringen fondsen beschikbaar stellen, bijvoorbeeld voor NGO's uit ontwikkelingslanden, om aan vN-bijeenkomsten te kunnen deelnemen. Maar dit is zeker nog geen algemene praktijk. Natuurlijk kleeft hier het bezwaar aan van een mogelijke inkapseling van NSA's door regeringen, waardoor eerstgenoemde wellicht hun autonomie dreigen te verliezen (Reinalda 1997). Een betere optie, met minder gevaar voor coöptatie, is het creëren van meer institutionele ruimte voor NSA's om in het politieke proces te kunnen participeren. Dit kan bijvoorbeeld door de vigerende spelregels aan te passen. Zo heeft de VN in de loop der jaren de toegangsregels voor NGO's sterk versoepeld (Willets 1996b). Ook nationale NGO's en NGO's zonder formele 'consultatieve status' bij de vN mogen nu bijvoorbeeld aan conferenties deelnemen (mits ze aan bepaalde criteria voldoen, zoals geweldloosheid). Maar ook op dit punt is nog verbetering denkbaar.

4 Overheden en internationale organisaties kunnen ook zoeken naar nieuwe vormen van deliberatie, ter versterking van de inbreng van NSA's in het politieke debat. Men kan denken aan: enquêtes, burgerpanels, referenda, ronde tafels, ombudsmannen, brede maatschappelijke debatten (Bovens et al. 1995). Terwijl dit soort initiatieven reeds op lokale en nationale schaal vorm krijgt, blijft de mondiale schaal echter achter. Dat is enerzijds te begrijpen (want hoe organiseer je een 'mondiaal burgerpanel'?), anderzijds ontbreekt het vooralsnog aan creatieve ideeën om deze lokale initiatieven naar een mondiale schaal te vertalen (waarbij ik heel goed besef dat ook dit essay op dat punt weinig biedt).

5 Ofschoon ik weinig geloof hecht aan de haalbaarheid van nieuwe mondiale instituties op de korte termijn, is het nadenken over de wenselijkheid van een 'parlement van maatschappelijke organisaties' op wereldschaal, als alternatief voor een 'echt' wereldparlement, naast de Algemene Vergadering van de vN, in ieder geval een eerste stap. Deze 'derde kamer', zoals die in de Nederlandse verhoudingen wordt genoemd, zou gericht moeten zijn op het genereren van maatschappelijk draagvlak en oplossingsrichtingen voor beleidskwesties, daar waar het 'gewone' parlement - op wereldschaal de Algemene Vergadering - de bredere politiek-ideologische richting vastlegt en regering en 'derde kamer' controleert (Dubbink 1999). Natuurlijk kleven er nadelen aan dit idee. Zo kan het leiden tot onwenselijke formalisering en bureaucratisering van maatschap- 
pelijke organisaties. Bovendien spelen juist ook NGO's een grote rol in het bredere politiek-ideologische debat (zoals de 'anders-globaliseringsbeweging'). Niettemin is verdere ideevorming rondom zo'n mondiale 'derde kamer' mijns inziens zinvol.

6 De vraag is of overheden en internationale organisaties NSA's meer moeten gaan controleren om het kaf van het koren te scheiden, bijvoorbeeld door strakkere criteria te stellen voor beleidsparticipatie, door publieke rapportage af te dwingen of door gedragscodes te ontwikkelen. In het algemeen ben ik daar niet zo voor, omdat de huidige situatie in de mondiale politiek eerder omgekeerd ligt, namelijk dat er een noodzaak is dat NSA's juist regeringen controleren. Een omkering van dit rollenpatroon zou deze 'controleurs van de macht' wel eens monddood kunnen maken. Bovendien heb ik er vertrouwen in dat NSA's elkaar onderling steeds meer in de gaten (gaan) houden. Zo kennen we in NGO-kringen vele vormen van corporate watch, en het mooie is dat die praktijk onlangs is aangevuld met een NGO watch, gefinancierd vanuit het bedrijfsleven. Zo houden deze spelers elkaar in de gaten en worden eventuele misstappen publiek gemaakt. Behalve dat regeringen en internationale organisaties mondiale democratiseringsprocessen kunnen versterken, door NSA's actief te ondersteunen, kunnen laatstgenoemde ook zelf wat doen.

7 Vanuit de gedachte van de 'associatieve democratie' dienen NSA's allereerst aan een versterking van de interne democratie te werken, bijvoorbeeld door verkiezing van leiders, medezeggenschap, transparantie, vergroting van de 'burgerrechten' in interne besluitvorming, debat, kwaliteitspanels, referenda, polls, etc. Soms kan dat betekenen dat de juridische rechtsgrond van een organisatie beter kan worden gewijzigd (bijvoorbeeld van een stichting naar een vereniging).

8 Tegelijkertijd moeten we ons, vanuit het perspectief van de 'deliberatieve democratie', niet alleen op deze organisatorische democratisering blind staren. NSA's die (daarnaast) bezig zijn hun expertise te versterken, hun visies te schragen en het publieke debat op te zoeken alsmede bereid zijn van anderen te leren, versterken eveneens de (mondiale) democratie. Mijn ervaring is dat (veel) NSA's dit allemaal reeds doen, maar zeker waar het om sociaal leren gaat, is verbetering nog heel wel mogelijk. Vaak nog zijn bijvoorbeeld NGO’s eerder ideologische dan reflexieve organisaties. Met andere woorden: reflexiviteit moet veel meer nadruk krijgen.

9 Meer politieke macht brengt de eis met zich mee dat meer externe verantwoording wordt afgelegd. Langzaam maar zeker ontstaat er een traditie van publieke verslaglegging, niet alleen wat betreft financiële kwesties, maar ook ten aanzien van maatschappelijke en ecologische kwesties. Wat dat laatste betreft is het bedrijfsleven in de regel veel verder dan NGO's. Hier moet nog een hele inhaalslag worden gemaakt.

IO NSA's kunnen elkaar natuurlijk ook onderling ondersteunen, en niet alleen de hand bij overheden ophouden. Het bedrijfsleven kan bijvoorbeeld NGO's ondersteunen (ofschoon ook hier coöptatie dreigt), rijke en grote NGO's kunnen weer hun armere en kleinere collega's ondersteunen, etc. Wederom, dit gebeurt al in de praktijk, maar het kan altijd meer en beter. 


\subsection{CONCLUSIE}

De architectuur van global governance is het gevolg van twee vormen van verplaatsing van de politiek: politieke globalisering en transnationalisering. Het eerste behelst een (gedeeltelijke) overdracht van macht en soevereiniteit van de natiestaat naar internationale organisaties, het tweede van statelijke naar nietstatelijke actoren (NSA's). Empirisch onderzoek laat inderdaad zien dat de macht van NSA's in de mondiale politiek is toegenomen: in de besluitvorming, in de constructie van politieke discoursen en wat betreft zelfregulering. Dit essay heeft onderzocht in hoeverre deze toename van politieke macht van NSA's als een democratiseringsproces kan worden opgevat. Vanuit klassieke democratieopvattingen is dit duidelijk niet het geval. NSA's lijken eerder het 'democratische tekort' op mondiale schaal te versterken, daar zij immers ongekozen organisaties zijn en zo op het oog vooral uit zijn op behartiging van het eigenbelang. Dit laatste beeld is echter eenzijdig. Vanuit een reflexive action-model kan worden betoogd dat NSA's meer voor ogen hebben dan louter eigenbelang; vanuit een 'deliberatieve democratie'-model kan worden beredeneerd dat NSA's de politieke deliberatie, en daarmee de democratie, versterken. En vanuit een 'associatieve democratie'-model kan worden betoogd dat NSA's de output-legitimiteit van het politieke proces vergroten en ook via deze weg de democratie versterken. Met andere woorden, vanuit deze perspectieven gaan politieke empowerment van NSA's en mondiale democratisering wel degelijk samen.

Dit democratiseringsproces kan uiteraard worden versterkt. Zo kunnen regeringen en intergouvernementele organisaties een meer responsieve houding ten opzichte van NSA's ontwikkelen, de legitimiteit van NSA's breder definiëren dan louter in termen van representativiteit, het werk van NSA's ondersteunen, de politieke deliberatie stimuleren en nadenken over institutionele hervormingen, die de mogelijkheden voor NSA's om politiek te interveniëren verruimen. NSA's zelf zouden de interne democratie dienen te versterken, meer externe verantwoording moeten afleggen, meer openstaan voor sociale leerprocessen en elkaar onderling dienen te ondersteunen.

Overigens wordt met al deze suggesties niet bedoeld dat 'mondiale democratisering' geheel samenvalt met deze NSA's en hun activiteiten. Integendeel, ze betreffen slechts één van de potentiële centra van mondiale democratie. Ook nationale regeringen en parlementen hebben hun rol te spelen, ook de EU en VN, en wellicht op de (zeer) lange termijn ook een wereldparlement. 


\section{LITERATUUR}

Albrow, D. (1996) The Global Age. State and Society Beyond Modernity, Oxford: Polity Press.

Arts, B. (2003) 'Non-State Actors in Global Governance. Three Faces of Power', MPP Preprint Series, no. 2003/4, Bonn: Max Planck Project Group on Common Goods.

Arts, B., M. Noortmann en B. Reinalda, (red.) (2001) Non-state Actors in International Relations, Aldershot: Ashgate.

Arts, B. (2001) 'International Policy Arrangements of State and Non-State Actors', in B. Arts, M. Noortmann en B. Reinalda (red.) Non-state Actors in International Relations. Aldershot: Ashgate, 41-58.

Arts, B. (1998) The Political Influence of Global NGOs. Case Studies on the Climate and Biodiversity Conventions, Utrecht: International Books.

Bachrach, P. en M. Baratz (1962), 'Two Faces of Power', American Political Science Review 56, 1962: 947-952.

Bendel, J., (red.) (200o) Terms of Endearment. Business, NGO’s and Sustainable Development, Sheffield: Greenleaf Publ.

Bièvre, D. de (2002) The WTO and Domestic Coalitions: The Effects of Negotiations and Enforcement in the European Union, Florence: Diss. European University Institute.

Boehmer-Christiansen, S. (1994) 'Scientific Uncertainty and Power Politics: The Framework Convention on Climate Change and the Role of Scientific Advice', in B. Spector, G. Sjöstedt en I. Zartman: Negotiating International Regimes. Lessons Learned from the United Nations Conference on Environment and Development (UNCED). London: Graham \& Trotham/Martinus Nijhoff: 171-180.

Bovens, M. et al. (1995) De verplaatsing van de politiek. Een agenda voor democratische vernieuwing, Amsterdam: Wiardi Beckman Stichting.

Castells, M. (1996) The rise of the network society, Cambridge: M A: Blackwell Publ.

Colás, A. (2002) International civil society: social movements in world politics, Cambridge: Polity Press.

Dahl, R. A. (1961) Who Governs? Democracy and Power in an American City, New Haven: Yale University Press.

Dale, G. (2001) 'Merging rivulets of opposition: perspectives of the anti-capitalist movement', Millennium-Journal of International Studies 30, 2: 365-374.

Dicken, P. (1998) Global shift: transforming the world economy, London: Chapman (3th ed.).

Dubbink, W. (1999) Duurzaamheid als patstelling. Over de onvriendelijke betrekkingen tussen openbaar bestuur, markt en 'civil society', Delft: Eburon.

Feld, W. en R. Jordan (1983) International Organizations. A Comparative Approach, New York: Praeger.

Furtak, F. T. (1997) Nichtstaatliche Akteure in den internationalen Beziehungen: NGO's in der Weltpolitik, München: tuduv-Verl.-Ges., Reihe Politikwissenschaft, 73 .

Giddens, A. (1984) The Constitution of Society. Outline of the theory of structuration, Cambridge: Polity Press. 
Grugel, J. (2003) 'Democratisation studies globalisation: the coming of age of a paradigm', The British Journal of Politics \& International Relations 5, 2: 258-283.

Gunningham, N., P. Grabosky en D. Sinclair (1998) Smart Regulation, designing Environmental Policy, Oxford: Oxford University Press.

Hajer, M.A. (1995) The Politics of Environmental Discourse. Ecological Modernization and the Policy Process, Oxford: Oxford University Press.

Hajer, M.A. (200o) Politiek als vormgeving, Amsterdam: Vossius AUP.

Held, D. en A. McGrew, (red.) (2002) Governing Globalization. Power, Authority and Global Governance, Cambridge: Polity Press.

Higgott, R.A., G. Underhill en A. Bieler, (red.) (200o) Non-State Actors and Authority in the Global System, London, etc.: Routledge.

Hirst, P. en G. Thompson (1996) Globalization in question. The international economy and the possibility of governance, Cambridge: Polity Press.

Hirst, P. (2000) 'Democracy and Governance', in J. Pierre, (red.) (2000), Debating Governance. Authority, Steering and Democracy, Oxford: Oxford University Press, 13-35.

Keohane, R.O. en J.S Nye, (red.) (1971) Transnational Relations and World Politics, Cambridge: Harvard University Press.

Keohane, R.O. en J.S. Nye (200o) 'Introduction', in Joseph S. Nye and John D. Donahue (2000), Governance in a globalizing world. Washington: Brookings Institution Press: 1-44.

Kersbergen, K. van, R.H. Lieshout en G. Lock (1999) Expansion and Fragmentation. Internationalization, Political Change and the Transformation of the Nation State, Amsterdam: Amsterdam University Press.

Knill, C. en D. Lehmkuhl (2002) 'Private actors and the state: Internationalization and changing patterns of governance', Governance - An International Journal of Policy and Administration 15, 1: 41-63.

Korey, W. (1998) NGO's and the universal declaration of human rights: a curious grapevine, New York: St. Martin's Press.

Morss, E. (1991) 'The New Global Players: How They Compete and Collaborate', World Development 19, 1: 55-64.

Nye, J.S. en J.D. Donahue (2000) Governance in a globalizing world, Washington: Brookings Institution Press.

Pierre, J. (red.) (200o) Debating Governance. Authority, Steering and Democracy, Oxford: Oxford University Press.

Reinalda, B. (1997) Private in Form and Public in Purpose: (I)NGO's as Political Actors in World Politics, Paper for the ECPR 25th Joint Sessions of Workshops, Bern, Switzerland, March 1997.

Risse-Kappen, Th. (red.) (1995) Bringing transnational relations back in: non-state actors, domestic structures and international institutions, Cambridge: Cambridge University Press.

Rosenau, J.N. en Czempiel (red.) (1992) Governance without government: order and change in world politics, Cambridge: Cambridge Univ. Press.

Scholte, J.A. (2000) 'In the foothills: relations between IMF and civil society', in R.A. Higgott, G. Underhill en A. Bieler, (red.) (2000) Non-State Actors and Authority in the Global System, London, etc.: Routledge: 256-273. 
Schot, J. van der, en H. van de Veen (1997) ‘De nieuwe macht van NGO’s’, in K. Waagmeester (red.), Houdbare Economie. Kroniek van Duurzaam Nederland. Amsterdam: NCDO/Kok Agora: 197-209.

Stokkom, B. van (2003) 'Deliberatie zonder democratie? Ongelijkheid en gezag in interactieve beleidsvorming', Beleid en Maatschappij 30, 3: 153-165.

Strange, S. (1988) States and Markets, London: Pinter.

Strange, S. (1996) The Retreat of the State. The Diffusion of Power in the World Economy, Cambridge: Cambridge University Press.

United Nations Commission on Global Governance (1995) Our Global Neighborhood, Oxford: Oxford University Press.

Waltz, K.N. (1979) Theory of International Politics, New York: McGraw-Hill.

Willett, P., (red.) (1996a) The consciousness of the world: the influence of non-governmental organisations in the UN system, London: Hurst \& Company.

Willets, P. (1996b) 'From Stockholm to Rio and beyond: the impact of the environmental movement on the United Nations consultative arrangements for NGO's', Review of International Studies 22, 1996: 57-80. 


\title{
6 PUBLIEKE VERANTWOORDING IN DE MAATSCHAPPELIJKE DIENSTVERLENING
}

\author{
H.O. Dijstelbloem en P.L. Meurs ${ }^{1}$
}

\subsection{HEEFT DE MAATSCHAPPELIJKE DIENSTVERLENING EEN LEGITIMITEITSPROBLEEM?}

De maatschappelijke dienstverlening in de verzorgingsstaat (zoals gezondheidszorg, onderwijs, welzijn, arbeidsvoorziening en volkshuisvesting) wordt gekenmerkt door een bijzondere spanning. Enerzijds is er sprake van een publiek belang en van publieke middelen die voor het realiseren van die publieke belangen worden ingezet, terwijl anderzijds de feitelijke besteding van de middelen en de wijze waarop de diensten worden geleverd in handen is van (vaak) particuliere instellingen en daar werkzame professionals. In de loop der jaren is - met de uitbouw van de verzorgingsstaat - de rol van de overheid bij het vormgeven van de maatschappelijke dienstverlening groter geworden. De maatschappelijke dienstverlening is in zekere zin verstatelijkt. Tegelijkertijd is sprake van een vergaand proces van professionalisering van diezelfde diensten. De dienstverlening zelf is complexer geworden, evenals de instellingen die de diensten leveren.

Deze twee ontwikkelingen: meer overheidsbemoeienis en meer professionele en expertinzet hebben geleid tot een ingewikkeld stelsel van toezicht en verantwoordingsrelaties tussen overheid (overheden) en maatschappelijke instellingen. Dit stelsel heeft z'n beste tijd gehad, zo wordt gezegd. Het antwoord wordt gezocht in een andere rol van de overheid: sturen op afstand, op hoofdlijnen en op resultaat. Deze trend wordt veelal samengevat onder de term governance. Het gaat dan om nieuwe vormen van sturing, toezicht en verantwoording waarbij delen van de uitvoering en controle van beleid terecht zijn gekomen bij gedecentraliseerde en meer lokaal en zelfstandig werkende uitvoeringspraktijken (instellingen) die beter dan de centrale organen kunnen inspelen op wensen en behoeften van gebruikers. Voor de maatschappelijke dienstverlening is dit zeker geen noviteit, immers in de meeste gevallen is juist het particulier initiatief leidend geweest, zowel in termen van beleid als in termen van uitvoering.

Op dit moment is sprake van een zoektocht naar nieuwe arrangementen die enerzijds recht doen aan het publieke belang dat in het geding is en anderzijds recht doen aan de eigen aard van de dienstverlening zelf en de noodzakelijke professionele ruimte om een kwalitatief goede dienst te kunnen leveren. Arrangementen bovendien die recht doen aan de positie van de gebruiker. Als we de huidige discussies als graadmeter mogen nemen, dan is er nog veel werk te doen in dit opzicht. Overheid en politiek vinden dat ze te weinig greep hebben op de betrokken instellingen; betrokken professionals en maatschappelijke instellingen klagen over een overdaad aan bureaucratie en informatieplicht die hen afhoudt van het echte werk en hun noodzakelijke professionele vrijheid beknot; burgers 
zien zich te vaak geconfronteerd met een black box waar zij geen invloed op kunnen uitoefenen terwijl de mogelijkheden om voor een andere aanbieder te kiezen beperkt zijn.

In dit hoofdstuk onderzoeken we hoe het gesteld is met de publieke verantwoording van de maatschappelijke dienstverlening. Verantwoording is bij uitstek een term die past bij democratie. Bestuurders leggen verantwoording af over hun beleid en laten publieke controle op hun handelen toe. Het vormt een voorname bron van legitimiteit. De vraag is of dit in de maatschappelijke dienstverlening adequaat is geregeld. Doet daar niet veeleer de kwaliteit van de dienstverlening ertoe in plaats van wie er allemaal mee kan praten bij de uitvoering daarvan? Gesteld in termen van het openingshoofdstuk van deze Verkenning: gaat het niet veeleer om output-legitimiteit in plaats van om input-legitimiteit? En zo ja, wat heeft dat met democratie te maken? In dit hoofdstuk onderzoeken we daarom welke manieren van verantwoording het meest beloftevol zijn als het erom gaat ook de professionaliteit en de kwaliteit, kortom de resultaten van de dienstverlening te stimuleren.

\section{2 'VERPLAATSING' VAN DE POLITIEK}

In de maatschappelijke dienstverlening is het laatste decennium onmiskenbaar sprake geweest van een tendens om de verantwoordelijkheid weer te leggen bij zelfstandige en professionele organisaties die belast zijn met de dienstverlening zelf en ook in belangrijke mate beleidsbepalend zijn. Zij kunnen immers beter dan centrale organen - zo luidt de redenering - inspelen op wensen, verlangens en problemen van hun gebruikers. Voorzover de centrale organen nog invloed hebben betreft dat vooral de uitgaven op macroniveau (collectieve-lastendruk) en het in meer procedurele zin zorgen voor een voldoende kwaliteitsniveau. Toch ontstaan er ook nieuwe problemen als het gaat om de publieke aanspreekbaarheid van het beleid. Pierre en Guy Peters (200o) noemen dit het probleem van 'de legitimiteit van de traditionele politieke verantwoording'. Verplaatsing van beleid betekent dat opnieuw moet worden nagedacht over de invulling van de wijze waarop verantwoording wordt afgelegd. Nieuw ontwikkelde arrangementen leiden soms tot nieuwe vormen van 'zelfbestuur', maar de politiek blijft de hoofdverantwoordelijke voor het functioneren ervan en het toezicht erop. De vraag is dan welke vormen van maatschappelijke verantwoording horen bij 'losgemaakte' sectoren.

De overheid staat hier voor een lastige taak. Vanuit de gedachte van de verzorgingsstaat gaat er een speciale 'zorg' van de overheid uit ten aanzien van (bijvoorbeeld) de gezondheid, het onderwijs, het welzijn en de huisvesting van burgers. Tegelijkertijd is de overheid voor het aanbieden van die zorg grotendeels aangewezen op de initiatieven en expertise die aanwezig zijn binnen de particuliere instellingen. Het zijn de instellingen, de medewerkers en de professionals die de directe relatie onderhouden met hun 'klanten' en die op primair niveau de beschikbaarheid en inzetbaarheid van diensten en middelen moeten regelen. 
Toch rust het oog van het publiek op de politiek verantwoordelijken en is het de (centrale) overheid en haar gekozen politici die erop worden aangesproken.

Deze aanspreekbaarheid blijkt lastig te regelen. Enerzijds vindt de controle op de maatschappelijke dienstverlening op meerdere locaties plaats - en daarmee ook de beleidsuitvoering, de beslissingen, de verantwoordelijkheid - en is die nu voor een deel gelegd bij diegenen die werken in de praktijk en de problemen het beste kennen. Anderzijds kent de maatschappelijke dienstverlening onmiskenbaar een publieke dimensie, in het karakter van de dienst en de uitvoering daarvan, en is de overheid op grond van de formulering van de sociale grondrechten ook verantwoordelijk voor een goede zorg daaromtrent. Waar de verantwoordelijkheid voor een deel verplaatst is, zijn er weinig nieuwe mogelijkheden gekomen voor het publiek om bevoegde beleidsbepalers aanspreekbaar te houden.

Deze situatie is ietwat diagnosticerend onder woorden gebracht met de term 'de verplaatsing van de politiek'. De term is een verzamelnaam voor verschillende bewegingen die er samen voor zouden hebben gezorgd dat de politiek, begrepen als de plaats waar door representanten van de samenleving afwegingen worden gemaakt over maatschappelijke problemen, stilaan is verschoven naar voor de burger niet inzichtelijke locaties en domeinen. De term is in Nederland gangbaar geworden nadat hij als titel figureerde van een uitgave van de Wiardi Beckman Stichting (Bovens et al. 1995). Beck et al. (1994) spreken in dit verband over 'subpolitiek'. Zij doelen daarbij op de rol van actoren van buiten het politieke systeem en de invloed die deze uitoefenen op de politieke agenda zonder dat zij in de democratische zin van het woord gelegitimeerd zijn om dat te doen. De vele (legitimiteits)problemen die onder de noemer 'verplaatsing van de politiek' kunnen worden gebracht, wachten in veel gevallen nog steeds op een (vanuit democratisch perspectief) bevredigende behandeling. In een bijdrage aan een debat over de 'gangen van de macht' in Socialisme en Democratie heeft Bovens uiteengezet wat de kern was van de analyse van de verplaatsing van de politiek zoals hij die samen met Kalma, Becker, Derksen en Witteveen in 1995 had opgesteld. "Ons betoog”, zo stelt Bovens daar, "kwam erop neer dat als de politieke machtsuitoefening zich verplaatst, je dan ook moet nadenken over een verplaatsing van de democratische sturing en verantwoording" (Bovens 2002: 15).

Het sterke punt van deze diagnose is dat ze aangeeft dat er een probleem kan bestaan met besluitvormingsprocessen die niet democratisch gelegitimeerd zijn. Nadeel is dat 'democratische legitimatie' beperkt is uitgewerkt en dat de these van de verplaatsing nog wat gaten laat zien. Immers, het idee van verplaatsing suggereert dat er ooit een centrale plaats was waar de politiek zich bevond (of hoort te bevinden). Echter, in Nederland is altijd sprake geweest van een 'gedeelde politieke ruimte'. Maatschappelijke tegenstellingen over politieke vraagstukken zijn vaak tot een oplossing gebracht in 'overlegrondes' tussen de voormannen van verschillende maatschappelijke instellingen (de zuilen) of belangenverenigingen (werkgevers en werknemers). Een land als Nederland met een sterk corporatistisch verleden kent vele verschillende publieke en private instellingen met een 
maatschappelijke taak, die in een losse verhouding tot de staat staan (van omroepverenigingen tot woningbouwcorporaties). Ten tweede vinden er altijd verschuivingen plaats in de verhouding tussen wat centraal en decentraal geregeld wordt, waardoor er in die zin geen sprake is van verplaatsing maar eerder van opkomende en wegvallende bestuursaccenten (bijvoorbeeld herordeningen van de taken van rijk, provincies en gemeenten). Ten derde is 'verplaatsing' vaak ook willens en wetens gebeurd, bijvoorbeeld in geval van verzelfstandigingsoperaties, het op afstand plaatsen van instellingen, en zijn de procesmatige connotaties van 'verplaatsing' niet op zijn plaats (een kanttekening die Bovens c.s. zelf ook hebben geplaatst).

Het meer algemene probleem met de these van Bovens c.s. is dat wanneer men spreekt van een 'verplaatsing', daar een eerdere plaatsbepaling aan voorafgaat. Een verplaatsing gaat immers 'van iets naar iets'. Niet alle genoemde tendensen echter staan in eenzelfde soort relatie tot het parlement. Wie al te gemakkelijk alle 'verplaatsingen' over een kam scheert wekt ten onrechte de illusie dat het parlement in alle gevallen de oorspronkelijke politieke brandhaard was. Het eenzijdig veronderstellen van het 'parlement' als de natuurlijke plaats van het bedrijven van politiek leidt vrijwel automatisch tot eenzelfde oplossingsrichting, namelijk het (opnieuw) versterken van de democratische controle op de vormen van verplaatsing.

Het grote voordeel van een democratische politieke structuur is dat er allerlei mechanismen zijn bedacht die het mogelijk maken om een goede controle mogelijk te maken op de uitoefening van de macht, omdat deze voor een belangrijk deel in de openbaarheid wordt uitgeoefend. Uitvoerende instellingen en particuliere instellingen met een maatschappelijke taak die vaak belendend tegen de politieke instituties aanhangen, of 'in de schaduw van de hiërarchie' opereren, zijn veel moeilijker te controleren. Nadeel van de these van de verplaatsing is echter dat ze op een misverstand omtrent de verscheidenheid van politieke mechanismen zou wijzen, wanneer gedacht wordt dat de enige remedie tegen een verondersteld democratisch tekort is gelegen in een versterking of terugkeer van de publieke verantwoording in de vorm van (bijvoorbeeld) meer 'publiek debat' (vgl. De Vries 2002). De meest voor de hand liggende democratische reactie op een verplaatsing van de politiek is een roep om rekenschap en publieke controle. Dat is echter maar één manier om democratische legitimiteit te waarborgen, namelijk input-legitimiteit. Ook het concept van de 'scheiding der machten' of het creëren van 'tegenmacht' is daartoe een manier. Dergelijke vormen zijn vooral mogelijkheden om de output-legitimiteit te versterken. Dat betekent dat er een minder zwaar accent komt te liggen op de inventarisatie van de wil en de wens van burgers, maar meer gekozen wordt voor oplossingen die juist enigszins onafhankelijk van deze wil worden geconstrueerd door vormen van outputlegitimiteit, bijvoorbeeld omdat ze meer duurzaamheid, solidariteit, geloofwaardigheid en kennis geacht worden te garanderen (Majone 1996; Cohen en Sabel 1997; Scharpf 1999; 2003). 
In het vervolg van deze bijdrage zal worden gezocht naar adequate verantwoordingsmechanismen die niet alleen de input-legitimiteit van de uitvoeringspraktijken versterken, maar ook de kwaliteit en doelmatigheid ervan. We doen dit door een onderscheid aan te brengen tussen drie vormen van verantwoording. Vervolgens toetsen we deze vormen op hun beloftes voor het probleemoplossende vermogen van instellingen: dragen ze bij tot meer leervermogen in de uitvoering?

\subsection{DRIE VORMEN VAN VERANTWOORDING}

De afgelopen jaren is er uitvoerig over het thema 'maatschappelijke verantwoording' gerapporteerd. ${ }^{2}$ Sinds 1998 rapporteert de Algemene Rekenkamer periodiek over de toezichthoudende rol bij verzelfstandigde overheidsorganisaties. ${ }^{3}$ Dat de kwestie van de verantwoording daar een pregnant thema is bleek wel toen in 2000 vijf zelfstandige bestuursorganen (zво's) hun Handvest publieke verantwoording uitbrachten waarin zij een sterkere rol bepleitten voor de maatschappelijke verantwoording. Ook stelden ze dat de ministeriële verantwoordelijkheid vooral als sluitstuk van publieke verantwoording moet worden beschouwd in plaats van als startpunt. ${ }^{4}$ In 2001 kwam het kabinet daarbovenop nog eens met de Kaderstellende visie op toezicht.

Ondanks deze initiatieven is er nog veel onduidelijkheid over de precieze inhoud en betekenis van het begrip 'maatschappelijke verantwoording'. De aanbevelingen van de verschillende commissies vertonen naast overeenkomsten ook vele verschillen, ingegeven door ongelijkheden in perspectief en doelstelling van het advies evenals door verschillen in samenstellingen, organisatie en taakstelling van de betreffende sector en de specifieke problemen waar die zich voor gesteld zien. Vanuit verschillende brancheorganisaties is gesteld dat hier twee verschillende visies op het verantwoordingsvraagstuk spelen (NTMO 2003: 50). Waar de overheid de instellingen in de maatschappelijke dienstverlening (brancheorganisaties spreken van 'maatschappelijke ondernemingen') vooral aanspreekt op de inputkant van hun functioneren (juridische status, bevoegdheid, financiën), zijn de instellingen zelf vooral gericht op de outputkant waarin het maatschappelijk belang, de klantgerichtheid en de kwaliteit van de dienstverlening centraal staan.

Het overheidsperspectief zou berusten op de visie dat de privaatrechtelijke grondslag van veel instellingen in de maatschappelijke dienstverlening in de eerste plaats een functionele indeling vormt om publieke taken (zorg, wonen, onderwijs) zo effectief mogelijk te kunnen uitvoeren, met daarbij een sterk maatschappelijk draagvlak om de legitimiteit ervan te versterken en de doelmatigheid te verbeteren. Daartegenover is de 'eigen oriëntatie' van de sectoren te stellen die niet berust op een vorm van functionele decentralisatie, maar haar wortels heeft in het particulier initiatief vanwaaruit op een zelfstandige wijze algemene belangen worden gediend. Daarbij zouden 'het eigen initiatief, de eigen legitimatie, de (horizontale) verantwoordelijkheid en de interne controle voorop(staan)' (NTMO 2003: 51). 
De tegenstelling die hier wordt gepostuleerd is die tussen horizontale en verticale vormen van verantwoording. Hoewel de termen 'horizontaal' en 'verticaal' onzes inziens niet erg gelukkig zijn, is duidelijk dat er gezocht wordt naar alternatieven naast de klassieke hiërarchische verantwoordingsrelatie uit het staatsrechtelijke leerstuk van de ministeriële verantwoordelijkheid, die tegelijkertijd zouden kunnen dienen om de kwaliteit van de dienstverlening en de oriëntatie van de instellingen te verbeteren. Het denken over 'maatschappelijke verantwoording' betreft aldus zowel het afleggen van verantwoording en de controle daarop (bijvoorbeeld door middel van raden van toezicht) als het versterken van de betrokkenheid van de stakeholders (klanten, gebruikers, samenwerkende instanties of intermediaire organisaties) van de instellingen in de betreffende sector. Immers, stakeholders kunnen in het kenbaar maken van hun wensen en verlangens ook informatie verschaffen over het functioneren van de instellingen. Verantwoording kan daardoor wellicht een dubbelrol innemen in die zin dat zij ondersteunend is voor zowel de democratische legitimiteit (door mechanismen voor inspraak, representatie, controle, en formulering van maatschappelijke doelstellingen) als de maatschappelijke kwaliteit (goede dienstverlening, professionele kwaliteit, prioriteiten, relevante oriëntatie).

Samenvattend lijken er drie elementen te onderscheiden in het begrip verantwoording:

1 een politiek-hiërarchische verantwoordingsstructuur waarin het functioneren van instellingen allereerst onder de ministeriële verantwoordelijkheid valt;

2 een verantwoordingsstructuur waarin vooral intern en extern toezicht op maatschappelijke instellingen wordt uitgeoefend;

3 een verbreding van de verantwoordingsrelatie waarin door middel van overleg, inspraak of medezeggenschap wordt gestreefd naar een versterking van de legitimiteit van de instellingen.

In de volgende paragrafen zullen deze vormen achtereenvolgens behandeld worden.

\subsection{DE POLITIEK-HIËRARCHISCHE VERANTWOORDINGS- STRUCTUUR}

De klassieke vorm van verantwoording in een democratische rechtsstaat is de verticale verantwoording, waar sectoren en instellingen weliswaar in relatieve vrijheid kunnen opereren maar altijd binnen de 'schaduw van de hiërarchie'. Die hiërarchie bestaat uit de positie van de politiek benoemde minister. Staatsrechtelijk bezien behelst de verantwoordelijkheid van de minister twee componenten. Ten eerste moet het beleid van de overheid overeenkomen met de voorkeuren van de bevolking. De beleidsvrijheid van de overheid op grond van het electorale mandaat staat daartoe onder controle van het parlement. Ten tweede behoort het tot de taakverantwoordelijkheid van de minister om ervoor te zorgen dat de overheidsorganisatie goed functioneert (Scheltema 200o). Verantwoording in bestuurlijke zin kan in zijn brede betekenis worden opgevat als de plicht tot het afleggen van rekenschap (Tuurenhout 1992). Deze verantwoording vindt plaats 
aan een bepaald forum (van Gunsteren 1974). Een dergelijk forum is in het geval van de minister de Tweede Kamer. ${ }^{5}$

De vraag naar de reikwijdte en precieze invulling van de ministeriële verantwoordelijkheid is de afgelopen tien jaar met enige regelmaat onderwerp van discussie geweest. ${ }^{6}$ In deze discussie is de aandacht vooral uitgegaan naar de verhouding tussen minister en ambtenaren en naar de verhouding tussen de minister en zelfstandige bestuursorganen. Zowel incidenten die een indicatie konden vormen voor een dieperliggend probleem vormden daarvoor de aanleiding (hooggeplaatste ambtenaren die 'buiten de minister om' een andere uitleg gaven aan het beleid in de media), als vraagstukken omtrent de juiste inrichting van nieuwe bestuurlijke arrangementen (zво's). Deze punten betreffen het functioneren van de overheidsorganisaties en niet de eerste vorm van verantwoordelijkheid van de minister, de overeenstemming van het beleid met de voorkeuren van de bevolking.

De grens van de verantwoordelijkheid van de minister is de reikwijdte van zijn bevoegdheid om instructies te geven. Wanneer instellingen (zoals zво's) in hun functioneren niet onder het gezag vallen van de minister, vervliegt de mogelijkheid hem daar verantwoordelijk voor te houden (Scheltema 200o). De verantwoordelijkheid om de beleidsinhoud in overeenstemming te laten zijn met het regeringsbeleid daarentegen vervalt daarmee niet. Zoals door veel auteurs is opgemerkt, zal bij verplaatsing van de uitvoering van een publieke dienst ook aandacht moeten worden besteed aan de verplaatsing van het democratisch toezicht (Bovens et al. 1995; Van der Meer en Ham 2001). Toch is het bepalen van de doelstellingen van de maatschappelijke dienstverlening primair een politieke taak. Als vertolker van het publieke belang door een proces van collectieve wilsvorming is het in eerste instantie een politiek besluit dat aangeeft wat de doelen zouden moeten zijn waaraan de gezondheidszorg, het onderwijs of de volkshuisvesting zouden moeten voldoen (conform de eerste component van de ministeriële verantwoordelijkheid). Het publieke belang dat in een bepaalde sector de inzet vormt, laat zich veelal in redelijk abstracte waarden formuleren. Zo staan voor het onderwijs de kwaliteit en de toegankelijkheid centraal, en let de overheid tevens op de doelmatigheid en de bestelsamenhang. Dergelijke doelstellingen zijn niet zozeer directieven als wel principes; concreet beleid valt er nauwelijks van af te leiden maar is er in algemene zin wel aan te toetsen. Ingevulde doelstellingen zijn al concreter van aard, bijvoorbeeld ' 500.000 woningen erbij in 2010'. Op een dergelijke doelstelling is een minister af te rekenen. Tegelijk zegt het behalen van dat aantal woningen nog niets over de wijze waarop naar wensen van toekomstige bewoners is geluisterd, of er overleg met huurders of bewonersverenigingen is geweest, wat er aan overleg met gemeenten heeft plaatsgevonden, of en in hoeverre er doordacht beleid is opgesteld rond de benodigde sociale voorzieningen (onderwijs, openbaar vervoer) in een bepaalde wijk. Een nader bepaald en concreter ingevuld publiek belang betoont zich al snel meer divers en gecompliceerder van aard dan een eenduidige doelstelling. 


\subsection{TOEZICHT EN CONTROLE}

Naast de politieke verantwoordelijkheid in een hiërarchische vorm van sturing, zijn er, zoals gezegd, ook andere vormen van verantwoording. Het voornaamste verschil is dat in de eerste vorm sprake is van onderschikking terwijl de tweede uitgaat van nevenschikking. In plaats van een concentratie van de verantwoordelijkheid onder politieke macht is de verantwoordelijkheid in het tweede geval juist verdeeld over een veelheid aan publieke (en private) instituties.

Zoals reeds vermeld hebben verschillende adviescommissies zich gericht op de vraag naar de verbetering van het toezicht in de sectoren zorg en onderwijs in een periode van verzelfstandiging en schaalvergroting. ${ }^{7}$ De commissies zijn er evenals het kabinet van uitgegaan dat toezicht door of vanwege de minister niet kan worden vervangen door 'horizontale' vormen van toezicht. Tegelijk stelden ze vast dat de bestaande toezichtarrangementen niet helder waren en dat de aangetroffen toezichtpraktijken grote verschillen vertoonden. Beide zochten de oplossing vooral in het verstevigen van de positie en het verbeteren van het functioneren van de raad van toezicht.

Toezicht kan in twee betekenissen worden opgevat. In de eerste plaats als het verticale toezicht, veelal een hiërarchische verantwoordingsplicht en sturingsrelatie aan en door de figuur van de minister. Deze vorm is in de vorige paragraaf besproken. In de tweede plaats als intern toezicht, vaak in de vorm van een raad van toezicht (in navolging van de raad van commissarissen in het bedrijfsleven). Deze vorm is de laatste jaren in veel instellingen geïntroduceerd. Dat lijkt twee oorzaken te hebben. De ene leidt naar het overheidsinitiatief om door middel van dergelijke raden instellingen onder toezicht te plaatsen zodat er een adequate vorm was voor de invulling van de ministeriële verantwoordelijkheid. Dit is vooral aan de orde bij zво's en geldt in feite niet voor de particuliere organisaties die in de maatschappelijke dienstverlening actief zijn. De andere leidt naar de gegroeide behoefte om instellingsbesturen slagvaardiger te maken (zoals bij gezondheidsinstellingen, culturele instellingen en hogescholen op advies gebeurde) (Luursema et al. 2003: 25-26). De directies worden bestuur in de zin van de wet en de besturen worden raden van toezicht met expliciet in de statuten vermelde bevoegdheden. De Algemene Rekenkamer (2002) plaatst dergelijke raden van toezicht onder het interne toezicht: toezicht op het bestuur door een orgaan binnen een en dezelfde rechtspersoon.

De positie en de legitimiteit van de raden van toezicht is en blijft onderwerp van debat. Globaal gesproken kunnen er drie posities worden onderscheiden:

1 versterking van de legitimiteit van het toezicht door de onafhankelijkheid van de toezichthouders te waarborgen;

2 versterking van de legitimiteit van het toezicht door de representativiteit van de toezichthouders te waarborgen;

3 versterking van de legitimiteit van het toezicht door de minister recht van benoeming en decharge te verlenen. 
De praktijk leert dat er ook combinaties voorkomen. In de gezondheidszorg hebben de raden van toezicht bijvoorbeeld de wettelijke verplichting om een van de zetels te laten bezetten op basis van een bindende voordracht door de cliëntenraad. Ook in het onderwijs is er sprake van een dergelijke verplichting. Daarnaast zien we in de Wet op de Ondernemingsraden een artikel dat ondernemingsraden de mogelijkheid biedt een voordracht te doen. Uiteraard gaat het altijd om posities zonder last of ruggespraak. Deze vormen kunnen echter ook gezien worden als een 'oplossing' voor het democratisch tekort van raden van toezicht die primair via coöptatie tot stand komen.

Voor een aantal instellingen - zoals bijvoorbeeld de universiteiten en de academische ziekenhuizen of de Informatiebeheer Groep - geldt dat de minister de raad van toezicht benoemt. De vraag dient zich aan of dit model niet voor meer uitvoeringsorganisaties zou moeten gelden. Ten slotte is de laatste jaren een intensief debat gaande over de vraag of er niet - vergelijkbaar met een vergadering van aandeelhouders - sprake zou moeten zijn van een raad die toezicht houdt op het functioneren van de raad van toezicht, waarin belanghebbenden zitting hebben.

De Rekenkamer reserveert de term toezicht voor het verticale toezicht; horizontale verantwoording waarin belanghebbenden (burgers, klanten) invloed hebben op het beleid van de rechtspersoon, kan in de visie van de Rekenkamer het verticale toezicht nooit vervangen. ${ }^{8}$ Horizontale verantwoording is een minder verplichtende vorm van verantwoording en vindt vaak op basis van vrijwilligheid plaats. Voorbeelden zijn certificering van kwaliteitsborgingsystemen, benchmarking van publieke instellingen, op burgers gerichte kwaliteitshandvesten en kwaliteitsbeoordelingen door toezichthoudende instanties. Waar toezicht ook de mogelijkheid tot interventies en sancties impliceert, zijn de mogelijkheden in het geval van de horizontale verantwoording van een andere aard. ${ }^{9}$

De initiatieven die in de sectoren zelf worden ondernomen, wijzen op de wens om ook de horizontale verantwoordingsmechanismen beter vorm te geven. ${ }^{10}$ Het is dan ook de vraag of de verticale verantwoordelijkheid en het interne toezicht de beste ijkpunten zijn om de aanvullende of vervangende waarde van de horizontale verantwoording en toezicht aan af te kunnen meten. Als het inderdaad wenselijk wordt geacht om voice en zeggenschap van gebruikers te versterken, dan is het van belang de horizontale vormen van verantwoording verder te ontwikkelen. Aan de andere kant blijft het gevaar dat dergelijke mechanismen zich ontpoppen tot de zoveelste rituele democratiseringsdans. Wanneer de bevoegdheden en de mogelijkheden tekortschieten is het symbolische karakter al snel groter dan de daadwerkelijke interveniërende werking die ervan uit zou kunnen gaan. Naast controle en interventie enerzijds en medezeggenschap en inspraak anderzijds is er wellicht nog een derde weg mogelijk, namelijk een richting die zich in eerste instantie richt op het probleemoplossend vermogen van instellingen. Deze lijn zal in de laatste paragraaf worden geschetst. 


\subsection{VERBREDING VAN DE VERANTWOORDING}

\subsubsection{KWALITEIT VAN DE DIENSTVERLENING}

Zoals uit het voorgaande bleek is 'maatschappelijke verantwoording' niet alleen een manier om de input-legitimiteit van de sectoren te versterken, maar heeft zij ook betrekking op de kwaliteit van de dienstverlening van de sectoren, oftewel de output-legitimiteit. De inspraak bij een bewonersvereniging kan nog zo goed geregeld zijn, als het te lang duurt voordat er een monteur komt die het lekken van het dak repareert neemt het vertrouwen en het draagvlak van een dergelijke instelling snel af. Vereenvoudigd gesteld: naast manieren om door inspraak de betrokkenheid te vergroten zullen daar behaalde resultaten aan toe moeten worden gevoegd die het in de instellingen gestelde vertrouwen eer aan doen teneinde niet alsnog met een vertrouwenstekort te worden opgezadeld.

Hoewel doelmatigheid en kwaliteit van de dienstverlening belangrijke bronnen van (output-)legitimiteit zijn, stuit het extern afdwingen van deze doelen in de praktijk al snel op de gesloten deur (de autonomie) van de professional. De professional treedt de consument tot op zekere hoogte onafhankelijk tegemoet. Dat kan op gespannen voet staan met vormen van (leken)inspraak of soms zelfs met overwegingen van maatschappelijk belang wanneer dit betekent dat het zelfstandig afwegingskader van de betreffende expert poreus wordt en dient toe te geven aan externe eisen. In dit verband kan gewezen worden op de verschillende initiatieven die in gang zijn gezet om enerzijds meer inzicht te bieden in de prestaties van uitvoeringsorganisaties en professionals en anderzijds meer werk te maken van kwaliteitsverbetering van de dienstverlening zelf. In verschillende sectoren wordt gewerkt met prestatie-indicatoren die onder meer door cliënten zijn opgesteld, vindt er vergelijkend onderzoek plaats en worden er beoordelingen gegeven. In enkele sectoren is meedoen aan benchmark-onderzoek verplicht en dienen de uitkomsten te worden gepubliceerd. Wat de kwaliteit betreft is er sprake van visitaties, vormen van erkenning en 'peer review'. Ook worden de klachtmeldingen benut voor evaluatie en verbetering van de werkprocessen.

Aan deze initiatieven kleven twee gevaren. Ten eerste dat informatievoorziening en probleemoplossing worden verward. Belangrijk is niet, of niet alleen, te constateren dat de uitvoerder achterblijft bij de afgesproken prestaties, maar waarom dat gebeurt. Het gevaar bestaat dat prestatie-indicatoren alleen als controlerend instrument worden ingezet en dat het achterliggende doel, kwaliteitsverbetering van de dienstverlening, uit beeld verdwijnt. Ten tweede dat het zwaartepunt van de instelling verschuift naar wat gemeten wordt en dat belendende activiteiten en doelen genegeerd worden. Prestatienormen zijn vaak een versmalling van het feitelijke taken- en activiteitenpallet van een instelling. Door deze normen dwingend op te leggen vindt zodoende niet een verbetering van de dienstverleningskwaliteit plaats maar juist een verschraling ervan. 


\subsubsection{INSPRAAK EN MEDEZEGGENSCHAP}

Typische vormen van inspraak op lokaal niveau zijn medezeggenschapsorganen als de ouderraad in het onderwijs, de patiëntenraad in de gezondheidszorg en huurders- en bewonersorganisaties in de huisvesting. Dergelijke institutionele voorzieningen zijn afkomstig uit de democratiseringsgolf van de jaren zeventig en zijn berucht vanwege hun zwakke legitimiteit, matige representativiteit en geringe effectiviteit. In het oog springt vooral de vraag naar de reikwijdte van de inspraak van deze organen. Terwijl ze idealiter hun ervaringskennis zouden kunnen aanwenden voor de oplossing van problemen van structurele aard, lijken ze zich in de praktijk vooral te richten op meer tastbare problemen die zich voordoen in de directe belevenissfeer van degenen die ze vertegenwoordigen: de omstandigheden aan het ziekbed van de patiënt, voorzieningen op school, etc. Verwonderlijk is dit niet. Inspraak en medezeggenschap is vaak weinig geprofessionaliseerd en de ervaringen spelen veelal op het concrete niveau van de dienstverlening; op dat niveau wordt zichtbaar en voelbaar wat de tekortkomingen zijn en wat het oplossingsvermogen is van het betreffende organisatieonderdeel.

Achilleshiel echter is onveranderlijk hun onvermogen om kwesties aan te pakken die de schaal van de lokale situatie overstijgen. Daarnaast spelen veel van de problemen waar scholen, ziekenhuizen of lokale vestigingen van woningbouwcorporaties mee te kampen hebben, op meer plaatsen. Inspraak, representatie en medezeggenschap zijn lokaal georganiseerd terwijl de problemen meestal structureel zijn en op meer plekken opduiken en dus breder over de sectoren verspreid liggen. Oftewel: hier doemt een coördinatieprobleem op. Lokale vormen van democratisering zijn onvoldoende zolang dit niet verbonden is met fora die ook bovenlokale problemen kunnen oplossen. Want om die problemen het hoofd te kunnen bieden (en op zijn minst: er met het hoofd bij te kunnen) is een blik over de grenzen van de eigen instelling heen onontbeerlijk.

Naast deze geïnstitutionaliseerde vormen van inspraak en medezeggenschap is er sprake van een groeiend aantal belangenorganisaties buiten de directe context van de instelling zelf. In deze organisaties worden deelbelangen gebundeld en wordt getracht vormen van tegenmacht te ontplooien. Voorbeelden zijn de vereniging Per Saldo die de belangen behartigt van personen met een 'persoonsgebonden budget', en de Vereniging van ouders met hoogbegaafde kinderen. Meer in het algemeen zien we dat de Consumentenbond zich steeds actiever profileert in de publieke dienstverlening, met name in de gezondheidszorg.

\subsubsection{EEN VOORBEELD: PUBLIEKE VERANTWOORDING IN DE VOLKS- HUISVESTING}

De verantwoordelijkheid voor het opstellen van beleid verschilt sterk per sector. Zo is de minister van Volksgezondheid verantwoordelijk voor de tekorten in de zorg, maar wordt op het terrein van de Volkshuisvesting door de corporaties op de kapitaalmarkt voorzien in hun financieringsbehoefte (Godfroij en De Jager 
1997). De bruteringsoperatie van 1995 (waarin de uitstaande leningen aan de corporaties van de rijksoverheid werden verevend met het totaal van objectsubsidies die zij nog tegoed hadden (Klijn 1995)) betekende dat de dominante positie van de rijksoverheid sterk werd ingekrompen ten gunste van een grotere zelfstandigheid van de corporaties. Met de verplaatsing van beleid moest echter ook tegemoetgekomen worden aan een adequate verplaatsing van verantwoordelijkheid. Om daarin te voorzien moeten corporaties aan een aantal voorwaarden voldoen om als toegelaten instelling te worden geaccepteerd. Deze zijn: het beschikbaar stellen van geschikte woonruimte aan de doelgroep, zorgen voor financiële continuïteit, duurzame kwaliteit van het woningbezit, adequate bewonersparticipatie en leefbaarheid van de woonomgeving. Corporaties zijn verplicht om een Intern Toezichthoudend Orgaan in te stellen en verschillende jaarverslagen (jaarrekening, financieel jaarverslag, volkshuisvestelijk verslag) te overleggen. De minister komt slechts via de gemeente in beeld. Pas als de gemeente op basis van deze verslagen een uitspraak doet dat de corporatie een andere gedragslijn moet volgen, kan zij eventueel de minister van VROM vragen om maatregelen te nemen, zoals het besluit om een 'aanwijzing' te geven en (in een uiterst geval) zonodig de toelating in te trekken. Daarnaast is voorzien in een vorm van maatschappelijke verantwoording op meer lokaal niveau voor de gebruikers: de instelling van bewonerscommissies en een klachtenregeling.

Bij elkaar opgeteld lijkt het erop dat met de bruteringsoperatie en het aan de kant zetten van een belangrijk instrument voor overheidssturing (financiering) niet is ingeleverd op de mogelijkheden en de wil van corporaties om de sociale doelstelling van het huisvestingsbeleid na te streven. Echter, de precieze consequenties moeten in veel gevallen nog blijken, en van verschillende zijden wordt gewaarschuwd voor een al te groot optimisme. Zo worden vraagtekens gezet bij het met verve uitgedragen zelfbeeld van de corporaties als maatschappelijke ondernemingen die onderdeel zouden uitmaken van een (zoals het CDA het tot voor kort onomwonden noemde) 'gerevitaliseerd maatschappelijk middenveld':

"Het zijn vastgoedbedrijven die door het lage benodigde rendement op eigen en op vreemd vermogen, en door kruissubsidiëring, in staat zijn tot een kwalitatief goed en voor de lagere inkomensgroepen betaalbaar woningaanbod. Maar het is wat overdreven om ze te beschouwen als een constituerend deel van de civil society" (Van der Schaar 2002).

Als redenen daarvoor noemt Van der Schaar de te grote bedrijfsmatige, professionele en bestuurlijke autonomie; het gebrek aan platform dat ze bieden aan burgers voor zelforganisatie; en het gemis aan de mobilisatie van openbaar debat over maatschappelijke problemen. Corporaties lijken de financiële gezondheid van hun instellingen en een 'buffer' van voldoende eigen kapitaal te laten prevaleren boven hun sociale doelstellingen.

Deze bezwaren in aanmerking nemende lijkt het erop dat door de bruteringsoperatie weliswaar veel verantwoordelijkheid en handelingsvrijheid is verschoven 
van de overheid naar de corporaties, maar dat de daadwerkelijke invulling van de maatschappelijke verantwoordelijkheid zich nog verder zal moeten uitkristalliseren.

Een recent idee om die maatschappelijke doelstelling te versterken is geopperd door de voorzitter van branchevereniging Aedes. Het voorstel komt erop neer om de verantwoordingsrelatie op lokaal niveau in te richten als een stakeholdersdialoog met betrokkenen uit de 'omgeving' van het werkgebied van de corporatie. Hoewel deze betrokkenheid nog niet is ingevuld, moeten we daarbij denken aan huurders, scholen, gemeente, politie, wijkwerkers, winkeliers etc. De kwaliteit van de stakeholdersdialoog zou bewaakt moeten worden door de raad van toezicht van de corporatie. Consequentie hiervan is wel dat de huurdersverenigingen geen deel meer zouden uitmaken van de raad van toezicht.

Voor dit voorstel is veel te zeggen. Democratisering (of legitimering) van instellingen te laten plaatsvinden via vertegenwoordiging van betrokkenen in de raad van toezicht is een ongelukkige figuur. De belangen en het soort betrokkenheid van dergelijke stakeholders zijn te divers om via een raad van toezicht goed tot hun recht te kunnen komen. Bovendien is een raad van toezicht er in de eerste plaats voor de controlefunctie en in de tweede plaats voor de kritische adviesfunctie. De raad is niet het forum om een verbreding van de maatschappelijke verantwoording in op te nemen.

Echter, om een stakeholdersdialoog niet tot een wassen neus te laten verworden zijn enkele concrete waarborgen nodig. Hoewel dit niet de plaats is daar en detail uitwerking aan te geven of voorstellen voor te doen, biedt een dergelijk initiatief wel degelijk mogelijkheden er institutionele verbeelding op los te laten. De afspraken tussen overheid en corporaties die in de nasleep van de bruteringsoperatie zijn gemaakt bevatten nog immer een vacature voor een versterking van de sociale doelstelling van de woningbouwcorporaties. De doelstellingen daarin zijn namelijk weinig concreet en moeilijk te operationaliseren. Hier zou een stakeholdersdialoog uitkomst kunnen bieden. Het idee zou dan zijn om in een dialoog met de direct betrokkenen invulling te geven aan de sociale doelstellingen en afspraken te maken over de uitvoering daarvan. Het bestuur zou daarover verslag moeten opmaken en de raad van toezicht ziet toe op naleving daarvan.

\subsubsection{EEN MAGER RESULTAAT}

Het begrip verantwoording kan in een smalle en in een bredere betekenis worden opgevat. In de smalle zin is verantwoording vooral het afleggen van rekenschap en het voorzien in mogelijkheden daartoe door het geven van informatie over de mate waarin doelen zijn behaald en resultaten gerealiseerd (een controledoel). In de bredere betekenis gaat het vooral om een responsieve rol van organisaties en instellingen waarbij mede op basis van informatie en dialoog instellingen zich laten informeren door belanghebbenden en rekening houden met hun wensen en bij de realiseren van hun doelstellingen (een leerdoel). Instellingen vervullen in 
deze zin ook een maatschappelijke rol. Noch in de smalle noch in de brede betekenis is er onzes inziens voldoende vooruitgang geboekt in termen van input- en outputlegitimiteit. Zoals in de inleiding gesteld, zijn wij op zoek gegaan naar verantwoordingsinstrumenten die niet alleen de legitimiteit van de uitvoeringspraktijken versterken maar ook de kwaliteit en doelmatigheid ervan. De oogst is mager.

\section{Stapeling van verantwoordingsinstrumenten}

In de zoektocht naar vormen van verantwoording is veel aandacht besteed aan controle en weinig aan leervermogen. We zien in de praktijk een stapeling van verantwoordingsinstrumenten. Met behoud en soms zelfs uitbreiding van instrumenten voor verticale verantwoording is er ook geïnvesteerd in vormen van horizontale verantwoording. Hoewel er geen twijfel bestaat over het feit dat de ene vorm de andere niet kan vervangen, is er weinig duidelijkheid en weinig consensus over hoe de verschillende vormen zich tot elkaar verhouden. Het resultaat is een overdaad aan toezicht en controle zonder dat er coördinatie en afstemming plaatsvindt. Nieuwe vormen worden geïntroduceerd zonder dat er een relatie wordt gelegd met bestaande toezichtsarrangementen.

\section{Verschuiving van input-legitimiteit naar output-legitimiteit}

Hoewel het valt toe te juichen dat verantwoordingsmechanismen ook de nadruk leggen op output-legitimiteit, menen wij een verschuiving van input-legitimiteit naar output-legitimiteit waar te nemen zonder dat er een duidelijke visie is op wat die output zou moeten zijn en zonder dat er consensus is over wie de output zou kunnen en moeten definiëren. Het effect hiervan is een overdaad aan instrumenten aan de outputzijde, zoals prestatie-indicatoren en verplichte benchmarks, zonder dat duidelijk is wat de norm is waaraan de maatschappelijke instellingen moeten voldoen en zonder bijbehorende kosten-batenafweging. Dit leidt tot perverse effecten zoals het sturen op diensten die wel meetbaar en kwantificeerbaar zijn en de productie van gegevens waar niets mee wordt gedaan. Bovendien staat dit haaks op het professionele karakter van de dienstverlening en wordt onvoldoende rekening gehouden met het feit dat de kwaliteit veeleer wordt bepaald door het proces van dienstverlening zelf dat zich niet makkelijk laat vertalen in outputindicatoren.

\section{Beperkt probleemoplossend vermogen en uitholling van legitimiteit}

De effectiviteit van de verantwoordingsinstrumenten is beperkt en de mogelijkheid om met deze instrumenten inzicht te krijgen in de kwaliteit en doelmatigheid van de maatschappelijke dienstverlening is eveneens gering. Verantwoording dreigt een doel op zich te worden en het onderscheid tussen informatie ten behoeve van de verbetering van de kwaliteit van de professionele dienstverlening enerzijds en ten behoeve van informatie over de prestaties van de organisatie anderzijds wordt onvoldoende gemaakt. De inspraak en medezeggenschapsinstrumenten ritualiseren en routiniseren. 


\subsubsection{NIEUWE WEGEN: ZOEKTOCHT}

De meest gewenste situatie voor de maatschappelijke dienstverlening bestaat uit een combinatie van vormen van verantwoording die zowel de legitimiteit (input) als de kwaliteit, toegankelijkheid en doelmatigheid van de maatschappelijke dienstverlening (output) versterken. Van een dergelijk programma kunnen hier alleen maar de contouren geschetst worden. Het vereist veranderingen op het gebied van cultuur, structuur en bestuur.

\section{Van regelgeving naar probleemoplossing}

Waar centrale overheden over het algemeen excelleren in het uitvaardigen van regels en richtlijnen aan instellingen, zou hun centrale positie ook kunnen worden gebruikt om bijvoorbeeld de informatie-uitwisseling van goede praktijkvoorbeelden en nieuwe initiatieven te faciliteren. Er is een omslag nodig, zo hebben Cohen en Sabel (1997) betoogd, van een traditie van regelgeving naar een traditie waarin probleemoplossingen centraal staan. Die omslag zou het beter mogelijk moeten maken lokale experimenten te stimuleren. Daarvoor moeten de betrokkenheid bij en het vertrouwen van belanghebbenden in verschillende maatschappelijke instellingen worden versterkt, hun voice ('zeggenschap') worden verstevigd en de gerichtheid op het oplossen van problemen worden aangewakkerd. De stakeholders van bijvoorbeeld scholen, woningbouwcorporaties en ziekenhuizen bezitten nu eenmaal relevante (lokale) kennis. Ze hebben een gedeeld belang bij de oplossing van een prangend probleem. Ze kunnen concrete probleemdefinities leveren en hebben de mogelijkheid direct toe te zien op de implementatie en uitvoering van oplossingen.

Deze strategie zou kunnen betekenen dat er niet zozeer wordt gezocht naar representatieve organen als wel naar personen en groepen die betrokken zijn bij de dienstverlening zelf en mee willen denken over oplossingen. Een belangrijke ondersteuning daartoe zou geleverd kunnen worden door overheidsorganisaties die vanuit hun positie een goed overzicht hebben 'op het veld' (zoals de Inspectie) en die de uitwisseling en ervaring met geslaagde experimenten kunnen begeleiden en coördineren. Daarnaast vereist deze benadering een open en responsieve houding van de zijde van de dienstverleners; de nieuwe professional.

\section{Fijnmazige structuren}

In het proces van 'verantwoorden' (van iemand, over iets, aan een forum) zijn verschillende aspecten te onderscheiden: normeren, informeren, beoordelen en eventueel optreden.

1 Het normeren betreft het bepalen waarover verantwoording moet worden afgelegd. Wat zijn de doelstellingen, hoe gaan die gehaald worden, met welke middelen, tegen welke prijs, enzovoorts? Vervolgens moet worden bezien welke indicatoren het meest geschikt zijn om het naleven van deze normen te volgen. Het vaststellen van normen is een zaak van politieke afweging. De politiek bepaalt het mandaat en de handelingsruimte van een instelling. De indicatoren worden niet noodzakelijkerwijs door de politiek vastgesteld; zij 
zijn nauw verbonden met de werkpraktijk van instellingen en worden bij voorkeur door hen bepaald.

2 Informeren kan geschieden door verslaglegging en openbaarheid van resultaten en kan zowel eenrichtingsverkeer zijn (alleen openheid bieden) als tweerichtingsverkeer (ook tot verbetering en bijstelling komen). Een manier om in dit tweerichtingsverkeer te voorzien is benchmarking. Hierin schuilt echter het gevaar dat de leereffecten die van benchmarking kunnen uitgaan verworden tot een nieuwe vorm van prestatiemeting. In die zin is het een mooi voorbeeld van hoe een instrument dat bedoeld is om kwaliteit te verbeteren, misbruikt wordt om een oordeel te vellen. Dat gebeurt wanneer cijfers en indicatoren worden gebruikt als 'streefgetallen' en benchmarking het dwingend opleggen van de 'best practices' van een instelling aan alle andere soortgelijke instellingen wordt. Informeren gaat pas samen met 'leren' als benchmarking weer wordt gebruikt zoals het oorspronkelijk bedoeld is: als informatie voor de instellingen zelf, op basis waarvan zij kunnen leren, vergelijken en eigen prestaties kunnen verbeteren en juist niet als een vergelijkingsinstrument door de buitenwereld zoals de overheid of andere stakeholders.

3 Beoordelen betreft het oordeel over het functioneren. De meeste voorbeelden en voorstellen in de praktijk zijn gericht op het zelfsturende vermogen van de sectoren zelf: branchecodes, toelating als aan bepaalde gedragsregels voldaan en dus ook royement als het niet gebeurt, vormen van accreditatie en kwaliteitskeurmerken. Daarnaast zijn er voorbeelden van organisaties van consumenten en patiënten die een oordeel vellen over de prestaties van een organisatie en deze openbaar maken. Dat laatste is een belangrijk instrument om verbetering af te dwingen en een dergelijke benadering grijpt direct in op de reputatie van de dienstverleners in kwestie. Een derde vorm van beoordeling is dat instellingen zich - al dan niet vrijwillig - onderwerpen aan een externe beoordeling. In het onderwijs is het visitatiesysteem bekend.

4 Het optreden ten slotte behelst zowel sanctie- als interventiemechanismen: een aanwijzing door de minister, onder toezicht plaatsen door inspecties, ingrijpen door de raad van toezicht, actiever optreden door de brancheorganisaties, en eigenlijk ook het 'stemmen met de voeten' door klanten (de exitoptie, hoewel vaak zwak ontwikkeld door de sterke afhankelijkheid van consumenten). Ook op het gebied van het optreden is veel in ontwikkeling. In de gezondheidszorg is een pleidooi gehouden voor het instellen van een kamer voor de zorg, vergelijkbaar met de Ondernemingskamer, waar belanghebbenden het disfunctioneren van een raad van toezicht aanhangig kunnen maken. De Ondernemingskamer kan een onderzoek instellen en een aanwijzing geven (de raad van toezicht naar huis sturen). Een andere mogelijkheid - een vorm van zelfbinding - is dat stichtingen in hun statuten opnemen wie zij als belanghebbenden aanmerken en deze in staat stellen om eventueel disfunctioneren aanhangig te maken (enquêterecht). Te denken valt verder aan de instelling van een 'vereniging van ouders en verzorgers' in het leerplichtig onderwijs en het toekennen van interventiemacht aan groepen betrokkenen. 
Deze vier aspecten van verantwoording zijn niet alleen fasen in een proces, ze kunnen ook als afzonderlijke functies worden beschouwd. Er valt dan een oplopende 'graad van bemoeienis' in te lezen, van eenzijdig aanbieden van informatie door instellingen (zonder veel mogelijkheid tot respons) tot verregaand tweerichtingsverkeer tussen dienstverlener en forum, uitmondend in mogelijkheden tot interventie door de laatste. De kunst is om een dusdanige structuur te ontwerpen dat deze verschillende functies alle hun plaats krijgen zonder dat een forum wordt overvraagd en zonder dat er overlap of leemtes tussen de fora zijn.

\section{Terughoudendheid en precisie in de rol van de overheid}

Deze andere manier van werken is alleen mogelijk als er ook sprake is van precisie en terughoudendheid in het bestuur. Het is van belang dat de overheid bepaalt waarop zij toezicht wil houden. Wat zijn de uitgangspunten waaraan instellingen zich moeten houden en waarop zij worden afgerekend. Anders gezegd: welke 'kroonjuwelen' staan in het overheidsbeleid centraal en mogen niet worden verzaakt? Welke doelen stellen maatschappelijke instellingen zich, hoe borgen zij de kroonjuwelen, wat doen zij nog meer en waar zijn zij op aanspreekbaar? Wie zijn de belanghebbenden en welke verantwoordelijkheid dragen zij bij de beoordeling van beleid en praktijk van de uitvoering? Waar het op aankomt is dat de speelruimte van maatschappelijke instellingen duidelijk is en dat ook helder wordt wat de kaders zijn die de overheid stelt. Deze speelruimte en kaders zijn uiteraard niet voor eeuwig gegeven maar aan verandering onderhevig. Met de informatie die wordt gegenereerd door de fijnmazige verantwoordingsstructuur die wij zojuist hebben beschreven, kunnen kaders en speelruimte worden bijgesteld. Deze bepalen het mandaat waarmee maatschappelijke instellingen hun werk kunnen verrichten en invulling kunnen geven aan de sociale doelstellingen die zijn gesteld. Een dergelijk mandaat bepaalt waar instellingen minimaal aan gehouden zijn. Dit is het publieke belang waar zij op aangesproken en afgerekend worden. Daarnaast kunnen zij - gegeven de eigen speelruimte en verantwoordelijkheid - uiteraard meer doen! Het gegeven mandaat is politiek in de klassieke zin en dient derhalve bij uitstek tot stand te komen in het spel tussen regering en parlement dat kenmerkend is voor onze representatieve parlementaire democratie; verantwoording, verticaal en horizontaal en intern en extern, is altijd supplementair aan de centrale belangenafweging op nationaal niveau en kan daar nooit voor in de plaats komen. 


\section{NOTEN}

Met dank aan het commentaar en de suggesties van Paul Frissen, Ewald Engelen en de leden van de WRR-projectgroep 'Governance en maatschappelijke dienstverlening'.

Bijvoorbeeld voor de sector van de volkshuisvesting (commissie Intern Toezicht Woningbouwcorporaties 1998), de gezondheidszorg (commissie Health Care Governance 1999), cultuur (commissie Cultural Governance 2000) en onderwijs (commissie Transparant Toezicht Hogescholen 200o). Een speciaal netwerk van brancheorganisaties in de sectoren wonen, zorg en onderwijs bevordert de verdere ontwikkeling van governanceregelingen en branchecodes (Netwerk Toekomst Maatschappelijke Onderneming).

'Verantwoording en toezicht bij rechtspersonen met een wettelijke taak', zie www.rekenkamer.nl (10 september 2003).

De vijf zelfstandige bestuursorganen zijn het Kadaster, de Informatiebeheer Groep, het Centraal Orgaan Opvang Asielzoekers, Staatsbosbeheer en de Rijksdienst voor het Wegverkeer. Op 15 mei 2004 heeft de Sociale Verzekeringsbank zich als zesde partij hierbij aangesloten. Zie: www.publiekverantwoorden.nl (14 juni 2004).

5 In het proces van het afleggen van verantwoording worden door verschillende auteurs drie fasen onderscheiden, die overeenkomen met verschillende betekenissen van het begrip 'verantwoording' (Tuurenhout 1992; Cliteur 1999; Van Thijn en Van Dijk 200o). In de eerste plaats kan verantwoordelijkheid betrekking hebben op een causale relatie, en geeft zij verband aan tussen twee gebeurtenissen in termen van oorzaak en gevolg ('wie heeft het gedaan'). In de tweede plaats betekent verantwoordelijkheid het mogelijk maken van het afleggen van rekenschap, door informatie te verschaffen over gebeurtenissen waarop men wordt aangesproken (bijv. door het parlement). In de derde plaats is er de uiteindelijke taakverantwoordelijkheid voor het opstellen en uitvoeren van beleid dat aan niemand anders dan de minister kan worden toegeschreven en waarvoor een sanctie wordt opgelegd als deze in gebreke blijft. Zie onder meer Tuurenhout, M. (1992), het rapport van de externe commissie Ministeriële Verantwoordelijkheid (Kamerstukken II, 21 427, nrs. 40 en 41 (1992-1993)), Jürgens (1993), het rapport van de Commissie Holtslag (1998), Cliteur (1999), Peper (1999), Geelhoed zoals geciteerd in het NRC Handelsblad van 7 augustus 1999, het WRR-rapport Het borgen van publiek belang (2000), Van Thijn en Van Dijk (2000), Rosenthal (2000) en Scheltema (2000). Commissie Health Care Governance en Commissie Transparant Toezicht Hogescholen.

"Gebruikersraden, cliëntenraden, ledenraden en soortgelijke organen waarin deze belanghebbenden zijn vertegenwoordigd, oefenen ongetwijfeld invloed uit, maar kunnen vrijwel nooit interveniëren in het beleid van directie of bestuur (van de RWT).”

De Algemene Rekenkamer hanteert de volgende definitie van toezicht: “Toezicht is het verzamelen van informatie over de vraag of een handeling of zaak voldoet 
aan de daaraan gestelde eisen, het zich daarna vormen van een oordeel daarover en het eventueel naar aanleiding daarvan interveniëren”.

10 Zie de initiatieven van het NTMO en de Handvestpartijen. 


\section{LITERATUUR}

Algemene Rekenkamer (2003) 'Verantwoording en toezicht bij rechtspersonen met een wettelijke taak'.

Beck U., A. Giddens, S. Lash (1994) Reflexive modernization; politics, tradition and aesthetics in the modern social order. London: Polity Press.

Bovens, M., W. Derksen, W. Witteveen, P. Kalma en F. Becker (1995) De verplaatsing van de politiek, Amsterdam: Wiardi Beckman Stichting.

Bovens, M.A.P. en M. Scheltema (1999) 'Rechtsstatelijke redeneerpatronen', blz. 137-172 in W. Derksen, M. Ekelenkamp, F.J.P.M. Hoefnagel en M. Scheltema (red.) Over publieke en private verantwoordelijkheden, WRR Voorstudies en achtergronden nr. V105, Den Haag: Sdu Uitgeverij.

Bovens, M.A.P. (2000) De vierde macht revisited, oratie.

Cliteur, P. (1999) 'Ambtenaar en politiek. Over de anarchie in ons openbaar bestuur', blz. 134-145 in Liberaal Reveil.

Cohen, J. en Ch. Sabel (1997) 'Directly-deliberative polyarchy' in European Law Journal 3: 313-342.

Elte, R., D. van Est, C. van Montfort en I. van der Weijde (2003) 'Horizontalisering van toezicht en verantwoording in de publieke sector', blz. 24-29 in Openbaar Bestuur mei 2003.

Externe Commissie Ministeriële Verantwoordelijkheid (Kamerstukken II, 21 427, nrs. 40 en 41 (1992-1993)).

Eijlander, Ph. et al. (2001) Modernisering onderwijswetgeving, eindrapport, Schoordijk Instituut oktober 2001.

Godfroij, A.J.A en de B. Jager (1997) 'Besturen en toezicht houden in de volkshuisvesting', in Bestuurskunde 6, 2: 46-55.

Jürgens, E.C.M. (1993) 'Het rapport van de commissie-Scheltema over de ministeriële verantwoordelijkheid', in Bestuurskunde 2, 5: 248-252.

Klijn, E.H. (1995) 'De stille revolutie in de volkshuisvesting', in Bestuurskunde 4, 2: 53-61.

Leeuwen, W.D. van (2002) 'Herstel van horizontale hechting', in: Christen Democratische Verkenningen 2002: 7-9.

Luursema, M., M. van Twist et al. (2003) Toekomst voor raden van toezicht?, Assen: Koninklijke van Gorcum.

Majone, G. (1989) Evidence, argument \& persuasion in the policy process, New Haven and London: Yale University Press.

Majone, G. (1996) 'Temporal consistency and policy credibility: why democracies need non-majoritarian institutions', Working paper RSC no 96/57.

Meer, J. van der en M. Ham (2001) De verplaatsing van de democratie, Amsterdam: De Balie.

Ministerie van Binnenlandse Zaken en Koninkrijksrelaties (2001) Kaderstellende visie op toezicht, Den Haag.

Netwerk Toekomst Maatschappelijke Onderneming (2003) De waarde van de maatschappelijke onderneming geborgd, Hilversum: NTMO.

Peper, B. (1999) 'Op zoek naar samenhang en richting', in NRC Handelsblad 13 augustus 1999. 
Pierre, J. en B. Guy Peters (200o) Governance, politics and the state, New York: St. Martin's Press.

Raad voor het Openbaar Bestuur (200o) Bestuurlijke samenwerking en democratische controle, Den Haag: ROB.

Rosenthal, U. (200o) 'Macht en controle op de macht: de dringende behoefte aan publieke controle', in: Nederlands Juristen Blad: 1703-1706.

Van der Schaar, J. (2002) 'Vraagsturing, maatschappelijk ondernemerschap en woonbeleid', Amsterdamin: Christen Democratische Verkenningen 7, 8, 9: 153-161.

Scharpf, F. (1999) Governing in Europe, effective and democratic?, Oxford: Oxford University Press.

Scharpf, F. (2003) 'Problem solving, effectiveness and democratic accountability in the EU', MPIfG Working Paper 03/1.

Scheltema, M. (2000) 'Voldoet de ministeriële verantwoordelijkheid nog bij een professionele overheidsorganisatie?’, in Nederlands Juristen Blad 38: 1861-1867.

Thijn, E. van en P. van Dijk (200o) 'Parlementaire controle en ministeriële verantwoordelijkheid', in Bestuurskunde 9, 5: 209-218.

Tuurenhout, M. (1992) Parlementaire controle en ambtelijke verantwoordelijkheid, Arnhem.

Vries, G. de (2002) 'Doen we het zo goed? De plaats van het publieke debat over medische ethiek in een democratie', in Krisis 3: 239-59.

Westerloo, G. van (2003) Niet spreken met de bestuurder, Amsterdam: De Bezige Bij.

Wetenschappelijke Raad voor het Regeringsbeleid (2000) Het borgen van publiek belang, Rapporten aan de Regering nr. 56, Den Haag: Sdu Uitgeverij.

Witteveen, W., B. van der Klink et al. (2002) De sociale rechtsstaat voorbij. Twee ontwerpen voor het huis van de rechtsstaat, WRR Voorstudies en achtergronden nr. V116, Den Haag: Sdu Uitgeverij. 


\title{
7 DEWEY EN DE NIEUWE POLITIEKE KWESTIES IN DE KENNISSAMENLEVING
}

\author{
H.O. Dijstelbloem, C.J.M. Schuyt en G.H. de Vries
}

\subsection{DE CONFRONTATIE MEt 'UNidentified Political objects'}

Het ligt voor de hand te denken dat als democratie ergens gerealiseerd kan worden, het in een kennissamenleving is. De aanwezigheid van een bevolking van hoogopgeleide burgers en de technische mogelijkheden om zich te informeren en discussies te voeren vormen immers de gunstige voorwaarden voor een bloeiende democratische cultuur. Toch staan de zaken er minder rooskleuring voor. De huidige democratie wordt geconfronteerd met de opkomst van een nieuwe categorie van problemen, zoals rond klimaatverandering, genetisch gemodificeerd voedsel en nano-technologie. Het gaat daarbij om kennisintensieve, onuitgekristalliseerde kwesties die zowel om politieke als wetenschappelijke aandacht vragen. De legitimatie van besluiten die erover genomen worden is op beide terreinen problematisch. Naar analogie van de afkorting UFO zullen wij spreken van unidentified political objects, UPO's (Dijstelbloem 2003). ${ }^{1}$ Met betrekking tot UPO's bestaat binnen wetenschappelijke kring nog onvoldoende overeenstemming om van vaststaande feiten te kunnen spreken en vindt, mede door het ontbreken van duidelijkheid over maatschappelijke gevolgen, het politieke handelen onder grote onzekerheid plaats.

Agendering van het probleem van de UPO's is hoogst relevant in een kennissamenleving. Twijfel aan het vermogen van een democratie om met 'kennis' om te gaan is echter allerminst nieuw. Al sinds het klassieke Athene is kritisch commentaar geleverd op de wijze waarop democratische samenlevingen met kennis omgaan. Dat het volk een stem heeft in besluiten over belangrijke problemen kan volgens de critici alleen maar uitlopen op een mislukking. De zaken waar een goed bestuur zich op moet richten strekken zich immers uit over langere termijn en vragen om een oriëntatie op een algemeen belang. Dat vereist kennis. De opinies van het volk zijn kortzichtig en stoelen op onvoldoende inzicht. $\mathrm{Zij}$ worden gedreven door eigenbelang, zijn wispelturig en vatbaar voor manipulaties door machthebbers. De schaduw van Plato hangt nog steeds over de democratie heen. Ook al wordt het in de moderne tijd als de 'dictatuur van de meerderheid' geformuleerd, het in twijfel trekken van de epistemologische kwaliteiten van de democratie is een terugkerend fenomeen. Het oordeel valt even zo vaak negatief uit.

Een uitzondering hierop vormt de Amerikaanse pragmatist Dewey. Dewey vraagt expliciet aandacht voor de epistemologische kwaliteiten van de democratie (Geuss 2001). Dat wil uiteraard niet zeggen dat hij meent dat de waarheid bij meerderheid van stemmen wordt bepaald. Traditioneel wordt epistemologie oftewel kennistheorie gezien als het vakgebied waarin getracht wordt een filoso- 
fische theorie te ontwikkelen over de wijze waarop en de voorwaarden waaronder 'kennis' ontstaat. Weinig filosofen denken dat democratie tot die voorwaarden behoort. Dewey verzet zich echter tegen dit soort epistemologie. Hij verkiest een kennistheorie die pragmatisch is en stelt zich daarbij op het standpunt dat 'intelligent denkwerk' relatief is aan concrete problematische situaties. Vanuit dat gezichtpunt bezien hebben democratische instituties, waar zij bijdragen aan het probleemoplossend vermogen van een samenleving, wel degelijk een functie bij het verwerven van kennis. In dit hoofdstuk zullen aan de hand van Deweys gedachtegoed, met de nadruk op The public and its problems (1927), de epistemologische kwaliteiten van democratie worden onderzocht.

De opbouw van dit hoofdstuk is als volgt. Eerst omschrijven we de specifieke problematiek van de UPO's. We bespreken de uitdaging voor kennissamenlevingen om een nieuwe legitimatie te zoeken voor de behandeling van de politieke en epistemologische kwesties waarvoor ze door deze UPO's worden gesteld. We bepleiten dat er conceptuele ruimte nodig is om de politieke behandeling van dergelijke UPO's te verbeelden (par. 7.2). Daarna illustreren we deze problematiek aan de hand van een typisch voorbeeld van een UPO: de uitbraak van aids in Nederland. Begin 1983, toen aids Nederland net had bereikt, was er nog geen virus geïdentificeerd. Onduidelijk was nog of aids een zogenaamde lifestyleaandoening was (en slachtoffers eiste door een chronische weerstandsvermindering onder invloed van drugsgebruik en een voorgeschiedenis van geslachtsziekten) of dat er een virale actor in het spel was. De angst voor een dodelijke epidemie, het gevaar van stigmatisering van homoseksuelen, de relatie van de nieuwe ziekte met seks en de bedreiging van de bloedvoorraad vormden de ingrediënten voor een explosieve situatie. Zowel het politieke als het wetenschappelijke zicht op de kwestie was beperkt. Toch moest er beleid worden opgesteld en maatregelen worden genomen (par. 7.3). Na deze casus te hebben besproken laten we aan de hand van Dewey zien dat het denken in termen van 'zeggenschap' zowel praktisch als conceptueel onvoldoende soelaas heeft geboden. In plaats daarvan stellen we voor Deweys omkering van de notie van het publiek in een democratie te volgen. Door het publiek te definiëren als 'zij die gevolgen van een actie ondergaan', in plaats van als een bestaande gemeenschap waarvan de collectieve wil dient te worden vastgesteld, komen we tot andere inzichten over de manier waarop in een democratie zeggenschap en inspraak van betrokkenen en de kennis van experts georganiseerd kunnen worden (par. 7.4). Ten slotte onderzoeken we hoe op basis van deze analyse een herbezinning kan plaatsvinden op de rol die democratische instituties kunnen spelen om het probleemoplossende vermogen van een samenleving te versterken (par. 7.5).

\subsection{NIEUWE KWESTIES IN DE GREAT SOCIETY}

De notie van een 'democratie' is ontstaan of uitgevonden in een relatief kleine en overzichtelijke gemeenschap, de antieke stadstaat. Het mag opmerkelijk worden genoemd dat haar kernideeën vervolgens van toepassing zijn verklaard op moderne, complexe samenlevingen. De schaal van de moderne staat, de 
complexiteit van de maatschappelijke problemen, de ondoorzichtigheid van de bestuursmachine en de bureaucratie, de ingewikkelde sociale relaties waarin burgers zich bevinden, al deze verhouden zich immers maar moeizaam tot het originele idee van democratie waarin een relatief kleine elite van vrije burgers een stadstaat bestuurt. Dewey spreekt daarom van de spanning tussen democratie op 'kleine schaal' en de uitdagingen van de Great Society (Ryan 1995). Die spanning vereist een nieuwe manier van denken over politiek.

Het interessante van Deweys conceptie van politiek is dat hij politiek niet situeert in een overzichtelijke gemeenschap, maar er van meet af aan van uitgaat dat politiek er is omdat we in een samenleving met vreemden leven, met mensen die niet direct betrokken zijn bij onze alledaagse transacties maar daarvan wel de gevolgen zullen ondervinden. Dewey trekt met andere woorden de consequenties uit het feit dat we in een Gesellschaft en niet meer in een Gemeinschaft leven waarin iedereen de ander kent en overzicht bestaat. De Gemeinschaft bleef ondertussen wel zijn ideaal. Het normatieve probleem waarvoor Dewey zich gesteld zag kan dan ook als volgt worden geformuleerd: hoe kan in een Great Society datgene worden gecreëerd wat we appreciëren in een Gemeinschaft, namelijk het face-to-face-contact, het overleg, het wederzijds begrip, solidariteit, het rekening houden met elkaar?

De methode die Dewey voor ogen stond was een combinatie van wetenschappelijk onderzoek met democratie. Deze verstrengeling is in zijn ogen allesbehalve een 'technocratische' oplossing. Technocratie verwerpt hij. Een technocratie is niet alleen moreel gezien twijfelachtig en vatbaar voor allerlei gevaren (tirannie door experts), maar heeft ook epistemologische bezwaren. Wanneer machtsuitoefening in handen is van een kleine groep van experts, zijn de bestuurders niet alleen doof voor de opinies van het volk over allerlei misstanden en gepercipieerde problemen, maar wordt ook geen gebruik gemaakt van de kennis die in de samenleving op lokaal niveau aanwezig is. Niet alleen sluit de regerende klasse zich zo af van de belangen die ze geacht wordt te dienen, het zal haar uiteindelijk ook aan de kennis ontbreken om oplossingen te bedenken. Dewey maakt korte metten met het bekende argument van Plato voor een regering van wijzen, dat het net zo min verstandig is het maken van een schoen over te laten aan een leek als het bestuur van een staat aan niet ter zake deskundigen. Ook al is de schoenmaker de expert op het gebied van het verzinnen van een oplossing, de drager weet het beste waar de schoen knelt, aldus Dewey. Het probleemoplossend vermogen van een staat wordt versterkt als gebruik wordt gemaakt van lokaal aanwezige kennis, van wat tegenwoordig 'ervaringskennis' en 'lekenexpertise' wordt genoemd.

Daarmee is de kous echter niet af. De UPO's waarmee de kennissamenleving te kampen heeft, stellen ons immers niet voor zere tenen of een steentje in de schoen. UPO's betreffen problemen waarmee nog niemand ervaring heeft. Zij treden met name in kennissamenlevingen naar voren. Kennissamenlevingen worden met twee soorten nieuwe problemen geconfronteerd. 
In de eerste plaats is er sprake van de introductie van nieuwe entiteiten. Dat kunnen objecten zijn zoals nieuwe technologieën. In een lab wordt een nieuw product of procédé ontwikkeld en de rest van de wereld heeft met de consequenties te maken. De ketens die activiteiten met publieke consequenties verbinden worden daarbij steeds langer. Een technologie die in de Verenigde Staten ontwikkeld is, werpt zijn schaduwen af in andere delen van de wereld. Een UPO kan echter ook de gedaante hebben van een entiteit die in de natuurlijke wereld opduikt, zoals een nieuwe ziekte of een virus. Nemen we het begin van de aidsepidemie in Nederland, dan wordt duidelijk dat zich een UPO voordeed. Toen de eerste slachtoffers werden opgenomen was nog volstrekt onduidelijk hoe het besmettingspatroon verliep en of de ziekte overdraagbaar was via bloed of seksueel contact. Toch moesten er maatregelen getroffen worden.

In de tweede plaats is er sprake van het vervagen van grenzen. Er bestaat onduidelijkheid over de manier waarop problemen moeten worden ingekaderd. Bezien we hetzelfde voorbeeld (aids) dan blijken kennis en ervaring uit verschillende hoeken nodig om een volledig beeld te krijgen van de omvang en de gevolgen van de epidemie. Virologen richtten zich op de identificatie van de oorzaak van de ziekte, epidemiologen op het verspreidingspatroon ervan. Nieuwe inzichten over aids druppelden Nederland binnen, eerst uit de Verenigde Staten en later uit andere landen, maar of ze overeenstemden met de lokale, Nederlandse context was niet evident. Nederland zelf beschikte ondertussen over een uniek project waarmee voorspellingen konden worden gedaan over de verspreiding: een cohort homoseksuelen dat in het kader van een onderzoek naar de werking van het hepatitis-B-vaccin samenwerkte met de Amsterdamse GG\&GD. Resultaten daarvan werden geëxtrapoleerd voor de verspreiding van aids. Het opstellen, vergelijken en toepassen van deze epidemiologische modellen voor de nieuwe ziekte vereiste echter een nauwkeurig beeld van de sociaal-culturele omstandigheden en inzicht in de wijze waarop die repercussies hadden voor de verspreiding van de nieuwe ziekte. Als aids door seksueel contact wordt overgebracht, mogen we er dan wel van uitgaan dat de manier waarop zulke contacten in San Francisco plaatsvinden gelijk is aan die in Amsterdam? Of bestaan er lokale culturen en zijn de epidemiologische verspreidingsmodellen daarom niet uitwisselbaar?

Als gevolg van het kennisintensieve karakter van deze kwesties staan democratieën voor de uitdaging om op twee fronten met nieuwe antwoorden te komen.

Het eerste front betreft problemen rond zeggenschap. Complicatie daarbij is dat de hedendaagse politiek niet alleen gebruik van wetenschappelijke kennis voor oplossingen vereist (dat is niets nieuws), maar dat veel problemen niet anders zijn te formuleren dan in termen van experts. Een individuele burger kan vaststellen dat een naaste ernstig ziek wordt. Dat er sprake is van een epidemie van een nog onbekende ziekte, met een nog onbekend verspreidingspatroon, vereist echter specialistische kennis, statistische technieken, bloedonderzoek en toegang tot medische databanken. 
Het tweede betreft problemen van macht, te weten de macht van experts. Indien alleen wetenschappers over een geprivilegieerde toegang beschikken tot de ins en outs van een probleem, hoe valt dan te voorkomen dat, in plaats van de daartoe aangestelde bestuurders en politici, zij daadwerkelijk de besluiten nemen? Bedacht moet worden dat UPO's geen puur technische problemen zijn. Ondanks de wetenschappelijke kennis die vereist is om de problemen te identificeren spelen ook normatieve, morele kwesties een rol. Zo zijn er in het geval van aids in Nederland van het begin af aan twee ziektes bestreden: een lichamelijke, die leidt tot verspreiding en besmetting met aids, en een sociale, die in het slechtste geval stigmatisering en discriminatie van risicogroepen (zoals homoseksuelen) tot gevolg heeft. Over normatieve aspecten behoort in de eerste plaats politiek geoordeeld te worden. Die aspecten zijn echter nauw verweven met de technisch-wetenschappelijke aspecten van het probleem.

Verschillende modellen en tradities van democratie stellen andere manieren voor om met deze vraagstukken rond zeggenschap en macht om te gaan. Deze modellen van democratie zijn te verhelderen aan de hand van het onderscheid dat Scharpf (1970) heeft aangebracht tussen 'input-legitimiteit' en 'output-legitimiteit'.

Ligt in besluitvormingsprocessen vooral de nadruk op de input-legitimiteit, dan betekent dat een sterke accentuering van mechanismen die participatie, interactie en debat bewerkstelligen om zodoende de betrokkenheid en de zeggenschap van verschillende partijen bij de beleidsvoering (en zo mogelijk de acceptatie ervan in een later stadium) te vergroten. Wordt daarentegen het accent op de output-legitimiteit gelegd, dan wordt de legitimiteit vooral gevoed door de resultaten van getroffen maatregelen, ondersteund door een geloofwaardige beleidsuitvoering en beteugeling van de uitvoerende macht van de desbetreffende instituties.

Dit onderscheid biedt vele voordelen voor het analyseren van de verhouding tussen zeggenschap en legitieme machtsuitoefening in een democratie en de verhouding tussen de verschillende checks and balances. Het is vooral de inputlegitimiteit waarop wij aan de hand van Dewey onze kritiek zullen richten. De ideeën die Scharpf onder deze noemer schaart kenmerken zich door de nadruk die ze leggen op het belang van algemene wilsvorming en de aandacht voor het begrip soevereiniteit. Met Rousseau als vlaggenschip wordt de aandacht gevestigd op de noodzakelijkheid van de vorming van een collectieve wil in een democratie. Deze notie van een collectieve wilsvorming staat echter op gespannen voet met de problemen die zich voordoen in een kennissamenleving. De introductie van nieuwe entiteiten en de complexe grensafbakening van problemen maakt dat de groep van burgers die de gevolgen van een kwesties ondervindt van geval tot geval kan verschillen, partieel is en weinig continuïteit of houvast vertoont. Om dat in kaart te brengen is de kennis van experts onmisbaar. De problemen die in het geding zijn kunnen niet op basis van bestaande politieke meningen worden geïdentificeerd. De vraag die zich dan aandient is hoe de positie van de expert moet worden bepaald. In de volgende paragraaf zal deze proble- 
matiek rond zeggenschap en macht worden geillustreerd aan de hand van het reeds genoemde typische voorbeeld van een UPO: de introductie van aids in Nederland.

\subsection{DE UITBRAAK VAN AIDS IN NEDERLAND}

Het Nederlandse aids-beleid wordt in het buitenland vaak gezien als een schoolvoorbeeld van een geslaagde samenwerking tussen verschillende belangengroepen (bloedbanken, homobeweging, medische diensten) die een verregaande polarisatie heeft voorkomen zodat grote maatschappelijke spanningen of discriminatie en stigmatisering van de homo's is uitgebleven. ${ }^{2}$ Aan de frontlinie werd druk overleg gevoerd tussen vertegenwoordigers van de homobeweging (COC), de Nederlandse Vereniging van Hemofiliepatiënten (NVHP), het Centraal Laboratorium van de Bloedtransfusiedienst (CLB) en de Amsterdamse Gezondheidsdienst (GG\&GD). Toch is ook Nederland een bloedschandaal niet bespaard gebleven en zijn er in de begindagen onnodige slachtoffers gevallen onder de hemofiliepatiënten. De aantallen zijn echter aanzienlijk minder hoog dan in andere Europese landen (Bovens et al. 2003). Met enige goede wil zou men dan ook kunnen zeggen dat door het breed gevoerde overleg en de redelijke resultaten daarvan het beleid zowel legitiem als effectief is geweest. Dit beeld wordt met enige graagte uitgedragen door de homobeweging en overgenomen door verschillende auteurs (Van Wijngaarden 1989, 1992; Sandfort 1998). Immers, zo wordt geredeneerd, zonder al te veel overheidsbemoeienis heeft het overleg tussen de verschillende partijen tot een redelijk effectief beleid geleid.

Dit beeld van een zichzelf regulerend, goed gestroomlijnd overleg volgens het boekje van het 'poldermodel', is door verscheidene andere auteurs evenwel onderuitgehaald. Duyvendak concludeert dat het overleg tussen experts, belanghebbenden, ervaringsdeskundigen en andere geprivilegieerde representanten de dood in de pot is geweest voor een breed publiek debat (Duijvendak 1997). De politieke context en de structuur van het overleg waren zijns inziens zodanig dat er geen ruimte bestond om tot een tegengeluid te komen of van buitenaf invloed uit te oefenen op de koers van het beleid. Mooij heeft gewezen op de merkwaardige uitruil van 'inspraak' en 'het dragen van verantwoordelijkheid voor de voorlichting van de achterban' die tussen de homobeweging en de overige partijen zou zijn getroffen (Mooij 1993). De ontstane 'beheerste politiek' is volgens Mooij vooral het resultaat van de belangenovereenkomst tussen de homobeweging en de (para)medische beroepsgroepen. Uit angst dat de homobeweging weg zou lopen van de vergadertafel, de contacten verbreken en haar eigen gang zou gaan, moest zij gelijmd worden. Daar moest natuurlijk wel iets tegenover staan. In ruil voor hun betrokkenheid bij gesprekken over eventuele maatregelen, campagnes en voorlichting kregen de voormannen van de homobeweging medezeggenschap in het te voeren beleid. Daartegenover stond als wederdienst dat de spreekbuizen van de homogemeenschap hun achterban overtuigden van de noodzaak van gedragsveranderingen. Inspraak voor verantwoordelijkheid, dat was volgens Mooij de deal. 
Vuijsje echter stelt grote vraagtekens bij de wenselijkheid van die rol voor de homobeweging (Vuijsje 1997). Zijn stelling is dat de Nederlandse cultuur van politieke correctheid en 'tolerantie boven alles' debet is geweest aan het verlenen van de toonaangevende rol die de homobeweging heeft bedongen. Volgens hem zijn de hemofiliepatiënten daar uiteindelijk slachtoffer van geworden. Homoorganisaties hebben in zijn ogen grandioos misbruik gemaakt van de angst bij de overheid om beticht te worden van discriminatie. In plaats van bijvoorbeeld de Wet op de Infectieziekten op de nieuwe ziekte van toepassing te verklaren, was de moraal van het verhaal dat homoseksuelen zelf een folder maakten met twee naakte mannen op de voorzijde om verantwoordelijkheidsbesef te kweken bij homoseksuele donoren. Terwijl de homobeweging een goed georganiseerde organisatie was, die bovendien politiek zeer bewust was, waren de hemofiliepatiënten getalsmatig in de minderheid (tegenover honderdduizenden homo's stonden zo'n 1300 hemofiliepatiënten) en kenmerkten zij zich als gevolg van hun lichamelijke kwetsbaarheid door terughoudendheid. In een klimaat waarin iedere schijn van discriminatie al als een doodzonde werd beschouwd, hebben volgens Vuijsje de homo-organisaties hun positie, identiteit en culturele verworvenheden uitgebuit.

Een eerste observatie die kan worden gemaakt is dat de organisatie van de inputlegitimiteit uiterst selectief en onuitgebalanceerd is verlopen. Als het de bedoeling was om volledigheid na te streven in de deelname van belangengroepen aan het overleg is deze opzet niet geslaagd. Vertegenwoordigers van harddrugsgebruikers (intraveneuze drugsgebruikers) en de beroepsorganisatie van prostituees (de Rode Draad) ontbraken bijvoorbeeld. Zij traden pas later toe. In het risicoveld dat in kaart werd gebracht aan de hand van de besmetting door de bloedvoorraad zijn andere vormen van besmetting en het gedrag van andere bevolkingsgroepen (intraveneuze drugsgebruikers, prostituees) daardoor aanvankelijk onvoldoende verdisconteerd.

Daarnaast verschilde het vermogen van deelnemende partijen om hun belang met expertise of door mobilisatie van de achterban te dienen te veel om van een gelijkwaardige deelname te kunnen spreken. De samenstelling van de overleggroep verhulde bovendien spanningen. De GG\&GD heeft niet direct iets te zeggen over de bloedvoorraad, maar hield via haar contacten met het COC en CLB invloed. In de onderhandelingen was de GG\&GD onmisbaar. Het CLB op zijn beurt slaagde er niet in op directe wijze met het COC te overleggen, maar vond een bemiddelaar in de persoon van de directeur van de afdeling infectieziekten van de GG\&GD. En de NVHP was weer te zeer afhankelijk van het CLB en de buitenlandse leveranciers om überhaupt een radicaal standpunt te kunnen innemen. Zowel de representatie van groepen als de mogelijkheid om met kracht van argumenten posities te verdedigen was onvoldoende om van serieuze input-legitimiteit te kunnen spreken. Toch baseerde de staatssecretaris voor Volksgezondheid zijn afwezigheid in het overleg op de veronderstelling dat de legitimiteit voldoende gewaarborgd was. Als het, omgekeerd, de bedoeling was geweest om de besluitvorming te organiseren met het oog op maximaliseren van de output- 
legitimiteit, zou men hebben mogen verwachten dat meer werk was gemaakt van onafhankelijke kennisinbreng en van beoordeling door anderen dan de direct betrokkenen. Ieder van de aanwezigen in de besluitvorming vertegenwoordigde op de een of andere manier echter een groep die direct bij de gevolgen van de aids-epidemie betrokken was. Het gevolg daarvan was dat de (impliciete) probleemdefinitie die door dit overlegorgaan werd opgesteld niet overeenkwam met wat achteraf bezien maatschappelijk het meest gewenst zou zijn geweest.

Wat de verschillende auteurs echter over het hoofd lijken te zien wanneer zij het hebben over de beginperiode van het Nederlandse aids-beleid, en over 'ziektezelfbestuur' (Van Wijngaarden 1989) spreken, is dat in het overleg de bescherming van de bloedvoorraad centraal stond, en niet de volksgezondheid. De verschillende actoren, zoals de NVHP, het COC en het bloedwezen, onderhandelden met elkaar om de veiligheid van het bloed en de mensen die daar afhankelijk van zijn, te kunnen blijven garanderen. De besmetting van Nederlanders die niet direct met transfusie of stollingspreparaten in aanraking kwamen, was daar een afgeleide van en zeker geen hoofdonderwerp. De bloedvoorraad heeft voor ieder van de actoren een andere betekenis.

De volksgezondheid en de risico's voor de Nederlandse bevolking kwamen in de bijeenkomsten slechts aan bod in zoverre zij gerelateerd waren aan de kwestie van het bloed. De stelling dat het beleid over de volksgezondheid aan het veld kon worden overgelaten, omdat belangenbehartigers en experts al onderling tot maatregelen kwamen, is dan ook onhoudbaar. Het idee dat onder deze omstandigheden zoiets als een consensusgerichte aanpak of 'ziekte-zelfbestuur' vanzelf zou kunnen ontstaan, kan niet anders dan een illusie worden genoemd. De politiek was verhuisd naar een medisch-wetenschappelijk beraad, dat op zijn beurt bijkans barstte van de onverenigbare belangen. Het gevolg daarvan was dat de verantwoordelijkheid voor het beleid niet was ingevuld, maar ter plekke moest worden verdeeld en bevochten. Achteraf bezien gaf het dan ook geen pas dat de toenmalige staatssecretaris van Volksgezondheid het te voeren beleid aan 'het veld' overliet. In een rapport dat de Nationale Ombudsman in 1995 deed verschijnen (op verzoek van de Nederlandse Vereniging van Hemofiliepatiënten, de NVHP) wordt dan ook gesteld dat de overheid, in casu de toenmalige staatssecretaris van Volksgezondheid, Van der Reijden, "achter de feiten/ontwikkelingen aanliep en/of niet voldoende op de hoogte was van de stand van zaken, dan wel zich te lijdelijk heeft opgesteld" (Nationale Ombudsman 1995). Ten aanzien van de vormgeving van zeggenschap en gelegitimeerde machtsuitoefening kan de conclusie niet anders luiden dan dat beide onvoldoende gerealiseerd zijn.

Achteraf gezien is een van de meest verbazingwekkende karakteristieken van de Nederlandse aanpak van aids dat stilzwijgend het uitgangspunt voor de te treffen maatregelen verschoof van het veiligstellen van de volksgezondheid naar de bescherming van de bloedvoorraad. De relevante vraag is dan ook hoe het overleg en het beleid eruit hadden gezien indien deze verplaatsing niet had plaatsgevonden en de groep die de besluiten voorbereidde wel de volksgezondheid als 
uitgangspunt had genomen. Op zijn minst zouden de hemofiliepatiënten beter gehoord en behandeld zijn. In het meest extreme geval had men dan waarschijnlijk een veel hardere opstelling jegens de homobeweging ingenomen. Wie had daartoe echter de regie moeten nemen?

\subsection{HET PUBLIEK ALS GEVOLG. DEWEYS IDEE VAN DEMOCRATIE}

Deweys pragmatische politieke filosofie vormt een alternatief voor het denken in termen van 'zeggenschap' en 'macht' of op zijn minst een aanvulling daarop. In de benadering die hij in The public and its problems (1927) uiteen heeft gezet wordt de legitimiteit van de behandeling van een politieke kwestie niet gewaarborgd door a priori een notie van het 'collectieve' te hanteren, maar door het bepalen van de omvang en de reikwijdte van een bepaalde politieke kwestie. Het 'publiek' is niet gegeven, maar afhankelijk van de kwestie die in het geding is.

Dewey introduceert daarmee een andere opvatting over wie het 'publiek' of de relevante gemeenschap is die bij democratische besluitvormingsprocessen in het geding is. In het zeggenschapsmodel wordt politiek gedragen door een gemeenschap die over het te voeren beleid overlegt. De legitimiteit van de democratische besluitvorming berust uiteindelijk bij die gemeenschap. In Deweys opvatting is politiek echter niet in de eerste plaats een zaak van een gemeenschap van mensen die met elkaar overleggen, maar een zaak die ontspruit uit de omstandigheid dat private handelingen en transacties consequenties kunnen hebben voor vreemden die niet direct bij deze handelingen of transactie betrokken zijn. Dewey spreekt daarbij van een publiek dat bestaat uit: "all those who are affected by the indirect consequences of transactions to such an extent that it is deemed necessary to have those consequences systematically cared for" (Dewey 1927: 15-16). Verschillende private transacties zullen in het algemeen consequenties hebben die aandacht verdienen voor uiteenlopende niet direct bij die transacties betrokkenen. 'Publiek' is dus een relatieve term. Een publiek is dan ook iets anders dan een gemeenschap. Er is op voorhand geen reden te denken dat degenen die deel uitmaken van een publiek enige sociale band met elkaar hebben. De staat komt daarbij in beeld als behartiger van de publieke zaak, dat wil zeggen als de instantie die er zorg voor draagt dat het publiek georganiseerd wordt en dat degenen die voor de indirecte gevolgen van private handelingen komen te staan adequaat beschermd of gecompenseerd worden (Nelis et al. 2004).

De analyse die Dewey geeft komt in veel opzichten overeen met de manier waarop in de economische theorie over 'externe effecten' wordt gesproken. Negatieve externe effecten (gevolgen van een daad die anderen schade berokkent) zijn een vorm van marktfalen. Niet bij een transactie betrokken partijen zullen kosten moeten maken om hun welvaartsvermindering te compenseren, zonder dat deze kosten verrekend worden in de prijs van het product waarop de transactie betrekking heeft. Om in dergelijke situaties ervoor te zorgen dat de kosten wel aan een bepaalde partij worden toegerekend kan naar de rechter worden gestapt. Maar als de kosten aan niemand kunnen worden toegerekend is een derde partij (de staat, 
de overheid) nodig die er zorg voor draagt dat de externe kosten alsnog worden verrekend of door wettelijke maatregelen te nemen de gevolgen van transacties beperkt. Dewey neemt deze redeneerwijze over. Van een 'publieke zaak' spreekt hij waar de gevolgen van transacties de private sfeer waarin die transacties plaatsvinden te buiten gaan. Het 'publiek' bestaat uit degenen die met deze gevolgen worden geconfronteerd. Het is de taak van de staat om er zorg voor te dragen dat de gevolgen beperkt blijven, of het publiek adequaat te compenseren.

Voor het denken over democratie en de democratische praktijk van probleemhantering heeft dit grote implicaties. In de klassieke opvatting over democratie vormt de staat een voorwaarde voor een democratie: zij verschaft de instituties en de instrumenten (de middelen) die het proces van collectieve wilsvorming mogelijk maken dat moet leiden tot de formulering en realisatie van algemene belangen (het doel, zoals welvaart). Dewey draait de relatie om. Hij vereenzelvigt niet op voorhand 'de staat' met 'het publiek' maar onderkent dat de staat een veelvoud van publieken moet bedienen. De legitimiteit van de politiek berust dus niet bij een gegeven gemeenschap, maar in de manier waarop zorg gedragen wordt voor de gevolgen van private transacties waarmee publieken geconfronteerd worden. In plaats van een essentialistische speurtocht naar wat een staat is, kiest Dewey voor een functionalistische benadering. Hij concentreert zich op de taken die een staat en zijn functionarissen krijgen toebedeeld. Dewey onderkent dat mensen door zeer uiteenlopende banden aan elkaar worden gesmeed. Zulke banden kunnen het karakter van familie- of bloedbanden hebben, zij kunnen door geografische omstandigheden worden gecreëerd (rivieren en bergen scheiden mensen of veroordelen hen tot elkaar) of economisch van aard zijn. Pas waar de gevolgen van transacties binnen zulke associaties anderen, buiten die associatie treffen, is er sprake van een publieke aangelegenheid en komt de politiek in het vizier.

“The lasting, extensive and serious consequences of associated activity bring into existence a public. In itself it is unorganized and formless. By means of officials and their special powers it becomes a state. A public articulated and operating through representative officers is the state; there is no state without a government, but there is also none without the public" (Dewey 1927: 67).

In tegenstelling tot bijvoorbeeld Rousseau postuleert Dewey de staat niet als iets wat de private wil van mensen overstijgt in de vorm van een collectieve wil. De staat bedient verschillende publieken. In die zin onderscheidt Deweys concept van de staat zich ook van de pluralistische conceptie. Pluriformiteit van verschillende gemeenschappen in een staat is niet iets wat vanuit zijn visie wordt gewaardeerd als een vruchtbare grond voor bijvoorbeeld de vitaliteit van het politieke debat of de verscheidenheid aan levensvormen. Dewey ziet pluriformiteit als een gegeven dat voorafgaat aan de staat. De reikwijdte van de staat wordt niet bepaald door de omvang van de aanwezige gemeenschappen, maar is afhankelijk van de consequenties van bepaalde acties en de functie die aan de staat worden toebedeeld. 
Hoe kunnen functies aan een staat worden toebedeeld op grond van de consequenties die acties van mensen hebben? Hoe kan worden bepaald of een kwestie van dien aard is dat ze politiek is, het private overstijgt, publiek wordt en een staat vereist om een 'regeling' te treffen? In principe is niets uitgezonderd en kan alles een politieke kwestie worden. In de traditionele theorieën over democratie die zeggenschap centraal stellen hangt de vraag welke kwesties onderwerp zijn van politiek beraad, af van het blikveld, de interesses en belangen van mensen om ze te agenderen en de moeite die politici nemen daar weerklank aan te geven. Of een object onderwerp is van publiek beraad is dus een zaak van wils- en meningsvorming.

Geheel anders blijkt het alternatief van Dewey. In zijn benadering is de bepaling van 'het publiek' geen zaak die voorafgaat aan de uitvoering van de wil ten aanzien van een bepaald politiek object, maar volgt zij daarop. Voorop staat bij hem niet de legitimiteit van de behandeling van een politieke kwestie door een gegeven 'collectief', maar het bepalen van de omvang en de reikwijdte van een bepaalde politieke kwestie om zo het relevante publiek in kaart te brengen. Object van politiek zijn dus kwesties die publieke consequenties hebben. Kwesties die alleen private gevolgen hebben zijn niet politiek relevant. Het onderscheid tussen publiek en privaat wordt bepaald door de mate van externe effecten van een kwestie. Overstijgen de effecten van een handeling de actoren die bij een transactie zijn betrokken (laten we zeggen: zijn er zaken die zo onzeker of algemeen zijn dat ze niet in een contract tussen twee partijen kunnen worden opgenomen), dan zijn die consequenties een publieke zaak.

Op dit punt is het belangrijk te onderstrepen dat het onderscheid tussen publiek en privaat bij Dewey niet overeenkomt met dat tussen sociaal en individueel. Een sociale handeling heeft een privaat karakter zolang de gevolgen ervan de betrokken actoren niet overstijgen. Maar een individuele daad kan een publiek karakter hebben doordat de gevolgen daarvan meer mensen, vreemden, treffen (Dewey 1927: 12-14). Dewey onderscheidt zich dus van een Rousseauiaanse lezing door zijn notie van het 'publiek'. De conceptie van het publiek is het hypothetische element in zijn theorie. Dit publiek is geen bestaande body politic maar wordt gevormd uit verschillende geassocieerde mensen en groepen. De rol van de staat daarbij is de effectieve regulering van zowel incidenten als systematische negatieve gevolgen.

In een van de eerste besprekingen van The public and its problems in 1929 merkt William Hocking op dat een groot deel van de redenering van Dewey bestaat uit het in kaart brengen van een bepaalde stand van zaken (de externe effecten). Hoe kom je te weten wat de gevolgen van een handeling of transactie zijn en hoe wordt aan de hand daarvan beoordeeld of iets publiek of privaat is? In de eerste plaats hangt het af van de kennis die men heeft van de mogelijke gevolgen van een handeling. In de tweede plaats hangt het af van wat wordt verstaan onder een 'gevolg'. In de derde plaats is het oordeel van de betrokkenen van belang over wat voor soort gevolgen nadere zorg behoeft (en dus onderwerp van politiek beraad 
moet worden). Ten slotte is het niet van tevoren ingevuld wie beschouwd wordt als 'direct betrokken' bij een bepaalde zaak. Het hangt dus van nogal wat factoren af wanneer iets gedefinieerd kan worden als een 'politiek object'. In zekere zin is dit een zaak van framing, het vaststellen van het juiste kader waarbinnen bezien kan worden of de gevolgen van een actie privaat zijn en waarbuiten ze als publiek gelden. Het framen van een probleem is het vaststellen van een adequaat kader waarbinnen het probleem beoordeeld dient te worden.

Vanuit Deweys perspectief is de fout die in de eerste dagen van het Nederlandse aids-beleid gemaakt is, dat te snel beslist is welke groepen over dat beleid mee zouden dienen te spreken. Niet alleen zijn daardoor groepen die voor dat beleid relevant zijn - zoals intraveneuze drugsgebruikers en prostituees - pas laat bij het beleid betrokken geraakt. Ook is de focus te snel exclusief komen te liggen op de bescherming van de bloedvoorraad, in plaats van de vraag te stellen in welke opzichten er sprake was van een volksgezondheidprobleem. De staat heeft dus gefaald. In plaats van het overleg over te laten aan enkele groepen waarbij de uitkomst in belangrijke mate bepaald werd door de vraag wie in dat overleg het hoogste woord kon voeren, had zij in de situatie van onzekerheid die in die eerste periode bestond moeten vaststellen welke publieken bij deze kwestie in het geding waren. De experts hadden aan die inventarisatie een bijdrage moeten leveren in plaats van zelf als spreekbuis te fungeren van de verschillende belanghebbenden. Een onderscheid tussen de vraag 'welk publiek gaat deze zaak aan' en 'wie heeft er kennis van deze kwestie' is daarvoor onontbeerlijk.

\subsection{CONCLUSIE: DE SAMENLEVING ALS LABORATORIUM?}

Dewey wordt algemeen als een van de aartsvaders van de deliberatieve democratie beschouwd. Hij verdient die titel niet omdat hij de nadruk legt op de noodzaak zeggenschap uit te breiden naar groepen die dreigen buitengesloten te worden van de politieke beraadslaging, maar vooral voor zijn pleidooi voor de epistemologische kwaliteiten van deliberatie. Argumenten als zou deliberatie een goede zaak zijn omdat zij de politiek dichter bij de burger brengt, draagvlak creëert, of de legitimiteit van politiek versterkt, zijn aan hem niet besteed. Wie de publieke zaak ter harte gaat, moet in de ogen van Dewey om te beginnen de publieken in kaart brengen die bij een kwestie in het geding zijn. Besturen vanuit een ivoren toren is ongewenst. Maatschappelijke problemen vereisen kennis van uiteenlopende praktijken. Vandaag de dag zijn de ideeën van Dewey onder meer terug te vinden in de zoektocht naar nieuwe manieren van besturen die lokale kennis en wetenschappelijke inzichten verenigen door vergelijking en selectie van best practices. ${ }^{3}$

De ideale combinatie die Dewey voor ogen stond van democratie en kennis, heeft veel weg van een maatschappelijk laboratorium. Over de precieze rol van de staat is Dewey in The public and its problems niet erg uitgesproken. Het sterke punt van zijn analyse schuilt eerder in zijn idee van het publiek als een a posteriori- in plaats van een a priori-gegeven. De betrokkenheid van deze publieken en de 
daarin aanwezige lokale kennis zijn onmisbaar in een democratisch ideaal. Van de wijze waarop dit het beste kan geschieden zijn vooralsnog slechts de contouren aan te geven. Het vinden van die procedure is een taak van de democratie, een oplossing die niet op voorhand is te bepalen. De voorwaarden daarvoor bestaan uit vrij publiek debat, onderzoek, open communicatie en een experimentele houding. Voor een vitale democratie is het volgens Dewey niet noodzakelijk dat het politieke proces gericht is op de inclusie en participatie van individuen en groepen. Politiek en de staat dienen zich te concentreren op het oplossen van problemen, meer dan op de vorming van de collectieve wil. De participatie van burgers in de politiek bestaat uit kennisinbreng en in handelend en vormend optreden. In deze interpretatie is het gedachtegoed van Dewey, gecombineerd met de these van de toegenomen maatschappelijke kennisontwikkeling, nog steeds levensvatbaar.

De grootste kracht van Deweys benadering schuilt niet in het opstellen van een geheel nieuw ontwerp van de procedures en de instellingen van de democratie in Nederland. De bijdrage die we op grond van zijn gedachtegoed kunnen formuleren bestaat veeleer uit de ontwikkeling van een andere zienswijze, een frisse kijk op bestaande instituties en hun taakuitoefening om manieren te vinden die het probleemoplossend vermogen versterken.

De lakmoesproef in Deweys ideeën is de test of epistemologische deliberatie effectief probleemoplossend vermogen stimuleert. De kwesties waar de Verenigde Staten zich als Great Society voor gesteld hebben gezien tijdens de vele decennia dat Dewey intellectueel actief was, kunnen uiteraard niet als 'eenvoudig' worden afgedaan, maar onderkend moet worden dat de hedendaagse democratie wordt geconfronteerd met nieuwe, complexe technologische en wetenschappelijke kwesties die hiervoor als UPO's zijn aangeduid.

UPO's ontstaan 'in het wild'. Het zijn objecten in wording die zich niet aandienen als een direct plaatsbaar fenomeen. Een prudente, democratische samenleving is echter zo ingericht dat ze adequaat op nieuwe problemen kan inspelen. Dat vereist niet noodzakelijkerwijs nieuwe instellingen, noch nieuwe vormen om zeggenschap te organiseren. Iedere moderne democratische staat kent reeds instituties die probleemoplossend vermogen stimuleren en die voorkomen dat laksheid of willekeur van zittende bestuurders onmiddellijk tot verval of ongelukken leidt. De constitutionele inrichting van het politieke en epistemologische landschap is echter geen vaststaand beeld; bij ieder groot probleem dat de kop opsteekt moeten instituties zichzelf opnieuw uitvinden en ontdekken. De urgentie wordt steeds opnieuw ingegeven met veranderende problemen. Immers, niet altijd is te voorspellen wat voor kwesties om aandacht vragen of wat zich als een nieuw controversieel object zal aandienen. Noch de politieke, noch de epistemologische verantwoordelijkheid is bij voorbaat adequaat geregeld.

Bij de intreding van een nieuw controversieel object treedt een dubbele identificatieplicht op, namelijk politiek en epistemologisch. Dat vraagt om een herover- 
weging van de bestaande organisatie van politiek en expertise. De conclusie die lijkt te kunnen worden getrokken is dat het denken over democratie in termen van een vooraf bestaande gemeenschap die collectief haar wil vormt over politieke issues onvoldoende aandacht heeft voor de urgente kennisintensieve kwesties als UPO's en hun gevolgen. Zeker waar de gevolgen van problemen de landsgrenzen overschrijden bestaat er behoefte aan nieuwe manieren om het publiek dat in het geding is in kaart te brengen. Een andere manier van kijken, die de 'kwestie' zelf centraal stelt en op grond daarvan op zoek gaat naar het relevante publiek is een optie die niet onopgemerkt mag blijven. 


\section{NOTEN}

De term 'UPO' (Dijstelbloem 2003) is gebaseerd op een uitspraak van Jacques Delors en een serie publicaties in het Franse dagblad Le Monde diplomatique waarin, analoog aan de bekende term UFO (Unidentified Flying Object) de EU wordt aangeduid als un objet politique non identifié. De zwakke representatieve democratie, de nog niet uitgekristalliseerde machtsverhouding tussen het Parlement, de Commissie en het Hof en de weinig transparante beleidseffecten van de EU voor de lidstaten en (daardoor) de geringe belangstelling van burgers voor dit project, hebben iets gecreëerd wat veel weg heeft van een buitenaards politiek object. Deze casus is een bewerking van het eerder verschenen artikel van H. Dijstelbloem (2000) 'Overleg geslaagd, patiënt overleden. De eerste dagen van het Nederlandse aids-beleid' in: Filosofie $\&$ Praktijk (21) 2: 3-21. Een hedendaagse erfgenaam van Dewey als Sabel pleit in dat verband voor vormen van 'deliberatieve coördinatie', een soort beargumenteerd overleg tussen instituties en stakeholders die gezamenlijk leren van hun ervaringen (Cohen en Sabel 1997). Cohen en Sabel volgen de consequenties van Deweys visie echter maar voor de helft en nemen nog steeds de behandeling van 'kwesties' op in het zeggenschapsmodel. 


\section{LITERATUUR}

Bovens, M., P. 't Hart en B. Guy Peters (2001) Success and failure in public governance: a comparative analysis, Cheltenham: Edward Elgar.

Dewey, J. (1927) The public and its problems, Chicago: The Swallow Press.

Dijstelbloem, H. (200o) 'Overleg geslaagd, patiënt overleden. De eerste dagen van het Nederlandse aids-beleid', in Filosofie \& Praktijk (21) 2: 3-21

Dijstelbloem, H. (2003) 'The trouble with unidentified political objects', paper gepresenteerd op de conferentie Concepts of politics, Rotterdam, 15-16 september 2003.

Festenstein, M. (1997) Pragmatism and political theory, Cambridge: Polity Press.

Geuss, R. (2001) History and illusion in politics, Cambridge: Cambridge University Press.

Hocking, W. (1929) 'Book review: The public and its problems, by John Dewey', in Journal of Philosophy vol. XXVI no. 12, 6 juni 1929.

Mooij, A. (1993) Geslachtsziekten en besmettingsangst, Amsterdam: Boom.

Nationale Ombudsman (1995) Openbaar rapport over HIV-besmetting onder Hemofiliepatiënten, rapportnummer 95/271.

Nelis, A., G. H. de Vries en R. Hagendijk (2004) ‘Stem geven’ en 'publiek maken’. Wat patiëntenverenigingen ons kunnen leren over democratie', in Krisis 2004 (te verschijnen).

Ryan, A. (1995) John Dewey and the High Tide of American Liberalism, New York: W.W. Norton \& Co.

Sandfort, T. (1998) The Dutch response to HIV, London: UCL Press.

Scharpf, F. (1970) Demokratietheorie zwischen Utopie und Anpassung, Konstanz: Universitätsverlag.

Vuijsje, H. (1997) Correct, Amsterdam: Contact.

Wijngaarden, J. van (1989) 'AIDS-beleid in Nederland', in H. Vuijsje en R. Coutinhol Dilemma's rondom AIDS, Amsterdam: Swets en Zeitlinger.

Wijngaarden, J. van (1992) 'The Netherlands: AIDs in a consensual society', in D.L. Kirp, R. Bayer AIDS in the industrialized democracies, New Brunswick: Rutgers University Press. 


\title{
8 DEMOCRATISERING VAN DE EU: PERMANENTE EVENWICHTSKUNST
}

\author{
M. Sie Dhian $\mathrm{Ho}^{1}$
}

\subsection{INLEIDING}

Hoe democratisch is de EU? Wie te rade gaat bij de snelgroeiende literatuur over democratisering van de EU stuit op alarmkreten, sussende woorden en meer neutrale diagnoses. Dat geldt zowel voor analyses van het Europese bestuur als de demos. Zo waarschuwt Larry Siedentop in zijn Democracy in Europe dat het bestuur van de Unie zich dreigt te ontwikkelen tot een 'regering van vreemden' of zelfs een 'gecentraliseerde tirannie' die vanuit een verafgelegen hoofdstad regels oplegt als leefden wij in een absolutistische staat (Siedentop 200o). Andrew Moravcsik daarentegen ziet weinig aanleiding voor alarmisme. Constitutionele checks and balances, indirecte democratische controle via nationale regeringen en de toenemende bevoegdheden van het Europees Parlement zijn volgens Moravcsik dusdanig dat zorgen over het democratisch tekort van de Unie misplaatst zijn (Moravcsik 2002a). Andere auteurs wijzen op het 'sui generis'-karakter van de EU en de intellectuele revolutie die nodig is om democratische instituties te ontwerpen voor dit politieke systeem dat noch staat, noch organisatie van staten is (bijv. Meny 2003: 11).

Ook ten aanzien van de demos lopen de diagnoses uiteen. Auteurs als Offe en Scharpf wijzen erop dat de collectieve identiteit in de Unie zwak ontwikkeld is bij ontbreken van een gemeenschappelijke geschiedenis, taal, cultuur en etniciteit. Waar burgers niet het gevoel hebben tot een Europese gemeenschap te behoren, wordt meerderheidsbesluitvorming al snel als een bedreiging ervaren en ontbreekt de solidariteit voor vergaande herverdelingsmaatregelen (Offe 1998; Scharpf 1999: 8-9). Howe meent daarentegen dat de Europese demos opgevat moet worden als een burgerlijke, politieke entiteit, die verder ontwikkeld kan worden door de codificatie van gedeelde burgerlijke waarden en door structuren te ontwerpen die politieke participatie de moeite waard maken. De ontwikkeling van een democratische cultuur zal de ontwikkeling van de democratische instituties volgen, doordat gebruik wordt gemaakt van de democratische instituties. Dit proces kan worden versterkt door een welbewuste strategie gericht op socialisatie van burgers in de Europese democratische cultuur en een opvoeding tot Europees burgerschap, zoals nationale identiteiten ook eens geconstrueerd zijn (Howe 1995: 28-34; zie ook Van Mierlo 2002: 37-8). Weer andere auteurs verwerpen rigide definities van identiteit en burgerschap, maar zien het optimisme over de mogelijkheden van een burgerlijke, politieke betrokkenheid van burgers bij het Europese project niet bevestigd in de werkelijkheid. Volgens hen staat de zoektocht naar manieren om burgers uit verschillende lidstaten deel te maken van een Europese democratische cultuur pas aan het begin (zie bijv. Warleigh 2003). 
Als de diagnose zou luiden dat er sprake is van een democratisch tekort en het voorschrift dat de Unie moet democratiseren, hoe zouden we dat dan moeten doen? De antwoorden op deze vraag, bijvoorbeeld recentelijk in de discussie rond de Europese Conventie, lopen eveneens sterk uiteen. Sommigen bepleiten een parlementarisering van de EU, door versterking van de bevoegdheden van het Europees Parlement. Anderen benadrukken de noodzaak om de controle van regeringen van de lidstaten door hun respectieve nationale parlementen te versterken. Weer anderen menen dat prioriteit gegeven moet worden aan vergroting van de transparantie, de creatie van een Europese publieke sfeer en het zoeken naar alternatieven voor politiek-bestuurlijke verantwoording zoals maatschappelijke verantwoording, verantwoording aan peers en juridische vormen van verantwoording.

Democratisering van de Unie blijkt aldus een oefening in koorddansen waarbij flink aan weerszijden van de balanceerstok wordt getrokken. Diagnoses van het democratisch tekort van de Unie en pleidooien voor oplossingsrichtingen lopen sterk uiteen. Deze onenigheden vloeien voort uit het feit dat democratisering van de Unie een 'dubbel betwist' begrip is. Ten aanzien van zowel de 'goede ontwikkeling van het Unie-systeem' (het integratiedebat) als de 'goede invulling van democratie' (het democratiedebat) bestaan rivaliserende perspectieven. In dit hoofdstuk wordt eerst een beschrijving gegeven van de ontwikkeling van het bestuur en de demos in de Unie (par. 8.2), gevolgd door een waardering van het 'democratisch tekort' en suggesties voor oplossingsrichtingen vanuit vier ideaaltypische perspectieven op de Europese integratie (par. 8.3). Ten slotte worden de implicaties van het integratiedebat besproken voor het debat over democratisering van de Europese Unie (par. 8.4).

\subsection{ONTWIKKELING VAN DE EUROPESE DEMOCRATIE}

Sinds 1958 hebben de EU-lidstaten aanzienlijke bevoegdheden overgedragen aan de EU. Democratisering van de Unie heeft daarbij in het begin weinig prioriteit gehad. De Unie heeft haar legitimiteit primair ontleend aan de bijdrage aan het welzijn van de burgers van de Unie, en heeft zich lang in een stilzwijgende instemming van de bevolking kunnen verheugen. Deze kwam de nationale politieke elites gelegen, die weinig belang zagen in democratisering van de Unie. Niet zelden werd democratisering gekoppeld aan het idee van staatsvorming, en de ontwikkeling van een Europese superstaat was voor het merendeel van de nationale elites een onwelkome gedachte, zodat met het één ook het ander werd afgewezen. Dat kon aanvankelijk ook gerechtvaardigd worden want de Europese Economische Gemeenschap (EEG) werd toch vooral gezien als een internationale organisatie, zij het een heel specifieke. Verbreding van het bereik van de Unie en verdieping van de samenwerking moesten nog komen. Hoe anders bleek dat vijfenveertig jaar later te liggen. Tijdens de laatste Intergouvernementele Conferentie (IGC) waarin de EU-lidstaten hebben onderhandeld over een Europese Grondwet (en het voorbereidend werk hiervoor door de Europese Conventie) werd democratisering wel tot één van de drie hoofdthema's uit-geroepen: de Unie moest democratischer, transparanter en efficiënter worden. 


\subsubsection{BESTUUR}

Het bestuur van de EU wordt hieronder beschreven door achtereenvolgens te kijken naar de input, throughput en output/outcomes/feedback van het politieke systeem. Bij de input gaat het dan om de steun en erkenning voor gezagsdragers, de instemming met de heersende spelregels van het systeem en de formulering van eisen en verwachtingen ten aanzien van beleid door burgers. Bij de throughput gaat het om de wijze van besluitvorming. Vanuit democratisch oogpunt zijn dan met name van belang de deelname van burgers of hun vertegenwoordigers aan de beleidsvorming; de wijze waarop besluiten worden genomen; en de wijze waarop met minderheidsstandpunten wordt omgegaan. De output, outcomes en feedback betreffen tot slot respectievelijk de uitkomsten van het beleidsproces, de maatschappelijke effecten (inclusief langetermijneffecten) van die uitkomsten en de terugkoppeling in termen van steun en eisen aan het politieke systeem. Vanuit democratisch perspectief gaat het vooral over de mate waarin de uitkomsten van het beleidsproces en hun effecten bijdragen aan het welzijn van de demos, de verantwoording van het beleid, en de responsiviteit van het systeem (de mate waarin ervaringen met het beleid en oordelen over de uitkomsten van beleid leiden tot bijsturing ervan).

Het systeemmodel wordt hier slechts gebruikt als hulpmiddel bij de beschrijving. Uiteraard is dit een vereenvoudiging van hoe de democratische instituties zich hebben ontwikkeld. In de werkelijkheid lopen de fasen in elkaar over (zo anticiperen beleidsmakers al in de throughput-fase op de verantwoording die ze zullen moeten afleggen in de outputfase). Bovendien is er sprake van een permanente herhaling van het beleidsproces. Deze iteratie volgt niet alleen de electorale cyclus, maar ook die van al dan niet geheel afgeronde beleids- en/of issuecycli. Naarmate er sprake is van vele parallel verlopende beleids- en/of issuecycli en een snelle iteratie van het proces, vertoont het geheel mogelijk evenveel gelijkenis met een 'permanent lerende organisatie' als met een systeem met een duidelijk te onderscheiden input, throughput en output (zie de bijdragen van Dijstelbloem, De Vries en Schuyt, en Sabel). Ten tweede worden het politieke systeem en de beleidsfasen nadrukkelijk niet als normatief model voor beleidsvorming gepresenteerd. Zo zijn er goede argumenten aan te voeren voor het niet strikt scheiden (in personele en temporele zin) van besluitvorming en uitvoering en voor een meer incrementeel en pragmatisch proces (zie de bijdrage van Sabel in deze bundel).

\section{Input}

De verdragen (met name het Verdrag betreffende de Europese Unie en het Verdrag tot oprichting van de Europese Gemeenschappen) vormen de fundamenten van de Europese samenwerking; samenwerkingsstructuren en -procedures worden hierin geregeld. Tot nu toe hebben de lidstaten de voorkeur gegeven aan een intergouvernementele totstandkoming van de verdragen. De onderhandelingen vinden plaats in een intergouvernementele conferentie (IGC) van de lidstaten van de Unie, waarna het verdrag alleen rechtsgeldig wordt indien alle lidstaten instemmen met het resultaat van deze onderhandelingen. Het wordt 
aan de lidstaten overgelaten hoe binnenslands wordt vastgesteld of er van instemming sprake is. Veelal werd volstaan met een stemming in het parlement, maar steeds vaker wordt een referendum uitgeschreven.

De prijs van deze intergouvernementele procedure is geweest dat verdragen tot stand zijn gekomen in een weinig transparant diplomatiek onderhandelingsproces, met beperkte mogelijkheid voor burgers of hun vertegenwoordigers om direct deel te nemen aan de deliberatie, en de beperking van de keuze in de ratificatiefase (zowel in het geval van parlementaire stemming als referenda) tot instemming dan wel verwerping (take it or leave it). Om de democratische legitimiteit van de grondstructuur van de Europese Unie te versterken is bij de voorbereiding voor de komende verdragswijziging voor het eerst afgeweken van het puur intergouvernementele format. Het ontwerp voor de grondwet waarover de IGC in juni 2004 overeenstemming heeft bereikt is opgesteld door een Europese Conventie, waaraan naast regeringsvertegenwoordigers ook nationale parlementariërs en europarlementariërs hebben deelgenomen.

De democratische legitimering van het politieke leiderschap van de Europese samenwerking is ook van oudsher indirect georganiseerd. De belangrijkste benoemingen in de Unie worden door de lidstaten gecontroleerd. De regeringen van de lidstaten worden democratisch gekozen, waarmee zowel hun afvaardiging naar de Raad van Ministers als de Europese Raad democratisch gelegitimeerd wordt geacht. Ook de benoeming van de voorzitter van de Europese Commissie was tot 1994 een Chefsache, in handen van de staatshoofden en regeringsleiders van de Unie bijeen in de Europese Raad. Maar sinds het Verdrag van Maastricht is de invloed van het Europees Parlement op de benoeming van de Commissie toegenomen. Het Verdrag bepaalde dat de zittingsperiode van de Commissie parallel zou gaan lopen met die van het Europees Parlement, dat het Parlement geconsulteerd zou worden over de door de Europese Raad voorgedragen kandidaat commissievoorzitter, en dat de gehele Commissie aan het Parlement zou worden voorgelegd ter goedkeuring. Het Parlement interpreteerde vervolgens de consultatieplicht als een recht om te stemmen over de kandidaat voor het commissievoorzitterschap, een interpretatie die is gecodificeerd door het Verdrag van Amsterdam.

Overigens is het maar de vraag in hoeverre de toegenomen invloed van het Europees Parlement op de benoeming van de Europese Commissie een werkelijke democratisering inhoudt, zolang Europese verkiezingen zo duidelijk second order national contests zijn (Reif en Schmitt 1980). Europese verkiezingen gaan de facto over nationale issues en spelen zich af tussen nationale politieke partijen die vooral uit zijn op het nationale pluche (Hix 1999: 180). De opkomst voor deze verkiezingen ligt zo'n 15 tot 20 procent lager dan die bij nationale algemene verkiezingen en daalt gestaag. In 1999 was de opkomst voor de gehele EU minder dan 50 procent, terwijl in Nederland slechts 30 procent de gang naar de stembus maakte. Een en ander maakt het lastig om uit de resultaten van Europese parlementsverkiezingen af te leiden wat voor Europese Commissie de kiezers zouden willen (Lord 1998: 36). 


\section{Throughput}

De overdracht van bevoegdheden naar de EU heeft geleid tot een verschuiving van wetgevingsmacht van de wetgevende naar de uitvoerende macht. Terwijl parlementen een belangrijke rol spelen in de totstandkoming van nationale wetgeving, is in Brussel de Raad van Ministers (die wordt gevormd door leden van de uitvoerende macht van de lidstaten) de dominante actor in het besluitvormingsproces.

Het optreden van de regeringen in de Raad van Ministers wordt gecontroleerd door de nationale parlementen. Naast hun bovengenoemde sleutelrol in de ratificatieprocedure voor verdragen hebben nationale parlementen daartoe een reeks van mogelijkheden. Zo kunnen zij voorafgaand aan raadsbijeenkomsten invloed uitoefenen op de onderhandelingsstrategie van hun minister en hem na afloop van de raadsbijeenkomst ter verantwoording roepen over het bereikte resultaat. Ze kunnen ontwerpwetgeving aan een onderzoek onderwerpen en hebben invloed op de omzetting van Europese richtlijnen in de nationale wetgeving (Lord 1998, 54-5). Maar in de praktijk verschillen nationale parlementen sterk in de mate waarin zij hun controletaak waarmaken. Beroemde voorbeelden van actieve parlementaire commissies zijn het Europese Zaken-comité van de Deense Folketing en de Scrutiny Committees van het House of Commons en House of Lords. Eerstgenoemde heeft de bevoegdheid om de onderhandelingspositie van de Deense minister te autoriseren, en de Britse minister kan zijn onderhandelingspositie pas innemen als het scrutiny process in het House of Commons is afgerond.

Veel parlementen slagen er echter maar ten dele in hun regering systematisch te controleren. Parlementariërs hebben moeite te ontwaren wie op welk moment waar beslissingen neemt in het conglomeraat van instituties dat de Raad van Ministers inmiddels is geworden (de Raad van Ministers kent momenteel negen formaties waarin vakministers elkaar ontmoeten rondom thematisch gedefinieerde beleidsterreinen; onder dit niveau werken zo'n 185 voorbereidende raadswerkgroepen en -commissies (Crum 2003: 163)). Parlementen klagen over het gebrek aan openbaarheid van raadsbijeenkomsten; informatie komt vaak moeilijk en laat beschikbaar en de vergaderingen vinden achter gesloten deuren plaats, waardoor moeilijk te achterhalen is hoe hun minister de nationale standpunten verdedigd heeft. Daar komt nog bij dat ministers op terreinen waar gekwalificeerde meerderheidsbesluitvorming de regel is, overstemd kunnen worden in de Raad, waarna nationale parlementen die immers alleen hun minister ter verantwoording kunnen roepen met lege handen staan. Aan de andere kant blijken weinig nationale parlementariërs het de moeite waard te vinden zich te verdiepen in de veelal zeer specialistische en technische Europese materie. Tijd geïnvesteerd in Europese dossiers levert binnenslands politiek minder op dan de regering op de huid te zitten over pensioenregelingen of de veiligheid op straat.

Naast de indirecte legitimering van Unie-besluitvorming via nationale parlementen, is de directe legitimering versterkt door de toegenomen invloed van het Europees Parlement. Het Parlement, dat sinds 1979 direct verkozen wordt, heeft een steeds belangrijkere rol gekregen in de totstandkoming van Europese wetge- 
ving. Oorspronkelijk bestond die rol alleen uit niet-bindende adviezen van het Parlement aan de Raad (advies- of raadplegingsprocedure). De Europese Akte bracht hier verandering in door de samenwerkingsprocedure te introduceren en voor een beperkt aantal kwesties parlementaire instemming voor te schrijven (instemmingsprocedure). De samenwerkingsprocedure betekende een versterking van het Europees Parlement, omdat de Raad in eerste lezing, nadat het Parlement over een commissievoorstel was geraadpleegd, nog niet een definitief besluit kon nemen, maar een zogenaamd 'gemeenschappelijk standpunt' moest formuleren. Dit gemeenschappelijk standpunt ging voor een tweede lezing naar het Parlement, hetgeen de Commissie de gelegenheid gaf om het voorstel aan te passen aan de wensen van het Parlement. Het Verdrag van Maastricht maakte vervolgens de kwaliteitssprong door het Europees Parlement daadwerkelijk wetgevende bevoegdheid toe te kennen door invoering van de medebeslissingsprocedure. In de medebeslissingsprocedure, die sinds het Verdrag van Amsterdam op vrijwel alle interne marktgebieden van toepassing is, besluiten de Raad en het Parlement gezamenlijk en heeft het Parlement dus een vetorecht.

Ondanks de toegenomen bevoegdheden wordt de invloed van het Europees Parlement door velen nog als onbevredigend ervaren. Deels heeft dat te maken met belangrijke bevoegdheden waarover het Parlement nog niet beschikt. Zo is zijn power of the purse, de mogelijkheid om beleidsprioriteiten te stellen door belastingopbrengsten toe te kennen dan wel te onthouden aan beleidsterreinen, structureel beperkt. Het Parlement heeft geen zeggenschap over de inkomsten van de Unie (er worden geen Europese belastingen geheven) en zijn bevoegdheden ten aanzien van de uitgaven zijn beperkt. De begroting is onderverdeeld in verplichte uitgaven (waartoe de Gemeenschap verplicht is als gevolg van de Verdragen of reeds genomen besluiten, zoals de landbouwuitgaven) en niet-verplichte uitgaven, en alleen over de laatste groep heeft het Parlement het laatste woord. Daarnaast onttrekken belangrijke beleidsterreinen zoals het gemeenschappelijk buitenlands en veiligheidsbeleid en de strafrechtelijke samenwerking zich nog steeds aan de wetgevende bevoegdheden van het Parlement. Maar behalve tekortschietende bevoegdheden speelt het gebrek aan publiek profiel het Parlement parten. De lage opkomst bij Europese verkiezingen en hun second order-karakter, de geringe aandacht van de media en het ontbreken van een Europese publieke sfeer leiden ertoe dat, in de woorden van Ben Crum, “(...) europarlementariërs al te vaak nog parlementje spelen buiten het zicht van de publieke opinie” (Crum 2003: 167).

In de vertegenwoordigende functie wordt binnen de Unie niet alleen door nationale parlementen en het Europees Parlement voorzien, maar ook in belangrijke mate door functionele vertegenwoordiging. Gespecialiseerde belangengroepen en andere directbetrokkenen treden in dit geval op als intermediair tussen maatschappij en Uniebestuur (Lord 1998: 75). Zo adviseren grote aantallen advies-comités (bestaande uit vertegenwoordigers van de Commissie, nationale ambtenaren, en functionele experts of betrokkenen) bij de voorbereiding van commissievoorstellen en de uitvoering van Europese regels. Daarnaast opereert een leger aan lobbyisten in Brussel. 
De besluitvorming in de Europese Unie wordt gekenmerkt door een extreme consensusdemocratie. Uit angst voor de dictatuur van de meerderheid, en gegeven de zwak ontwikkelde Europese identiteit en de grotendeels indirecte legitimatie van Unie-beslissingen, worden de meeste beslissingen bij consensus genomen. Ook waar formeel beslissing bij gekwalificeerde meerderheid mogelijk is (waarbij 'gekwalificeerde meerderheid' overigens neerkomt op een meerderheidsnorm die in nationale staten slechts gebruikelijk is voor grondwetswijzigingen, namelijk ruim $70 \%$ ), wordt in de praktijk veelal nog steeds gestreefd naar consensusbesluitvorming. Toename van diversiteit binnen de Unie, onder andere als gevolg van diverse uitbreidingsrondes, doet vrezen dat een andere ongewenste situatie vaker voor zal gaan komen: de dictatuur van de minderheid. Deels uit zorg om de slagvaardigheid van de Unie zijn er nieuwe vormen van governance ontstaan, die een (tijdelijke) uitweg kunnen vormen tussen de weinig aantrekkelijke alternatieven van blokkade van besluitvorming voor ruim 500 miljoen burgers en overstemming van een minderheid op gevoelige issues. Het betreft ten eerste nauwere samenwerking tussen een beperkt aantal EU-lidstaten. En ten tweede niet-bindende vormen van coördinatie tussen lidstaten. Beide vormen van samenwerking vertonen in de praktijk veelal een aanzienlijke dynamiek, en kunnen uitgroeien tot samenwerking tussen alle lidstaten (via een zwaan-kleefaan-effect) en bindende samenwerking (WRR 2003).

Mede in het licht van de consensuscultuur in de Unie heeft Fritz Scharpf gewaarschuwd voor een asymmetrie tussen negatieve en positieve integratie. Deze asymmetrie ligt volgens hem al besloten in de constitutionele orde van de Unie. Met betrekking tot veel negatieve integratiemaatregelen (zoals het verbieden van nationaal beleid dat de concurrentie binnen de interne markt verstoort) zijn de Europese Commissie en het Europese Hof van Justitie door de Europese verdragen namelijk al toegerust om op te treden, zonder tussenkomst van de lidstaten. De vrijmaking van de interne markt kan aldus in een relatief apolitiek, technisch proces worden gerealiseerd door Commissie en Hof. Voor de meeste positieve integratiemaatregelen (zoals regulering van markten op Europees niveau) is daarentegen een beslissing van de Raad nodig, die gezien de consensuscultuur van de Unie wel eens lang op zich kan laten wachten indien er grote en gevoelige verschillen bestaan tussen lidstaten (joint decision trap). De situatie wordt nog verergerd, aldus Scharpf, doordat staten onder condities van mondialisering en marktintegratie in Europa zullen gaan concurreren met beleid en regulering teneinde kapitaal aan te trekken, en dat zal op veel terreinen een race to the bottom tot gevolg hebben. Aangezien het vinden en handhaven van de balans tussen marktliberalisering en sociale bescherming een van de kerntaken van de democratie is, vormt de neoliberale bias van de Europese samenwerking een bedreiging van de democratie.

\section{Output, outcomes en feedback}

De Europese Unie brengt verschillende typen beleidsoutput voort. Deze zouden kunnen worden onderscheiden in vijf typen: regulering/liberalisering/wederzijdse erkenning, herverdelend beleid, macro-economisch stabilisatiebeleid, 
beleid ten aanzien van de burger en mondiaal beleid (vrij naar Hix 1999: 8). Duidelijk verschil met nationale staten is dat regulering/liberalisering/wederzijdse erkenning vooralsnog de hoofdmoot vormt van de beleidsoutput, van maatregelen ter volmaking van de interne markt tot milieuregels en sociaal beleid. Vergeleken met nationale staten produceert de Unie voorts veel minder herverdelend beleid (het aandeel van herverdelend beleid binnen de begroting verschilt een factor 25 à 30 tussen nationale staten en de Unie, afhankelijk van de wijze van meting). Dat laat overigens onverlet dat het herverdelende beleid van de Unie een grote impact heeft voor specifieke groepen (met name boeren).

Typerend voor de outcomes van uniebeleid is dat ze pas na enige tijd voelbaar worden. Dat komt ten eerste doordat Europese richtlijnen pas in werking treden nadat ze in nationale wetgeving zijn omgezet. Daarnaast weten lidstaten soms overgangsperioden te bedingen (bijv. op het gebied van milieubeleid). Burgers hebben derhalve een slecht overzicht over de beleidsoutput en -effecten. Alleen specifieke groepen burgers en hun belangenorganisaties (bijv. boeren, banken en verzekeraars) staan in direct contact met de instituties van de Unie. Anderen zijn aangewezen op nationale elites, die veelvuldig aan de verleiding toegeven om beleidsuitkomsten van de nodige spin te voorzien. 'Brussel' krijgt dan al snel de schuld van pijnlijke beleidseffecten (scapegoating), terwijl gunstige beleidsuitkomsten gretig worden geclaimd. De feedback-mechanismen van het Europese politieke systeem zijn relatief zwak vergeleken met die van andere politieke systemen. Belangrijke missende schakel zijn hier de media; Europese media zijn nauwelijks ontwikkeld en nationale media zijn weinig gericht op de Europese politiek.

Patronen van verantwoording voor beleidsuitkomsten in de Unie wijken eveneens af van die van nationale staten. Dat geldt ten eerste voor de verantwoording van de uitvoerende macht aan politieke leiders. De uitvoerende macht van de Unie is gefragmenteerd over een veeltal beleidsnetwerken (beleidsgemeenschappen) die niet alleen bevolkt worden door ambtenaren van Commissie en Raad, maar ook door grote aantallen ambtenaren van nationale ministeries. Klassieke patronen van democratische verantwoording die steunen op het idee van hiërarchische controle van de uitvoerende macht door gekozen politici passen slecht op deze netwerken (Lord 1998: 86). De beleidsvorming binnen die netwerken wordt namelijk niet gekenmerkt door een duidelijke top-down-arbeidsverdeling tussen beslissende politici en technisch-uitvoerende ambtenaren, maar door een brede politieke doelomschrijving gevolgd door een gezamenlijk zoek-, onderhandelings- en leerproces binnen de beleidsgemeenschappen.

De verantwoording van politieke leiders aan de volksvertegenwoordiging stuit in de Unie op een aantal complicaties. Ten eerste het gebrek aan transparantie van de Unie-beleidsvorming voor parlementariërs. Deels is dit een gevolg van de complexiteit van de beleidsnetwerken van de Unie, waarbinnen het lastig is aan te wijzen wat precies wanneer en door wie is besloten, en deels van de geheimhouding die de onderhandelingstrajecten van het raadswerk kenmerkt. De tweede complicatie betreft het meerlagige governance-karakter van de beleids- 
netwerken, waarbij de bevoegdheden van de Unie voor een aanzienlijk deel worden uitgeoefend door instellingen van de lidstaten. De afwezigheid van een duidelijke scheiding van verantwoordelijkheden van uitvoerende instanties op de twee niveaus en het ontbreken van bevoegdheden van het Europees Parlement om de uitvoering op alle niveaus te controleren, brachten John Peterson tot de vaststelling dat de lidstaten besloten hebben tot "pooling of sovereignty without pooling accountability" (gecit. in Lord 1998: 91). Het zijn ook deze omstandigheden waaronder blame-shifting een voor de hand liggende optie is om verantwoordelijkheid te ontlopen (bijv. tussen de uitvoerende apparaten van individuele lidstaten en de Europese Commissie in het geval van de BSE-crisis).

Er bestaat geen equivalent van het systeem van ministeriële verantwoordelijkheid in de EU. Het Europees Parlement heeft niet de bevoegdheid om individuele commissarissen naar huis te sturen. Het Europees Parlement heeft sinds de jaren negentig wel geijverd voor dit recht. De afwezigheid van deze formele bevoegdheid heeft het Parlement overigens in januari 1999 niet verhinderd om twee aparte moties van wantrouwen in stemming te brengen tegen de commissarissen Edith Cresson en Manuel Marin, die verantwoordelijk werden gehouden voor nepotisme- en fraudezaken binnen hun Directoraat-Generaal. Hoewel deze moties dus geen rechtskracht hadden, oefenden de media en verschillende lidstaten druk uit op deze commissarissen om in geval van aanname van de moties van wantrouwen ontslag te nemen. Er werd echter geen meerderheid bereikt voor deze moties. Dezelfde zaak maakte duidelijk dat er binnen de Commissie geen cultuur bestaat waarin een individuele commissaris zich onder bepaalde omstandigheden verplicht zou voelen om op te stappen (Hix 1999: 47-49). Het Europees Parlement heeft wel de bevoegdheid om de hele Commissie naar huis te sturen, indien een dubbele meerderheid binnen het Parlement een motie van wantrouwen ondersteunt. Toen precies dit dreigde te gaan gebeuren na de publicatie van het rapport van onafhankelijke deskundigen over corruptie- en fraudepraktijken onder Europese ambtenaren heeft de Commissie van Jacques Santer de eer aan zichzelf gehouden en is en bloc opgestapt.

De verantwoording van volksvertegenwoordiging en politieke leiders ten opzichte van het electoraat verloopt doorgaans via periodieke verkiezingen. Hoe zit het met de mogelijkheden van Europese kiezers om 'af te rekenen' met hun vertegenwoordigers en leiders in de Unie? Wat het supranationale politieke leiderschap van de Europese Commissie betreft staat het publiek zo goed als met lege handen. De enige mogelijkheid tot electorale terugkoppeling is dat kiezers in verkiezingen voor het Europees Parlement parlementsleden vervangen door andere, die op hun beurt enige invloed hebben op de samenstelling van de nieuwe Commissie. Maar hierboven is al uiteengezet waarom deze indirecte weg tekortschiet. Het intergouvernementele leiderschap van de Raad en Europese Raad kan slechts stapsgewijs worden vervangen doordat individuele lidstaten in nationale algemene verkiezingen individuele leden van de Raad en Europese Raad vervangen door andere. In democratieën maakt electorale terugkoppeling het mogelijk dat onvrede over beleid wordt toegespitst op verantwoordelijke 
personen of regeringen, die om die reden het veld moeten ruimen. In de Unie dreigt echter het gevaar dat door de onmogelijkheid voor het Europese publiek to throw the rascals out onvrede over beleid uitmondt in delegitimering van het hele Unie-systeem (Lord 1998: 93).

Te midden van relatief zwakke systemen van politiek-bestuurlijke en politieke verantwoording kan de Europese burger in bepaalde gevallen verhaal halen bij de rechter of de ombudsman. De EU voorziet in een sterk ontwikkeld systeem van juridische verantwoording: een systeem van regels dat wordt gehandhaafd door een onafhankelijke rechterlijke macht en toegankelijk is voor alle burgers (Lord 1998: 96). Ook vindt in toenemende mate verantwoording tussen professionals in het publieke domein plaats via de vaststelling van benchmarks, de gestructureerde evaluatie van elkaars werk en het speuren naar best practices.

\subsubsection{DE DEMOS}

Velen zien als grootste probleem voor democratisering van de EU het ontbreken van een demos met een collectieve identiteit. Zij wijzen erop dat de ontwikkeling van democratische politiek altijd twee componenten behelst: de evolutie van institutionele structuren en de ontwikkeling van een sense of belonging. Hoewel in institutionele termen aanzienlijke stappen zijn gemaakt in de democratisering van de Unie, blijft de laatste component achter. Zo kon het gebeuren dat het vertegenwoordigend lichaam van de Europese burgers, het Europese Parlement, vorig jaar als grootste 'winnaar' uit de Europese Conventie kwam zonder dat de overgrote meerderheid van de Europese burgers dit überhaupt is opgevallen. Desalniettemin staat een dergelijke ingrijpende institutionele hervorming aan de wieg van verdere democratisering van de Unie. Instituties moeten dusdanig worden ingericht dat politieke activiteit van burgers effect kan sorteren. Het lot van de Europese democratisering hangt dan af van de vraag of burgers, indien deze instituties eenmaal bestaan, ook van deze mogelijkheden gebruik gaan maken (Warleigh 2003: 125).

De EU is geen natiestaat en zal dat (voorlopig) niet worden. Belangrijk gegeven is dus dat er ook niet dezelfde vergaande identiteitsvorming, gemeenschapszin en loyaliteit vereist zijn binnen de Europese demos om democratische Europese samenwerking te dragen. Vooralsnog hoeft de Europese demos niet de gemeenschapszin op te brengen voor een geweldsmonopolie van de Unie, Europese belastingen en ingrijpende herverdelingsprogramma's, of de opoffering van zonen voor het Europese leger. Een sense of belonging tot de politieke gemeenschap EU is echter wel vereist. Anders dreigt een Europese beslissing die niet in het belang van een bepaalde lidstaat is de Europese samenwerking in zijn geheel te delegitimeren in die lidstaat.

Duidelijk is dat een Europese identiteit alleen tot stand zal komen als zij mede geconstrueerd wordt. Er is geen voor de hand liggend 'primordiaal' gedefinieerd 'oergevoel' van gemeenschap. In dit opzicht verschilt de Unie overigens niet ten 
principale van natiestaten. Ook in natiestaten is het gemeenschapsgevoel een dynamisch verschijnsel geweest dat door de tijd is toegenomen en is beïnvloed door structuren, instituties en acties ter bevordering ervan (taalregime, onderwijs, dienstplicht, ontstaan levendige politieke arena, enz.). In afwezigheid van een primordiale identiteit kan de Europese identiteit worden gezien als een burgerlijke, politieke identiteit, gebaseerd op gedeelde waarden, belangen en praktijken, als een identiteit die naast andere identiteiten bestaat en deze niet uitsluit (vgl. Weiler, Haltern en Mayer 1995, Weiler 1995).

Het Europese burgerschap heeft echter nog weinig om het lijf. Formeel is het nog onderontwikkeld, in afwezigheid van zowel plichten die een gevoel van wederzijdse verantwoordelijkheid kunnen voeden als een breed scala van rechten. Praktisch zijn er onvoldoende mogelijkheden voor politiek engagement en is er te weinig aandacht in natie-staten voor de politieke socialisatie van Europese burgers, van de 'dubbele democraten' zoals Van Mierlo ze heeft genoemd (Warleigh 2003: 120; Van Mierlo 2002). Meer openheid en transparantie van het Europese bestuur is overigens een cruciale stap in het scheppen van omstandigheden waarin praktisch Europees burgerschap zich kan ontwikkelen. Voorwaarde voor een groter Europees engagement is dat burgers de EU bovendien ervaren als een gezagscentrum dat voor hen relevante, tot de verbeelding sprekende, besluiten neemt (Pijpers 1999: 38).

\subsection{HET INTEGRATIEDEBAT}

De waardering van de huidige situatie in de EU en de gedachtevorming over hoe een eventueel geconstateerd democratisch tekort te verminderen, is sterk afhankelijk van iemands visie op wat de $\mathrm{EU}$ is en/of zou moeten worden.

Vier perspectieven bepalen het debat in wetenschaps- en beleidspraktijk: het neofunctionalistisch, liberaal-intergouvernementeel, federaal en multi-level governance-perspectief. Hieronder wordt ingegaan op de belangrijkste uitgangspunten van deze benaderingen en de kritiek daarop, hun diagnose van de staat van de Europese democratie en aangedragen oplossingsrichtingen.

\subsubsection{HET NEOFUNCTIONALISTISCHE PERSPECTIEF}

Het neofunctionalisme was het richtinggevende perspectief in de beginjaren van de Europese Gemeenschap, maar delen van dit gedachtegoed spelen nog steeds een rol in het huidige debat. In het neofunctionalistische denken van grondlegger van de Europese integratie Jean Monnet en wetenschappers als Haas, Lindberg en Scheingold was de Europese samenwerking een uniek proces. De politieke bestemming van dit unieke proces werd omwille van politieke gevoeligheden bewust niet benoemd, maar veel neofunctionalisten hadden ontegenzeggelijk een federale toekomst in het achterhoofd. De Europese integratie werd gezien als een technocratisch proces, geleid door een elite van verlichte ambtenaren uit de lidstaten en de Europese Commissie, met als doel vrede en veiligheid te bereiken.

De legitimiteit van het integratieproces werd gezocht in de gewenste uitkomsten 
ervan voor de burgers, met relatief weinig aandacht voor democratische procedures. De nadruk lag op de resultaten die de technocratische voortrekkers tezamen met corporatistische netwerken van belanghebbende maatschappelijke groepen en multinationals zouden boeken voor het ongeïnformeerde publiek. Deze resultaten zouden een consensus of apathy of permissive consensus opleveren onder de bevolking, die de technocratische elite in staat zou stellen het integratieproject voort te zetten. Die integratie zou volgens de neofunctionalisten gradueel verlopen. Door sterke onderlinge afhankelijkheden in de economie zou als gevolg van integratie in bepaalde sectoren druk ontstaan voor integratie in andere sferen (functionele spill-over). Bovendien werd verwacht dat actoren binnen lidstaten zich meer op het niveau van de Europese Gemeenschap (EG) zouden gaan richten naarmate ze zouden merken dat daar de (de)regulering tot stand komt waar zij belang bij hebben (politieke spill-over).

Wat betreft de instituties van de EG waren kernvragen voor de neofunctionalisten op welke manier langzamerhand de politieke loyaliteit van burgers naar de instituties van de Gemeenschap zou kunnen verschuiven, en hoe binnen de Gemeenschap een balans kon worden gevonden tussen supranationale elementen (met name Europese Commissie en Europese Hof) en intergouvernementele (de Raad van Ministers). Compromis wat betreft de institutionele balans is geworden de 'communautaire methode', die grosso modo neerkomt op de volgende inrichting van de samenwerking: de Europese Commissie is de enige bron van wetgevings- en beleidsvoorstellen; deze voorstellen worden goedgekeurd door de Raad van Ministers en het Europees Parlement; de beleidsuitvoering is toevertrouwd aan de Commissie en de lidstaten; en het Europese Hof van Justitie ziet toe op de naleving van het Europese recht.

Op het neofunctionalisme is veel kritiek gekomen, met name als gevolg van het onvermogen ervan om de feitelijke loop van de Europese integratie te verklaren (denk aan de perioden van stagnatie van de integratie, maar ook het verminderen van de permissive consensus in de jaren tachtig en negentig van de vorige eeuw). Desalniettemin zijn elementen van het neofunctionalisme nog duidelijk aanwezig in de huidige discussie over democratisering. Zo nam de Nederlandse regering de Europese Conventie in de beginperiode weinig serieus. In plaats van gepraat over de finalité politique (incl. democratische hervormingen) zou de burger liever zien dat er goed beleid wordt gemaakt in Brussel, aldus de regering. Ook de nadruk van de Nederlandse regering in de Conventie op het belang van het behoud van het 'communautaire evenwicht', veel meer dan op democratisering van de Unie, past in de neofunctionalistische traditie.

Gevraagd naar de toestand van de Europese democratie zou de neofunctionalist zijn zorg uiten over het vermogen van de (uitgebreide) Unie om gewenst beleid te produceren voor de Europese burgers. Oplossingsrichtingen voor onvrede met de Europese samenwerking zouden door de neofunctionalist dan primair gezocht worden in institutionele hervormingen die de Unie slagvaardiger maken en de realisatie van beleidsoutput beter garanderen. 


\subsubsection{HET LIBERAAL-INTERGOUVERNEMENTELE PERSPECTIEF}

Kritiek op het neofunctionalisme nam in de jaren tachtig de vorm aan van een rivaliserend perspectief op de Europese integratie, het liberaal-intergouvernementalisme, dat het scherpst is verwoord door Andrew Moravcsik. In het liberaal-intergouvernementalisme zijn staten de dominante actoren in het integratieproces en wordt de Europese integratie niet gezien als een uniek proces maar als een uitingsvorm van internationale samenwerking. Moravcsiks theorie is 'liberaal' in die zin dat de voorkeur van een land voor Europese integratie geacht wordt een resultante te zijn van (veranderingen in) voorkeuren van binnenlandse groeperingen, en 'intergouvernementeel' in zijn interstatelijke onderhandelingsperspectief op het integratieproces. Supranationale kenmerken van de Europese Gemeenschap, in het bijzonder de bevoegdheden van de Europese Commissie en het Europese Hof van Justitie, worden volgens Moravcsik geaccepteerd door de lidstaten omwille van efficiencywinst (vermindering transactiekosten) en als welkom extern drukmiddel ten opzichte van binnenlandse oppositie.

In een polemisch artikel aan de vooravond van de Europese Conventie, getiteld In Defence of the 'Democratic Deficit', betoogt Moravcsik dat de wijdverbreide kritiek op de stand van de democratie in de EU ongegrond is, indien we redelijke criteria hanteren voor de beoordeling van democratisch bestuur. Verschillende constitutionele beperkingen van materiële, fiscale, bestuurlijke, juridische en procedurele aard voorkomen dat de Unie tot een 'superstaat' zou kunnen uitgroeien. Moravcsik is van oordeel dat de directe verantwoording via het Europees Parlement en de indirecte verantwoording via gekozen nationale ambtsdragers twee 'robuuste' democratische controlemechanismen zijn. In zijn beargumentering van deze robuustheid adresseert hij overigens weinig van de in paragraaf 2 geconstateerde beperkingen van de parlementaire controle. Evenmin gaat hij in op de empirische vaststelling dat beleidsvoorkeuren veelvuldig veranderen tijdens het verloop van het beleidsproces binnen de Europese beleidsnetwerken, waarmee een van de kernassumpties van zijn model (beleidsvoorkeuren komen binnenslands volgens een democratisch proces tot stand, waarna ambtenaren en ministers met een bepaald mandaat naar Brussel vertrekken) onhoudbaar blijkt. In die gevallen waar veeleer van een gemeenschappelijke problem-solving-benadering binnen meerlagige beleidsnetwerken sprake is dan van interstatelijke onderhandeling is het de vraag of deze processen kunnen worden gelegitimeerd en verantwoord via hiërarchische principal-agent-schema's tussen zowel politiek en bestuur en binnenlands publiek en gemandateerde uitvoerende macht.

Sterker is zijn argumentatie, in navolging van Majone (1996), dat het een algemene trend is in moderne democratieën om bepaalde functies welbewust te delegeren aan technocraten en ten dele af te schermen van directe politieke strijd. In plaats van de EU geïsoleerd te bekijken, moeten de lidstaten in hun symbiotische relatie met de Unie worden bezien. Die symbiose wordt gekenmerkt door een arbeidsverdeling, waarbij de Unie zich met name heeft gespecialiseerd in precies die gedelegeerde functies (denk aan de centrale bank, en technische regulering 
bijvoorbeeld van voedselveiligheid en medicijnen, enz.). In nationale democratieën wordt de verantwoording voor deze functies niet georganiseerd via directe participatie en meerderheidsbesluitvorming, maar via indirecte vertegenwoordiging, professionele socialisatie en peer review, en checks and balances. Logischerwijs verloopt de verantwoording in de Unie dan evenmin via directe betrokkenheid van burgers of via parlementen.

De functies waarin de Unie zich heeft gespecialiseerd hebben nog een kenmerk gemeen: ze spreken weinig tot de verbeelding van de burger. Moravcsik betoogt dat van de vijf meest gevoelige issues in West-Europese democratieën - gezondheidszorg, onderwijs, openbare veiligheid, pensioenen en sociale zekerheidsbeleid - geen enkel een primaire Unie-bevoegdheid is. Zijn diagnose is dan dat de geringe participatie van burgers eerder te wijten is aan gebrek aan gevoelde politieke relevantie van de zaken die op het spel staan in Europa dan gebrek aan mogelijkheden om politiek te participeren (zie ook Pijpers 1999). Zelfs indien een veel uitgebreider scala van democratische participatiemogelijkheden zou bestaan en de Europese burgers wel een sterke gemeenschappelijke Europese identiteit zouden voelen, zouden deze issues de burger niet uit de leunstoel krijgen. Indien onder deze omstandigheden toch referenda of parlementaire verkiezingen worden uitgeschreven, dreigt het risico dat zij - bij gebrek aan een geïnformeerd en substantieel betrokken publiek - ten prooi vallen aan instabiele plebiscitaire en populistische politiek. Moravcsiks argumentatie over de bestaande taakverdeling snijdt zeker hout waar het de samenwerking in het verleden betreft. Maar met het verdrag van Maastricht (met de introductie van samenwerking op de terreinen van het buitenlands beleid en politie en justitie) en al helemaal sinds het verdrag van Amsterdam (met de integratie van het Schengen-acquis in de Unie) is de basis gelegd voor Unie-maatregelen op een veel breder scala van beleidsterreinen. De vraag is of met de uitbouw van deze beleidsterreinen op Unieniveau niet een van de kernargumenten van Moravcsiks analyse ernstig wordt afgezwakt.

Wat betreft de door Scharpf en anderen geagendeerde asymmetrie tussen negatieve en positieve integratie en de vermeende neoliberale bias van de Europese samenwerking merkt Moravcsik op dat er weinig empirisch bewijs is van een race to the bottom. Integendeel, de EU heeft herregulering op veelal hoog niveau tot stand gebracht. Als de door Scharpf aangeduide bias bestaat, dan moeten de effecten daarvan nog in de toekomst blijken. Daarbij betwijfelt Moravcsik of de oorzaak van de bias in de constitutionele orde ligt, zoals Scharpf heeft betoogd. Veeleer meent hij dat het te maken heeft met de verdeling van politieke voorkeuren ten aanzien van de specifieke issues: zo is herregulering ten aanzien van veiligheid op het werk en met betrekking tot het milieu wel tot stand gekomen omdat er maar weinigen tegen zijn, maar komt belastingharmonisatie niet tot stand omdat verschillende lidstaten het niet in hun belang achten. 
Ook ten aanzien van de slagvaardigheid van de Unie na de uitbreiding is Moravcsik relatief optimistisch. De zorg dat de besluitvorming in de Unie tot stilstand zal komen als gevolg van het grote aantal lidstaten en de grote verschillen in beleidsvoorkeuren tussen hen diskwalificeert hij als folk wisdom. Aangezien de meeste issues compromissen tussen coalities betreffen, doet het aantal lidstaten er niet zo toe, aldus Moravcsik. De Unie kent een rijke traditie van het smeden van compromissen. Deze redenatie gaat echter wel erg kort door de bocht: immers, een van de belangrijke en beproefde instrumenten om consensus tot stand te brengen in het verleden, side-payments, zal niet meer op dezelfde schaal inzetbaar zijn in een Unie met meer dan 25 lidstaten en met een acquis van de huidige omvang (zie Philippart en Sie Dhian Ho 20ooa). Grote doorbraken in de Europese integratie zoals de monetaire unie waren alleen mogelijk door de (tijdelijke) verliezers van die maatregelen financieel te compenseren (structuurfondsen).

Moravcsik erkent dit argument overigens wel. Als uitweg wijst hij op de mogelijkheid voor lidstaten die verder willen integreren om dat in kleiner verband te doen (d.w.z. zonder de lidstaten die ze anders hadden moeten compenseren). Sinds het verdrag van Amsterdam (en vooral na de herziening van de procedures in het verdrag van Nice) kan deze 'nauwere samenwerking' plaatsvinden binnen het kader van de EU, volgens de standaardprocedures van de Unie, met dezelfde garanties voor betrokkenheid van de Commissie, het Europees Parlement en het Hof als voor andere Unie-samenwerking gelden. Hoewel de democratische procedures voor de deelnemende lidstaten aldus gegarandeerd zijn, zou bij herhaaldelijk gebruik van de mogelijkheid tot nauwere samenwerking wel in het oog moeten worden gehouden of de externe effecten voor de lidstaten die niet tot deelname in staat zijn niet negatief zijn, en moet worden zorg gedragen voor mechanismen die deelname van die landen in later stadium faciliteren (zie ook Philippart en Sie Dhian Ho 20oob).

Liberaal-intergouvernementalisten concluderen met andere woorden dat er weinig bewijs is van een democratisch tekort van de EU, indien we realistische criteria hanteren (lees: rekening houden met trends die in nationale staten ook plaatsvinden, zoals delegatie van functies naar instituties die zijn afgeschermd van directe politieke strijd) en de Unie niet in isolement beschouwen maar in symbiose met de lidstaten (lees: rekening houden met de taakverdeling die bestaat tussen beide niveaus). Moravcsiks aanbeveling aan de EU luidt dan ook: "if it ain't broke, don't fix it" (Moravcsik 2002b).

Voorzover lidstaten met een intergouvernementeel perspectief op de Europese integratie (zoals het Verenigd Koninkrijk, Zweden, Denemarken en Oostenrijk) in de context van de Europese Conventie wel erkenden dat de democratische legitimiteit van de Unie te wensen overlaat, hebben zij benadrukt dat de sleutel tot verdere democratisering ligt in de democratische controle van de Raad van Ministers door de nationale parlementen. Hiertoe hebben zij voorstellen ingediend ter versterking van de positie van nationale parlementen ten opzichte van hun regeringen (vgl. Crum 2003: 386-7). 


\subsubsection{HET FEDERALE PERSPECTIEF}

Het perspectief van de federale staat, ook wel het 'Westfaalse' model genoemd, schetst de EU als een politiek systeem in ontwikkeling, dat uiteindelijk vergelijkbaar zal zijn met de moderne federale staat (Philippart en Sie Dhian Ho 20oob; Caporaso 1996). In dit model wordt meer dan in het intergouvernementele perspectief de nadruk gelegd op een ongedifferentieerde Europese institutionele orde die alle beleidsterreinen bestrijkt. Als de Unie zich in deze richting zou ontwikkelen, moeten aldus de federalisten de democratische procedures en verantwoordingsarrangementen ook aan dezelfde eisen voldoen als gebruikelijk is in nationale staten. Of de Unie zich tot een quasi-staat ontwikkelt, waarvan het bereik zich uitstrekt tot nagenoeg alle beleidsterreinen, moet de toekomst uitwijzen. Daarnaast zijn nationale democratieën de laatste decennia eveneens aan ingrijpende veranderingen onderhevig (denk bijvoorbeeld aan de proliferatie van zelfstandige bestuursorganen). De vraag is of de federalisten voldoende rekening houden met trends die zowel nationale staten als de EU raken, en die mogelijk om nieuwe vormen van democratische verantwoording vragen.

Vanuit het federale perspectief is er aanzienlijke reden tot zorg met betrekking tot de democratische legitimering van het Unie-optreden. Zo stelt Van Staden aan de orde dat noch de Raad van Ministers noch de Europese Raad als collectief lichaam verantwoording schuldig is aan enig ander lichaam, op Europees niveau noch op nationaal niveau, hetgeen volgens hem een schrijnend democratisch tekort betekent (Van Staden 2003: 23).

Aanhangers van het federale staatsperspectief menen dat de hoofdoorzaak van het democratisch tekort van de Unie is gelegen in de afwezigheid van een politieke unie (gedefinieerd als een Europese regering) en de zwakke band tussen het EU-systeem van governance, het Europees Parlement en het oordeel van Europese burgers in Europese verkiezingen (Van Staden 2003: 46). Via hun stem voor de Europese verkiezingen hebben Europese burgers onvoldoende invloed op de selectie van politieke leiders in de Unie en de richting van de Europese politiek.

De enige remedie voor het democratisch tekort is de installering van een federale regering die volledige verantwoording schuldig is aan het Europees Parlement en responsief is ten aanzien van de politieke voorkeuren van de Europese burgers. Of in de woorden van de Duitse minister van Buitenlandse Zaken Joschka Fischer in zijn beroemd geworden speech aan de Humboldt Universiteit in Berlijn (Fischer 2000):

“... there is a very simple answer: the transition from a union of states to full parliamentarization as a European Federation, something Robert Schuman demanded 50 years ago. And that means nothing less than a European Parliament and a European government which really do exercise legislative and executive power within the Federation. This Federation will have to be based on a constituent treaty." 
Vanuit de academia heeft Arend Lijphart een soortgelijke oproep gedaan om een parlementair stelsel met evenredige vertegenwoordiging in te voeren in de EU, waarbij hij - explicieter dan Fischer - aangaf dat de Europese regering zou moeten voortkomen uit de Europese Commissie (Lijphart 2002: 5):

"In de EU moeten daarom een premier en een kabinet de uitvoerende macht vormen, die verantwoordelijk is voor en onderworpen aan het vertrouwen van een Europese wetgevende macht die door het volk wordt gekozen via evenredige vertegenwoordiging (of, om preciezer te zijn, aan het lagerhuis van een tweekamerstelsel). (...) Omdat evenredige vertegenwoordiging niet meer controversieel is, is de belangrijkste stap in de richting van dit doel de transformatie van de huidige Europese Commissie tot zo'n Europees kabinet."

Dergelijke radicale voorstellen tot democratisering langs federale lijn zijn uiteindelijk in de context van de Europese Conventie niet naar voren gebracht. Voorstellen van lidstaten die wel in federale richting wijzen, concentreerden zich op een versterking van het Europees Parlement (bijvoorbeeld het Beneluxvoorstel om de voorzitter van de Commissie te laten kiezen door het Europees Parlement).

\subsubsection{HET MULTI-LEVEL GOVERNANCE-PERSPECTIEF}

Het multi-level governance-perspectief zet zich af tegen zowel het liberaal-intergouvernementele als het federale model. Beide zouden gevangene zijn van een staatscentrisch denken, waarbij de Unie ofwel gezien wordt als een vorm van internationale samenwerking tussen staten (liberaal-intergouvernementalisme), ofwel als een staat in wording (federalisme). Daarmee miskennen zij het ontstaan van complexe, functionele transnationale beleidsgemeenschappen waarbinnen zowel de vorming van beleidsvoorkeuren als de Europese beleidsvorming feitelijk plaatsvindt (vgl. Marks, Hooghe en Blanks 1996; Craig 1999).

De nadruk in de literatuur over multi-level governance heeft tot nu toe vooral gelegen op empirische studies die het bestaan van dergelijke beleidsnetwerken aantoonden en studies die vanuit een effectiviteits- en leermotief naar de verbetering van governance-methoden streefden. De normatieve kant van dit perspectief, en dan met name het denken over de democratische inbedding van de nieuwe vormen van governance, is nog relatief weinig ontwikkeld. Zorg vanuit het multi-level governance-perspectief is dat de democratiseringsinspanning zich richt op de nationale context (versterking greep van nationale parlementen op hun respectievelijke, in de Raad optredende, regeringen) en supranationale context (via versterking bevoegdheden Europees Parlement), terwijl de vorming van beleidsvoorkeuren en beleid in de Unie veeleer plaatsvindt binnen transnationale netwerken dan in min of meer gescheiden nationale en supranationale contexten. De democratiseringsinspanning zou zich veel meer op die transnationale netwerken moeten richten. 
Een eerste vereiste voor democratisering van transnationale netwerken is een grotere openheid en transparantie. Dat geldt zowel ten aanzien van de actoren die de Europese beleidsnetwerken bevolken, als de deliberatie en besluitvorming binnen die netwerken en de gerealiseerde beleidsresultaten. Aangezien klassieke vormen van politiek-bestuurlijke verantwoording lastig toe te passen zijn op transnationale netwerken (zie subparagraaf 8.2.1), moet naar andere vormen van verantwoording worden gezocht, zoals maatschappelijke, professionele en juridische verantwoording. Deze vormen van verantwoording bieden vooral een alternatief voor coördinatiekwesties waarover brede politieke consensus bestaat en waarbij de kwaliteit en rechtmatigheid van de uitvoering centraal staan. Voor herverdelingskwesties en anderszins gepolitiseerde issues, waarbij sprake is van conflicterende belangen en/of waarden zijn zij minder geschikt.

Ook is gesuggereerd dat als tegenhanger van de Europese beleidsnetwerken verantwoordingsnetwerken zouden kunnen worden gevormd. Doordat verschillende verantwoordingsfora (bijvoorbeeld nationale parlementen en nationale en transnationale NGO's) informatie uitwisselen en bijvoorbeeld beleidsresultaten van nationale instellingen in Europees kader op hetzelfde moment publiekelijk aan de orde stellen, kunnen zij meer greep krijgen op het geheel dan wanneer ieder voor zich op verschillende momenten tracht de nationale inbreng in het Europese beleidsnetwerk te controleren. Princen wijst er echter op dat het fundamentele probleem van 'de vele handen' blijft bestaan (besluiten zijn niet terug te voeren op een enkele persoon of instantie met wie kan worden 'afgerekend'). Daarnaast leveren netwerken van verantwoordingsfora volgens hem zelf een probleem van de vele handen op. De meeste verantwoordingsfora zijn immers op hun beurt weer verantwoording schuldig aan anderen (bijv. ambtenaren aan ministers; ministers aan parlement; parlement aan kiezers). Voor kiezers, aan het eind van de verantwoordingsketen, zal het mogelijk niet meevallen inzicht te krijgen in de kwaliteit van de controle die Europese verantwoordingsnetwerken hebben uitgeoefend over Europese beleidsnetwerken (Princen 2004).

\subsection{IMPLICATIES VOOR HET DEMOCRATIEDEBAT}

Uit voorgaande beschrijving van de ontwikkeling van bestuur en demos in de $\mathrm{EU}$, en behandeling van het integratiedebat, kan een viertal conclusies voor het democratiedebat worden getrokken. Ten eerste dat bij de inrichting van het Europese bestuur keuzes ten aanzien van de integratiekwestie dominant zijn geweest. De feitelijk bestaande bestuurssituatie in de EU is niet het product van een welbewuste toepassing van een bepaalde democratieperspectief, maar zoals Ben Crum het verwoordt (Crum 2003: 380 ):

“... a dialectic between the expediency of delegating tasks to supranational institutions and the desire of Member State governments to retain intergovernmental control”. 
De democratiseringskwestie heeft pas recenter aan belangstelling gewonnen. Dit brengt onder andere met zich mee dat posities die nu worden ingenomen binnen het democratiseringsdebat (bijvoorbeeld in de Europese Conventie) veelal een afgeleide zijn van standpunten ten aanzien van de integratiekwestie. Lidstaten met een intergouvernementele voorkeur zoeken democratisering primair in versterking van de greep van nationale parlementen op hun regeringen in de Raad; voorstanders van een federaal Europa pleiten voor versterking van de bevoegdheden van het Europees Parlement en ontwikkeling van de Europese Commissie tot Europese regering die aan het Europees Parlement verantwoording schuldig is.

Een tweede opmerking betreft de verhouding tussen de verschillende integratieperspectieven. In plaats van rivaliserende theorieën over de essentie van het Europese bestuur, zou men ze beter kunnen zien als benaderingen die elk één aspect van het Europese bestuur benadrukken. Zo beschouwd is het Europese bestuur een hybride van communautaire, intergouvernementele, federale en transnationale elementen. Op bepaalde momenten (bijv. tijdens intergouvernementele conferenties over verdragswijziging) of op bepaalde beleidsterreinen (bijv. het gemeenschappelijke buitenland- en veiligheidsbeleid) draagt het bestuur intergouvernementele kenmerken. Op andere momenten of in andere sferen zijn de overige vormen van bestuur dominant (vgl. Weiler, Haltern en Mayer 1995, Craig 1999).

Ten derde valt een zekere goodness offit te ontwaren tussen bepaalde vormen van bestuur/integratiemodi en bepaalde democratietheorieën (vgl. Weiler, Haltern en Mayer 1995, Craig 1999). Zo sluiten de in de inleiding van deze bundel onderscheiden directe en indirecte democratiebenaderingen - die democratie doorgaans concipiëren als een set van (statelijke) instituties - goed aan bij de staatscentrische benaderingen uit het integratiedebat (liberaal-intergouvernementele en federale perspectief). De associatieve en deliberatieve stroming, die gewoon zijn over democratie te denken in termen van principes, lenen zich relatief goed voor toepassing op de 'sui generis' communautaire structuren en de transnationale beleidsnetwerken die centraal staan in het neofunctionalisme en de multilevel governance-benadering.

De hybride structuur van het Europese bestuur in combinatie met de goodness of fit tussen bepaalde integratiemodi en bepaalde democratietheorieën betekent ten slotte dat een gedifferentieerde, incrementele en cumulatieve democratiseringsstrategie voor de Unie waarschijnlijk het meest succesvol zal zijn. Omdat zo'n strategie recht doet aan de verschillende vormen van bestuur die naast elkaar bestaan binnen de Unie, evenals aan de gevoeligheden binnen het integratiedebat die mede tot de bestaande hybride structuur hebben geleid. Gegeven de pluraliteit aan standpunten met betrekking tot zowel het gewenste integratietraject als de invulling van democratie, kan democratisering van de Unie niet anders zijn dan permanente evenwichtskunst. 
NOTEN

1

De auteur is Jacques Pelkmans erkentelijk voor inspirerende gesprekken over het thema en uitgebreid commentaar op een eerdere versie. Ook dankt zij Deirdre Curtin voor haar co-referaat tijdens de WRR-workshop waar een eerdere versie werd gepresenteerd en waar ook Tjitske Akkerman, Ewald Engelen, André Krouwel, Jacques Pelkmans, Alfred Pijpers, Sebastian Princen, Bart Tromp en Michiel Scheltema nuttig commentaar gaven. 


\section{LITERATUUR}

Benelux Governments (2002), 'A Balanced Institutional Framework for an Enlarged, More Effective and More Transparent Union', Brussels, 4 December.

Caporaso, J.A. (1996) 'The European Union and Forms of State: Westphalian, Regulatory or Post-Modern?', in Journal of Common Market Studies, 34, 31.

Craig, P. (1999) 'The Nature of the Community: Integration, Democracy, and Legitimacy', pp. 1-54 in P. Craig and Gráinne de Búrca, The Evolution of EU Law, Oxford: Oxford University Press.

Crum, B. (2003), 'Vertegenwoordigende democratie in de Europese Unie: een verkenning van de institutionele mogelijkheden', blz. 155-191 in J. Pelkmans, M. Sie Dhian Ho en B. Limonard (red.) Nederland en de Europese grondwet, Amsterdam: Amsterdam University Press.

Crum, B. (2003), 'Legislative-Executive Relations in the EU', in: Journal of Common Market Studies, June, 41, 3: 375-95.

Fischer, J. (2000) From Confederacy to Federation, Speech at the Humboldt University, Berlin, 12 May.

Hix, S. (1999) The Political System of the European Union, Houndmills, Basingstoke, ampshire and London: Macmillan Press Ltd.

Howe, P. (1995) 'A Community of Europeans: The Requisite Underpinnings', in Journal of Common Market Studies, vol. 33, 1: 27-46.

Lijphart, A. (2002) 'Hoe moet de Europese Unie geregeerd worden? Doe maar gewoon ...', in M. Sie Dhian Ho (red.) Democratisering van de Europese Unie, themanummer B en $M, 29,1:$ 4-7.

Lord, C. (1998) Democracy in the European Union, Sheffield: Sheffield Academic Press Ltd. Majone, G. (red.) (1996) Regulating Europe, London: Routledge.

Marks, G., L. Hooghe en K. Blank (1996) 'European Integration from the 1980s: StateCentric v. Multiple-Level Governance', in Journal of Common Market Studies 34, 3: $341-378$.

Meny, Y. (2003) 'De la democratie en Europe: old concepts and new challenges', in Journal of Common Market Studies, vol. 41, 1: 1-13.

Mierlo, H.A.F.M.O. van 'De vitaliteit van de nationale staat', in De vitaliteit van de nationale staat in het Europa van de $21^{e}$ eeuw. WRR lecture 2002, Den Haag: Stenfert Kroese: 31-43.

Moravcsik, A. (2002a) 'In Defence of the 'Democratic Deficit': Reassessing Legitimacy in the European Union', in Journal of Common Market Studies, vol. 40, 4: 6o3-24.

Moravcsik, A. (2002b) 'If it ain't broke, don't fix it!', in Newsweek, March 4: 15.

Offe, C. (1998) 'Demokratie und Wohlfahrtsstaat: Eine europäische Regimeform unter den Stress der europäischen Integration', in Wolfgang Streeck (red.) Internationale Wirtschaft und nationale Demokratie: Herausforderungen für die Demokratietheorie. Frankfurt am Main: Campus.

Philippart, E. en M. Sie Dhian Ho (200oa) 'From uniformity to flexibility - The management of diversity and its impact on the EU system of governance', in G. de Burca en J. Scott (red.) Constitutional change in the EU: From uniformity to flexibility, Oxford: Hart Publishing. 
Philippart, E. en M. Sie Dhian Ho (200ob) 'Answering EU's Need for Policy Laboratories and Sub-Systemic Schemes: Reflection on the Reform of Closer Cooperation', in Current Politics and Economics of Europe, vol. 10, 1: 51-71.

Pijpers, A. (1999) De mythe van het democratisch tekort. Een discussiebijdrage over de Europese politiek, Den Haag: Nederlands Instituut voor Internationale Betrekkingen 'Clingendael', oktober.

Princen, S. (2004, nog te verschijnen) 'Verantwoordingsregimes en Europese integratie', in: M. Bovens c.s. Jaarboek Beleid en Maatschappij 2004.

Reif, K. en H. Schmitt (1980) 'Nine Second-Order National Elections: A Conceptual Framework for the Analysis of European Election Results', in European Journal of Political Research, vol. 8, 1: 3-45.

Scharpf, F.W. (1999) Governing in Europe. Effective and Democratic? Oxford: Oxford University Press.

Siedentop, L. (2000) Democracy in Europe, London: Allen Lane/Penguin.

Staden, A. van (2003) The Right to Govern: The Democratic Legitimacy of the European Union, Den Haag: Clingendael Institute, November.

Warleigh, A. (2003) Democracy in the European Union, London, Thousand Oaks, New Delhi: Sage Publications.

Weiler, J.H.H., U.R. Haltern en F.C. Mayer (1995), 'European Democracy and Its Critique', pp. 4-39 in J. Hayward, The Crisis of Representation in Europe, London: Frank Cass \& Co Ltd.

Weiler, J.H.H. (1995), 'Does Europe Need a Constitution? Reflections on Demos, Telos, and the German Maastricht Decision', in: European Law Journal, 1: 219-258.

Wetenschappelijke Raad voor het Regeringsbeleid (2003), Slagvaardigheid in de Europabrede Unie, Rapporten aan de Regering nr. 65, Den Haag: Sdu Uitgevers. 


\title{
9 BEYOND PRINCIPAL-AGENT GOVERNANCE: EXPERIMENTALIST ORGANIZATIONS, LEARNING AND ACCOUNTABILITY
}

\author{
C.F. Sabel
}

\subsection{INTRODUCTION}

The success of LPF, like the success of similar populist movements that preceded it in Austria, France, Switzerland and elsewhere, raises grave questions about the legitimacy of democratic inputs to public decision-making and the efficacy of public action however decided. At the very least these successes signal an impaired responsiveness of the democratic state to its electorate: a democratic deficit. Coming at a time of economic well being, shifts in party allegiance of a magnitude not seen since the 1920 are thus widely and rightly seen as extending beyond democratic criticism of this or that incumbent government into a protest against the way contemporary representative democracy works. ${ }^{1}$

The causes of this democratic distress are many. But there is substantial agreement that an important source of the protest is disappointment with the way government provides public goods such as education, health care, public security, and with the regulatory rules regarding, for example, the environment, to which civil society actors must respond (Van den Brink 2002). Among politicians of many political colors and in the high reaches of the civil service there is further agreement that government fails at these tasks because it tries to solve too many public problems directly, and too often with rigid, bureaucratic methods. The state fails to deliver in key areas where sustained public engagement is necessary, even while meddling wastefully in matters where it is not. These failures, it is further claimed, are especially burdensome for increasingly diverse and vulnerable social groups. As government is manifestly less able today than in recent decades to protect the vulnerable against the insecurity associated with market economies by social insurance, it must assure solidarity by providing those particular forms of education and other services that enable citizens, as individuals and families in different settings to respond effectively to the risks they face. In short, the state's failure as a service provider becomes all the more onerous, and all the more objectionable to broad groups of citizens, as effective service provision becomes key to public well being (Esping-Anderson 2002; O’Donnell 2004; Trubeck and Zeitlin 2003).

Very generally those who see the democratic deficit in the Netherlands as connected to the misdirection of state effort agree that the solution is for government itself to intervene less, and above all less directly, in civil society. On the contrary, to the extent possible, the state should encourage or require civil society actors to supervise themselves in the provision of services and rules, and limit its own intervention to monitoring the self-supervision of civil society actors. 
Instead of issuing detailed regulations, or specifying how services are to be provided, the state would set general goals, monitoring the efforts of appropriate actors to achieve those goals by means of their own devising. The state would then intervene only when the efforts of the latter fall short. In this way the state could respond to the growing need to customize for the domestic economy and polity the general provisions of EU and international law to which it is increasingly subject, while responding to the demands of evermore 'mature' and 'individualized' citizens for public performances tailored to their particular situation. Within this very general framework concrete proposals for improving services and regulatory rule making currently under discussion in the Netherlands (and of course hardly there alone) go in two, apparently contradictory directions (ministerie van Binnenlandse Zaken 2003; Projectbureau Operatie Jong 2004)

The bottom-up proposals insist on the need to subject the local or street-level instances of public service administrations to popular control through a locally constituted citizens' or clients' council, or to delegate responsibility for service provision or rule making to civil society actors such as firms, NGOs and trade unions or professional associations. When the emphasis is on direct democracy in service provision these initiatives often go by the name of 'interactive governance'. When the emphasis is on increased civil society participation in problem solving, especially through rule making, they go by the name of 'self-regulation'.

The top-down proposals for reform focus on making public administration accountable for achieving the broad goals set by the relevant political authorities. A chief instrument to this end is the translation of those general aims into detailed administrative targets - a 50 percent decrease, say, of assaults per month in a crime-ridden area, or a 50 percent decrease in the school drop-out rates - so that compliance with directives is easy to measure, and incentive systems correspondingly easy to design. Reforms aimed to increase accountability in this way often go by the name of 'new public management' (NPM).

In practice, of course, these proposals are often complements, not competitors, and the boundaries among them are in any case blurred. Increased client input can heighten accountability within the framework of NPM while opening a social space for self-regulation or more direct forms of democracy. Nonetheless, the distinctions between top-down and bottom-up service-provision/regulatory responses to the recent political cataclysms are useful points of orientation for discussion of the prospects of democracy in relation to state reform in the Netherlands and generally.

In this note I follow the consensus in assuming that the democratic deficit is linked to the misdirection of state efforts, and join the general conclusion that government should reduce direct management of civil society in favor of extended monitoring in 'the second line' of the efforts of civil society actors to achieve generally agreed goals (ministerie van Binnenlandse Zaken 2003). My central claim is that current debate over bottom-up and top-down governance 
reform - in disregard of the lessons of contemporary, practical success in collective problem solving - ignores important organizational innovations, without which the reallocation of control rights to civil society actors is unlikely to result in the social learning about the effective pursuit of the broad, imprecise goals 'effective' or 'adequate' education - implied by the turn to service-oriented solidarity. I argue further that these innovative, problem solving institutions, though not intrinsically democratic, can be configured in ways that address familiar problems in representative, deliberative, direct and associational democracy; and that, so configured, they are compatible with the Dutch tradition of sharing democratic sovereignty between parliament and extra parliamentary bodies. The core of the paper discusses the principles informing these new organizations; illustrates their operation as regulatory rule makers and providers of a new kind of public service; and speculatively defends their democratic aptitude in general and in the setting of consensual democracy characteristic of the Netherlands in particular. The argument is in three parts.

Part 1 argues that the apparent differences in the top-down and bottom-up proposals for service/regulatory reform obscure a deeper commonality. Both assume that there are civil society actors (principals) who already know what needs to be done to solve collective problems. From this they conclude reasonably enough that the problem is to give these principals the authority to do themselves what needs to be done (under continuing public supervision), or to instruct public functionaries (agents) to act on their, and the public's, behalf.

But what if, as I and many other assume, there are no principals in civil society not even the political parties that connect it to the agents in public administration - with the robust and panoramic knowledge needed for this directive role? Then the problem for reform is at least as much determining ways how actors can discover together what they need to do, and how to do it, as determining which actors ought to be the principals in public decision-making. At the limit, if there are no actors capable of setting goals with the precision needed to guide effective public action, governance reform must attend simultaneously to institutionalizing public or social learning and allocating decision-making rights - rather than assuming, as often is the case now, that learning is automatic when the 'right' constellation of principals is in control.

Part 2 then looks in some detail at a new class of networked, experimentalist organizations that assume the provisionality of their goals. They institutionalize social learning by routinely questioning the suitability of their current ends and means, and periodically revising their structures in light of the answers. I use promising developments in the reform of public schools and the regulation of food safety in the us to illustrate how such organizations are effectively addressing problems that seemed beyond the reach of principal-agent governance in the provision of crucial services and regulatory rule making. The aim is to suggest, though not of course to pretend to demonstrate, that insofar as defects in the provision of public goods are at the heart of the problem of the democratic deficit in the Nether- 
lands and elsewhere, experimentalist institutions are at the heart of solution. But this is far from the whole story. Just as there are good reasons to think that a democratizing redistribution of control rights will not lead automatically to the social learning necessary when goals can not be fixed ex ante, so there is reason to doubt that experimentalist institutionalization of social learning will lead by itself to more democratic control of key services and regulatory regimes. So we need to ask whether, and eventually in what way, experimentalist institutions can be democratically domesticated? Part 3 looks at this question from the vantage point of two reasonable worries about the new, networked institutions.

The first is that the kinds of formalization of knowledge on which these institutions depend create infernal possibilities for forms of social control, at best eliciting the pointless pursuit of arbitrary, narrow goals associated with some forms of NPM, and at worst destroying the autonomy of professionals, clients and citizens, as in the Foucauldian nightmare of all truth seeking as a mask for inescapable social discipline. In response I will try to show that these organizations encourage forms of reason giving and deliberation that seem as antithetic to narrow rule following as to unwitting subservience to a social script. On the contrary, experimentalist institutions seem to make explicit, and thereby transform and render accessible to collaboration and public review, traditional forms of professional autonomy and interest group influence. Experimentalism invites, I will argue, though it does not automatically create, a form of directly deliberative and democratic control over key institutions, making not only professions but also other such primordial or 'natural' stakeholder groupings (labor or trade organizations, organized confessions), available to review by their peers, clients, and wider public circles in ways that check their authority. Configured to be accountable in this way, the argument continues, experimentalism potentially mitigates the most salient defects of deliberative and associational democracy - the two most frequently discussed alternatives to representative government. Put another way, experimentalist institutions can be both effective problem solvers under modern conditions of pervasive uncertainty and 'locally' democratic in the sense that service providers, clients and other stakeholders can be held mutually accountable.

The second and related worry is whether locally democratic experimentalist service providers and rule making regimes can be made subject to democratic control by the parliament and judiciary. If not, there is danger of parallel government(s), effective within distinct precincts, but beyond overall public control and unable by themselves to generate some substitute for the latter as a forum for setting society-wide priorities and reviewing existing commitments. Here I argue that the Netherlands, as a past master of consensus democracy, has vast experience in integrating parliamentary decision-making with the organized deliberations of civil society. Some of this legacy may encumber Dutch society with entrenched veto powers and deep expectations at odds with the emergent needs. But we will see that a society that (almost always) thinks of sovereignty as shared between the legislature and civil society already has some important institutional 
resources with which to link the directly deliberative possibilities of experimentalist institutions to administrative, and thence parliamentary review. Indeed, establishing such a link by re-conceiving the division of labor - and thus the separation of powers - among parliament, the administration, and the judiciary may be the best way for the Netherlands to renew, yet again, equal and mutually informing commitments to self government through social consensus and deep respect for the diversity of groups and the integrity of individuals.

\subsection{BEYOND PRINCIPAL-AGENT GOVERNANCE: EXPERIMENTALIST ORGANIZATIONS AND NEW PUBLIC GOODS}

On one level, NPM and interactive governance - the top-down and bottom-up responses in the Netherlands to the challenge of improved service provision could not be more different. NPM seeks to revive representative government by tightening the grip of parliamentary government on administration enough that electoral outcomes actually redirect state efforts as voters intend - or at least enough so that failure to act as instructed can be sanctioned at the next election. This driving idea of NPM is taken directly and openly from us economics of the 1980 , and notions of corporate governance reform associated with it. Just as shareholders wrest control over private corporations from managers (who were sometimes thought to be out just for themselves, sometimes colluding with the work force against consumers and equity owners) so the citizens are to retake control of their state from public officials and interest groups (Boston et al. 1996).

Where NPM thus strikes some as business friendly, or, more neutrally, technocratic, interactive governance has a grass-roots aspect. It implicitly abandons (though it seldom directly attacks) representative government, bypassing parliamentary law making and the ensuing delegation of rule making authority to administrative bodies. Instead it puts control of state action in the hands of those most immediately affected by it: the users of key services or the entities subject to regulatory rules. Such control may be exercised through local advisory councils empowered to instruct, or create alternatives to, local levels of public administration, or through deliberative bodies making rules for particular sectors or problem areas. Either way the result is to displace representative democracy with a directly democratic alternative (Denters et al. 2003).

But on another, more fundamental level NPM and interactive governance are the same, not different. Both assume that there exists in the polity or in civil society principals who, because of their current situation (as voters, or as the bearers of some relevant local knowledge) know with high precision what needs to be done, even if they cannot fully solve some problem in advance of any effort actually to do so. Accordingly the chief problems for governance are identifying the knowledgeable actors and devising institutions that keep the agents that execute tasks firmly under the control of these principals who, correctly, conceive them. In the case of interactive governance this leads, at the limit, to collapsing execution into conception (principals as their own agents, or the public equivalent of the owner- 
operated firm). In the case of NPM it leads, as we will see in a moment, to a radical separation of conception from execution. But these differences are simply contextspecific means to the common end of maintaining the fidelity of state action to the intentions of legitimate principals. A brief review of the travails of NPM in practice will show how its shortcomings prompt consideration of interactive governance; and an even briefer look at the shortcoming of interactive governance will underscore the untenability of the key assumptions underpinning both.

The assertion of 'straight-line' accountability from voter to administrative agent in NPM requires the separation of conception from execution in public programs. Otherwise self interested agents will use any chance to collaborate in the design of programs to recommend goals that make themselves responsible for the most rewarding tasks - and the public take the hindmost. ${ }^{2}$ The NPM alternative is for politically appointed ministers, supported by expert staff and hired consultants, to determine strategy, and for civil service managers, eventually complemented or supplanted by private contractors, to execute it. By the same logic the scope of responsibility of individual ministries, and the programs within them, is narrowed, reducing the danger that self-interest can use competing purposes as a lever for its own ends. Clearer, narrower goals in turn reduce the need for middle managers to break complex tasks into simpler ones and set priorities among competing programs. The overall result is a narrow, flat administrative structure whose front-line managers clearly understand their purpose as increasing the satisfaction of the citizens (now recast as customers). This is government by results, where the latter are measured by progress on global performance indicators: (improvements in) crime rates, numbers of unemployed persons placed in jobs, test scores (of the competence of students at various grade levels and their teachers), school completion rates, and so on.

A consequence - for some reformers the very purpose - of these reforms is a reduction in the scope of government itself. The clearer the purposes of government, and the more measurable the results of its actions, of course, the easier it is to translate the tasks of public administration into contracts, and to hold contractual partners to account for breaches. This makes it easier for government, first, to contract with private parties, instead of its internal units, for the provision of service: what mattered to the public as citizens and consumers, after all, was the contractual terms and the respect accorded them. Straight-line accountability thus makes the monopoly of public administration on service provision contestable in theory. Making it contestable in fact took an endless series of battles that are already becoming hard to recall now that they have been mostly won.

The successes of the NPM in establishing the contestability of public administration and devolving authority are indisputable and largely taken for granted by the vast middle of the modern democratic polities. But measured by its own standard - as a movement to restore accountability and effectiveness to government - the results of the principal-agent movement are equivocal at best. Government in Great Britain, perhaps the country that has remained most faithful to the original 
NPM project, is arguably less accountable, and on balance, no more effective than before, for two reasons connected to the principal-agent underpinnings of the reform movement itself.

First, it proves impossible to separate strategy from implementation, or more generally, conception from execution. Those who carry out orders, it was (again) discovered, learn not only how to refine the execution of tasks, but also which tasks, and in which sequences, might be worth pursuing. Nor is it just public or private sector service providers who acquire knowledge relevant to goal setting in this way. Citizen users of the services provided also turn out to have knowledge relevant to public choices; indeed, at the limit, citizens often prove to be coproducers (and hence co-authors) of services as well as consumers of them. In practice, therefore, the administrative bodies responsible within the NPM framework for operational implementation of departmental policy often develop a near monopoly of expertise in their area, so that strategic choices (new ends) often emerge from innumerable small, local decisions about means - a classic case (from the NPM standpoint) of tail wagging dog.

Second, narrowing programs in the interest of accountability has the unintended consequence of making it difficult to co-ordinate relations among the narrower entities. Given specific tasks, and encouraged by new incentive systems to focus exclusively on them, and contract with others to provide collateral services, what is to induce the agencies, especially at the crucial local or street level where clients meet administration, to cooperate among themselves to solve problems requiring joint action? Put another way, horizontal learning between principals and agents in related activities proves as necessary as learning among principals and agents working in a single domain.

The upshot is that the conscientious application of NPM principles typically goes hand in hand with the discovery of what the British call 'cross-cutting' or 'wicked problems': problems, like the reform of schools or the provision of treatment to substance abusers, that both draw on the local knowledge of service providers and service users and require co-ordination of service provision across a wide range of formal jurisdictions. It is no coincidence that the wicked problems appear just where the new, solidarity sustaining services need to be provided. The citizens at risk, and therefore in need of such assistance, can usually benefit from a service such as job training only if it is provided with an idiosyncratic bundle of others, such as child care, transportation, and psychiatric support. The same logic applies to institutions in need of reform. A failing school typically needs not only to reorganize classroom pedagogy and the way teachers learn from each other, but also its relations to the local police, family protective services and substance abuse programs. As these necessary complements can hardly be furnished by one entity, bundling them appropriately is a wicked problem.

A clear manifestation of the recognition of wicked problems is the profusion, within any single system of NPM, of quantitative targets. The sovereign principal 
senses, for example, the complex interdependence of the public safety, education, housing, and transportation problems of large urban areas home to large immigrant populations. So it concludes contracts with large municipalities rewarding each, with further, perhaps increased subsidies, if it makes progress towards achieving, say, forty improvement goals, each presumed to be valuable in itself and even more valuable if achieved in combination with subsets of the others. But this recognition of the problem does nothing to solve it. On the contrary, multiplication of explicit goals gives the agent as much discretion as the delegation of broad, hence ambiguous authority. Since the agent cannot possibly do all the things the principal explicitly says or generally implies need doing, it is the agent, not the principal who chooses what goals are actually pursued. Thus, in the case of the municipal improvement contracts, it will be an open secret that the municipalities will be able to argue for some progress on some indicators. As the problems they face are likely to have gotten worse, not better, in time, it will be impossible to deny continuing subsidies, barring outright malfeasance.

One more thoroughgoing, though equally hapless effort to correct NPM in the face of wicked problems is to create a new, central bureaucratic elite (a commando center), with the flexibility to define crosscutting projects. But the creation of a commando center invites repetition of the self-deluded errors of the overreaching state in reaction to which the governance debate, ideas of NPM included, arose. A second and contrary organizational response is to devolve responsibility to local networks of participants and providers. The devolution of authority to local networks leads to some variant, formal or informal, of interactive governance.

Interactive governance is a more tender shoot than NPM. ${ }^{3}$ Its relation to the institutions of local government are much more complex than a statement of its animating principles would suggest. Hence interactive governance is perhaps better thought of as a rubric for a broad class of decentralizing reforms than as a definite program of reorganization; and given the brevity of the experience of these initiatives, and the paucity of evidence about them, it would be premature to venture an overall estimate of their potential and limits.

Still, even on the thin evidence available, it seems that interactive governance runs again and again into the same limit. While local knowledge is necessary for effective and legitimate action (a lesson, among others, of the failures of NPM), it is seldom sufficient. Thus municipal decentralizations undertaken in the name of interactive governance repeatedly discover that the local citizen-principals empowered by the initiatives have no clear idea of what to do with the powers or resources attributed to them - they know what they do not want, but not what they do. Or, if they do have preferences, these are more likely to reflect (microscopically) local interests - or the interests of a local institution with which they are affiliated - than anything like a conception of the local public good. Or if a local public with general ideas of reform does coalesce, the local 'implementers' have problems collaborating with the 'conceptualizers' at the next highest levels of municipal government. In short, where the NPM is hamstrung by the way it 
limits the ability of principals with (pseudo-)global knowledge to learn from local experience, interactive governance is hamstrung by way it limits the ability of local principals to learn from those with a more panoramic view.

The more general lesson of the shortcoming of NPM and interactive governance of course is that the principal/agent distinction, with its presumption of the separability of means from ends and of global from local knowledge, is untenable in practice. In currently complex settings, choices of means routinely influence choices of ends, and vice versa, just as global and local knowledge are mutually corrective, not hierarchically ordered. The interaction of ends and means and thus the indeterminacy of both - the limits on our ability to know what we want, and how to get it - that this experience suggests will surely be counter-intuitive to many. The principal/agent distinction rests, after all, on the bedrock assumption in much of economics and organizational sociology that ends are chosen prior to, and independent of means. Economists in particular are likely to find the idea that public goods such as education or public safety could be indeterminate in this way especially paradoxical, not to say implausible. In economics the utility, and so presumably the feasibility, of a public good is taken to be so self-evident that each potential beneficiary assumes all the others will want it too. Hence the free rider problem distinctive of public goods; since each consumer/client concludes (rationally but incorrectly) from the general attraction of the benefits to all that the others will shoulder the costs, no one does (unless obligated to pay their share by a collective decision obligating all). But the profusion of wicked problems shows that under current circumstances the joint organizational problems of determining just what kind of public good to provide and how to provide it are at least as crucial and refractory as the public finance problem of outwitting the free rider. To underscore the indeterminacy of collective services now urgently demanded, and hence the organizational challenges they pose, I will speak of the provision of new public goods.

If these two variants of principal-agent governance exhausted the choices for public decision-making, prospects for the provision of new public goods would be dark indeed. But NPM, interactive governance alternatives to it, and the governance debate more generally, overlook crucial, current innovations in the nature of organization itself. These innovations blur - but do not efface - the distinction between conception and execution, principal and agent, global and local, and so allow for co-ordination of changes of means and ends - social learning - unattainable by conventional institutions. These breakthroughs, pioneered, but no longer limited or even best exemplified by modern Japanese firms, are diffusing rapidly among the public administration service providers and public rule makers in the US and the EU. It is to this novel institutionalization of learning that we turn next. 


\subsection{EXPERIMENTALIST SERVICE PROVISION AND RULE MAKING IN PRINCIPLE AND PRACTICE: FOUR ILLUSTRATIONS}

Consider this highly stylized contrast between organizations before and after roughly $1980 .{ }^{4}$ In the century before 1980 the canonical organization was hierarchical and closed, and the determination of ends accordingly preceded and remained distinct from the elaboration of ends. Parliament (acting presumably on behalf of the voters) or headquarters (acting presumably on behalf of the stockholders) set goals. Ministries, administrative agencies or high managers parsed complex tasks into simpler, more manageable ones; organizational routines specified how to parse, execute and review the compliance of tasks. Subordinates were rewarded for complying with instructions; middle managers checked the conformity of activity to plan. This hierarchical subdivision of labor was taken to be the uniquely effective response to the problem of bounded rationality - the limited processing capacity of individual human beings - and hence the only means by which humans in organizations could master superhuman tasks. The precondition for hierarchy of course was and is (relative) stability. If the world changes before it is possible to recoup the enormous costs of designing complex goods and services, and the fixed organizations to produce them, investments in hierarchy are pointless.

After 1980, for reasons we do not know, and may never fully understand, the world becomes too volatile for hierarchies. Again for reasons, and by a path, that we are far from understanding, a new kind of organization emerges in response. The canonical form of this organization is federated and open. Decisions of higher units are shaped by lower ones, and the lower units can be formally outside the organization. Or, to capture the idea that information in the new organization flows up and down as well as sideways, they are said to be networked. General goals or designs are set provisionally by the highest level - parliament, a regulatory authority, or the relevant corporate executives through benchmarking: an exacting survey of current services, rules, products and processes, supplemented by assessments of what new and unproved variants might become available for use. Then the provisional goals are revised in light of proposals by lower level units responsible for executing key aspects of the overall task..$^{5}$ Once a service is being provided, initial rules are in place, or production begins, continuous monitoring detects errors and breakdown, uses these findings to trigger searches for the root causes of design or other flaws that escaped earlier examination. The goal of such root cause analysis is to trace disruption back to its original source, which may not be palpably linked to the proximate cause of the breakdown. Taken together routines such as benchmarking, simultaneous engineering, continuous monitoring, error detection and root cause analysis define methods for choosing provisional, initial goals and revising them in the light of more detailed, partial proposals arising from efforts to implement them. Put another way, the routines make it routinely possible to correct ends through the exploration of means and vice versa. In the pragmatism of Dewey and James it is the nature of our world, and our apprehension of it, that experience regularly 
unsettles our guiding assumptions. So we can think of these new institutions as pragmatist in that they systematically provoke doubt, in the characteristically pragmatist sense of an urgent suspicion that their own routines - habits gone hard, into dogma - are poor guides to current problem solving.

These features of networked organization have important implications for the principles and practice of governance. Compliance or accountability in the princi$\mathrm{pal} /$ agent sense of rule following is impossible. There are in effect no fixed rules, or, what comes to the same thing, a key rule is to continuously evaluate possible changes in the rules. Accountability thus requires not comparison of performance to goal or rule, but reason giving: actors in the new institutions are called to explain their use of the autonomy they are accorded in pursuing the corrigible goals. These accounts enable evaluation of their choices in the light of explanations provided by actors in similar circumstances making different ones, and vice versa. To encourage this kind of ongoing, mutual reflection, monitoring is continuous, or nearly so, rather than occasional or episodic; and it is less concerned with outcome measures than with diagnostic information - information that can redirect the course of 'treatment'. ${ }^{6}$ Where the failure to follow the rule in principal/agent systems is, in theory, immediately penalized, in pragmatist systems non-compliance in the sense of inability or unwillingness to improve or otherwise respond to change at an acceptable rate triggers, we will see, increased, capacity enhancing assistance from the oversight authority. Repeated failure to respond, even with assistance, is, however, likely to bring about the dissolution of the offending unit.

These federated organizations respond to the problem of bounded rationality not primarily by decomposing complex tasks into simple ones, but rather by creating search networks that allow actors quickly to find others who can in effect teach them what to do because they are already solving a like problem. Because they are good at searching 'rugged' terrains (in which there are many hillocks and mountains, but no soaring peak that affords a panoramic view) they are as well suited to volatile, rapidly changing settings as hierarchies are to stability. Through continuous, diagnostic monitoring the networked organizations ensure that they actually learn enough from current searches to direct successive ones towards promising goals. Though we will not pursue these themes here, this capacity to search routinely for new solutions makes the new organization robust in the face of disruptions that would cripple hierarchies; moreover, such robustness also seems to enhance their ability to discover efficiency-enhancing improvements inaccessible to hierarchies - so that the advantages of the new organizations in volatile settings have spill-over effects in more stable contexts as well.

To get a more precise idea of how these pragmatist institutions work, and especially how they can address the problems of service provision and rule making that confront the contemporary state, consider four variants of the networked organization. Three are drawn from the public or publicly regulated sectors; the fourth concerns the private manufacturing corporation. It is included to show 
that the principles at work here are applying equally well in the public and private sectors. Indeed, one of the reasons these principles work well in public rule making is precisely that they mesh with forms of management that spring from the same source.

\subsubsection{NEW PUBLIC SERVICE ORGANIZATION}

This type of institution is receiving increasing attention in various domains of policy studies, and for reasons noted above it is especially pertinent to discussion of service provision as a key element of renewed social solidarity. Well documented examples are schools in Texas, Kentucky, North Carolina and elsewhere in the Us that actually teach poor children of color to read and do mathematics with proficiency comparable to that attained by rich, white pupils.7 The new organizations have a clear purpose, fixed in the cases discussed here by state and federal laws - to provide all students an adequate education. But the reforms are built on the assumption that a workably precise definition of adequacy and a serviceable idea of how to build a school system that achieves this will be joint products of the disciplined search for the desired result.

As the foregoing suggests, the pragmatist solution to the problem of providing new public goods is to build an organization that detects and corrects errors at the lowest levels, and then adjusts the higher level structures to generalize successes and encourage more refined error detection, and so on. For example, all students learn to read by some idiosyncratic combination of decoding strings of letters/phonemes (phonics) and derivation of the meaning of words and sentences from context (whole language method). Teachers identify the strengths and weakness of each student's mixture of strategies by sampling their skills in brief, daily sessions, and suggest improvements (local diagnostic monitoring, or first-order error detection and correction). The performance of students in the same grade is measured periodically statewide by a standard test, allowing for the comparison of the performance of teachers within schools, schools, and districts (general diagnostic monitoring, or second-order error detection). The job of principals in this system is to create conditions in the school for generalizing the successes of the most successful teachers. The job of the principals' superior - the district supervisor - is to create conditions for diffusing the successes of the most successful principals, for example, by creating an academy for training aspirant principals in the new methods of school organization, or in providing programs in professional development by which more successful teachers within and across district school can help less successful ones. When individual schools fail to improve, the district supervisor's job is to intensify the assistance to the struggling facility. If the difficulties are incorrigible, the supervisor 'reconstitutes' - dissolves - the failing organization, and reassigns the students and the capable teachers elsewhere.

In this way the reformed school is invented through the piecemeal, but eventually comprehensive improvement of a crude, but serviceably provisional starting 
structure that supposes only the broadest, non-vapid agreement on goals and methods: The goal is simply that educational achievement (by mainstream measures) should not vary across groups in culturally salient hierarchies, and gaps should be closed by leveling up, not down. The method is that teachers must aid students to improve their individual bundles of learning strategies, and administrators must aid teachers and other administrators in doing this.

\subsubsection{ROLLING RULE REGULATION}

The rolling rule regime goes the new public service organization one better: it is almost all provisional goal, hardly any organization at all. More precisely, the rolling rule 'organization' is created by the bootstrapping efforts of the (civil society) actors to meet, then improve on, a broad goal set though benchmarking by a public authority. Perhaps the simplest case is a rule obligating each unit of a public or publicly regulated institution to measure itself against some performance standard - reliable and safe operations, continuous improvement in service provision - and correct shortfalls revealed by comparison with the performance of others facing similar situations. Thus utilities in the us nuclear power-generating industry must report disruptions in their operations to the Institute for Nuclear Power Operation (INPO), an industry-funded entity ultimately responsible to the Nuclear Regulatory Commission. INPO officials sift these near-miss reports to distinguish harmless disruptions from dangerous ones. Thorough analyses of the causes of the dangerous disruptions, and ways of preventing them, are then circulated as Significant Operating Experience Reports, or SOERs. Industry Operating Experience Reviews then periodically assess the ability of particular plants to effectively use the soeRs and other means to improve their own affairs. For purposes of this review, a team of specialists in a variety of areas evaluates the plant's troubles since the last INPO inspection, paying particular attention to the plant's own reports on how it has responded to sOERs. ${ }^{8}$

More elaborate forms of rolling rule regimes are emerging where minute variations in daily operations are less likely to signal the possibility of substantial, hidden risks. In such cases the government requires the regulated entity to present a plan in which it identifies the risks to which it is likely to be exposed; specifies how it will mitigate those hazards; regularly monitors whether the mitigating methods are effective; and, if need be, redefines the range of risks to which it is exposed. A regulatory oversight body then evaluates the adequacy of the plans, and the steps to realize them, against the benchmarks set by the best performers. The shift in the US in the 1990s from poke-and-sniff (organoleptic) methods of ensuring food safety to the hazard analysis of critical control points (HACCPs) shows the drift of developments (Department of Agriculture 1996, 2003a, $2003 \mathrm{~b}$ ). In the organoleptic method an inspector from the Federal Safety and Inspection Service examines every head of cattle or chicken being disassembled in a slaughterhouse for quality defects and especially signs of pathogens. The limitation of the method of course is that some pathogens may not be detectable by the usual examinations, so that meat products leaving the processing plant are 
not assuredly safe; and even if they are, pathogens introduced at later stages of the food supply chain would remain unnoticed. Under the HACCP regulations introduced by the us Department of Agriculture, meat and poultry processors have to identify all the points in their production processes where pathogens are likely to introduced; detail how they will reduce these risks and verify, by testing, the success of the adequacy of their measures. This HACCP plan must be complemented by a Standard Sanitation Operations Plan detailing the plant's regular housekeeping measures. The role of federal inspectors shifts from direct examination of animal carcasses to verification of the processors' hazard reduction systems. This verification starts with assessment of the adequacy of the HACCP plan (and the companion Standard Sanitation Operations Plan) and includes review of the plants test results as well as independent testing by the inspectors. Eventually the HACCP system is to cover every link in the food supply chain from farm to plate.

Similarly, the rolling rule regimes can be seen as the regulatory face of new public services. Such regimes typically require operating units to formulate and periodically revise strategies for increasing rates of improvement towards a general end. In the case of public school reform discussed above, for example, the general goal is to reduce and eventually eliminate the difference in performance in key subjects such as reading and mathematics between affluent, white students and poor students, who are often of color. In Texas the State governance regime accordingly requires periodic testing in these subjects by means of sophisticated standard test that (now) rewards the ability to conceptualize rather than rote learning. Each school must report the results of these tests disaggregated by economic and ethnic groups, and the State pools the data. Parents with children in a particular school can thus compare the rate of improvement of the relevant subgroup in that school to the 39 other schools in Texas demographically most similar to their children's. State and district officials can draw on the same data pool to identify persistently failing schools. Further disaggregation yields information about the performance of particular teachers and administrators that can guide reorganization at the district and school levels (Liebman and Sabel 2003).

\subsubsection{HIGH RELIABILITY ORGANIZATIONS}

'High Reliability Organizations' (HROs) typically operate in the public or publicly regulated sector (Rochlin et al., 1998; Sabel 21004b). HROs are well, but incompletely designed to perform without fail such extraordinarily demanding tasks as generating electric power through nuclear fission; launching and recovering jet aircraft rapidly from and back onto pitching, greasy flight decks; launching and recovering space shuttles; or fighting forest fires as they race through rough terrain. The designs are necessarily incomplete because the conditions under which the specified tasks are to be accomplished are changing continuously in more or less subtle ways. If the organization is not adjusted accordingly, it fails, catastrophically. HROs become disastrously unreliable if they assume that routine, (nearly) invariant success is the result of following invariant routines; 
and the organizational challenge is to avoid accidents day after day without imperceptibly making this assumption.

Key to this is error-detection and root-cause analysis disciplines. In the setting of HROs, the most important and characteristic of these is near-miss reporting and analysis. Near misses of course are accidents that only accidentally didn't happen. Near misses, and 'out-of-control' sequences that nearly produced them, trigger root-cause analysis meant to uncover and eliminate the background conditions from which arise the proximate sources of danger. We saw a moment ago how the root-cause analysis regimes are often regarded as a key element in the governance of HROs, and how they can become the backbone of regulatory regimes.

\subsubsection{DELIBERATELY INNOVATIVE FIRMS}

This is a familiar example of the new, networked organization: the firm whose very purpose is to produce innovative products or services. Perhaps the bestdocumented example is of design and production in the automobile industry (MacDuffie, Helper and Sabel 2000; Sabel 2004a).

The process starts when, say, the new-van design team sets the general performance characteristics of the vehicle by benchmarking the best features of current vans. Assessing the results of these probes, and again guided by reference to leading examples and comparison of possibilities, the team next provisionally subdivides or, to take a term from cognitive science, 'chunks' its general goals into subtasks - the design of an engine, or heating, ventilation and air conditioning system - and chooses a specialist team from inside or outside the parent company to realize the initial specifications.

After this initial chunking separate project teams elaborate all the provisional subsystems concurrently, applying to that task the same kind of evaluation of competitors' successful efforts and developmental possibilities used in the van team's first round of benchmarking. In addition, they benchmark the production processes central to their eventual products to ensure that the methods employed will meet or surpass the efficiency of their most capable competitors. Engine plants, for instance, will have to produce engines that are at least as cheap and warrantable as those of competitors making similar engines in comparable volumes.

Then the initial overall goals are modified by the methods of simultaneous or concurrent engineering, e.g. the engine-design group may find a way to better its target specifications or to cut its manufacturing costs if it can persuade other component groups that design characteristics should be modified accordingly.

Refinement of this iterated co-design continues once production begins by means of just-in-time and the error-detection and correction methods associated with it. In just-in-time production, parts are supplied to each workstation only as needed: ideally, one at a time. Hence disruptions are immediately visible. 
A breakdown at one station halts production by stopping the flow of parts to downstream operations.

To assure the flow of production, therefore, the source of disruption must be identified. This typically requires tracing long causal chains back to improbable origins by insistent questions sometimes called the 'five why's'. For example:

Why is machine A broken?

Why was the maintenance crew derelict?

Why is machine B always broken?

Why does the jam recur?

Why does the part overheat?
No preventive maintenance was performed.

It is always repairing machine B. The part it processes always jams. The part warps from heat stress. A design flaw.

Thus, as in the other cases, error detection and correction, like benchmarking and simultaneous engineering, reveal possibilities for improvement in unexpected (mis-)connections among the parts of complex endeavors; and the cumulative effect of these results is captured in improvements in the benchmark standards for various production processes.

Note, to underscore the radical, organizational novelty of the new instructions, that benchmarking, simultaneous engineering and error-detection methods like the 'five why's' are counter-intuitive from the vantage point of the classic hierarchies that dominated notions of cooperative efficiency before the watershed changes that we are dating to the 1980 os. In such classic organizations, long the paradigmatic case for organizational sociology, routines define tasks once and for all. They are effective in easing the burden on our bounded rationality because they become a kind of second nature, questioned only in exceptional circumstances: typically, when goals are reset, and the rules defining the tasks into which the new ends are parsed must be changed accordingly. It is simply oxymoronic from the perspective of such traditional hierarchies to try to do what the new, pragmatist institutions do as a matter of course: routinely question the suitability of current routines for defining and solving problems.

\subsection{BUT ARE EXPERIMENTALIST ORGANIZATIONS DEMOCRATIZ- ABLE?}

The foregoing suggests pragmatist institutions do indeed enable the social learning needed effectively to pursue imprecisely specified ends in general and provide new public goods in particular. But if the provision of new public goods is a necessary component of solidarity in today's democracy, provision of such goods is alone surely not sufficient to secure the legitimacy of government in any modern democracy. Experimentalist service providers and rule makers - experimentalist government in general - must be democratically accountable at least in the sense of being responsive to the (political) will of immediate stakeholders and 
beyond that to the public of the polity as a whole. If experimentalist institutions cannot be democratically domesticated, and still assuming they are indeed especially, perhaps uniquely, suited to collective problem-solving under current conditions, our democratic societies would face a fateful choice between effectiveness and fidelity to the principle of self-rule. Without pretending to fully address, let alone resolve, all the questions that arise in connection with the democratic vocation of experimentalist organizations, I want to address some relevant general, theoretical issues on the one hand and some practical, institutional ones on the other, and thereby provide at least elements of an overall approach to the many concerns tabled for now.

The first, general worry is that the new, pragmatist institutions are really at best (slightly more effective) cousins of the technocratic NPM reforms. They share with the latter an emphasis on performance metrics, 'flat' hierarchies, treating the client as at least a customer (if not a co-producer), and so on. Perhaps, this worry goes, the new institutions blur the distinction between principal and agent just enough to overcome the crippling defects of NPM, but not nearly enough to truly empower citizens/clients in the sense of giving them a potent voice in the choices that determine which services to deliver and how. This fear shades into the much more alarming prospect that, at worst, the new institutions are intended to disenfranchise the public precisely by creating sham forms of participation and consultation. The beneficiaries of this deception would be the technocratic rule makers and the organized interest groups - labor, capital, and the confessional associations - with which they all too comfortably consort.

A first response is that this self-serving and manipulative outcome, while clearly possible, is hardly inevitable. Decentralization of authority of the kind associated with the new organizations has demonstrably uprooted vested interests in ways long thought to be impossible by students of complex organizations. The well documented disentrenchment of traditional school authorities that went hand in hand with the introduction of experimentalist school reform in the Us is a case in point. Through the 1990 os public schools were widely referred to in the Us debate as an example of the un-reformability, by democratic means, of a key institution of democracy. Because successive cohorts of elected school authorities (the principals) entrenched conflicting rules favoring their separate values and interests, the interests groups (agents) running the school system were free to do whatever selfish impulse suggested (Chubb and Moe 1990). Coalitions of disaffected insiders and outsiders imposed the governance and organizational innovations described above, and the combination of decentralization of authority and transparency thus afforded has, so far, prevented a clandestine reassertion of power by new or old interests. That there are no conspicuous limits to this reform movement in those places where it has been undertaken does not mean of course that it will be automatically extended to include fully clients and citizens in decisionmaking - a problem to which we will return (but not resolve) momentarily. 
Reference to the transparency of the school reporting regime points to a second a deeper response to the worry about manipulative, sham reform. Because they are polycentric or polyarchic, experimentalist institutions are always out of reflective equilibrium. Inevitable variations in the performance of the various units provokes ongoing review and criticism of each in the light of the others' experience. ${ }^{9}$ This means that professionals - technocrats of all stripes - and the more or less formally organized interests with which they are affiliated must frequently explain why their actions differ from those of peers in like situations. Experts and interests, in other words, must justify themselves, again and again, in public, to deeply informed challenges to, respectively, their expertise and their claims of the legitimacy (or at least inevitability) of their interpretation of what their needs compel. Contrast this idea of continuing contestability of professional expertise in particular with the conventional presumption that fully certified professionals are qualified to make complex decisions on the basis of their own informed judgment alone, and are answerable to colleagues only if there is suspicion of negligence. Experimentalism thus seems more like a machine for disrupting potential conspiracies, especially technocratic cabals, than scaffolding for erecting them.

Note further that from this perspective it is possible to distinguish advantageously democracy built on experimentalist institutions from two near cousins, associative and deliberative democracy: two other, and more familiar alternatives to the form of representative government we know. ${ }^{10}$ Associative democracy assumes that the cooperation of certain groups - classically, labor and capital - is indispensable to the public interest. Such groups are accordingly given quasiconstitutional authority to bargain with each other, under the auspices of and in consultation with the government, in view of promoting public-regarding outcomes. But however effective and legitimate such arrangements may have been, it is clear today that associative democracy rests on the same flawed assumption of the panoramic powers of the sovereign principal that brings NMP, among reform efforts, to fail. It has proven in practice no more possible to identify which groups are the necessary and sufficient parties to public cooperation than to identify public principals who 'know' what is to be done in regard to particular reform projects. Experimentalist democracy, in contrast, is no more inclined to presume that the circle of participation in decision-making is fixed than to treat any body of expertise as self-validation. It is thus not hostage to the once-and-for all guesses about the identity of the 'natural' social partners that have in time paralyzed associative democracies.

Deliberative democracy, as its name suggests, is not hostage to interests. Quite the contrary, its aim is to so abstract decision-making from the trammels of everyday necessity that the decision makers are free to engage such deep reflection that their prior ideological or material preferences (if they had them at all) are likely to get sacrificed to the demands of public reason. In its purer, Madisonian forms, deliberative democracy is inclined to entrust power to a magisterial or senatorial elite, protected by wealth or tenure of office from the tugs of personal 
advancement or factional scheming. The classic stumbling block for deliberative democracy is thus not to disentrench interest groups, but rather to connect, yet not simply subordinate the deliberative elite to the everyday cares and concerns - the interests - of the everyday citizens of democracy.

Here too experimentalist democracy is promising. Like deliberative democracy, it induces citizens to change their preferences. But it aims to do this not by having the participants remove themselves from the world, but rather by opening themselves to it in a new, practically deliberative way. The mutual learning that grows out of and fosters problem solving in pragmatist institutions brings the actors to change their view of possibilities even as they put their identities at risk by reorienting their goals, their ideas of potential collaborations, and their understanding of fruitful problem-solving strategies. If this is too good to be true - because it assumes inhuman plasticity of the all too habit-bound human self - consider that individuals and groups only turn to pragmatist problem solving when pervasive uncertainty has thoroughly undermined their confidence in their inveterate problem-solving strategies (the market, more government) and the ideologies that articulate them. The determination to govern 'from the second line' in the Netherlands, for example, surely did not emerge from an insouciant delight in novelty. We do not go to the trouble of creating the elaborate learning institutions described above unless we think we have something to learn. Acknowledging our need to learn, we are less disposed to manipulate strategically the information we give and get, and the resulting surprises loosen the bonds of habit.

Thus where associative and deliberative democracy can be said to be inherently exclusive (of interest groups or practical interests), experimentalist democracy is at least potentially inclusive. Instead of addressing the plainly pertinent questions of whether and under what conditions experimentalist democracy might actually realize this potential, let me switch from general to practical themes and consider finally the possibility of an immediate, institutional response to the problems of accountability posed by the spread of public problem solving on pragmatist lines. An institutional response to the question of accountability is not of course substitute for a compelling theoretical justification. But in the history of democracy it has often been the case that institutional reform outran, and became a spur to theoretical reflection (think of the incorporation of organized interest groups into parliamentary regimes in roughly the first half of the last century). There are signs that this could be about to happen again, and in the Netherlands perhaps sooner than elsewhere.

From the institutional perspective a key condition of a shift towards experimentalist democracy is a change in the roles and relations of parliament and the administration. In the current principal/agent scheme parliament, mindful of the limits to its legislative capacity, delegates to an administrative entity the responsibility for the bootless task of detailed rule making, and periodically reviews the results. In experimentalist democracy, parliament makes framework laws committing society to broad goals - the provision of an adequate education to all. 
Administration provides the infrastructure (and eventually the enforcement discipline) with the help of which agents are able (and when necessary can be motivated) to set and revise standards in light of what they learn from pooling their efforts to improve. Parliament regularly reviews the results. So parliament in experimentalist democracy retains its centrality as that body most able to make the most comprehensive commitments to give effect to public values, and to reassess those commitments, values, and means of effecting them. ${ }^{11}$ Whether parliament is able to make more effective use of this centrality in experimentalism than it has of late in principal/agent governance depends naturally on whether the new administration can actually shift from rule making to the facilitation of pragmatist learning, and do this in a way that makes the civil society actors accountable to parliament even as they are to make themselves accountable. We are a long way from knowing whether such a vast reorientation will be undertaken, let alone succeed. But there is already evidence that the possibility of such a shift is being contemplated by a key actor in Dutch governance: the ministerial inspectorates. ${ }^{12}$

The role of the inspectorate is traditionally to ensure that administrative rules are observed in practice across the whole sweep of their ministry's jurisdiction: they enforce enforcement. But as the enforcers' enforcer the inspectors were also among the first to register the limits of governing by detailed rule, but still of general making, from the 'first line'. In time many of them became de facto grantors of waivers, allowing administrative bodies to desist in the application of the rules, in return, presumably, for some assurance that the regulated party was striving to achieve the larger purpose of the law given the particulars of its situation. More recently some of the inspectors have become quiet advocates of framework regulation. In time they could become champions of administration as information pooler, helping to create a system by which the civil society actors and parliament can build on the knowledge of opportunities and obstacles to improvement that until now has accumulated as a side product of the evaluation of compliance.

So as Dutch citizens insist on democratic renewal, and as the government contemplates radical changes in governance to provide the new social services that can underpin national solidarity, a key agent in traditional bureaucracy is urging convergent transformation of the administration. If ever bridges can be burned prudently, with full respect for democratic obligations, the Dutch have done so. What lies behind no longer works. The promise of the new pragmatist institutions is that we can learn together, and in a democratically accountable way, what will. 


\section{NOTEN}

I I would like to thank Michiel Scheltema and Anton Hemerijck for the generous hospitality and deeply engaging discussion during a recent visit to the WRR, in connection with which this paper was prepared, and from which it greatly benefited. I thank as well Ewald Engelen for the thoughtfully sceptical questions he raised, and his creative energy in helping to answer them. The following discussion of N PM draws on O'Donnell and Sabel 2001, which references current debates. See Denters et al. 2003 for an overview and good sample of recent research.

$4 \quad$ The following draws on Sabel 2004b forthcoming.

5 In industry this is often called 'simultaneous engineering'.

6 A diagnostic test of mathematic ability detects not just that a student fails to solve a certain kind of problem, but also reveals whether his or her difficulties were with translating the query posed in the question into a formal language or manipulating the formalism.

7 See Liebman and Sabel 2004 for a detailed review and effort to synthesize the vast literature in the light of our own research.

8 See Dorf and Sabel 1998 for further discussion.

9 Recall in this connection the emphasis pragmatist institutions put on diagnostic monitoring as opposed to global measures of output typical of N PM.

10 For further discussion see Cohen and Sabel 1997; Cohen and Sabel 2003; Gerstenberg and Sabel 2002.

11 We leave the coordinate changes in role of the judiciary to another time (for discussion in the Us setting see Sabel and Simon 2004).

12 See www.andereoverheid.nl/de_projecten/minder_en_anders/samenwerkende. 


\section{LITERATUUR}

Boston, J. et al. (1996) Public Management: The New Zealand Model, Oxford: Oxford University Press.

Bogason, Peter (2001) Fragmenteret forvaltning: Demokrati og netvaerksstyring I decentraliseret lokalstyre, Kopenhagen: Systime.

Brink, G. van den (2002) Mondiger of Moeilijker? Een Studie naar de Politieke Habitus van Hedendaagse Burgers. Voorstudies en Achtergronden V115, Den Haag: WRR.

Chubb, John E. en Terry M. Moe (1990) Politics, Markets and America's School, New York: Brookings Institution.

Cohen, Joshua en Charles F. Sabel (1997) ‘Directly-Deliberative Polyarchy’, European Law Journal 3, 4: 313-340.

Cohen, Joshua en Charles F. Sabel (2003) 'Sovereignty and Solidarity: EU and Us', in Governing Work and Welfare in a New Economy: European and American Experiments, Jonathan Zeitlin and David Trubek (red.) Oxford: Oxford University Press: 345-375.

Dorf, Michael C. en Charles F. Sabel (1998) 'A Constitution of Democratic Experimentalism', Columbia Law Review.

Denters, B., O. van Heffen, J. Huisman en P. Klok (red.) (2003) The Rise of Interactive Governance and Quasi-Markets, Den Haag: Kluwer Academic Publishers.

Department of Agriculture (1996), Food Safety and Inspection Service, 9 CFR Parts 304, 308, 310, 320, 327, 381, 416, and 417; (Docket no. 93-016F), RIN 0583-AB69. 'Pathogen Reduction; Hazard Analysis and Critical Control Point (HACCP) Systems'. Issued Thursday, July 25.

Department of Agriculture (2003a), Office of Inspector General, Great Plains Region Audit Report. 'Oversight of Production Process and Recall at ConAgra Plant (Establishment 969)'. Report no. 24601-2-KC.

Department of Agriculture (2003b), Food Safety and Inspection Service. 'Quarterly Enforcement' Report July 12003 through September 30.

Esping-Andersen, Gøsta with Duncan Gallie et al. (2002) Why We Need a New Welfare State. Oxford: Oxford University Press.

Gerstenberg, Oliver en Charles F. Sabel (2002) 'Directly Deliberative Polyarchy: An Institutional Ideal for Europe?', in Good Governance in Europe's Integrated Market, edited by Christian Joerges and Renaud Dehousse, Oxford: Oxford University Press: 289-341.

Hajer, M.A. en H. Wagenaar (red.) (2003) Deliberative Policy Analysis: Understanding Governance in the Network Society. Cambridge: Cambridge University Press.

Liebman, J. en Ch.F. Sabel (2003) 'A Public Laboratory Dewey Barely Imagined: The Emerging Model of School Governance and Legal Reform', NYU Journal of Law and Social Change, 23, 2: 183-304.

MacDuffie,J.P., S. Helper en Ch.F.Sabel(200o)'Pragmatic Collaborations: Advancing Knowledge while Controlling Opportunism', Industrial and Corporate Change, 9, 3 .

Ministerie van Binnenlandse Zaken (2003) Actieprogramma 'Andere Overheid', www. minbzk.nl/openbaar_bestuur/programma_andere/parlementair/programma _andere. 
O’Donnell, Rory (2004) 'Social Protection and Social Welfare: Integrating Services, Income Support Systems and Activist Measures'. NESC/NESF Discussion paper, April 16.

O’Donnell, Rory en Charles F. Sabel (2001) 'Democratic Experimentalism: What to do about Wicked Problems after Whitehall' in Devolution and Globalisation: Implications for Local Decision-Makers. Paris: OECD: 67-9o.

Projectbureau Operatie Jong (2004). Operatie Jong: Sterk en Resultaatgericht voor de Jeugd, operatie-jong.nl/nl/publicaties/Publieksversie.pdf

Rochlin, Gene I., Todd R. La Porte en Karlene H. Roberts (1998) 'The Self-Designing High-Reliability Organization: Aircraft Carrier Flight Operations at Sea', Naval War College Review, Washington, D.C., 51, 3: 97-113.

Sabel, Charles F. (2004a) 'Pragmatic Collaborations in Practice: A Response to Herrigel and Whitford and Zeitlin', Industry and Innovation, 11, ?: 81-87.

Sabel, Charles F. (2004b) 'Theory of a Real-Time Revolution', Organizational Studies, forthcoming.

Sabel, Charles F. en William Simon (2004) 'Destabilization Rights: How Public Law Litigation Succeeds', Harvard Law Review 117, 4: 1015-1101.

Sabel, Charles F. en Jonathan Zeitlin (2003) 'Active Welfare, Experimental Governance, Pragmatic Constitutionalism: The New Transformation of Europe', presented at the International Conference of the Hellenic Presidency of the European Union, 'The Modernisation of the European Social Model and EU Policies and Instruments', Ioannina, Greece, May 2003.

Sabel, Charles F. (1994) 'Learning by Monitoring: The Institutions of Economic Development' in Neil Smelser and Richard Swedberg (eds.) Handbook of Economic Sociology, Princeton: Princeton University Press and Russell Sage Foundation: 137-165.

Sorensen, Eva (2002) Politikerne og netvaerksdemokratiet: Fra suveraen politiker til metaguvernor, Kopenhagen: Jurist-og Okonomforbundets Forlag.

Trubek, David en Jonathan Zeitlin (red.) (2003) Governing Work and Welfare in a New Economy: European and American Experiments, Oxford: Oxford University Press. 


\title{
10 IDENTIFICATIE, KRITIEK OP HET GANGBARE LIBERALE MENSBEELD EN HET VERBAND TUSSEN MEDIA EN DEMOCRATIE
}

\author{
B. Pattyn
}

\subsection{INLEIDING}

De bezorgdheid ten aanzien van de democratie is niet algemeen en precies dat wordt als een probleem ervaren. Sommigen bekommeren zich over het feit dat anderen er zich helemaal niet om bekommeren. De mensen die zich zorgen maken, vinden dat democratie moet worden gekoesterd omdat de alternatieven gevaarlijk zijn, terwijl de mensen die zich geen zorgen maken, zich steeds vaker lijken af te vragen wat er aan een democratisch staatsbestel zo fantastisch is. Waarom geen sterke leider? Waarom geen regime met iemand die als een crisismanager orde op zaken stelt? Waarom niet iemand die duidelijk zegt waar het op staat en ingrijpt waar moet worden ingegrepen; iemand die een einde stelt aan de bedreigende migratie, een einde aan de zelfgenoegzaamheid van de 'politiek correcte' klasse; iemand die met drastische middelen veiligheid biedt? Waarom zo liederlijk doen over verkiezingen van kandidaten die allemaal op elkaar lijken, dezelfde loze beloften doen en uiteindelijk dezelfde soort beslissingen nemen? Waarom zo'n heisa als men eens voor iemand met doortastende ideeën heeft willen kiezen?'

Het verschil tussen beide groepen lijkt erin gelegen dat ze zich op een totaal andere manier met de samenleving identificeren. Die bewering is snel gemaakt. Haar verantwoorden vergt een omstandige uiteenzetting. Identificatie is immers niet iets triviaals maar een complex en ingrijpend proces dat iemands engagement diepgaand tekent. Het kan sterk verschillende vormen aannemen en daardoor ook sterk uiteenlopende morele en politieke visies inspireren. Over de redenen en de verregaande consequenties van die verschillen wordt zelden nagedacht. Dat heeft ongetwijfeld te maken met de hegemonie van het actuele liberale mensbeeld, niet alleen in de gewone omgang maar ook in de humane wetenschappen. In deze bijdrage wil ik toelichten waarom het belangrijk is met de verschillen in identificatiestijlen rekening te houden, niet alleen om de (ontbrekende) bezorgdheid ten aanzien van de democratie te kunnen analyseren, maar ook en vooral om de invloed van de media te kunnen interpreteren. Maar laat me eerst ingaan op het gangbare liberale mensbeeld en de redenen waarom dat mensbeeld het vandaag zo ongebruikelijk maakt identificatie ernstig te nemen.

\subsection{DE GANGBARE LIBERALE BELIJDENIS}

Lang voordat gewone mensen hun stem konden uitbrengen, beschouwden de gangmakers van de moderne tijd tolerantie als de meest verantwoorde levenshouding en lanceerden ze de notie van 'het vrije, autonome en onafhankelijke 
individu'. Ze veronderstelden dat iedereen die voor rede vatbaar is zijn medemensen als gelijken zal beschouwen en abstractie zal maken van religieuze of morele verschillen. Op die manier zouden fanatieke tegenstellingen worden ontzenuwd en zou er een einde komen aan de eindeloze reeks van bloedige religieuze conflicten. Om agressie in te dijken en om het individu te beschermen tegen excessieve sociale controle, leek het verstandig de bekeringsijver af te koelen, het collectieve enthousiasme voor traditionele gezagsaanspraken te temperen en alle bemoeizuchtige morele kaders te relativeren tot op het punt waarop men op basis van een minimale basisovereenkomst tot 'redelijke' afspraken zou kunnen komen. Sindsdien werden in Europa alle onvoorwaardelijke engagementen geruisloos naar de private sfeer afgeleid en werd van elk individu verwacht dat hij ongestoord en soeverein, maar in stilte, zijn eigen ultieme levensbeschouwelijke, morele en esthetische keuzes zou maken. De publieke heilsverwachting betrof niet meer primair en onvoorwaardelijk God, maar verschoof naar wat mensen allemaal gemeen lijken te hebben: een verlangen naar veiligheid, vrijheid en respect.

In welke mate de liberale belijdenis slechts een voor de hand liggend antwoord vormde op de ontluistering van de oude wereld en de versplintering van de religieuze eensgezindheid, is onduidelijk. Het is in elk geval een feit dat het liberale discours de morele legitimatie bood om de groepsdynamische doorbloeding van onvoorwaardelijke publieke idealen te limiteren. In de liberale rechtstaat worden geen ideologische, politieke, religieuze of morele idealen geduld die door emotionele bezetting een zodanig sacraal karakter hebben verkregen waardoor het lijkt toegestaan dat men ervoor over lijken gaat. Vandaag zijn traditionele groepsrituelen en collectieve emoties ondergeschikt aan de objectieve regels van de rechtsstaat en worden alle gezag en dogma's onderworpen aan de koele blik van de autonome wetenschapper die observeert, analyseert en vroeg of laat ontluistert. Politiek wordt in belangrijke mate beperkt tot het garanderen van veiligheid en vrijheden, het bevorderen van de gemeenschappelijke economische infrastructuur en het objectief regelen van het verkeer tussen burgers, verenigingen en instellingen.

De desacralisering van idealen lijkt nog steeds niet afgerond maar zet zich geruisloos door in allerlei publieke domeinen en draagt ertoe bij dat allerlei vormen van sociaal engagement hun evidente karakter verliezen. Zo vindt niemand het vandaag een goed idee om voor politieke overtuigingen letterlijk door het vuur te gaan of voor een ideologie zijn of haar leven te geven. Bij heldendom, religieuze ijver of 'sneuvelen voor het vaderland' hebben we onze bedenkingen. Het discrediteren van de onvoorwaardelijkheid van publieke idealen pacificeert, maar heeft wellicht ook kwalijke neveneffecten. Het creëert onverschilligheid ten aanzien van het publieke en daarom ook ten aanzien van de democratie.

Het discrediteren van 'onredelijke' groepsemoties ging aanvankelijk gepaard met de optimistische verwachting dat zodra men erin zal slagen de impact van denigrerende publieke gezagsaanspraken te smoren en de invloed van groepsdruk, 
fascinatie, vooringenomenheid, religieus fanatisme, traditie en gezag te relativeren, het individu zich eindelijk zal kunnen ontplooien als een vrij, humaan en creatief wezen dat in volle bewustzijn rationeel zal kunnen beslissen hoe aan het eigen leven vorm te geven. Volgens de romantische variant van deze visie zou elk individu in de grond vredelievend, redelijk en medemenselijk zijn en volgens de utilitaristische variant, uit welbegrepen eigenbelang opteren voor coöperatie en medemenselijkheid. In beide narratieve constructies veronderstelt men dat er met de mens op zich niets aan de hand is. Zowel in de berekeningen van de technocraten en de voorspellingen van de economen als in de verwachtingen die binnen ander sociaal-wetenschappelijk onderzoek worden gecultiveerd, verschijnen individuen als verstandige en vredelievende medemensen die bereid zijn tot samenwerking zolang hun verlangens voldoende worden bevredigd, hun noden begrepen, hun vragen eerlijk beantwoord, hun loket professioneel bediend, hun visie adequaat gecommuniceerd, hun persoonlijke preferenties ingewilligd...

Aan dit optimisme koppelt men vandaag de idee dat elk individu beschikt over het vermogen om voor zichzelf uit te maken wat goed en belangrijk voor haar is. Die koppeling is niet oorspronkelijk. Van heel wat filosofen die we vandaag als founding fathers van het liberale denken beschouwen, zijn er teksten die we vandaag ronduit als paternalistisch zouden brandmerken. Het blijkt immers dat ze opvoeding en morele training als van uitzonderlijk belang beschouwden en ervan overtuigd waren dat vrijheid belangrijk is omdat deze een voorwaarde vormt om zich menswaardig te kunnen inzetten voor allerhande sociale en morele idealen. In de gangbare maatschappelijke verstandhouding heeft dit positieve vrijheidsbegrip zijn vanzelfsprekende karakter enigszins verloren. Wat vandaag van belang lijkt is dat mensen vrij zijn en niet waarvoor mensen die vrijheid uiteindelijk aanwenden, omdat er geen eensgezindheid meer bestaat over wat die idealen precies inhouden en niemand zich geroepen voelt om specifieke idealen op de voorgrond te brengen. De gangbare idee is dat in laatste instantie iedereen voor zichzelf moet uitmaken wat de idealen zijn waarnaar men zal streven. De gangbare liberale belijdenis lijkt in die zin te zijn gedrenkt in subjectivisme. Elke twijfel omtrent de capaciteit van mensen om voor zichzelf uit te maken wat goed, belangrijk of mooi is, wordt zelfs onmiddellijk beschouwd als politiek incorrect. De redenering is dat omdat mensen evenwaardig zijn ook de keuzes die ze maken ons respect verdienen. Opvoeding, cultuuroverdracht en morele training worden daarom steevast 'ontmaskerd' als de poging van een elite om haar eigen voorkeuren op te dringen. Mensen, zo redeneert men, hoeven geen bevoogding: iedereen kan voor zichzelf uitmaken wat zijn of haar leven rechtvaardigt. De capaciteit om dat te doen, zo redeneert men, is voor iedereen dezelfde; er is derhalve geen behoefte aan een externe instantie die zich over de morele of esthetische kwaliteit van een mensenleven kan uitspreken, met uitzondering van de betrokkene zelf. De verbetenheid waarmee dit soort stelling wordt verdedigd verraadt dat het gangbare liberale discours iets verbergt en kan beschouwd worden als een reactieformatie. Ik kom daar in het derde deel van deze bijdrage op terug. 
Ook in de humane wetenschappen heeft de gangbare liberale ideologie ertoe bijgedragen dat men de voorkeur geeft aan theorieën waarin men een neutraal mensbeeld respecteert zoals bijvoorbeeld de rational choice theory. Het gezag van deze theorie berust niet op het feit dat ze op wetenschappelijk vlak haar nut heeft bewezen, want dat heeft deze theorie onvoldoende (Green en Shapiro 1996, Friedman 1996), maar wel op het feit dat deze visie in het actueel ideologisch klimaat een aangenaam karakter heeft. De rational choice-theoretici wekken immers de indruk dat er in een goed georganiseerde omgeving met het individu op zich niets aan de hand is. Ze onderschrijven de overtuiging dat er in deze onrechtvaardige wereld dan ten minste nog één domein is waarin alle mensen aan elkaar gelijk zijn: mensen zouden allemaal zijn toegerust met dezelfde rationele capaciteiten om voor zichzelf te kunnen uitmaken wat voor hen 'goed' is. Bovendien betreft die gelijkheid een domein dat we vandaag cruciaal achten: het domein waar ieder voor zichzelf een keuze maakt over hoe hij of zij het eigen leven zinvol zal uitbouwen.

Het vervelende is dat de eer die we mensen willen bewijzen door ze zonder onderscheid te beschouwen als rationele berekenaars van hun eigen voordeel, wellicht in strijd is met wat ze in werkelijkheid zijn. Mensen verschillen, ook in de capaciteit om voor zichzelf een goed leven uit te stippelen. In werkelijkheid gedragen mensen zich vaak irrationeel, inconsistent en gespleten. Ze lijken niet te beschikken over een conflictvrije, onveranderlijke en eenvormige persoonlijkheid en zijn in staat zichzelf het leven zuur te maken. Er zijn twee soorten gegevens die ons ertoe aan zouden moeten zetten de theorieën die door het gangbare liberale denken getekend zijn om te vormen: zelfmoordcijfers en stemresultaten. Het liberale denken gaat uit van een veel te idealistisch mensbeeld en heeft geen oog voor het drastische karakter van jaloezie, rivaliteit, afgunst, haat en zelfdestructie. Het is in deze context dat de kritiek van Carl Schmitt op het liberale denken onderschreven kan worden (Schmitt 2001). Onder de theorieën die het rivaliteitaspect beter in beeld brengen, zijn deze die zich enten op het begrip 'identificatie'.

\subsection{IDENTIFICATIE}

Tussen de trendy tunes van theorieën waarin wordt uitgegaan van een ondeelbaar rationeel subject met specifieke wensen en verlangens, klinkt de psychoanalyse dissonant. Freud beschouwde de psyche immers niet als een enkelvoudig principe waarin de ratio de kern vormt van de menselijke identiteit, maar als een verhouding van verschillende instanties die op verschillende, bewuste en onbewuste niveaus op elkaar ingrijpen en die vaak met elkaar in conflict zijn: driften, idealen, redeneringen, fantasieën, realistische observaties enzovoort. Die instanties zouden niet op zichzelf tot ontwikkeling komen. Ze worden gevormd in interactie met de fysieke en sociale omgeving en hebben bijgevolg een contingent of toevallig karakter. Volgens Freud kennen wensen en driften noch hun doel, noch hun bevredigingswijze 'van nature'. Het zijn allerlei concrete fysieke gewaarwordingen en intermenselijke ervaringen die hen vorm en richting geven. 
Er is voor Freud met andere woorden geen oorspronkelijk en ongenaakbaar 'ik' dat in een natuurlijk proces tot ontwikkeling komt volgens een genetisch gedetermineerd patroon. Het individu is het kwetsbare dynamische product van diverse nooit volledig beheersbare toevallige instanties en omstandigheden.

In verband met Freuds theorie stip ik drie relevante gezichtspunten aan met betrekking tot 'identificatie'. Freud raakte ervan overtuigd (1) dat morele idealen en principes door identificatie tot stand komen; (2) dat er een verband bestaat tussen het geïdealiseerde zelfbeeld en het moreel (de vitaliteit, de moed en het zelfvertrouwen wat men in het Frans met le moral, in het Engels met the morale aanduidt); en (3) dat er een verband bestaat tussen identificatie en groepsconformiteit.

(1) Volgens Freud komen iemands idealen tot stand door identificatie. Het ikideaal is naar zijn oordeel geen 'geweten' in de klassieke metafysische betekenis en ook geen cognitief vermogen (zoals bijvoorbeeld bij Kohlberg 1974). Het is een instantie die de eigen positie en het persoonlijke gedrag beoordeelt vanuit het gezichtspunt van de personen en de idealen waarmee het individu zich vereenzelvigt. Het radicale karakter van identificatie wordt in onze gewone omgangstaal en in veel sociaal-wetenschappelijk onderzoek vaak over het hoofd gezien omdat 'identificeren' als actief werkwoord suggereert dat mensen kunnen kiezen met wie of met wat ze zich identificeren. Dat is zelden het geval. Identificatie is veeleer iets wat je overkomt, zoals verliefd worden. Je kan misschien de condities van dat proces bijsturen door kritisch na te denken, maar de identificatie zelf kan je niet dwingen, zeker niet op prille leeftijd. Je wordt door een persoon of idealen zodanig gefascineerd en aangetrokken dat je de zin en de onzin van alles wat je doet, spontaan in het licht stelt van die idealen of van wat de persoon daar (in jouw perceptie) over vindt.

(2) Omdat het gangbare mensbeeld laat uitschijnen dat de kern van onze persoonlijkheid ondeelbaar is en dat ons streven uitsluitend gericht is op persoonlijk voordeel, gaan we er vandaag vaak aan voorbij dat ons streven zich destructief tegen onze eigen persoon kan keren. In Freuds visie wordt door identificatie de goedkeuring en de afwijzing die uitgaat van onze medemensen, de goedkeuring en de afwijzing van onszelf door onszelf. Het ik-ideaal maakt én deel uit van onze persoonlijkheid én neemt er kritisch afstand van. Het ik-ideaal kan ons bemoedigen, maar kan ons ook misprijzen of haten waardoor het alles wat we ondernemen onbewust blokkeert of discrediteert. Dat kan aanleiding geven tot besluiteloosheid, innerlijke onzekerheid, depressie en in extreme gevallen tot zelfmoord. Onze eigen idealen die we nauwelijks zelf kiezen, kunnen ons met andere woorden maken, maar ook breken. Ze kunnen ons doen opleven, vitaliseren, doen zwellen van trots, maar ze kunnen ons ook vernederen, diep kwetsen en ontmoedigen.

Affectie, genegenheid, respect, liefde en waardering gaan volgens Freuds eerste teksten terug op kwantitatieve hoeveelheden psychische energie. Er is, aldus 
Freud, schematisch gesproken eerst eigenliefde (met het daarbij horende narcistisch almachtsgevoel) en vanuit deze uitvalsbasis belangstelling voor de buitenwereld. Het individu gaat de psychische energie die in de primaire narcistische situatie in het zelf verzameld is, investeren in relaties met de buitenwereld. Als die investeringen worden beantwoord, vloeit er psychische energie terug waardoor de persoon zich gesterkt voelt en opnieuw gaat investeren in de buitenwereld. Als investeringen echter niet beantwoord worden, verliest het individu zijn psychische weerbaarheid. Hij kan zich dan op zichzelf terugplooien in een poging de narcistische uitgangspositie te herwinnen ${ }^{1}$ maar echt bevredigend is deze situatie niet.

Freuds energetische hypothesen komen minder absurd over als men zich realiseert dat moed, veerkracht en vitaliteit nauw verwant zijn met zelfrespect, zelfzekerheid, of zelfs met een zeker almachtsgevoel en dat die fenomenen verband houden met de steun, de liefde, de bemoediging en de waardering die mensen vanuit onze onmiddellijke omgeving eertijds aan ons hebben betoond of actueel betonen. Omgekeerd, als de initiatieven die we ondernemen niet worden gewaardeerd, als onze collega's onze bijdragen absurd vinden of als onze liefdesaanzoeken niet worden beantwoord, dan schamen we ons. Op dergelijke momenten zijn ons zelfrespect en onze zelfzekerheid verdwenen en kunnen we het gevoel hebben helemaal niets te betekenen. Het feit dat waardering in Freuds visie niet uitsluitend door de buitenwereld wordt opgebracht maar ook uitgaat van de verinnerlijkte anderen, maakt dat onze idealen niet alleen van informatief belang zijn als bakens bij het sturen van ons gedrag, maar dat ze ook en vooral van vitaal belang zijn. Als iemand beantwoordt aan zijn idealen neemt zijn kracht, trots, moed en zelfzekerheid toe. Wie daar niet in slaagt, voelt zich mislukt, belachelijk, tot niets in staat en nutteloos.

Om dat laatste te vermijden en onze idealen in overeenstemming te brengen met ons gedrag, kunnen we twee parcoursen bewandelen: ofwel passen we ons gedrag aan, ofwel onze idealen. Wat dat laatste betreft: mensen slagen er over het algemeen heel goed in zichzelf beter en edelmoediger aan zichzelf voor te stellen dan ze zijn. Ze houden niet op zich aan zichzelf aan te prijzen. Dat ze in het voortdurend bijstellen van hun private autobiografie op hallucinante wijze een loopje nemen met de werkelijkheid is zeer begrijpelijk als men bedenkt hoeveel er voor het individu aan gelegen is dat zijn of haar prestaties beantwoorden aan de eisen van zijn of haar ik-ideaal. Het ik-ideaal zal immers in functie van het al dan niet beantwoorden aan de verinnerlijkte idealen ofwel vitaliserend zelfrespect, moed en vertrouwen genereren ofwel misprijzen, moedeloosheid, onzekerheid en depressie. Het is niet verwonderlijk dat het precies het narcistisch streven naar zelfbehoud is dat het ik-ideaal verleidt het realiteitsprincipe in de schaduw te stellen en het subject het gevoel te geven dat hij, ondanks alles, 'erg goed is'. Bij adolescenten en volwassenen ent het zelfvertrouwen zich niet op een onverstoorbare zelfgenoegzaamheid, maar op een geïdealiseerd zelfbeeld. 
Freud is er steeds van overtuigd gebleven dat men de agressie die alles wat het geïdealiseerde zelfbeeld bedreigt, nooit zal kunnen onderschatten. Er is ons onbewust veel aan gelegen om alles wat ons geïdealiseerde zelfbeeld bedreigt, te beschouwen als majesteitsschennis en ons daarvoor vreselijk te wreken. De cultuur verhindert dat we dat op een beestachtige manier doen, maar er is volgens Freud niet veel nodig om door die dunne beschermlaag heen te breken.

Wat me voor mijn betoog belangrijk lijkt, is de idee dat mensen hun vitaliteit ontlenen aan de gedachte dat het leven dat ze leiden de moeite waard is en dat ze bijzonder gevoelig zijn voor de bevestiging van hun waardepatroon. Mensen zullen alles wat hun zelfbeeld bedreigt instinctief en meedogenloos haten.

(3) Freuds theorie doet begrijpen waarom we vooral voor onze intimi op onze hoede zijn. Hun oordeel ligt ons nauw aan het hart (omdat we ons altijd spontaan met hen identificeren) en daarom is hun vermogen om ons te stichten of te breken veel groter dan dat van vreemden. Alle intieme relaties zijn volgens Freud dan ook ambivalent, met uitzondering van de moeder-kindrelatie. Toch blijken er groepen te bestaan waarin mensen zonder kritische distantie aan elkaar vastklitten en alles wat ellende veroorzaakt, projecteren buiten hun 'wij-domein'.

Volgens Freud kan dat omdat in een massa mensen hun ik-ideaal laten samenvallen met de idealen van hun groep. Een dergelijke identificatie is verlokkelijk omdat in een conformistische groep het individu zich niet meer bedreigd hoeft te voelen door het oordeel van anderen. Wie zijn of haar ik-ideaal kwetst, kwetst immers het ideaal van de groep die zich met een collectieve narcistische haat massaal op de agressor zal wreken. Daardoor zal alle angst voor kwetsende intimiteit, voor persoonlijke verwijten, voor individueel falen in een conformistische groep smelten als sneeuw voor de zon. Het individu kan zich dan verschuilen achter de brede schouders van het 'wij' en zich ongenaakbaar voelen. Groepsconformiteit geeft bovendien aanleiding tot de accumulatie van de energetische bezetting van eigenschappen die binnen die groep geïdealiseerd worden. Wie zich aan de idealen van de groep overgeeft, kan zich koesteren aan het narcistische almachtsgevoel en verliest elk kritisch zelfbewustzijn. Alle onvolmaaktheden worden in dergelijke groepen geprojecteerd op mensen en instellingen die de collectieve idealen bedreigen en zich bevinden buiten de cirkel van de fellow-feeling. De haat tegen alles wat het gemeenschappelijk narcistische zelfbeeld bedreigt, kan in conformistische groepen vreselijke vormen aannemen. ${ }^{2}$

In Massenpsychologie und Ich-Analyse (1921) stelt Freud het zo voor dat de enige manier om kritische distantie te kunnen nemen van groepsidealen erin bestaat om in verschillende groepen te participeren. De ene loyaliteit zal de andere in evenwicht brengen. Dat is volgens Freud de enige manier om het kritische vermogen van het ik-ideaal op te drijven, want in het kritische vermogen van ons rationele denkvermogen had hij weinig of geen vertrouwen.

Jacques Lacan heeft Freuds identificatiebegrip aangevuld en het loont de moeite daar even op in te gaan. Lacan introduceerde het onderscheid tussen imaginaire 
en symbolische identificatie. In zijn eerste teksten suggereert hij dat imaginaire identificatie zich voordoet op het niveau van de beeldvoorstelling, terwijl symbolische identificatie zich voltrekt op basis van het culturele betekenissysteem. Nog sterker dan Freud ontluisterde Lacan de idee dat de menselijke identiteit rond een ondeelbare kern is opgebouwd. ${ }^{3}$ Zelfs het eigen lichaamsbeeld is iets wat we niet vanzelf als een eenheid percipiëren. Kleine kinderen moeten de notie dat hun lichaam één geheel vormt, verwerven en ze moeten zelfs leren hun lichaam met 'ik' te benoemen. Lacan karakteriseert de fase waarin deze inbezitneming zich voltrekt met de term 'spiegelstadium'. De zelfbeleving van kinderen is in die fase betrokken op de lichaamsverschijning van zichzelf en van anderen tegenover zichzelf. ${ }^{4}$ Deze imaginaire identificatie is structureel belangrijk omdat wanneer ze faalt het individu geplaagd kan worden door het schrikbeeld dat zijn lichaam zal verbrokkelen, uiteenvallen of ontbinden zoals in de schizofrenie. De verschijning van de andere maakt het eigen lichaamsbeeld heel, maar kan bij agressief gedrag ook precies het omgekeerde doen vrezen. Het spiegelstadium wordt immers gekenmerkt door onmiddellijkheid en exclusieve wederkerigheid. Het is alsof er noch temporeel, noch ruimtelijk iets bestaat wat de eigen persoon van de persoon waarmee het individu zich spiegelt doet verschillen. Er is onmiddellijkheid omdat het ontbreekt aan een derde term vanwaaruit het verschil kan worden vastgesteld. In de duale verhouding wordt rivaliteit daarom beleefd in de zenuwachtige modus van voor of tegen, ik of jij, domineren of gedomineerd worden, winnen of verliezen.

In tegenstelling met de imaginaire identificatie heeft de symbolische identificatie betrekking op het innemen van een positie binnen een door het sociale systeem gestructureerd veld van abstracte verhoudingen. De imaginaire identificatie van 'Dat ben ik!' met de vinger wijzend naar het eigen lichaam is anders dan de symbolische identificatie 'Ik ben Jantje en ik zit in het eerste leerjaar'. In het eerste geval manifesteert zich datgene waarnaar verwezen wordt. In het tweede geval is 'Jantje' een naam die gegeven werd door een moeder en een vader, een naam waaraan, nog voordat Jantje het levenslicht zag, een specifieke verwachting werd gekoppeld; het is een typisch Nederlandstalige naam, een naam die... en zo kunnen we steeds verder doorgaan. Datzelfde kunnen we doen op basis van de term 'leerjaar'. Ook dat begrip verwijst naar iets waar de identiteit van Jantje door getekend wordt, maar dat niet reëel aanwezig is: 'leerjaar' verwijst naar een klasje in een specifieke school in een specifiek dorp of een stadsbuurt met een concrete meester of juf. 'Eerste' verwijst naar de zes jaren van de lagereschoolvorming die kaderen in een specifiek Vlaams onderwijssysteem dat enz.

De tweede soort identificatie veronderstelt een vloed van verwijzingen die het onmogelijk maken dat datgene waarnaar verwezen wordt zich volledig hier en nu kan manifesteren. Vooral deze laatste vaststelling bracht Lacan tot de overtuiging dat zodra mensen zich in het symbolische systeem laten inschrijven, ze hun identiteit nooit kunnen laten samenvallen met iets wat volledig aanwezig is, wat duidelijk omschrijfbaar en tastbaar is. Het verwijzingssysteem maakt dat datgene waarmee we ons identificeren nooit perfect aanwezig kan worden gesteld; dat 
onze identiteit iets is wat we steeds te vervullen hebben; dat we over de code waardoor we worden gecodeerd niet zelf beschikken; dat we die code nooit helemaal kunnen beheersen; dat we afhankelijk zijn van anderen die die code interpreteren, uitbreiden, hercombineren, instellen, toepassen of verwaarlozen (ze kunnen je promoveren, ontslaan, een prijs toekennen, misprijzen, kwaad over je spreken...).

Volgens Lacan wordt het menselijk streven getekend door het verlangen om aan die afhankelijkheid en de daaraan verbonden onzekerheid een einde te stellen. Mensen willen de blinde vlek die door de oneindige reeks afwezige verwijzingen wordt gecreëerd, definitief invullen, ze willen definitief geliefd en begrepen worden zoals ze 'werkelijk' zijn, ze willen samenvallen met zichzelf, iets waarin ze structureel nooit kunnen slagen. ${ }^{5}$ Het verlangen om aan alle externe bepaling te ontsnappen en definitief samen te vallen met zichzelf verklaart waarom mensen verwoede pogingen doen om de veelheid van identiteitsbepalende factoren te reduceren door ze in de schaduw te stellen van zaken waarvan men aanneemt dat men er zijn complete identiteitsbepaling aan kan toeschrijven. Sommige mensen nemen bijvoorbeeld aan dat hun ras hun ware identiteit bepaalt of dat hun erfelijke materiaal alle merkwaardigheden van hun persoonlijkheid determineert, of dat wie ze zijn in de sterren geschreven staat, of dat ze door een god werden gezonden om een specifieke opdracht uit te oefenen. Lacan noemt ook dit soort 'verkorte' identificatie, imaginaire identificatie. Deze identificatie is er immers ook op gericht samen te vallen met iets waarvan men denkt dat men het duidelijk aanwezig kan stellen; iets waarnaar men met de vinger kan wijzen. Mensen bij wie dit soort verkorte identiteitsbevestigende systemen dominant zijn, zijn niet in het reine gekomen met de kunstmatigheid van hun bestaan. Ze hebben - in Lacans jargon uitgedrukt - de symbolische castratie niet aanvaard en maken onder andere gebruik van imaginaire identificatiemodellen om de structurele onmogelijkheid om met zichzelf samen te vallen, op te heffen.

Ik kan me voorstellen dat wetenschappers die het gewoon zijn met harde data en eenvoudige interpretatieschema's te werken dit soort theorieën te vergezocht zullen vinden. Laat me ze daarom enigszins concreter maken en tonen waar ze relevant kunnen zijn wanneer we nadenken over media en democratie.

Jonge kinderen, met name jongens, zijn bijzonder gevoelig voor identificatiemodellen die op hun almachtsgevoel appelleren zoals onoverwinnelijke ridders, onschendbare paracommando's en blitse superpolitiemannen. Meisjes zijn op hun beurt gevoelig voor figuren die hen in de roze droomwereld binnenvoeren van lieve pony's, Barbie-achtige vrouwenfiguren en hun dandy-achtige vrienden. In hun fantasiewereld is het onderscheid tussen veilig en vijandig absoluut. Wanneer kinderen ouder worden en hun identiteit verder differentieert, evolueert ook de manier waarop ze zich identificeren. Het zou te eenvoudig zijn als we zouden aannemen dat studenten hun identificatie met Rambo, Legolas of Beyoncé inruilen voor een identificatie met Einstein, Lou Andreas Salome of Wittgenstein. Het is immers niet alleen de interessesfeer die evolueert, maar ook 
de structuur van de identificatie zelf. Adolescenten gaan zich gaandeweg interesseren voor specifieke aspecten van iemands persoonlijkheid, ze begrijpen dat mensen vol tegenstrijdigheden zitten en krijgen oog voor evolutie, toeval en tragiek. Ze beseffen dat hun zelfbeeld meervoudig en complex is en dat het berust op diverse loyaliteiten die met elkaar in conflict kunnen treden en die ze eventueel op een originele manier combineren. Adolescenten en volwassenen erkennen (idealiter) grijswaarden. Maar met die erkenning erkennen ze meteen ook hun persoonlijke kwetsbaarheid: het feit dat wie ze zijn afhankelijk is van relaties waarvoor ze verantwoordelijkheid moeten opnemen, van projecten waarvoor ze zorg moeten dragen, van systemen waarin ze moeten presteren (thuis, op het werk, in de sport- of muziekvereniging). Het verwerven van een stabiele positie op basis van een symbolische identiteit veronderstelt een proces dat veel inzet en geduld vereist (opleiding, training, organisatie, strategische planning) en waarvan het resultaat pas op lange termijn zal worden bereikt, als het al zal worden bereikt.

Een imaginaire identificatie is minder betrokken op de reële wereld en sluit nauwer aan bij een fantasmatische droomwereld, maar biedt onmiddellijke genoegens. Ook in het leven van volwassenen blijven op allerlei niveaus de imaginaire beeldvoorstellingen deel uitmaken van de leefwereld. Film, reclameboodschappen, videoclips, covers van magazines, ze zijn zonder de onmiddellijke en appellerende beeldvoorstellingen ongenietbaar. Men kan zich echter wel voorstellen dat mensen die gekwetst zijn of gefrustreerd raken binnen het officiële betekenissysteem, zich sneller uitsluitend zullen terugplooien in een imaginaire leefwereld en hun zelfbeleving laten structureren door 'verkorte' identificatie. Dat verklaart hun fascinatie voor sterke leiders, de drang naar een letterlijke interpretatie van de Schrift of de Koran, hun gevoeligheid voor imaginair entertainment, het verlangen naar klare en definitieve normen en rechtvaardigingssystemen.

Het lijkt er ook op dat groepsconformiteit vaker berust op een imaginaire identificatie dan op een symbolische identificatie. De behoefte om zich achter de brede schouders van de conformistische groep te kunnen verschuilen en de behoefte om aan de ingewikkelde afhankelijkheid van externe bepalingen te ontsnappen door een 'verkorte' identiteit te koesteren, gaan ongetwijfeld vaak samen wanneer een individu zich in een onzekere en vernederende positie bevindt.

Mensen die vanuit hun liberale ingesteldheid de tegenstelling tussen hoge en lage cultuur willen pacificeren zullen het morele onderscheid tussen de imaginaire en de symbolische identificatie wellicht niet in dank aannemen. Ze houden het liever bij de idee dat elke vorm van identificatie evenwaardig is. Dat is natuurlijk correct in allerlei particuliere situaties. Als vader zal ik me echter zorgen maken als Legolas de held blijft van mijn zoon als hij vierentwintig wordt. Wat geldt op individueel vlak, geldt wellicht ook op het vlak van groepsvorming. Zo is een zelfbeleving op volwassen leeftijd die de facticiteit van het persoonlijke bestaan miskent en zwelgt in groepsgebonden almachtsfantasmen niet meteen ideaal te noemen, zeker niet als men zich bekommert over democratie. 


\subsection{RECHTVAARDIGING}

In de voorgaande paragraaf werd beargumenteerd hoe identificatie vitaliteit, moed en zelfvertrouwen kan genereren, of precies het omgekeerde: hatelijke zelfverwijten, verbittering en moedeloosheid. Of identificatie iemand zal dynamiseren of verzuren hangt af van de mentaliteit van de mensen of groepen waarmee die persoon zich identificeert. In de sociale wetenschappen suggereert het meest gangbare theoretische verklaringsmodel echter dat mensen uitsluitend betrokken zijn op zichzelf. Mensen zouden zich bij hun keuzes uiteindelijk laten leiden door een rationele berekening van wat hen persoonlijk de meeste bevrediging schenkt. Ook wie identificatie ernstig neemt zal moeten toegeven dat dat gezichtspunt niet per se onjuist is. Het punt is echter dat deze voorstelling van zaken de aandacht afleidt van het feit dat onze persoonlijke preferenties sterk betrokken zijn op wat anderen over die preferenties denken. In tegenstelling met wat het economisch paradigma vaak laat uitschijnen zijn niet de verlangens naar bezit, naar goederen of diensten primair, maar wel het verlangen om door anderen verlangd te worden. Volstrekt anoniem consumeren is zelden doel op zich, tenzij het gaat om mensen die aan een bepaald product of aan een bepaalde praktijk fysiek verslaafd zijn geraakt. Voor het overige zijn er weinig preferenties met een uitgesproken privaat karakter. Zo zal bijvoorbeeld het verlangen naar persoonlijke macht of bezit doorgaans deel uitmaken van een strategie om op anderen indruk te maken door in hun ogen van betekenis te zijn.

De strategieën om indruk te maken of om van betekenis te zijn voor anderen, zijn erg gevarieerd. Ze zijn afhankelijk van de verstandhouding van de groep waartoe men zich rekent. Soms suggereert de verstandhouding dat je om 'in' te zijn indruk moet kunnen maken met je geld, of dat je indruk moet maken met je fysieke verschijning of je charmes. In een andere context geldt je opleiding, je macht of je intellectuele gezag. In nog andere je inzet voor de groep, je leeftijd, het feit dat je kinderen hebt of de rangorde die je in een bepaalde instelling inneemt. De strategie zal dus erg verschillen, maar de overtuiging zelf dat men in de ogen van anderen iets essentieels te betekenen heeft is voor iedereen van vitaal belang.

Moderne mensen geven dat niet graag toe. Ze merken vaak op - paradoxaal genoeg omdat anderen dat van hen verwachten - dat ze zich weinig gelegen laten aan wat anderen van hen denken. Ze beweren dat het oordeel van anderen er helemaal niet toe doet omdat iedereen zélf kan en moet uitmaken of en op welke manier hij zijn bestaan gerechtvaardigd wil weten. In werkelijkheid echter zijn ze erg betrokken op het oordeel van anderen. Hoe men eruitziet, wat men heeft gestudeerd, welk soort functie men heeft, zelden zijn dit soort dingen belangrijker geweest dan tegenwoordig. Mensen haken ook vandaag naar de rechtvaardiging van hun bestaan en ondervinden daar schijnbaar meer moeilijkheden mee dan vroeger als we ons mogen baseren op cijfers over toenemende depressiviteit.

Het is niet echt verwonderlijk dat de discussie over wat een bestaan rechtvaardigt in de loop van de geschiedenis zo'n bloedig spoor heeft getrokken. Dat we de 
vragen over rechtvaardiging vandaag niet meer op dezelfde apocalyptische manier stellen als vroeger, komt, zoals in de eerste paragraaf werd toegelicht, doordat de tijdsfeer en de gangmakers van het liberale denken de theologische discussie over de rechtvaardiging hebben verbannen naar een 'vorige' tijd. Zoals in de eerste paragraaf werd gesuggereerd kon men door religie naar de privé-sfeer te verbannen en te belijden dat een persoon als autonoom wezen met natuurlijke verlangens en behoeften recht heeft op vrijheid, vrede en veiligheid, op maatschappelijk vlak de lont uit het kruitvat van de fanatieke discussies over het grote gelijk halen. Sindsdien nemen we de theologische discussies over rechtvaardiging niet langer 'bloedernstig' en schrikken we nauwelijks op wanneer blijkt dat niet elke cultuur dezelfde beslissing heeft genomen.

Zoals werd aangegeven bestaan er ook vandaag nog imaginaire en symbolische voorstellingen over wat een bestaan rechtvaardigt, maar er werd een soort stilzwijgende overeenkomst gesloten om die imago's en opvattingen, tolerant als we zijn, nooit of alleen in onze privé-vertrekken kritisch te bespreken. De eerste reflex waarmee mensen reageren op normatieve standpunten die iemand anders persoonlijke levensstijl in diskrediet zouden kunnen brengen, is te benadrukken dat die standpunten een zuiver subjectief karakter hebben en dat iedereen daar het zijne over kan, mag en moet denken. Alleen procedurele, organisatorische of nuttige regelingen kunnen publiekelijk worden verdedigd. De meer inhoudelijke ethische principes behoren tot het private domein. Het discours heerst waarin alles wat er enigszins toe neigt de rechtvaardiging van een particulier leven te doen wankelen, wordt gehekeld en gebrandmerkt als uit de tijd, paternalistisch, nostalgisch, of zoals in de humane wetenschappen als 'niet neutraal'. Die reactie pacificeert en behoedt ons ervoor mensen het gevoel te geven dat ze hun leven verknallen, en (vooral) omgekeerd: verhindert hen dat zij ons het gevoel geven dat we er helemaal niets van terechtbrengen. Het gangbare subjectivistische liberale discours kan in die zin worden opgevat als een reactieformatie die ons helpt vermijden dat we geconfronteerd worden met de mogelijke absurditeit van ons persoonlijk bestaan.

Zoals de meeste reactieformaties blijkt dat discours niet doeltreffend. Het helpt ons alleen wegkijken van de problemen. Want ondanks de belijdenis dat iedereen voor zichzelf kan uitmaken op welke manier hij zijn leven inhoud geeft, blijven groepsgebonden rechtvaardigende vooronderstellingen werkzaam, al fungeren die tegenwoordig 'onaangegeven', bijvoorbeeld via de reclame of het entertainment. ${ }^{6}$ De ideologie van het einde van de ideologie is in contradictie met onze feitelijke loyaliteiten ten aanzien van rechtvaardigende denkbeelden. Mensen zijn ook nu nog heel gevoelig voor publieke denkbeelden en verstandhoudingen en beseffen perfect aan welke rechtvaardigingsstandaard ze beantwoorden, alleen zijn die groepsgebonden standaarden geen voorwerp meer van publiek debat. Het debat zelf wordt weggevaagd met de liberale stelling 'dat iedereen wel voor zichzelf zal kunnen uitmaken wat belangrijk is in het leven'. Het gangbare liberale discours dat wordt gevoerd uit menslievendheid (men wil vermijden dat mensen worden gekwetst en men wil zelf niet gekwetst worden), riskeert ons blind te maken voor de onhaalbaarheid van de actuele meritocratische rechtvaardigheidsstandaard die 
veel meer medeburgers tot wanhoop drijft dan we ons willen realiseren.

De manier waarop je volgens Bernard Williams kan uitmaken of denkbeelden en projecten voor mensen een bestaansrechtvaardigend karakter hebben is nagaan in welke mate die mensen, wanneer ze zouden gedwongen worden om die denkbeelden of projecten definitief op te geven, nog de moed zouden hebben verder te leven (Williams 1981). Uit Williams' analyses blijkt dat rechtvaardigende projecten niet in functie staan van het persoonlijke bestaan, maar veeleer omgekeerd dat men zijn persoonlijke bestaan in functie stelt van dit soort projecten. Rechtvaardigende projecten willen realiseren, valt niet samen met streven naar eigenbelang. Mensen zijn immers vaak bereid een goed deel van hun persoonlijke comfort en van hun gezondheid op te offeren om dergelijke projecten te realiseren. Wat hun moed en zelfvertrouwen schenkt is de overtuiging dat als ze doen wat ze denken te moeten doen, ze een gerechtvaardigd bestaan leiden.

Maar wat wanneer door een gebrekkige doorbloeding van publieke idealen zich in onze sociale omgeving geen of onvoldoende 'sacrale' projecten meer aandienen? Dan worden mensen geconfronteerd met een soort verveling zoals Vladimir en Estragon in Wachten op Godot en krijgen ze het moeilijk zichzelf ervan te overtuigen dat er redenen zijn om het eigen leven belangrijk of betekenisvol te vinden. Wie niet geïntrigeerd wordt door projecten met een onvoorwaardelijk karakter, wordt wellicht sneller geplaagd door een agressief ik-ideaal of wordt, wat op hetzelfde neerkomt, depressief. Ook al schijnt het aantal mensen dat daar vandaag last van heeft hoog op te lopen, er is eigenlijk niemand die met overtuiging een uitzondering wil vormen op de regel. Iedereen wil leven bij gratie van de gedachte een gerechtvaardigd bestaan te leiden. Dat laatste is tenslotte ook de reden waarom onze meest intieme relaties voor ons zo van belang zijn. In Sartres bewoording: "C'est là le fond de la joie d'amour: nous sentir justifier d'exister" (Sartre 1943, 420, geciteerd in Visker 2003, 41).

\subsection{VIER TYPES GROEPSIDENTIFICATIE}

Omdat het oordeel van anderen veel ingrijpender is dan we gewoonlijk willen toegeven, ligt het voor de hand dat we ons zullen engageren in dat soort relaties en dat we aansluiting zullen zoeken bij dat soort groepen die het voor ons mogelijk maken om ons persoonlijk bestaan te rechtvaardigen. Maar de speelruimte om zelf het soort groepen te kiezen waarin we 'ons goed voelen' of 'onszelf kunnen zijn' is veel kleiner dan het liberale paradigma doet voorkomen. Mensen bevinden zich in groepen voor ze zich daar goed en wel bewust van zijn. Mensen worden bijvoorbeeld geboren met een bepaalde nationaliteit, een bepaalde huidskleur, een bepaald geslacht, een bepaalde fysieke verschijning en hebben in de loop van hun leven een bepaalde leeftijd, of ze dat nu fijn vinden of niet. Niemand kan zomaar voorbij aan de idealen die gelden in groepen waartoe men spontaan wordt gerekend (blank of zwart, allochtoon of autochtoon, jong of oud) of aan de idealen die in de hoofdcultuur of in de gangbare publieke opinie als belangrijk gelden (schoonheidsidealen, inkomensstandaarden, areaal van te bezitten goederen). Het is voor iedereen die zichzelf wil respecteren een zaak van eer (of zelfs van overleven) om de groeps- 
idealen die het eigen levensproject in vraag stellen, te kunnen pareren.

Je kan niet verhinderen in een specifieke samenleving geboren te zijn en je kan ook niet altijd bepalen in welke subgroepen je door je opleiding verzeild geraakt. Wat mensen wel kunnen doen is de manier waarop ze zichzelf met hun samenleving en hun subgroepen identificeren bijstellen met het oog op de rechtvaardiging van hun persoonlijke identiteit. Binnen éénzelfde samenleving kunnen er met andere woorden diverse identificatiestijlen worden ontwikkeld die elk beantwoorden aan een specifieke rechtvaardigingsstrategie. Het soort identificatie waarvoor men opteert, bepaalt niet alleen de definitie van het eigen zelfbeeld, maar ook de perceptie van de samenleving: hoe die samenleving functioneert, hoe de rollen zijn gedefinieerd, op basis van welke begrippen cruciale onderscheidingen worden gemaakt, op wie men alle zonden van Israël schuift en dergelijke. De scripts van deze identificatiestijlen zijn voorhanden. In elke samenleving zijn er verschillende grooves waardoor de voorspelbaarheid van het gedrag, ondanks de onzin over postmoderne originaliteit, vandaag erg groot is gebleven. Het lijkt me mogelijk om vier identificatiestijlen te onderscheiden op basis van (1) de aard van de rechtvaardigingsstrategieën; (2) het soort begrenzing van de begripscategorieën en de roldefinities; (3) de hegemonie van ofwel symbolische ofwel imaginaire identificatie; (4) de aard van de solidariteit (solidariteit met het welzijn van de groep, solidariteit op basis van conformiteit, of solidariteit op basis van taakverdeling); (5) de aard van de limieten die aan het verlangen worden gesteld (stabiele, onstabiele verwachtingspatronen). Ik ontleen deze typering aan Mary Douglas die in haar werk inzichten van Emile Durkheim en Basil Bernstein gecombineerd heeft (Douglas 1970, Douglas and Ney 1998). Ik beoog echter geen letterlijke interpretatie van haar paradigma.

\section{Figuur 10.1 Vier types groepsidentificatie}

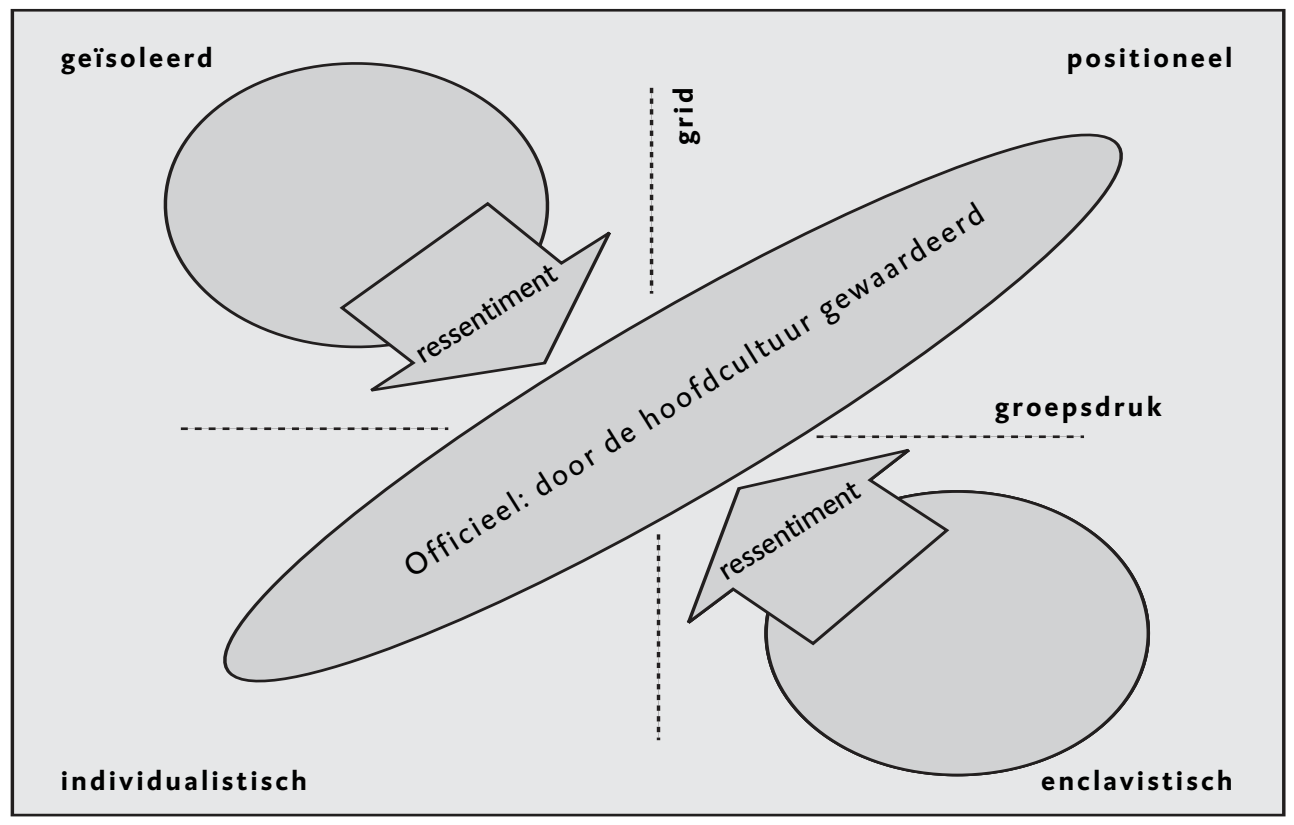


(1) In een positionele identificatiestijl wordt de samenleving gepercipieerd als een groep waarin de rollen duidelijk zijn omschreven en waarin die rollen toegewezen worden op basis van niet-verworven eigenschappen zoals leeftijd, geslacht of afkomst. Men percipieert duidelijke categorieën (strong grid) en acht de transgressie tussen de sferen die door die categorieën worden afgebakend als ongehoord, bijvoorbeeld tussen man en vrouw, publiek en privaat, jong en oud, religieus en profaan. De communicatie in deze sfeer wordt beheerst door verwijzing naar gemeenschappelijke verhalen en vanzelfsprekend geachte regels waardoor uitleg en verantwoording tot een minimum kunnen worden herleid (restricted code). Men percipieert de samenleving als een complex systeem van op elkaar afgestemde instellingen die elk specifieke bevoegdheden veronderstellen. Die bevoegdheden zouden samen gericht zijn op het instandhouden van het gemeenschappelijk systeem. Rechtvaardiging, eer en respect worden volgens dit type identificatie toegekend op basis van het trouw vervullen van de opgelegde taak en worden voortdurend in verband gebracht met het algemeen belang. Men gaat er van uit dat vaste verwachtingspatronen het menselijk verlangen limiteren en misprijst het realiseren van persoonlijke ambities wanneer geen rekening wordt gehouden met het gemeenschappelijke belang. Personen die 'lagere' functies uitvoeren voelen zich binnen dit systeem niet noodzakelijk misprezen omdat hun functie, hoe bescheiden die ook moge zijn, onmiddellijk wordt geïnterpreteerd als noodzakelijk voor de goede werking van het maatschappelijk systeem. ${ }^{7}$ De samenleving wordt binnen dit type identificatie bureaucratisch geacht en niet gemakkelijk te verleiden tot structurele heroriëntering. Tijd wordt er gedacht in termen van generaties. In wat zich vandaag aanwezig stelt, stelt zich ook het verleden aanwezig en het traditiebesef doet vanzelf denken aan de generaties aan wie het systeem zal worden overgedragen. De positionele of hiërarchische verstandhouding bemoeilijkt het vrije verkeer van ideeën door een strikte regulering van wie er over wat recht van spreken heeft. De socialisering en de cultuuroverdracht verlopen er zichtbaar en top-down. Bij het rechtvaardigen van het eigen bestaan is dienstbaarheid voor de groep als organische gemeenschap van cruciale betekenis.

(2) Mensen die zich gë̈soleerd voelen, identificeren zich met geen enkele groep.

Bij hen komt de samenleving over als ingewikkeld en kafkaiaans. Het is een onpersoonlijk systeem zonder mededogen dat hen aan de kant heeft geschoven. Ze hebben weinig zelfrespect, voelen zich afgewezen, gefrustreerd en kwetsbaar. Er is geen rechtvaardiging van hun bestaan, wat voor deze mensen nog meer een prangend probleem vormt dan materiële armoede.

(3) Wie zich op een individualistische manier met de samenleving identificeert percipieert de samenleving als een competitief ingestelde gemeenschap. Men veronderstelt er dat alles wat men doet en laat moet kunnen worden verantwoord en uitgelegd, want men kent weinig gezag toe aan traditionele gewoonten of afspraken (elaborated code). Alles is bespreekbaar en alles kan worden veranderd. Alle posities worden voor iedereen toegankelijk geacht mits men de nodige kwalificaties (diploma, financiële middelen) verworven heeft. Men beschouwt de 
samenleving als een meritocratie en wordt lastig als iets het verlangen dreigt te limiteren. Men veronderstelt dat mensen zich alleen kunnen rechtvaardigen als ze steeds meer en steeds beter presteren. Dit soort identificatie legitimeert de hoop om in de toekomst een betere positie te verwerven ofwel door reële capaciteiten te benutten ofwel door kansspelen. De rechtvaardiging van het eigen bestaan wordt niet afgemeten aan de dienstbaarheid voor de groep, maar staat in functie van de persoonsontwikkeling. Dit kan twee vormen aannemen. Ofwel berust de rechtvaardiging op het harde utilitair-individualistische discours waarin zonder blozen wordt gesteld dat ook in de mensenwereld het recht van de sterkste geldt en dat het er daarom op aan komt macht en bezit te accumuleren. Ofwel berust de rechtvaardiging op een expressief-individualistisch discours waarin de persoon wordt beschouwd als een ommuurde tuin die moet worden gecultiveerd. Hier wordt aangestuurd op de ontwikkeling van de literaire, muzikale, culinaire of esthetische smaak, lichaamsverzorging en huis- en tuindecoratie.

(4) De enclavistische identificatie kenmerkt zich door groepsconformiteit. Men percipieert een sterke groepsdruk, maar weinig gedifferentieerde categorieën en rollen. Alle aandacht gaat naar de oppositie tussen het 'wij' en alles wat de wijgroep bedreigt: criminelen, vreemdelingen, epidemieën. De identificatie kenmerkt zich door een zeker ressentiment tegen de officiële cultuur omdat men ervaart dat die officiële samenleving het individu misprijst. Daarom worden de vertegenwoordigers van de officiële cultuur op de korrel genomen. Het is in dit type verstandhouding dat Freuds beschrijving Massenpsychologie und IchAnalyse en Durkheims 'solidariteit op basis van conformiteit' het best passen (Durkheim 1902). De bundeling van emoties die aan de idealen van de groep een bijna sacraal karakter verlenen biedt aan de individuele leden houvast en een sterke, weliswaar imaginaire, identiteitsbeleving. In dit groepstype wordt het kritisch vermogen van het individu opzij geschoven. Elk verwijt aan het adres van een individu is wegens de conformiteit een verwijt aan het adres van de groep die zich 'als één man' keert tegen de 'vijandige' elementen. In Durkheims bewoording neemt de collectiviteit dan wraak tegen wat door afwijking van het gangbare identificatiepatroon het collectief bewustzijn schade toebrengt. Het soort straf dat geëist wordt is er niet op gericht de aangerichte schade te herstellen, maar de dader te doen boeten. De tegenstelling gerechtvaardigden en nietgerechtvaardigden valt samen met het behoren tot de in- of tot de out-group. Ook de persoonlijke ambities worden in dit soort groep gemeenschappelijk gebundeld in verachtingen ten aanzien van het welslagen van de groep in een soort eindtijdelijkheid.

Douglas heeft erop aangedrongen deze theorie niet te interpreteren als een normatieve theorie. Wil men identificatiestijlen beoordelen dan moet men rekening houden met de functies die dit soort stijlen kunnen hebben. Voor het opkomen voor een gemeenschappelijk belang, bijvoorbeeld betere arbeidsvoorwaarden in een bedrijf of minder verkeer door een residentiewijk, is het aangewezen dat de leden van het actiecomité zich een enclavistische identificatie- 
stijl aanmeten. Een competitieve stijl op de werkvloer zou ertoe bijdragen bureaucratische onverzettelijkheid te doorbreken en tot sterkere prestaties aan te zetten. Elke betrachting veronderstelt zijn type groepsidentificatie.

\subsection{MODERNE MEDIA EN ACTUELE IDENTIFICATIESTIJLEN}

Laten we uitgaan van de veronderstelling dat de hegemonische perceptie van hoe onze samenleving zich voordoet de voorbije vijftig jaar is verschoven van een positionele typering naar een individualistische. Die hypothese spoort met de vaststelling dat individueel verantwoordelijkheidsbesef en competitiviteit in onze moderne 'informatiemaatschappij' sterk zijn toegenomen (Elchardus, Marx en Pelleriaux 2003). Het punt is dat weinig mensen erin slagen om hun persoonlijk bestaan in het licht van de dominante identificatiestijl te rechtvaardigen.

Alleen intelligente, goed opgeleide, aantrekkelijke en jonge mensen lijken aan de ongelimiteerde objectieven te kunnen voldoen en kunnen hun bestaan gerechtvaardigd weten. Door ons sociale-zekerheidssysteem is het aantal mensen dat materieel wordt uitgesloten in principe vrij beperkt. Een materieel onderkomen alleen biedt echter onvoldoende beschutting tegen de denigrerende indruk van geen betekenis te zijn. Spontaan zoeken deze mensen dan ook een ander cultureel onderkomen. Dat doen ook de mensen die zich in materieel opzicht wel kunnen handhaven, maar die vinden dat hun bestaan niet voldoet aan de standaard van de officiële cultuur.

\section{Figuur 10.2 Actuele verschuivingen in de groepsidentificatie}

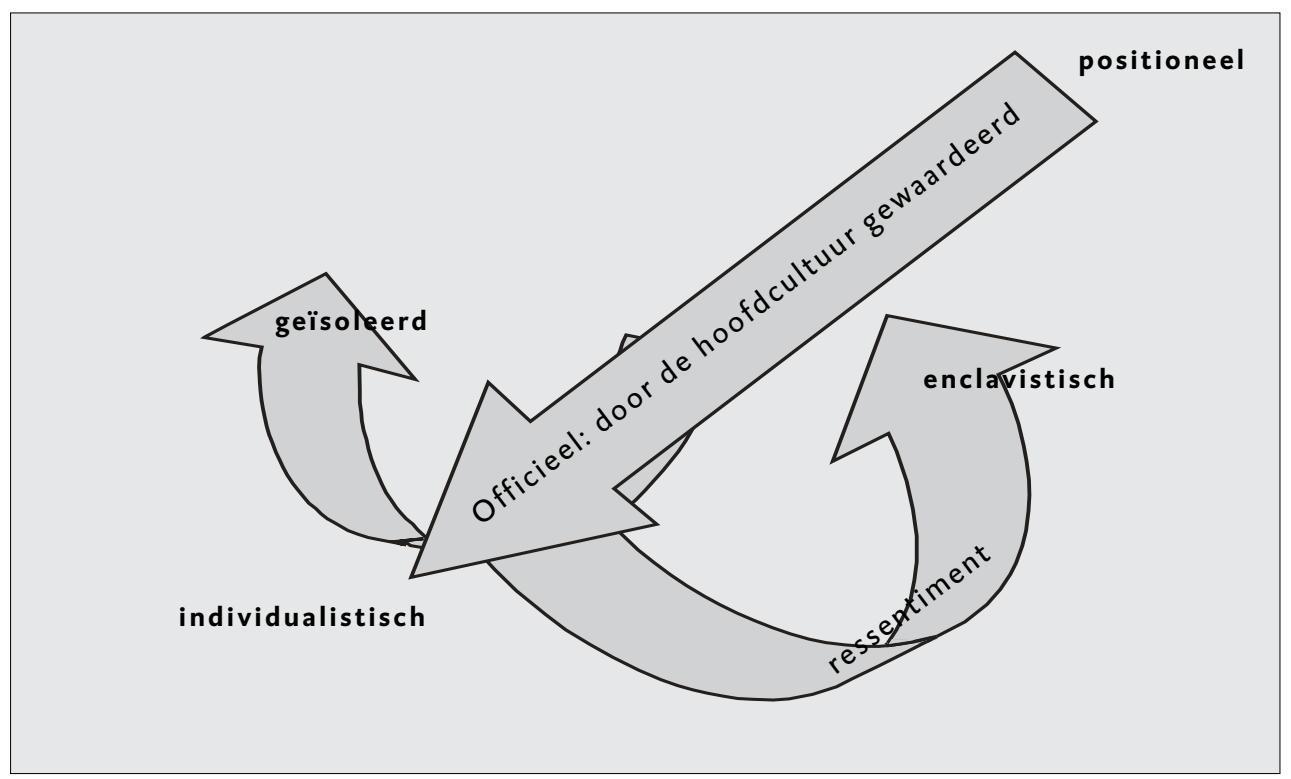

De competitieve opleidingssfeer en de arbeidssfeer zijn vooralsnog niet de enige sferen die iemands zelfrespect bepalen. Er zijn nog steeds talloze subgroepen waarmee mensen zich kunnen identificeren; bijvoorbeeld hun familie, hun 
vriendenkring, hun sportverenigingen, de buurtwerking, NGO's, milieubewegingen, of de klassieke politieke en culturele verenigingen. Maar dit soort engagement is niet evident voor mensen die zich binnen de officiële prestatiegerichte atmosfeer onzeker voelen. Elke identificatie veronderstelt immers dat een individu zich kwetsbaar opstelt zoals in de voorgaande paragrafen werd beschreven. Een pijnloos en minder riskant alternatief wordt geboden door de media.

Identificatie met een groep veronderstelt niet noodzakelijk dat mensen zich op basis van concreet gedrag voor een concrete groep inzetten - wat bijvoorbeeld zou kunnen worden afgeleid op basis van hun officiële lidmaatschap, het frequenteren van vergaderingen, het voeren van briefwisseling, het corresponderen via e-mails of het actief deelnemen aan activiteiten. Groepsidentificatie kan ook berusten op passieve sympathie die enkel tot uiting komt in emotionele reacties wanneer er zich iets speciaals met de referentiegroep voordoet. Identificatie is ook mogelijk met groepen die er eigenlijk niet eens zijn. Zo is identificatie mogelijk met fictieve referentiegroepen die geënsceneerd worden in soapfeuilletons of die kunstmatig worden gecreëerd rond de huisstijl van een televisienet, of rond een consumptieartikel of rond een opinie. Voor wat het mechanisme van de rechtvaardiging betreft, maakt het niet noodzakelijk veel verschil of een groep een sterk virtueel karakter heeft of niet. In principe kan elke van deze soort groepen in aanmerking komen voor identificatie, ook al zal de identificatie met de ene groep wellicht een meer imaginair karakter hebben en met een andere groep een veeleer symbolisch karakter.

Massamedia worden vaak voorgesteld als informatieverstrekkers. Individuen maken er gebruik van om tegemoet te komen aan hun individuele behoefte aan specifieke informatie. Wat ons op die manier ontgaat, is dat ook massamedia aansturen op identificatie met een groep, al is die groep virtueel. Televisie kijken of radio beluisteren is afstemmen op communicatie van of over een groep. Mensen participeren via woord en beeld aan datgene waar een grote groep andere mensen zich op datzelfde moment ook op concentreren. Ze stellen zich in verbinding met wat 'er' gebeurt en voelen zich bevoorrechte getuigen van zaken die op dat moment in het brandpunt staan van de aandacht van een specifieke gemeenschap. De audiovisuele media zouden lang niet zo aantrekkelijk zijn indien mensen niet voortdurend beseffen dat ze kijken of luisteren naar iets waar grote groepen andere mensen op datzelfde moment ook naar kijken of luisteren (vandaar het relatief geringe aandeel tijd dat aan het bekijken van video of $d v d$ wordt besteed in verhouding tot bijv. tv-kijken).

Als massacommunicatie spoort met een vorm van groepsidentificatie, dan ligt het voor de hand dat je massacommunicatie kan karakteriseren op basis van Douglas' group-grid schema. In figuur 10.3 maken we die oefening met een classificatie van het soort informatie waaraan mensen vanuit een specifieke identificatiestijl belang zullen stellen. 
(1) In de klassieke positionele groepsverstandhouding past de omschrijving van wat Luc Van Poecke 'paleo-televisie' noemt: het type openbare omroep klassieke stijl (Poecke 1993). Er is een duidelijke opvatting over wat belangrijk en niet belangrijk is, en er is duidelijkheid over wie dat kan uitmaken en wie niet. Een aantal experts zet zich in om de brede bevolking te informeren, onderwijzen en cultureel verantwoord te amuseren. De duidelijke professionele afbakening van bevoegdheden en de afgrenzingen van sferen maakt van de media één van de vele bronnen van informatie om zich over een onderwerp een opinie te vormen. Vanuit een positionele opvatting over de samenleving is men geïnteresseerd in informatie die betrekking heeft op het welzijn van de samenleving in brede zin. Men is geïnteresseerd in het functioneren van allerlei instellingen met betrekking tot de organisatie van de gezondheidszorg, de werkgelegenheid, de infrastructuur, de internationale betrekkingen. Men beschouwt de diverse media als fora waar de diverse geledingen van de samenleving hun eigen posities, culturele expressievormen en standaarden zichtbaar maken in het licht van hun gemeenschappelijke loyaliteit ten aanzien van de staat.

\section{Figuur 10.3 Massacommunicatie geclassificeerd in functie van de vier types groepsidentificatie}

\section{geïsoleerd}

Weinig of geen communicatie omdat er geen loyaliteit bestaat tegenover om het even welke groep.

\section{positioneel}

Informatie over het functioneren van allerlei instellingen met betrekking tot het algemeen welzijn (organisatie van de gezondheidszorg, werkgelegenheid, infrastructuur, internationale betrekkingen).

Breed publiek forum waar de diverse geledingen van de samenleving hun eigen posities, culturele expressievormen, en standaarden zichtbaar maken in het licht van hun gemeenschappelijke loyaliteit ten aanzien van de staat.

Informatie over wat het gemeenschappelijk bewustzijn verstoort of verontrust (externe fysieke bedreiging, epidemieën, voedselonveiligheid) en over wat de rechtvaardigingsstrategieën van de groep onderuithaalt.

Informatie over wat zich aan de grens voordoet tussen 'het wij' en 'de anderen' waarop fouten worden geprojecteerd: politiek vluchtelingen, criminelen, politici...

Informatie over wat men als lid van de groep behoort te weten om 'in' te zijn, op de hoogte te zijn, mee te kunnen praten, vaak betreft dat roddel, ophefmakende geruchten, verdachtmakingen in verband met publieke figuren.

Net-profiel beantwoordt aan een gezellige thuisomgeving waarin de rechtvaardiging van de in-group wordt gecontrasteerd met een boosaardige buitenwereld.

enclavistisch

(2) Mensen die hun samenleving percipiëren als een competitief ingestelde verzameling individuen die voornamelijk op zichzelf zijn aangewezen, zijn geïnteresseerd in informatie die hun eigen persoon aangaat. Ze interesseren zich veel 
minder voor wat hun samenleving als nationale en politieke identiteit doormaakt. De op de eigen persoon gerichte interesses nemen hoofdzakelijk twee vormen aan. Materialistische interesses: informatie over beleggingen, aandelenkoersen, vacatures, professionele vaardigheidstrainingen; en expressief individualistische interesses: informatie over binnenhuisinrichting, kleding, psychotherapie, lichaamsverzorging, culinaire gerechten, film, muziek, literatuur, reizen, voorzover die betrekking hebben op de ontwikkeling van een (veronderstelde) unieke levensstijl. Er doet zich, voor wat deze interessesfeer betreft, een contradictie voor. Terwijl het individu geïnteresseerd is in informatie over de verdieping en de verrijking van zijn persoonlijke leven, volgt hij vaak trends en modegebonden stijlen. De tekenen waarmee het individu zichzelf als een soort uniek kunstwerk modelleert zijn net zo goed geënt op een groepsverstandhouding in het licht waarvan die expressievormen worden beschouwd als geslaagd of mislukt. Het individu is met andere woorden zijn unieke persoon bij gratie van de groep die dit soort van affirmatie belangrijk vindt.

(3) In de geïsoleerde sfeer is bitter weinig communicatie.

(4) Informatie die een enclavistische identificatie versterkt is informatie over wat het gemeenschappelijk bewustzijn verstoort of verontrust (externe fysieke bedreiging, bomaanslagen binnen de eigen grenzen, kans op epidemieën, voedselonveiligheid) en over al datgene wat de rechtvaardigingsstrategieën van de eigen groep onderuithaalt. Er is binnen deze sfeer een bijzondere preoccupatie met wat zich aan de grens afspeelt tussen 'het wij' en 'de anderen'. Nieuws is nieuws over het front en over de uitroeiing van het kwaad dat zich onder ons bevindt. Aan de overzijde van het front bevinden zich de vreemdelingen en onder ons de criminelen waartegen hard moet worden opgetreden. De groepssfeer is emotioneel geladen en kan snel omslaan: vreugde, walging, verontwaardiging, triomf, neerslachtigheid... In een enclavistische sfeer is de groepsdruk sterk en wordt non-conformiteit niet toegelaten. Mensen die moeilijk doen, moeilijke woorden gebruiken, niet uit hun woorden komen, er niet goed uitzien, vervelende of saaie dingen zeggen worden gemeden. Er is in dit soort mentaliteit ook interesse voor informatie over wat men als lid van de groep behoort te weten om 'in' te zijn, op de hoogte te zijn, mee te kunnen praten en vaak betreft dat roddel, ophefmakende geruchten, verdachtmakingen in verband met publieke figuren.

Het marketinggedreven mediabeleid van de laatste tien jaar heeft ertoe bijgedragen dat de aard van de media die bij een specifiek doelpubliek horen, steeds nauwkeuriger de communicatie is gaan representeren van het type groepsverstandhouding waarin dat doelpubliek onderkomen zoekt. Het feit dat de verschillende types massacommunicatie in toenemende mate representatief zijn voor een reeks subculturen binnen de samenleving blijkt uit recente studies van Marc Elchardus en zijn onderzoeksteam. Volgens Elchardus zouden er zich binnen de Vlaamse samenleving duidelijk onderscheiden culturele ruimtes voordoen waarvan de verstandhouding overeenstemt met het type mediagebruik. Elke culturele 
ruimte zou gekenmerkt worden door een specifieke rangorde van denkbeelden, levensstijlen, politieke voorkeuren, consumentenvoorkeuren, muziekstijlen, filmgenres en dergelijke. De onderzoekers onderscheiden vier tot vijf van dergelijke verstandhoudingen: populair, macho, amusement, alternatief en cultureel correct. De nieuwe politieke breuklijnen tussen aan het ene uiterste Vlaams Blok (extreem rechts, staat voor veiligheid en is vreemdelingonvriendelijk) en aan het andere uiterste progressief Groen zouden samenhangen met de culturele ruimtevorming die de klassieke ideologische breuklijnen lijken te vervangen. De sociale controle die uitging van de oude ideologische zuilen was expliciet terwijl de sociale controle die vandaag uitgaat van de vaak anonieme groep mensen die dezelfde culturele ruimte bewonen, veel onopvallender maar daarom niet minder efficiënt is. Ze gaat deze keer niet uit van een duidelijke instantie: een leraar, een priester, een ideoloog of een politiek denker maar van een symbolisch bemiddeld referentiekader waaraan het individu via onderwijs, advertenties en media langdurig wordt blootgesteld. De consistentie van de symbolische indices waarmee iemand zichzelf markeert of laat markeren, draagt ertoe bij dat men aan de hand van iemands muziekvoorkeur of iemands opleiding vrij betrouwbare voorspellingen kan maken over diens politieke visie, arbeidsvreugde of de schoolresultaten van diens kinderen (Elchardus en Glorieux 2002).

\subsection{DISCUSSIE EN PRAKTISCHE BESLUITEN}

Je kan moeilijk van mensen verwachten dat ze sympathie betuigen met een cultuur die hen misprijst. Hoe sterker de verwerping die uitgaat van de officiële samenleving, hoe onzekerder mensen zich zullen voelen en hoe sterker ze zich zullen terugplooien op een vreemdelingen onvriendelijke gezelligheidsverstandhouding. De onhaalbaarheid van de rechtvaardigingsstandaard van de individualistische en competitief ingestelde hoofdcultuur werkt de toename van 'enclavistisch' georiënteerde communicatie in de hand. Op zich brengt enclavistische communicatie de gezelligheid en de roddel van de traditionele conformistische solidariteit van het dorp terug, inclusief het dialect. Het spoort met het verlangen naar een sterke leider, meer veiligheid, minder onduidelijkheid en meer conformiteit. Van dat soort zaken is er in principe nooit genoeg. Bovendien roept agressie tegenover de buitenwereld scherpe tegenreactie op in subculturen met eenzelfde enclavistische verstandhouding. Mocht er tussen die groepen fysieke agressie ontstaan, dan riskeert men een geweldspiraal. Ondanks de imaginaire veiligheid die een enclavistische identificatie lijkt te bieden, biedt dit soort verstandhouding geen echt onderkomen, in ieder geval niet het onderkomen dat mensen opnieuw vervult met voldoende zelfrespect, moed en zelfvertrouwen om hun persoonlijk leven en dat van hun samenleving zorgzaam uit te bouwen.

Het lijkt weinig waarschijnlijk dat de financiële groepen die de media bezitten, doelbewust vorm geven aan de identificatiestijlen die met mediacommunicatie verweven zijn. De logica van een commercieel en/of competitief mediabeleid zal er echter wel toe bijdragen dat netprofielen en doelpubliekprofielen omwille van kijk-, luister- en oplagecijfers steeds accurater de verstandhouding tot uitdruk- 
king zullen brengen waarin specifieke segmenten van onze samenleving zich 'thuis' voelen.

Tijdens de discussie naar aanleiding van deze bijdrage werd gesuggereerd dat misschien nu de tijd is aangebroken om de subjectivistische liberale belijdenis op te geven en opnieuw een positief vrijheidsbegrip in te stellen. Er zou opnieuw met meer moed en vastberadenheid moeten worden gewezen op hartverwarmende idealen en projecten. Of een dergelijke strategie heilzaam zal zijn hangt in belangrijke mate af van welke instantie die 'voorbeeldige' taak op zich zal nemen. Het lijkt weinig waarschijnlijk dat de overheid dat kan doen en het is ook niet raadzaam dat gezagvolle instellingen zoals universiteiten, kerken, vakbonden, culturele verenigingen of politieke partijen die taak op zich nemen. Het zou de vernedering en het minderwaardigheidsgevoel van de kwetsbare groepen in de samenleving alleen maar versterken. Het genereren van projecten die het bestaan rechtvaardigen moet van onderuit worden gestimuleerd. Mensen beschikken over veel vrije tijd en gezien hun gemiddeld drie uur televisiekijken per dag, over nog veel meer vrije tijd. Indien ze een fractie van die tijd zouden investeren in kleinschalige sociale en culturele projecten, dan kan ik me voorstellen dat er op lange termijn een mentaliteitsverandering op gang kan worden gebracht. Het genadeloze karakter van de meritocratie zoals die zich vandaag laat gelden, kan alleen doorbroken worden wanneer er zich op heel diverse domeinen en sferen netwerken ontwikkelen waarin mensen zich gewaardeerd voelen omdat ze er bijvoorbeeld niet graag gemist worden. Veel van die sferen bestaan: op de eerste plaats de gezinnen, andere kunnen wellicht versterkt worden of vernieuwd.

Je kan de recente culturele evolutie waarin de media een belangrijke rol spelen door eenvoudige morele richtlijnen wellicht nooit wijzigen. Wat wellicht wel gestimuleerd kan worden, is een publiek debat over de feitelijke actuele standaarden die een menselijk bestaan vandaag lijken te rechtvaardigen. Tot nu toe hebben commerciële instanties de gangbare liberale ideologie gebruikt om zonder blozen ondermaats entertainment en verbrande berichtgeving in de ether te brengen met het excuus dat men het aan de burger zelf wel kan overlaten wat hij mooi en belangrijk vindt. Elke inhoudelijke discussie over esthetische en morele idealen werd op die manier systematisch van de tafel geveegd. Op het ogenblik dat sociale wetenschappers er opnieuw in slagen de samenleving een spiegel voor te houden waarin individuen zien op basis van welke rechtvaardigheidsstandaarden ze hun leven inrichten, zal er wellicht meer vrijheid ontstaan om de eigen identificatiestijl bij te stellen. Mensen zullen dan niet meer onbewust beantwoorden aan gewoonten, trends en stijlen. Misschien proberen ze dan een alternatieve koers. Willen we de autonomie van iedere burger respecteren dan zullen we, trouw aan de klassieke verlichtingsidealen, als wetenschapper ook duidelijk moeten maken tot wat soort van uitzichtloze en gewelddadige situatie we riskeren af te glijden als burgers zich niet opnieuw in alternatieve groepen en verenigingen engageren die een breder rechtvaardigingspotentieel genereren dan de actuele meritocratie en de virtuele media. Voor wat Vlaanderen betreft zijn daar geen zeeën van tijd meer voor. 


\section{NOTEN}

In latere teksten benadrukt Freud dat er niet alleen positieve maar ook negatieve psychische energie bestaat, energie die erop gericht is te ontbinden en te vernietigen. Dat onderscheid maakte het mogelijk de sadistische en de masochistische positie te begrijpen.

2 “Individueel hebben wij, Hutu's en Tutsi's, niets tegen elkaar. Maar in groepsverband laten we ons meeslepen, scheppen we een klimaat van angst voor elkaar. Dan denken we niet meer zelfstandig, dragen we geen individuele verantwoordelijkheid meer voor onze daden. Dan wordt alles vertaald in termen van 'wij' en 'zij' - en 'zij', dat is een andere soort, een ander ras, dat zijn geen levende wezens." Uit het dagboek van Els de Temmerman, zaterdag 23 april 1994 in De doden zijn niet dood. Rwanda, een ooggetuigenverslag, blz. 34 (Globe). GrootBijgaarden, Roularta Books/Var/Scoop, 1994.

3 Lacan verzette zich met hand en tand tegen de tendens binnen de Internationale Psychoanalytische Vereniging om het 'ik' opnieuw en tegen Freuds intuïtie in een centrale functie toe te schrijven zoals Hartmann in Hartmann (1964).

Jongeren en volwassenen zijn daar ook nog steeds op betrokken. De wijze waarop iemand beweegt, glimlacht, intimideert, imponeert, zich onderdanig voordoet e.d. wordt via onze betrokkenheid op lichaamsbeelden geregistreerd en is van fundamenteel belang in onze dagelijkse omgang met andere mensen en in de audiovisuele communicatie.

Op zichzelf is dat maar goed ook. Indien we volmaakt gelukkig zouden zijn zou er niets meer bestaan dat ons op dreef hield.

Reclamemakers zijn succesvol wanneer ze erin slagen mensen het gevoel te geven dat wanneer ze een bepaald product kopen hun bestaan betekenisvoller wordt. Hun stilering van wat als een betekenisvol leven moet worden beschouwd, kan in die zin moeilijk worden onderschat.

De eer van de postbode in het positionele groepsverband is niet zijn salaris, niet zijn bevoegdheid, maar zijn bijdrage tot het goed functioneren van het postwezen waarvan het respect dat de samenleving voor die noodzakelijke functie opbrengt weerspiegeld wordt in zijn uniform. Vandaag dragen postbodes in België petjes. 


\section{LITERATUUR}

Douglas, M. (1970) Natural Symbols. Explorations in Cosmology, London: Barrie and Rockliff/Cresset Press.

Douglas, M. en S. Ney (1998), Missing Persons. A Critique of the Social Sciences, University of California Press.

Durkheim, E. (1902) De la division du travail social, Paris: Alcan.

Friedman, J. (red.) (1996) The Rational Choice Controversy: Economic of Politics Reconsidered, Yale: University Press.

Elchardus, M. en I. Glorieux (red.) (2002) De symbolische samenleving, Tielt: Lannoo.

Elchardus, M., I. Marx en K. Pelleriaux (2003) 'De nieuwe sociale kwestie: Begripsverduidelijking en hypothesevorming', in De nieuwe sociale kwesties, Antwerpen/Apeldoorn: 11-30.

Green, D.P. en I. Shapiro (1996) Pathologies of Rational Choice Theory. A Critique of Application in Political Science, Yale: Yale University Press.

Hartmann, H. (1964) Ego-psychology and the problem of adaptation, New York: International Universities Press.

Kohlberg, L. (1974) 'Moral stages and moralisation, the cognitive developmental approach', in Th. Lickona (ed.) Moral development and behavior, New York: Holt.

Poecke, L. van (1993) 'Mediacultuur en mediaconstitutie in het licht van de postmoderne zwakke classificatie en framing. Deel 1: van moderniteit naar post-moderniteit', in Communicatie 23, 2: 1-22.

Poecke, L. van (1993), 'Mediacultuur en mediaconstitutie in het licht van de postmoderne zwakke classificatie en framing. Deel 2: Van paleo- naar neo-televisie', in Communicatie 23, 3: 1-27.

Sartre, J.P. (1943) L'être et le néant. Essai d’ontologie phénoménologique, Paris: Gallimard.

Schmitt, C. (2001) Het begrip politiek, Amsterdam: Boom.

Visker, R. (2003) 'Enfance, transcendance et moralité des valeurs: Pour un républicanisme actuel', in A-M Dillens (red.) La Pluralisme des Valeurs. Entre Particulier et Universel, Brussel: Publications des Facultés universitaires Saint-Louis.

Williams, B. (1981) 'Persons, character and morality', in Moral Luck, Cambridge: Cambridge University Press. 


\title{
MACHT OF ONMACHT VAN DE MEDIA? ENKELE KANTTEKENINGEN BIJ EEN ACTUEEL DEBAT
}

\author{
D.W.J Broeders en W.B.H.J. van de Donk ${ }^{1}$
}

"The correct relationship of a journalist to a politician is that of a dog to a lamppost." Jeremy Paxman, Brits Journalist, 1990

"Bild, Bams und Glotze"

Gerhard Schröder in antwoord op de vraag wat er nodig is om te regeren in een mediacratie

“Ce qui importe, c'est de bien voir dans l'omnipotence obsédante du 'médiatique' un symptôme de crise. Dans le procès assez vain que la démocratie instruit inlassablement contre les medias, c'est son propre process et son propre délabrement qui sont en jeu."

J.C. Guillebaud, Esprit, mars-avril 1993

\subsection{INLEIDING: MEDIAMACHT IN DEBAT}

De media hebben het gedaan. Politici kunnen hun verhaal niet meer kwijt omdat journalisten alleen nog maar interesse hebben in een korte quote en dan bij voorkeur een die een beetje past in het programma of die toch tenminste de vooraf betrokken positie bevestigt. De macht van de media om 'de werkelijkheid' in zorgvuldig voorbereide beelden en frames aan de man te brengen, is veel groter dan de mogelijkheden van politici om hun eigen boodschap over het voetlicht te brengen. Politici klagen steen en been over de journalisten die de werkelijkheid bewerken, elkaars berichten overschrijven, hypes creëren en onzorgvuldig werk leveren. Het Nederlandse staatshoofd liet (on)bedoeld zelfs de quote van het jaar 1999 over de media in de media los, toen ze haar frustraties bondig en met een goed gevoel voor haar doelgroep samenvatte in de oneliner: 'de leugen regeert'.

De leugen regeert. Intussen is het de naam van een succesvol vaRA-programma dat probeert bij te dragen aan een nieuwe trend: journalisten worden ter verantwoording geroepen. Daarmee lijkt de journalistiek niet te ontsnappen aan een meer omvattende maatschappelijke trend: verantwoording en openbaarheid. Maar ook in dit programma wordt de jury samengesteld uit leden van de eigen beroepsgroep. Burgers klappen op de tribune, maar het onbehagen blijft, en strekt zich doorgaans uit tot het functioneren van 'de media'.

Al die macht van 'de media' zit vooral de politiek danig dwars. Politici hebben er dan ook als eersten 'last' van. De media zijn officieel onafhankelijk, en geen bondgenoten. Maar in de alledaagse praktijk zijn media en politiek tot elkaar veroordeeld en steeds (meer) van elkaar afhankelijk. Politici hebben, ondanks de opkomst van SMS en internet, eigenlijk geen andere effectieve - laat staan doel- 
matige - manier om hun achterban in korte tijd in groten getale te bereiken en de media kunnen en willen in hun berichtgeving niet om de Haagse werkelijkheid heen. De journalistiek bepaalt, zo wordt verondersteld, in belangrijke mate wat er morgen in Den Haag gebeurt. Al die (veronderstelde) ${ }^{3}$ macht zou de media toch een groot genoegen moeten doen. Wie machtig is, wordt niet snel in een hoek gedreven. Toch zit nu ook de journalistiek de laatste jaren in de hoek waar de klappen vallen. Net zoals de andere democratische instituties verliezen journalistiek en media in aanzien en gezag (SCP 2002). De veronderstelde samenhangen zijn intussen aanleiding voor het nodige onderzoek naar de ontwikkelingen in de media en de meer algemene crisis waarin onze democratie zou verkeren (Norris 2000; Elchardus 2002).

De positie en het functioneren van de media staan intussen ook in de eigen kolommen ter discussie. Ook binnen de beroepsgroep woedt het debat over het hoe, waarom en wat te doen in alle hevigheid (zie bijv. NVJ 2003; Broertjes 2004; Prenger en De Vree 2004). Men is in verwarring. Deftige kwaliteitskranten zien hoe een 'collega' uit de commerciële omroep de Haagse wereld weken domineert. Eerder nog heilige en veilige codes over de onderlinge betrekkingen tussen journalisten en politici in het in de gebouwen van de Tweede Kamer gevestigde Nieuwspoort worden nu met weinig ontzag voor de traditie gebroken in een oplopende concurrentie om scoops en nieuws. Hoofdredacteuren worden uitgedaagd om aan debatten deel te nemen in plaats van die te verslaan; journalisten krijgen kritische vragen terug. De verwarring in de beroepsgroep lijkt intussen niet minder groot dan die in kringen van politieke partijen: ook in die zin delen ze in de meer algemene malaise waarin de democratie lijkt te verkeren. Zeker na de moord op Pim Fortuyn werd de beschuldigende vinger naar zowel politiek als journalistiek uitgestoken. Beiden werden door een groot en mondig deel van het electoraat beschuldigd van stigmatisering en demonisering. Het onder meer door de Rotterdamse hoogleraar Beunders geuite verwijt dat de symbiose met de 'Haagse' politiek tot een verkeerd en geïnstitutionaliseerd soort van bedrijfsblindheid had geleid, en een disfunctioneren daar waar het gaat om het agenderen van echte maatschappelijke problemen, kwam hard aan. In de ogen van vele politici hadden de media veel te veel macht, in de ogen van de burgers was die macht niet goed gebruikt.

\subsection{MAAR: IS MACHT WEL HET PROBLEEM?}

Vaak wordt het argument gehoord dat de macht van de media het probleem is. De media zijn out of control en de oplossing wordt, vaak zonder die diagnose verder ter discussie te stellen, al even haastig als consequent gezocht in een uitbreiding van de controle op de media. Een aantal recente rapporten probeert die diagnose, soms ondersteund door uitgebreid empirisch onderzoek, wat verder te brengen. Zo vroeg de Raad voor Maatschappelijke Ontwikkeling (RMO 2003) onlangs aandacht voor de 'medialogica' waarin burger, politiek en journalistiek elkaar gevangen houden. Het is veelzeggend dat na het verschijnen van dat rapport in de media zelf vooral het daarop gebaseerde pleidooi voor een media-watchinstituut 
en een jaarlijks verantwoordingsdebat in de Tweede Kamer aandacht kregen: voor de analyses was veel minder aandacht. Niet lang daarna volgde de Raad voor het Openbaar Bestuur (RОв 2003) die zich op politiek en bestuur richtte in zijn aanbevelingen. Naast aanbevelingen voor zelfreflectie op de eigen houding ten opzichte van de media beval de Rов het bestuur aan om op sommige punten zelf 'media te spelen'. Om de eigen boodschap goed over het voetlicht te brengen is het volgens hem zinvol om een eigen overheidskrant op te zetten en zendtijd op de televisie te kopen.

Maar niet alleen adviesorganen zitten met de macht van de media in de maag, ook in de wetenschap woedt het debat volop. In 2001 bepleitte Rosenthal dat de media als zevende macht in het almaar uitdijende rijtje van machten opgenomen moest worden en - dan immers erkend als macht - ook gecontroleerd moet worden door de andere machten. In de praktijk betekende dit voornamelijk voorstellen voor parlementaire controle op de media. Net als de RMO bepleitte hij een jaarlijks plenair debat over de werking en rol van de media en zag hij verder noodzaak voor een parlementair onderzoek en voor een volledig onafhankelijke raad van toezicht. De constatering van het feit dat de media macht hebben leidt in dit soort beschouwingen meestal direct tot de conclusie dat die macht beteugeld of beter gecontroleerd moet worden. De diagnose stuurt de oplossingsrichting. Vaak wordt die conclusie wel erg snel getrokken en bovendien beperkt tot de relatie politiek-journalistiek: de machtsbalans tussen beide wordt daarbij al even helder als onterecht als een zero-sum game gezien, en elke verschuiving moet in die termen worden gecorrigeerd. Nog afgezien van de vraag of de diagnose wel klopt of volledig is, kunnen we ons de vraag stellen of het problematiseren van de rol van de media in termen van macht, machtsverdeling en machtsevenwichten wel zo productief is, en of dit ons het zicht op een meer adequate diagnose ontneemt.

Want de door Rosenthal bepleite erkenning van 'de media' als afzonderlijke macht in het totale machtenspel van de democratie is feitelijk een evidentie (zie ook Ramonet 2003). Geen van de hierboven aangehaalde auteurs en adviseurs zal dat ontkennen. Het feit dat media (reële) macht hebben binnen de democratie moet immers worden gezien als een integraal onderdeel van, zoniet een belangrijke voorwaarde voor het adequaat functioneren van de democratie. De vraag is wel of het hier om het soort van macht gaat waarover we doorgaans spreken als we verwijzen naar de machten van de trias politica. De 'macht' waarover media moeten beschikken is toch vooral het vermogen om tussen die machten en de burgers te bemiddelen en te zorgen voor een permanent kritisch volgen van die macht door middel van een open en op basis van feiten en duidingen te voeren debat. Van Praag onderscheidt drie vitale functies van de media in de democratie. ${ }^{4}$ Het gaat daarbij om de informatiefunctie, de platformfunctie en de kritische functie (ten opzichte van de elite). Het uitoefenen van deze functies door de media is onontbeerlijk voor de controle van machten, en daarmee voor het evenwicht in het bredere democratische spectrum. De media of beter gezegd de journalistiek hebben macht nodig om hun rol als countervailing power ten 
aanzien van de politiek (en andere maatschappelijke actoren) te spelen. Hoewel een teveel aan macht natuurlijk problematisch is, en een teveel aan niet te controleren macht al helemaal, moet de vraag gesteld worden of dat nu de termen zijn die ons in staat stellen het centrale probleem van dit moment scherp in beeld te krijgen.

Wij denken van niet. De frustratie die de verhoudingen tussen de hedendaagse journalistiek en de politiek kenmerkt is wellicht eerder toe te schrijven aan een groeiend gebrek aan zekerheid over de eigen rol en, bijgevolg, over de wederzijdse rolopvattingen binnen het democratische bestel. Die onzekerheid zien we zowel aan de zijde van de politiek en de daarmee verbonden democratische instituties, als in de sfeer van de media zelf. Beide krijgen te maken met het gedrag van de al even boze als onvoorspelbare burgers van de wispelturige samenleving. De groeiende onzekerheid over de veranderingen in de eigen maatschappelijke positie, de spelregels, en een daarmee samenhangend onvermogen om de eigen rol tegen de achtergrond van een zich veranderend maatschappelijk decor adequaat (opnieuw) te definiëren en te spelen, verklaart wellicht meer dan het denken in termen van (een teveel aan) macht en de controle daarop. In hoeverre zijn journalisten in het huidige (media)landschap in staat hun functies om informatie te verschaffen, een platform te bieden voor meningsvorming en het kritisch volgen van de elite gestalte te geven? De onmacht van de media in deze zin begrepen (het niet of onvoldoende kunnen voldoen aan deze vitale maatschappelijke opdracht) is naar onze overtuiging een blinde vlek in het debat, die we graag verder willen verkennen in onze bijdrage aan deze bundel. Het gebruik van macht en tegenmacht is uiteraard niet los te zien van de bredere maatschappelijke context waarin media en politiek functioneren. De manier waarop eenieder zijn rol vervult, wordt immers mede bepaald en gewaardeerd tegen de achtergrond van die bredere veranderingen in de samenleving en in het medialandschap. Grote maatschappelijke veranderingen zijn van invloed op de context waarin de media (en daarmee de journalistiek) functioneren en deze zijn wellicht zo groot dat er eerder behoefte is aan een creatieve herijking en vernieuwing van de eigen rolopvatting, dan aan een poging om de eerder bestaande rolopvatting te hervinden.

\subsection{VAN TOEN NAAR NU, NAAR LATER: VERSCHUIVENDE PANELEN}

Zowel 'de' politiek als 'de' media lijken ontevreden met (en onzeker over) hun plaats en rol binnen het democratische bestel en hun rol ten opzichte van elkaar. Er lijkt sprake van een gebrek aan consensus over wat hun rol moet zijn en tegelijkertijd een consensus over het feit dat die rol in de toekomst anders ingevuld moet worden. Geen van beide is gebaat bij de weinig flatteuze labels die laatste tijd worden gehanteerd. De dramademocratie van Elchardus (2002) waarin de politici als acteurs in het door de media geschreven scenario worden opgevoerd en de medialogica van de RMO waarin politici zich voegen naar de timing en de sjablonen die de media in hun berichtgeving hanteren, zijn geen beelden waar de politicus zich bij neer zal willen leggen. Tegelijkertijd is het beeld van de mediacratie waarin de machtsverhouding tussen openbaar bestuur en de media door- 
slaat in de richting van de laatste, uiteindelijk ook geen wenselijk beeld voor de journalist (bijv. Hendriks en Korsten 2001; Brants 2002). Hoewel sjablonen en stereotyperingen van alle tijden zijn, lijkt er in het huidige tijdsgewricht wel iets meer aan de hand.

De eigen taakopvattingen van media en politiek en die ten opzichte van elkaar zijn in de afgelopen decennia nogal verschoven (Wijfjes 2003). De mooie, inmiddels al vaak buiten de oorspronkelijke context gebruikte metafoor van de schuivende panelen die Schuyt voor de verzorgingstaat hanteerde, is misschien ook hier verhelderend. Hij gebruikte de metafoor om de ontwikkeling/toekomst van de verzorgingsstaat te duiden. Het eerste paneel stond voor de voorbije industriële samenleving, het tweede voor de ontwikkelde verzorgingsstaat en het derde voor de komende postindustriële samenleving (Schuyt 1986). Elk van deze panelen heeft zijn eigen kenmerken, samenhang en paradigma's. Natuurlijk zijn die panelen telkens enigszins ideaaltypisch, en kunnen ze niet zonder enige afstand tot de niet altijd eenduidige empirische werkelijkheid worden uitgetekend. Dat geldt uiteraard ook voor wat er - in het licht van zo'n paneel - kan worden gezegd over de ideaaltypische invulling van de rol van de media. Het verwarrende is ook dat de panelen elkaar deels overlappen waardoor elementen van elk van de panelen zich tegelijkertijd voordoen. De contouren van het nieuwe paneel zijn in zicht maar door de overlap met het oude paneel nog niet scherp op het netvlies te krijgen. Een constatering die men in het huidige debat over het medialandschap vaker tegenkomt is dat er nu sprake is van een nieuwe periode of een nieuw paradigma, maar dat het nog te vroeg of te moeilijk is om die goed te kunnen schetsen en af te bakenen. In de terminologie van de metafoor zou men kunnen zeggen dat elementen van de eerdere panelen het zicht op de nieuwe realiteit nog te veel benemen. Ook in het kader van de media en de democratie zijn in de literatuur vaker opeenvolgende panelen te benoemen.

Van Cuilenburg en McQuail (2003) spreken in een recent artikel over media policy paradigm shifts van drie opeenvolgende beleidsparadigma's voor het mediabeleid in de westerse wereld. Op basis van een analyse van het medialandschap en de veranderingen daarin (introductie van bepaalde techniek, bepaalde sociaal-culturele verhoudingen etc.) komen zij tot een kernschets in paradigma's. Het eerste paradigma noemen zij the paradigm of emerging communications industry-policy dat zo ongeveer tot de Tweede Wereldoorlog van kracht was. Het tweede is het paradigma van de public service media-policy, hetgeen loopt tot het eind van de jaren tachtig, begin jaren negentig van de vorige eeuw. De derde fase is die waar we nu in zitten en waarin naarstig naar een nieuw paradigma gezocht wordt. Ook in termen van mediabeleid en de bijbehorende paradigma's is de huidige tijd dus moeilijk te duiden. Toch zijn er interessante pogingen om dat te doen.

Bovens kwam op basis van de dominante mediatechnologieën voor massacommunicatie tot een andere typering. In zijn boek De digitale republiek (2003) onderscheidt hij vier types van de 'mediacratie' aan de hand van het dominante 
medium. Achtereenvolgens zijn dit de pamflettendemocratie, de krantendemocratie, de televisiedemocratie en de internetdemocratie. Ook hier geldt volgens Bovens dat de lagen elkaar weliswaar opvolgen, maar elkaar niet uitsluiten. Het gaat hem vooral om de meerwaarde en (het uitblijven van) de revolutie van dit laatste medium voor de democratie. Wat precies de onderscheidende kenmerken van de komende internetdemocratie zullen zijn, kan nog niet gezegd worden. Daarvoor is het speelveld nog te veel in beweging en Bovens wijst er terecht op dat vaak eerst de logica van het vorige medium op de technologische nieuwkomer wordt geplakt (de eerste kranten leken op pamfletten, de eerste televisieprogramma's hadden kenmerken van de krant etc.) voordat het nieuwe medium tot volle wasdom komt. Het nieuwe verschijnt meestal in de vorm van het oude: de eerste auto's leken ook op postkoetsen (zie ook Van de Donk 2000 en Paulussen 2004).

Een derde typologie kan bijvoorbeeld worden ontleend aan Van Praag (2003) die de veranderende relatie tussen politiek en media onlangs in drie - opeenvolgende - modellen uitwerkte. Het eerste model is dat van de partisan logic, waarin de politiek georganiseerd is in massapartijen en de journalistiek verslag legt van de ontwikkelingen in de politiek. De tweede periode die in Nederland vanaf de jaren zestig inzet is die van de public logic, waarin de journalist zich losmaakte van de politiek en zich met de publieke zaak begon te identificeren. Het huidige model, dat grofweg vijftien jaar geleden van start ging, is dat van de media logic. Hierin gaat het medium zelf een steeds belangrijkere rol spelen en betreedt de journalist ook steeds meer zelf het podium.

Zoveel auteurs, zoveel typologieën. Gedeelde kenmerken zijn er echter ook. Zo hebben alle auteurs moeite met de karakteristieken van het huidige model en komen de indelingen in de tijd over het algemeen redelijk overeen; de scharnierpunten lijken dus al beter zichtbaar dan het meest recente model of paradigma. Bovendien is er een veelvoud aan omstandigheden aan te wijzen die van invloed zijn op de hoofdspelers (journalistiek, politiek en burger), hun rolopvattingen en hun onderlinge verhouding. Die verhoudingen zullen onder invloed van meer algemene veranderingen in het medialandschap waarschijnlijk nog wel de nodige wijzigingen ondergaan. Veel is nog onzeker, maar enkele contouren van die veranderingen laten zich al wel uittekenen. Dat landschap zal onder invloed van de naar verwachting binnen nu en vijf jaar doorzettende golf van personalisering (interactie) en digitalisering van de (vooral audiovisuele) media grondig gaan veranderen (bijv. Van Vliet 2001a en 2001b; Paulussen 2004). Zo is er de rol van technologische en economische ontwikkelingen (wordt de journalist en zijn redactie straks niet 'afhankelijk' van de welwillendheid en de strategie van netwerkbeheerders? gaat de kijker zijn 'eigen' camerapositie kiezen?), sociaalculturele ontwikkelingen (van massamedia naar steeds meer op specifieke groepen en diensten toegesneden 'kassamedia') en ook de rol van Europa, vanwaaruit het functioneren van het medialandschap steeds meer als dat van een 'gewone' markt wordt begrepen. ${ }^{5}$ 
In de volgende paragrafen proberen we, zonder de pretentie van volledigheid, enkele van die ontwikkelingen die wijzen op een paneelverandering nader te duiden. Op die manier hopen we het zicht op het nieuwe paneel iets te vergroten, en bij te dragen aan de discussie over wat deel is van de troebele overgang en wat deel is van het nieuwe paneel.

\subsection{A ChANGe in the Weather or a Climate Change?}

Achteraf zijn tijdsperiodes altijd eenvoudiger te benoemen; met de tijd worden de contrasten met de voorgaande periode immers groter en zijn hypes te onderscheiden van trends en revoluties. Volgens de meeste auteurs verkeren we echter al weer enige tijd in het nieuwe paneel, dat zo rond het begin van de jaren negentig is ingezet. In de drie perspectieven die hierboven zijn aangehaald, worden verschillende ontwikkelingen genoemd die aan de basis van het scharnierpunt liggen. Van Cuilenburg en McQuail stellen dat het nieuwe beleidsparadigma vooral wordt gedreven door economische (marktdenken) en technologische logica's. Bovens ziet de opkomst van het internet als nieuw medium uiteraard als het scharnierpunt, en Van Praag benoemt de commercialisering en de concurrentie op de (sterk verruimde) mediamarkt als drijfveer voor verandering in sociaalculturele zin. Ook Mommaas (2003) wees recentelijk op de fundamentele betekenis van de opkomst van commerciële televisie. Al deze zaken zijn natuurlijk in zekere mate met elkaar verweven, en kleuren zo het zich allengs ontwikkelende 'paneel' tegen de achtergrond waarvan de rol van politiek en media en hun onderlinge verhoudingen worden bepaald. Voordat we over die herijking in meer algemene zin wat opmerkingen willen maken, staan we stil bij vier dominante ontwikkelingen die dat paneel lijken te kleuren:

1 De onvoltooide professionalisering van de mediaberoepsgroep;

2 De rol van commercie, commodificering en competitie in het medialandschap ('van massamedia naar kassamedia');

3 Ontwikkelingen in het publieke domein ('versplintering');

4 De positie van de burger/consument.

Alle vier de ontwikkelingen lijken van belang voor een nieuwe duiding van de rol van media, journalistiek en hun onderlinge verhoudingen. De centrale stelling die we willen betrekken is dat het voor de discussie over de toekomstige relatie tussen politiek, samenleving en media nuttig is om te bezien wat die ontwikkelingen betekenen (kansen, bedreigingen) voor de huidige, nog in het vorige paneel verankerde rolopvatting van media en journalistiek, en welke kiemen voor vernieuwing van die rol daarin liggen besloten. We zijn ons ervan bewust dat we daarmee de evenzeer noodzakelijke analyse van ontwikkelingen in de eigen wereld van politici en bestuurders laten liggen, die natuurlijk evenzeer aandacht moet krijgen in pogingen de onderlinge verhoudingen tussen politiek en media te herijken. Maar de nadruk in onze discussiebijdrage hier ligt op het bezien van de rol en het vermogen van de journalistiek zelf om die (nieuwe) rol te kunnen waarmaken. 


\subsubsection{ONVOLTOOIDE PROFESSIONALISERING}

De professionalisering van de journalistiek wordt vaak in een adem genoemd met de ontzuiling van het Nederlandse mediastelsel, en zet in de jaren zestig in. Kranten ontkoppelden zich van politieke partijen en kregen steeds meer een zelfstandige rol, omroepen volgden later en langzamer. Een van de belangrijkste inhoudelijke veranderingen was de wisseling van perspectief. Gaandeweg werd het nieuws niet langer meer uitsluitend aan de hand van de agenda en interpretatie van de autoriteiten gebracht, maar steeds meer vanuit het perspectief van de burger of het publiek (Van Vree et al. 2002: 84). De journalistiek ontwikkelt zich in deze jaren naar de rol van waakhond van politici en bestuurders. Het is deze rol waar de journalistiek zich nog steeds het liefst op voor laat staan en waar critici - in de woorden van Van Praag - vaak met heimwee op terugkijken (zie ook Wijfjes 2004).

Vanwege de gevoelige relaties tussen journalistiek, persvrijheid en recht op vrije meningsuiting staat de overheid zich weinig regulerende bevoegdheden toe, en is het dominante model voor de 'sturing' van de journalistiek dat van de zelfregulering. Die is (daarom) echter in hoge mate informeel en niet vastgelegd of institutioneel verankerd, enkele uitzonderingen zoals het redactiestatuut daargelaten (Bardoel 2003; zie ook Prenger en De Vree 2004). In de ogen van Wijfjes is het zelfs de aard van de journalistieke cultuur zelf die zich tegen een al te sterke professionalisering verzet:

"De journalistiek kent dan ook een bescheiden regelsysteem, dat nergens formeel is opgetekend en dat slechts marginaal en altijd vrijblijvend in de openbaarheid wordt getoetst of gecontroleerd door de beroepsgroep zelf. Dat kan ook moeilijk anders, want het wezen van de journalistiek is de vrijheid voor iedere burger om zich te oriënteren op cultuur en samenleving, om een mening te formuleren of om de eigen cultuur te ontplooien" (Wijfjes 2004: 512).

Zelfregulering en professionalisering gaan echter meestal gepaard met de ontwikkeling van beroepsorganisaties, opleidingsinstituten en de formulering van beroepscodes. Bij de journalistiek ging dat allemaal iets anders:

“De opleidingen zijn er gekomen, maar ze zijn niet voorgeschreven en er zijn talloze journalisten die ze nooit bezocht hebben. Er is een soort beroepsorganisatie, maar lidmaatschap is niet verplicht en vele journalisten zijn geen lid. Het beroep is niet beschermd en een formele beroepscode is er ook al niet” (Oosterbaan 2003).

De zelfregulering van de journalistieke professie is daarmee dus aanzienlijk losser dan die van vele andere beroepsgroepen en heeft dus ook niet altijd even scherpe tanden. Institutionalisering en professionalisering van de beroepsgroep lijken steeds meer nodig en steeds minder mogelijk. Ook bij andere beroepsgroepen is een sterke beroepsorganisatie geen automatische garantie tegen ongewenste 
bijwerkingen van marktwerking en competitie. Ontwikkelingen in de accountancy, het notariaat, de advocatuur en de medische wereld geven weinig gronden voor een onvoorwaardelijk optimisme.

Met de professionalisering en de 'bescherming' van het beroep is journalist ook langzamerhand een gewoon beroep geworden. De krantenjournalisten in vaste dienst zijn overwegend oud en blank en gaan om vijf uur naar huis om te eten. De waakhond waakt van negen tot vijf, en is bovendien sterk naar binnen gericht; het commentaar van collega's en redacteuren wordt aanzienlijk hoger aangeslagen dan de meningen van het lezerspubliek, waarover men niet al te hooggespannen verwachtingen heeft (Deuze 2002). Op kritiek wordt soms gevoelig gereageerd (“dikke pennen hebben dunne huiden", stelde NRC-journalist Mark Kranenburg) en het redactiestatuut, dat vooral de uitgevers op afstand moest houden, wordt nu ook tegen een al te grote invloed van lezers en burgers ingezet.

Bardoel signaleert dat de journalistiek haar contacten met de macht beter heeft onderhouden dan haar antennes naar de samenleving. In discussies over het functioneren van de publieke omroep valt te beluisteren dat veel van de daar beoogde vernieuwingen stuiten op een CAO die alle jonge talenten doet uitwijken naar flex-contracten met commerciële partijen. Tegelijkertijd is de beroepsgroep ook sterk verbreed; de medewerkers van de NOs, het RTL-nieuws en 'Hart van Nederland' vallen allemaal onder de noemer journalist. Daarmee wordt het de vraag of het uittekenen van een 'gemiddelde journalist' door de grotere variëteit in het medialandschap wel een zinvolle grondslag is voor een beroepsorganisatie die de toon moet zetten voor de maatschappelijke verantwoording. Bovendien vindt die professionalisering plaats in een tijd waarin de commercialisering de traditionele positie van journalisten (en van hoofdredacteuren meer in het bijzonder) onder druk zet (Prenger en De Vree 2004).

\subsubsection{COMMERCIALISERING EN CONCURRENTIE}

Mede dankzij technologische ontwikkelingen, de toenemende druk van zowel abonnees als adverteerders en de introductie van commerciële partijen in het bestel doen overwegingen van winst en verlies zich steeds sterker voelen in het medialandschap. Binnen het domein van de berichtgeving is een soort dubbele veldslag aan de gang; om de lezer en kijker enerzijds en om de inkomsten vanuit reclame anderzijds. Een gezaghebbende mediawetenschapper formuleert het scherp voor de Amerikaanse situatie: "De focus van de journalistiek is verschoven van datgene wat de gemeenschap nodig heeft naar datgene wat de adverteerder wil” (Ben Bagdikian, geciteerd in Prenger en De Vree 2004: 122). Zeker in die delen van het medialandschap waar de adverteerder de dienst uitmaakt (bij bladen zonder abonnees, bij omroepen zonder leden) ontstaat wellicht een nieuwe noodzaak om de onafhankelijkheid van de berichtgeving te beschermen. Het behoeft geen uitleg dat ook deze twee 'veldslagen' met elkaar samenhangen. Het medialandschap, in de eerdere panelen nog sterk bezet door stabiele en relatief rolvaste instituties (met sterk positieve externe effecten op het functioneren van politieke 
democratie) lijkt zich steeds meer te ontwikkelen als een markt als alle anderen. Commercialisering en een publieke rol sluiten elkaar niet uit, maar liggen ook zeker niet in elkaars verlengde. De druk is volgens Wijfjes echter erg hoog:

"De verviervoudiging van de journalistieke beroepsgroep en de explosie van het aantal mediakanalen sinds de jaren tachtig wakkerden een concurrentieslag aan die zelfs de kritisch geëngageerde journalistiek onder sterke commerciële invloed bracht” (2004: 507).

De culturele hegemonie in de wereld van het nieuws is volgens hem bovendien overgegaan van het klassieke dagblad naar de nu zo dominante televisie, hetgeen de vluchtigheid en emotionaliteit in de berichtgeving versterkt. In een dergelijke turbulente omgeving is het niet eenvoudig om de journalistieke functies in de democratie (informatie, platform en kritische functie) zuiver te houden.

Dit heeft de bakens voor zowel de journalistiek als de politiek aardig verzet. De journalist moet vaker over zijn schouder kijken, jaagt op de scoop waar zijn talloze collega's ook op uit zijn, en moet in meer algemene termen leuker, onderhoudender en scherper zijn dan de anderen om de zap-grage kijkers en lezers bij de les (of: geamuseerd) te houden. Voor de politicus kan nagenoeg hetzelfde verhaal opgehangen worden; ook deze moet scherp, to the point en onderhoudend zijn, wil hij of zij het oog van de camera en de kiezer vasthouden. De snelheid van nieuwsgaring is bovendien sterk opgevoerd; de televisie kan grote verhalen (breaking news) op elk gewenst moment het publieke domein inbrengen, maar ook de kleinere verhalen verschijnen in recordtempo op het internet. De druk van de concurrentie en de snelheid van het medium hebben ertoe geleid dat journalistiek steeds meer wordt beschreven in termen van horserace-verslaggeving, packjournalism, mediahypes, frames en medialogica (bijv. RMO 2003; Bardoel 2003; Van Praag 2003). Amerikaanse onderzoekers spraken al in de jaren tachtig over de 'melodramatische imperatief' die steeds pregnanter inwerkt op met name de politieke verslaggeving. Complexe zaken moeten simpel worden voorgesteld, en bij de daartoe onvermijdelijke reductieslag is er een sterke voorkeur voor de koppeling van verhalen aan personen (Nimmo en Combs in Witteveen 1992).

Empirisch onderzoek naar de mate waarin dergelijke vormen van competitie en commercie de wereld van de voor democratie en politiek relevante delen van de mediamarkt binnendringen en domineren is nog weinig voorhanden. Maar dat boodschap en medium steeds meer van elkaar kunnen worden ontkoppeld, dat er tal van nieuwe mediamarkten ontstaan en dat de 'boodschap' steeds meer op verzoek en tegen betaling bij de consument-burger (de eerdergenoemde trend van commodificering) kan worden bezorgd lijkt duidelijk. Ook zullen er nieuwe partijen zijn die invloed krijgen op de mate waarin informatievoorziening publiek (openbaar, toegankelijk) blijft of meer privaat van karakter wordt. Mondiale mediaondernemingen dringen de Europese mediamarkt binnen, en zullen de markten (ook de nichemarkten) graag opzoeken. De techniek geeft hun tal van mogelijkheden voor nieuwe business. 


\subsubsection{VERSPLINTERING VAN HET PUBLIEKE DOMEIN}

Het publieke domein waar pers, politiek en de burger elkaar ontmoeten, is als gevolg van technologische ontwikkelingen en verscherpte concurrentieverhoudingen van vorm en karakter veranderd. Technologische ontwikkelingen hebben schaarste van aanbod van mediaproducten een bijna achterhaald begrip gemaakt in het medialandschap. Journalistiek, publiek debat en meningsvorming zijn te vinden op een potentieel ongelimiteerd aantal televisiekanalen en ook op het internet is debat en informatie in alle smaken voorhanden. Het publieke domein zoals zich dat in het Nederlandse medialandschap manifesteert is dus aanzienlijk veranderd en versplinterd. Het is internationaler geworden door het grote aantal zenders en daarmee op sommige punten ook minder Nederlands. De recente oorlog in Irak werd door Nederlanders van dag tot dag gevolgd, maar niet per se op dezelfde kanalen. Nederland drie moet concurreren met de commerciële zenders, maar ook met CNN en Al Jazeera. Dat op de twee laatste zenders bijna twee verschillende oorlogen te volgen waren, maakt dat het publieke domein enerzijds verrijkt wordt (in termen van pluriformiteit), maar anderzijds ook veel polemischer en verhitter is. Amerikaanse en Arabische discoursen dringen via de kabel en de schotel het Nederlandse discours binnen en zorgen voor nieuwe botsingen.

Ook binnen dat deel van het medialandschap dat zich in hoofdzaak op Nederland richt is de versplintering groot. Twintig jaar geleden haalde het achtuurjournaal nog moeiteloos vier miljoen kijkers per avond, nu is één miljoen kijkers genoeg om het een 'goede dag' te noemen. Nederlanders halen hun publieke informatie dus steeds minder uit één, gezamenlijke plaats. Daarmee is het publieke domein versnipperd maar ook hier weer pluriformer geworden; politiek is bijvoorbeeld iets anders binnen de context van 'Hart van Nederland', 'Barend en Van Dorp' of 'Den Haag Vandaag'. Toch is het allemaal publiek domein en wordt het bekeken door (verschillende groepen) burgers en kiezers. Deze versnippering legt een stevige claim op de Nederlandse politicus die niet langer meer kan volstaan met een Haags standaardverhaal dat door Haagse journalisten doorvertaald wordt. Hij moet het zelf uit gaan leggen op een manier die bij de verschillende delen van het publiek past, daarbij spelen ook elementen als persoonlijke stijl en uitstraling een steeds grotere rol (Van Praag 2003; Van Zoonen 2002). Gek genoeg staat met de enorme toename van het aanbod van informatie juist de informatiefunctie van de journalistiek in de democratie onder druk. Door de enorme toename van het media-aanbod in den brede is het veel makkelijker geworden om je als mediaconsument geheel af te keren van de aangeboden informatie. Voor wie dat wil is het zeer eenvoudig geworden om een mediawereld te creëren waarin journalistieke informatie geen rol meer speelt (zie ook de bijdrage van Pattyn in deze bundel).

Het karakter van het publieke domein lijkt ook veranderd te zijn. Strijd lijkt een veel belangrijkere plaats in te nemen dan vroeger: het domein is steeds meer een arena geworden. Natuurlijk speelden personen ook in vroeger tijd een belangrijke rol, maar de impact van de huidige beeldcultuur lijkt het belang van personen 
verder te versterken. De media onderling jagen op de scoop, de journalisten strijden om de beste gast of het beste interview, de verslaggevers jagen en jutten politici op en verleiden ze tot politiek meer gewaagde uitspraken. Politici doen op veel punten hetzelfde en willen de concurrenten aftroeven, willen optreden in de best bekeken programma's en spelen journalisten en programmamakers genadeloos tegen elkaar uit als het ze zo uitkomt. Jensma, de hoofdredacteur van het NRC, sprak onlangs over de noodzaak paal en perk te stellen aan wat hij omschreef als het 'mediagedrag' van politici. Die beschouwen de media als een podium voor de eigen ambities, waarvan de regie zoveel mogelijk in eigen handen moet blijven. De studio of de vergaderzaal van de Tweede Kamer: de grenzen vervagen. De vice-voorzitter van de Raad van State signaleerde in het jaarverslag van 2003 min of meer hetzelfde probleem, zij het vanuit de tegenovergestelde invalshoek.

“De politieke controle wordt afhankelijk van de media en hun prioriteiten. De journalisten worden beschouwd als stem van de 'misnoegde burgers'; belanghebbende deelnemers in plaats van kritische waarnemers. $\mathrm{Zij}$ worden het richtsnoer voor de politieke agendering en (vervolgens) voor het bestuurlijk handelen" (Raad van State 2004: 18).

Er is bovendien zoiets als een wapenwedloop gaande. Het Binnenhof lijkt nagenoeg door journalisten belegerd: in 1998 waren er tweehonderd parlementair journalisten geaccrediteerd, de concurrentie kan dus niet anders dan moordend zijn (Van Vree et al. 2002; Prenger en Van Vree 2004). De overheid heeft daar inmiddels een klein legertje tegenover gesteld. Anno 2002 lopen er in Den Haag voor een totaal aan $158,5 \mathrm{fte}^{6}$ aan persvoorlichters bij de ministeries rond die tot taak hebben het beleid op een zo gunstig mogelijke manier over het voetlicht te brengen. Volgens een rapport van Berenschot (2003) bedraagt de totale omvang van de communicatiefuncties bij alle ministeries exclusief Algemene Zaken, 764 arbeidsplaatsen. Daarbij mogen nog 201 communicatiemedewerkers van de Rijksvoorlichtingsdienst opgeteld worden. De Staatscourant voldoet dus allang niet meer. Deze cijfers zijn wellicht ook indicatief voor de onderlinge verhoudingen tussen journalistiek en bestuur waarin wederzijds wantrouwen en achterdocht steeds belangrijkere ingrediënten geworden zijn. Een andere vraag is hoe deze strijd zich verhoudt tot de burger, waaraan beide professies op hun eigen manier verantwoording schuldig zijn.

\subsubsection{POSITIE VAN DE BURGER-CONSUMENT}

Van Praag (2003: 158) stelt dat politiek en journalistiek tot op zekere hoogte in hetzelfde schuitje zitten. Beide opereren in een vragersmarkt en hebben te maken met kiezers en consumenten die minder trouw en minder voorspelbaar zijn geworden: "Zappende kijkers en zwevende kiezers hebben in hun gedrag zeer veel met elkaar gemeen.” De vraag intussen is wie er eigenlijk zweeft: de kiezer of de politicus. Dat 'de' burger de verhoudingen tussen politiek en journalistiek met wantrouwen beziet, is de laatste tijd op vele manieren gebleken. In de media- 
aandacht rond de politieke opkomst van Pim Fortuyn vermoedde een deel van de lezers en kiezers een te intieme symbiose tussen politiek en bestuur, die zij beschuldigden van demonisering van de opkomende politicus, met alle bekende electorale gevolgen van dien. Het model van de strijd tussen journalistiek en de gevestigde politiek wordt echter ook niet altijd gewaardeerd. De ongemeen harde strijd tussen de regering-Blair en de BBC over het hoofd van wapenexpert dr. Kelly heeft in ieder geval één duidelijke uitkomst gekregen: het toch al lage vertrouwen van de Engelse burger in de media is tot onder het vriespunt gezakt. Auntie Beeb is flink gedeukt. Het vertrouwen van de burger in de media werd in vorige panelen wellicht makkelijker en meer vanzelfsprekend gegeven: aan de eigen krant werd binnen de zuil nauwelijks getwijfeld en de journalist was misschien ook betrouwbaarder toen het proces van losmaken van de zuil een waakhond van hem maakte. De ene vanzelfsprekendheid werd door de andere vervangen: de verwachtingen ten aanzien van de rol van de journalist waren duidelijk. Vanaf het moment dat de journalist steeds meer zelf onderdeel van de arena werd en het strijdperk betrad, is dat al veel minder vanzelfsprekend en is het vertrouwen moeizamer geworden. In dit proces zijn ook de journalistieke functies in de democratie dichter tegen elkaar gekropen, tot op het punt dat ze moeilijk ontwarbaar geworden zijn. Het lijkt soms wel of de kritische en de platformfunctie in de informatiefunctie zijn gekropen. Met enig cynisme merkte minister Donner van Justitie tegenover een gehoor van journalisten hierover onlangs het volgende op:

"Symptomatisch is dat mijn betogen in de Kamer, als zij worden afgedrukt, op de opiniepagina staan, terwijl wat de verslaggever ervan vindt als nieuws op de voorpagina staat. Begrijp me goed. Ik ben niet verongelijkt, ik vind de opiniepagina een groot goed. Maar het doet wel de vraag rijzen wat het nieuws is en wat de mening" (Donner 2004).

Ook in de journalistiek staat het thema van de objectiviteit van de informatiefunctie ter discussie (Van Vree 2004). Pieter Broertjes, voorzitter van het genootschap van hoofdredacteuren, bepleitte in de jaarlezing van 2004 dat kranten dat vertrouwen beter kunnen claimen op basis van een duidelijk kenbaar gemaakte identiteit dan op basis van een mythische journalistieke objectiviteit:

"Journalistieke organisaties, onontbeerlijk voor een sterke democratie, moeten uit hun schulp kruipen en beter over het voetlicht brengen wie ze zijn en hoe ze werken. Lezers, kijkers, luisteraars zijn niet dom en vermoeden toch wel een journalistieke voorkeur en maatschappelijke agenda. Voor de draad ermee, zeg ik met mijn collega Jensma, en weg met het professionele neutralisme!”

Bardoel (2003: 8) haalt Splichal aan die signaleert dat de uitingsvrijheid, die in de democratie zo centraal staat, in de loop der tijd als het ware is weggehaald bij de burger en is overgedragen aan media-instituties, met alle gevolgen van dien. Wellicht dat de boodschap van de afgelopen jaren is dat de burger die uitingsvrij- 
heid deels weer aan het terughalen is. Processen van ont- en deïnstitutionalisering gaan hand in hand met een belangrijkere rol van zelfbewuste individualisering, die bijdraagt aan maatschappelijke verhoudingen waarin vertrouwen niet meer voor eeuwig, vanzelfsprekend en zonder voorwaarden vooraf wordt gegeven. Anderzijds is er het fenomeen van de hype en de emotie, die zich soms lastig verdragen met het door individualisering veronderstelde beeld van de bewuste en zelfstandig kiezende burger.

In een wereld met veel keus en relatief kleine verschillen tussen de keuzemogelijkheden heeft de burger en mediaconsument bovendien een flinke hoeveelheid macht in handen gekregen. Die macht is afhankelijk van het moment en nooit individueel, maar wordt wel degelijk gevoeld. Politici hoeven maar terug te denken aan de verkiezingen van mei 2002, en journalisten en programmamakers komen de macht van de burger tegen in kijk- en oplagecijfers. Zoals de journalistiek (in naam van de burger) in een vorig paneel het paternalisme van de politiek en zuilen aanvocht, vecht 'de' burger nu op vele manieren het paternalisme van politiek en journalistiek aan. Wellicht zou je zelfs kunnen zeggen dat de burger, in navolging en met behulp van de journalistiek, nu ook zelf de arena ingeklommen is.

\subsection{EEN NIEUW PANEEL, EEN NIEUW PROFIEL?}

In het voorgaande hebben we geprobeerd de metafoor van de schuivende panelen te gebruiken om de verschuivende achtergrond van het functioneren van de media en de journalistiek te duiden. Zonder dat er sprake is van een zeer dwingende tekening, is het wel mogelijk om te zien hoe de meer algemene maatschappelijke verhoudingen doorwerken in positie en rol van de media, meer in het bijzonder de journalistiek. Van trouwe verslaggever naar kritische waakhond: het zijn natuurlijk ideaaltypische profielen, die in de alledaagse werkelijkheid voortdurend worden opgemengd. Wat zou het beeld tegen de achtergrond van het zich nu ontwikkelende paneel worden? De vraag dringt zich daarbij overigens op of het op grond van de hierboven beschreven ontwikkelingen in de relevante omgeving van de media nog wel mogelijk is om te spreken van een paneel zoals we het kenden uit de voorbije tijd. Het zou wel eens zo kunnen zijn dat de veranderingen vergeleken met het vorige 'paneel' er vooral in bestaan dat het tekenen van één en bovendien een eenduidig paneel op basis waarvan een vanzelfsprekende en eenduidige rol van media en journalistiek te benoemen en verankeren is, niet langer mogelijk is. De versplintering van het publieke domein en de door commercialisering bevorderde heterogenisering van de 'journalistieke' professie zijn wellicht geen kenmerken van de overgang naar een nieuw paneel, maar eerder een onrustig onderdeel van het nieuwe paneel zelf. Een constatering die voor zowel het functioneren van de media als het functioneren van de democratie van betekenis kan zijn. Wijfjes stelt dat de journalistiek en de maatschappij elkaar op dit punt spiegelen: 
"De journalistiek is, net als de samenleving die ze weerspiegelt, in transitie. Onafhankelijkheid, objectiviteit, zorgvuldig taalgebruik, afstandelijkheid en geëngageerd waarheidsstreven hebben duidelijk aan belang ingeboet. Interactiviteit, beeldbaarheid, vrijblijvend engagement, tijdelijke emotionele binding en snel wisselende persoonlijke keuzes zijn juist belangrijker geworden. In die dynamische, postmoderne cultuur staan betrouwbaarheid, geloofwaardigheid en verantwoordelijkheid weliswaar onder druk, maar het is toch niet te verwachten dat ze als kernwaarden snel en volledig opgegeven zullen worden" (Wijfjes 2004: 512).

Vanuit dit perspectief zou het debat moeten gaan over de toekomstige rol van de media en hun verhouding tot de politiek, en voorbij de wat eendimensionale en ook niet bijzonder vruchtbare discussies over machtsverhoudingen moeten kijken. Het moet wel over macht gaan, maar dan macht begrepen als vermogen en mogelijkheid om de onomstreden rol van de media als voorwaarde en verwerkelijking van democratie opnieuw te ontwikkelen tegen de achtergrond van ingrijpende veranderingen. De functies die de journalistiek in de democratie dient te vervullen, staan onder druk en lijken ook steeds meer vermengd te worden. Met name de informatiefunctie staat onder druk, enerzijds van de mogelijkheden van burgers om zich in hun mediagedrag aan informatie te onttrekken en anderzijds van een vermenging met de andere meer opiniërende functies van het platform en het kritisch volgen van de elite. De discussie moet worden gericht op de vraag hoe de huidige onmacht van de media, in termen van het vermogen om het maatschappelijke debat te voeden en te prikkelen, moet worden beoordeeld tegen de achtergrond van het bredere decor van de huidige tijd. Daarbij komen bij uitstek de beroepsgroep en de burger zelf in beeld; binnen een democratisch bestel past de overheid immers terughoudendheid.

De vraag kan worden gesteld of het tegen die verwarrende achtergrond van een heterogeen en veranderlijk maatschappelijk decor nog wel goed mogelijk is om de ook nu al kwetsbare processen van professionalisering en institutionalisering van de beroepsgroep nieuwe impulsen te geven. Wellicht dat de differentiatie en de heterogeniteit in de rollen en verantwoordelijkheden die journalisten en andere mediawerkers ontwikkelen en krijgen toebedeeld, reden is om professionalisering niet uitsluitend op het niveau van de beroepsgroep als geheel te ontwikkelen, maar daarin meer variëteit te bevorderen. Het zou wel eens zo kunnen zijn dat mechanismen van verantwoording en ethiek meer op het niveau van de mediaorganisaties (kranten, omroepen) moeten worden ontwikkeld, en relatief minder op het niveau van de beroepsgroep als geheel.

Wij zien de tegenstrijdigheden: institutionalisering op het niveau van de beroepsgroep lijkt meer dan ooit noodzakelijk maar tegelijkertijd steeds minder makkelijk gezien de ontwikkelingen binnen en in de omgeving van de beroepsgroep. Mechanismen van aanspreekbaarheid en verantwoordelijkheid die nu op het niveau van de beroepsgroep zijn neergelegd, zijn wellicht beter op hun plaats op het voor burgers en consumenten minder abstracte en meer aanspreekbare 
niveau van de afzonderlijke mediaorganisaties. Die kunnen dan ook vormen kiezen die passen bij het medium: een krant zal anders opereren dan de redactie van een internetsite, de televisie weer anders dan de radio. Binnen de dagbladpers zijn de eerste initiatieven opgestart en deze verschillen ook al onderling. Sommige kranten hebben een ombudsman ingesteld en in andere kranten neemt de hoofdredactie de handschoen van de lezer op (Bardoel en D’Haenens 2003). Verschillende mediaorganisaties zetten dus eigen accenten inzake verantwoording en professionaliteit. Dat heeft niet alleen met het medium te maken, maar ook met de rol die een organisatie zich toeëigent of die zij krijgt toegeschreven in het maatschappelijke debat. Of moet er toch maar gewerkt worden aan een algemeen recht op weerwoord dat ongeacht het medium de positie van de mediaconsumenten versterkt?

Gezien de vele verschuivingen en de enorme toename van het aanbod en de aanbieders komt in onze ogen vooral ook de positie van de burger als mediaconsument steeds meer in beeld. De mogelijkheden van de burger om op een verantwoorde manier met de veelheid aan informatie om te gaan en om daarop te reageren, vraagt tegen de achtergrond van het nieuwe paneel wellicht meer de aandacht dan de vrijheid van mediaproducenten die door de toegenomen (technologische) middelen sowieso gewaarborgd lijkt. De toerusting van de burger om mediaproducenten op hun plicht te wijzen en ze via procedures en andere mechanismen ter verantwoording te roepen, is echter maar een kant van de medaille. Het actieve recht van de burger brengt ook zo zijn plichten met zich mee. Het gaat om meer dan het recht van de burger om de fouten bij de ander te benoemen, hij draagt ook zelf verantwoordelijkheden (of zou die meer moeten dragen). Hamelink (2000: 40o) wijst ook op deze dubbelzijdigheid: "Media consumption should be viewed, like professional media performance, as a social practice which implies moral choices and the assumption of accountability for these choices". Zeker in een tijd dat de democratie zich lijkt te bewegen in de richting van een toeschouwersdemocratie (De Beus 2001), lijkt het gepast erop te wijzen dat het recht op meningsuiting voor burgers steeds meer gepaard zou moeten gaan met een plicht tot meningsvorming. Dat vraagt uiteraard om een medialandschap waarin het vervullen van die plicht ook mogelijk is, en om een debat over democratie waarin ook de verantwoordelijkheid van de burger zelf weer meer als wezenlijke voorwaarde voor een vitale democratie wordt onderkend. 


\section{NOTEN}

1 Dit paper werd in een eerste versie gepresenteerd ten behoeve van een seminar tijdens de WRR-lecture op 27 november 2003. De auteurs danken Mark Elchardus, Philip van Praag, Jan Kleinnijenhuis en Rene Cuperus voor hun commentaar op een eerdere versie.

2 De tabloids Bild, Bild am Sonntag en de televisie.

3 Zie voor een empirische kanttekening bij deze veronderstelling ('de politieke agenda heeft een onverminderd grotere invloed op de media-agenda dan omgekeerd'), Kleinnijenhuis, 2003: 203.

$4 \quad$ Philip van Praag maakte dit onderscheid op de WRR-workshop 'Media en democratie' in Den Haag op donderdag 13 mei 2004.

5 Prenger en de Vree wijzen er in dit verband terecht op dat het niet slechts gaat om commercialisering, maar veeleer om de door verdergaande mogelijkheden van digitalisering (en daarmee verbonden vormen van 'conditional access') bevorderde trend van commodificering van journalistieke producties.

6 Mondelinge informatie secretariaat Voorlichtingsraad (Rijksvoorlichtingsdienst). 


\section{LITERATUUR}

Bardoel, J. (2003) Macht zonder verantwoordelijkheid? Media, mediabeleid en de kwaliteit van de openbare informatievoorziening, Inaugurele rede, Katholieke Universiteit Nijmegen.

Bardoel, J. en L. d'Haenens (2003) 'Media en maatschappelijke verantwoordelijkheid. Van theorie naar praktijk', in RMO (2003) Medialogica, Advies 26. Den Haag.

Beus, J. de (2000) 'Veerkracht en misnoegen in de duurzame democratie: de kernstaten sinds 1989', blz. 33-59 in F. Becker et al. (red.) De toekomst van de democratie. 21ste Jaarboek voor het democratisch socialisme, Amsterdam: wBS/De Arbeiderspers.

Berenschot (2003) Nulmeting structuur en werkwijze directies communicatie, Berenschot.

Bovens, M. (2003) De digitale republiek. Democratie en rechtstaat in de Informatiemaatschappij, Amsterdam: Amsterdam University Press.

Brants, K. (2002) ‘Naar een mediacratie?’, in J. van Holsteyn en C. Mudde (red.) Democratie in verval, Amsterdam: Boom.

Broertjes, P. (2004) Jaarrede tijdens de 45ste jaarvergadering van het Nederlands Genootschap van Hoofdredacteuren, 16 april 2004 in Hotel Tjaarda Oranjewoud in Friesland.

Cuilenburg, J. van \& D. McQuail (2003) 'Media policy paradigm shifts. Towards a new communications policy paradigm', European Journal of Communication, Vol. 18(2): 181-207.

Deuze, M. (2002) Journalists in the Netherlands. An analysis of the people, the issues and the (inter)national environment, Amsterdam: Aksant.

Donk, W.B.H.J. van de (2000) 'Nieuwe technologie, nieuwe economie, nieuwe overheid?’, blz.350-378 in R.M.Weehuizen (red.) Toekomst@werk.nl. Reflecties op economie, technologie en arbeid, Den Haag: STT.

Donner, P.H. (2004) Toespraak naar aanleiding van het NVJ-onderzoek naar de persvrijheid in Nederland, http://villamedia.nl/n/nvj/nieuws/2004mei3_donner.shtm, 3 mei 2004.

Elchardus, M. (2002) De Dramademocratie, Tielt: Lannoo.

Elshtain, J.B. (1997) ‘The Displacement of Politics', in J.A. Weintraub \& K. Kumar (eds.) Public and Private in Thought and Practice: perspectives on a grand dichotomy, Chicago: University of Chicago Press.

Geerardyn, A. en G. Fauconnier (2000), 'Hybrid forms in marketing communication: The increasingly fuzzy boundaries between information and commerce', blz. 329-355 in B. Pattyn (red.) Media Ethics. Opening Social Dialogue, Leuven: Peeters.

Hamelink, C. (200o) 'Ethics for media users', blz. 393-401 in B. Pattyn (ed.) Media Ethics. Opening Social Dialogue, Leuven: Peeters.

Hendriks, F. en A. Korsten (2001) 'Media in de politieke democratie', Bestuurskunde, 10 nr. 7: 278-291.

Jensma, F. (2003) Zelfreflectie en zelfkritiek in de media, Schlichting college, 12 November 2003, Nijmegen.

Kleinnijenhuis, J. (2003) 'Het publiek volgt media die de politiek volgen', in RMO (2003) Medialogica. Over het krachtenveld tussen burgers, media en politiek, Advies 26, Den Haag: 153-211. 
Lecomte, P. (1993) Communication, Télévision et Démocratie, Lyon: Presses Universitaires de Lyon.

Mommaas, H. (2003) Vrije tijd in een tijdperk van overvloed, Amsterdam: Dutch University Press.

Norris, P. (2000) 'The Impact of Television on Civic Malaise', in S.J. Pharr, R.D. Putnam (eds.) Disaffected Democracies. What's troubling the trilateral countries? Princeton: Princeton University Press.

NVJ (2003) Discussienota: hoe verder met de journalistiek?, 15 april 2003.

Praag, Ph. van (2003) 'Partijen in de mediacratie', in F. Becker, M. Sie Dhian Ho, W. van Hennekeler en B. Tromp (red.) Politieke partijen op drift, Amsterdam: wBS/De Arbeiderspers.

Raad van State (2004) Jaarverslag 2003, Den Haag: Raad van State.

Ramonet, I. (2003) 'Le cinquième pouvoir' in Le Monde Diplomatique, Octobre 2003: 1, 26. RMO (2003) Medialogica. Over het krachtenveld tussen burgers, media en politiek. Advies 26, Den Haag.

ROB (2003) Politiek en media. Pleidooi voor een LAT-relatie, Den Haag.

Oosterbaan, W. (2003) Het programma van de krant. Triomf en tekortkomingen van het Journalisme, Inaugurele Rede Erasmus Universiteit Rotterdam.

Prenger, M., F. van Vree (2004) Schuivende grenzen. De vrijheid van de journalist in een veranderend medialandschap, Uitgave van de Nederlandse Vereniging van Journalisten (s.1.).

Paulussen, S. (2004) Journalistiek@Internet.be. Een studie naar de mogelijkheden en gevolgen van internet voor de journalistieke nieuwsgaring en nieuwsproductie, Dissertatie Universiteit Gent, Faculteit der Politieke en Sociale Wetenschappen.

Rosenthal, U. (2001) 'De media: machtsuitoefening en controle op de macht', Bestuurskunde, 10 nr. 7: 292-298.

Schuyt, K. (1986) 'De verzorgingsstaat met het oog op morgen', in K. Schuyt en R. van der Veen (red.) De verdeelde samenleving, Stenfert Kroese: Leiden/Antwerpen.

Sociaal Cultureel Planbureau (2002) Sociaal en cultureel rapport 2002. De kwaliteit van de quartaire sector, Den Haag: Sdu.

Vliet, H. van (2001) Where Television and Internet meet. . New experiences for rich media, Paper Telematica-instituut Technische Universiteit Twente, (www.telin.nl).

Vliet, H. van, N. van Stelten (2001) Next Generation Television, Telematica Instituut, Technische Universiteit Twente.

Vree, F. van, C. Vos, H. Wijfjes en J. Bardoel (2003) 'Het ontstaan van een politiek-publicitair complex 1960-2002', voorstudie bij RMO-advies 26: Medialogica. Den Haag: RMO.

Vree, F. van (2004) De wereld als theater. Journalistiek als culturele praxis, Oratie Universiteit van Amsterdam, 18 maart 2004.

Wijfjes, H. (2004) Journalistiek in Nederland 1850-20oo. Beroep, cultuur en organisatie, Amsterdam: Boom.

Witteveen, W.J. (1992) 'De Journalist als burger', in H.R. van Gunsteren, P. den Hoed (red.) Burgerschap in praktijken (deel II). Den Haag: Sdu.

Zoonen, L. van (2002) 'Plezier en politiek in de entertainment-samenleving', Socialisme $\mathbb{\&}$ Democratie 2002, 12: 22-30. 


\title{
12 SEMI-DIRECTE CONSENSUSDEMOCRATIE. ZES VOORSTELLEN VOOR DEMOCRATISCHE INNOVATIE EN VERDIEPING IN NEDERLAND
}

\author{
A. Krouwel
}

"No act (of representatives) can be law, unless it has been ratified by the people in person: and without that ratification nothing is a law."

(J.J. Rousseau)

\subsection{ALLES VOOR HET VOLK, ZONDER HET VOLK}

\subsubsection{INSTITUTIONELE INERTIE}

Nederland is vanuit een politiek-institutioneel perspectief een oerconservatief land. Ons politieke systeem lijkt een bijna 'natuurlijke' neiging tot conservatisme en inertie in zich te dragen; de belangrijkste politieke instituties bestaan al sinds de Franse overheersing en de belangrijkste innovatie van ons democratisch bestel dateert al weer van de periode van 1917-1919, waarin uiteindelijk het algemeen kiesrecht en een proportioneel kiesstelsel werden ingevoerd (Aerts et al. 1999). Diverse regeringscommissies, alle discussies over verandering van het kiesstelsel of invoering van een referendum en viervoudige kabinetsdeelname van D66 hebben hier niets aan kunnen veranderen. De Nederlandse politieke elite blijkt niet bereid om de politieke instituties en besluitvormingsprocedures aan te passen aan de nieuwe tijd, terwijl een meerderheid van de bevolking al langere tijd voorstander is van politiek-institutionele hervormingen (Andeweg 1989; SCP 2003). In de zeer dynamische twintigste eeuw waarin de Nederlandse samenleving fundamentele veranderingen heeft ondergaan, hebben slechts vier kleine 'amendementen' plaatsgevonden in het institutionele raamwerk van de consensusdemocratie: in de jaren zestig en zeventig de invoering van het fenomeen 'inspraak' en de komst van de Ombudsman (een Zweedse uitvinding), in de jaren negentig het raadgevende referendum op lokaal niveau (nu ruim veertig keer toegepast in Nederland) en vormen van zogeheten interactieve beleidsontwikkeling (Denters et al. 2003; Edelenbos en Monnikhof 2001). Deze vier amendementen zijn echter geen daadwerkelijke democratische innovaties, maar instrumenten die naadloos aansluiten bij de vrijwel onveranderlijk paternalistische houding van politici en bestuurders in ons land (Duyvendak en Krouwel 2000). Door vele auteurs wordt dan ook een democratisch tekort van de Nederlandse politiek gesignaleerd (Gladdish 1972; Glastra van Loon 1998; Jurgens 1991). Naast deze institutionele inertie en onwilligheid tot modernisering heeft de politieke elite een paternalistische houding ten opzichte de bevolking, die bitter weinig invloed kan uitoefenen op de selectie van machtshebbers. 


\subsubsection{PATERNALISTISCHE EN GESLOTEN BENOEMINGSCULTUUR}

Politicologen die Nederland beschrijven, wijzen meestal als eerste op het elitaire karakter van de politieke besluitvorming en politieke rekrutering in ons land en op de politieke passiviteit van de bevolking (Daalder 1974; Lijphart 1968). De voormalige Leidse hoogleraar Hans Daalder karakteriseerde de Nederlandse bevolking als 'lijdzaam' (Daalder 1974, 1995). De beroemdste 'Nederlandse' politicoloog, Arend Lijphart, stelt eveneens dat de passieve houding van de bevolking een van de fundamentele kenmerken is van de Nederlandse consensusdemocratie (Lijphart 1968; zie ook McRea 1974; Pennings 1991; Van Praag 1993). Deze specifieke politieke cultuur is het resultaat van de historische ontwikkeling van de Nederlandse natie, die lange tijd diep verdeeld was langs godsdienstige scheidslijnen. De sociale en politieke organisatie van de verschillende godsdienstige groepen weerspiegelde zich in scherp afgebakende 'zuilen'. Deze verzuiling bleek krachtig genoeg om nieuwe emancipatiebewegingen, zoals de arbeidersbeweging, in te kapselen binnen deze traditie. In het eerste decennium van de twintigste eeuw verscherpten de verhoudingen tussen de zuilen zich, met name ten aanzien van de ontwikkeling van een verzorgingsstaat (de 'sociale kwestie'), de vrijheid van onderwijs en het kiesstelsel (Bosmans 1990). Om de scherpe politieke conflicten tussen de christelijke partijen, de sociaal-democraten en de liberalen te 'paciferen' is een zeer kenmerkende politieke praktijk en cultuur in Nederland ontstaan die door de politicoloog Arend Lijphart (1968, 1984, 1999) wordt gekenmerkt als een consensusdemocratie.

Volgens Lijphart wordt onze politieke cultuur, naast de hoge mate van passiviteit van de bevolking, gekenmerkt door depolitisering, pragmatisme, corporatisme en een gesloten bestuurscultuur. Dominant is een zakelijke en resultaatgerichte houding bij politiek overleg en doorgaans vermijdt men scherpe ideologische conflicten. Om de tegenstellingen niet op de spits te drijven worden gevoelige kwesties 'gedepolitiseerd' door overleg achter gesloten deuren, geheimhouding, de vertaling van conflicten in technocratische of juridische vraagstukken of uitstel van beslissingen om 'de zaken nog eens goed te bestuderen'. Een groot deel van de politieke discussies vindt niet plaats in het openbaar maar in fractiekamers en coalitieoverleg. Deze geheimhouding dient ertoe om het accommodatieproces tussen de verschillende visies en belangen af te schermen van overmatige publiciteit. Bij alle actoren binnen de consensusdemocratie bestaat doorgaans een hoge mate van verdraagzaamheid en pragmatische aanvaarding van de politiek-ideologische verschillen tussen maatschappelijke groepen. In plaats van pogingen om een ander te overtuigen van het eigen gelijk tracht men eerder werkbare compromissen te vinden die voor iedereen aanvaardbaar zijn.

Deze belangenafstemming geschiedt voornamelijk door middel van corporatistische overlegstructuren, waarbij de overheid bepaalt welke belangengroepen relevant genoeg zijn en als representatief kunnen worden beschouwd om deel te nemen aan het accommodatieproces. Deze belangengroepen zijn in hoge mate geïnstitutionaliseerd in de politieke besluitvorming, waarbij men doorgaans de 
middelen naar evenredigheid over de verschillende groepen tracht te verdelen (het principe van proportionaliteit). De verwevenheid van belangengroepen, politieke partijen en de staat heeft geleid tot vergaande specialisatie, bureaucratisering en verkokering van het ambtenarenapparaat, waardoor het besluitvormingsproces voor burgers ondoorzichtig en afstandelijk is geworden. Volksvertegenwoordigers stellen zich tijdens het besluitvormingsproces vaker op als vakdeskundigen dan als vertegenwoordigers of belangenbehartigers.

In de Nederlandse consensusdemocratie is de verhouding tussen de uitvoerende macht en wetgevende macht omgekeerd aan de democratische logica: in principe regeert de regering en de volksvertegenwoordiging intervenieert daarin minimaal. Politieke fracties committeren zich in vergaande mate aan coalitieafspraken die formeel worden vastgelegd in een gedetailleerd regeerakkoord (Timmermans en Andeweg 2000). Hierdoor is er sprake van een proces van toenemend monisme, waarin de uitvoerende macht en de volksvertegenwoordigers niet tegenover elkaar staan maar een 'kartel' vormen (Kirchheimer 1954; Krouwel 1999, 2003a).

Daaraan gekoppeld bestaat een sterke appointive culture in plaats van een elective culture voor de allocatie van politieke macht, waarbij slechts een minimum aan publieke ambten direct door het volk wordt gekozen (Andeweg en Irwin 2002). De uitvoerende macht vindt haar oorsprong weliswaar in de wetgevende macht, maar de volksvertegenwoordigers in het parlement spelen een ondergeschikte rol bij de personele invulling daarvan. Nog duidelijker is de benoemingscultuur terug te vinden in het grote aantal publieke ambten waar burgers geen enkele invloed op kunnen uitoefenen (burgemeesters, Commissarissen van de Koningin, voorzitter van de Algemene Rekenkamer, vice-voorzitter van de Raad van State, de Ombudsman, voorzitter van de publieke omroep, enz.).

\subsubsection{CRISIS VAN DE REPRESENTATIEVE DEMOCRATIE?}

In alle discussie van de afgelopen jaren is veelvuldig gewezen op deze institutionele en culturele gebreken van de Nederlandse representatieve democratie en op de problemen die voortkomen uit onze politieke cultuur en het institutionele conservatisme (Rosenthal 2002; Van Schie 2002). Vooral aan de inputkant van het politieke stelsel, daar waar de burgers hun politieke preferenties in het politieke systeem brengen, is een duidelijk legitimiteitsprobleem te signaleren. Dit legitimiteitsprobleem uit zich ten eerste in een vertrouwensbreuk tussen burgers en de belangrijkste instituties van de liberale democratie. Burgers zijn ontevreden over de, in hun ogen, geringe capaciteit van overheden om hun problemen op te lossen (Lawson en Merkl 1988; Pharr en Putnam 2000). Omdat politieke besluitvorming door politici steeds vaker wordt voorgesteld als 'het managen van de staat', bewandelen burgers steeds vaker de juridische in plaats van de politieke weg of zoeken zij 'buitenparlementaire' oppositie en actiemiddelen (Dekker 2002; Smets 2004; Dekker en De Hart 2004). Hierdoor komen burgers steeds meer tegenover de politiek te staan en worden zij cynisch. Het gevolg is 
een duidelijke afname van het vertrouwen bij burgers in democratische instituties als het parlement, het juridische systeem, de politie en vooral politieke partijen. ${ }^{1}$ Van alle politieke instituties genieten politieke partijen meestal het minste vertrouwen van burgers (Dalton en Wattenberg 2000: 265; Keman en Krouwel 2003).

Het legitimiteitsprobleem wordt eveneens zichtbaar in de vermindering van de deelname aan politieke besluitvorming. Hoewel Nederlandse burgers massaal aangeven geïnteresseerd te zijn in politiek, is de interesse in partijpolitiek duidelijk verminderd en verdwijnt hun binding met politieke partijen in een rap tempo. De participatie van burgers bij verkiezingen is afgenomen, er is een scherpe daling van het partijlidmaatschap en partijactivisme en we zien een sterke afname van identificatie met en steun aan de conventionele politieke partijorganisaties. ${ }^{2}$ Vooral bij zogenaamde second-order elections voor gemeenten, provincies en de EU is de opkomst sterk afgenomen (Reif en Schmidt 1980). Hoewel veel Nederlanders stabiel zijn in hun stemgedrag (Kolk 200oa: 95), bestaat er in Nederland eveneens een toenemend aantal kiezers dat niet alleen 'alterneert' tussen politieke partijen onderling, maar ook tussen wel en niet stemmen (Van de Meerendonk 1997; Aarts 200o). Een meer permanente exit-optie is steeds populairder geworden: het aantal constante thuisblijvers is toegenomen van zes à acht procent in de jaren zeventig tot ongeveer vijftien procent in de jaren negentig. Vooral diegenen die minder sterke bindingen hebben met maatschappelijke en politieke organisaties zijn weinig geneigd om deel te nemen aan een verkiezing. Ook opleiding, politieke interesse en politiek zelfvertrouwen zijn van invloed op verkiezingsdeelname (Aarts 2000: 59-70). Het lijkt erop dat een toenemend deel van de kiezers de keuze maakt om op specifieke institutionele momenten van politieke participatie af te zien. Dat wil niet zeggen dat ze volkomen politiek apathisch zijn of voor altijd verloren zijn voor het politieke proces. Tussen de vijf en tien procent van de thuisblijvers komt de volgende verkiezing weer op. We moeten deze trend dus niet overdrijven, maar wel constateren dat er een legitimiteitsprobleem bestaat. Sinds de afschaffing van de opkomstplicht in 1971 komt gemiddeld een kwart van het electoraat niet meer opdraven bij landelijke verkiezingen en het aantal niet-stemmers is nog veel hoger bij lokale, provinciale en Europese verkiezingen. Bij de Europese verkiezingen van 1999 en 2004 kwam respectievelijk slechts dertig en veertig procent van de kiesgerechtigden op.

Politieke participatie, politieke interesse en politiek vertrouwen van burgers is van wezenlijk belang voor het functioneren van een democratisch stelsel omdat de overheid daaraan haar legitimiteit ontleent. Hier komen we bij de fascinerende paradox van de moderne democratie zoals die wordt geschetst door de Amerikaanse politicoloog Robert Dahl (200o). Er is een toenemende mate van acceptatie en steun voor principes van de representatieve democratie, maar eveneens een toenemende ontevredenheid over het functioneren ervan en een toenemend wantrouwen ten aanzien van gezagsdragers en de belangrijkste instituties binnen het democratische stelsel, zoals politieke partijen. 
In Nederland is deze paradox duidelijk zichtbaar. Het overgrote deel van de Nederlandse bevolking koestert democratische opvattingen en volgens het Sociaal Cultureel Planbureau (SCP) is er meer politieke interesse bij burgers dan ooit tevoren (SCP 2003; Dekker en De Hart 2002; Praag en Uittenhoeve 1999). Er is eveneens een grotere bereidheid tot politieke actie en burgers hebben een groot politiek zelfvertrouwen (SCP 2003; SCP 1997; SCP 1994). Verder blijkt dat de vrijheid van demonstratie en protest door negentig procent van de bevolking wordt onderschreven. Een ruime meerderheid van de burgers heeft een positief oordeel over contacten met ambtenaren en is zeer tevreden over het daadwerkelijk functioneren van de overheid, dat wil zeggen over de output. Bovendien vindt ongeveer zestig tot zeventig procent van de Nederlanders 'de politiek' belangrijk en men ziet een cruciale rol weggelegd voor politieke partijen. Echter, wanneer je meer specifiek vraagt naar het vertrouwen in de politiek (niet de overheid!) ontstaat een heel ander beeld. Bijna zeventig procent van de mensen sluit het nadrukkelijk uit dat zij ooit contact zullen zoeken met een politieke partij of een politieke vertegenwoordiger om hun probleem op te lossen.

Kortom, de democratie zelf wordt door de burgers niet ter discussie gesteld en burgers waren cognitief en materieel nog nooit zo goed geoutilleerd om aan de democratische besluitvorming deel te nemen. Waar burgers tegen ageren en van weglopen is de typische institutionele uitwerking van de democratie in een representatieve partijdemocratie. Mijns inziens is een groot deel van de huidige legitimiteitsproblematiek terug te voeren op transformatie van de belangrijkste intermediair tussen de staat en de burger: de politieke partijen. De representatieve en mobiliserende rol die politieke partijen traditioneel vervulden, lijkt nagenoeg verdwenen. Deze functionele transformatie van politieke partijen zal ik hieronder verder uitwerken.

\subsubsection{FUNCTIEVERLIES EN GEDAANTEWISSELING VAN POLITIEKE PARTIJEN}

De ontwikkeling van moderne representatieve democratieën was nagenoeg ondenkbaar zonder politieke partijen, omdat deze organisaties een aantal cruciale functies vervulden binnen het democratische proces en de verschillende elementen van dat proces met elkaar verbinden (Schattschneider 1942: 1). In het proces van democratisering vervulden politieke partijen een aantal representatieve functies die het mogelijk maakten dat grote groepen burgers opgenomen werden in de politieke gemeenschap: met behulp van duidelijke ideologische profilering creëerden partijen politieke identiteiten, mobiliseerden zij burgers voor een duidelijk politiek project en structureerden zij de electorale opties door de articulatie en afweging van maatschappelijke belangen en door de formulering van beleid. Naast representatieve functies vervullen partijen eveneens een aantal procedurele functies: partijen rekruteren en selecteren politieke elites, zij verzorgen de organisatie en personele bezetting van parlement en regering en voeren, namens de bevolking, de controle uit op de uitvoerende macht (Mair 2002). We moeten echter constateren dat politieke partijen een drastische gedaantewisseling hebben ondergaan sinds hun ontstaan aan het einde van de negentiende 
eeuw en steeds minder in staat lijken om de cruciale verbindende schakel te vormen tussen burgers en de staat. Partijen worden geconfronteerd met erosie van de traditionele sociale structuur waaruit zij voortkomen en met burgers die zich in toenemende mate afkeren van de partijdemocratie. Hierdoor zijn de traditionele politieke partijen in Nederland overduidelijk aan functionele erosie onderhevig, vooral in termen van representatieve functionaliteit.

Politieke partijen hebben het vertrouwen van de burgers verloren en de ledenorganisaties van Nederlandse politieke partijen stellen weinig meer voor: in het eerste decennium na de Tweede Wereldoorlog was nog ongeveer vijftien procent van de Nederlandse bevolking partijlid, nu is minder dan drie procent van de bevolking lid van een politieke partij. Hoewel nieuwe en kleinere partijen een stabiel of zelfs toenemend aantal leden hebben en de afgelopen twee jaar het 'linkse' blok (sP, GroenLinks, PvdA en D66) zelfs weer leden won, is er over het algemeen toch een neerwaartse trend in partijbinding via het lidmaatschap. Alle partijen bij elkaar hebben nu minder leden dan de KVP alleen in de vijftiger jaren. Daarbij moet worden aangetekend dat veelal minder dan tien procent van de leden deelneemt aan de interne besluitvorming binnen politieke partijen (Gallagher 1988; Hillebrand 1992). Omdat politieke partijen steeds minder (financieel) afhankelijk zijn van leden bestaan er weinig prikkels voor de partijleiding om de interne besluitvorming te democratiseren. In de meeste partijen kunnen leden maar weinig daadwerkelijke invloed uitoefenen op bijvoorbeeld de selectie van kandidaten (Krouwel 1999). Daarnaast wordt er op partijcongressen of partijbijeenkomsten steeds minder aan besluitvorming gedaan, maar verworden deze vaak tot media-events waarop aan de buitenwereld kan worden getoond dat de partij achter de politieke leider staat en regierungsfähig is. Dit alles maakt een actief partijlidmaatschap niet echt aantrekkelijk. Duidelijk is dat politieke partijen minder in staat zijn burgers aan zich te binden via een langdurig lidmaatschap en het institutionele verval van de partijen maakt dat zij steeds minder fungeren als multifunctionele politieke collectieven. De representatieve functies, vooral in termen van mobilisatie en integratie van burgers, evenals de articulatie van hun belangen worden vaker overgenomen door andere intermediaire organisaties zoals sociale bewegingen en de media, of ze vervallen eenvoudigweg. Er is in Nederland duidelijk sprake van een representatieprobleem.

Via het corporatistische besluitvormingsproces spelen de leiders van politieke partijen nog wel een rol in de formulering en afweging van belangen en eveneens zijn partijen nog bronnen van politieke ideeën en beleidsvoorstellen, maar over het algemeen concentreren politieke partijen zich steeds sterker op hun rekruteringsfunctie en op het verwerven van bestuurlijke macht. Dat wil overigens niet zeggen dat politieke partijen deze procedurele functies (de rekrutering van politieke elites, de organisatie van parlement en regering en de controle van de uitvoerende macht) ook effectief vervullen. Op het procedurele niveau zijn nu vergelijkbare tekenen van functieverlies waar te nemen. Door het sterk monistische Nederlandse politieke bestel was de controlefunctie van politieke partijen al niet sterk ontwikkeld, maar de concentratie van macht bij de party in public office 
wordt steeds pregnanter. De buitenparlementaire partijorganisatie (the party on the ground) en de parlementaire fractie worden steeds meer gemarginaliseerd en ondergeschikt gemaakt aan de bestuurlijke ambities van de partijleiding. Deze functionele concentratie op het verwerven van bestuurlijke posities zet vooral de rekruteringsfunctie van de traditionele politieke partijen sterk onder druk, juist op een moment dat deze rekruteringsfunctie aan kwalitatieve erosie onderhevig is. De politieke elite wordt uit een steeds smallere groep van beroepspolitici en ambtenaren geworven en geselecteerd, met als gevolg dat verschillende beroepsgroepen en sociale klassen duidelijk ondervertegenwoordigd zijn. ${ }^{3}$ Daar staat echter tegenover dat vrouwen wel in toenemende mate toegang hebben gekregen tot de politieke macht. Door de smalle rekruteringsbasis van partijen is een hoge mate van professionalisering en technocratisering opgetreden in de politieke arena. Deze functionele transformatie of zelfs functioneel verval van de traditionele politieke partijen heeft hun monopolie op de rekrutering van machtsdragers langzaam maar zeker ondermijnd. Het representatietekort van partijen leidt ertoe dat politieke entrepreneurs steeds vaker succesvol electoraal appelleren aan het gevoel bij burgers van dissociatie met hun politieke 'vertegenwoordigers'.

\subsubsection{DISSOCIATIE VAN BURGERS MET VOLKSVERTEGENWOORDIGERS}

Deze dissociatie van burgers met hun vertegenwoordigers, evenals de toenemende rekrutering van politici uit de ambtenarij, heeft een verregaande versmelting van politieke partijen met de staat tot gevolg. De institutionele en personele versmelting van politieke partijen met het staatsapparaat is op verschillende manieren zichtbaar. Allereerst maken politieke partijen in toenemende mate gebruik van staatsmiddelen in plaats van maatschappelijke bronnen. Eveneens trachten de traditionele partijen te overleven en zich af te schermen van concurrentie van nieuwkomers door middel van juridische bescherming via de staat. De gevestigde partijen hebben een complex stelsel van formele reguleringen ontwikkeld, onder andere ten aanzien van partijregistratie, mediatoegang, politieke campagnes, toekenning van staatsfinanciering, registratie van kandidaten, financiering van de parlementaire organisatie en op het terrein van internationale samenwerking (Krouwel 2003).

Door de voortdurende toekenning van uitgebreidere staatsfinanciering en alsmaar minder scherpe scheiding tussen partijpolitieke organisaties en de formeel 'neutrale staatsbureaucratie' is de staat 'partijdig' geworden en zijn partijen 'verstatelijkt'. Burgers zien het verschil niet meer tussen een politieke en een bureaucratische activiteit. Deze toenemende osmose van politieke partijen en staat schept de ruimte voor nieuwe vormen van politieke mobilisatie buiten de gevestigde partijen om, vooral in nieuwe sociale bewegingen en populistische 'partijen'. Deze populistische partijen kenmerken zich door een sterke antisysteemhouding en mobilisatie tegen de gevestigde politieke elite. Zij richten zich tegen de traditionele intermediaire organisaties en bestaande politieke instituties van de representatieve democratie. Kortom, de traditionele politieke partijorganisaties zijn in afnemende mate in staat het verbindende element te zijn 
tussen (groepen van) burgers met hun belangen en het democratische proces van besluitvorming.

Wanneer dit representatieve en procedurele functieverlies verder doorzet en partijen, door hun versmelting met de staatsinstituties eveneens steeds minder in staat zijn als schakel te fungeren tussen de verschillende elementen van de democratie, zal het representatieprobleem van de Nederlandse democratie nog verder toenemen. Hierboven is gesteld dat de Nederlandse democratie een duidelijk legitimiteitsprobleem heeft in termen van vertrouwen en participatie van de bevolking en een representatieprobleem in termen van dissociatie van burgers en politieke partijen die zich steeds verder terugtrekken uit de samenleving en versmelten met de staat. Naast deze twee problemen is er nog een derde democratisch probleem, dat wordt geïmporteerd door het proces van Europese integratie. Dit proces ondermijnt het vermogen van nationale volksvertegenwoordigers om effectieve controle uit te oefenen op de beleidsvorming door de uitvoerende macht. Het probleem van controle en verantwoording zal ik hieronder uitwerken.

\subsubsection{IMPORT VAN EEN DEMOCRATISCH CONTROLEPROBLEEM VIA DE EU}

Alsof het Nederlandse politieke stelsel nog niet voldoende onder druk staat, wordt via het proces van politieke eenwording in Europa nog een probleem met de politieke controle en verantwoording binnengehaald. Het proces van Europese integratie heeft het functioneren en de logica van nationale politieke stelsels veranderd. Ten eerste is het proces van politieke verantwoording op het nationale niveau gebleven, terwijl de beleidsontwikkeling grotendeels naar het supranationale niveau is verschoven. Hoewel politieke partijen en hun leiders nog steeds afhankelijk zijn van de nationale politieke context voor het veroveren van een populair mandaat en politieke macht, hangt hun succes steeds meer af van beleid dat wordt geformuleerd op het supranationale niveau. Anders gezegd: politiek is nog steeds een nationaal proces, terwijl beleidsformulering steeds meer supranationaal van karakter wordt.

Nationale politieke elites maken echter dankbaar gebruik van de mogelijkheid om beleid te formuleren op het Europese niveau, omdat zij zich daardoor grotendeels kunnen onttrekken aan parlementaire controle. Nationale sociaal-economische kwesties domineren nog steeds de nationale politieke agenda's en politieke leiders worden door burgers voornamelijk beoordeeld op basis van het gevoerde sociaal-economische beleid. Kiezers kijken voornamelijk naar de toename van hun inkomen en welvaart en de ontwikkeling van de verzorgingsstaat als verzekering voor de zieke en oude dag. In de meeste Europese landen, Nederland in het bijzonder, is het proces van Europese integratie zelf totaal geen onderdeel van politieke competitie tussen de dominante politieke partijen. ${ }^{4}$ Zelfs politieke campagnes voor Europese verkiezingen hebben voornamelijk een nationale focus en zijn meestal een populariteitstest voor de zittende regering (Van der Eijk en Franklin 1996). Tegelijkertijd is een toenemend aantal kwesties binnen de damp- 
kring van EU-autoriteit gebracht, in het bijzonder het politiek cruciale macroeconomische beleid (zie Schmitter 1996: 125).

Doordat de arena voor beleidsontwikkeling zich verplaatst via de nationale uitvoerende macht naar de instituties van de $\mathrm{EU}$, is de bewegingsruimte voor beleidsformulering voor regeringen op het nationale niveau beperkter geworden (Streeck 1996: 83-85). Tegelijkertijd heeft deze disconnectie tussen de nationale arena voor politieke machtsvorming en de supranationale arena voor beleidsvorming tot gevolg dat nationale regeringen steeds meer autonomie verkrijgen ten opzichte van nationale politieke partijen en hun parlementaire vertegenwoordigers. Het nationale parlement heeft nu minder mogelijkheden voor controle over hun nationale regering (Raunio 2002; Raunio en Wiberg 200o). Of zoals Raunio en Hix concluderen:

"(O)verall, the ability of parliaments to control executives has declined since the 1950s, and the process of European integration is certainly one of the reasons why this has happened - providing executives with an arena for action away from domestic parliamentary scrutiny, and a monopoly on information in an ever larger portfolio of public policies" (2000: 163).

Beleid geformuleerd op het Europese niveau daalt met enige vertraging af in nationale parlementen, waar regeringsleiders vervolgens doen alsof zij voor een voldongen feit staan en niets meer kunnen ondernemen. Het feit dat zij meestal zelf hebben meegewerkt aan de totstandkoming van dat Europese beleid wordt zelden benadrukt. Impopulaire maatregelen worden vaak afgeschoven op anonieme origine in Brussel, alsof er geen nationale verantwoordelijkheid bestaat. Vaak zijn beleidsuitkomsten ook het resultaat van package deals op een Europese top, zodat ieder beleidsonderdeel niet op zijn eigen merites kan worden beoordeeld. Het nationale parlement kan moeilijk de minister of de premier terugsturen, omdat dat praktisch niet mogelijk is (men moet wachten tot de volgende top) of het zou een enorm gezichtsverlies betekenen en de positie van de minister in de volgende onderhandelingsronde aanzienlijk verzwakken. De zeer gefragmenteerde controle over de vaak complexe wet- en regelgeving die vanuit Brussel in Den Haag neerslaat maakt het voor nationale parlementariërs moeilijk om beleidsveranderingen tot stand te brengen, laat staan een radicale beleidswijziging. Dat verkleint de responsiviteit van politici aanzienlijk. Terwijl leden van de regeringspartijen nog binnen het partijgremium invloed kunnen uitoefenen, worden oppositiepartijen door deze ontwikkelingen ontwapend. Belangengroepen staan machteloos in de nationale politieke arena en verleggen hun beïnvloedingsactiviteiten in toenemende mate naar Brussel. Dit verzwakt nationale parlementariërs verder omdat zij nu niet langer met de steun in de rug van belangengroepen ministers tot beleidswijzigingen kunnen dwingen.

Deze ontwikkelingen hebben de uitvoerende macht niet verzwakt, integendeel, men kan duidelijk stellen dat het proces van Europese integratie nationale regeringen en nationale partijpolitieke elites heeft versterkt. Een van de belangrijkste 
gevolgen van Europese integratie is dat politieke macht steeds meer verschuift van het parlement en de politieke partijen naar de uitvoerende macht (Moravcsik 1994), in het bijzonder de minister-president (King 1994; Webb en Poguntke 2004). Wanneer nationale politieke partijleiders een stabiele regering leiden zijn zij zeer goed in staat om een belangrijke rol te spelen in het supranationale beleidsvormingsproces. Op het Europese niveau zijn zij niet aan democratische controle onderworpen en op het nationale niveau is de controle op de Europese activiteiten van leden van de regering minimaal. Deze controle van nationale partijleiders over de Europese beleidsvorming wordt veroorzaakt door de suprematie van nationale politieke partijen in de rekrutering van Europese politici (MEP's en Commissarissen). Doordat nationale partijleiders een grote mate van controle hebben over de politieke carrière van Europese politici kunnen zij een substantieel niveau van loyaliteit en discipline afdwingen. Het gevolg is dat de transnationale partijorganisaties vrij zwak zijn en tot op zekere hoogte verdeeld. In ieder geval hebben ze weinig autonomie ten opzichte van het nationale partijleiderschap (als ze er al niet deel van uitmaken).

Dezelfde nationale politieke leiders domineren ook de Europese uitvoerende macht (Raad van Ministers en de Commissie), waarover het Europese Parlement weinig of geen controle kan uitoefenen: het zogenaamde democratische tekort van Europa. De Europese uitvoerende macht hoeft geen verantwoording af te leggen aan het Europese Parlement. Weliswaar kan het Europese Parlement de Commissie naar huis sturen, maar het is verder zeer beperkt in zijn democratische bevoegdheden. Daarnaast is er ook een zeer zwakke link tussen de 'wil van het volk' zoals dat uit Europese verkiezingen naar voren komt en de samenstelling van de supranationale uitvoerende macht. De EU is noch een parlementair stelsel waar de executieve macht voortkomt uit de volksvertegenwoordiging, noch een presidentieel stelsel waar de uitvoerende macht rechtstreeks wordt gekozen (Hix 1997). De Europese uitvoerende macht bestaat uit nationale politici in de Raad van Ministers en Commissarissen die benoemd zijn door nationale regeringen. Het feit dat nationale politici de dominante actor zijn op het Europese niveau hoeft op zichzelf nog geen reden te zijn voor een tekort aan democratische verantwoording omdat zij uiteindelijk verantwoording verschuldigd zijn aan hun nationale volksvertegenwoordiging. Echter, zoals hierboven is beschreven kunnen nationale parlementen hun controlerende taak niet effectief vervullen en kan het Europese Parlement deze democratische leemte niet vullen.

Ten slotte is er het probleem van de geringe legitimiteit van het supranationale beleidsvormingsproces en de instituties van de EU. Naast het feit dat veel burgers nauwelijks begrijpen hoe de EU in elkaar steekt en weten wie daar politiek opereren, zijn velen van hen weinig geïnteresseerd of zelfs ontevreden met het functioneren van de Europese besluitvorming. Dit blijkt vooral uit de lage opkomst bij Europese verkiezingen en de hoge mate van onvrede ten aanzien van de belangrijkste EU-organen. De algemene houding van burgers ten opzichte van specifieke democratische instituties wordt steeds negatiever (Van Deth en Scarbrough 1995; Pharr en Putnam 200o; Plasser 1999). Als je hier het probleem van de ondoorzichtigheid 
van de Eu bij optelt en de aanhoudende stroom van schandalen rondom vergoedingen voor europarlementariërs, dan is het niet vreemd dat veel burgers zich absoluut niet gerepresenteerd voelen door politici in Brussel. In dat licht is het niet verwonderlijk dat Peter Mair concludeert dat:

“(T)he European dimension enhances an already existing tendency within modern democracies to separate the world of politics from that of the wider society, and hence helps to accentuate the popular turning away from traditional politics” (Mair 2000: 29).

Het afnemende vertrouwen in de centrale instituties en actoren van de representatieve democratie, de functionele verschraling van politieke partijen en het verminderde vermogen van responsiviteit van nationale politieke systemen ten aanzien van de preferenties van burgers leiden tot een toenemend politiek cynisme en apathie. De ontkoppeling tussen het politieke proces op het nationale niveau en de beleidsformulering op het supranationale niveau, waardoor de controlerende functie van nationale parlementen wordt uitgehold, voedt dit proces van erosie van politiek vertrouwen en politieke participatie verder.

\subsection{DRIE DEMOCRATISCHE PROBLEMEN: LEGITIMITEIT, REPRESENTATIE EN CONTROLE}

Uit de voorgaande analyse van het Nederlandse politieke stelsel komen drie problemen naar voren, namelijk een legitimiteitsprobleem, een representatieprobleem en een controle- en verantwoordingsprobleem. Deze veelheid aan problematieken in de moderne Nederlandse democratie is terug te voeren op de onoplosbare paradox van de representatieve democratie: de zwakke schakel tussen de volkswil en de liberaal-constitutionele politieke instituties. Of zoals Scarrow het verwoordt:

"(T)he challenge of creating political structures whose legitimacy rests on their dual claims to accurately reflect the popular will and to expediously handle the demands of governance in a modern state" (2001: 652).

Hieronder zal worden ingegaan op het specifieke karakter van de drie democratische problemen.

\subsubsection{HET LEGITIMITEITSPROBLEEM}

Allereerst het legitimiteitsprobleem binnen de representatieve democratie. Legitimiteit heeft betrekking op de vraag of burgers vertrouwen hebben en actieve of passieve steun geven aan het politieke systeem als zodanig en aan specifieke gezagsdragers. Een systeem is legitiemer wanneer burgers er actief aan deelnemen, indirect via de intermediaire organisaties van het maatschappelijk middenveld of direct binnen de politieke instituties van de staat, zoals bij verkiezingen. 
De algemene sociale participatie van de Nederlandse bevolking is hoog en blijft stabiel (Dekker en De Hart 2004), maar zoals we hebben gezien vertoont de participatie binnen de formele politieke instituties en politieke partijen een neerwaartse trend. Echter, politieke participatie moet niet uitsluitend in kwantitatieve termen worden geformuleerd, ook de kwaliteit is van belang. Het betreft hier de politieke kennis en ervaring van het leiderschap van burgers en intermediaire organisaties, hun financiële en personele middelen evenals hun handelingsrepertoire. Deze zijn logischerwijze (maar niet lineair) verbonden met hun mobilisatiepotentieel, hun politieke invloed en hun effect op de democratische besluitvorming.

Voor de legitimiteit van een regime hoeft de steun en dat vertrouwen niet actief en direct zichtbaar te zijn. Ook passieve aanvaarding van het gezag van bestuurders duidt op legitieme machtsuitoefening (zie Weatherford 1992). De steuncomponent van het legitimiteitsbegrip verwijst tegelijkertijd naar actieve steun aan gezagsdragers (door middel van politieke participatie van burgers, het betalen van belasting en het nakomen van andere burgerplichten). Van belang is of burgers het gezag van specifieke bestuurders aanvaarden en akkoord gaan met de machtsuitoefening van die bestuurders. Deze aanvaarding van gezag heeft op haar beurt te maken met het vertrouwen dat burgers hebben in het politieke systeem als geheel en in specifieke politici in het bijzonder. Uit de literatuur blijkt dat politiek vertrouwen een relationeel begrip is (het vertrouwen is gericht op een persoon of institutie) en ook conditioneel (mensen vertrouwen niet alles en iedereen). Vertrouwen is ook een relatief begrip, omdat men zelden iemand volkomen vertrouwt.

In de politiek geldt hetzelfde. De meeste burgers vertrouwen slechts bepaalde politici, politieke instituties en organisaties en dan meestal in beperkte mate en ook nog op een specifiek terrein (Levi en Stoker 200o). Dit relatieve en voorwaardelijke vertrouwen is veelal gebaseerd op eerdere ervaringen met politici, organisaties en instituties. De betrouwbaarheid van politici en instituties is, volgens de literatuur, allereerst afhankelijk van de mate van overeenstemming tussen de geleverde prestaties en de normatieve verwachtingen van burgers (Miller 1974; Miller en Listhaug 1999). Deze morele dimensie van betrouwbaarheid behelst dus de integriteit van diegene die vertrouwd wordt (Citrin en Muste 1999): is de actor toegewijd aan de belangen van diegenen die het vertrouwen moeten geven, door welke belangen wordt de actor gemotiveerd, is de actor betrouwbaar, voorspelbaar en consistent in zijn of haar handelingen? Een tweede dimensie van de vertrouwensfactor wordt gevormd door meningen en evaluaties van de competenties van de actoren. De vraag hierbij is of politici in staat worden geacht daadkrachtig, efficiënt, effectief en kundig te handelen in overeenstemming met hun beloften zodat resultaten worden bereikt die in overeenstemming zijn met de verwachtingen van burgers.

Over het effect van politiek vertrouwen lopen de wetenschappelijke resultaten uiteen. Vaak wordt onderscheid gemaakt tussen vertrouwen in de zittende 
machtshebbers en in het politieke systeem als geheel (voor een overzicht zie Levi en Stoker 200o). Politiek wantrouwen is funest voor een politiek systeem wanneer het gehele stelsel als onbetrouwbaar wordt gezien. Wanneer echter specifieke politici of instituties niet integer of incompetent worden bevonden, dan blijft er een democratische opening. Uit de meeste literatuur komt naar voren dat vertrouwensoordelen 'partijdig' zijn en zijn gericht op specifieke actoren. Burgers hebben minder vertrouwen in een regering als ze er niet op gestemd hebben. Tevens wordt het vertrouwen in politieke actoren beïnvloed door de tevredenheid met het gevoerde beleid en de toegedichte leiderschapskwaliteiten van de zittende machtshebbers. Daarnaast toont onderzoek aan dat er een duidelijke link bestaat tussen vertrouwen en politieke participatie. Burgers die wantrouwen in de elite combineren aan een gevoel van politieke handelingsbekwaamheid (efficacy) nemen vaker actief deel aan het politieke proces. ${ }^{5}$ Eveneens kunnen specifieke vormen van participatie worden gekoppeld aan politiek wantrouwen. Een belangrijke uitkomst is dat het wantrouwen in bepaalde autoriteiten steeds algemener kan worden en dat een dergelijk algemeen wantrouwen duidelijk van invloed is op politieke houdingen en gedrag (Easton 1975; Sigelman et al. 1992). Dit duidt erop dat politiek wantrouwen, een cruciale factor van cynisme, relatief en voorwaardelijk is, in de loop van de tijd aan verandering onderhevig is en kan worden gebruikt voor de mobilisatie van kiezers. Onderzoeken uit de Verenigde Staten van Amerika tonen bijvoorbeeld aan dat wantrouwige burgers eerder gaan stemmen wanneer ze de mogelijkheid hebben om te kiezen voor een outsider en dat een dergelijk effect nog wordt versterkt wanneer deze buitenstaander anti-regeringsthema's op de politieke agenda plaatst (Luks en Citrin 1997).

Samengevat: de democratische dimensie van legitimiteit verwijst naar actieve en passieve steun aan het politieke systeem en zijn gezagsdragers en naar het vertrouwen dat burgers hebben in machtshebbers in termen van hun integriteit en competentie.

\subsubsection{HET REPRESENTATIEPROBLEEM}

Het tweede democratische probleem dat uit de analyse opdoemt is het representatietekort. Veel burgers voelen zich weinig of niet gerepresenteerd door hun vertegenwoordigers in de wetgevende organen van het politieke systeem. In parlementaire stelsels, zoals het Nederlandse, waar de uitvoerende macht voortkomt uit de wetgevende macht en sprake is van verregaand monisme, wordt een nog groter representatietekort gevoeld door burgers. Het representatietekort ligt in onze democratie voornamelijk binnen de politieke partijen. Zoals hierboven is geschetst is er sprake van functioneel verval van politieke partijen in termen van representatie. De binding tussen burger en politieke representanten in het parlement is enerzijds verzwakt omdat partijen niet langer verschillende sociale groepen vertegenwoordigen en mobiliseren, maar zich bijna zonder uitzondering richten op de brede middenklasse. Anderzijds zijn partijen in Nederland elkaar beleidsmatig zo dicht genaderd dat burgers makkelijker kunnen wisselen van 
politieke voorkeur. Deze ontwikkelingen, die sterk samenhangen met de ontzuiling, leiden tot een zwakke partijbinding bij veel Nederlandse kiezers. Daarnaast hebben politieke partijen zelf het zwaartepunt van hun activiteiten verlegd van de mobilisatie van burgers en de articulatie en aggregatie van hun belangen naar meer procedurele functies. Echter, ook in termen van procedurele functionaliteit is duidelijk sprake van een kwalitatieve vermindering: de politieke elite wordt uit een steeds smallere sociale basis gerekruteerd, voornamelijk uit de bureaucratisch-politieke sfeer. Door de eenzijdige samenstelling van alle parlementaire fracties is het voor burgers ook moeilijker zich duidelijk te identificeren met een politieke partij. Deze ontwikkeling past in een meer algemene sociale ontworteling van partijen, waarbij partijen hun heil steeds meer zoeken in functionele en personele verknoping met de staat en hun ledenorganisatie verwaarlozen. Hierdoor wordt het voor burgers steeds moeilijker en onaantrekkelijker om te participeren binnen politieke partijen. Partijen hebben een groot aantal van hun leden verloren in de afgelopen decennia en zijn in verregaande mate gecentraliseerd en geprofessionaliseerd. We hebben gezien dat de Nederlandse politieke cultuur elitaire en paternalistische trekken heeft, waardoor deze problemen nog eens worden versterkt.

Wanneer we verschillende vormen van representatie in de geschiedenis bekijken, zijn er ruwweg vier modellen te onderscheiden (Maddens 1994). Het eerste representatiemodel is het trustee model of het bewindvoerdersmodel. Dit is het elitaire perspectief op vertegenwoordiging, waarbij het centrale idee is dat niet alle burgers politiek actief kunnen zijn. Voor politieke activiteiten zijn bepaalde kwaliteiten nodig en burgers dienen uitsluitend leden uit de gemeenschap te herkennen en aan te wijzen om voor hen de publieke zaken te behartigen. Dit type representatie valt samen met de elite- of caucus-partij uit de 19e eeuw. Deze elitepartijen werden gekenmerkt door een kleine groep van politici uit de hoogste sociale klasse met hun eigen lokale electorale basis. Elitepartijen waren niet veel meer dan losse allianties van gekozen vertegenwoordigers waartussen de coördinatie en interne besluitvorming aanvankelijk niet veel verder ging dan ad hocoverleg over stemgedrag. Voor het verwerven van electorale steun gebruikten deze traditionele lokale notabelen hun persoonlijke contacten en eigen financieel vermogen voor een carrière in de politiek (Duverger 1963: 62-67). Uitgebreide politieke campagnes waren niet nodig omdat electorale stelsels voornamelijk gebaseerd waren op geografisch beperkte kiesdistricten en het electoraat bleef veelal beperkt tot een gering percentage gefortuneerde mannen. Hierdoor konden kandidaten persoonlijk vrijwel alle kiesgerechtigden bereiken (Krouwel 2004). Dit model was dominant in Nederland voor de totstandkoming van het algemeen kiesrecht in 1917-1919 toen Nederland nog een districtenstelsel had. Echter, de elitaire en regenteske stijl van Nederlandse politici doet soms nog wel denken aan dit model.

Het tweede representatiemodel is dat van de delegate ofwel afgevaardigde. In dit model moeten politici worden gezien als woordvoerder van bepaalde specifieke belangen. Vooral in de periode van de verzuiling, ruwweg van 1917 tot begin jaren 
zeventig, was dit model dominant in Nederland. Dit model past het best bij de buitenparlementaire politieke massaorganisaties die de bevolking mobiliseerden op basis van hun sociale positie of religieuze overtuiging. Volgens Duverger (1963) was het kenmerkende van deze massapartijen dat zij een specifieke sociale of religieuze groep mobiliseerden en in hoge mate het leven van de achterban penetreerden. Leden waren permanent actief binnen de partij zelf maar ook in verwante sociale organisaties, ook in de periodes tussen verkiezingen.

Het derde representatiemodel is het mandaatmodel. De primaire actor in dit model is niet de politicus maar de politieke partij die een mandaat heeft van de kiezers. De politicus is er uitsluitend om dat mandaat uit te voeren. Dit model hangt sterk samen met het concept van de catch-all party en het politiek ondernemerschap. Politieke partijen trachten een zo breed mogelijk electoraat aan te spreken door hun programma te ont-ideologiseren en parlementariërs te rekruteren die op een pragmatische en technocratische wijze het door de burgers gewenste beleid kunnen uitvoeren. Het vierde model is het resemblance-model, ook wel het afspiegelingsmodel of positieve-actiemodel genoemd. Binnen dit perspectief van representatie moet een parlement zo veel mogelijk een afspiegeling zijn van de gehele samenleving. De pogingen van politieke partijen om minderheden en vrouwen proportioneel in hun politieke organisatie op te nemen vallen binnen dit model.

Uit dit korte overzicht komt een zekere historische ontwikkeling naar voren waarbij representatie zich ontwikkeld heeft van een elitair bewindvoerdermodel, via het afgevaardigdenmodel naar meer contemporaine vormen van representatie: het mandaat- en afspiegelingsmodel. Uit deze vier modellen lijkt het mandaatmodel het meest bruikbaar in het huidig tijdsgewricht. Het bewindvoerdermodel is te elitair voor de moderne mondige en politiek vaardige burger en kan leiden tot nog grotere politieke passiviteit van de bevolking. Het afgevaardigdenmodel gaat te veel uit van duidelijk te onderscheiden sociale groepen die ook als collectief kunnen worden vertegenwoordigd. In Nederland lijkt dat problematisch. Aan het afspiegelingsmodel kleven een aantal nadelen zoals tokenism en cliëntelisme, maar het past wel in de Nederlandse traditie van proportionaliteit en evenredigheid. Het mandaatmodel laat het duidelijkst modern burgerschap toe: burgers kunnen hun politieke mandaat geven aan de politicus die zij vertrouwen in het nastreven van een specifiek of het algemene belang. Ook is dat mandaat niet oneindig en onvoorwaardelijk (zoals bij het elitaire trusteemodel of het afgevaardigdenmodel), het is tijdelijk en beperkt.

\subsubsection{HET VERANTWOORDINGSPROBLEEM}

De derde democratische dimensie die naar voren komt in de discussie over indirecte democratie is politieke verantwoording. In de Engelstalige literatuur wordt onderscheid gemaakt tussen responsibility (verantwoordelijkheid dragen) en accountability (verantwoordelijkheid afleggen). Politieke accountability verwijst naar de beperkingen die worden opgelegd aan het gedrag van machtsdragers door middel van politieke controle en sanctiemechanismen. Van Kersbergen en Van 
Waarden hebben de relatie tussen democratische accountability en controle als volgt verwoord:

"(A)ny concentration of power carries immediately the danger of arbitrariness, of abuse, corruption, and advancing self interest by those in control. Therefore, in the course of history societies have not only centralised political and economic power in such organisations, but they also gradually developed a system of checks and balances to control the exercise of power, and to prevent its abuse and arbitrary application, to protect citizens, consumers, and workers against powerful actors and powerful organizations" (2004: 156).

In de politiek is de ultieme sanctie dat het vertrouwen in een politicus wordt opgezegd. Hoewel niet alle democratische stelsels een dergelijke vertrouwensregel kennen, moet verantwoording worden gezien als het raamwerk van wederzijdse checks and balances tussen de verschillende machten. Welke controle kan het parlement uitoefenen? Kunnen burgers rechtstreeks ingrijpen als het in hun ogen verkeerd gaat met het gedrag van politiek verantwoordelijken? Bij verantwoording is het van belang dat verantwoordelijkheden duidelijk zijn en niet diffuus worden gelaten en dat er transparante vormen en procedures zijn voor het afleggen van verantwoording.

Hierboven is reeds aangegeven dat het verdiepingsproces van de Europese eenwording in toenemende mate de democratische controle van nationale parlementen ondermijnt en dat leden van de regering zich kunnen onttrekken aan de nationale verantwoordingsmechanismen. Maar in het Nederlandse politieke bestel zelf zit ook een probleem in termen van verantwoording en controle, omdat het parlement de regering eigenlijk niet echt controleert.

De kern van de politieke verantwoordelijkheid van ministers is vastgelegd in artikel 42, paragraaf 2 van de Grondwet: 'De Koning is onschendbaar; de ministers zijn verantwoordelijk.' Uit dit artikel blijkt ondubbelzinnig dat ministers voluit verantwoordelijk zijn voor alles wat hun ministerie aangaat. Uiteraard leggen ministers deze verantwoording af aan het parlement, de rechtstreeks gekozen vertegenwoordigers van het volk. Het is een cruciaal beginsel in de democratie, want wanneer dit beginsel zou worden losgelaten, draagt niemand meer de verantwoordelijkheid voor wat de overheid doet. $\mathrm{Nu}$ is het natuurlijk niet zo dat bij iedere fout de minister onmiddellijk moet aftreden. Wanneer ministers de fouten erkennen en beterschap beloven, kan het zijn dat de volksvertegenwoordiging nog steeds het vertrouwen in de minister heeft. Een politiek excuus waarbij de verantwoordelijkheid wordt genomen is een belangrijk element in de democratie. Echter, in Nederland is het beginsel van de absolute politieke ministeriële verantwoordelijkheid losgelaten en zijn verantwoordelijkheidstructuren zeer diffuus geworden. In hun boek De sorry-democratie schilderen Van Thijn en zijn medeauteurs (1998) een onthutsend beeld van deze uitholling van ministeriële verantwoordelijkheid. Aan de hand van een aantal politieke crisissituaties laten zij zien dat de politieke en bestuurlijke verantwoordelijkheden in 
Nederland niet goed gescheiden zijn of worden ontlopen. De oorzaken voor deze diffuse verantwoordelijkheidsstructuur moeten volgens Van Thijn c.s. worden gezocht in de complexiteit van de besluitvorming en het grote aantal instanties dat betrokken is bij de totstandkoming van beleid. Het boek kan ten onrechte het idee wekken dat deze uitholling van het democratische grondbeginsel van ministeriële verantwoordelijkheid uitsluitend in crisissituaties naar voren komt. Echter, noch een crisissituatie noch de complexiteit of het brede maatschappelijk overleg is de belangrijkste oorzaak van het ontbreken van een cultuur van publieke verantwoording door gezagsdragers. De diepere oorzaak ligt besloten in de typische politiek-bestuurlijke inrichting van ons land en de daaraan gerelateerde regentencultuur onder bestuurders.

In ons parlementaire stelsel zijn de politieke verantwoordelijkheden diffuus geworden omdat de grondwettelijke scheiding der machten niet langer goed functioneert. Er heeft zich een sterke monistische tendens voorgedaan waarbij de 'regeringsfracties' zijn versmolten met de ministers die de partij aan het kabinet heeft geleverd. Hierdoor vervullen parlementariërs geen duidelijke controlerende rol. Ministers worden eerder 'uit de wind' gehouden dan ter verantwoording geroepen voor hun daden. Regering en parlement staan dan ook niet tegenover elkaar, maar ministers en regeringsfracties vormen een partijkartel, waarbij de coalitiepartijen zich binden aan een gedetailleerd regeerakkoord waarover discussie wordt gemeden. Hierdoor accepteert de volksvertegenwoordiging keer op keer een slap excuus van een minister zonder deze daadwerkelijk verantwoordelijk te houden voor falend beleid. Dit wordt veroorzaakt door het feit dat wij uitsluitend coalitiekabinetten kennen, waarbij tussentijdse ministerswisselingen, zoals in Groot-Brittannië, problematisch zijn.

Bij onze westerburen is het een jaarlijks terugkerend ritueel dat bij de zogenaamde cabinet reshuffle slecht functionerende ministers worden gedegradeerd of vervangen. In Nederland is het vertrek van een minister onmiddellijk een verstoring van het broze evenwicht tussen de coalitiepartijen. Om de meestal brede coalities overeind te houden (ons kiesstelsel genereert nu eenmaal geen parlementaire meerderheden) achten politici het wenselijk om de inhoudelijke discussies zo veel mogelijk aan het zicht van de burger te onttrekken. Openlijke conflicten kunnen immers gemakkelijk leiden tot een discussie over het ministeriële functioneren. Dat creëert natuurlijk niet een omgeving waar men wordt gedwongen verantwoordelijkheid te nemen en verantwoording af te leggen. Het Nederlandse stelsel gunt weinig ruimte aan de controlefunctie van het parlement en aan publieke verantwoording van machtshebbers. Het tegenspel wordt dan ook meer verwacht vanuit het maatschappelijk middenveld, maar datzelfde maatschappelijk middenveld wordt door de regering ruimhartig gesubsidieerd. Veel van deze organisaties zijn niet alleen financieel afhankelijk van de overheid, maar hebben in onze corporatistische overlegdemocratie ook nog eens een geprivilegieerde positie in de beleidsvorming. Zij zullen zich dus doorgaans coöperatief opstellen om hun privileges niet te verliezen. 
Hierboven zijn, op basis van een analyse van het politieke systeem van Nederland, drie democratische problemen gesignaleerd: een legitimiteitsprobleem, een representatieprobleem en een probleem van democratische verantwoording en controle. De opdracht waar we nu voor staan is institutionele innovaties voor te stellen die deze problemen kunnen verhelpen of ten minste verlichten.

\subsubsection{DEMOCRATISCHE VERDIEPING DOOR INSTITUTIONEEL MAATWERK}

Mijns inziens kan democratische verdieping in Nederland uitsluitend plaatsvinden met behulp van institutionele innovaties die de drie democratische problemen gelijktijdig aanpakken, die aansluiten bij de dominante politieke cultuur en functioneel zijn ingebed in de bestaande instituties van de representatieve democratie. Institutionele innovaties moeten dus worden getoetst op hun vermogen om de legitimiteit van het politieke systeem te verhogen (zowel in termen van actieve en passieve politieke steun als in termen van het vertrouwen in de integriteit en competentie van machtshebbers). Verder moeten institutionele innovaties voldoen aan de moderne eisen van representatie. Ik heb hierboven betoogd dat dit betekent dat het mandaatmodel van representatie centraal moet staan, al kan dat worden aangevuld met elementen uit het afspiegelingsmodel, omdat dit laatste goed aansluit bij de Nederlandse politieke cultuur. In termen van verantwoording moeten institutionele innovaties voldoen aan de eisen van duidelijk afgebakende verantwoordelijkheden en transparante procedures voor het afleggen van verantwoording.

Aangezien de politieke cultuur en de politieke instituties sterk met elkaar zijn verbonden, heeft het weinig zin Fremdkörper in te bouwen die niet aansluiten bij het dominante politieke gedrag. Dit conservatief ogende standpunt is in de Nederlandse context radicaal: de politieke elite is in staat gebleken om, tegen de volkswil in, veranderingen in het institutionele raamwerk tegen te houden. Maar een weloverwogen en goed doordachte strategie voor democratische verdieping is niet uitsluitend een pragmatische houding. Uit onderzoek naar lokale democratie blijkt heel duidelijk het gevaar van de invoering van incidentele en slecht ingebedde instituties en procedures om deelname van burgers aan de politieke besluitvorming te verhogen (Monnikhof, Edelenbos en Krouwel 2003). Wanneer nieuwe instituties niet volledig transparant zijn en niet goed zijn ingebed in het formele democratische besluitvormingsproces van de representatieve democratie, ontstaan er naast de formele instituties parallelle 'symbolische' ceremonies waarin burgers op grote schaal participeren en hun input geven, maar die geen enkel effect genereren. Als er parallelle besluitvormingsstructuren ontstaan, kunnen politici dit gehele proces ontlopen of verlaten op het moment dat de uitkomsten hen niet zinnen. Wanneer een hoge mate van burgerparticipatie geen enkel effect heeft op de uitkomst en de democratische machtsverhoudingen, dan zullen burgers nog meer gedesillusioneerd raken en nog cynischer worden ten aanzien van de politiek. Om dat te voorkomen moet een exit-optie voor politiek verantwoordelijken worden vermeden. In het volgende deel zal ik een aantal instrumenten uit de stal van de directe 
democratie bespreken die democratische verdieping in het Nederlandse politieke stelsel kunnen aanbrengen.

\subsection{DIRECTE DEMOCRATIE ALS OPLOSSING VOOR HET DEMOCRATISCH TEKORT?}

\subsubsection{EENZIJDIGE OPLOSSINGEN WERKEN NIET}

Als reactie op deze complexe, multidimensionale crisis van de representatieve democratie zijn in de loop der tijd vele voorstellen gedaan. Sommige voorstellen blijven binnen het bestaande constitutionele raamwerk en trachten bijvoorbeeld het stemmen bij verkiezingen eenvoudiger en toegankelijker te maken. Om dit te bereiken moeten burgers kunnen stemmen per computer, moet men stembureaus langer open houden of het mogelijk maken over meerdere dagen je stem uit te brengen. Tevens wordt gedacht aan het houden van verkiezingen op een vrije dag en stemmen op stations of winkelcentra. Dat laatste wordt af en toe al in de praktijk gebracht, zonder al te veel resultaat. Dat is niet verwonderlijk want onderzoek heeft uitgewezen dat deze voorstellen de opkomst wel met enkele procentpunten kunnen verhogen (d.w.z. onder bepaalde omstandigheden, want het moet bijvoorbeeld niet gaan regenen of sneeuwen), maar het raakt niet de kern van de hierboven geschetste democratische problematiek.

Om de veronderstelde kloof tussen burgers en bestuurders in Nederland te dichten worden al sinds de jaren '6o verdergaande voorstellen naar voren gebracht, zoals het inzetten van instrumenten van de directe democratie. De meeste voorstellen hebben betrekking op de invoering van referenda om zodoende burgers directe invloed te geven op een specifiek beleidsvoorstel, terwijl er eveneens wordt gepleit om een aantal bestuurders rechtstreeks door de burgers te laten kiezen. Bij het laatste type voorstel valt meestal het oog op burgemeesters, maar er wordt ook al decennialang nagedacht over de rechtstreekse verkiezing van de premier. Op dit moment is het meest in het oog springend het regeringsvoorstel om het kiesstelsel te wijzigen in een zogenaamd 'gemengd stelsel', zoals dat in Duitsland bestaat, waarbij kiezers zowel op een partijlijst kunnen stemmen als rechtstreeks op een kandidaat binnen hun kiesdistrict. Verder zijn er voorstellen en experimenten met vormen van interactieve beleidsontwikkeling waarbij burgers eerder en langer bij de besluitvorming worden betrokken, of burgers worden verzocht in commissies mee te discussiëren, burgerpanels, buurtparlementen en alle andere vormen waarbij burgers worden verzocht zich met de publieke zaak te bemoeien.

Op soortgelijke wijze lopen alle voorstellen om meer politiek dualisme te creëren uit op grote verwarring. Zo zien vele gemeenten in het land in de voorstellen van de Staatscommissie Dualisme een pleidooi om minder 'politiek' te handelen en wethouders te benoemen van buiten de raad. Feitelijk is dat het einde van de politiek en is het openbaar bestuur gereduceerd tot management, waardoor de toch al broze relatie tussen burgers en bestuurders nog verder wordt ondermijnd. 
Dit staat haaks op andere voorstellen en experimenten die in de richting gaan van het meer direct verantwoordelijk maken van bestuurders aan de bevolking, zoals de rechtstreeks gekozen burgemeester. Het idee is dat rechtstreeks gekozen bestuurders met een duidelijk mandaat van de bevolking, eventueel aangevuld met de mogelijkheid om hem of haar tussentijds weg te sturen (een zgn. recall) een duidelijkere link tussen burgers en bestuurders zal creëren. Landen waarin de uitvoerende macht rechtstreeks wordt gekozen, zowel op lokaal, regionaal als nationaal niveau, hebben bijna zonder uitzondering dezelfde democratische problemen als Nederland. In veel landen met meer directe vormen van democratische mandatering is de politieke participatie zelfs lager en het politieke wantrouwen en cynisme hoger. Tevens leidt een dergelijke persoonlijke strijd niet altijd tot de strijd tussen alternatieve politieke visies en duidelijke politieke programma's die aan de kiezers worden voorgelegd.

$\mathrm{Al}$ dit soort voorstellen zijn te eenzijdig en te ad hoc. Instituties worden voorgesteld in isolatie van elkaar en zonder duidelijke inbedding in de bestaande instituties van de consensusdemocratie. Zij zijn gedoemd te mislukken, omdat zij niet de kern van het hierboven geschetste multidimensionale democratische probleem raken en niet aansluiten bij de dominante politieke cultuur. Om te zien of er instrumenten zijn die wel een gelijktijdige impact kunnen hebben op de drie centrale problemen van de democratie (legitimiteit, representatie en verantwoording), die geïncorporeerd kunnen in het huidige institutionele raamwerk en die passen binnen de consensusdemocratie en de bijbehorende politieke cultuur in Nederland, zal hieronder een aantal instrumenten van de directe democratie worden geëvalueerd op basis van deze criteria.

\subsubsection{DEFINITIES VAN DIRECTE, SEMI-DIRECTE EN REPRESENTATIEVE DEMOCRATIE}

Over de precieze definitie van directe democratie bestaat geen overeenstemming. Sartori (1987: 111-112) maakt onderscheid tussen directe democratie, referendumdemocratie, electorale democratie en representatieve democratie. Representatieve democratie definieert hij als "an indirect democracy in which the people do not themselves govern but elect representatives who govern them" (Sartori 1987: 111). In een electorale democratie komen machtshebbers eveneens via verkiezingen aan de macht, maar die zijn niet noodzakelijkerwijs 'representatief'. Hier valt te denken aan totalitaire en autoritaire systemen waar verkiezingen worden gehouden die volledig worden beheerst door de zittende autoriteiten. Directe democratie kan volgens Sartori simpelweg worden beschouwd als een democratie zonder vertegenwoordigers en zonder representatieve mechanismen voor machtsoverbrenging (representational transmission belts). Dit type democratie moet echter worden onderverdeeld in verschillende typen, waarbij de grootte van de populatie van cruciaal belang is. Zodra een gemeenschap te groot wordt om op een locatie tezamen te komen - ruwweg een paar duizend burgers - is er niet langer sprake van een waarneembare directe democratie. Daarboven wordt een directe democratie al redelijk 'indirect' in termen van waarneming, inbreng 
en gelijkwaardige deelname. Vandaar het onderscheid met een referendumdemocratie waar de burgers niet langer samenkomen om direct te beslissen, maar dat doen via een stemming. Een referendum is dus niets meer of minder dan een instrument om het 'omvangsprobleem' van de directe democratie op te lossen. Een referendumdemocratie is direct omdat zij besluitvorming toelaat zonder intermediairen, maar zij verliest in 'directheid' in termen van interactie tussen de deelnemers. "It is, so to speak, a direct democracy of isolated, discrete individuals - not of interacting participants" (Sartori 1987: 112).

Sartori kon zich niet voorstellen dat burgers een belangrijke rol spelen bij de formulering van de vraag die aan het volk wordt voorgelegd. De meeste deelnemers aan het referendum zullen geen actieve rol spelen in het maatschappelijke debat, maar passieve toeschouwers blijven. Het cruciale verschil tussen directe en indirecte democratie is dat in een directe democratie van burgers wordt gevraagd (constant) rechtstreeks te participeren in de uitvoering van macht, terwijl het in een indirecte democratie vooral gaat om de beperking en controle van gekozen machtshebbers. Het is daarom beter te spreken van directe democratie (van kleine gemeenschappen waar alle leden van de polis op basis van gelijkwaardigheid direct met elkaar interacteren en beslissen), semi-directe democratie (waar vormen van directe democratie in aangepaste vorm bestaan, meestal binnen een structuur van representatieve democratie) en representatieve democratie (waar alle belangrijke politieke besluitvorming is gedelegeerd aan gekozen vertegenwoordigers van het volk).

$\mathrm{Nu}$ we een werkbare definitie van democratietypen hebben is het van belang de empirische vormgeving ervan nader te onderzoeken om te zien op welke wijze Nederland van een puur representatieve democratie naar een semi-directe democratie kan worden getransformeerd. Hiervoor kijk ik naar operationele definities van directe democratie in de politicologische literatuur. ${ }^{6}$ Directe democratie wordt in de empirische literatuur soms gedefinieerd als een besluitvormingswijze waarbij burgers rechtstreeks het beleid bepalen, dus zonder tussenkomst van politieke representanten, of besluiten over beleid in plaats van partijen en vertegenwoordigers (Frey en Stutzer 2003). Deze definitie beperkt de directe democratie tot besluiten over beleid, en daarmee tot referenda en volksinitiatieven.

Ruimere definities, zoals "decisions directly made by citizens and not by their representatives" (Scarrow 2001: 651), maken het mogelijk om ook besluiten over de personele invulling van een politiek ambt onder de definitie te scharen. In de kern komt het verschil tussen directe en representatieve democratie in deze ruime definities neer op het verschil tussen directe en gedelegeerde besluitvorming. Als meest genoemde vormen van directe democratie ten aanzien van personen wordt dan vaak verwezen naar recall-procedures. Deze drie instrumenten, volksinitiatief, referendum en recall, vormen in de literatuur de kern van de directe democratie (Cronin 1989). 
Er zijn vele vormen van referenda en volksinitiatief en verschillende recall-procedures. Voordat we deze verschillende typen bespreken en analyseren welke instrumenten het best passen bij de Nederlandse consensusdemocratie met zijn specifieke institutionele inrichting en politieke cultuur, moeten we eerst de argumenten van voor- en tegenstanders van de directe democratie langslopen. Dit geeft een duidelijker beeld van welke types instrumenten van directe democratie effectief kunnen worden ingepast in de representatieve democratie, zonder dat een dergelijk hybride systeem nieuwe problemen creëert (zie Hamlin 1999).

\subsubsection{PLEBISCITAIRE OF POPULISTISCHE VARIANT VAN (DIRECTE) DEMOCRATIE}

De kern van het populistische gedachtegoed is het idee van volkssoevereiniteit, volgens welke 'het volk' wordt gezien als de enige en ultieme bron van legitieme machtsuitoefening. ${ }^{7}$ Vanuit dat idee van volkssoevereiniteit koppelen populisten weerzin van de traditionele partijpolitiek en de representatieve democratie aan scherpe kritiek op de moraal van de politieke en culturele elite die in de ogen van een populist niet representatief is voor de daadwerkelijke volkswil (Laclau 1979). Populisten ageren tegen politieke bemiddelaars (de traditionele politieke partijen, vakbonden en belangengroepen) die de directe expressie van de volkswil slechts 'in de weg staan' (Kitschelt 2002: 179). Deze intermediaire organisaties en structuren moeten zo snel mogelijk verdwijnen omdat ze door de politieke elite uitsluitend worden gebruikt om het volk uit elkaar te spelen en verdeeld te houden. Deze intermediaire organisaties en instituties worden door de niet-representatieve, incompetente en corrupte elite ook gebruikt als mechanisme om aan de macht te blijven. De 'horizontale' garanties van de constitutionele democratie die door liberalen en communitaristen worden geprezen, worden door populisten verafschuwd en dienen te worden vervangen door directe 'verticale' banden tussen het volk en zijn leiders. Intermediaire organisaties als politieke partijen maken het voor het volk onmogelijk om hun leiders rechtstreeks te kiezen en om voor het volk belangrijke kwesties op de politieke agenda te zetten. Het primaat van het volk moet zo snel mogelijk hersteld worden (Meny en Surel 2000: 11-13).

De daadwerkelijke belangen van het volk spelen in de representatieve democratie geen rol. De traditionele elite heeft vooraf bepaald welke sociale groepen en specifieke belangen toegang tot de macht krijgen, daarbij is te veel inmenging van de bevolking ongewenst. Het politiek pluralisme en het splijtende denken in sociale scheidslijnen wordt van de hand gewezen omdat het de formulering van het algemene belang in de weg staat. In de ogen van de populist is de traditionele politieke elite bovendien hypocriet omdat zij zich pluralistisch voordoet, maar zelf een gesloten en homogene clique vormt die noch democratisch handelt, noch representatief is voor de bevolking. Populisten willen het corrupte en gesloten machtskartel van de elite doorbreken door meer directe mandatering van politieke autoriteit (Papadopoulos 2000: 5). Daarom leggen populisten sterk de nadruk op het singuliere politieke leiderschap. 
Het soevereine volk is de enige legitieme entiteit en omdat populisten als enige de echte noden en wensen van het volk zeggen te begrijpen, de daadwerkelijke belangen van het volk te vertegenwoordigen en deze als enige verwoorden, kunnen zij democratische legitimiteit claimen (Shils 1956). Singulier leiderschap wordt als superieur gezien ten opzichte van de diffuse gedeelde verantwoordelijkheden van de oude elite. Collectieve besluitvorming en machtsuitoefening betekenen namelijk dat uiteindelijk niemand verantwoordelijk kan worden gehouden voor het falende beleid. We zien bij populisten dus een visie van een uniforme gesloten politieke klasse die tegenover het volk staat. Het volk wordt eveneens als een monistische eenheid afgeschilderd en de zogenaamde sociale scheidslijnen die de traditionele politieke klasse gebruikt om het volk te segregeren worden door populisten ontkend (Laclau 1979). Populisten zien maar twee scheidslijnen: die tussen het monolithische volk en het establishment en tussen deze incompetente 'politieke klasse' en de populistische leider zelf (Schedler 1996). De enige manier om deze situatie te doorbreken is het omzeilen van de politieke intermediairen en een rechtstreekse relatie te creëren tussen het volk en zijn leiders (Papadopoulos 200o: 7). Alleen dan kan de stem van het volk luid en duidelijk doorklinken in het politieke leiderschap van een land (Barney en Laycock 1999).

\subsubsection{LIBERALE VISIE OP DE (DIRECTE) DEMOCRATIE}

In de liberale democratiebenadering staat niet het volk als eenheid, maar het afzonderlijke individu centraal. Het liberaal-democratische uitgangspunt kan worden samengevat als dat van burgers die zich politiek moeten kunnen informeren, zelfstandig opinies moeten kunnen vormen en zich in vrijheid politiek moeten kunnen engageren. Directere vormen van democratie worden verdedigd met het argument dat deze instrumenten meer ruimte bieden voor publieke reflectie en debat, meer publieke participatie en vrijwillige organisatie, waardoor mensen worden uitgenodigd elkaar te overtuigen in plaats van elkaar te overheersen. Er komen in een vrije en open maatschappelijke discussie meer en betere argumenten naar voren die wellicht zouden worden genegeerd in de beperkte discussies tussen beroepspolitici. Tevens komen de visies en ideeën van minderheden beter naar voren omdat het in het debat om de kwaliteit van het argument gaat en niet om de politieke kracht achter een idee. Eveneens stimuleert de behartiging van individuele belangen een pluralistische politieke cultuur en creëert zij een rijk geschakeerd maatschappelijk middenveld waarin burgers naar hartelust kunnen participeren als zij daar behoefte toe voelen. De machtsuitoefening van velen zorgt voor een betere accommodatie van alle belangen, een betere sociale balans en een grotere legitimiteit van de besluitvorming. Het feit dat de macht niet in handen is van enkelen, maar is verdeeld over velen leidt tot een systeem van checks and balances en empowerment van het politieke individu. Daardoor ontstaat meer waardering voor het vermogen van derden om tot een eigen oordeel te komen.

Vanuit dit liberale perspectief wordt een zware nadruk gelegd op politieke vrijheden, vooral de vrijheid van meningsuiting, persvrijheid en vrijheid van vergade- 
ring. Individuen moeten de grootst mogelijke autonomie hebben in de politieke besluitvorming, die uit de handen van enkelen moet worden genomen en moet worden overgedragen aan velen. Ieder individu moet zelf verantwoordelijk worden gemaakt en burgers moeten het recht om de toekomst van hun staat te bepalen in eigen hand nemen. Wanneer vanuit de liberale visie wordt gepleit voor meer directe vormen van democratie, dan wordt meestal gesteld dat referenda en volksinitiatieven legitiemer zijn dan besluiten door vertegenwoordigers. Terwijl volksvertegenwoordigers gemakkelijk kunnen worden beïnvloed door belangengroepen of special interests, zijn burgers minder makkelijk beïnvloedbaar. Vrije burgers zullen het vraagstuk dat voorligt tegemoet treden vanuit een duidelijke en oprechte expressie van hun gedachten en belangen. Door middel van het volksinitiatief en het referendum behouden burgers ook agenda bepalende capaciteiten. Meestal is het niet eens nodig om daadwerkelijk te komen tot een initiatief of een referendum, omdat de mogelijkheid ervan al voldoende is om politici 'bij de les te houden'. Wanneer zij beseffen dat de mogelijkheid bestaat dat burgers een besluit herroepen, zullen zij wel uitkijken om besluiten te nemen die te veraf liggen van het algemeen belang (de aggregatie en afweging van alle individuele belangen).

Liberale pleiters voor directe democratie staan vaak een menging van directe en representatieve democratie voor. $\mathrm{Zij}$ zien het referendum en het volksinitiatief als een goede aanvulling op de representatieve democratie. Het is eenvoudigweg ondoenlijk om alle beslissingen door burgers te laten nemen. Dat is verkwisting van tijd en geld voor iedereen en het zou een te grote inspanning van burgers vragen. Verder zijn liberale voorstanders van directe democratie minder negatief over volksvertegenwoordigers, die niet als inherent slecht worden gezien maar als deskundigen die eenvoudigweg niet goed kunnen inschatten wat de preferenties zijn van het volk. Bovengenoemde argumenten legitimeren de introductie van instrumenten van directe democratie voor belangrijke vraagstukken en besluiten.

\subsubsection{ELITAIRE VISIE OP DE DIRECTE DEMOCRATIE}

Vanuit het elitisme is scherpe kritiek op de directe democratie uitgeoefend. Massale participatie van burgers in de besluitvorming zou leiden tot een rule of the mob, tot populistische wetgeving van slechte kwaliteit, politieke anarchie en chaos, en onteigening van gefortuneerde burgers die welvaart genereren voor de gehele samenleving. Omdat het niet bon ton is om te zeggen dat de meeste burgers weinig verstand hebben van politiek verhullen critici van directe democratie hun visie meestal in meer functionalistische termen: de grootte en complexiteit van moderne samenlevingen laat eenvoudig niet toe dat alle burgers deelnemen aan de besluitvorming. Een dergelijk systeem is technisch en praktisch uitsluitend mogelijk in een samenleving met slechts enkele duizenden burgers.

Een zachtere variant stelt dat de meeste burgers weinig interesse hebben voor de publieke zaak en te druk zijn met andere zaken. Vanuit het perspectief van het 
elitisme wordt een zekere specialisatie positief belicht: het maakt burgers vrij om economische, artistieke of recreatieve activiteiten te ontplooien ter verhoging van het individuele welzijn, terwijl professionele politici en bureaucraten zich bekommeren om de publieke zaak. Tevens wijzen tegenstanders van directe democratie terecht op problemen die ontstaan met minderheidsopinies: zo lonkt het gevaar van een permanente onderdrukking en marginalisering van minderheidsopinies terwijl eveneens het gevaar bestaat dat de besluitvorming zo fragmenteert dat gepassioneerde minderheden uiteindelijk de doorslag geven. Bij veel referenda komt slechts een gering aantal burgers hun stem uitbrengen, dus dit gevaar is niet uitsluitend denkbeeldig (Butler en Ranney 1994; Kobach 1993; Leduc 2002).

Uit Amerikaans onderzoek blijkt tevens dat er achter volksinitiatieven en referenda vaak meer geld zit van machtige belangengroepen dan achter verkiezingscampagnes van kandidaten. In veel gevallen is het moeilijk te achterhalen welke organisaties campagnes voor referenda financieren en is er vaak bitter weinig publieke discussie over deze referenda. Daarnaast is de formulering van de vragen op het stemformulier vaak vaag en is de exacte vraagstelling van tevoren bijna niet bekend bij de kiezers. Ten slotte worden veelvuldig rechtszaken aangespannen tegen de uitslag van referenda, waardoor de effectiviteit van initiatieven en referenda op zijn minst discutabel is (Smith 2002). Een ander tegenargument is dat bij een referendum de politieke en publieke discussie wordt beperkt door de voorliggende opties en er geen discussie is over alternatieven (Butler en Ranney 1978: 226).

Daarnaast kunnen instrumenten van de directe democratie ook worden misbruikt door machtshebbers. Referenda in het bijzonder zijn vaak op een antiparlementaire en personalistische wijze gebruikt. In autoritaire regimes worden referenda gehouden om de afwezigheid van de representatieve democratische instituties te verbloemen (verkiezingen en volksvertegenwoordiging). Tijdens het bewind van Franco in Spanje, in Chili onder Pinochet, in Iran, Algerije, Ivoorkust, Nigeria, Peru, Tunesië en vele andere niet-democratische regimes zijn referenda gebruikt ter compensatie van het representatietekort.

Voorstanders van het referendum wijzen op de vergroting van legitimiteit van politieke besluiten en van de betrokkenheid van de burgers bij de besluitvorming via een referendum. Burgers krijgen meer directe invloed en een mogelijkheid zich rechtstreeks over een bepaald beleidsvoorstel uit te spreken, terwijl zij bij verkiezingen slechts een stem op een van de politieke partijen kunnen uitbrengen. Verder zou het referendum leiden tot meer openbaarheid van de politieke discussie.

Uit deze korte beschouwing blijkt dat instrumenten van directe democratie niet per definitie bijdragen aan de kwaliteit van de democratie en zelfs door machtshebbers kunnen worden misbruikt voor de legitimatie van non-democratisch handelen. Voor een democratische verdieping in Nederland is het noodzakelijk institutioneel maatwerk te leveren, waarbij de negatieve effecten van direct 
democratische instrumenten worden geminimaliseerd en de democratische problematiek zo veel mogelijk wordt verholpen. Om de juiste keuze te kunnen maken is het noodzakelijk dieper in te gaan op de verschillende instrumenten van de directe democratie.

\subsection{INSTITUTIES VAN DE DIRECTE DEMOCRATIE: REFERENDUM, VOLKSINITIATIEF EN RECALL}

\subsubsection{TYPEN EN WERKING VAN REFERENDAEN VOLKSINITIATIEF}

In de literatuur over referenda en volksinitiatief zijn verschillende typologieën ontwikkeld. ${ }^{8}$ Referenda verschillen allereerst in termen van de initiator: dat kan een regering zijn of een andere machtshebber, een meerderheid in het parlement of een parlementaire minderheid of een deel van de bevolking (al dan niet in gezamenlijkheid met belangengroepen). Een tweede aspect waarop referenda te onderscheiden zijn is de mate van 'constitutionele dwang'. Hierbij gaat het om het feit of een referendum grondwettelijk verplicht is (mandatory) of dat het een facultatief referendum betreft (Uleri 1996: 6). Een derde onderscheid betreft het object van een referendum: gaat de volksstemming over een reeds aangenomen wet door het parlement of over een nog te agenderen politieke kwestie. Eveneens kan onderscheid worden gemaakt tussen referenda die consultatief zijn en referenda die bindend zijn. Op basis van deze criteria kan het volgende schema worden opgesteld.

Tabel 12.1 Typen volksinitiatief en referenda

\begin{tabular}{|c|c|c|c|c|}
\hline \multirow[t]{2}{*}{ Initiator } & \multicolumn{2}{|l|}{ Bindend } & \multicolumn{2}{|l|}{ Consultatief } \\
\hline & $\begin{array}{l}\text { Voorliggend wets- } \\
\text { voorstel }\end{array}$ & $\begin{array}{l}\text { Nog te agenderen } \\
\text { voorstel }\end{array}$ & $\begin{array}{l}\text { Voorliggend } \\
\text { wetsvoorstel }\end{array}$ & $\begin{array}{l}\text { Nog te agenderen } \\
\text { voorstel }\end{array}$ \\
\hline $\begin{array}{l}\text { Uitvoerende } \\
\text { of wetgevende }\end{array}$ & $\begin{array}{l}\text { Decision-promoting } \\
\text { referendum* }\end{array}$ & (onlogische variant) & $\begin{array}{l}\text { Consultative } \\
\text { referendum }\end{array}$ & Advisory referendum \\
\hline Volksinitiatief & $\begin{array}{l}\text { Citizen-veto, rejec- } \\
\text { tive or abrogative } \\
\text { referendum, peti- } \\
\text { tionary referendum } \\
\text { (repeal of existing } \\
\text { law) }\end{array}$ & $\begin{array}{l}\text { Direct initiative } \\
\text { (the citizens proposal } \\
\text { becomes effective } \\
\text { law instantaneously) }\end{array}$ & $\begin{array}{l}\text { Citizen- } \\
\text { amendment }\end{array}$ & $\begin{array}{l}\text { Plebiscitary, agenda- } \\
\text { setting referendum } \\
\text { = indirect initiative } \\
\text { (the proposal is } \\
\text { placed on the parlia- } \\
\text { mentary agenda) }\end{array}$ \\
\hline
\end{tabular}

* Om spraakverwarring te voorkomen is in deze tabel de Engelstalige terminologie gehandhaafd.

Als we allereerst de referenda geïnitieerd door de wetgevende of uitvoerende macht nalopen, dan zien we in de cel linksboven het meest traditionele type referendum. Veelal zal dit een verplicht (mandatory) referendum betreffen, want anders is er voor een regering of parlement geen reden om het volk nog eens om zijn mening te vragen. Vaak betreft een dergelijk referendum een grondwetswijziging of een andere belangrijke constitutionele amendering. Een bindend refe- 
rendum over een nog niet vastgelegd wetsvoorstel is een onlogische variant want dan zou een niet bestaand voorstel onmiddellijk wet worden.

De volgende twee typen referendum die door de uitvoerende of wetgevende macht kunnen worden geïnitieerd zijn het consultatieve en het adviserende referendum. Bij het consultatieve referendum betreft het een wetsvoorstel waarover de regering wil bepalen in welke mate er steun bestaat bij de bevolking voor dit wetsvoorstel. Wanneer een meerderheid van de bevolking zich uitspreekt tegen het wetsvoorstel kan het parlement het desalniettemin aannemen en invoeren, want het betreft hier een consultatieve variant van het referendum (Suski 1993). $\mathrm{Bij}$ een adviserend referendum kan een regering de bevolking verzoeken zich uit te spreken over een nog te agenderen voorstel. Wanneer een meerderheid van de bevolking het voorstel aanneemt komt het op de parlementaire agenda.

Op de onderste rij in tabel 12.1 zijn verschillende vormen van referenda afgezet die door het volk kunnen worden geïnitieerd (Neijens en Van Praag 1999: 5). Van deze volksinitiatieven of door het volk geïnitieerde referenda is allereerst het volksveto van belang. Hierbij gaat het om een referendum dat burgers hebben georganiseerd om een bestaand wetsvoorstel naar de prullenbak te verwijzen. Een tweede vorm van volksinitiatief is de meest vergaande vorm van directe wetgevende macht voor burgers. Burgers kunnen door middel van een referendum een compleet wetsvoorstel laten aannemen dat dan onmiddellijk de kracht van wet krijgt, zonder dat het nog parlementaire discussie of goedkeuring behoeft. Hiermee kunnen parlementaire vertegenwoordigers volkomen worden gepasseerd en gaat de burger zelf op de stoel van de wetgevende macht zitten.

Het volksamendement is een referendum waarin het volk aangeeft niet tevreden te zijn met een bestaande wet en een voorstel doet ter amendering van deze wetgeving. De regering kan dit consultatieve referendum negeren en alsnog gewoon de oorspronkelijke wet invoeren, maar wanneer een grote meerderheid zich tegen een bepaalde wet heeft uitgesproken ontstaan er dan natuurlijk wel politieke en praktische problemen (LeDuc 2002: 73). Het laatste type is het agenda bepalende referendum, waarbij burgers een, al dan niet volkomen afgerond, voorstel doen dat bij meerderheid op de politieke agenda van het parlement wordt geplaatst. Na ampel beraad kan het parlement deze uitspraak van het volk natuurlijk negeren door de wet te verwerpen, maar dat zullen kiezers hen dan waarschijnlijk niet in dank afnemen.

\subsubsection{RECALL-PROCEDURES}

In een brede definitie van directe democratie, waarbij het gaat om besluiten die zijn gemaakt door het volk, dus zonder tussenkomst van hun vertegenwoordigers, passen ook besluiten over personen. Hoewel rechtstreekse verkiezingen van machtshebbers meestal worden gezien als een van de vele vormen van representatieve democratie, worden recall-procedures door sommige auteurs wel tot de directe democratie gerekend (Cronin 1989). Eigenlijk is dat niet logisch. Recall- 
procedures betreffen regels waarmee een bestuurder tussentijds uit het ambt kan worden gezet wanneer een bepaald aantal burgers dat wenst. Voorstanders van dergelijke procedures stellen dat recalls de controle van het volk over zijn machthebbers versterkt omdat politici altijd kunnen worden weggestuurd. Het stelt burgers in staat om eventuele 'fouten' die bij verkiezingen zijn ontstaan te corrigeren. Dergelijke procedures zouden ook de politieke vervreemding en het cynisme bij de burgers wegnemen. Als burger is men immers gemachtigd om politici naar huis te sturen en dat geeft een machtig gevoel. Er zou eveneens een lerend effect uitgaan van deze recall-procedures omdat het kiezers laat nadenken over de duur van het mandaat dat men volksvertegenwoordigers en bestuurders geeft.

Tegenstanders wijzen juist op het ondemocratische en onpraktische karakter van deze procedures. Vaak is een veel kleiner aantal kiezers nodig om een politicus uit de macht te zetten dan het aantal dat op hem of haar heeft gestemd tijdens de verkiezingen. Dat betekent dat gepassioneerde en goed georganiseerde minderheden continu politici uit het ambt kunnen zetten. Hoewel het op het niveau van de staten in de vs niet vaak gebeurt, worden wel regelmatig lokale bestuurders door recall-procedures uit het ambt gezet. Tegenstanders van recalls wijzen ook op het ongeduld van veel kiezers. Vaak duurt het even voor een politicus het puin van zijn of haar voorganger heeft geruimd, nieuwe mensen heeft benoemd en ambtenaren met het nieuwe beleid aan het werk heeft gezet, voordat de resultaten van het nieuwe beleid zichtbaar worden. Als burgers dan uit ongeduld een dergelijk zorgvuldig en consciëntieus handelende politicus naar huis sturen, wordt het een bestuurlijke chaos en het publieke ambt wordt er ook niet aantrekkelijker op. Er zullen uitsluitend nog onzorgvuldige en opportunistische politici overblijven.

\subsection{INSTITUTIONELE INNOVATIES TER VERDIEPING VAN DE NEDERLANDSE DEMOCRATIE}

\subsubsection{CONSENSUSDEMOCRATIE EN DIRECTE DEMOCRATIE}

Na deze analyse van de drieledige democratische problematiek in Nederland en de bespreking van mogelijke institutionele innovaties vanuit het perspectief van de directe democratie zal in dit deel worden nagegaan welke instituties een democratische verdieping kunnen bewerkstelligen (d.w.z. het Nederlandse politieke systeem naar een semi-directe democratie kunnen laten transformeren), alsmede de problemen van legitimiteit, representativiteit en controle en verantwoording kunnen minimaliseren. Hierboven zijn al enkele criteria geformuleerd waaraan institutionele innovaties moeten voldoen: ze moeten effectief kunnen worden ingepast in het bestaande institutionele raamwerk van de representatieve democratie en aansluiten bij de politieke cultuur van de consensusdemocratie.

\section{Invoering van een volksinitiatief}

Uitgangspunt van de democratische verdieping is dat de institutionele innovaties goed aansluiten bij het bestaande institutionele raamwerk en de dominante poli- 
tieke cultuur. Dit om te voorkomen dat de vermenging van vormen van representatieve democratie met instrumenten van de directe democratie leidt tot deadlock.

Vatter (2000) heeft een poging gedaan om verschillende vormen van directe democratie te verbinden met de theorie van de consensusdemocratie. Allereerst moeten we vaststellen dat Zwitserland, waar het frequentst gebruik wordt gemaakt van het referendum en het volksinitiatief, eveneens een consensusdemocratie is en dat vormen van directe democratie blijkbaar goed te verbinden zijn met een dergelijk institutioneel raamwerk (Kobach 1993; Ladner en Brändle 1999). Lijphart, die de theorie van de consensusdemocratie heeft ontwikkeld, stelt zelf dat de directe democratie niet eenduidig bij de meerderheids- of bij de consensusdemocratie aansluit (Lijphart 1984: 31). Vatter (2000: 172-176) laat echter zien dat bepaalde vormen van referendum en volksinitiatief theoretisch goed te verbinden zijn met de consensusdemocratie. Op basis van een zeer rudimentair onderscheid tussen referenda (de vraag of een meerderheid of een minderheid nodig is om een referendum te initiëren) koppelt Vatter plebiscites en mandatory-referenda aan meerderheidsdemocratieën, en volksinitiatieven en optionele referenda aan consensusdemocratieën. De argumentatie hierbij is dat deze laatste typen referenda kunnen worden geïnitieerd door een minderheid tegen een besluit van een parlementaire meerderheid. Door middel van volksinitiatieven kan een minderheid eveneens wetgeving initiëren en agenderen zonder dat een parlementaire meerderheid nodig is. Bescherming van de rechten van minderheden, een cruciaal kenmerk van consensusdemocratieën, staat hierbij centraal. Lindahl en Van Roermond (2000: 29) komen eveneens tot de conclusie dat het referendum verenigbaar is met democratische representatie, niet zozeer als een nuttige aanvulling op het vertegenwoordigende stelsel als wel omdat het referendum één van de mogelijke manieren is om vertegenwoordiging vorm te geven.

Uit bovenstaande analyse kan worden geconcludeerd dat het referendum goed kan worden ingepast in de representatieve democratie. Directe vormen van democratie vergen een hoge mate van deelname van burgers aan discussies en besluitvorming en moeten daarom beperkt blijven tot die onderwerpen waar burgers zelf van aangeven het belangrijk genoeg te vinden om politiek te participeren. Vandaar dat verplichte referenda en referenda die worden geïnitieerd door de uitvoerende macht niet gewenst zijn. Evenmin moet men in Nederland het consultatieve of adviserende referendum invoeren. Bij dergelijke referenda kan een enorme participatie van de bevolking uiteindelijk zonder enig resultaat blijven, waardoor de legitimiteit van de besluitvorming nog verder wordt ondergraven.

Het volksinitiatief, daarentegen, is een goed middel waarmee burgers daadwerkelijke invloed op de politieke agenda en op wetgeving kunnen uitoefenen. Er moet niet worden gekozen voor een verwerpend en afbrekend referendum, omdat negatieve politieke participatie zo veel mogelijk dient te worden voorkomen. 
Indien het parlement wetgeving aanneemt tegen de zin van de bevolking, dient er naast de bestaande middelen van politiek verzet de mogelijkheid te zijn om een andere wet in het parlement in te brengen of een amendement op de wet in te dienen via een dergelijk volksinitiatief.

\section{Steun aan maatschappelijke organisaties om volksinitiatieven te ontplooien}

Gekoppeld aan de invoering van het volksinitiatief moet de facilitering van maatschappelijke organisaties vanuit de overheid worden herzien. Maatschappelijke organisaties moeten financiële middelen kunnen krijgen wanneer zij burgers bijstaan in het voorbereiden van volksinitiatieven. Dit past uitstekend in de consensusdemocratie, omdat regeringen op deze wijze feitelijk hun oppositie financieren. Vanzelfsprekend vergt dit duidelijke regels over de financiering van dergelijke campagnes, waarbij voor- en tegenstanders totale financiële openheid van zaken moeten geven. Een bijkomend voordeel is dat belangengroepen zich niet langer eenzijdig zullen richten op deelname aan het corporatistische overleg met de overheid, maar vaker samen met burgers zullen optrekken om wetgeving te initiëren of te wijzigen. Hierdoor kan het huidige machtskartel van partijen en belangengroepen opengebroken worden.

\section{Invoering van een gemengd kiesstelsel}

Een gemengd kiesstelsel sluit goed aan bij de bestaande instituties en politieke cultuur van de consensusdemocratie, terwijl het tegelijkertijd het legitimiteitsprobleem kan verkleinen. In een dergelijk systeem mag een kiezer zowel een stem uitbrengen op een kandidaat die op een partijlijst staan, maar heeft hij daarnaast nog een tweede stem die kan worden uitgebracht op een kandidaat die rechtstreeks wordt gekozen binnen een kiesdistrict. Om de proportionaliteit te optimaliseren kan ervoor worden gekozen om, voor de lijststemmen, Nederland te blijven beschouwen als één kiesdistrict. Dit hybride stelsel combineert de voordelen van het systeem van proportionele representatie en die van een meerderheidsstelsel. Dit gemengde stelsel versterkt de binding tussen kiezer en gekozene, doordat men rechtstreeks een vertegenwoordiger in het parlement kiest. Indien die persoon een meerderheid van stemmen behaalt, heeft men bovendien een 'eigen' vertegenwoordiger in het parlement.

Het probleem van 'verspilde stemmen' blijft natuurlijk wel bestaan voor diegenen die op een kandidaat hebben gestemd die niet rechtstreeks wordt gekozen, maar de tweede stem van de burger zal meestal wel tot representatie leiden. Dit gemengde stelsel moet dan ook worden ingevoerd zonder kiesdrempel, omdat het al in het voordeel werkt van de grotere partijen. Wanneer electorale minderheden echter redelijk geconcentreerd zijn, zoals dat in Nederland het geval is met de klein-christelijke partijen, zullen dergelijke politieke groeperingen zowel via directe mandaten vertegenwoordigers krijgen als via het lijststelsel. Hierdoor blijft de representatie van minderheden gewaarborgd, maar is deze niet langer het enige uitgangspunt. Een ander voordeel van dit stelsel is dat het aansluit bij de minder sterke partijbinding van burgers. Aangezien de meeste Nederlanders een 
bepaalde mate van binding hebben met meer dan één partij en vaak ook duidelijke coalitievoorkeuren hebben, is het goed dat met de twee stemmen ook de richting van de kabinetssamenstelling kan worden aangegeven. Eveneens laat het een combinatie toe van tactisch stemmen bij de districtskandidaat en een 'gewetensstem' in het lijststelsel.

Voor politieke partijen is het voordeel van het gemengde stelsel dat zij hun populaire kandidaten kunnen inzetten in verschillende districten en zodoende een sterkere binding met de kiezers kunnen bewerkstelligen. Hoewel een dergelijk hybride kiesstelsel wel leidt tot twee soorten van parlementariërs binnen fracties, namelijk diegenen die een eigen direct kiezersmandaat hebben en diegenen die via de lijst in het parlement zijn gekomen, hoeft dat niet automatisch te leiden tot meer verdeelde fracties en minder fractiediscipline (Shugart en Wattenberg 2001). In Duitsland is dat in ieder geval niet waar te nemen. Wel is het zo dat parlementariërs met een direct mandaat vaker een leidersrol opeisen in een fractie, maar dat is vanuit democratisch oogpunt ook wenselijk: zij hebben immers een rechtstreeks kiezersmandaat. De combinatie van populaire direct gekozen kandidaten en meer technocratische en gespecialiseerde parlementariërs die via de lijsten in de volksvertegenwoordiging komen, doet ook recht aan de al bestaande taakverdeling.

De invoering van een gemengd kiesstelsel kan leiden tot verdergaande verpersoonlijking van de politiek, hetgeen niet uitsluitend negatief is. Allereerst moeten we stellen dat representatieve democratie per definitie leidt tot aandacht voor persoonlijkheden. Immers, wij geven onze beslissingsbevoegdheid over publieke zaken voor een aantal jaren aan onze volksvertegenwoordigers. Indirecte, representatieve democratie gaat dus altijd over het vertrouwen in personen en daarom ook over persoonskenmerken. Eveneens is het logisch dat politieke partijen kandidaten proberen te werven die voor een breed publiek aantrekkelijk zijn. De rekrutering van een politieke elite is immers een cruciale functie van politieke partijen. Wanneer zij politici kunnen afvaardigen die het vertrouwen genieten van veel mensen, dan is dat goed voor de democratie. Een bijkomend voordeel van personalisering van de politiek is dat er meer politieke betrokkenheid en participatie bij burgers ontstaat.

Er kleven natuurlijk wel nadelen aan de personalisering van de politiek. Ten eerste wordt een democratie zeer kwetsbaar wanneer deze te veel afhankelijk is van personen in plaats van duurzame instituties en van de autoriteit die verbonden is aan een ambt. Maar deze kwetsbaarheid gaat verder dan politieke moord. De politicoloog Linz heeft veelvuldig gewezen op de gevaren van machtsconcentratie bij politieke systemen waar persoonlijkheden domineren. Naast het gevaar van ziekte en geestelijke instabiliteit zijn individuen altijd kwetsbaar voor ongewenste beïnvloeding, bedreiging, afpersing en machtsmisbruik. Wanneer individuele personen te veel macht verwerven kunnen zij in de verleiding komen om besluiten te nemen die ingaan tegen de belangen van grote groepen burgers. Een ander nadeel is dat door de nadruk op de persoonlijke kenmerken, de aandacht 
voor inhoudelijke verschillen naar de achtergrond verdwijnt. Doorgeschoten en buitenproportionele aandacht voor persoonlijke kenmerken, (uiterlijke) eigenaardigheden, sympathieën en hobby's ridiculiseren het democratische proces, terwijl het in een democratie zou moeten gaan over een inhoudelijke keuze uit beleidsalternatieven. Om deze gevaren te minimaliseren moet de invoering van een gemengd stelsel gepaard gaan met de invoering van duidelijke en stringente wetgeving ten aanzien van politieke partijen en hun kandidaten.

\section{Nieuwe Wet op de Politieke Partijen}

De wetgeving op het gebied van de politieke partijen is in Nederland uitermate zwak en inconsistent (Krouwel 2004). In de Nederlandse wetgeving wordt het bestaan van politieke partijen nauwelijks erkend en hebben zij haast een extralegem-status (Elzinga 1990). In de constitutie wordt het bestaan van politieke partijen totaal genegeerd. Partijen hebben geen aparte status onder het Nederlands recht en vallen volkomen onder het burgerlijk recht. Hierdoor worden parlementariërs formeel beschouwd als burgers met een individueel mandaat en stemmen zij formeel 'zonder last' (Art. 67.3 Grondwet). Het Nederlands recht eist ook geen specifieke organisatievorm van politieke partijen. Registratie op basis van Artikel 2 van het Handelsregisterwet is voldoende (Kieswet Art. G1). Partijen worden uitsluitend erkend in het Reglement van Orde van het parlement (Art. 11), waar de verdeling van spreektijd wordt geregeld, terwijl de Kieswet (Art. G en H) en de Mediawet (Art. 39g) wel een aantal partijfuncties erkennen. Partijen worden hier echter 'politieke groeperingen' genoemd en de vereisten voor erkenning van dat label blijven onduidelijk. De enige directe wettelijke erkenning van politieke partijen is te vinden in de Wet Subsidiëring Politieke Partijen uit 1999, waar partijen worden gedefinieerd als associaties die zijn geregistreerd onder Artikel Gi van de Kieswet. Deze juridische ontkenning van het bestaan van politieke partijen leidt ook tot problemen wanneer een partij de democratische spelregels overtreedt of zich niet aan de wet houdt.

Een nieuwe wet op de politieke partijen moet enerzijds tot doel hebben de belangrijke functie die politieke partijen hebben in een democratie te erkennen en te formaliseren, terwijl anderzijds deze wet kan worden gebruikt om de interne structuur van politieke partijen te democratiseren. Analoog aan de Duitse partijwet, die de democratische taken van partijen expliciet maakt, kan van partijen worden geëist dat hun interne structuur democratisch is en dat zij openheid van zaken geven over hun financiën (Scheider 1990; Poguntke 1994). Door middel van dergelijke wetgeving kan langzaam maar zeker een meer elective culture ontstaan onder Nederlandse politici. Wanneer ze in hun eigen partij gewend raken om in open competitie met anderen een politieke positie te veroveren, zullen ze dat ook buiten de eigen politieke organisatie accepteren. De wet moet er ook toe leiden dat politieke partijen hun rol drastisch herzien. In deze nieuwe partijwet moeten, net als in Duitsland, de publieke taken van partijen worden geëxpliciteerd, zoals het bevorderen van het publieke debat, de organisatie van parlement en regering en het zorg dragen voor een krachtige band tussen burger en staat. Partijen moeten zich concentreren op datgene waar ze goed in 
zijn en wat onomstreden tot hun taak behoort: het garanderen van openheid (transparantie) van de democratische besluitvorming en de bewaking van de rechtmatige procedures.

Vanzelfsprekend moeten politieke partijen hiervoor de financiële middelen krijgen, maar tegelijkertijd moet de wet de verknoping van partijen met de staat tegengaan door duidelijke grenzen aan het gedrag van partijen en hun vertegenwoordigers te stellen. Ook moet in de wet een duidelijke regeling komen over de financiering van verkiezingscampagnes, die immers door de rechtstreeks gekozen kandidaten voor het parlement een steeds belangrijkere plaats in zullen gaan nemen in het democratische proces. De huidige wetgeving ten aanzien van partijfinanciering is te vaag en biedt te veel ruimte voor misbruik (Nehmelman 2000; Krouwel 2003b).

\section{Leider van de oppositie}

In deze nieuwe wet op de politieke partijen moet eveneens een specifieke regeling komen voor de aanwijzing van een formele leider van de oppositie. Net als in Groot-Brittannië, waar de leider van de oppositie al sinds 1937 een formele status heeft, moet de fractieleider van de grootste partij (of een andere kandidaat die door de gezamenlijke oppositie naar voren wordt geschoven) deze formele taak op zich nemen. De leider van de oppositie heeft als politieke opdracht om met de regering (de minister-president en andere ministers) in debat te gaan en een alternatief beleid aan te geven. Het parlementaire vragenuurtje en de regeringspropaganda van het 'gesprek met de minister-president' dienen te worden vervangen door een wekelijks debat tussen regeringsleden en de oppositieleider. Hoewel op het eerste gezicht de schijn gewekt kan worden dat het aanwijzen van een formele oppositieleider ingaat tegen de consensusdemocratie, sluit het juist uitstekend aan bij onze politieke cultuur. Ook binnen de coalitie wordt een premier aangewezen, meestal de leider van de grootste regeringspartij en dit patroon wordt dus eenvoudigweg gekopieerd op het niveau van de oppositie. Verder past het in de consensusdemocratie omdat het alle oppositiepartijen stimuleert, ondanks de programmatische verschillen, samen te werken en een alternatief voor het regeringsbeleid te formuleren.

Vanzelfsprekend blijven de mogelijkheden voor een inhoudelijke inbreng in alle plenaire debatten en commissievergaderingen door individuele partijen bestaan. Het betreft hier slechts een specifieke regeling voor een wekelijks debat tussen regering en oppositie waarin de politieke verschillen worden benadrukt en waarbij de verantwoording door de regering over het gevoerde beleid centraal staat. De invoering van een formele oppositieleider zal ook het publieke debat stimuleren en men kan een mogelijke toekomstige premier al vergelijken met de zittende minister-president. Net als in het Verenigd Koninkrijk zal de leider van de oppositie ook materiële en personele ondersteuning ontvangen om zijn of haar rol goed te kunnen vervullen. Hiermee wordt ook voorkomen dat de oppositie 'slapend rijk wordt' en zonder al te veel inspanning de stem van de ontevreden burger zal ontvangen. 


\section{Versterking van het parlement en 'mini-enquêtes'}

Om meer tegenwicht te kunnen bieden aan leden van de regering, die een enorme kennisvoorsprong en een heel ambtenarenapparaat tot hun beschikking hebben, inclusief spin doctors en overheidsvoorlichters, moeten parlementsleden ook meer ondersteuning krijgen bij hun controlerende taak. Om de controlerende taak van parlementariërs te ondersteunen moet een parlementair onderzoeksbureau worden opgericht dat, onafhankelijk van ambtenaren die onder een minister ressorteren, parlementair onderzoek kan uitvoeren naar het beleid van de regering. Hiervoor is eveneens verscherpte wetgeving nodig om meer openbaarheid van informatie te verkrijgen.

Deze wetswijziging moet worden aangevuld met een regeling die het mogelijk maakt 'parlementaire mini-enquêtes' te houden. Er moet een parlementair controlemiddel komen dat ligt tussen het eenvoudigweg ter verantwoording roepen van een minister in de Tweede Kamer en het zware middel van een parlementaire enquête. Binnen dit mini-enquêterecht moeten ook ambtenaren kunnen worden gehoord. Deze maatregelen zullen preventief werken op het gedrag van bewindslieden en ambtenaren. Meer frequente en permanente controle van de regering en het ambtenarenapparaat heeft als positief neveneffect dat ook zaken aan de oppervlakte komen die wel goed zijn gegaan, waar bewindslieden en ambtenaren wel integer en adequaat hebben gehandeld. Nu wordt het zware wapen van de parlementaire enquête uitsluitend ingezet als het al overduidelijk is dat er van alles is misgegaan. Hierdoor ontstaat bij de burgers steeds opnieuw het beeld van een falende overheid. Dat eenzijdige beeld moet worden gekeerd omdat het geen recht doet aan de vele overheidsinspanningen die wel het gewenste positieve effect voor de samenleving sorteren.

\subsubsection{ZES VOORSTELLEN VOOR DEMOCRATISCHE VERDIEPING VAN DE NEDERLANDSE CONSENSUSDEMOCRATIE}

De hierboven voorgestelde wijzigingen zijn in tabel 12.2 verbonden met de democratische problematiek die in paragraaf 12.1 en 12.2 is geschetst. De instrumenten zijn in de tabel weliswaar gekoppeld aan het democratische probleem waar het in hoofdzaak op is gericht, maar de meeste voorstellen zullen tevens een positief effect hebben op de andere problemen.

De legitimiteit van het Nederlandse politieke stelsel (in termen van participatie en vertrouwen) zal worden vergroot door de directe verkiezing van een deel van de parlementariërs. Door middel van een nieuwe wet op de politieke partijen zullen ook binnen deze organisaties alle functies door middel van verkiezingen worden vervuld. Hierdoor ontstaat langzamerhand een elective culture in plaats van de huidige benoemingscultuur.

Deze directe verkiezingen raken natuurlijk ook aan het representatieprobleem, maar dat wordt toch in eerste instantie verlicht door de invoering van een indirect volksinitiatief dat zowel agenda-zettend kan zijn als amenderend op reeds 
bestaande wetgeving. Hierdoor kan de bevolking rechtstreeks ingrijpen op de politieke agenda van het parlement. Dit type referendum past het beste in onze consensusdemocratie omdat het een minderheidsveto behelst en voorkomt dat wetgeving aan een minderheid wordt opgelegd. Er volgt altijd nog een parlementair debat na een dergelijk referendum, zodat de meeste nadelen van dit instrument (simplificatie, gepassioneerde minderheden en manipulatie door belangengroepen) kunnen worden geminimaliseerd. Belangengroepen worden uitgenodigd om in de openbaarheid en met volledige openheid van zaken wetgevingsinitiatieven te ondersteunen. Op dergelijke wijze wordt, geheel in lijn met de Nederlandse consensusdemocratie, het maatschappelijk middenveld gestimuleerd om een vooraanstaande rol te spelen in de beleidsontwikkeling. Nu echter niet aan de tafel met de regering en achter de gesloten deuren van het corporatistische overleg, maar midden in de samenleving met de burgers samen. Hierdoor worden ook burgers machtiger ten opzichte van het bestaande politieke kartel van politieke partijen, de staat en machtige belangengroepen.

Ter verlichting van het controle- en verantwoordingsprobleem is er het voorstel om een meer duaal stelsel op het nationale niveau te creëren, dat aansluit bij de invoering van een gemengd kiesstelsel. Een formele leider van de oppositie krijgt de specifieke taak om de regering effectief en continu te controleren. Hiermee wordt tegengas gegeven aan de huidige monistische tendens waarbij de meerderheid van de regeringsfracties automatisch bewindslieden steunt. Bovendien kan een dergelijke 'schaduwpremier' door zijn formele status internationaal optreden en op die manier de toenemende macht van premier en ministers enig tegenwicht geven.

Tabel 12.2 Democratische problemen en oplossingen

\begin{tabular}{|c|c|c|}
\hline & Grondwettelijke wijzigingen & Wijziging in wetgeving \\
\hline Legitimiteitsprobleem & Gemengd kiesstelsel & Wet op politieke partijen \\
\hline Representatieprobleem & $\begin{array}{l}\text { Indirect volksinitiatief en } \\
\text { citizen-amendement }\end{array}$ & $\begin{array}{l}\text { Overheidsfacilitatie op basis van } \\
\text { participatieve activiteiten en steun } \\
\text { aan burgers bij voorbereiden } \\
\text { volksinitiatieven }\end{array}$ \\
\hline $\begin{array}{l}\text { Probleem van demo- } \\
\text { cratische controle en } \\
\text { verantwoording }\end{array}$ & $\begin{array}{l}\text { Invoering van een formele } \\
\text { 'leider van de oppositie' }\end{array}$ & $\begin{array}{l}\text { Versterking van het parlement } \\
\text { door middel van eigen onderzoeks- } \\
\text { faciliteiten en 'mini-enquêtes' }\end{array}$ \\
\hline
\end{tabular}

De perfecte democratie bestaat niet. Het enige wat we kunnen doen is permanent blijven nadenken over institutionele innovaties die de problemen verlichten. En deze dan ook daadwerkelijk invoeren! 


\section{NOTEN}

1

7

8

Zie Eurobarometer 2004; Dekker en De Hart 2002; Dekker et al. 2004; Praag en Uittenhoeve 1999.

Zie Eijk en Niemoller 1983; Tillie 1995; Katz en Mair 1992; 1994a; Schmitt en Holmberg 1995; Kolk 20oob: 138.

Zie Blondel 1985; Blondel en Thiebault 1991; NCW 1993; Eldersveld et al. 1996; Krouwel 1999.

Zie Binnema 2002, 2003; Dauderstädt 2003; Hix 1997; Mair 2000; Raunio en Wiberg 2000; Ray 1999; Taggart 1998.

Zie Miller 1974; Craig en Maggiotto 1981; Luks en Citrin 1997; Tarrow 2000. Zie Budge 1996; Butler en Ranney 1994; Cronin 1989; Gallagher en Uleri 1996; Hamon 1995; Ladner en Brändle 1999; Luthardt 1994; Papadopoulos 1995; 1998; Rourke et al. 1992; Suski 1993.

Zie Abts 2004; Canovan 1984; 1999; 2002; Piccone 1994; Taggart 1995; 1996; Hayward 1996.

$8 \quad$ Zie Butler en Ranney 1994; Hamon 1995; Hug en Tsebelis 2002; LeDuc 2002; Linder 1994; Möckli 1994; Suski 1993; Gallagher en Uleri 1996; Vatter 2000. 


\section{LITERATUUR}

Aarts, K. (2000) Opkomst in J. Thomassen en K. Aarts (2000) Politieke veranderingen in Nederland 1971-1998: kiezers en de smalle marges van de politiek, Den Haag: Sdu: 57-76.

Abts, K. (2004, te verschijnen) 'Het Populistisch Appèl. Voorbij de Populaire Communicatiestijl en ordinaire democratiekritiek', in Tijdschrift voor Sociologie.

Aerts, R., H. de Liagre-Bohl, P. Rooy en H. te Velde (1999) Land van kleine gebaren. Een politieke geschiedenis van Nederland, Nijmegen: SUN.

Andeweg, R.B. (1989) 'Institutional Conservatism in the Netherlands: proposals for and resistance to change', West European Politics, vol. 12: 42-6o.

Andeweg, R.B. en G.A. Irwin (2002) Governance and Politics of the Netherlands, Houndmills/New York: Palgrave Macmillan.

Barney, D.D. en D. Laycock (1999) 'Right-Populists and Plebiscitary Politics in Canada' Party Politics, vol. 5, 3: 317-339, London: Sage Publications.

Binnema, H. (2002) European integration and the survival of political parties, paper voor het Politicologenetmaal, Noordwijkerhout, mei 23-24 2002.

Binnema, H. (2003) Three sorts of Europe. The Europeanisation of party programmes in the Netherlands and the United Kingdom, paper voor de ECPR-Conferentie, september 2003, Marburg.

Blondel, J. (1985) Government ministers in the contemporary world, London: Sage.

Blondel J. en J.L. Thiébault (red.) (1991) The Profession of Government Minister in Western Europe, London.

Bomberg, E. (2002) The Europeanisation of Green Parties: Exploring the EU's Impact, West European Politics, vol. 25, 3: 29-50.

Borg, S. (1995) Electoral Participation in Deth and E. Scarbrough (red.) (1995) The impact ofvalues. Oxford: Oxford University Press: 441-459.

Bosmans, J. van (1990) Staatkundige vormgeving in Nederland, Assen: Van Gorcum.

Budge, I. (1996) The New Challenge of Direct Democracy, Cambridge: Polity Press.

Butler, D. en A. Ranney (1994) Referendums around the world, Washington D.C.: American Enterprise Institute.

Castenmiller (1988) Participatie in beweging. Ontwikkelingen in politieke participatie in Nederland, Rijswijk: Sociaal en Cultureel Planbureau.

Canovan, M. (1984) 'People, Politicians and Populism', Government and Opposition, vol. 19, 3: 312-327.

Canovan, M. (1999) 'Trust the People! Populism and the Two Faces of Democracy', Political Studies, vol. 27: 2-16.

Canovan, M. (2002) 'Taking Politics to the People: Populism as the Ideology of Democracy', in Y. Mény en Y. Surel (red.) Democracies and the Populist Challenge, Houndmills: Palgrave: 25-44.

Citrin, J. en C. Muste (1999). Trust in Government and System Support. Measures of Political Attitudes, J. Robinson, L. Wrightsman and P. Shaver: Measures of Political Attitudes, New York, Academic Press, 465-532.

Craig, S. C. en M. A. Maggiotto (1981) 'Political Discontent and Political Action', Journal of Politics 43, 2: 514-522. 
Cronin, T. (1989) Direct Democracy, The Politics of Initiative, Referendum and Recall, Cambridge: Harvard University Press.

Daalder, H., (1974) Politisering en lijdelijkheid in de Nederlandse politiek, Assen: Van Gorcum.

Daalder, H. (1995) Van Oude en Nieuwe Regenten. Politiek in Nederland, Amsterdam: Bert Bakker.

Dahl, R. (2000) ‘A Democratic Paradox?’, Political Science Quarterly, vol. 115, 1: 35-40.

Dalton, R. en M.P. Wattenberg (2000) Parties without Partisans. Political Change in Advanced Industrial Democracies, Oxford: Oxford University Press.

Dauderstädt, M. (2003) Conflicting distributive interests in a deepening and widening Europe - A challenge to the emerging Europolity, achtergrondpaper bij het project 'Changing Party Systems in a Deepening and Widening Europe', Bonn: Friedrich Ebert Stiftung.

Dekker, P. (2002) Niet-stemmers: een onderzoek naar achtergronden en motieven in enquêtes, interviews en focusgroepen, Rijswijk: Sociaal Cultureel Planbureau.

Dekker, P. en J. de Hart (2002) 'Participatie', in Sociaal en Cultureel Rapport 2002, Rijswijk: Sociaal en Cultureel Planbureau.

Dekker, P. en J. de Hart (2004) 'Vrijwillig associëren', in J.W. Duyvendak en M. Hurenkamp (red.) Kiezen voor de kudde. Lichte gemeenschappen en de nieuwe meerderheid: 167-184, Amsterdam: Van Gennip.

Dekker, P., C. Maas-de Waal en T. van der Meer (2004) Vertrouwen in de rechtspraak. Theoretische en empirische verkenningen voor een monitor, SCP Werkdocument 102, Den Haag: Sociaal en Cultureel Planbureau.

Denters, B., O. van Heffen, H. Huisman and P.J. Klok (eds.) (2003) The rise of interactive governance and quasi-markets, The Hague: Kluwer.

Deth, J. van, en E. Scarbrough (red.) (1995) The impact of values, Oxford: Oxford University Press.

Duverger, M. (1954/1963) Political parties: Their organization and activity in the modern state, London: Methuen.

Duyvendak, J.W. en A. Krouwel (2001) Interactieve beleidsvorming: voortzetting van een rijke Nederlandse traditie? in J. Edelenbos en R. Monnikhof(red.) (2001): 17-32.

Easton, D. (1975) 'A Re-Assessment of the Concept of Political Support', British Journal of Political Science, vol. 5: 435-457.

Edelenbos J. en R. Monnikhof Lokale interactieve beleidsvorming. Een vergelijkend onderzoek naar de consequenties van interactieve beleidsvorming voor het functioneren van de lokale democratie, Utrecht: Lemma.

Eijk, C. van der, en M. Franklin (red.) (1996) Choosing Europe? The European Electorate and National Politics in the Face of Union, Ann Arbor: University of Michigan Press.

Eijk, C. van der, en B. Niemoller (1983) Electoral Change in the Netherlands. Empirical Results and Methods of Measurement, Dissertation: University of Amsterdam.

Eldersveld, S., L. Stromberg en W. Derksen (red.) (1995) 'Local Elites', in Western Democracies. A Comparative Analysis of Urban Political Leaders in the US, Sweden and the Netherlands, Boulder CO: Westview Press.

Elzinga, D. (1990) 'Die Institutionen der politischen Partei in den Niederlanden', in Tsatsos, D.Th. et al. (1990) Parteienrecht im Europäischen Vergleich. Die Parteien 
in den democratischen Ordnungen der Staaten der Europäischen Gemeinschaft, Baden-Baden, Nomos Verlagsgesellschaft: 508-544.

Eurobarometer (2004) Eurobarometer 61.

Frey, B.S. en A. Stutzer (2003) Direct Democracy: Designing a Living Constitution, IEER Working Paper 167, University of Zurich http://papers.ssrn.com/sol3/papers. cfm?abstract_id $=452081$

Gallagher, M. en M. Marsch (red.) (1988) Candidate Selection in Comparative perspective. The Secret Gardens of Politics, London: Sage.

Gallagher, M. en P.V. Uleri (red.) (1996) The Referendum Experience in Europe, London: MacMillan.

Gladdish, K.R. (1972) ‘Two Party vs. Multi-Party: The Netherlands and Britain’, Acta Politica, vol. 7: 342-361.

Glastra van Loon, J. (1998) 'Ons kiesstelsel is ondemocratisch', in NRC Handelsblad 21 juli 1998.

Hamlin, A. (1999) The Voice of the People, Constitutional Political Economy, vol.10:367-374.

Hamon, F. (1995) Le referendum. Etude Comparative, Paris: Librairie generale de droit et de jurisprudence.

Hayward, J. (1996) Élitism, Populism, and European Politics, Clarendon Press: Oxford.

Hillebrand, R. (1992) De antichambre van het parlement. Kandidaatstelling in Nederlandse politieke partijen, Leiden: Dswo Press.

Hix, S. (1997) 'Executive Selection in the European Union: Does the Commission President Investiture Procedure Reduce the Democratic Deficit?', European Integration online Papers, vol. 1, 21, http://www.eiop.or.at/eiop/texte/1997-021a.htm.

Hug, S. en G. Tsebelis (2002) 'Veto Players and Referendums Around the World', Journal of Theoretical Politics, vol. 14, 4: 465-515.

Jurgens, E. (1991) 'Fractiocratie aan het Binnenhof', in NRC Handelsblad 21 december 1991.

Kaase, M. (1990) 'Mass Participation', in K. Jennings en J.W. van Deth (red.) Continuities in Political Action: 23-66, New York: De Gruyter.

Katz, R. S. en P. Mair (red.) (1992) Party Organizations in Western Democracies 196o1990: A Data Handbook, London: Sage.

Katz, Richard S. en Peter Mair (red.) (1994a) How Parties Organise: Change and Adaptation in Party Organisations in Western Democracies, London: Sage.

Katz, Richard S. en Peter Mair (1994b) 'Changing Models of Party Organization: The Emergence of the Cartel Party', in Party Politics, vol. 1, 1: 5-28, London: Sage.

Keman, H. en A. Krouwel (2003) Cynical voters, new parties and the rise of political entrepreneurs in European representative democracies, paper gepresenteerd op de ECPR-conferentie 18-21 september 2003, Marburg.

Kersbergen, K. van en F. van Waarden (2004) '"Governance” as a bridge between disciplines: Cross-disciplinary inspiration regarding shifts if governance and problems of governability, accounability ad legitimacy', European Journal of Political Research, vol. 43, 2: 143-171.

King, A. (1994), 'Chief Executives in Western Europe', in I. Budge en D. McKay (red.) Developing Democracy: 150-163, London: Sage.

Kirchheimer, O. (1954) 'Party Structure and Mass Democracy in Europe', in F.S. Burin, en K.L. Shell (red.) (1969) Politics, Law and Social Change: Selected Essays of Otto Kirchheimer: 245-268, New York: Columbia University Press. 
Kirchheimer, O. (1966) 'The Transformation of Western European Party Systems', in J. LaPalombara en M. Weiner (red.) (1966) Political Parties and Political Development: 177-200, New Jersey: Princeton University Press.

Kitschelt, H. (2000), 'Citizens, politicians, and party cartellization: political representation and state failure in post-industrial democracies', European Journal of Political Research, vol. 37: 149-179.

Kitschelt, H. (2002) 'Popular Dissatisfaction with Democracy: Populism and Party Systems', in Y. Mény en Y. Surel (red.) Democracies and the Populist Challenge: 179-196, Houndmills: Palgrave.

Kobach, K. (1993) The referendum: Direct Democracy in Switzerland, Darmouth: Aldershot.

Kolk, H. van der (200oa) 'Aarzelende, zwevende en wisselende kiezers', in J. Thomassen en K. Aarts (2000) Politieke veranderingen in Nederland 1971-1998: kiezers en de smalle marges van de politiek: 93-106, Den Haag: Sdu.

Kolk, H. van der (20oob) 'Het afnemende belang van godsdienst en sociale klasse', in J. Thomassen en K. Aarts (2000) Politieke veranderingen in Nederland 1971-1998: kiezers en de smalle marges van de politiek: 121-138, Den Haag: Sdu.

Krouwel, A. (2003a) 'Otto Kirchheimer and the Catch-all Party', West European Politics, vol. 26, 2: 23-40.

Krouwel A. (2003b) Partisan States. Legal regulation of political parties in France, Germany, The Netherlands and the United Kingdom, Nijmegen: Ars Aequi Libri/Wolf Legal Publishers.

Krouwel, A. (1999) The catch-all party in Western Europe 1945-1990. A study in arrested development, Ph.D. Vrije Universiteit Amsterdam.

Laclau, E. (1979) Politics and Ideology in Marxist Theory, London: Verso.

Ladner, A. en M. Brändle (1999) 'Does direct democracy matter for political parties? An empirical test in the Swiss cantons', Party Politics: vol. 5, 3: 283-302.

Lawson, K. en P. Merkl (red.) (1988) When Parties fail: Emerging Alternative Organizations, Princeton: Princeton University Press.

Leduc, L. (2002) 'Referendums and Initiatives: The politics of Direct Democracy', in L. Leduc, R.G. Niemi en P. Norris (red.) Comparing Democracies 2. New Challenges in the Study of Elections and Voting: 70-87, London: Sage.

Levi, M. en L. Stoker (2000) 'Political Trust and Trustworthiness', Annual Review of Political Science, vol. 3: 475-507.

Lijphart, A. (1968), Verzuiling, pacificatie en kentering in de Nederlandse politiek, Amsterdam: De Bussy.

Lijphart, A. (1977), Democracy in Plural Societies: A Comparative Exploration. New Haven: Yale University Press.

Lijphart, A. (1984) Democracies. Patterns of majoritarian and consensus government in twenty-one countries, New Haven: Yale University Press.

Lijphart (1999) Patterns of Democracy Patterns of Democracy: Government Forms and Performance in Thirty-Six Countries, New Haven: Yale University Press.

Lindahl, H. en B. van Roermund (2000) 'Is er een plaats voor het referendum in de representatieve democratie?’, Openbaar bestuur, vol. 10, 1: 26-29.

Linder, W. (1999) Swiss Democracy. Possible Solutions to Conflict in multicultural societies, London: MacMillan. 
Luks, S. en J. Citrin (1997). Revisiting Political Trust in an Angry Age, Jaarvergadering van de Midwest Political Science Association, Chicago.

Luthardt, W. (1994) Direkte Demokratie. Ein Vergleich in Westeuropa, Baden-Baden: Nomos.

Maddens, B. (1994) 'Kiesgedrag en partijstrategie : de samenhang tussen de beleidsmatige profilering van de partijen en het kiesgedrag van de Vlamingen op 24 november 1991', Proefschrift Katholieke Universiteit Leuven.

Mair, Peter (200o). 'The limited impact of Europe on national party systems', West European Politics vol. 23, 4: 27-51.

Mair, P. (2002) 'Populist Democracy vs. Party Democracy', in Yves Mény en Yves Surel (red.) Democracies and the Populist Challenge: 81-98, Basingstoke: Palgrave.

Marks, G. en C. Wilson (200o) 'The Past in the Present: A Cleavage Theory of Party Response to European Integration', British Journal of Political Science, vol. 30 : 433-459.

McRea, K. (red.) (1974) 'Consociational Democracy. Political Accomodation in Segmented Societies', Toronto: Carleton.

Meerendonk, B. van de (1997) 'Zwevende kiezers', Doctoraalscriptie Politicologie, Faculteit der Beleidswetenschappen, Katholieke Universiteit Nijmegen.

Mény, Y. en Y. Surel (red.) (2002) Democracies and the Populist Challenge, New York: Palgrave.

Miller, A. en O. Listhaug (1999) 'Political Performance and Institutional Trust', in P. Norris (red.) Critical Citizens. Global Support for Democratic Governance: 204-216, Oxford: Oxford University Press.

Miller, A.H. (1974) 'Political Issues and Trust in Government: 1964-1970', The American Political Science Review, vol. 68, 3: 951-972.

Millward, A.S. (1992) The European Rescue of the Nation-State, Berkeley: University of California Press.

Millward, A.S. et al. (1993) The Frontier of National Sovereignty, London.

Möckli, S. (1994) Direkte Demokratie. Ein Internationaler Vergleich, Bern: Haupt.

Monnikhof, R.A.H., J. Edelenbos en A.P.M. Krouwel (2003) 'Power to the People? Rule configurations and power games in interactive governance', in B. Denters, O. van Heffen, H. Huisman en P.J. Klok (red.) The rise of interactive governance and quasi-markets: 43-67, The Hague: Kluwer.

Moravcsik, A. (1994) Why the European Community strengthens the state: Domestic politics and international cooperation, Workingpaper 52. Cambridge: Harvard University Press.

Moravcsik, A. (2002) 'In Defense of the "Democratic Deficit": Reassessing the legitimacy of the European Union', Journal of Common Market Studies, vol. 40, 4: $603-634$.

Nehmelman, R. (2000) 'Ondoorzichtige Partijfinanciering. De Wet Subsidiering Politieke Partijen en de financiële verantwoordingsplicht van politieke partijen', in DNPP Jaarboek 1999: 156-174.

NCW (1993) 'Een democratie van ambtenaren en leraren. Onderzoek naar de beroepsachtergrond van politici', speciale uitgave De Werkgever: Den Haag.

Nijens, P. en Ph. van Praag (red.) (1999) De Slag om IJburg, campagne media, publiek, Amsterdam: Het Spinhuis. 
Papadopoulos, Y. (1995) 'Analysis of Functions and Dysfunctions of Direct Democracy: Top-Down and Bottom-Up Perspectives’, Politics \& Society, vol. 23, 4: 421-448. Papadopoulos, Y. (1998) Democratie directe, Paris: Economica.

Papadopoulos, Y. (2000) National Populism in Western Europe: An Ambivalent Phenomenon, Online paper, Institut d'Etudes Politiques et Internationales, Université de Lausanne. (http://www2.unil.ch/iepi/pdfs/papadopoulosi.pdf)

Pennings, P. (1991) Verzuiling en ontzuiling: de lokale verschillen. Opbouw, instandhouding en neergang van plaatselijke zuilen in verschillende delen van Nederland na 1880. Kampen: Kok.

Pharr, S.J. en R. Putnam (200o) Disaffected Democracies. What's Troubling the Trilateral Countries?, Princeton NJ: Princeton University Press.

Picone, P. (1994) 'From the Left to New Populism', Telos 101: 173-208.

Plasser, F. (1999) Culture of Mistrust: Politischer Zynismus in den USA', Östereichische Zeitschrift für Politikwissenschaft, 4 (1999): 405-418.

Poguntke, T. (1994) 'Parties in a Legalistic Culture: The Case of Germany', in R. Katz en P. Mair (red.) How Parties Organize. Change and Adaptation in Party Organizations in Western Democracies: 185-215, London: Sage.

Praag, C. van en W. Uitterhoeve (1999) Een kwart eeuw sociale verandering in Nederland. Kerngegevens uit het Sociaal en Cultureel Rapport 1998, Nijmegen: Sun.

Praag, Ph. van (1993) 'Hoe uniek is de Nederlandse consensusdemocratie', in U. Becker (red.) Nederlandse politiek in historisch en vergelijkend perspectief: 151-178, Amsterdam.

Raunio, T. (2000) 'Losing independence or finally gaining recognition? Contacts between MEPs en national parties', Party Politics, vol. 6, 2: 211-223.

Raunio, T. (2002) 'Why European Integration Increases Leadership Autonomy Within Political Parties', Party Politics, vol. 8, 4: 405-422.

Raunio, T. en S. Hix (200o) 'Backbenchers Learn to Fight Back: European Integration and Parliamentary Government', West European Politics, vol. 23, 4: 142-168.

Raunio, T. en M. Wiberg (200o) 'Does Support Lead to Ignorance? National Parliaments and the Legitimacy of EU Governance', Acta Politica, vol. 35, 2: 146-168.

Ray, L. (1999) 'Measuring Party Orientations Toward European Integration: Results from an Expert Survey', European Journal of Political Research, vol. 36: 283-306.

Reiff, K. en H. Schmitt (1980) 'Nine Second-Order Elections - A Conceptual Framework for the Analyisi of European Election Results', European Journal of Political Research, vol. 8, 1: 3-44.

Rosenthal U. (red.) (2002) Het democratisch tekort. Tekortkomingen en remedies, Elsevier: 's-Gravenhage.

Rourke, J.T., R.P. Hiskes en C.E. Zirakzadeh (1992) Direct democracy and international politics. Deciding international issues through referendums, Boulder: Lynne Rienner Publishers.

Sartori, G. (1987) The Theory of Democracy Revisited, New Jersey: Chatham House.

Scarrow S. (2001) 'Direct Democracy and Institutional Change. A Comparative Investigation', Comparative Political Studies, vol. 34, 6: 651-665.

Schattscneider, E.E. (1942) Party Government, New York: Rinehart \& Company.

Schedler, A. (1996) 'Anti-Political-Establishment Parties, Party Politics', vol. 2, 3: 291-312, London: Sage Publications. 
Schie, P.G.C. van (red.) (2002) Het democratisch tekort: interpretaties en remedies, Den Haag: Telderstichting.

Schmitt, H. en S. Holmberg (1995) 'Political Parties in Decline?', in Klingemann and Fuchs, Citizens and the State: 95-133, Oxford: Oxford University Press.

Schmitter, P.C. (1996) 'Imagining the Future of the Euro-Polity with the Help of New Concepts', in G. Marks, F.W. Scharpf, P.C. Schmitter en W. Streeck (red.) Governance in the European Union: 121-159, London: Sage.

Schmitter, P.C. (2000) How to democratize the European Union - and why bother?, Lanham, Rowman \& Littlefield.

Schneider (1990) 'Die Institutionen der politischen Partei in der Bundesrepublik Deutschland', in D.Th. Tsatsos et al. (1990) Parteienrecht im Europäischen Vergleich. Die Parteien in den democratischen Ordnungen der Staaten der Europäischen Gemeinschaft: 160-181, Baden-Baden: Nomos Verlagsgesellschaft.

Sociaal en Cultureel Planbureau (1994) Sociale en culturele verkenningen, Rijswijk: SCP Sociaal en Cultureel Planbureau (1997) Sociale en culturele verkenningen, Rijswijk: SCP. Sociaal en Cultureel Planbureau (2003) Sociale en culturele verkenningen, Rijswijk: SCP. Shils, E. (1956) The Torment of Secrecy, London: Heinemann.

Sigelman, L. en C.K. Sigelman, et al. (1992) 'The public and the paradox of leadership: an experimental analysis', American Journal of Political Science vol. 36: 366-385.

Smets, K. (2004) Political Youth Participation: old explanations, new insights and a theoretical contribution. Doctoraalscriptie Politicologie: Vrije Universiteit Amsterdam.

Streeck, W. (1996) ‘Neo-Voluntarism: A New European Social Policy Regime?’, in G. Marks, F. Scharpf, P.C. Schmitter en W. Streeck (1996) Governance in the European Union: 64-94, London: Sage Publications.

Suski, M. (1993) Bringing in the people. A comparison of constitutional forms and practices of the referendum, Dordrecht: Martinus Nijhoff Publishers.

Taggart, P. (1995) 'New Populist Parties is Western Europe', West European Politics, vol. 18, 1: 34-51.

Taggart, P. (1996) The New Populism and the New Politics, London: MacMillan.

Taggart, P. (1998) 'A touchstone of dissent: Euroscepticism in contemporary Western European party systems', European Journal of Political Research, vol. 33, 2: 363388.

Taggart, P. (200o) Populism, Buckingham: Open University Press.

Taggart, P. (2002) 'Populism and the Pathology of Representative Politics', in Y. Mény en Y. Surel (red.) Democracies and the Populist Challenge: 62-8o, New York: Palgrave.

Tarrow, S. (2000). 'Mad Cows and Activists: contentious politics in the trilateral countries', in S. Pharr en R. Putnam Disaffected Democracies: What's Troubling the Trilateral Democracies: 270-289, Princeton NJ: Princeton University Press.

Thijn, E. van, et al. (1998) De sorry-democratie : recente politieke affaires en de ministeriële verantwoordelijkheid, Amsterdam: Van Gennep.

Tillie, J. (1995) 'Partijvoorkeur, partijconcurrentie en stemgedrag', in J. van Holsteyn en B. Niemoller (red.) De Nederlandse Kiezer 1994: 236-245, Leiden: Dswo Press.

Timmermans A. en R.B. Andeweg (200o) 'The Netherlands: Still the Politics of Accommodation?’, in W.C. Müller en K. Strøm (red.) Coalition Governments in Western Europe: 356-398, Oxford: University Press. 
Thomassen, J. (1995) 'Support for Democratic Values', in H.D. Klingemann en D. Fuchs Citizens and the state: $386-416$, Oxford: Oxford University Press.

Thomassen, J.J.A. et al. (1983) De verstomde revolutie. Politieke opvattingen en gedragingen van Nederlandse burgers na de jaren zestig, Alphen aan den Rijn: Samsom.

Uleri, P.V. (1996) 'Introduction', in M. Gallagher en P.V. Uleri (red.) (1996) The Referendum Experience in Europe: 1-19, London: MacMillan.

Vatter, A. (2000) 'Consensus and direct democracy: Conceptual and empirical linkages', European Journal of Political Research, vol. 38, 2: 171-192.

Weatherford, M. S. (1992) 'Measuring Political Legitimacy', The American Political Science Review, vol. 86, 1: 149-167.

Webb, P. en Poguntke (red.) The Presidentialization of Politics - A Comparative Study of Modern Democracies, Oxford: Oxford University Press. 


\title{
13 DEMOCRATISERING IN PERSPECTIEF. DE DELIBERATIEVE DEMOCRATIE
}

\author{
T. Akkerman
}

\begin{abstract}
“Dit moet een vergissing zijn!” zei Amerigo, "hoe zou deze man kunnen stemmen?” "Ja, hier is zijn medische verklaring," zei de priester: "motorisch gestoord. Moeder, u helpt hem, nietwaar?” “Maar natuurlijk, die arme Giuseppe!”, antwoordde de moeder. (...) “Maar praten,” zei de voorzitter, met een opgeheven vinger alsof hij zich verontschuldigde voor zijn twijfel, "kan hij helemaal niet?” “Praten niet, meneer de voorzitter," zei de priester, “zeg, kun jij praten? Nee, je praat niet? U ziet het, hij praat niet. Maar hij begrijpt wel. Weet je wie zij is, ja? Is ze lief? Ja? Hij begrijpt het. Trouwens, de vorige keer heeft hij ook gestemd." “Jazeker,” zei de moeder, "deze stemt altijd.”
\end{abstract}

In Een dag op het stembureau beschrijft Italo Calvino een verkiezingsdag in Italië in 1953. Hoofdpersoon is de door verlichtingsidealen geïnspireerde intellectueel Amerigo. Hij wordt als stemmenteller van het stembureau in het gesticht Cottolengo geconfronteerd met vrolijke gekken en stervende oudjes die 'geholpen' door de nonnen hun stem op de christen-democraten uitbrengen. De dag op het stembureau stelt zijn geloof in rede en vooruitgang danig op de proef. Het kiesrecht - een van de belangrijkste stappen op weg naar de emancipatie van het volk - blijkt een deceptie. Toch geeft Amerigo niet op. Wie niet onnozel is, peinst hij, moet uitgaan van twee principes: zich nooit te veel illusies maken en erin blijven geloven dat alles wat je kan doen van nut kan zijn.

Deliberatieve democratie is een stroming die op vergelijkbare verlichtingsidealen gebaseerd is. Het is een intellectuele traditie die weliswaar sterke wortels heeft in de kritische theorie, maar die zich in toenemende mate richt op 'doen wat van nut kan zijn'. Deliberatieve democratie is een verzamelnaam voor degenen die deliberatie belangrijker vinden dan stemmen. Om te kunnen stemmen moet men op zijn minst kunnen praten. Stemmen vereist een zekere mate van autonome oordeelsvorming, zoals de ervaring op het stembureau in het gesticht Cottolengo leert. De bewoners begrijpen niet wat er op het stembiljet staat of kunnen hun mening niet meer kenbaar maken. De redelijkheid die Amerigo verwacht van kiezers is van een elementair niveau: spraakvermogen is vereist om simpelweg een politieke voorkeur te kunnen uiten. Deliberatieve democratie gaat nog een stap verder. Ze vereist niet alleen communicatievermogen om een voorkeur kenbaar te maken, maar ook om van gedachten te kunnen wisselen. Het gaat om meer dan het uiten en registreren van politieke voorkeuren. Politieke preferenties moeten op basis van uitwisseling van informatie en argumenten getoetst, afgewogen en zo nodig bijgesteld worden. Deliberatie veronderstelt bovendien dat de deelnemers aan een publieke dialoog primair streven naar wederzijds begrip. $\mathrm{Om}$ die reden contrasteert men deliberatie wel met debat, voorzover het laatste vooral een wedstrijdkarakter heeft en gericht is op het aftroeven van tegenstanders. Het verlichtingsoptimisme van deliberatieve democratie is dus minder bescheiden 
dan dat van de stemmenteller uit het verhaal van Calvino, omdat het hogere eisen stelt aan de politieke oordeelsvorming. Cruciaal is dan ook de vraag in hoeverre deliberatieve democraten de politieke participatie willen uitbreiden. Moeten dergelijke eisen aan alle burgers gesteld worden of kan de reikwijdte ervan beperkt worden tot politieke elites? Dat is ook een belangrijke vraag in verband met de vernieuwing van het democratische bestel in Nederland.

Daaraan vooraf gaat de vraag of wij ons anno 2004 in Nederland net zoveel zorgen moeten maken om de kwaliteit van onze democratie als Amerigo dat deed in 1953 met betrekking tot de Italiaanse democratie. Is er eigenlijk noodzaak tot vernieuwing en in welke richting? Mijns inziens is daar inderdaad reden toe. Ik zal dan ook beginnen met een diagnose van de zwaktes van ons politieke bestel. Vervolgens schets ik wat deliberatieve democratie inhoudt en ga ik nader in op een aantal omstreden uitgangspunten. Ten slotte formuleer ik een aantal voorstellen voor vernieuwing.

\subsection{EEN TWEEZIJDIG PROBLEEM}

Ik signaleer twee belangrijke ontwikkelingen die de vertegenwoordigende democratie ook in Nederland onder druk zetten. Enerzijds bestaat er een probleem aan de input-zijde van beleid: de representatieve functies van politieke partijen zijn ernstig verzwakt. Anderzijds bestaat er een probleem aan de output-zijde: de politieke verantwoording is in toenemende mate aan slijtage onderhevig.

\subsubsection{REPRESENTATIVITEIT}

Laat ik beginnen met de representatieve dimensie. Er is niet alleen in Nederland maar ook elders in de gevestigde democratieën sprake van een verzwakking van de vertegenwoordigende instituties. In de gevestigde democratieën valt vrijwel overal te constateren dat er een dalende opkomst is bij verkiezingen, dat politieke partijen kampen met ledenverlies en dat het vertrouwen in politieke partijen bijzonder laag is. In deze situatie neigen sommige waarnemers ertoe een crisis uit te roepen. Pessimistisch, maar vaak opgewekt van toon, signaleren zij de laatste stuiptrekkingen van onze vertegenwoordigende democratie, schrijven zij de politieke partijen af als overleefde instellingen of bepleiten zij de afschaffing van de volksvertegenwoordiging. Zo'n crisisbesef lijkt mij vooralsnog overdreven. (Daalder 2002; Pharr en Putnam 2000). In geen van de gevestigde democratieën blijkt vooralsnog dat het vertrouwen in het systeem als zodanig tanende is. In recente democratieën, zoals bijvoorbeeld in Latijns-Amerika, ligt dat mogelijk anders, maar dat laat ik hier buiten beschouwing. Wel wordt in verschillende landen een dalend vertrouwen in politieke instituties gesignaleerd (Pharr en Putnam 200o). Daarbij moet aangetekend worden dat dit niet zonder meer geldt voor de kleine landen in West-Europa. Nederland kent zelfs een opmerkelijk hoog politiek vertrouwen (Katzenstein 20oo). Ook als het gaat om trends die zouden wijzen op verzwakking van de politieke cultuur of van de civil society, zoals die met name in de Verenigde Staten gesignaleerd worden, lijkt Nederland 
een relatief gunstige uitzondering te vormen (Dekker en de Hart 1999; Akkerman, Hajer en Grin 2004). Het is belangrijk om dergelijke verschillen binnen de gevestigde democratieën te signaleren. Het wijst erop dat de democratische cultuur in de kleine landen relatief sterk is, ondanks de problemen die zich ook hier voordoen.

Kern van het probleem aan de input-zijde is de rol van politieke partijen. Politieke partijen richten zich in toenemende mate op stemmenmaximalisatie ter wille van regeringsdeelname. Ze gedragen zich als marktpartijen zonder eigen principes of ideologie. In de loop van de tweede helft van de $20 e$ eeuw zijn hun representatieve functies, zoals integratie en mobilisatie, de articulatie en afweging van belangen en de formulering van beleid, meer en meer uit het zicht verdwenen. Daarmee hebben politieke partijen hun bestaansrecht echter nog niet verloren. Partijen hebben naast representatieve ook bestuurlijke functies, zoals rekrutering voor publieke ambten, coalitievorming, verdeling van posten en gedisciplineerde steun in het parlement. Van verzwakking van deze bestuurlijke functies is geen sprake, integendeel! De politieke partij is dus primair een bestuurderspartij geworden (Bartolini en Mair 2001).

In toenemende mate richten de gevestigde partijen zich op de gematigde kiezer in het midden. Ze kunnen zich om die reden moeilijk profileren op grote, programmatische lijnen. Kiezers kunnen daardoor ook gemakkelijker gaan 'zweven', want partijen onderscheiden zich alleen nog op onderdelen of door de persoonlijkheid van de lijsttrekker (Van der Brug en Van der Eijk 2003). De opkomst van radicale protestpartijen, zoals de LPF in Nederland, valt mede te verklaren door deze convergentie naar het midden (Kitschelt 1995; Keman en Pennings 2003; Akkerman 2003a; Krouwel 2004). Aan de uiterste linker- en rechterzijde is ruimte ontstaan voor electorale winst. Van die ruimte hebben nieuwe rechts-radicale en populistische partijen in verschillende landen gebruik gemaakt. Mede dankzij deze protestbewegingen terzijde van het midden staan gevestigde partijen onder druk om zich ook weer meer programmatisch te profileren (Gunther, Montero en Linz 2002). Men ziet dan ook hier en daar een trend naar de programmatische partij. Deze programmatische partij is weliswaar nog steeds gericht op stemmenmaximalisatie door campagnes, maar doet dit op basis van een ideologische agenda. In Oost- en Centraal-Europa zijn er verschillende voorbeelden te vinden van programmatische partijen. In het Westen vertonen de Britse Conservatieve Partij en de Republikeinen in de Verenigde Staten sinds de jaren tachtig een dergelijke ontwikkeling. Weliswaar werden deze partijen meer consensusgericht toen ze regeringspartijen waren, maar ze worden bij de les gehouden door nieuwrechtse stromingen of partijen. Vooral tijdens verkiezingscampagnes is de verleiding groot om te polariseren, zoals de aanzet van de Republikeinen tot een hernieuwde cultural war rond het homohuwelijk in de verkiezingscampagne van toenmalig presidentskandidaat Bush laat zien.

Het verschijnsel van de programmatische partij doet zich sinds kort ook in Nederland voor. Hier leek sprake van een duidelijke trend naar catch-all-en 
bestuurderspartij in de jaren negentig van de vorige eeuw. Onder de paarse kabinetten vervaagden de programmatische verschillen tussen de vier grote partijen. De PVDA was doelbewust meer naar het midden geschoven in de tweede helft van de jaren tachtig en de VVD werd in de paarse kabinetten gedomineerd door de liberale vleugel. Die trek naar het midden maakte ook dat kiezers 'wispelturiger' werden, omdat hun voorkeuren minder exclusief vertegenwoordigd werden door een van de grote partijen. Het lijkt er in Nederland echter op dat inmiddels het model van de programmatische partij met name in de VVD voet aan de grond krijgt. De rechtervleugel heeft zich mede onder druk van het succes van de LPF kunnen profileren door middel van een ideologisch bevlogen programma. Dankzij de druk van populistische of radicaal-rechtse partijen of bewegingen moeten sommige gevestigde partijen nieuwe manieren zoeken om ook de zijflanken te dekken. Ze doen dat door zich programmatisch meer te profileren. In die zin kan men stellen dat het een zegen is dat er bijvoorbeeld dankzij ons kiesstelsel ruimte is voor protestpartijen die een dergelijke druk kunnen uitoefenen op gevestigde partijen. Dat maakt het voor de grote partijen moeilijk om gevoelige issues, waarover de eigen achterban verdeeld is, dood te zwijgen. Anderzijds laten de voorbeelden van de Verenigde Staten en Groot-Brittannië zien dat die druk ook via (rechts-)radicale bewegingen binnen een partij tot stand kan komen.

Populistische bewegingen of partijen kunnen dus gevestigde partijen in gunstige zin corrigeren, maar ze kunnen ook bijdragen aan verdere ondermijning van het gezag van politieke partijen. Ze manifesteren zich immers als anti-partijen. Populistische partijen geven een politieke stem aan die groepen kiezers die politiek apathisch zijn of die cynisch zijn ten opzichte van de gevestigde partijen (zie ook de bijdrage van Verhoeven aan deze bundel). Zij vullen daarmee het representatieve tekort aan, maar het is de vraag of zij erin zullen slagen de kiezers op de langere duur te binden en of ze het gezag van gevestigde partijen niet eerder zullen verzwakken dan versterken.

\subsubsection{VERANTWOORDING}

Een tweede ontwikkeling doet zich voor aan de outputkant. Er is sprake van een afnemende competentie van de overheid door verandering van het internationale en nationale krachtenveld. Al langere tijd wordt gesignaleerd dat ons nationale politieke bestel verandert door internationalisering, verplaatsing van competenties naar supranationale organisaties en delegatie naar private of semipublieke instanties. Omdat het (subjectieve dan wel objectieve) vermogen van de overheid om politieke problemen rond veiligheid, immigratie, werkgelegenheid of sociale stelsels op te lossen afneemt, wordt de wisseling van kiezersgunst groter. Zittende regeringen verliezen steeds sneller het vertrouwen van de kiezers, zoals de Duitse sociaal-democraten en de Franse conservatieven in korte tijd merkten. 
Output-legitimiteit wordt soms in minimale zin opgevat als zuiver instrumenteel. Men beschouwt beleid dan voornamelijk als een technocratisch proces dat men het beste aan ambtelijke of andere deskundigen over kan laten. Dan zou het erom gaan de beste manieren te vinden om beleidsdoelen te bereiken. Verantwoording kan in zo'n optiek uitstekend langs niet-politieke weg, namelijk via professionals of via de juridische weg, gegarandeerd worden. De legitimiteit van de Europese Unie is lange tijd voornamelijk op deze wijze gefundeerd (zie de bijdrage van Sie Dhian Ho in deze bundel). Wanneer echter beleid gepolitiseerd raakt, volstaat instrumentele legitimiteit niet meer. Dat gebeurt bijvoorbeeld wanneer politieke elites openlijk hun meningsverschillen over het monetaire beleid gaan uitvechten of wanneer groepen burgers waar gaan nemen dat de EU meer en meer competenties verwerft op voor hen omstreden en gevoelige beleidsterreinen, zoals immigratie of sociale zekerheid. Prestaties van de overheid als zodanig zijn dan niet langer de maatstaf, maar de doelstellingen zelf komen in het geding. Soms dreigt ook de manier waarop een doelstelling het beste gerealiseerd kan worden onderwerp van politieke strijd te worden, zoals in het geval van het Stabiliteitspact. Politisering van beleidskeuzes en doelen ontstaat met name als er voor politieke outsiders, zoals eurosceptische partijen, kans op succes is. In situaties van politisering verandert output-legitimiteit van karakter. Een regering die de door haar gestelde doelen - van bijvoorbeeld terugdringing van het aantal WAO-gerechtigden naar 25.00o - haalt, heeft daarmee haar beleid nog niet gelegitimeerd. Output-legitimiteit kan in zulke situaties niet altijd losgekoppeld worden van input-legitimiteit. De kiezers rekenen dan niet alleen af op prestaties, maar evalueren beleid ook met betrekking tot verschillende, eventueel strijdige, politieke doelstellingen.

Politisering betekent niet alleen dat er conflicterende belangen op het spel blijken te staan, maar ook dat beleidsprestaties via politieke en democratische weg afgerekend moeten kunnen worden. De verantwoordelijkheid van de zittende politieke partijen staat op het spel. Of de treinen al dan niet op tijd rijden is dan niet meer de enige maatstaf, maar ook of ze in privé-handen zijn of in die van de overheid (Van Doorn 2002). Een actieve instemming, waarbij de mogelijkheid van beoordeling van verantwoordelijkheid en eventuele sancties in het geding zijn, is onontkoombaar in situaties van democratische politisering. Output-legitimiteit impliceert in een volwaardig democratische betekenis dan ook de mogelijkheid van burgers om achteraf met het gevoerde beleid in te stemmen en de zittende regering opnieuw te kiezen dan wel het beleid af te keuren en nieuwe bestuurders aan te stellen. Daarom wordt het van belang onder wiens verantwoordelijkheid publieke diensten vallen.

Met betrekking tot de prestaties van de overheid doen zich dus spanningen voor rond de mate waarin bepaalde beleidsterreinen ge(re)politiseerd raken. Ook wat betreft de output-legitimiteit blijken politieke partijen en parlement terrein verloren te hebben. In verschillende beschouwingen wordt gezocht naar alternatieve vormen van verantwoording. Zulke alternatieven voor de functies van controle en verantwoording van partijen in het parlement zijn bijvoorbeeld 
directe informatie via internet, kwaliteitshandvesten, burgerfora, monitoren, ombudslieden, visitatiecommissies, rekenkamers en externe toezichthouders. Dat zijn de nieuwe procedures en instanties die de controlerende functie van partijen zouden moeten aanvullen. Daarnaast worden directe vormen van verantwoording aan burgers via plebiscitaire procedures, zoals referendum of recall, voorgesteld ter vervanging van de rol van politieke partijen (Bovens en Michels 2002). Dergelijke vormen van toezicht en verantwoording zijn al volop in ontwikkeling. Er is zelfs sprake van golven van delegatie: na delegatie van uitvoering volgde delegatie van verantwoording. Al die nieuwe vormen van controle kunnen zelfs leiden tot een pathologie van delegatie, omdat ze op hun beurt de vraag oproepen wie toezicht houdt op de toezichthouder (Magnette et al. 2003). Met zoveel checks and balances groeit immers het probleem van de vele handen. Het wordt steeds moeilijker om vast te stellen wie er verantwoordelijk is. Er gaan dan ook enerzijds stemmen op om de 'grijze tussenlaag' terug te dringen ten gunste van de controle door de volksvertegenwoordiging, anderzijds zijn er pleitbezorgers van een terugdringing ten gunste van directe vormen van toezicht en verantwoording door burgers (Tjeenk Willink 2003).

Er is dus sprake van een dubbelzijdig tekort; zowel wat betreft input-legitimiteit als output-legitimiteit hebben politieke partijen moeite om hun klassieke functies van representatie en controle op het bestuur te vervullen. Beide kanten kwamen naar voren in de verkiezingen van 2002. Het succes van de LPF bleek enerzijds gebaseerd op de representatieve rol die de kiezers bij de gevestigde partijen misten. De LPF had zijn winst vooral te danken aan de agendering van thema's als immigratie en veiligheid die door de gevestigde partijen genegeerd waren (Van Praag 2003). Verschillende groepen kiezers hadden het gevoel dat de gevestigde partijen hun belangen links of rechts lieten liggen. De LPF bood hen hoop op een nieuwe aanpak. Anderzijds was er ook sprake van ontevredenheid over de prestaties van de overheid.

De verkiezingen werden ook een afrekening met het beleid van de paarse regering ten aanzien van de publieke voorzieningen. De 'puinhopen van paars', zoals wachtlijsten in de gezondheidszorg, werden door Fortuyn tot centraal thema van de verkiezingen gebombardeerd. De media namen dit beeld over en vervolgens bleken ook de kiezers de zittende partijen hierop te willen afrekenen (Kleinnijenhuis et al. 2003). ${ }^{1}$ Het is opmerkelijk dat de ontevredenheid over de publieke sector in dit geval vooral gebaseerd was op de perceptie van overheidsbeleid via de media. Uit onderzoek van het SCP naar de quartaire sector blijkt bijvoorbeeld dat gebruikers van de gezondheidszorg minder ontevreden waren dan nietgebruikers (SCP 2002). Dit duidt erop dat de publiciteit rond wachtlijsten en de campagne rond de 'paarse puinhopen' een belangrijke rol hebben gespeeld. Percepties van output via de media zijn waarschijnlijk minstens zo belangrijk geworden bij verkiezingen en voor het vertrouwen van burgers in de overheid als objectieve prestaties. De rol van de media verdient dan ook de nodige aandacht als het gaat om afnemende output-legitimiteit. Het succes van populistische partijen illustreert de structurele problemen waarmee gevestigde partijen in 
Nederland en elders te kampen hebben. Vernieuwingsvoorstellen zouden een antwoord moeten proberen te geven op deze tweezijdige problematiek. Enerzijds gaat het om de vraag hoe vanuit het perspectief van deliberatieve democratie representatieve functies versterkt zouden kunnen worden, zodat kiezers in programmatisch opzicht werkelijk iets te kiezen hebben. Anderzijds doet zich de vraag voor hoe deliberatieve democratie bij kan dragen aan een betere verantwoording van beleid.

\subsection{WAT IS DELIBERATIEVE DEMOCRATIE?}

Deliberatieve democratie is gebaseerd op een oud idee, waarvan de antecedenten al te vinden zijn in de klassieke Griekse politieke filosofie. Met de opkomst van de moderne democratie zijn het vooral politieke denkers als Edmund Burke, John Stuart Mill en John Dewey die het belang van deliberatie benadrukt hebben. In de jaren tachtig van de vorige eeuw kwam de term weer naar voren via het werk van Bernard Manin en Joshua Cohen. In de jaren negentig was het een invloedrijke stroming geworden, waartoe zowel John Rawls als Jürgen Habermas zichzelf rekenden (Bohman en Rehg 1997; Dryzek 2000).

De term deliberatieve democratie is inmiddels ook in Nederland ingeburgerd geraakt. Sinds de jaren tachtig van de vorige eeuw is deze theoretische stroming binnen de Amerikaanse politicologie naar voren gekomen. In de jaren negentig heeft deze theoretische stroming zich verbreed naar empirisch onderzoek op verschillende terreinen, zoals bestuur en beleid, media, parlement en gerechtshoven. Ook heeft deliberatieve democratie geïnspireerd tot praktijkgerichte experimenten, zoals deliberatieve polls en burgerjury's. Zo is deze kleine intellectuele stroming die zich op hoog abstractieniveau bezighield met democratische vernieuwing uitgegroeid tot een breed en veelzijdig alternatief. Die ontwikkeling naar een meer praktijkgerichte vernieuwing heeft ook met zich meegebracht dat er inmiddels verschillende stromingen binnen dit model te onderscheiden zijn.

Uitgangspunt is dat men het beste kan regeren door discussie, een idee dat in de 19e eeuw zeer invloedrijk was (Manin 1997). Democratische besluitvorming zou idealiter op uitwisseling van argumenten gebaseerd moeten zijn in plaats van op aggregatie van gegeven voorkeuren. Discussie is essentieel om een optimale afstemming van belangen te kunnen bereiken en om op die manier het publieke belang vorm te geven. Deliberatieve democratie staat dus lijnrecht tegenover populistische en liberaal-economische modellen van politiek. De volkswil uit zich volgens de laatste benadering op directe wijze en via een ongedifferentieerde meerderheid. Voorkeuren van kiezers zijn een gegeven, men hoeft ze slechts te registreren. Dat gebeurt bijvoorbeeld door op locatie de mensen aan te horen of meer systematisch door het houden van opiniepeilingen. Het is welbekend dat marktonderzoek naar kiezersvoorkeuren een groeiende bedrijvigheid is. ${ }^{2}$ Dergelijke opvattingen van democratie als afstemming van beleid op verzamelingen van kiezersvoorkeuren zijn niet alleen te vinden bij populistische partijen, maar zijn ook wijdverbreid binnen gevestigde partijen. 
Het deliberatieve model daarentegen verwerpt het uitgangspunt van gegeven voorkeuren van burgers die slechts opgeteld hoeven te worden. Een meerderheidsmodel schiet volgens deliberatieve democraten tekort in een maatschappij als de onze die pluralistisch is wat betreft waarden en divers qua belangen. Democratische besluitvorming kan dan ook niet gebaseerd zijn op aggregatie van gegeven voorkeuren. Om optimale uitkomsten van beleid te bereiken in een situatie van strijdige belangen is het vaak nodig om af te wijken van directe voorkeuren van groepen kiezers. Het voorbeeld van onverenigbare beleidsvoorkeuren van belastingverlaging, verplichte besteding van veertig procent van het budget aan onderwijs en terugdringing van het begrotingstekort, zaken die via referenda in Californië totstandgekomen zijn, maakt duidelijk dat het publieke belang iets anders is dan een optelsom van meerderheidsvoorkeuren. Via uitwisseling van informatie en argumenten kunnen voorkeuren afgewogen en bijgesteld worden. Discussie is essentieel om een optimale afstemming van belangen te kunnen bereiken.

Deliberatie is ook van belang om op vreedzame wijze met politieke conflicten om te gaan. Met stemmen of onderhandelen alleen kan men vaak moeilijk diepgaande, morele conflicten beslechten. Stemmen en onderhandelen berusten op een smalle moraal, die geen motivatie biedt voor betrokkenheid bij en begrip voor de positie van tegenstanders. In situaties van grote sociaal-economische ongelijkheid of van grote getalsmatige ongelijkheid kunnen zulke procedures bovendien gemakkelijk tot misbruik van macht leiden. Deliberatieve democratie is gebaseerd op het uitgangspunt dat democratie een zekere mate van wederkerigheid vereist. Dat wil niet zeggen dat deliberatieve democratie van politici of burgers vraagt om altruïstisch te zijn, maar het vereist wel een coöperatieve houding. Gutmann en Thompson geven onder meer het voorbeeld van het conflict rond abortus in de Verenigde Staten. Zij wijzen erop dat het hier gaat om een diepgaand moreel conflict tussen pro-life- en pro-choice-groepen, waarbij normatieve overeenstemming uitgesloten is. Deliberatie kan echter bijdragen aan een werkbare overeenkomst en een minimalisering van het conflict. Het vereist dat men de argumenten van de tegenstanders serieus neemt en dat men zoekt naar manieren om elkaar tegemoet te komen. Van pro-choice- zijde zou men bijvoorbeeld financiële ondersteuning van adoptieprogramma's kunnen voorstellen. Een dergelijke economy of disagreement vereist communicatie op basis van een zekere mate van vertrouwen (Gutmann en Thompson 1996; Gutmann 2003; Scharpf 2000; Forester 1999). Het is de vraag hoe realistisch het is om een dergelijke actieve tolerantie, gebaseerd op nieuwsgierigheid en bereidheid tot communicatie, van burgers in het algemeen of zelfs van politieke elites te verwachten (Dryzek 2003; Akkerman 2003b).

Een derde reden, ten slotte, om deliberatieve democratie te propageren is dat zij bij uitstek de methode is om de epistemische kwaliteit van politieke besluitvorming en uitvoering te vergroten. De proliferatie van kennis in de zogenaamde informatiseringmaatschappij brengt met zich mee dat overheidsinstellingen in belangrijke mate voor hun informatievoorziening afhankelijk zijn geworden van 
actoren in het veld. Op allerlei beleidsterreinen, variërend van gezondheidszorg tot milieubeleid, wordt geëxperimenteerd met vormen van kennisuitwisseling die actoren uit het veld betrekken bij beleidsvoorbereiding en - uitvoering. Deliberatieve democratie is een van de belangrijke noemers waaronder nieuwe vormen van uitwisseling van kennis via kleinschalige en horizontale beleidsnetwerken ontwikkeld worden.

\section{$13 \cdot 3$ OMSTREDEN UITGANGSPUNTEN}

Om mijn benadering te verhelderen zal ik de meest omstreden uitgangspunten van deliberatieve democratie bespreken en daarbij mijn positie nader toelichten.

\subsubsection{CONSENSUSVORMING}

Het eerste punt betreft consensusvorming. Consensusvorming door middel van redelijke argumenten wordt nogal eens beschouwd als kernidee van de deliberatieve democratie. Consensus moet dan opgevat worden als overeenstemming op basis van normatieve gronden. Het is bijvoorbeeld geïmpliceerd in Rawls' opvatting van redelijkheid en het is ook een belangrijke doelstelling van Habermas' communicatieve rationaliteit. Habermas heeft in zijn latere werk echter afstand genomen van het idee dat er een homogene volkswil zou zijn en meer nadruk gelegd op de pluralistische complexiteit van hedendaagse maatschappijen. Bovendien koos hij een meer pragmatische benadering waarin de vertaling van consensus naar uitvoerbare en bindende besluiten meer gewicht kreeg (Habermas 1996). Niettemin bleef de nadruk op consensus in zijn latere werk bestaan. Dat is inmiddels door anderen ter discussie gesteld. Vrij breed is het idee geaccepteerd dat een optimale consensus niet nodig is. Redelijke discussie kan bijvoorbeeld ook uitmonden in een 'werkbare overeenstemming', waarbij men om verschillende redenen instemt met een bepaalde koers (Benhabib 1996; Dryzek 1990). Bovendien is er in toenemende mate aandacht voor diepe meningsverschillen, waarover geen overeenstemming bereikt kan worden. Morele conflicten hebben een belangrijke plaats gekregen in de deliberatieve democratie (Gutmann and Thompson 1996). Deliberatieve democratie gaat dus niet uit van een homogene gemeenschap of een algemene volkswil. Consensusvorming, in de zin dat uiteindelijke instemming van iedereen op basis van normatieve gronden vereist is, wordt niet (meer) als ideaal beschouwd.

De suggestie dat aan deliberatieve democratie een politiek gemeenschapsideaal ten grondslag ligt kan gewekt worden door de nadruk die in sommige deliberatieve stromingen gelegd wordt op face-to-face-communicatie, op de ontwikkeling van wederzijds begrip en op formulering van argumenten in termen van algemeen belang. Toch wordt inmiddels afstand genomen van Gemeinschaftsidealen, zoals dat bijvoorbeeld doorklinkt in het werk van Dewey, of van het klassieke, republikeinse ideaal van de polis, zoals dat bij Aristoteles te vinden is (zie bijdrage Dijstelbloem, Schuyt en De Vries in deze bundel). Deliberatieve democraten erkennen nadrukkelijk dat er diepe, onoverbrugbare verschillen in over- 
tuiging kunnen zijn en dat bovendien schaarste van middelen een volledige overeenstemming vaak onmogelijk maakt. Dat neemt niet weg dat het van groot belang is om oplossingen te vinden die zo veel mogelijk recht doen aan de verschillende morele overtuigingen of belangen.

Men zou deliberatieve democratie dan ook vooral kunnen beschouwen als een stroming die een democratisch ethos bevordert dat gericht is op overbrugging van morele conflicten. Een cultuur die toegesneden is op een massademocratie met diepe culturele scheidslijnen vereist volgens deze benadering vooral actieve vormen van tolerantie. Een liberaal idee van tolerantie dat gebaseerd is op passiviteit en dat slechts juridische grenzen stelt, voldoet niet meer. Een veeleisender ethos is nodig. Actieve tolerantie vergt een nieuwsgierige houding en bereidheid tot communicatie met degenen wiens opvattingen men afkeurt. Communicatie is er niet noodzakelijk op gericht dat men het eens wordt, maar het richt zich wel op totstandkoming van begrip tussen culturen die diepgaand verschillen. Begrip en accommodatie van etnische, religieuze of andere gemeenschappen is echter een streven dat nadrukkelijk beperkt wordt door de grenzen van de liberale rechtsstaat (Gutmann 2003; Barry 2001). ${ }^{3}$ Deliberatieve democratie is dus niet gericht op een multiculturele samenleving - in de betekenis dat groepsrechten voorrang kunnen hebben op individuele rechten - maar streeft naar open communicatie en overbrugging van morele conflicten.

In dit opzicht kan men de ambities van de deliberatieve democratie hooggestemd noemen. Michael Walzer benadrukt bijvoorbeeld dat tolerantie in passieve zin, bijvoorbeeld in de vorm van onverschilligheid of stoïcijnse erkenning van het recht om anders te zijn, geen geringe prestatie is (Walzer 1997). Deliberatieve democraten hebben tot nu toe te weinig aandacht besteed aan de voorwaarden waaronder deliberatie de beste methode is om morele conflicten te beslechten. Het zou in sommige situaties zelfs averechts kunnen werken. De ruimte ontbreekt hier om nader op die voorwaarden in te gaan (zie Akkerman 2003b). Ik volsta met erop te wijzen dat het in ieder geval van belang is om een onderscheid te maken tussen burgers in het algemeen en politieke elites. Van de laatste mag in een land als Nederland, met zijn sterke democratische instituties en lange traditie van overleg, verwacht worden dat zij de noodzaak van communicatie hoog houden.

\subsubsection{ARGUMENTEREN OF STEMMEN}

Het tweede omstreden uitgangspunt betreft de prioriteit van argumenten. Deliberatieve democraten vinden argumentatie belangrijker dan stemprocedures. Dat neemt niet weg dat men om praktische redenen - tijd is tenslotte schaars - het belang van stemmen onderkent. Stemmen voorkomt een eindeloze uitwisseling van argumenten. Deliberatieve democraten ontkennen doorgaans dat stemmen ook om principiële redenen de voorkeur verdient. Toch zou men kunnen stellen dat stemmen het beste tegemoetkomt aan het democratische principe van gelijkheid. Het principe van one person, one vote vormt om die reden van oudsher de 
kern van de vertegenwoordigende democratie. Toch valt er op dit principe wel wat af te dingen, omdat een dergelijke procedurele opvatting van gelijkheid zijn beperkingen heeft. Stel dat men mag stemmen over het voorstel om 10.0oo euro van alle namen in het telefoonboek onder a $\mathrm{t} / \mathrm{m}$ h over te hevelen naar alle namen onder i t/m z. Het voorstel zou zeker met zo'n tweederde meerderheid aangenomen worden, en ieders stem is gelijk gewogen, maar ik zou (met mijn in dit geval ongelukkige achternaam) terecht het idee hebben dat mijn stem me relatief erg duur komt te staan. Daarom hoort deliberatie op zijn minst vooraf te gaan aan stemmen.

Toch is de procedurele gelijkheid van stemmen een belangrijk principe, zeker in het licht van de kritiek dat deliberatieve democratie nieuwe vormen van uitsluiting voortbrengt. Status en hiërarchie bepalen vaak het gewicht van argumenten en de retorisch sterken zullen domineren (Sanders 1997; Van Stokkom 2003). Het is daarom wel eens de democratie van de grote bekken genoemd (Hartman 2000). Daarbij kan aangetekend worden dat dergelijke mechanismen indirect ook een rol kunnen spelen bij stemprocedures, bijvoorbeeld in verkiezingscampagnes die gedomineerd worden door 'grote bekken' of door grote portemonnees. In beide gevallen zijn er ook mogelijke tegenmaatregelen, zoals een evenredige verdeling van spreek- of zendtijd, beperking van de invloed van geld en dergelijke, om een level playing field te creëren. Dat neemt niet weg dat stemmen uiteindelijk minder hoge drempels opwerpt dan deliberatie en dat het de enige manier is om ieders belang even zwaar te laten meewegen. Deliberatieve democratie zie ik dan ook als een noodzakelijke aanvulling op en niet als een vervanging van het kiesrecht. Het is een noodzakelijke aanvulling, omdat kiesrecht ingebed moet zijn in een democratische cultuur van kennis van en meningsvorming over maatschappelijke vraagstukken en van actieve tolerantie ten opzichte van andersdenkenden. Zonder zo'n democratisch ethos zou het kiesrecht weinig voorstellen.

\subsection{DE DEMOCRATISCHE DIMENSIE}

Deliberatieve democraten hebben een gemeenschappelijke voorkeur voor deliberatie, maar als het om de democratische dimensie van die deliberatie gaat lopen de meningen nogal uiteen. In het algemeen zijn deliberatieve democraten voor een verdergaande participatie van burgers dan het kiezen van vertegenwoordigers die in hun naam onderling van gedachten zullen wisselen. Hoe dat echter moet gebeuren, daarover verschillen de meningen. De doelstellingen van deliberatie enerzijds en democratie anderzijds kunnen op gespannen voet staan. Deliberatie komt vooral tot zijn recht in kleinschalige interacties. Persoonlijke en directe communicatie biedt om verschillende redenen gunstigere voorwaarden voor een optimale afweging en afstemming van argumenten dan grootschalige, intermediaire communicatie (Akkerman 2003b). De democratische doelstelling, voorzover gericht op de meningsvorming van alle burgers, vereist grootschalige vormen van communicatie.

- Face to face-communicatie in kleinschalige netwerken. Een verdergaande participatie van burgers wordt soms nagestreefd door deliberatieve fora niet te 
beperken tot parlement of rechtszalen, maar uit te breiden naar het zogenaamde middenveld. Meningsvorming vindt dan plaats met actieve deelname van burgers of vertegenwoordigers van belangengroepen in vaak informele en kleinschalige fora binnen beleidssectoren, zoals bijvoorbeeld door de politiek filosofen Gutmann en Thompson voorgestaan wordt. Ook beleidsanalisten en bestuurskundigen die deliberatieve democratie in het vaandel hebben opgenomen, zijn doorgaans sterk gericht op dergelijke kleinschalige vormen van beleidsontwikkeling of uitvoering waarin stakeholders van gedachten wisselen (Cohen en Sabel 1997; Forester 1999; Hajer en Wagenaar 2003).

- Daarnaast kan een stroming onderscheiden worden die meer gericht is op grootschalige en intermediaire communicatie. Deze stroming is met name geïnspireerd door Habermas. Zijn opvatting van communicatieve rationaliteit en zijn geschiedschrijving van de ontwikkeling van een relatief autonome publieke sfeer in de 17e en 18e eeuw inspireerden verschillende deliberatieve democraten (Cohen 1989; Bohman 1996; Dryzek 1990). Media en de civil society vormen in deze optiek de belangrijkste pijlers van deliberatieve democratie.

Naast het onderscheid tussen directe en indirecte communicatie is ook van belang waar men het primaat van de politiek legt. Ligt dat met name bij de volksvertegenwoordiging, zoals in de klassieke opvatting van deliberatieve democratie, of bij associaties of direct bij de burgers zelf? Deliberatieve democratie is bijvoorbeeld verbonden met voorstellen voor associatieve democratie (Cohen en Rogers 1995) en met voorstellen voor nieuwe vormen van directe democratie (Fishkin 1995; Fung en Wright 2001).

\subsection{DELIBERATIEVE DEMOCRATIE EN VERNIEUWING}

Wat kan deze benadering bijdragen aan democratische vernieuwing en verdieping in Nederland anno 2004? Er zijn zoals hierboven aangegeven twee stromingen te onderscheiden, enerzijds gericht op kleinschalige vormen van deliberatie, anderzijds een stroming gericht op grootschalige, intermediaire communicatie. De eerste benadering is met name gericht op de ontwikkeling van interactief beleid, dat wil zeggen dialoog in kleinschalige, informele beleidsnetwerken. Deze ontwikkeling wordt als een belangrijk alternatief voor of aanvulling op de representatieve democratie beschouwd. Interactief beleid (interactive governance) biedt in deze visie een mogelijkheid tot democratisering van onderop. Het biedt beleidsmakers en analisten een alternatief voor top-down-management en verticale vormen van verantwoording. Het is ook een model dat het meest geschikt is om de epistemische kwaliteit van democratische beleidsvoering te optimaliseren. Het verhogen van de kwaliteit van beleidsontwikkeling met behulp van veelzijdige expertise, die ook praktische en lokale kennis omvat, is een belangrijke doelstelling van deliberatieve democratie. 


\subsubsection{DELIBERATIE IN KLEINSCHALIGE NETWERKEN}

Beleid is niet alleen een kwestie van powering, maar ook van puzzling. Om problemen te traceren, een nieuwe aanpak te ontwikkelen en kennis over best practices over te dragen, is een coöperatieve en open dialoog tussen betrokkenen van groot belang. In deze benadering ligt het zwaartepunt bovendien bij een ontwikkeling van onderop, beginnend op lokaal niveau of op de werkvloer. Voorzover het gaat om leren lijkt het me uitermate zinvol om het belang van deliberatie in scholen, bedrijven, buurten of ziekenhuizen centraal te stellen. Problematischer is mijns inziens dat kleinschalige deliberatie ook model staat voor democratische vernieuwing van onderop. Charles Sabel spreekt bijvoorbeeld van een directly deliberative polyarchy en Archon Fung en Eric Olin Wright propageren democratic deliberative empowerment (Cohen en Sabel 1997; Fung en Wright, 2001).

Het model van Fung en Wright draait om directe en kleinschalige vormen van deliberatieve democratie. Dergelijke vormen van burgerparticipatie hebben echter een beperkte reikwijdte. Verantwoording, advisering of besluitvorming via directe democratie is immers bijzonder arbeidsintensief. Met burgerparticipatie moet dan ook slim en zuinig omgegaan worden. Tijd is schaars. Om die reden wordt gelukkig al van verschillende kanten gepleit, onder meer door de Raad voor Openbaar Bestuur, voor een meer selectieve toepassing van interactief beleid dan nu gebruikelijk is ( gen kunnen burgerparticipatie en directe vormen van democratie slechts een aanvullende rol spelen binnen een vertegenwoordigend stelsel.

Bovendien gaat het in de cases die Fung en Wright beschrijven om initiatieven van onderop. Bij interactief beleid in Nederland daarentegen ligt het initiatief meestal bij de overheid. Een van de mogelijke nadelen daarvan is dat burgerparticipatie voornamelijk ervaren wordt als een van bovenaf opgelegde plicht tot participatie of als afschuiven van verantwoordelijkheid door de overheid. Het cynisme zou vooral bij kiezers die al ontevreden zijn over de gevestigde politiek door dergelijke initiatieven versterkt kunnen worden. Het beleid van New Labour in Groot-Brittannië heeft duidelijk gemaakt dat een dergelijk risico niet denkbeeldig is (Akkerman, Hajer en Grin 2004).

Ten slotte betekent een goed gebruik van informele en formele vormen van burgerparticipatie vooral ook dat zorgvuldig afgewogen wordt in welke mate verantwoordelijkheden gedeeld kunnen worden. In dit opzicht is te hopen dat het model van empowerment dat Fung en Wright propageren niet als een algemeen model bedoeld is, want het legt een bijzonder zware verantwoordelijkheid bij burgers. De door Fung onderzochte experimenten met burgerparticipatie in het onderwijs in Chicago bijvoorbeeld impliceerden dat de schoolraad, waarin een meerderheid van de leden bestond uit ouders, de bevoegdheid had om het schoolhoofd te benoemen, prestatiecontracten uit te schrijven, schoolplannen te ontwikkelen en het budget goed te keuren. Deze experimenten waren redelijk geslaagd, volgens Fung, maar daarbij moet bedacht worden dat het stadsbestuur 
in allerlei opzichten gefaald had. Het onderwijs stond er beroerd voor en die noodsituatie was een reden om ouders vergaande bevoegdheden te geven. Het ging dus om een noodsituatie en niet om een algemeen model van empowerment. Het is niet te hopen dat (lokale) overheden zo structureel falen dat er niets anders op zit dan dat burgers zelf het bestuur op zich nemen.

Kortom, het model van Empowered Deliberative Democracy zoals Fung en Wright dat voorstaan heeft een beperkte reikwijdte en neigt te veel naar zelfbestuur. Op lokaal niveau kan het echter bijdragen aan vernieuwing van directe vormen van democratie door de nadruk die op deliberatie gelegd wordt. Het blaast een oud ideaal dat ten grondslag lag aan de vertegenwoordigende democratie nieuw leven in, namelijk het idee van regeren door discussie.

In vergelijking met de benadering van Fung en Wright is de benadering van Charles Sabel sterker gericht op leren en minder op empowerment. Het scheppen van goede condities voor innovatie is een belangrijk doel van Sabel. Die invalshoek is des te belangrijker als men bedenkt dat dit ook in Nederland in de discussie over interactief beleid een van de belangrijke kritiekpunten is. Interactief beleid zou weinig mogelijkheid bieden voor innovatie. Waar burgers direct betrokken zijn bij ruimtelijke inrichting, bijvoorbeeld, ontstaat nogal eens de neiging naar conservatisme (Edelenbos en Monnikhof, 2001; Van Stokkom, 2003). Daartegenover biedt de benadering van Sabel meer ruimte voor professionele autonomie. Hij pleit bijvoorbeeld voor het (tijdelijk) op afstand zetten van toezicht- en controlefuncties, of die nu uitgeoefend worden van bovenaf door bijvoorbeeld een onderwijsinspectie of van onderop door ouders of vakbonden. Op die manier krijgen professionals in scholen of ziekenhuizen de ruimte om problemen op de werkvloer op te lossen en prestaties te verbeteren (zie bijdrage Sabel aan deze bundel). Vervolgens zouden er coördinerende organisaties moeten zijn, zoals een inspectie of een brancheorganisatie die best practices identificeert en uitwisseling daarvan coördineert. Een dergelijke aanpak zou bijzonder zinvol kunnen zijn om prestaties in onderwijs, zorg of andere beleidssectoren te bevorderen.

Een belangrijke beperking van beide modellen is dat ze gebaseerd zijn op kleinschalige, persoonlijke interacties. Voorzover grootschalige vormen van democratie daarbij in het vizier komen, is dat in de vorm van een groot web van netwerken van professionals, experts en belangengroepen. Dergelijke deliberatieve vormen van governance bieden weliswaar het voordeel van een flexibele en fijnzinnige afstemming op contextspecifieke beleidsproblemen. In democratische zin leveren ze echter problemen op. Ook als men uitgaat van een gemengde democratie, waarin belangengroepen via interactief beleid een belangrijke rol spelen, is het democratische gehalte van governance zwak. In de eerste plaats is er de kwestie van de representativiteit. Hoe wordt enigermate gegarandeerd dat belangengroepen gelijkelijk toegang en invloed hebben in Haagse of Brusselse netwerken? 
Een mogelijkheid zou zijn om civic forums in te stellen, naar het voorbeeld van Noord-Ierland, Schotland en Londen. Deze raden zijn te beschouwen als alternatieven voor de traditionele overlegorganen op corporatistische grondslag. Het zijn consultatieve raden, gericht op beleidsontwikkeling, waarin naast vertegenwoordigers van werkgevers en werknemersorganisaties een breed scala van belangengroepen vertegenwoordigd is. In Noord-Ierland werd het forum constitutioneel vastgelegd in het Goede Vrijdag Akkoord. De bedoeling van een brede vertegenwoordiging van de civil society was om de politieke tegenstellingen te overbruggen door middel van een meer deliberatieve instelling van niet-gekozen vertegenwoordigers van de civil society (Meehan 2001; Lindsay 2004). Een dergelijke benadering is niet zonder meer relevant voor gevestigde democratieën met sterke overlegtradities. Men zou bijvoorbeeld in de Nederlandse situatie minder bang hoeven te zijn voor politisering en verkiezing van vertegenwoordigers niet hoeven uit te sluiten.

Een tweede punt is dat de governance-benadering te weinig oog heeft voor de grootschalige problemen van democratisch bestuur. Met andere woorden, de focus ligt te eenzijdig bij kleinschalige en deliberatieve vormen van puzzling en is te weinig gericht op grootschalige en democratische vormen van powering. Om de mogelijkheden van grootschalige vormen van deliberatie te exploreren is het noodzakelijk om de rol van de media in ogenschouw te nemen. Publiciteit speelt niet alleen empirisch gezien een belangrijke rol in de beoordeling van beleidsprestaties, maar is ook in normatieve zin een onontbeerlijke schakel voor democratische vormen van verantwoording en van representativiteit.

\subsubsection{PUBLICITEIT EN INTERMEDIAIRE COMMUNICATIE}

Deliberatieve democratie kent een belangrijke stroming, geïnspireerd door Habermas, die intermediaire en grootschalige communicatie centraal stelt. Voor een democratie is een open en relatief autonome publieke sfeer van groot belang vanuit het oogpunt van informatievoorziening, articulatie en afweging van belangen en politieke verantwoording. Dat impliceert dat oppositiepartijen, nieuwe partijen, belangengroepen en burgers actief tegenwicht bieden tegen mogelijke tendensen naar oligopolies van gevestigde c.q. regeringspartijen in de publieke sfeer. Het is vanuit dit oogpunt dat ik versterking van het publieke debat bepleit. Voor alle duidelijkheid, ik pleit dus niet voor meer debat - kamerleden doen wat dat betreft goed hun best - maar voor meer competitie en openheid. Kartelvorming in de politieke arena is funest omdat ze een eenzijdige visie bevordert en informatiemonopolies in stand houdt, bijvoorbeeld als de oppositie over het beleid rond Schiphol of over de politieke steun aan de oorlog tegen Irak geen politiek debat kan afdwingen. Om die reden is het van belang posities van minderheden in nationaal of Europees parlement te versterken. Het zou echter kunnen zijn dat ook de oppositiepartijen zo vervreemd geraakt zijn van de publieke opinie dat zij belangrijke zaken niet meer aankaarten. De verkiezingen van 2002 hebben aangetoond dat dit geen denkbeeldig scenario is; zoals bekend was er een nieuwe partij nodig om het immigratie- en integratiebeleid op de poli- 
tieke agenda te krijgen. Ons open kiesstelsel met relatief lage kiesdrempel en lage drempel wat betreft financiële ondersteuning bleek toen redelijk effectief in het tegengaan van kartelvorming.

Daarnaast kunnen ook directe vormen van democratie de druk op de ketel houden. Volksinitiatieven kunnen een belangrijk middel zijn om beleid rond issues die door regerende partijen buiten de politieke agenda gehouden worden ter discussie te stellen. Het beste voorbeeld is misschien wel het adviserend initiatief, zoals men dat in Oostenrijk kent. Dit volksinitiatief stelt burgers in staat een issue op de parlementaire agenda te zetten. Het lijkt op een petitie, maar vereist een minimum aantal burgers die het initiatief ondersteunen en het resulteert in een formeel wetsvoorstel dat volledige behandeling van het parlement vereist. In tegenstelling tot bijvoorbeeld het initiatief in Zwitserland of sommige Amerikaanse staten resulteert het niet in een referendum. Dergelijke initiatieven zijn effectieve middelen om de agenda te beïnvloeden, want ze trekken veel aandacht van de media. Ook oppositiepartijen maken in Oostenrijk dankbaar gebruik van dit middel (Müller 1991). Zo'n initiatief zou dus een aanvulling kunnen zijn op de voorstellen van kamervoorzitter Weisglas om de positie van minderheden in het parlement te versterken door de meerderheidsblokkade van de helft-plus-één voor ondervraging van een minister in de Tweede Kamer aanzienlijk te verhogen. Thom de Graaf en anderen hebben recentelijk de invoering van zo'n initiatief bepleit (De Graaf et al. 2002). Ook is het burgerinitiatief opgenomen in het ontwerp van de grondwet voor de EU. Het is een manier om de voorwaarden voor een open en competitief debat te versterken en kartelvorming van gevestigde partijen te voorkomen.

Versterking van het publieke debat is bij uitstek van belang met betrekking tot het beleid van de EU. Bij de Europese verkiezingen is de opkomst in Nederland (met $29,9 \%$ in 1999) dramatisch laag. Dat is in de eerste plaats te wijten aan het structurele probleem dat de kiezers bij Europese verkiezingen niet het idee hebben dat ze met hun stem enige invloed uitoefenen op de regeermacht. Voor de samenstelling van Europese Commissie of Europese ministerraden maakt de uitslag van de verkiezingen geen verschil (Van der Eijk 1996; Koele en Peeperkorn 2004). In Nederland met zijn coalitieregeringen is dat ook al niet gemakkelijk, maar daar heeft de kiezer toch nog het idee dat stemmen van invloed is op de regeringssamenstelling. Daarbij komt nog eens dat de verschillen tussen partijen moeilijk waar te nemen zijn. Van een publieke en politieke discussie is in het algemeen nauwelijks sprake en in verkiezingstijd wordt die afzijdige houding voortgezet. Kwesties die voor burgers uitermate belangrijk zijn, zoals de vraag welke competenties de EU zou moeten hebben, komen in het politieke debat niet of nauwelijks aan de orde. Toch valt er in dit opzicht verandering te bespeuren, omdat sommige partijen, ten dele onder druk van nieuwkomers zoals de LPF, zich openlijk kritisch opstellen ten aanzien van Europa. Het zou jammer zijn als het belang van de EU alleen wint door toenemende euroscepsis. 
Om omstreden kwesties op de agenda te krijgen is blijkbaar meer nodig. Ook hier zouden directe vormen van democratie, zoals referenda, een impuls kunnen geven. Dat lukt echter alleen als politieke partijen zich niet afzijdig houden, zoals zij bij lokale referenda nogal eens plegen te doen. Referenda worden vaak gezien als procedures die reflectie en discussie niet bepaald bevorderen omdat ze een digitale ja/nee-keuze impliceren. Er zijn echter vormen denkbaar die deliberatie bevorderen. Een referendum met meerdere opties - soms een preferendum genoemd - kan een interessant alternatief zijn (Enthoven 2003). Bij verschillende lokale referenda in Nederland zijn meerdere keuzemogelijkheden voorgelegd, onder meer bij gemeentelijke herindelingen en onlangs nog bij het referendum in Utrecht over het stationsgebied. De vraagstelling voor dergelijke referenda kan ontwikkeld worden op basis van een keuze-enquête onder de bevolking, een methode die ook al meerder malen is toegepast.

Ten slotte is er in verschillende andere landen - onder andere in Denemarken rond de invoering van de euro - geëxperimenteerd met deliberatieve polls en burgerjury's in combinatie met nationale referenda. Daarbij wisselt een representatieve groep burgers in het kader van de campagnes rond een referendum enkele dagen met elkaar en met deskundigen en politici van gedachten over de betreffende vraagstelling. Dergelijke vormen van discussie blijken vaak tot effect te hebben dat burgers hun aanvankelijke opinies in belangrijke mate bijstellen. Deliberatieve polls vormen dan ook een belangrijk alternatief voor de 'domme' polls die slechts voorkeuren registreren. Uitgebreide media-aandacht, met name via de televisie, moet deze intensieve informatievoorziening en meningsvorming een publiek karakter geven in de hoop dat een breder publiek de uitkomsten van dergelijke burgerfora als stemadvies kan gebruiken. Het zou een uitgelezen moment zijn om zo'n deliberatieve poll te houden met vertegenwoordigers van burgers uit alle lidstaten van de Europese Unie nu er een Grondwettelijk verdrag voorligt en daarover in verschillende landen nationale referenda gehouden zullen worden. Met voldoende media-aandacht in de verschillende lidstaten zou daarmee een eerste aanzet tot een publieke sfeer op Europees niveau gegeven kunnen worden. ${ }^{4}$

De media hebben echter niet alleen politieke functies, maar kunnen ook bijdragen aan een democratische cultuur. De discussie zou, zoals Broeders en Van de Donk terecht opmerken in deze bundel, minder eenzijdig gericht moeten zijn op de verhouding tussen media en politiek, maar verbreed moeten worden naar de maatschappelijke of culturele functies van de media. De media hebben ook een verantwoordelijkheid als bemiddelaar tussen verschillende bevolkingsgroepen. Zij moeten zorg dragen voor hoor en wederhoor door bijvoorbeeld ook minderheden een platform te bieden en op zijn minst verschillende invalshoeken met betrekking tot maatschappelijke conflicten te bieden. Daarnaast is de vraag van belang of burgers in voldoende mate gebruik maken van de informatieve functies van de media. Onze democratie is wel getypeerd als toeschouwersdemocratie, dat wil zeggen een democratie waarin de nieuwe politieke elite gevormd wordt door communicatie-experts, en burgers passieve televisiekijkers geworden zijn. 
Inderdaad kan men spreken van een nieuwe elite van communicatie-experts; de overheid alleen al heeft er vijfduizend in dienst (Ruler en Smithuis 2004). Of deze groep echter de invloed heeft die haar in het kader van een toeschouwersdemocratie toegeschreven wordt is twijfelachtig (zie bijdrage Broeders en Van de Donk). Het veronderstelt dat communicatie-experts bij uitstek degenen zijn die de politieke agenda bepalen door maatschappelijke scheidslijnen uit te vinden en deze politiek te exploiteren. Zij kunnen dat doen omdat de maatschappij gefragmenteerd is en de burgers overwegend passief zijn (Manin 1997). De voorstelling van een versplinterde en gefragmenteerde publieke sfeer, zoals in de toeschouwersdemocratie verondersteld wordt, behoeft nuancering met betrekking tot de Nederlandse situatie. Het beeld van een vergaande individualisering en maatschappelijke en politieke fragmentatie moet bijgesteld worden (Duyvendak en Hurenkamp 2004). ${ }^{5}$ Ook het beeld van passieve burgers is wat Nederland betreft onjuist. In dit opzicht is de toeschouwersdemocratie te sterk geënt op de Amerikaanse situatie. Daar gaat een meerderheid van de burgers niet meer stemmen en een belangrijk deel van de televisiekijkers is zelfs afgehaakt wat betreft informatie- en nieuwsvoorziening (Patterson 2002). In Nederland is dat vooralsnog niet het geval, maar een dergelijke minimale activiteit wat betreft mediagebruik is vanuit het oogpunt van deliberatieve democratie een elementaire vereiste van burgerschap. 


\section{NOTEN}

$1 \quad$ Het is interessant dat de afrekening waarschijnlijk minder telde dan de representatieve functie. Al voordat het item van de paarse puinhopen gelanceerd werd stonden de kiezers van de LFP achter Fortuyn. Zijn programma rond immigratie had meer aantrekkingskracht dan zijn afrekening met het gevoerde beleid van paars.

2 Het college van Rotterdam, bijvoorbeeld, laat iedere vier maanden onderzoeken wat de burgers van allerlei kwesties vinden of hoe bekend individuele bestuurders van de stad zijn. Het Amsterdamse Bureau voor Onderzoek en Statistiek meldt dat in de afgelopen drie jaar de onderzoeksopdrachten met $40 \%$ zijn toegenomen. Zie NRC Handelsblad, 2004.

3 Brian Barry, die in Nederlandse politieke kringen bewonderd wordt om zijn kritiek op het multiculturalisme, wijst er eveneens nadrukkelijk op dat ook liberalen pragmatisch zijn als het gaat om interventie en onzeker over de beste middelen om het doel van bescherming van individuele vrijheid te bereiken. Zie Barry 2003.

4 Een voorstel daartoe is ontwikkeld door James Fishkin en Kasper M. Hansen.

5 Mogelijk is er wel sprake van gesegmenteerd mediagebruik via etnische lijnen of langs de lijn van opleiding. Zo zijn er aanwijzingen dat met name Turken sterk op de eigen lokale media of media in Turkije gericht zijn. Deze vorm van segmentatie gaat weliswaar gepaard met relatief grote politieke interesse en activiteit, maar blijft sterk gericht op de eigen groep (Van der Bijl, 2003). Daarnaast zou er sprake kunnen zijn van een scheidslijn tussen commerciële en publieke omroepen langs de lijn van lager en hoger opgeleiden. Zo wordt wel aangenomen dat LPF-kiezers sBs-kijkers zijn. 


\section{LITERATUUR}

Akkerman T. (2001) 'Urban debates and deliberative democracy', in Acta Politica, Spring 2001: 71-88.

Akkerman, T. (2003a) 'Radicaal en respectabel populisme', in ABG 37, febr. 2003: 10-11

Akkerman, T. (2003b) 'Talking, voting and violence'. Paper gepresenteerd tijdens de workshop 'Deliberative Democracy \& Sensitive Issues', 25 en 26 maart 2003. Amsterdam.

Akkerman, T., M. Hajer en J. Grin (2004) 'The interactive state: democratisation from above?’, in Political Studies, 52,1: 82-96.

Barry, B. (2001) Culture and equality, an egalitarian critique of multiculturalism, Cambridge: Polity Press.

Bartolini, S. en P. Mair (2001) 'Challenges to Contemporary Political Parties', in L. Diamond, R. Gunther (red.) Political Parties and Democracy, Baltimore: John Hopkins University Press: 327-345.

Benhabib, S. (red.) (1996) Democracy and Difference: Contesting the Boundaries of the Political, Princeton University Press.

Bijl, P. v.d. (2003) Verbindingen in beeld. Mediagebruik, sociaal kapitaal en politieke participatie van etnische gemeenschappen in Amsterdam, Scriptie Politicologie, UvA.

Bohman, J. (1996) Public Deliberation: Pluralism, Complexity and Democracy, Cambridge, Mass, MIT.

Bohman, J. en W. Rehg (1997) Deliberative Democracy: Essays on Reason and Politics, Cambridge: Mass. MIT Press.

Bovens, M.A.P. en A.M.B. Michels (2002) 'Politiek zonder partij: een gedachteoefening', in J. v.d. Heijden en J. Schrijver (red.) Representatiefversus participatief, Den Haag: Eburon.

Brug, W. v.d.en C. v.d. Eijk (2003) 'Enige nuances: misverstanden over kiezers in het algemeen en de verkiezingen van 2002/2003 in het bijzonder', in R. Coops et al. (red.) Een politieke aardverschuiving, Alphen a/d Rijn: 74-98.

Cohen, J. (1989) 'Deliberation and Democratic legitimacy', in A. Hamlin en P. Pettit (red.) The Good Polity: Normative Analysis of the State, Oxford: Basil Blackwell: 17-34.

Cohen, J. en C. Sabel (1997) ‘Directly Deliberative Polyarchy', European Law Journal, 3: 313-342.

Cohen, J. en J. Rogers (1995) ‘A Proposal for Reconstructing Democratic Institutions', in: E. Olin Wright (red.) Associations and Democracy, London: Verso: 7-101.

Daalder H. (2002) 'Parties: Denied, Dismissed, or Redundant? A Critique', in R. Gunther, J.R. Montero, J.J. Linz (red.) Political Parties. Old Concepts and New Challenges, Oxford: Oxford University Press: $39-58$.

Diamond, L. en Gunther R. (red.) (2001) Political parties and democracy, Baltimore: John Hopkins University Press.

Doorn, J.A.A. van (2002) 'Democratie in de overgang. Van collectieve beheersing naar geordende vrijheid', in P.G.C. Van Schie (red.) Het democratisch tekort, Den Haag: Telderstichting: 7-55. 
Dryzek, J.S. (1990) Discursive Democracy: Politics, Policy and Political Science, New York: Cambridge University Press.

Dryzek, J.S. (200o) Deliberative Democracy and Beyond, Liberals, Critics, Contestations, Oxford: Oxford University Press.

Dryzek, J.S. (2003) 'Alternatives to Agonism and Analgesia: Deliberative Democracy in Divided Societies', paper gepresenteerd tijdens de workshop 'Deliberative Democracy \& Sensitive Issues', 25 en 26 maart, Amsterdam.

Duyvendak, J.W. en M. Hurenkamp (red.) (2004) Kiezen voor de kudde. Lichte gemeenschappen en de nieuwe meerderheid, Amsterdam, Van Gennep.

Edelenbos, J. en R. Monnikhof (red.) (2001) Lokale interactieve beleidsvorming. Een vergelijkend onderzoek naar de consequenties van interactieve beleidsvorming voor het functioneren van de lokale democratie, Utrecht: Lemma.

Eijk, C. van der (1996) Choosing Europe? The European electorate and national politics in the face of the union, Michigan: University of Michigan Press.

Enthoven, G. (2003), 'Geef burgers een echte keus', in NRC Handelsblad, 14 sept.

Etty, E. (2004) 'De stelling van Joop Daalmeijer: Rechts geluid moet terug op tv, op Nederland 2', in NRC Handelsblad, 17 april.

Fishkin, J.S. (1995) The Voice of The People. Public Opinion \& Democracy, New Haven: Yale University Press.

Forester, J. (1999) The Deliberative Practitioner. Encouraging Participatory Planning Processes, Cambridge Mass: MIT.

Fung, A. en E.O. Wright (2001) 'Deepening Democracy: Innovations in Empowered Participatory Governance', Politics \& Society, 29, 1: 5-41.

Graaf, Th. de, R. van Boxtel, W. Sorgdrager en G. Schouw (2002) Wil de nieuwe overheid nu opstaan!, Den Haag.

Gunther, R., J.R. Montero, J.J. Linz (red.) (2002) Political Parties. Old Concepts and New Challenges, Oxford: Oxford University Press.

Gutmann, A. en D. Thompson (1996) Democracy and Disagreement, Cambridge, Mass: Belknap Press.

Gutmann, A. (2003) Identity in Democracy, Princeton University Press.

Habermas, J. (1996) Between Facts and Norms: Contributions to a Discourse Theory of Law and Democracy, Cambridge Mass: MIT Press.

Hajer, M. en H. Wagenaar (red.) (2003) Deliberative Policy Analysis: Understanding

Governance in the Network Society, Cambridge: Cambridge University Press.

Hartman, I. (200o) Democratie van de grote bekken; Leer je wat van het publieke debat?, Amsterdam: IPP.

Katzenstein, P.J. (2000) 'Confidence, Trust, International Relations, and Lessons from Smaller Democracies', in Pharr S.J. en R.D. Putnam (red.) Disaffected Democracies. What's Troubling the Trilateral Countries?, Princeton University Press: 121-149.

Kitschelt, H. (1995) The Radical Right in Western Europe. A Comparative Analysis, Ann Arbor: University of Michigan Press.

Kleinnijenhuis, J., D. Oegema, J. de Ridder, A. van Hoof A. en R. Vliegenthart (2003) De puinhopen in het nieuws. De rol van de media bij de Tweede-Kamerverkiezingen van 2002, Alphen a/d Rijn. 
Koele, T., M. Peeperkorn (2004) ‘Burger blijft thuis bij tweederangsverkiezingen’, de Volkskrant, 22 mei.

Krouwel, A. (2004) 'De kiezer zweeft stabiel', in J.W. Duyvendak en M. Hurenkamp (red.), Kiezen voor de kudde. Lichte gemeenschappen en de nieuwe meerderheid, Amsterdam: Van Gennep.

Lindsay, I. (2004) 'The New Civic Forums', in Political Quarterly, 71, 4: 404-412.

Magnette, P., C. Lequesne, N. Jabko en O. Costa (2003), 'Conclusion: Diffuse democracy and the Europen Union: the pathologies of delegation', Journal of European Public Policy, 10, oktober: 834-840.

Manin, B. (1997) The Principles of Representative Government, Cambridge University Press, 1997.

Meehan, E. (2001) 'The Civic Forum', paper gepresenteerd tijdens de ESF Conference 'Beyond Representative Government', Nijmegen, 9-10 november.

Müller, W.C. (1991) 'Plebiscitary agenda-setting and party strategies. Theoretical considerations and evidence from Austria', in Party Politics, 5,3: 303-315.

NRC Handelsblad (2004), 'Lokale peilingen steeds populairder', 10 april.

Patterson, T.E (2002) The vanishing voter: public involvement in an age of uncertainty, New York: Knopf.

Pennings, P. en H. Keman (2003) 'The Dutch Parliamentary Elections in 2002 and 2003: The Rise and Decline of the Fortuyn Movement', Acta Politica, 38,1: 51-69.

Pharr, S.J. en R.D. Putnam (red.) (200o) Disaffected Democracies. What's Troubling the Trilateral Countries?, Princeton University Press.

Praag, Ph.van (2003) 'The Winners and Losers in a Turbulent Political Year', Acta Politica, $38,1: 5-23$.

RОВ (2002), Primaat in de polder. Nieuwe verbindingen tussen politiek en samenleving.

Ruler, B. en J. Smithuis (2004) 'Journalisten kunnen niet tellen', in de Volkskrant, 15 mei.

Sanders, L.M. (1997) 'Against Deliberation', Political Theory, 25, 3: 347-376.

Sociaal Culturrel Planbureau (2002) Sociaal en Cultureel Rapport 2002: De kwaliteit van de quartaire sector, Den Haag: Sdu.

Scharpf, F. W. (200o) 'Interdependence and Democratic Legitimation', in S.J. Pharr en R.D. Putnam (red.) Disaffected Democracies. What's Troubling the Trilateral Countries?, Princeton University Press: 101-121.

Stokkom, B. van (2003) 'Deliberatie zonder democratie? Ongelijkheid en gezag in interactieve beleidsvorming', $B$ en $M, 30,3: 153-165$.

Tjeenk Willink, H.D. (2003) Algemene beschouwingen in Raad van State, Jaarverslag 2003: 11-37.

Walzer, M. (1997) On Toleration, Yale University Press. 


\title{
14 ASSOCIATIEF-DEMOCRATISCHE DROMEN OVER VERPLAATSTE POLITIEK
}

\author{
E.R. Engelen
}

\subsection{INLEIDING}

Aan ieder stelsel van representatieve democratie ligt het 'moderne' beginsel van arbeidsdeling ten grondslag. Schaalvergroting en toenemende complexiteit hebben een geleidelijk proces van specialisering in gang gezet, dat er uiteindelijk toe heeft geleid dat politieke besluitvorming in het democratische centrum van de staat is uitgegroeid tot een dagtaak die exclusief is toegevallen aan een geprofessionaliseerde politieke elite. De kiezer kiest - een partij, een programma, een representant - en doet dat periodiek; en de politicus representeert, delibereert en controleert en doet dat continu. Daarvoor zijn zo op het oog goede redenen: de burger heeft wel wat anders aan zijn hoofd, en de complexiteit van het hedendaagse bestuur vereist een mate van deskundigheid waar nu eenmaal niet iedereen over beschikt.

Zo bezien is de vermaledijde 'kloof' tussen kiezer en gekozene inherent aan het democratische bestel dat in Nederland in een aantal wetgevingsgolven vanaf het midden van de 19de eeuw tot stand is gekomen. Zo bezien ook is het niet de populistische revolte van 2002 die verklaring behoeft, maar juist de geringe frequentie van dit type revoltes tegen een geprofessionaliseerde politieke kaste.

Uiteraard hangt de beoordeling van zowel kloof als revolte af van het ingenomen democratische perspectief. In de theorie van de vertegenwoordigende democratie wordt de burger vooral beschouwd als sociaal en economisch subject dat zich slechts bij hoge uitzondering tot het politieke bedrijf bekent. Democratie functioneert in dit perspectief louter als ultiem controle-instrument ter beteugeling van staatswillekeur. Hierin volstaat dan ook deelname aan de laagste trede van de participatieladder: kiezen. Democratie is een ' $k$ waad' dat noodzakelijk is geworden met het ontstaan van het grotere 'kwaad' van de staat en zijn geweldsmonopolie. Burgerparticipatie is slechts instrumenteel en vertegenwoordigt geen waarde op zichzelf.

In de theorie van de directe democratie worden de burger wel democratische motieven toegeschreven. In principe streeft de burger naar zelfbestuur - al dan niet in eigen kring - en als hij dat in werkelijkheid niet doet komt dat door blokkerende instituties. Het is niet zo dat de burger zich uit vrije wil terugtrekt in het particuliere bestaan, zoals de theorie van de vertegenwoordigende democratie wil, maar hij wordt juist kleiner gemaakt dan hij kan zijn door een vertegenwoordigend stelsel dat de hogere treden van de participatieladder heeft gereserveerd voor een participatie-elite en de burger daarmee niet in staat stelt te proeven van het ware democratische leven. 
Beide beoordelingen kunnen in de discussie over oorzaken en achtergronden van de populistische revolte van 2002 worden vernomen. Volgens de vertegenwoordigende democraat is stilzwijgende instemming met het centrale bestuur de dominante gemoedstoestand van de burger. Afnemende participatie is geen indicatie van afnemende tevredenheid maar juist van toenemende tevredenheid. Dat betekent dat de verklaring voor plotseling oplaaiende electorale onvrede elders moet worden gezocht. En veelal wordt dan gewezen naar gebreken in de publieke dienstverlening: wachtlijsten, vertragingen, open grenzen, etc. Plotseling oplaaiende onvrede die zich manifesteert via electorale verschuivingen zou dus juist de robuustheid bewijzen van het macropolitieke bijsturingmechanisme dat democratie volgens de representatieve democraat in wezen is.

De diagnose van de directe democraat staat hier haaks op. Volgens hem schuilt de oorzaak van de revolte in het vertegenwoordigende democratische bestel zelf en de gemankeerde participatie die het de burger biedt. Het instrument van vertegenwoordiging mag dan functioneel zijn geweest in een tijd van grote kennisverschillen, in een samenleving waarin steeds grotere groepen burgers hooggeschoold en mondig zijn, past een dergelijke vorm van geïnstitutionaliseerde bevoogding veel minder. Herziening van het democratische bestel is nodig om het paternalistische monopolie van een egoïstische politieke kaste op democratische besluitvorming te doorbreken en te vervangen door het bestuur van, voor en door het volk dat volgens de directe democraat de essentie van democratie is.

In dit hoofdstuk onderschrijf ik geen van beide diagnoses en oplossingsrichtingen, of beter: ik onderschrijf delen van beide diagnoses en kom op basis daarvan tot een andere oplossingsrichting. Ik deel de mening van de directe democraat dat de burger meer kan zijn dan waar hij onder condities van een vertegenwoordigend democratisch stelsel toe in staat wordt gesteld. Maar ik wijs zijn verwachting af dat gekozen burgemeesters, districtenstelsels, direct recall en referenda de democratische droom zullen realiseren. Er zijn nu eenmaal (grote) verschillen in kennis, participatievermogen en participatielust tussen burgers, en er zijn nu eenmaal belangrijke voordelen verbonden aan besluitvorming door deskundigen en dus aan een zekere mate van specialisering. Oftewel, ik deel tevens de diagnose van de vertegenwoordigende democraat dat arbeidsdeling en dus een zekere kloof tussen kiezer en gekozene in grote, complexe polities onvermijdelijk zijn. Dit betekent dat voor de verdergaande democratische behoeftes van burgers een andere locatie moet worden gezocht. Associatieve democratie - het democratietheoretische perspectief vanwaaruit dit hoofdstuk is geschreven - zoekt deze in grotere verantwoordelijkheden en bevoegdheden voor democratische associaties. Juist in het niet-politieke bestaan van burgers gaan grote mogelijkheden voor effectieve participatie schuil, omdat het juist daar gaat om zaken die hen aangaan en waar zij over onvervangbare informatie beschikken, namelijk de lokale kennis van de gebruiker/werknemer/ouder/patiënt. Oftewel, associatieve democratie tracht de gebrekkige participatiemogelijkheden van de politieke vertegenwoordigende democratie te compenseren door het belang van niet-politieke domeinen te versterken en deze vervolgens te openen voor directe participatie op het lokale 
niveau en voor participatie via vertegenwoordiging op het niveau van het domein als geheel.

Onderwijs bijvoorbeeld, is een publieke dienst die veel Nederlandse burgers ter harte gaat. Momenteel staat deze sector in hoge mate onder directe controle van de centrale overheid en in mindere mate de lokale overheid. Omdat scholen en beroepsorganisaties een betrekkelijk geringe autonomie hebben voelen de meeste ouders weinig reden om de wettelijke medezeggenschapskanalen te gebruiken. Als gevolg daarvan verloopt de democratische controle goeddeels via het weinig effectieve en weinig verplichtende kanaal van de vierjarige electorale cyclus, zowel de nationale als de lokale.

Door nu scholen, beroepsorganisaties en beroepsbeoefenaars meer autonomie te geven bij het uitvoeren van hun publieke dienstverleningstaken verschuift ook het belang van de klassieke politieke verantwoordingskanalen naar niet-politieke verantwoordingskanalen als de ouderraden en medezeggenschapsraden.

Verwacht mag dan ook worden dat als gevolg van decentralisatie en devolutie de motivatie van ouders en leerlingen om zich met het bestuur van de school te bemoeien zal toenemen; er staat simpelweg meer op het spel! Daarnaast betekent een hechtere vervlechting van school en ouders dat op microniveau meer en beter kan worden ingespeeld op verschillende ouderwensen en dat op mesoniveau meer en beter collectief kan worden geleerd wat werkt en wat niet, door middel van variatie en selectie.

Tezelfdertijd is echter ook op het niveau van koepelorganisaties en beroepsorganisaties effectieve democratische controle vereist. Geen macht zonder tegenmacht! Omdat het hier gaat om niveaus die wat verder van klas en school afstaan en om kwesties die veelal een hogere abstractiegraad hebben, zullen de meeste ouders zich niet geroepen voelen om te participeren noch zullen zij over de vaardigheden en kennis beschikken om dat effectief te kunnen doen. Hier zijn institutionele voorzieningen nodig die hen daartoe in staat stellen, zoals formele medezeggenschapsrechten, opleidingen, cursussen, financiële compensatie, etc. Bovendien zal op enigerlei wijze moeten worden gezorgd voor representativiteit en verantwoording en zullen dus explicieter dan momenteel het geval is ouderorganisaties moeten mediëren tussen school en koepelorganisatie en zullen zij periodiek hun eigen representativiteit en inclusiviteit moeten aantonen. Niet alleen omdat zo de controlecirkel (wie controleert de controleurs?) kan worden gesloten, maar ook omdat zo een kennisinfrastructuur gerealiseerd kan worden die concrete en abstracte, particuliere en universele, praktische en theoretische kennis weet te combineren.

Dit voorbeeld illustreert vier kenmerken van associatieve democratie. Ten eerste dat democratische participatie niet alleen moreel wenselijk is maar ook functioneel is. Oftewel, meer participatiemogelijkheden is niet alleen beter omdat het meer recht zou doen aan de notie van volkssoevereiniteit als ultieme grondslag voor machtsuitoefening, maar ook omdat het bijdraagt aan kwalitatief hoogwaardigere 
besluitvorming en betere publieke dienstverlening. Ten tweede dat de functie van participatie niet alleen schuilt in haar vermogen om de uitoefening van macht te controleren maar ook in haar vermogen om door middel van de vertegenwoordiging van relevante perspectieven en inzichten kennis en informatie in het besluitvormingsproces in te brengen die anders zouden ontbreken. Ten derde dat het directe en vertegenwoordigende vormen van inspraak tracht te combineren. Met de directe democraat deelt de associatieve democraat het morele uitgangspunt dat meer zelfbestuur zowel wenselijk als mogelijk is. Met de vertegenwoordigende democraat, daarentegen, deelt hij het inzicht dat dit niet in alle gevallen zo is. Wel op het lokale niveau (school, buurt, dienst en bedrijf) waar zowel betrokkenheid als kennis te vinden is, niet op het bovenlokale niveau waar betrokkenheid niet vanzelfsprekend is en kennis schaars is. En ten vierde dat vooral in de niet-politieke domeinen directe participatiemogelijkheden moeten worden gecreëerd. Politiek in klassieke zin gaat over belangenafwegingen tussen domeinen. Als zodanig kleeft haar altijd een zekere mate van abstrahering van alledaagse vraagstukken aan. Binnen domeinen daarentegen staat het oplossen van concrete problemen meer centraal. Dit genereert een grotere betrokkenheid van burgers, waardoor het morele project van democratisering ook het beste daar gestalte kan krijgen. Bovendien zijn beroepsbeoefenaars, beroepsorganisaties en instellingen (scholen, ziekenhuizen, verzorgingstehuizen, sociale diensten, welzijnsinstellingen en CWI's) voor een adequate dienstverlening aangewezen op de probleemdefinities en praktische oplossingsvoorstellen die aan de kant van gebruikers/ouders/patiënten leven.

Anders dan veel directe en vertegenwoordigende democraten identificeert de associatieve democraat democratie dus niet met een specifieke set van instituties als de Eerste en Tweede Kamer, parlementsverkiezingen, Provinciale Statenverkiezingen, politieke partijen, etc. Veeleer gaat het om een set van besluitvormingsregels - one (wo)man, one vote, 'het beste argument moet ook het zwaarste wegen', 'de meeste stemmen tellen', 'iedereen evenveel spreektijd', 'geen macht zonder tegenmacht', 'van, voor en door het volk', etc. - die overal waar collectieve besluiten worden genomen zouden moeten worden toegepast.

Datzelfde geldt voor 'politiek'. Ook 'politiek' identificeert de associatieve democraat niet met de democratische aansturing van het centrale staatsapparaat, maar met een bepaald type besluit - namelijk redistributieve belangenafweging - dat overal plaatsvindt, niet alleen in het 'politieke' domein, maar ook in 'sociale', 'economische' en 'culturele' domeinen. Het associatief-democratische pleidooi voor 'politisering' en 'democratisering' van deze domeinen moet derhalve worden gezien tegen de achtergrond van het dominante spreken over democratie en politiek in termen van statelijke instituties. Volgens de associatieve democraat is de 'politiek' al lang 'verplaatst', is politiek nimmer uitsluitend statelijke politiek geweest en geeft het dus geen pas om te spreken van 'verplaatsing'. Om retorische redenen zal ik mij in het navolgende toch van deze termen bedienen.

Ik begin dit hoofdstuk met een korte uiteenzetting over herkomst, achtergronden en kenmerken van de associatieve democratietraditie. Vervolgens weeg ik de 
uitdagingen die in deze verkenning zijn geïdentificeerd en schets ik de contouren van de oplossingen die hiervoor vanuit associatief-democratisch perspectief zouden kunnen worden geformuleerd. Tot slot ga ik in op een aantal 'lastige kwesties' die ofwel zijn blijven liggen ofwel door de associatief-democratische 'oplossingen' zelf worden opgeroepen.

\subsection{WAT IS ASSOCIATIEVE DEMOCRATIE WEL EN WAT NIET?}

Hoe verschillend de uitgangspunten ook mogen zijn, alle associatieve democraten die deze naam waardig zijn delen de diagnose dat de crisis van de 'moderne' overheid bestaat uit een mengsel van kwaliteitsproblemen en responsiviteitstekorten die herleid kunnen worden tot de spanning tussen toenemende complexiteit enerzijds en de structurele beperkingen van een centralistisch bestuurssysteem anderzijds. Met neoliberalen als Hayek en neoconservatieven als Oakeshott nemen zij afscheid van een zuiver discursief, cognitivistisch kennisconcept en benadrukken zij het belang van de zogenaamde tacit knowledge die ligt ingebed in gebruiken, tradities en praktijken. Anders dan neoliberalen betogen, volgt daar volgens associatieve democraten niet automatisch de oplossing van meer marktwerking uit. Associatieve democraten schuiven aan bij het recente institutionalisme in de sociale wetenschappen dat meerdere coördinatiemechanismen onderscheidt naast markt en staat. Op grond daarvan menen zij dat (mede)bestuur door associaties evenveel recht doet aan het inzicht dat de menselijke rationaliteit principieel 'beperkt' is als de Hayekiaanse markt. Bovendien menen zij dat associatief bestuur meer recht doet aan het morele inzicht dat individuele autonomie onder condities van wederzijdse afhankelijkheden collectief zelfbestuur vooronderstelt.

Het gedachtegoed van de associatief-democratische traditie is gebaseerd op drie kernbeginselen:

1 Preferenties, belangen en doelen zijn niet gegeven maar moeten ontdekt worden, zowel door bestuurders als hun onderdanen en zowel door kiezers als gekozenen. Dit impliceert niet alleen een breuk met de rationalistische premissen van het controledenken dat is gebaseerd op de bewaking van gegeven doelen tegen opportunistisch gedrag (zie bijdrage van Sabel in deze Verkenning), maar wijst ook in de richting van het belang van deliberatie als onderdeel van democratische besluitvorming. Mits institutioneel mogelijk, zijn individuen uitstekend in staat om hun particuliere belangen via de confrontatie met de particuliere belangen van anderen te herformuleren in publieke termen. In de woorden van Joshua Cohen en Joel Rogers:

Vertrekkend vanuit een faire uitgangssituatie en gegeven de verwachting dat de uitkomsten van het deliberatieproces voor iedereen bindend zullen zijn, mag worden aangenomen dat de participanten meer open zullen staan voor de belangen van anderen dan onder andere condities het geval zou zijn geweest (1995: 260). 
Anders dan in de deliberatieve democratietheorie, die deliberatie modelleert naar de wetenschappelijke discussie en van deelnemers een belangeloze bijdrage verwacht en daarmee een groot beroep doet op klassiek-rationalistische deductieve en abstraherende vaardigheden, gaat het hier om praktische deliberatie, dat wil zeggen: deliberatie over concrete problemen door burgers die een duidelijke emotioneel-affectieve betrokkenheid hebben bij de kwestie.

2 Democratische besluitvorming kan het beste daar gebeuren waar ook de implementatie ervan moet plaatsvinden. Niet alleen om besluit en implementatie zo dicht mogelijk bij elkaar te brengen, maar ook om de pool van deelnemers aan de besluitvorming zo veel mogelijk te laten samenvallen met diegenen die de gevolgen ervan ondervinden en om zo veel mogelijk gebruik te kunnen maken van hun probleempercepties. In de woorden van Paul Hirst:

“De beginselen van associatieve democratie staan haaks op zowel het centralisme van de moderne staat als op zijn soevereiniteitsclaim. Associatieve democratie behelst een opdeling van verantwoordelijkheden in zo veel mogelijk afzonderlijke domeinen, zowel territoriale als functionele en het terugbrengen ervan tot zo kleinschalig mogelijke en zo lokaal mogelijke autoriteiten" (1994: 26).

Functionele en territoriale decentralisatie derhalve, of subsidiariteit, heeft niet alleen tot doel om de kwaliteit van de besluitvorming te verhogen maar ook om de mogelijkheden voor actieve democratische participatie te vergroten.

3 Medebestuur door associaties is alleen dan acceptabel wanneer deze associaties zijn gestoeld op vrijwilligheid. "De kern van de theorie," aldus Hirst, "is de vrijheid van individuen om zich te verenigen” (1994: 49). Individuele autonomie valt alleen te garanderen wanneer de gemeenschappen waarvan een individu deel uitmaakt gekozen gemeenschappen zijn, geen lotsgemeenschappen. Dat, op zijn beurt, vereist constitutioneel verankerde civiele, politieke en sociale rechten die het burgers niet alleen formeel toestaan om de associatie te verlaten (exit) maar hen daar, mocht zulks nodig zijn, eveneens materieel toe in staat stellen.

Associatieve democratie komt dus neer op een combinatie van delegeren van overheidstaken naar kleinschaligere semi-publieke verenigingen bij gelijktijdige democratisering van deze verenigingen en een zo omvattend mogelijke invulling van het bestaande stelsel van constitutioneel gewaarborgde rechten. Zij behelst met andere woorden een complementaire benadering van de bestaande vertegenwoordigende democratie en het daaraan opgehangen staatsapparaat in plaats van een vervangende. Associatieve democratisering is niet bedoeld als alternatief voor de bestaande representatieve instituties maar juist als aanvulling erop (Bader 2001: 36-37). 
Aan de bovengenoemde kernprincipes kunnen uiteraard verschillende - meer of minder radicale - invullingen worden gegeven. De minimumvariant is van Cohen en Rogers. In antwoord op de complexiteitstoename van moderne samenlevingen en het navenante verlies aan sturingscapaciteit en legitimiteit van centrale overheden betogen zij dat ruimere beschikkingsbevoegdheden voor 'associatieve arena's' de effectiviteit (en daarmee de output-legitimiteit) van moderne staten kan vergroten. Het gaat hen dus primair om ontlasting van centrale overheidsinstanties door formulering, implementatie, uitvoering en controle van beleid over te dragen aan het 'maatschappelijke middenveld'. Anders dan in het katholieke (en conservatieve (Burke!)) corporatisme dat er sterk toe neigt om de dragers van dat middenveld gelijk te stellen aan 'natuurlijke' gemeenschappen, benadrukken Cohen en Rogers juist het kunstmatige karakter van de medebesturende associaties. Bovendien zien zij een belangrijke rol weggelegd voor de centrale overheid bij het herscheppen van het maatschappelijke middenveld. Van 'grote stuurman' dient de staat zich te transformeren in een regisseur die de associaties in de gelegenheid stelt om eigenhandig maatschappelijke vraagstukken bij de hoorns te nemen. Associatieve democratisering is bij Cohen en Rogers dus uiteindelijk een taak van de centrale overheid en daarmee een top-downproces dat wordt afgedwongen door een groeiend crisisbewustzijn bij diezelfde centrale overheid.

In de maximumvariant van Paul Hirst, daarentegen, krijgen vrijwillige associaties zowel meer als belangrijkere overheidstaken toebedeeld, waaronder de verantwoordelijkheid voor bovenminimale verzorgingsarrangementen op het gebied van scholing, welzijn, huisvesting en gezondheidszorg bij een gegarandeerd basisinkomen. Volgens Hirst moet dan ook niet van secundaire associaties worden gesproken, zoals Cohen en Rogers in de titel van hun essay ('Secondary associations and democratic governance') doen, maar juist van primaire. Omdat de arrangementen die moderne verzorgingsstaten bieden onder Hirsts regime van associatieve democratie grotendeels een zaak van burgers zelf zijn geworden, kan en moet de centrale overheid zich beperken tot de klassieke taken van interne en externe veiligheid, aangevuld met faciliterende taken op het vlak van belastingheffing en financiering, bemiddeling, coördinatie en controle; "het gaat er niet om bereik en omvang van het publieke voorzieningenniveau te verkleinen, als wel om de wijze waarop deze voorzieningen worden verstrekt aan direct staatstoezicht te onttrekken," aldus Hirst (1994: 117).

Hoewel Hirst dus minder dan Cohen en Rogers op de sturingscapaciteit van centrale overheden vertrouwt, draait het ook bij hem om het afstoten van taken en verantwoordelijkheden - inclusief de bijbehorende financiële middelen - naar lagere en/of niet-statelijke organen. En uiteindelijk is dat proces ook bij Hirst een proces van zelftransformatie, waardoor ook bij hem een betrekkelijk grote bevoegdheid, vooral in de voorwaardelijke sfeer, in handen van de centrale overheid blijft liggen. Niet alleen leidt associatieve democratisering, om met Hirst te spreken, niet tot verkleining van 'bereik en omvang van het publieke-voorzieningenniveau'; omdat het een voorwaardelijke overdracht betreft gaat zij tevens gepaard 
met de noodzaak om een fiks toezichthoudend apparaat op te tuigen. In beide gevallen ligt het initiatief voor associatieve democratisering dus bij de staat, wat voldoende politieke speelruimte vooronderstelt alsmede voldoende capaciteit.

Het is duidelijk dat dit hoge eisen stelt aan de kwaliteit van de sociaal-economische context - namelijk een zekere mate van gelijkheid - en alleen leefbaar is wanneer substantiële civiele, politieke en sociale rechten constitutioneel zijn gegarandeerd, teneinde stabiliteit en bestaanszekerheid te waarborgen. Door middel van het stimuleren van kleinschalige, innovatieve productieclusters hoopt Hirst economische machtsconcentraties op te breken en de sociaal-economische kansengelijkheid te creëren die sinds Tocqueville als sine qua non voor een vitale democratische maatschappij geldt. En door associatieve democratie niet te presenteren als vervanger maar als complement van de vertegenwoordigende democratie, hoopt Hirst de bestaanszekerheden te kunnen garanderen die noodzakelijk zijn voor de gewenste individuele en collectieve experimenteerlust.

Op basis van het voorgaande mag het duidelijk zijn dat niet alle in deze Verkenning geïdentificeerde 'uitdagingen' vanuit het perspectief van de associatieve democraat even relevant zijn. Juist doordat associatieve democratie zowel uitgaat van als streeft naar een pluralisering van soevereiniteit, politiek, bestuur en democratie zijn de kwesties die in deze Verkenning worden aangeduid als 'verplaatsing van de politiek', 'de kloof tussen burger en bestuurder' en de 'Europeanisering van beleid' voor de associatieve democraat niet zozeer 'uitdagingen' als wel uitnodigingen aan rivaliserende democratietheoretische perspectieven om eens 'associatief te denken'. Om de breedte van het oplossingenpalet van de associatief-democratische traditie te demonstreren presenteer ik hieronder, onder het kopje 'Verplaatste politiek', een aantal institutionele voorstellen die het democratisch tekort waarin de actuele 'verplaatsingen' uitmonden kunnen wegnemen.

Minder relevant zijn mijns inziens de uitdagingen die zijn besproken als 'mediatisering' en 'kennismaatschappij'. Het eerste beschrijft vooral hoe van de voornaamste terugkoppelingsmechanismen in vertegenwoordigende democratische stelsels - de electorale cyclus, de rechter, de media - er één dominant wordt en tussen de kiezer en de gekozene zijn eigen, vertekenende lens plaatst. Hoewel een vitale publieke sfeer cruciaal is voor een vertegenwoordigend stelsel - en waar relevant zal ik dan ook zeker de institutionele voorwaarden ervoor aanstippen - ben ik desalniettemin van mening dat daaraan in Nederland op nationaal niveau momenteel weinig schort. Met Broeders en Van de Donk in hun bijdrage aan deze Verkenning ben ik van mening dat niet de media het probleem zijn, maar het wegvallen van alternatieve terugkoppelingsmechanismen en dan met name de implosie van politieke partijen als intermediair tussen kiezer en gekozene als gevolg van deïdeologisering en het ontbreken van richtinggevende vergezichten bij vrijwel alle politieke partijen. Maar in plaats van een pleidooi voor herstel van het politieke primaat houdt de associatieve democraat een pleidooi voor een andere arbeidsverdeling tussen staatsorganen en vrijwillige associaties, 
waardoor het belang van het stelsel van vertegenwoordigende democratie ter waarborging van de volkssoevereiniteit afneemt en haar inherente institutionele gebreken minder prangend worden.

Parallel daaraan is de associatieve democraat van mening dat de thematisering van de media in deze Verkenning te zeer gebukt gaat onder het oude 'centrumdenken' dat nu net via de term 'verplaatsing van de politiek' wordt bekritiseerd. Wie accepteert dat politiek en democratie niet exclusief aan Den Haag toevallen, wordt onmiddellijk het belang gewaar van andere, niet-landelijke informatiekanalen. Het voert te ver deze hier te thematiseren maar dit inzicht levert wel zo'n relativering van de landelijke mediadiscussie over 'mediatisering' op dat ik haar zonder blikken of blozen een eigen plaats meen te kunnen ontzeggen.

Het verwante punt dat een vitale sfeer van 'openbaarheid' bij uitstek de plaats is waar een 'burgerlijke gemeenschap' wordt geproduceerd, die nodig zou zijn voor de redistributieve solidariteit waarop hedendaagse verzorgingsstaten zijn gestoeld, is mijns inziens om twee redenen onjuist. Ten eerste omdat de mate van gemeenschapszin die verzorgingsstaten zouden vereisen sterk wordt overschat; onderzoek wijst uit dat het merendeel van de verzorgingsarrangementen is toegesneden op de wensen en eisen van de middenklasse die niet toevallig ook voor het leeuwendeel van de financiering ervan opdraait (Deleeck 2001). Ten tweede omdat 'gemeenschapszin' niet zozeer het product is van een moreel appèl als wel van een gedeelde geschiedenis van succesvolle conflictbeslechting en het daardoor toenemende besef van wederzijdse afhankelijkheid. Oftewel, gemeenschapzin is niet een potentiële eigenschap van een gegeven 'demos' die via een moreel appèl kan worden wakker geroepen, maar het product van tijdelijk opgeloste conflicten over wat in gegeven gevallen de 'demos' nu eigenlijk is (Hirschman 1995).

Even sceptisch staat de associatieve democraat ten opzichte van wat met een modewoord de 'kennismaatschappij' wordt genoemd. Ook hier gaat het niet om 'nieuwe' vraagstukken maar om problemen die inherent zijn aan de spanning tussen politieke gelijkwaardigheid enerzijds en de onmiskenbare expertise die interventies in complexe maatschappijen nu eenmaal vereisen. Als zodanig is het vraagstuk hoe om te gaan met professionaliteit en deskundigheid in een democratische context een van de rode draden in dit hoofdstuk. De kwestie hoe en wanneer besluitvorming die een grote mate van deskundigheid vereist te politiseren, komt op meerdere momenten naar voren. Om die reden bespreek ik haar niet afzonderlijk. Anders ligt dat met de claim dat als gevolg van toenemende maatschappelijke complexiteit nieuwe organisatorische regimes noodzakelijk zijn die zich slecht verhouden tot geïnstitutionaliseerde en daardoor starre vormen van inspraak, toezicht en controle. Omdat het hier mijns inziens gaat om de kennissociologische pendant van de bestuurssociologische claim van verplaatste politiek, ga ik op die plaats onder het kopje 'Complexiteit, leervermogen en democratie' nader op deze stelling in. Nog weer anders ligt het met het probleem van de participatie-elite en de institutionele garanties voor politieke gelijkheid. 
Omdat dit een kwestie is waar ieder democratietheoretisch perspectief mee worstelt, bespreek ik haar in de slotparagraaf als een van de lastige kwesties waar ook de associatief-democratische onderzoeksagenda vooralsnog geen afdoende antwoord op heeft.

\subsection{VERPLAATSTE POLITIEK? VERPLAATSTE DEMOCRATIE!}

Inherent aan stelsels van representatieve democratie is, zoals gezegd, een zekere afstand tussen kiezer en gekozene en tussen burger en bestuurder. De stelling van de 'kloof'-denkers is echter dat deze afstand als gevolg van een aantal ontwikkelingen sterk is toegenomen en dat als gevolg daarvan de betrokkenheid van de gemiddelde burger bij het functioneren van de representatieve democratie is afgenomen. Een en ander zou blijken uit dalende participatiecijfers, zowel in termen van lidmaatschap van politieke partijen als van opkomstpercentages bij nationale verkiezingen. De ontwikkelingen die hier debet aan zijn worden gezocht bij toenemende complexiteit van de besluitvorming waardoor zij verder af komt te liggen van de belevingswereld van de burger, afnemende relevantie van het Haagse politieke centrum als gevolg van verplaatsingstendensen, en deïdeologisering van het politieke debat als gevolg van ofwel de ideologische dominantie van het neoliberalisme ('we're all neoliberals now') ofwel toenemend pragmatisme bij politici en bestuurders. Over de vraag of dat erg is wordt vervolgens al even verschillend gedacht. Directe democraten menen van wel en bepleiten ruimere participatiemogelijkheden om de kloof te dichten, terwijl vertegenwoordigende democraten veel minder ongelukkig zijn met de 'permissive consensus' die uit het geringe enthousiasme van de burger zou blijken. Wat vindt de associatieve democraat?

Allereerst moet worden bedacht dat lidmaatschap van politieke partijen en opkomst bij verkiezingen niet het hele scala aan participatiemogelijkheden dekt. Zoals Verhoeven in zijn bijdrage aan deze Verkenning laat zien is het correcter om te spreken van een verandering van de participatie dan van een vermindering ervan. Burgers blijken wel degelijk democratische neigingen te hebben maar geven deze in toenemende mate gestalte via allerlei minder geprofileerde vormen van politiek activisme. Hoe deze verschuiving te duiden?

Deze vraag valt uiteen in twee delen: waardoor wordt zij veroorzaakt en hoe moet zij worden beoordeeld? Het probleem met de gangbare verklaringen complexiteit en verplaatsing - is dat zij niet tegelijk juist kunnen zijn. Verplaatsing zou immers vooral een antwoord op bestuurlijke overcomplexiteit zijn en dus moeten uitmonden in minder en helderdere deliberatie in het politieke centrum. Hoewel er mijns inziens wel degelijk verplaatsingstendensen waarneembaar zijn (zie beneden), ben ik toch geneigd om de oorzaak voor de verschuiving in participatie vooral te leggen bij toenemende in plaats van afnemende complexiteit als gevolg van een misplaatst streven naar voortgaande en wellicht zelfs verscherpte politieke en bestuurlijke controle vanuit het politieke centrum. Dit is mogelijk gemaakt door en heeft tegelijk geresulteerd in een 
verdergaande professionalisering van politiek en bestuur waardoor de mogelijkheden voor burgers om zich te identificeren met hun vertegenwoordigers verder zijn verminderd. Oftewel, het probleem is een zich verder professionaliserende politiek als gevolg van gemankeerde verplaatsing in plaats van een steeds 'leger' wordend politiek centrum als gevolg van een teveel aan verplaatsing, zoals herstellers van het politieke primaat menen.

Hoe de verschuiving te beoordelen? Als mijn diagnose klopt is de verschuiving vooral te wijten aan het uitsluitgedrag van de politieke en bestuurlijke elite. Als zodanig valt de burger weinig te verwijten. Hij ervaart een toenemende distantie tot het politieke centrum, wendt zich als gevolg daarvan af van de participatiekanalen die naar dat centrum leiden en keert zich naar andere participatievormen die naar andere participatiefora voeren. Tot zover niets aan de hand. Problematischer is dat deze participatievormen een sterk ad hoc-karakter hebben, instabiel van aard zijn en dat de mogelijkheden om er gebruik van te maken ongelijk zijn verdeeld. Oftewel, er is dringend behoefte aan een institutioneel regime dat op een lager niveau en in buitenpolitieke domeinen directe en indirecte participatiemogelijkheden biedt en in voldoende faciliterende en compenserende voorzieningen kan voorzien om de ergste democratische effecten van sociaal-economische ongelijkheden te voorkomen. Associatieve democratie is zo'n institutioneel regime en staat voor de poging politiek en bestuur daar te leggen waar de lokale expertise en de enthousiaste betrokkenheid is. Hieronder zal ik dat verder concretiseren.

In zowel het publieke debat als in de wetenschappelijke reflectie daarop is de topos van 'verplaatste politiek' als gevolg van of in antwoord op het functionele failliet van centrale sturing door middel van 'command and control' wijdverbreid. Maatschappelijke differentiatie heeft niet alleen geleid tot een exponentiële vermenigvuldiging van het aantal locaties waar centrale regels moeten worden toegepast maar ook tot een toenemende verscheidenheid van deze locaties. Als gevolg daarvan worden centrale overheden in toenemende mate geconfronteerd met de grenzen van hun ken- en leervermogen alsmede met de grenzen van hun handelingsvermogen. De overheid ontbeert simpelweg de 'handen' en 'ogen' die nodig zijn om op veel verschillende locaties tegelijk effectief te kunnen interveniëren. Het antwoord daarop is een deels bedoelde - liberalisering, privatisering, verzelfstandiging - en deels onbedoelde - globalisering - verplaatsing van besluitvorming, implementatie en toezicht geweest.

Veel discussie is er vervolgens onder wetenschappers ontstaan of wel van 'verplaatsing' kan worden gesproken. Verplaatsing suggereert immers dat er ooit een gouden tijd was waarin centrale overheden wel over voldoende capaciteiten beschikten om hun collectieve wilsbesluiten ook daadwerkelijk in de gewenste maatschappelijke veranderingen om te zetten. En zoals de geschiedenis van het meso- en macrocorporatisme in de meeste ontwikkelde economieën leert is het kwestieus of dat zo is. Integendeel, soevereiniteit lijkt altijd diffuus te zijn geweest en de nationale 'politieke ruimte' altijd gedeeld, en goeddeels vanwege 
dezelfde functionele redenen die volgens 'verplaatsings'-denkers ten grondslag liggen aan de hedendaagse verplaatsingen (Crouch 1993). Wat uiteraard onverlet laat dat de verplaatsing van bestuur naar lokale en bovennationale (EU, multinationale organisaties) overheden wel degelijk 'nieuwe' ontwikkelingen zijn.

Onduidelijk is het daarnaast of het bij deze verplaatsingen gaat om empirische ontwikkelingen of om normatieve (on)wenselijkheden. Sommigen benadrukken het structurele karakter ervan, terwijl anderen juist wijzen op hun politieke essentie. In het eerste geval is er geen alternatief, en in het tweede geval is het onzeker wat het alternatief zou moeten zijn. Een derde groep bestrijdt dat de verplaatsing een omvang heeft aangenomen die geen weg terug meer toestaat en wijst in plaats daarvan op het onverminderde belang van nationale instituties, nationale wetten en regels en het nationale parlement als centrum van politieke besluitvorming. Een vierde groep stelt dat er alleen sprake is van een 'verplaatsingsretoriek' maar dat er in feite een toenemende centralisering heeft plaatsgevonden. Oftewel, deregulering, privatisering en liberalisering leiden niet tot minder regels en een kleinere overheid maar juist tot meer regels en een grotere overheid (Majone 1990).

Het is duidelijk dat theoretische premissen en normatief gewenste uitkomsten bij de beoordeling van de ontwikkelingen in de richting van een postnationaal politiek systeem in alle vier de gevallen onontwarbaar met elkaar zijn verknoopt.

In de literatuur worden vier verplaatsingsbewegingen onderscheiden. Dat zijn:

I van centrale overheid naar vrijwillige associaties en semi-private hiërarchieën (Zво's) binnen de kerndomeinen van de verzorgingsstaat (onderwijs, gezondheidszorg, welzijn, etc.);

II van centrale overheid naar multinationale ondernemingen als gevolg van hun gegroeide bewegingsruimte (en 'exit'-mogelijkheden) waardoor de grenzen van de markten waarop deze ondernemingen actief zijn steeds minder samenvallen met die van de discretionaire bevoegdheden van nationaal verankerde instellingen en instituties;

III van centrale overheid naar multinationale vormen van sectoraal en/of functioneel bestuur;

IV van nationale staat naar Europese Unie.

Hoe deze vier verplaatsingsbewegingen te beoordelen vanuit associatief-democratisch perspectief? Ten eerste zijn deze verplaatsingen volgens de associatieve democraat reële ontwikkelingen, ook al monden zij niet uit in een eenduidige verschuiving van soevereiniteit naar boven/buiten/beneden. Dit weerspiegelt het inzicht dat de diffusie van soevereiniteit niet een nulsomspel is. Wat het ene politieke centrum aan soevereiniteit wint gaat niet automatisch ten koste van het andere. Noch resulteert verplaatsing in een superstaat op supranationaal niveau. Eerder leidt zij tot een nieuw, complex politiek systeem bestaande uit meerdere lagen, meerdere actoren en meerdere beleidsterreinen, waarbinnen de machts- en bevoegdheidsverdelingen per sector en per laag verschillende (en verschuivende) 
vormen kunnen aannemen, en dat om die reden ook het beste kan worden aangeduid als 'meerlagig bestuur' (multi-level governance) of 'polycentrisch bestuur' (polycentric governance) (Hirst \& Thompson 1999).

Ten tweede gaat het volgens de associatief democraat bij deze verplaatsingen niet om noodzakelijke ontwikkelingen (geen false necessities (Unger 1987)), maar om effecten van doelbewuste politieke besluiten. Dat betekent echter niet dat nostalgische stappen terug in de richting van het primaat van de nationale politiek nog makkelijk zouden zijn te zetten, afgezien van de vraag of dat wenselijk zou zijn. Politieke beslissingen kunnen net zo onomkeerbaar zijn als natuurwetten. Wel betekent het dat het scala aan veranderingsmogelijkheden groter is dan in het deterministische kamp wordt voorgesteld en dat politieke strategie dus verschil kan maken (Bader 2001: 57-58).

Ten derde is de associatief democraat van mening dat niet de internationalisering van beleid per se het probleem is als wel de vorm die deze supranationalisering onder neoliberale condities heeft aangenomen (' $U$ w globalisering is de mijne niet!'). Grotere internationale bewegingsvrijheden voor monopolistische economische machtsconcentraties zijn in de plaats gekomen van nationale beschermingsconstructies voor werknemers. Oftewel, de Keynesiaanse verzorgingsstaat van weleer is vervangen door een neoliberaal regime van vrij kapitaalverkeer.

Wat stelt de associatieve democraat daar tegenover? Uitgaand van het principe dat er geen machtsuitoefening mag plaatsvinden zonder enige vorm van democratische controle, impliceren de vier genoemde verplaatsingstendensen een parallelle verplaatsing van de democratie. Overal waar politieke besluitvorming plaatsvindt - waarbij onder 'politiek', conform Laswell, iedere beslissing moet worden verstaan die collectieve redistributieve consequenties heeft (Laswell 1936) - dienen betrokkenen in ieder geval indirect en in ieder geval achteraf over controle- en correctiemechanismen te kunnen beschikken. Juist omdat de associatief-democratische traditie zich niet heeft vastgepind op een van de historische institutionele verschijningsvormen van de democratische principes is zij bij uitstek geschikt om concrete, gecontextualiseerde institutionele ontwerpvoorstellen te doen die dat mogelijk moeten maken. Hieronder schets ik iets uitvoeriger hoe de democratisering van het polycentrische bestuurssysteem in wording eruit zou kunnen zien. Ik eindig deze paragraaf met de bespreking van de parallelle kennissociologische claim dat dergelijke bestuurssystemen een antwoord zouden zijn op groeiende maatschappelijke complexiteit, wier superioriteit vooral zou schuilen in hun flexibiliteit. Om die reden zouden zij zich verzetten tegen institutionalisering en daarmee hun legitimiteit vooral ontlenen aan bestuurlijke effectiviteit in plaats van aan democratische inbreng.

\subsubsection{DEMOCRATISERING VAN DE VERZORGINGSSTAAT}

Het is duidelijk dat de klassieke verzorgingsstaat momenteel aan fundamentele transformatie blootstaat. Van een uitkeringsfabriek verandert zij langzaam in een 
publieke dienstverlener (Esping-Andersen et al. 2003). Dat betekent dat de kwaliteit van de diensten die sectoren als onderwijs, welzijn, volkshuisvesting en gezondheidszorg verlenen steeds belangrijker wordt voor de passieve en actieve legitimiteit van de centrale overheid. Burgers zijn bereid te betalen voor goede, op maat gesneden diensten, maar gaan mokken wanneer daaraan niet wordt voldaan. Dat onderkennende hebben de meeste overheden de laatste twee decennia uitvoerig geëxperimenteerd met nieuwe vormen van aansturing van deze sectoren. Centraal in deze experimenten hebben de doelstellingen van kostenbeheersing en responsiviteit gestaan. Marktwerking was het voornaamste instrument om deze doelstellingen te realiseren. Naar het zich laat aanzien is dat geen onverdeeld succes geweest. De kosten zijn gestegen, de kwaliteit is gedaald en de responsiviteit is afgenomen. Volgens de associatieve democraat heeft dat vooral te maken met de recentralisering waarmee de introductie van marktwerking gepaard ging. Meer marktwerking (exit) vereist meer transparantie; alleen wanneer diensten onderling vergelijkbaar zijn kan de cliënt een beredeneerde keuze maken. Meer transparantie vereist meer standaardisering; om ervoor te zorgen dat het eindproduct een constante kwaliteit heeft en dus door de tijd heen vergelijkbaar is, dient het productieproces zodanig te zijn ingericht (gestandaardiseerd) dat het niet langer stoelt op de ervaring van de uitvoerder maar in principe door iedereen zou kunnen worden verricht. Meer standaardisering leidt tot meer bureaucratie; standaardisering behelst de 'veruitwendiging' van de kennis van de expert, de vervanging van de laatste door lager geschoolde of minder bedreven uitvoerders, en de introductie van een nieuwe laag van lijnmanagers die de uitvoerders vervolgens moeten aansturen en controleren. En meer bureaucratie mondt uit in grotere organisaties en dus in (re)centralisering; standaardisatie is kostbaar en legt organisaties daardoor de logica van de schaalvoordelen op. In plaats van de one size fits all-oplossing van marktwerking, standaardisatie en schaalvoordelen, onderscheidt de associatieve democraat drie schaalniveaus - het microniveau van de uitvoering, het mesoniveau van de instelling en het macroniveau van de sector - en voorziet op deze niveaus verschillende vormen van democratische controle.

Op het microniveau van de uitvoering is correctie en controle door cliënten cruciaal. Daarvoor is concurrentie echter een te grof instrument. Alleen in het geval van scherpe structurele ongelijkheden kunnen 'vouchers' (in het onderwijs) of 'persoonsgebonden budgetten' (in de gezondheidszorg) een effectief instrument zijn om toegang tot kwaliteitsdiensten af te dwingen en segregatie te doorbreken, zoals de ervaringen met 'vouchers' in het Amerikaanse basisschoolsysteem leren (Owens 2002). In alle andere gevallen moeten de segregerende effecten van zelfselectie worden afgezet tegen de eventuele winsten in termen van kwaliteitsprikkels. Bovendien leert de ervaring dat deze winsten vaak illusoir zijn. School-, verzekeraars- en tandartskeuze blijken in de praktijk een dermate hoge investering van de kant van de cliënt in de relatie te vooronderstellen dat concurrentie tussen instellingen als gevolg van het met de voeten stemmen van de cliënt nauwelijks van de grond komt. 
Beter is het daarom om in te zetten op democratische controlemechanismen die uitvoerders en instellingen veel directer toegang bieden tot de multidimensionale kennis die nodig is om adequaat te kunnen inspelen op veranderende wensen en eisen. De bestaande medezeggenschapsraden, cliëntenraden en patiëntenraden vervullen deze functie momenteel maar tot op zekere hoogte. $\mathrm{Zij}$ worden gedomineerd door 'witte' hoogopgeleide tweeverdieners en fungeren vooral als klachtenbureaus. Om de betrokkenheid van cliënten bij deze democratische instituties te vergroten dienen de bevoegdheden ervan te worden uitgebreid (de medezeggenschap moet ergens over gaan) en om de elitaire effecten van sociaal-economische ongelijkheden tegen te gaan zouden de faciliteiten van deze raden voor de werving, selectie en scholing van raadsleden moeten worden vergroot.

Op mesoniveau moet worden gedacht aan een complexe mix van drie controlemechanismen: (1) hiëarchische aansturing door de centrale overheid via kaderstellende doelen gecombineerd met (2) zelfregulering door beroepsorganisaties (tuchtrecht en visitatie door peers) en (3) controle op het management van de instelling door raden van toezicht bestaande uit 'geprofessionaliseerde' representanten van cliënten, uitvoerders en kroonleden. 'Geprofessionaliseerd' wil in dit geval zeggen: ter zake kundig en betaald, terwijl via externe cliëntenorganisaties kan worden gezorgd voor voldoende representativiteit van de zaakwaarnemer. De kroonleden hebben in dit systeem uitdrukkelijk als mandaat het optimaliseren van het leervermogen van de instelling door kennisuitwisseling tussen instellingen en bindende normstelling (benchmarking) binnen sectoren.

Op het macroniveau van de sector als geheel speelt lokale kennis nauwelijks een rol en vereist responsiviteit minder een terstond reageren op nieuwe vraagstukken. Om die redenen kan worden volstaan met de traditionele terugkoppelingsmechanismen van de vertegenwoordigende democratie en de rechtsstaat, zoals politieke partij, omvattende vrijwillige associaties, pers, verkiezingen en de rechter. Het probleem is echter dat geen van deze mechanismen momenteel adequaat functioneert en dat er een verschuiving heeft plaatsgevonden in de mate waarin zij worden gebruikt. Met name het functioneren van politieke partijen, vakbonden en werkgeversorganisaties staat momenteel ter discussie. Hoe representatief zijn zij? Zijn zij niet gegijzeld door een oligarchische elite? Hoe responsief zijn zij aan leden en kiezers? In de slotparagraaf kom ik op deze kwestie terug.

Als gevolg daarvan is het belang van met name pers en rechter sterk toegenomen. Dat heeft vertekenende effecten. Zowel rechter als pers zijn zeer incidentgevoelig. Alleen wanneer zaken ernstig misgaan (rampen) komen ze voor de rechter en is er media-aandacht. Omdat bestuurders voor inzicht in de maatschappelijke effecten van hun interventies in toenemende mate van deze kanalen afhankelijk zijn, wordt hun beeld van de maatschappij vertekend door de incidentenlogica die inherent is aan beide mechanismen. Daarnaast is de toegang tot bestuurlijke aandacht via deze mechanismen ongelijk verdeeld. Rechtszaken vereisen geld en expertise waar niet iedereen over kan beschikken, terwijl media-aandacht onvoorspelbaar en in hoge mate willekeurig is. Als controlemechanismen schie- 
ten zij derhalve tekort en hebben zij aanvulling nodig via andere terugkoppelingsmechanismen.

De associatieve democraat meent dat herstel van de feedback-functie van politieke partijen een gepasseerd station is (wat niet wil zeggen dat hun selectie- en scholingsfuncties achterhaald zijn!) en zet in plaats daarvan in op de facilitering van staatswege van sectorale vrijwillige associaties (ouderorganisaties, patiëntenorganisaties) door financiële middelen ter beschikking te stellen, de 'politieke ruimte' actief te delen en/of organisatorische expertise aan te bieden. Het is uitdrukkelijk niet de bedoeling om een nieuw feedback-monopolie te installeren. Conform het complementaire uitgangspunt van de associatief-democratische traditie is onderhoud van de traditionele terugkoppelingsmechanismen van de representatieve democratie, al was het maar als zekerheidsklep, bepaald geen luxe, maar ook zeker geen panacee. Alleen in combinatie met een andere arbeidsverdeling tussen staat en maatschappij is het zinvol om te experimenteren met het inbouwen van directe democratische procedures zoals momenteel wordt overwogen. Alleen dan kunnen namelijk de plebiscitaire effecten ervan die we in de Verenigde Staten kunnen waarnemen worden gedempt.

\subsubsection{DEMOCRATISERING VAN DE MULTINATIONALE ONDERNEMING}

Multinationale ondernemingen zijn politieke spelers geworden die op twee borden spelen: het nationale bord (waar van oudsher al werd gespeeld door grote, beursgenoteerde ondernemingen) en het bovennationale (regionale of mondiale) bord. Meer en meer zitten multinationale ondernemingen, zowel individueel als collectief, aan tafel bij de beraadslagingen die door experts en regeringsvertegenwoordigers op multinationaal niveau over risicobepaling, standaardisering, domeinnaamverdeling, handelsstromen, rentestanden etc. worden gevoerd. En ook meer en meer zijn zij erin geslaagd om hun winsten op het bovennationale bord te verzilveren op het nationale bord.

Als gevolg daarvan heeft de relatie van multinationale ondernemingen tot nationale overheden de afgelopen drie decennia radicale wijzigingen ondergaan. Dat blijkt niet alleen uit de sinds de jaren zeventig dalende loonkostenvoet in de particuliere sector, maar kan ook worden afgelezen aan het publieke debat van de laatste twee decennia waarin de belangen van de multinational succesvol zijn geherformuleerd in termen van het publieke belang: wat goed is voor het concurrentievermogen van Philips is goed voor het concurrentievermogen van Nederland, en dat is: lagere belastingen en premies, minder regels en minder werknemersrechten.

Het probleem is echter dat multinationale ondernemingen ondanks het privatistische neoliberale jargon waarmee zij zichzelf beschrijven ('wij zijn a-politieke, monofunctionele organisaties en zijn slechts uit op maximalisatie van de aandeelhouderswaarde') wel degelijk politieke invloed uitoefenen en politieke beslissingen nemen. Door werknemers te ontslaan wentelt de onderneming de verant- 
woordelijkheid voor de kosten van de sociale reproductie van de werknemer en zijn gezin af op de collectieve sector. Door de investering in een nieuw luchtfilter met twee jaar uit te stellen veroorzaakt de onderneming externe milieueffecten die de kwaliteit van het leven van vele omwonenden kunnen schaden. Door eigen aandelen in te kopen redistribueert de onderneming gelden van werknemers naar aandeelhouders. Door zichzelf een pensioenpremievakantie toe te kennen onttrekt de onderneming spaargelden aan toekomstige generaties. Oftewel, vrijwel iedere strategische ondernemingsbeslissing heeft externe effecten en zou om die reden op een of andere wijze democratisch gecontroleerd moeten worden. Hoe?

Het wordt eentonig, maar weer stelt de associatieve democraat zijn hoop op een mix van controlemechanismen. Ook multinationale ondernemingen zijn nog altijd nationaal ingebed. Niet alleen moeten zij ergens fiscaal en juridisch gevestigd zijn, ook de bedrijfscultuur, de samenstelling van de raad van bestuur en raad van commissarissen, de locatie van de holding en de onderzoeks- en ontwikkelingsafdeling zijn veelal nationaal van aard (Ruigrok en Van Tulder 1995; Hirst en Thompson 1999). ${ }^{1}$ De meeste multinationale ondernemingen zijn nationaal verwortelde ondernemingen met activiteiten in meerdere landen. Dat betekent dat zij in principe nog altijd onderworpen zijn aan nationale wetgeving op het gebied van ontslagbescherming, arbeidsomstandigheden, scholing, medezeggenschap, milieurichtlijnen, verantwoordings- en boekhoudregels en vennootschapsbelasting. Wel proberen ondernemingen in toenemende mate staten tegen elkaar uit te spelen in hun poging om het nationale regulerende raamwerk naar de eigen wensen te snijden. Tot voor kort was het dreigement van bedrijfsverplaatsingen echter meer retoriek dan werkelijkheid. Recentelijk lijkt daar met een nieuwe golf van verplaatsingen (vooral naar India) verandering in te komen. Daarbij moet echter worden bedacht dat een lage kostenomgeving veelal ook een lage kwaliteitsomgeving is. Oftewel, met name kwaliteitsproducenten hebben er baat bij om vast te houden aan hoge standaarden op ecologisch en arbeidsrechtelijk vlak (Vogel 1995; Streeck 1997; Thelen en Kume 2003). Met name de Europese Unie (EU) zou een rol kunnen spelen bij het verminderen van de interstatelijke coördinatieproblemen die het opheffen van de ondermijnende effecten van standaardverschillen in de weg staan. Met soft laws en de kennisuitwisseling in het kader van de open method of coordination lijken de lidstaten eerste schreden op deze weg te hebben gezet.

Recente schandalen leren dat het probleem niet alleen op het vlak van de regelgeving ligt maar evenzeer op het vlak van de handhaving. Centrale en supranationale overheden ontberen in het algemeen de 'handen' en 'ogen' die noodzakelijk zijn om naleving te controleren en af te dwingen op de vele locaties waar dat nodig is. Om dat controletekort op te vangen moet een grotere rol worden gegund aan externe actoren als non-gouvernementele organisaties (NGO's), pers, consumenten en institutionele beleggers en aan zowel interne als georganiseerde werknemers. Deels kan dat nationaal worden gefaciliteerd: effectieve controle door georganiseerde werknemers vereist naast geïnstitutionaliseerde medezeg- 
genschapskanalen ook een zekere mate van arbeidsrechtelijke bescherming, terwijl controle door institutionele beleggers een goed ontwikkeld aandeelhoudersparlement vooronderstelt met mogelijkheden om onderwerpen te agenderen, op afstand te stemmen en per belegger een substantieel aandeel te verwerven. Deels zal dat bovennationaal moeten worden georganiseerd.

\subsubsection{DEMOCRATISERING VAN BOVENNATIONALE ORGANISATIES}

Zoals gezegd wordt een groeiend deel van de traditionele coördinerende staatstaken op supranationaal niveau afgehandeld. De EU is daar een uitmuntend voorbeeld van, maar het geldt evenzeer voor zulke betrekkelijk obscure organisaties als de Advisory Committee for Trade Negotiations (ACTN), de Bank for International Settlements (BIS), het Bureau of European Consumer Unions (BECU), de International Accounting Standards Committee (IASC) of de World Association of Nuclear Operators (WANO) (Braithwate and Drahos 2000). En net als in het geval van de EU is de democratische legitimiteit van deze bovennationale organisaties problematisch. Vaak gaat het om technische kwesties die van de deelnemers aan de beraadslagingen een grote mate van deskundigheid vereisen. Het is duidelijk dat dergelijke kwesties niet via de representatieve kanalen aan de kiezer kunnen worden voorgelegd. Politisering brengt namelijk kosten met zich mee. Niet alleen in termen van tragere besluitvorming, maar ook in termen van suboptimale oplossingen (Scharpf 1988). De vraag is dus zowel wanneer wel en niet politiseren als hoe?

Een cruciaal onderscheid in dit verband is dat tussen coördinerende regels en redistributieve regels. Coördinerende regels zijn afspraken op het gebied van technische standaardisatie (ISO-normen, vrachtafspraken, maateenheden, internetnormen etc.). Omdat het hier, in speltheoretische termen, gaat om win-winsituaties, kan dit type regelgeving goed worden overgelaten aan zelfregulering door actoren uit de betreffende sector zelf. Dat geldt niet voor nulsomsituaties, oftewel redistributieve regels. Waar winnaars en verliezers kunnen worden geïdentificeerd is politisering niet alleen op haar plaats maar zal dat naar alle waarschijnlijkheid ook gebeuren (Scharpf 1997: 200).

Empirisch lijkt dat op te gaan. Jarenlang waren de onderhandelingen in het kader van de General Agreements on Tariffs and Trade (GATT) niets meer dan een serie voorbereidende gesprekken over een vrijhandelsregime, die werden gedomineerd door economen en juristen en waar weinig publieke belangstelling voor was. Dat veranderde toen met de totstandkoming van de World Trade Organization (WTO) de voorbereidende fase werd afgesloten en er een uitvoerende fase aanbrak. Plotseling werden de redistributieve effecten van het nieuwe regime zichtbaar en was het met name de anti-globaliseringsbeweging die met een serie spraakmakende protesten de publieke aandacht richtte op de redistributieve effecten ervan.

Het probleem is dat er weinig automatisch is aan dit proces: machtige belanghebbenden zijn veelal uitstekend in staat om redistributieve beslissingen te presente- 
ren als coördinerende. Oftewel, de beslissing of beraadslagingen coördinerend dan wel redistributief van aard zijn is zelf een door en door politieke beslissing. Om die reden zijn tegenmachten nodig die in staat zijn om dominante probleemdefinities te kunnen aanvechten. Deels bestaan deze al. In toenemende mate is sprake van een transnationale 'civil society', bestaande uit NGO's, die een belangrijke rol zou kunnen spelen bij het formeren van tegenmacht. Om algehele politisering te voorkomen zou bij controverse tussen internationale organisatie en NGO over de mate waarin zich redistributie voordoet ofwel kunnen worden gekozen voor arbitrage door de Verenigde Naties (vN) die toch al, via erkenning, een belangrijke rol hebben bij de legitimiteitscontrole van NGO's, ${ }^{2}$ ofwel voor arbitrage door nationale rechters, waarbij echter lastige jurisdictiekwesties opdoemen en het gevaar dreigt van regimewinkelen, dat wil zeggen, kiezen voor behandeling door het minst verplichtende juridische regime.

Zodra blijkt dat het om redistributieve afspraken gaat - zoals bij wTO, het Internationaal Monetair Fonds (IMF), Wereldbank, BIS-voorzieningenafspraken of internationale boekhoudnormen het geval is - is politisering opportuun. Hoe? Er zijn twee voor de hand liggende manieren om dat te doen. De eerste is door nationale vertegenwoordigers zitting te laten nemen in de desbetreffende internationale fora teneinde de eventuele redistributieve effecten in de technocratische beraadslagingen te kunnen laten inbrengen. De tweede is door dezelfde NGO's die zich in eerste instantie hadden opgeworpen als zaakwaarnemers van de verliezers een plaats aan tafel te gunnen teneinde de eventuele redistributieve consequenties in ieder geval te kunnen agenderen.

Uiteraard roept dit de vraag op wie de controleurs controleert. In het eerste geval is dat vrij simpel. Allereerst zijn zij verantwoording verschuldigd aan de regering die hen daar geplaatst heeft, vervolgens aan het parlement en uiteindelijk aan de kiezer. Zo'n getrapte verantwoordingsstructuur werkt alleen bij een goede informatievoorziening en een duidelijk politiek profiel van zowel vertegenwoordiger als kwestie. Maar zoals de greep van het Britse parlement op zijn Europese onderhandelaars leert (zie bijdrage Sie Dhian Ho aan deze Verkenning) is het niet onmogelijk om zoiets te organiseren. In het tweede geval zijn dat allereerst de leden van de NGO. Om ten minste een greintje aan interne democratische controle te garanderen zou de VN als erkenningseis (zie boven) het hebben van een verenigingsstructuur moeten stellen. Daarnaast kan gedacht worden aan de facilitering van vormen van wederzijdse controle die binnen de transnationale 'civil society' de laatste jaren weifelend tot stand zijn gekomen (zie bijdrage Arts aan deze Verkenning). Tegenover koepelorganisaties van NGO's staan koepelorganisaties van multinationale ondernemingen die over en weer de onderbouwing van elkanders claims tegen het licht houden en zo misbruik van machtsposities helpen voorkomen.

In beide gevallen gaat het om controle via het reputatiemechanisme. Op zijn beurt vooronderstelt dat een goed functionerende, kritische en pluriforme sfeer van openbaarheid die niet langer eenzijdig nationaal georiënteerd is. Ten dele 
bestaat zo'n sfeer van openbaarheid reeds. Kranten als de Financial Times, de International Herald Tribune, de Wall Street Journal en tijdschriften als The Economist en de New York Review of Books vinden in toenemende mate verspreiding onder een transnationale elite en kunnen worden gezien als de eerste tekenen van een internationale publieke sfeer in wording. Maar zoals in de titels van de genoemde media reeds doorklinkt ligt de nadruk sterk op financiële en economische berichtgeving en is het met de pluriformiteit van meningen maar matig gesteld. Heel anders ligt dat met de verbreiding van internet. De reeds genoemde anti-globaliseringsbeweging is een typisch transnationale netwerkorganisatie die goeddeels is gebouwd op de virtuele infrastructuur van het internet. Of dit de voorbode van een nieuwe transnationale sfeer van openbaarheid gaat vormen, is echter onzeker. Internet biedt zowel mogelijkheden voor universalisering als voor radicale particularisering.

\subsubsection{DEMOCRATISERING VAN DE EUROPESE UNIE}

In de discussie over het democratische tekort van de EU wordt door voorstanders van verdergaande democratisering nogal eens vergeten dat in hun democratiseringsvoorstellen allerlei institutionele vooronderstellingen doorklinken die onverenigbaar zijn met de feitelijke stand van zaken in het Europese integratiedebat. Het onderscheid volgend dat Sie Dhian Ho in haar bijdrage aan deze Verkenning heeft gemaakt, kunnen grofweg twee posities worden onderscheiden. De eersten (de federalisten, in de termen van Sie Dhian Ho) zien de EU als een nationale (federale) staat writ large, en de tweeden (neofunctionalisten, liberaal-intergouvernementalisten en multi-level governance-aanhangers) zien de EU als een afwijkend bestuurlijk systeem, waarbij men met elkaar van mening verschilt over de aard van die afwijking.

De democratietheoretici die democratie vooral identificeren met een specifiek institutioneel systeem kiezen met pleidooien voor een Europees parlement en een Europees kabinet naar nationaal model als vanzelf voor het federalistische kamp. Het probleem is niet alleen dat men zich daarmee in het Europese integratiedebat tot een nogal idealistische en marginale positie veroordeelt, maar ook dat men miskent dat de opmerkelijke effectiviteit van de EU als beleidsmachine in belangrijke mate te danken is aan de afwezigheid van traditionele vormen van besluitvorming, toezicht en controle. Oftewel, pleidooien voor democratisering van de EU naar nationaal model gaan voorbij aan het feit dat effectieve besluitvorming onder condities van grote diversiteit nu eenmaal een zekere mate van selectiviteit, achterkamertjespolitiek en expertocratie vereist, hoe suspect dat uit democratisch oogpunt ook is (Heritier 1999).

De asymmetrie tussen de relatief grote output-legitimiteit van de EU en haar gelijktijdige geringe input-legitimiteit is volgens de associatieve democraat terecht reden voor zorg, waarmee hij zich distantieert van de neofunctionalistische en liberaal-intergouvernementele theorieën van Europese integratie die in de EU vooral een 'doelgemeenschap' zien en geen 'politieke gemeenschap'. 
Volgens de associatieve democraat is dat - nog afgezien van de vraag of daarmee de EU wel juist gekarakteriseerd is - daarom geen afdoende argument tegen verdergaande Europese democratisering omdat het onderscheid tussen doelgemeenschap en politieke gemeenschap in het licht van de hier gehanteerde definitie van politiek onhoudbaar is. In beide gemeenschappen worden 'politieke' beslissingen genomen die in principe open zouden moeten zijn voor democratische inbreng en controle. Kortom, meer democratie is beter dan minder, ongeacht de aard van de 'gemeenschap'.

Dat wil echter niet zeggen dat de effectiviteit van de besluitvorming dus maar geofferd moet worden op het altaar van de democratisering. In plaats daarvan zou gezocht moeten worden naar vormen van besluitvorming, toezicht en controle die kunnen voorkomen dat de ondoorzichtigheid van het Europese bestuurlijke vlechtwerk te veel ruimte biedt aan particuliere georganiseerde belangen om de besluitvorming te gijzelen. Deze zoektocht zou echter zo veel mogelijk ontdaan moeten worden van allerlei institutionele vooronderstellingen teneinde zo nuchter mogelijk te kunnen onderzoeken welke arrangementen ten minste een minimum aan democratische controle opleveren. Mijn stelling is dat het associatiefdemocratische perspectief bij uitstek geschikt is voor zo'n zoektocht. Zoals boven uiteengezet beschouwt de associatief-democratische traditie democratie namelijk als een set van principes die in beginsel verschillende institutionele vormgeving kunnen krijgen en in beginsel zouden moeten gelden voor ieder besluitend forum, zowel politieke als niet-politieke.

De vormen van controle en toezicht waaraan dan kan worden gedacht zijn vormen van wederkerige controle tussen verschillende vrijwillige associaties die ook al zijn besproken in de vorige subparagraaf, of aan controle door min of meer representatief samengestelde beleidsnetwerken die, zoals in het kader van de open method of coordination, verantwoording verschuldigd zijn aan nationale en supranationale fora (Heritier 1999). Op deze manier kan tenminste zorg worden gedragen voor een minimum aan controle op misbruik zonder dat dit ten koste hoeft te gaan van de beleidseffectiviteit. Hoewel het naïef is om te verwachten dat het Europees Parlement ooit zal kunnen functioneren als wetgevende macht in traditionele zin, ${ }^{3}$ kan het wel degelijk een belangrijke functie krijgen als controleur in laatste instantie. Zoals momenteel al via een zogenaamd call backmechanisme voor Europese regulerende instanties geldt, zou het Europees Parlement vaker besluitvormingsbevoegdheden voorwaardelijk kunnen delegeren aan deskundige beleidsnetwerken om deze weer in te trekken zodra er signalen van misbruik of monopolisering komen. Het voordeel van zo'n mechanisme is dat het reactief is en de beperkte zoek- en controlecapaciteiten van het Europees Parlement dus niet overvraagd.

Het is de vraag of dit ook in de perceptie van de Europese burger veel van de klachten over het democratisch tekort zal wegnemen. Daarnaast zal dus onverdroten moeten worden gewerkt aan de constructie van een Europese publieke sfeer, Europese media, Europees burgerschap en een Europees verenigingsleven. 
Omdat het de EU echter aan dwangmiddelen ontbreekt om Fransen, Nederlanders, Belgen, Slowaken en Polen in Europeanen te transformeren - nationale dienstplicht en nationale leerplicht hebben meer bijgedragen aan de creatie van de nationale eenheidsstaat dan een mythische gedeelde etniciteit! - moet daar niet te veel van worden verwacht. Bovendien is een Europese 'gemeenschap' noch nodig noch wenselijk voor een verhoging van de democratische legitimiteit van de EU. Effectiever lijkt het te zijn om volgens associatief-democratisch recept de natiestaat door voortgaande verplaatsing van politiek en democratisch niveau minder 'vanzelfsprekend' te maken. Wie beseft reeds in een meerlagig bestuurlijk systeem te leven zal minder moeite hebben om het Europese niveau als een op zichzelf functionele en daardoor legitieme extra laag te accepteren. Oftewel, de oplossing voor het probleem van het Europese democratische tekort is meer een kwestie van bijgestelde verwachtingen dan van radicale institutionele vernieuwing.

\subsubsection{COMPLEXITEIT, LEERVERMOGEN EN DEMOCRATIE}

Hoewel ik geneigd ben het 'nieuwe' van de kennissamenleving te bagatelliseren, zal ik er voor het belang van de discussie van uitgaan dat zich inderdaad zoiets als een 'kennissamenleving' ontwikkelt en dat dit een belangrijke uitdaging voor het bestaande democratische stelsel betekent. De redenering loopt dan ongeveer als volgt: inderdaad is het probleem van deskundigheid in een democratische maatschappij een aloud probleem, maar door de toenemende complexiteit van hedendaagse samenlevingen en a fortiori de vraagstukken die zij opwerpen, is dat probleem verscherpt en zijn de oude instrumenten om de toenemende kennisongelijkheden die daarvan het gevolg zijn in afnemende mate in staat om deze te accommoderen.

De stelling is dat de aard van de vereiste kennis is veranderd (naast officiële, theoretische kennis is nu ook informele, belichaamde en contextuele kennis vereist); dat de aard van de problemen is veranderd (in plaats van redistributieve kwesties zijn in toenemende mate coördinatiekwesties gekomen); dat de aard van de effecten is veranderd (als gevolg van toenemende interdependentie zijn oorzaken nimmer enkelvoudig maar altijd meervoudig, wat eveneens meervoudige effecten tot gevolg heeft en beleidsmakers noopt tot grotere gevoeligheid voor negatieve en positieve neveneffecten); tot slot is de aard van de arena veranderd (in plaats van een enkelvoudig interventiecentrum zijn vele arena's gekomen die op velerlei wijzen interfereren).

In zekere zin wordt hier in kennissociologische termen hernomen wat boven in bestuurssociologische termen als de 'verplaatsing van de politiek' is besproken. Meer concreet gaat het hier om nieuwe kwesties en nieuwe risico's die oude definities, grenzen en afbakeningen overschrijden en derhalve om nieuwe vormen van expertise en professionaliteit vragen en die een grotere nadruk leggen op coördinatie. Epidemieën als sars, aids, de vogelpest, mond- en klauwzeer en de gekke-koeienziekte zijn uitmuntende voorbeelden van dit soort grensoverschrij- 
dende kwesties, maar hetzelfde geldt voor dalende beurskoersen in New York en Londen die via pensioenbeleggingen de vermogensposities van Nederlandse ondernemingen en overheden aantasten. In beide gevallen gaat het om complexe verschijnselen die meerdere beleidsterreinen bestrijken en voor hun 'oplossing' zijn aangewezen op verschillende soorten competenties die elkaar in 'normale' toestand nimmer ontmoeten. De vraag is dan hoe de flexibiliteit en het leervermogen dat dit van instituties, organisaties en individuen organiseren en deze vervolgens controleerbaar te maken.

De Amerikaanse socioloog Sabel stelt in zijn bijdrage aan deze Verkenning al zijn vertrouwen in het creëren van netwerkachtige organisaties die een geringe institutionele diepgang kennen en derhalve snel en adequaat kunnen reageren op veranderende omstandigheden. Onder condities van continue verandering die volgens Sabel kenmerkend zijn voor onze tijd leidt iedere vorm van institutionalisering tot vertraging en is zij daarom uit den boze. Zo bezien is het associatiefdemocratische antwoord op complexiteit, namelijk verplaatsing van bestuur, politiek en democratie, op zichzelf onvoldoende. Zolang deze verplaatsing loopt langs bekende territoriale grenzen en functionele afbakeningen is in Sabels optiek immers weinig gewonnen. Aan de andere kant gaat Sabels oplossing bijna apolitiek voorbij aan het feit dat onder condities van sociaal-economische ongelijkheid experimenteerruimtes gegijzeld kunnen worden door goedgeorganiseerde belangen die daar slechts met grote moeite weer uit te verdrijven zijn. Enige democratische controle ook binnen deze experimentele settings lijkt dus gewenst. Het probleem is echter dat controle structuur en stabiliteit vooronderstelt en dus enige mate van institutionalisering. Oftewel, ik erken dat de associatief-democratische traditie een extra stap zal moeten zetten om Sabels inzichten te verdisconteren, maar ben tezelfdertijd van mening dat Sabel zelf een controleprobleem heeft op te lossen.

Om een tipje van de sluier op te lichten hoe beide eisen met elkaar gecombineerd zouden kunnen worden, het volgende. Zinvol is volgens mij - weer - het beproefde onderscheid tussen redistributieve kwesties en coördinatiekwesties. De laatste hebben geen zware vormen van politieke controle nodig; alleen de eerste vereisen dat. Organisaties zouden derhalve moeten kunnen beschikken over de mogelijkheid om tijdelijke 'miniconstituties' in te stellen voor nieuwe prangende kwesties die onder een verlicht controlerend regime vallen (Unger 1987). De toestemming om dat te doen is afkomstig van het controlerende politieke orgaan binnen de desbetreffende organisatie (raad van toezicht, aandeelhoudersvergadering of medezeggenschapsraad) en is altijd voorwaardelijk; als blijkt dat het coördinatiespel duidelijke redistributieve consequenties heeft wordt de miniconstitutie ingetrokken en vallen de desbetreffende actoren weer onder het reguliere controlerende regime. In zekere zin is dit de organisationele pendant van het call back-mechanisme dat boven in het kader van het democratisch tekort van de EU werd besproken. Daarnaast zouden nationale parlementen, regioraden en gemeenteraden meer moeten gaan fungeren als scheidsrechter in laatste instantie waar burgers terecht kunnen als de huns inziens onterechte 
depolitisering van redistributieve kwesties niet via de zojuist geschetste organisatie-interne mechanismen aan de kaak kan worden gesteld. En weer geldt dat dit reactieve gebruik van de bestaande representatieve instituties als voordeel heeft dat het de beperkte vermogens van deze instituties niet overvraagt.

\subsection{LASTIGE KWESTIES}

Grofweg komen diagnose en therapie van de associatieve democratie erop neer dat er niet te veel politiek is verplaatst maar juist te weinig; dat verplaatste politiek moet worden aangevuld met verplaatste democratie; dat soevereiniteit actief moet worden verspreid; en dat de incidentenlogica van pers, rechter en, in toenemende mate, de politieke controle door het parlement niet moet worden tegengegaan maar juist moet worden geradicaliseerd. Gegeven de beperkte cognitieve en interveniërende mogelijkheden van het nationale democratische centrum in het posthiërarchische tijdperk moet het parlement worden omgevormd tot een nationale (en, in het geval van de EU, een supranationale) ombudsman die de klachten weegt, de mogelijke oplossingen inventariseert en de implementatie ervan actief volgt. Niets meer maar ook zeker niets minder. Dat hoeft daarom geen minimale democratie te zijn, omdat in een associatief-democratisch regime burgers elders naar hartelust hun democratische aandriften kunnen (niet hoeven!) botvieren. Zo bezien lijkt associatieve democratisering uitstekend aan te sluiten bij een groot aantal ontwikkelingen die in deze Verkenning ietwat zorgelijk als 'uitdagingen' aan de democratie zijn voorgesteld. Hoe zeitgemä $\beta$ is $\mathrm{zij}$ ?

Hieronder wil ik ingaan op twee fundamentele bedenkingen die tegen het medebestuur door vrijwillige associaties kunnen worden ingebracht. Dat zijn ten eerste haar elitaire en ten tweede haar corporatistische 'boventonen'.

\subsubsection{ELITAIR OF NIET?}

Vaak kan de empirische observatie worden gedaan dat uitbreiding van de participatiemogelijkheden voor burgers gepaard gaat met een toename van de participatielust van juist die burgers die toch al participeerden en niet met een toestroom van voorheen niet-participerende burgers. Ook dit is geen nieuw fenomeen maar lijkt inherent aan een representatief democratisch stelsel. Gebaseerd als zo'n stelsel is op het principe van arbeidsdeling probeert het verschillen in tijd, motivatie en kennis te accommoderen. Representatieve democratische stelsels bieden die burgers toegang tot de hoogste participatietreden - actief partijlidmaatschap en zitting nemen in vertegenwoordigende lichamen - die over bestuurlijke expertise en democratische vaardigheden beschikken, die daar voldoende satisfactie aan ontlenen en die daar voldoende tijd voor willen reserveren. Onder condities van sociaal-economische gelijkheid kan worden verondersteld dat de keuze om al dan niet politiek te participeren een vrijwillige is. Onder de meer realistische condities van structurele sociaal-economische ongelijkheden is die veronderstelling echter misplaatst; met geld kan immers zowel toegang tot kennis als 
tot participatiemogelijkheden worden gekocht, terwijl ook de wil om te participeren via socialisatiemechanismen een sociaal-economische component heeft.

Vanuit het oogpunt van politieke gelijkheid is dit moreel problematisch. Er bestaat dan ook een sterke politieke onderstroom om te komen tot meer gelijke participatiemogelijkheden. Conform het voorgaande richt dit politieke gelijkheidsprogramma zich ofwel op kennisverschillen, ofwel op capaciteitsverschillen, ofwel op motivatieverschillen. Experimenten met interactief bestuur in Nederlandse gemeenten, bijvoorbeeld, proberen via expertbijeenkomsten de kennistekorten van betrokken burgers te bestrijden, proberen via internet de democratische participatie zo veel mogelijk te voegen naar het drukbezette leven van burgers, en proberen via feestavonden en andere gezelligheidsbevorderende activiteiten de motivatie van burgers te vergroten. Bovendien wordt gehoopt dat van de participatieactiviteit zelf een motivatieveranderend effect uitgaat; wie eens de smaak van effectieve democratische participatie heeft geproefd wil nooit meer anders! Daarbij blijken verschillen in kennis en participatiemogelijkheden makkelijker te beïnvloeden dan motivatieverschillen. Alleen via een participatieplicht zijn de effecten ervan voor het participatiegedrag weg te nemen. Anders dan in het modieuze neo-republikeinse vertoog houdt de associatief-democratische traditie politieke participatie echter niet voor het hoogste goed en ziet zij participatieverplichtingen derhalve als onacceptabele inbreuken op de individuele vrijheid.

Dit gezegd zijnde is de belangrijkste vraag of verplaatsing van bestuur, politiek en democratie (als de associatieve democraat zijn zin krijgt) inderdaad leidt tot toenemende participatieverschillen en als dat zo is, hoe desalniettemin politieke gelijkheid kan worden gewaarborgd. Ten aanzien van het eerste lijkt inderdaad sprake van een verdere toename van een ongelijke verdeling van daadwerkelijke participatie. De nieuwe locaties van democratie worden net als de oude vooral bezet en gefrequenteerd door 'witte' hooggeschoolde tweeverdieners. Wat dat betreft is duidelijk sprake van een Mattheüseffect: hij die heeft zal gegeven worden. Omdat niet-participeren maar zeer ten dele kan worden beschouwd als een vrijwillige keuze, fungeren de participanten de facto als zaakwaarnemers van een electoraat dat minder hooggeschoold is, in toenemende mate 'zwart' en lager op de sociaal-economische ladder staat. Dat leidt niet alleen tot afwendgedrag en rancune, maar ondermijnt op de lange duur ook de legitimiteit van de democratische instituties zelf.

De vraag is dan hoe formele politieke gelijkheid materieel vorm te geven zonder vrijheidsberovende participatieplichten. Het belangrijkste antwoord van de associatief-democratische traditie op deze prangende vraag is de fragmentering van de polity. Door de pluralisering van democratische fora die associatieve democratisering impliceert, zijn de kansen voor groepen burgers om hun belangen en wensen ten gehore te brengen veel groter dan in het bestaande politieke bestel het geval is. Als zodanig biedt associatieve democratisering dan ook betere garanties 
tegen structurele politieke uitsluiting, wat uiteraard een belangrijke dimensie is van het democratische principe van politieke gelijkheid.

Een tweede middel is gelegen in de associatief-democratische nadruk op zelforganisatie. Meer dan andere democratietheorieën besteedt zij aandacht aan de voorwaarden voor de organisatie van belangen en zorgt zij voor effectieve facilitering van het organisatieproces. Als zodanig kan ook makkelijker worden gegarandeerd dat 'zaakwaarnemers' representatief zijn en (getrapt) verantwoording afleggen aan hun achterban. Politieke gelijkheid wil immers niet zeggen dat iedereen in gelijke mate meebeslist over dezelfde onderwerpen maar wel dat iedereen in beginsel in staat is diegenen die voor hen beslissen te corrigeren.

Het derde instrument is door ondervertegenwoordigde belangengroepen actief uit te nodigen om zitting te nemen in relevante fora via bijvoorbeeld geoormerkte zetels of gemanipuleerde kiesdistricten. Daarbij moet wel in het achterhoofd worden gehouden dat een hoge mate van inclusiviteit negatieve neveneffecten heeft in termen van afnemende effectiviteit van de besluitvorming. Er zal dus goed moeten worden nagedacht over de vraag wanneer wel en wanneer niet (Engelen 2004).

\subsubsection{CORPORATISME OF NIET?}

Zowel Cohen en Rogers, als Hirst en schrijver dezes is verweten dat wat zij verstaan onder associatieve democratie eigenlijk neerkomt op doodordinaire (neo)corporatisering, hetgeen uitdrukkelijk pejoratief is bedoeld. In het bijzonder gaan de bedenkingen uit naar de mate waarin associatieve democratie in staat zou zijn andere dan 'natuurlijke' klassenbelangen een plaats te geven in het bestuurlijke model, oligarchisering te voorkomen, en belangengroepsegoïsme tegen te gaan.

Het klassieke corporatisme was gebaseerd op zelfbestuur of medebestuur door a priori gegeven belangengroepen. Tijdens de hoogtijdagen van het neocorporatisme - de jaren vijftig en zestig - waren dat vooral de belangen van de kapitalistische klasse van eigenaars van de productiemiddelen en die van de onderdrukte klasse van werknemers. Veel arrangementen en instituties uit die decennia redistributieve verzorgingsarrangementen, tripartiete adviesraden en ondernemingsraden - weerspiegelen dat. Met de verburgerlijking van de arbeider en de proletarisering van de kapitaalbezitter als gevolg van de verspreiding van het aandelenbezit (o.a. door pensioenfondsen en beleggingsfondsen) zijn deze categorieën langzaam verwaterd. Tezelfdertijd zijn als gevolg van migratie, de seksuele bevrijding en de emancipatie van de vrouw nieuwe scheidslijnen zichtbaar geworden die zich maar lastig laten accommoderen door de corporatistische instituties en arrangementen van weleer. Pregnant zichtbaar wordt dat in de onderrepresentatie van vrouwen en migranten in klassieke corporatistische organisaties als vakbonden en instituten als ondernemingsraden. Als gevolg daarvan is de legitimiteit van zowel de bezetters van deze corporatistische posities als van 
de posities zelf in toenemende mate kwestieus geworden. Leidt bestuurlijke devolutie naar vrijwillige associaties omwille van functioneel bestuur niet altijd tot gijzeling van de bijbehorende prerogatieven door een egoïstische en disfunctionele oligarchie die zich daar niet dan met de grootste moeite weer van laat verdrijven (Olson 1965)?

Boven heb ik betoogd dat de associatief-democratische traditie het kunstmatige karakter van georganiseerde belangen benadrukt en daarin sterk verschilt van in ieder geval de conservatieve, fascistische en christen-democratische varianten van het corporatisme. Via subsidies, publieke erkenning, geoormerkte zetels en, meer algemeen, de devolutie van publieke bevoegdheden en bijbehorende middelen aan lagere functionele organen creëert de associatieve staat constant kristallisatiepunten waaromheen belangengroepen zich kunnen scharen. Dat laat evenwel onverlet dat deze maakbaarheid niet absoluut is. Er moet eerst noise zijn alvorens er een georganiseerde voice ten gehore kan worden gebracht (Offe 1995). Oftewel, ook in een associatief-democratische setting die actief middelen ter beschikking stelt voor de constructie van een georganiseerde stem moeten er minimumdrempels overschreden worden om daarvoor in aanmerking te komen. Daarbij kan worden gedacht aan soortgelijke drempels als momenteel in het Nederlandse electorale systeem zijn ingebouwd, maar dan ook in niet-politieke velden, lagere territoriale niveaus en beheerd door niet-statelijke organen.

De keerzijde van entry is uiteraard exit. Een deel van de vooral Angelsaksische kritiek op het neocorporatisme betreft de veronderstelling dat een stelsel van gedeelde soevereiniteit welgeorganiseerde belangengroepen de gelegenheid biedt om collectieve middelen ten eigen bate aan te wenden. Hoe functioneel gedeeld bestuur in eerste instantie ook mag lijken, na verloop van tijd mondt het onherroepelijk uit in een collectieve zwendelpraktijk (Olson 1965). Hoewel geformuleerd tegen de achtergrond van het ideaalbeeld van gelijke individuele politieke invloed en als zodanig geen doorslaggevend argument tegen (neo)corporatistische stelsels, is het evident dat reëel bestaande corporatistische arrangementen niet altijd uitblinken in aanpassingsvermogen. ${ }^{4}$ Zoals niet iedere vorm van ongenoegen (noise) meteen toegang kan krijgen tot geformaliseerde collectieve besluitvorming, zo moeten gevestigde belangen periodiek hun representativiteit kunnen aantonen om hun publieke erkenning te kunnen behouden. Uiteraard kunnen deze periodieke toetsingen op verschillende manieren worden georganiseerd. Zij kunnen bijvoorbeeld lopen via de band van het parlement in de vorm van het eerdergenoemde call back-mechanisme, de rechter zou hier een rol in kunnen krijgen, raden van deskundigen analoog aan het Nederlandse systeem van de kunstraden zouden periodiek over het lot van publiekelijk erkende associaties kunnen beslissen, maar ook zou gedacht kunnen worden aan een vouchersysteem dat burgers de bevoegdheid geeft om publieke middelen tijdens periodieke verkiezingen te redistribueren over een aantal erkende associaties. Het voordeel van dat laatste mechanisme is niet alleen zijn inhoudelijke neutraliteit en zijn direct democratische karakter, maar ook de voorwaardelijkheid die aan de erkenning is verbonden en die de mogelijkheid biedt om eisen ten aanzien van de 
interne democratie van de associatie ook daadwerkelijk af te dwingen (Schmitter 1995; zie ook Hirst 1994).

Resumerend kunnen we concluderen dat associatieve democratisering niet hetzelfde is als corporatisering omdat zij niet uitgaat van voorgegeven belangen waaromheen de gedeelde 'politieke ruimte' zou moeten worden geplooid, maar juist van het geconstrueerde, kunstmatige karakter van belangen en hun organisaties, wat meer mogelijkheden biedt om de mate van inclusiviteit en representativiteit van associaties 'politiek' te sturen. Dat laat evenwel onverlet dat dit pas een afdoende tegenargument tegen het corporatisme-verwijt is wanneer er effectieve institutionele mechanismen voor entry en exit zijn geïnstalleerd. Ik heb er hier drie besproken en heb de voorkeur gegeven aan een politieke markt voor associaties via een voucher-systeem, maar het is duidelijk dat meer werk van de associatieve democraat noodzakelijk is om deze schets overtuigend te maken.

Eveneens kunnen we concluderen dat associatieve democratie geen oligarchisering in de hand hoeft te werken. In feite mondt ieder representatief democratisch stelsel in meer of mindere mate uit in oligarchisering. Dat is inherent aan de ongelijkheden in kennis, mogelijkheden en motivatie waarop het principe van democratische arbeidsdeling is gebaseerd. Cruciaal is uiteraard de kwalificatie 'in meer of mindere mate'. Vanuit het oogpunt van politieke gelijkheid is minder oligarchisering te prefereren boven meer. Ook hebben we geconstateerd dat politieke ongelijkheden die voortvloeien uit vrije keuze minder kwalijk zijn dan ongelijkheden die voortvloeien uit omstandigheden (Dworkin 1981). Dit betekent dat politieke gelijkheid in bovenbedoelde zin een zekere mate van sociaaleconomische achtergrond gelijkheid vooronderstelt. Onder condities van globalisering die de dreigkracht van de factor kapitaal vis-à-vis de factor arbeid hebben vergroot, is deze voorwaarde in afnemende mate vervuld. Zoals we hebben gezien zijn de klassieke instrumenten van economische politiek niet langer bij machte om deze ontwikkelingen te weerstaan. Om die reden is de sociale en economische democratisering die door de associatieve democraat wordt voorgestaan wellicht een probater middel om de sociaal-economische voorwaarden voor een vitale democratische orde te creëren. 


\section{NOTEN}

1 Dat is precies de reden waarom ik hier van 'multinationale onderneming' spreek en niet van 'transnationale', zoals Arts in zijn bijdrage aan deze Verkenning doet.

2 Zie de bijdrage van Arts aan deze Verkenning voor een beschrijving van de erkenningsprocedure van NGO's door de vN.

3 Wat evenzeer geldt voor nationale parlementen; ook die zijn de laatste decennia meer en meer verworden tot gebrekkige controleurs achteraf.

4 Maar zie Visser en Hemerijck (1997) voor een overtuigend tegenvoorbeeld. 


\section{LITERATUUR}

Bader, V. (2001) 'Problems and Prospects of Associative Democracy. Cohen and Rogers Revisited': 31-70 in P. Hirst en V. Bader (red.) Associative Democracy. The Real Third Way, London: Frank Cass.

Braithwaite, J. en P. Drahos (200o) Global Business Regulation, Cambridge: Cambridge University Press.

Cohen, J. en J. Rogers (1995) 'Secondary Associations and Democratic Governance’: 7-100 in E.O. Wright (red.) Associations \& Democracy, London: Verso.

Crouch, C. (1993) Industrial Relations and European State Traditions, Oxford: Oxford University Press.

Deleeck, H. (2001) De Architectuur van de Welvaartsstaat opnieuw Bekeken, Leuven: Acco.

Dworkin, R. (1981) 'What Is Equality? Part 2: Equality of Resources', Philosophy $\mathbb{Z}$ Public Affairs 10, 3/4: 283-45.

Engelen, E. (2004) 'Problems of Descriptive Representation in Dutch Works Councils', Political Studies 52, 3 (te verschijnen).

Esping-Andersen, G. (met D. Gallie, A. Hemerijck en J. Myles) (2002) Why We Need a New Welfare State, Oxford: Oxford University Press.

Heritier, A. (1999) Policy Making and Diversity in Europe, Cambridge: Cambridge University Press.

Hirschman, A.O. (1995) A Propensity to Self-Subversion, Cambridge: Harvard University Press.

Hirst, P. (1994) Associative Democracy. New Forms of Social and Economic Governance, Oxford: Polity Press.

Hirst, P. en G. Thompson (1999) Globalization in Question. The International Economy and the Possibilities of Governance, Oxford: Polity Press.

Laswell, H.D. (1936) Politics. Who Gets What, When, How, New York: Smith.

Majone, G. (1990) Deregulation or Re-Regulation? Regulatory Reform in Europe and the United States, London: Pinter.

Offe, C. (1995) 'Some Skeptical Considerations on the Malleability of Representative Institutions': 114-132 in E.O. Wright (red.) Associations and Democracy, London: Verso.

Olson, M. (1965) The Logic of Collective Action. Public Goods and the Theory of Groups, Cambridge: Harvard University Press.

Owens, E. (2002) 'Taking the "Public" out of Our Schools: The Political, Constitutional, and Civic Implications of Private School Vouchers', A journal of church and state 44, 4: 717-48.

Ruigrok, W. en R. van Tulder (1995) The Logic of International Restructuring, London: Routledge.

Scharpf, F. (1970) Demokratietheorie zwischen Utopie und Anpassung, Konstanz: Universitätsverlag.

Scharpf, F. (1988) ‘The Joint-Decision Trap', Public Administration Review 66, 3: 239-78.

Scharpf, F. (1997) Games Real Actors Play. Actor-Centered Institutionalism in Policy Research, New York: Westview Press. 
Schmitter, P. (1995) 'The Irony of Modern Democracy and the Viability of Efforts to Reform Its Practice': 167-183 in E.O. Wright (red.) Associations and Democracy, London: Verso.

Streeck, W. (1997) 'Beneficial Constraints. On the Economic Limits of Rational Voluntarism': 197-219 in J.R. Hollingsworth and R. Boyer (eds.) Contemporary Capitalism. The Embeddedness of Institutions, Cambridge: Cambridge University Press.

Thelen, K. en I. Kume (2003) 'The Future of Nationally Embedded Capitalism. Industrial Relations in Germany and Japan’: 183-211 in K. Yamamura en W. Streeck (red.) The End of Diversity? Prospects for German and Japanese Capitalism, Ithaca: Cornell University Press.

Unger, R. (1987) False Necessity. Anti-Necessitarian Social Theory in the Service of Empowered Democracy, Cambridge, CA: Cambridge University Press.

Visser, J. en A. Hemerijck (1997) 'A Dutch Miracle'. Job Growth, Welfare Reform, and Corporatism in the Netherlands, Amsterdam: Amsterdam University Press.

Vogel, D. (1995) Trading Up : Consumer and Environmental Regulation in a Global Economy, Cambridge, Mass: Harvard University Press. 


\title{
15 PROBLEMEN VAN REPRESENTATIEVE DEMOCRATIE
}

\author{
B. Tromp
}

\section{1 'DIRECTE' DEMOCRATIE}

Een ruwe omschrijving van 'democratie' luidt dat deze een vorm van meningsen besluitvorming is waaraan alle betrokkenen op gelijke basis deelnemen. Wie zijn dan de betrokkenen? Het antwoord: diegenen van een samenlevingsverband die daartoe door die gemeenschap zijn gerechtigd, of, om het minder vriendelijk te zeggen, over de macht beschikken om zich dat recht toe te eigenen, waarbij als criterium meestal vooral geslacht en leeftijd gelden. In deze zin kenden menselijke gemeenschappen een oorspronkelijke democratie, waarin in het algemeen volwassen mannen van zo'n gemeenschap als ‘betrokkenen’ golden. Maar bij sommige Noord-Amerikaanse indianenstammen telden ook volwassen vrouwen als zodanig (vgl. Stavrianos 1992). Zulke menselijke gemeenschapen, gebaseerd op verwantschapsrelaties en van een mede daardoor beperkte grootte, vormden tienduizenden jaren de enige vorm van sociale organisatie.

Om verschillende redenen, waarvan bevolkingstoename en als gevolg daarvan schaalvergroting, waarschijnlijk de belangrijkste zijn geweest, bleken deze primitieve vormen van democratie niet houdbaar bij de vorming van vroege 'staten' en wereldrijken (Diamond 1997: 265 e.v.). Integendeel, deze maakten juist een eind aan deze oorspronkelijke vormen van democratie (Mann 1986: 39-40). Vanaf het zesde millennium voor Christus werden wereldrijken de dominante vorm van sociaal-politieke organisatie. Een wereldrijk kan ruwweg omschreven worden als een sociaal-politieke eenheid van grote omvang die geheel op zichzelf staat en een politiek centrum heeft dat zichzelf in stand kan houden door de kosten ervan af te wentelen op de bevolking van het rijk. In een wereldrijk is 'democratie' daarom onmogelijk. Een wereldrijk is één van de twee verschijningsvormen van wat Immanuel Wallerstein 'wereldsystemen' heeft genoemd (Wallerstein 1974). De andere is een wereldeconomie, die nu juist geen politiek centrum kent, maar een aantal met elkaar concurrerende politieke eenheden. Zo'n wereldeconomie vormde het wereldsysteem van de klassieke oudheid in het bekken van de Middellandse Zee in het eerste millennium voor Christus. Dit wereldsysteem telde enkele honderden stadstaten tot het in de tweede eeuw voor Christus getransformeerd werd in een wereldrijk door de meest roofzuchtige en succesvolle stadstaat, de Romeinse Republiek.

In een aantal van deze stadstaten functioneerde langere of kortere tijd een politiek bestel dat nu (maar niet toen) als 'democratie' bekend staat. Deze democratie is beschreven door Aristoteles van Stagyra. In zijn categorisering van politieke regimes maakt hij een onderscheid tussen drie vormen, waarna hij van elke vorm een 'goede' en een 'slechte' variëteit benoemt. Er zijn eenmans-, meermans- en allemansregimes, die hij vervolgens onderscheidt naar het criterium in het belang 
van wie de politieke macht wordt uitgeoefend. Dit kan zijn in het belang van de machthebber(s) dan wel in het belang van de politieke gemeenschap. Aldus construeert hij zijn fameuze indeling: tirannie-monarchie; oligarchie-aristocratie; en democratie-politè.

'Democratie' is bij hem dus de perverse vorm van het allemansregime. Iedereen neemt deel aan de macht, maar elkeen doet dit ten bate van zijn particulier belang. Anders dan in een politè waar het publieke belang voor alle deelnemers aan de menings- en besluitvormingsprocessen in de stadstaat voorop stond (Aristoteles 1988; Mulgan 1987). Geen wonder dat het begrip 'democratie' een negatieve connotatie behield zolang het met de geschiedenis van de stadstaten van de Antieke Wereld werd geassocieerd (vgl. Macpherson 1966: 1). Zie bijvoorbeeld de vertaling in het Engels van Thucydides' geschiedenis van De Peloponnesische Oorlog door Thomas Hobbes. Aan de vooravond van de zich toen al aftekenende conflicten tussen koning en parlement publiceerde de ogenschijnlijk wereldvreemde huisleraar van de hertog van Cavendish deze als een waarschuwing aan tijdgenoten voor de 'democratie' die Athene had vernietigd.

Beide vormen van Aristoteles' allemansregimes worden nu gelijkelijk beschouwd als voorbeeld van 'directe democratie'. Degenen die deel uitmaakten van de politieke gemeenschap waren ook zij die bindende besluiten namen, verzameld in de volksvergadering. Vrouwen, slaven en niet in Athene geboren mannen konden daar geen deel van uitmaken in de beroemdste van de democratische stadstaten. De volksvergadering was het hoogste besluitvormingsorgaan, maar daarnaast bestonden verschillende uitvoerende functionele instituties, variërend van ambten op het terrein van rechtspraak en administratie tot de legerleiding. Zo was Thucydides ooit strateeg van de Atheense legers, tot hij na een nederlaag door het schervengericht werd verbannen - een straf waaraan wij De Peloponnesische Oorlog te danken hebben. Deze ambten werden voor het merendeel vervuld op basis van loting, zodat elk lid van de politieke gemeenschap de kans kreeg voor een tijd deel uit te maken van het bestuur. Verkiezing was volgens deze opvatting van democratie geen democratisch maar een aristocratisch mechanisme. Het veronderstelt immers dat sommigen meer geschikt zijn om politieke macht uit oefenen dan anderen en vloekt zo met het uitgangspunt van een demos van gelijken en gelijkgerechtigden.

De tweede periode van directe democratie is die van de republikeinse regimes van Europese stadstaten in de Middeleeuwen. Ook hier gold dat de grenzen van deze 'directe democratie' uiteindelijk bepaald werden door de omvang van de demos. De Republiek Florence in de vijftiende eeuw kan als voorbeeld dienst doen. Van een bevolking van ruim 40.0oo konden alle volwassen mannen, uitgezonderd de geestelijke stand, deelnemen aan een Parlamento, een uitzonderlijke bijeenkomst, waarbij het stadsbestuur, de Signoria, zijn bevoegdheden aan deze vergadering overdroeg met de opdracht een Balia, een noodbestuur met algemene volmacht te kiezen om een binnen- of buitenlandse crisis te boven te komen. De eigenlijke demos van de Republiek bestond uit diegenen die op basis 
van hun status in aanmerking kwamen voor bestuurlijke functies. Dat waren in deze tijd tussen de 5.00o en 6.0oo volwassen mannen. Bestuurlijke functies, het lidmaatschap van de vele commissies waarin dit werd uitgeoefend, werden toegewezen door het lot. De zittingsduur van deze staatsorganen varieerde in het algemeen van twee tot vier maanden. Waar het aantal functies 1.650 bedroeg, resulteerde dit systeem erin dat jaarlijks meer dan 3.000 posten vacant kwamen en opnieuw bezet moesten worden. Iedereen die tot de demos in de bovenomschreven betekenis behoorde, had dus een grote kans tijdens zijn leven een veelheid van bestuurlijke functies te vervullen (Hale 1986: 15-20). Dat dit stelsel al snel de vorm van een façaderepubliek aannam (vgl. Martines 2003), hoeft ons hier niet bezig te houden. Het gaat erom duidelijk te maken hoe 'directe democratie' daadwerkelijk gestalte kreeg in twee historisch specifieke contexten, met als voornaamste beperkende factor de omvang van de demos. De laatste grote verdediger van deze vorm van democratie, Jean-Jacques Rousseau, stelde als noodzakelijke voorwaarde dat deze een zeer kleine staat betreft, waar alle burgers gemakkelijk samen kunnen komen en elke burger zonder veel moeite elke andere burger kent (Rousseau 1973: 240), maar ook latere theoretici van directe democratie in een andere context zoals Michail Bakoenin, zagen zeer goed onder ogen dat zo'n democratie gebonden was aan een beperkte schaalgrootte als het om de demos ging (Carr 1961).

'Directe democratie' is een neologisme, want de oorspronkelijke begripsinhoud van 'democratie' was dat leden van een demos zichzelf bestuurden. De centrale slotsom die de geschiedenis oplevert is dat democratie in deze zin alleen maar mogelijk is in politieke gemeenschappen die niet meer dan enkele duizenden leden tellen. Deze conclusie wordt bevestigd door hedendaagse voortzettingen van zulke democratie, zoals kantonale bijeenkomsten in Zwitserland of town meetings in kleine steden in Nieuw Engeland, voorzetting van een traditie die tot de zeventiende eeuw teruggaat. Zelfs in dergelijke politieke gemeenschappen (met minder dan 4.500 inwoners) neemt gemiddeld maar 19 procent deel aan zo'n bijeenkomst, en een nog veel lager neemt daadwerkelijk het woord (Dahl 1998: 110-111).

De verwachting dat nieuwe informatie- en communicatietechnieken aan deze beperking in de omvang van een politieke gemeenschap nodig voor directe democratie iets wezenlijks veranderen, is theoretisch niet overtuigend te argumenteren. De beperking van tijd staat immers los van de wijze van communicatie. Een toespraak houden op een agora, een artikel schrijven voor een opiniepagina of een stelling betrekken op een website, dat verschilt in wezen niet van elkaar, ook al verschilt het zo te bereiken publiek enorm in omvang. Maar als het gaat om reactie en interactie gelden min of meer dezelfde beperkingen in schaal. Het is zelfs eenvoudiger om een debat op één plaats rechtstreeks te voeren dan dit te laten verlopen langs schriftelijke of elektronische media. Een 'elektronisch Athene' is niet zozeer een utopie als wel een fata morgana (vgl. Voerman 1994). 
Ik stel daarom voor in het belang van intellectuele en politieke helderheid het begrip 'directe democratie' serieus en dus letterlijk te nemen. Van directe democratie is alleen sprake als bestuurders en bestuurden in beginsel identiek zijn. Als tegenwoordig van 'directe' democratie wordt gesproken, ook in dit WRR-project, gaat het om iets heel anders, namelijk om een bijzondere (en volgens schrijver dezes zelfs een perverse) vorm van vertegenwoordigende democratie (Tromp 2002b).

'Associatieve democratie' is evenmin als de 'directe democratie' zoals dit tegenwoordig foutief wordt gebruikt, een alternatief voor de oorspronkelijke democratie in een situatie waarin de schaalbeperkingen die daarvoor gelden niet van toepassing zijn. Men kan deze opvatten als een moderne variant van Cole's 'gildesocialisme', waarbij allerlei publieke en semi-publieke instanties hun beleid op democratische wijze bepalen. Zoals Engelen in zijn bijdrage aan deze bundel terecht noteert: het gaat hier niet om een alternatief van de bestaande instituties van representatieve democratie, maar om een aanvulling daarop.

'Deliberatieve democratie' vormt ook geen alternatief voor klassieke democratie in een grootschalige context. Het bouwt voort op de traditie van het politieke liberalisme, volgens welke besluitvorming plaats dient te vinden op basis van de uitwisseling van argumenten (en niet op basis van van tevoren ingenomen standpunten). Vanuit het perspectief hoe politieke democratie gestalte kan krijgen als het gaat om een demos die de maximale omvang geschikt voor klassieke democratie overschrijdt, stuit deze opvatting op het probleem dat zo'n debat niet mogelijk is als het gaat om meer dan een beperkt aantal deelnemers. Dat kunnen gekozenen zijn, maar dan gaat het om een modaliteit van representatieve democratie, niet om een alternatief daarvan. De tweede kanttekening is dat alleen in uitzonderlijke gevallen een uitkomst resulteert die voor iedereen bevredigend is, of tenminste aanvaardbaar. Het Indonesische moesjawara-systeem, waarbij de betrokken partijen doordiscussiëren tot zo'n uitkomst is bereikt, is wel als een model in dit opzicht voorgesteld, maar afgaande op de praktijk, niet overtuigend. Uiteindelijk stuit ook de deliberatieve democratie op Hobbes' quis judicabit - wie beslist. Ook herrschaftsfreie Kommunikation vereist uiteindelijk besluitvormingsregels, waarbij in een democratie de meerderheid de doorslag geeft. 'Directe', associatieve en deliberatieve vormen van democratie zijn waardevolle aanvullingen op een politiek stelsel gebaseerd op representatieve democratie, maar kunnen dit niet vervangen zodra het gaat om gemeenschappen die een bepaalde schaal te boven gaan.

\subsection{REPRESENTATIEVE DEMOCRATIE}

Directe democratie is dus gebonden aan een politieke gemeenschap van beperkte omvang. Als het gaat om meer dan enkele duizenden leden, wordt de identiteit van bestuurders en bestuurden feitelijk onmogelijk. De historische vormen van - een overigens beperkte - directe democratie in de middeleeuwse stadstaten van Europa zijn dan ook onbruikbaar gebleken bij de opkomst van de territoriale staat 
die vanaf ongeveer 1500 steeds meer de hoogste ('soevereine') en belangrijkste vorm van politieke organisatie is geworden (vgl. Mackenney 1989). Democratiseringsprocessen daarin konden pas plaatsvinden op basis van het principe van vertegenwoordiging - dat overigens al lang in niet-democratische vorm tot ontwikkeling was gekomen in het middeleeuwse constitutionalisme (Downing 1992). Instituties daarvan, zoals 'parlementen' en 'staten', vertegenwoordigende lichamen van standen, konden in verschillende Europese landen - onder andere Engeland, Nederland en Zweden - door de tijd heen getransformeerd worden in organen ten dienste van een nationale vertegenwoordigende democratie.

Schaalvergroting was het centrale argument om tot vormen van representatie te komen. Thomas Paine, de eerste die dit aanvoerde, stelde het aldus (Paine 1984: 180):

"Simple democracy was society governing itself without the aid of secondary means. By ingrafting representation upon democracy, we arrive at a system of government capable of embracing and confederating all the various interests and every extent of territory and population."

De overgang van simple democracy naar representatieve democratie bracht een aantal ingrijpende consequenties met zich mee. De mogelijkheden tot actieve en passieve politieke participatie nemen af naarmate de politieke gemeenschap groter is. Die veel grotere omvang maakt ook de waarschijnlijkheid van heterogeniteit - etnisch, religieus, cultureel, sociaal-economisch, enzovoorts - groter. Ook bij vormen van democratie was altijd sprake van structurele tegenstellingen binnen de demos. Maar in grootschalige politieke gemeenschappen is niet alleen sprake van de onvermijdelijkheid van tegenstellingen en conflicten, hun beteugeling en kanalisering vraagt om geheel andere institutionele voorwaarden dan die gelden in een directe democratie (Dahl 1989: 213 e.v.). Representatieve democratie (waarvoor Dahl het neologisme 'polyarchie' vergeefs ingang probeerde te doen vinden) kent twee dimensies: vrijwel de gehele volwassen bevolking telt als staatsburger, en de rechten van de staatsburger omvatten het recht oppositie tegen de zittende regering te voeren en deze langs de weg van verkiezingen door een andere te vervangen. Teneinde deze dimensies van representatieve democratie feitelijk te waarborgen, dienen er volgens Dahl zeven instituties te functioneren (Dahl 1989: 221):

1 Gekozen regeerders;

2 Vrije en eerlijke verkiezingen;

3 Vrijwel alle volwassen burgers hebben actief kiesrecht;

4 Vrijwel alle volwassen burgers hebben passief kiesrecht;

5 Vrijheid van meningsuiting;

6 Niet-gemonopoliseerde bronnen van informatie waartoe de burgers onbelemmerd toegang hebben;

7 Het recht om onafhankelijke verenigingen te vormen. 
Deze zeven instituties zijn noodzakelijk om vijf criteria voor het deugdelijk functioneren van een representatieve democratie te vervullen (Tromp 2002b: 362-363, naar Dahl):

- gelijkheid bij verkiezingen;

- effectieve participatie;

- goed geïnformeerd zijn;

- beheersing van de politieke agenda;

- inclusiviteit.

Dahl meende dat een echte democratie meer dimensies zou kunnen kennen dan de twee die hij heeft geïdentificeerd, en dat de bestaande representatieve democratieën niet volledig aan zijn twee dimensies voldoen; vandaar de introductie van 'polyarchie', letterlijk: 'velen regeren', in plaats van 'democratie' - het volk regeert (Dahl 1972: 8). Men zou de aarzeling van Dahl kunnen doortrekken naar een probleem dat vanaf het begin aan het concept van 'representatieve democratie' kleeft, namelijk de verschillende uitleg die aan het begrip 'representatie' wordt gegeven, een probleem dat zijn grond vindt in het feit dat representatie oorspronkelijk nu juist een niet-democratische institutie was, in de Middeleeuwen ontwikkeld ten dienste van monarchaal of aristocratisch bewind (vgl. Dahl 1989: 29).

Globaal kunnen twee opvattingen van politieke representatie worden onderscheiden. In de eerste is de gekozen vertegenwoordiger er om het landsbelang te dienen, zoals hij dat ziet, niet om de belangen of opvattingen van zijn kiezers te representeren. Dit is de liberale opvatting van representatie, die het scherpst onder woorden is gebracht door Edmund Burke in zijn rede voor de kiezers van Bristol op 3 november 1774. Daarin verwierp hij de opvatting dat hij als lid van het parlement gebonden was aan een mandaat of aan opdrachten van zijn kiezers. Want het parlement was niet 'een congres van ambassadeurs van verschillende en tegengestelde belangen, maar (...) een overleglichaam van één belang, dat van het geheel' (vgl. Thomassen 1991: 168, cursivering van Burke). In deze opvatting is de vertegenwoordiger op geen enkele wijze inhoudelijk gebonden aan zijn kiezers. Evenmin representeert hij ze in sociologisch opzicht, in termen van klasse, locatie, etniciteit, enzovoorts.

Daartegenover staat de opvatting dat een vertegenwoordiger zijn kiezers vertegenwoordigt in de zin dat hij hun belangen en opvattingen representeert, en/of niet van ze verschilt in sociaal opzicht. Een van de Founding Fathers van de Amerikaanse constitutie, John Adams, formuleerde deze opvatting als volgt:

"a representative legislature should be an exact portrait, in miniature of the people at large, as it should think, feel, reason and act like them" (gecit. door Pitkin 1967: 6o).

Men zou dit verschil in opvatting over de aard van politieke representatie kunnen vatten in de formule: vertegenwoordiging van het volk dan wel voor het volk; in Nederland heeft Ankersmit dit uitgewerkt als de tegenstelling tussen mimetische 
en esthetische representatie (Ankersmit 1987). Deze twee noties van representatie bestaan nog steeds naast elkaar en de voorkeur voor de ene dan wel de andere vertaalt zich in de eisen die aan de inrichting van het politieke stelsel worden gesteld, zoals de daaruit volgende keuze voor een meerderheidsstelsel, dan wel een kiesstelsel gebaseerd op evenredige vertegenwoordiging.

Representatieve democratie kent verschillende institutionele vormen. Ideaaltypisch komen deze voor als presidentiële en parlementaire stelsels; daaraan liggen de twee contrasterende opvattingen over representatie ten grondslag. Een presidentieel stelsel is immers in wezen gebaseerd op de gedachte dat één gekozene 'het volk' kan representeren en namens maar niet in opdracht van dit volk handelt. Een parlementair stelsel daarentegen, zeker als het gebaseerd is op evenredige vertegenwoordiging, geeft juist ruimte aan de mogelijkheid dat kiezers vertegenwoordigers aanwijzen op basis van een bepaald mandaat. Als het juist is, zoals Lijphart op basis van een vergelijkende studie van zesendertig democratische staten concludeert, dat zowel vanuit democratisch oogpunt als gemeten in het vermogen tot politieke prestaties, parlementaire stelsels beter functioneren dan presidentiële (Lijphart 1999), dan volgt daar impliciet uit dat de problemen van representatieve democratische stelsels zullen verschillen afhankelijk van het feit of ze tot de eerste dan wel de tweede categorie behoren. In het verband van dit hoofdstuk beperk ik mij daarom in hoofdzaak tot de problemen van representatieve democratie in een parlementair stelsel als het Nederlandse.

Uit het voorgaande volgt echter ook dat een diagnose over hedendaagse problemen van representatieve democratie afhankelijk is van de positie die men kiest ten aanzien van de aard van politieke representatie. De erflaters van Burke's in wezen antidemocratische opvatting van democratie nemen heden ten dage het standpunt in dat de kiezers zich niet met het beleid van de gekozenen moeten bemoeien. Walter Lippmann formuleerde het indertijd krasser dan hedendaagse politieke vernieuwers zouden durven, toen hij in The Public Philosophy (1956) van kiezers stelde: "Their duty is to fill the office and not to direct the officeholder” (gecit. door Arblaster 1996: 48). Toonaangevend voor deze opvatting van representatieve democratie is nog steeds de definitie die Schumpeter gaf in Capitalism, Socialism and Democracy:

“...the democratic method is that institutional arrangement for arriving at political decisions in which individuals acquire the power to decide by means of a competitive struggle for the people's vote" (Schumpeter 1966: 269).

In deze opvatting van democratie wordt de rol van het electoraat eigenlijk beperkt tot de mogelijkheid een zittende regering die haar periode heeft uitgediend weg te sturen, "to throw the rascals out". Daar staat tegenover - vide de vereisten van Dahl - de idee dat de opvattingen van de kiezers maatgevend moeten zijn voor de standpuntbepalingen van de gekozenen en het door hen gevoerde of goedgekeurde beleid. 
Zoals gezegd maakt het voor een diagnose van contemporaine problemen van representatieve democratie uit of men de eerste, minimalistische, opvatting van democratie huldigt, dan wel de tweede. Want het gaat hier om wat als het doel van representatieve democratie wordt gezien. Het negeren van deze distinctie verzwakt bijvoorbeeld de overtuigingskracht van Zakariahs verhandeling over de toestand van de democratie in de wereld, in zijn aanval op de 'the rise of illiberal democracy' (vgl. Zakariah 2003; en mijn bespreking Tromp 2004b). Ik verwerp deze minimalistische opvatting van vertegenwoordigende democratie, waarvan ik elders heb gesteld dat deze in de huidige maatschappelijke context dreigt over te gaan in vormen van plebiscitaire democratie, waarbij de rechtstreeks gekozenen zich bevrijd weten van elke illusie over een mandaat van de kiezers (Tromp 2002b).

In feite wordt de discussie over beide vormen van representatie gecompliceerd door een factor waarmee in veel van de theoretische beschouwingen geen rekening werd (en wordt) gehouden: de logica van de macht. Want hoe verhoudt bijvoorbeeld het uitgangspunt dat de gekozenen de ruimte hebben om gezamenlijk en in overleg, als een deliberatieve gemeenschap, tot de in hun ogen optimale beslissing te komen, desnoods in weerwil van de opvattingen van hun kiezers, zich tot een logica van de macht die juist ook in vertegenwoordigende lichamen tot factievorming leidt? Carl Schmitt heeft met sardonisch genoegen deze spanningen tussen fictie en feit van de parlementaire democratie uiteengezet. In analyse verdragen parlementarisme en democratie elkaar uiteindelijk niet (Schmitt 1985: 43).

“Das wesentliche des Parlaments ist (...) öffentliches Verhandeln von Argument und Gegenargument, öffentliche Debatte und öffentliche Diskussion, Parlamentieren, wobei zunächst noch nicht an Demokratie gedacht zu werden braucht."

Daarvan kan - zo al ooit - in een op algemeen kiesrecht gebaseerde politieke democratie geen sprake zijn en is ook geen sprake. Want in zo'n democratie zijn 'vertegenwoordigers' die enkel op hun eigen ratio steunen ondenkbaar. De parlementaire samenwerkingsverbanden - de enige vorm van politieke partij die Burke toelaatbaar achtte - heeft noodzakelijkerwijze plaatsgemaakt voor politieke partijen die de belangen en aspiraties van maatschappelijke groepen articuleren. In deze situatie, constateert Schmitt, komt van een werkelijke uitwisseling van argumenten in het parlement niets meer terecht,

"An seine Stelle tritt in den Verhandlungen der Parteien die zielbewusste Berechnung der Interessen und Machtchancen" (Schmitt 1985: 11).

Maar de verholen oplossing van Schmitt is de eliminatie van parlementarisme zowel als van politieke partijen, die de ruimte moet openen voor de identiteit van volk en leider à la Rousseau, iets wat logischerwijs alleen door middel van plebis- 
citaire democratie tot stand kan komen. Dan is, in lijn met de hier verdedigde opvatting van vertegenwoordigende democratie, het middel erger dan de kwaal.

De doeltreffendheid van Schmitts van 1923 daterende aanval is te danken aan de disjunctie tussen de ideeën van democratie, representatie en machtsvorming. In geen van de oorspronkelijke concepties van representatieve democratie was systematisch rekening gehouden met het feit dat om in een vertegenwoordigend lichaam tot beslissingen te komen, machtsvorming noodzakelijk is. En evenmin dat hetzelfde gold voor de mobilisatie van kiezers. Het ontstaan en bestaan van politieke partijen in en buiten het vertegenwoordigend lichaam als instrumenten van zulke machtsvorming bleef een Fremdkörper in de theorieën over representatieve democratie. Maar in de praktijk bleken zij al snel een noodzakelijkheid. Heden ten dage bestaat representatieve democratie op staatsniveau feitelijk nergens zonder gebaseerd te zijn op politieke partijen, wat ook de onderliggende opvatting in een politiek stelsel is. Maar politieke partijen in hun huidige vorm staan onder grote druk, in de kernstaten van het moderne wereldsysteem - waartoe niet toevallig alle zesendertig door Lijphart onderzochte stabiele democratieën behoren - en nog meer in de perifere en semiperifere zones van dit wereldsysteem (vgl. Becker et al. 2000, 2003) en ik sla hier een samenvatting van hun problemen over, om te signaleren dat hier een centraal probleem ligt voor representatieve democratie, met name voor de parlementaire variant.

\section{$15 \cdot 3$ PROBLEMEN EN OPLOSSINGSRICHTINGEN}

In het tweede deel van dit verhaal is het begrip 'representatieve democratie' nader besproken en zijn er de hoofdvormen van ontvouwd. In dit deel zijn ook fundamentele problemen van representatieve democratie aan de orde gesteld, die impliciet de criteria leveren voor de waardering van de werkelijk bestaande democratie, en dus ook voor voorstellen deze te vernieuwen. In dit derde deel wordt themagewijs en beknopt een aantal vraagstukken besproken die voor met name de representatieve democratie in Nederland relevant zijn. Deze besprekingen worden afgesloten met conclusies over mogelijke oplossingen. Daarbij gaat het in de hier verdedigde opvatting van representatieve democratie om drie niveaus: dat van de gekozenen, dat van de kiezers en dat van de intermediaire instituties daartussen.

\subsubsection{BURGER EN BESTUURDER}

Centraal bij dit thema staan allereerst structurele veranderingen die zich onder de staatsburgers zouden hebben voorgedaan, met als resultaat dat deze zich meer en meer ontevreden tonen over tekortschietende prestaties van de overheid, over gebrek aan invloed op het overheidsbeleid. Dit wordt in de hand gewerkt door waargenomen structurele verschillen in leefkansen en gegroeide onzekerheid over hun collectieve identiteit (Van den Brink 2002). In de tweede plaats is sprake van minder politieke participatie, zowel gemeten naar deelname aan verkiezingen als het lidmaatschap van politieke partijen. Andere vormen van participatie 
- leunstoellidmaatschap, episodisch betrokken zijn bij specifieke issues - lijken echter toe te nemen. Het is moeilijk vast te stellen in hoeverre van de eerstgenoemde processen inderdaad, en zo ja, in welke mate sprake is. Dat geldt minder voor het tweede proces, al bestaat ook daar de neiging het verleden mooier voor te stellen dan het is (bijv. Dekker en De Hart 2002).

Aangenomen dat deze ontwikkelingen zich in alle ernst voordoen, wat betekent dit dan voor de representatieve democratie in Nederland? De eerste processen zetten het politieke bestel als zodanig onder druk, want hier gaat het allereerst om de prestaties van de overheid, niet om de wijze waarop politieke besluitvorming geregeld is. De veronderstelde achterliggende oorzaak, de toegenomen assertiviteit van burgers, kan alleen maar verklaard worden uit een veelheid van structurele maatschappelijke ontwikkelingen, veelal gesommeerd onder de hoofdjes 'modernisering' en 'individualisering'. Wat echter achter deze tamelijk nietszeggende maar allesomvattende etiketten schuilgaat, leent zich in het algemeen niet tot successen voor welbewust ondernomen pogingen tot wijziging (vgl. Ellemers 1976). Daaruit volgt de slotsom dat deze trends als een gegeven moeten worden beschouwd, en dat het twijfelachtig is of wijzigingen in het politieke stelsel hier soelaas kunnen brengen. Of toch? Als Nederland in 2002 een first past the postkiesstelsel had gekend, dan was Pim Fortuyn wellicht postuum in RotterdamZuid gekozen tot lid van de Tweede Kamer (aangenomen dat dit gebied een kiesdistrict was geweest). Maar in alle andere kiesdistricten was waarschijnlijk niemand van de Lijst Pim Fortuyn gekozen. Met als gevolg geen 'opstand van het onbehagen'. Deze heeft zich alleen maar voor kunnen doen dankzij de laagdrempeligheid van het politieke stelsel in Nederland. Zo gezien is het paradoxaal dat de klagers over het gebrek aan responsiviteit van het Nederlandse politieke stelsel, van Fortuyn zelf tot de minister van Politieke Vernieuwing. De Graaf, de hoofdartikelenschrijvers van de Volkskrant en de fractievoorzitters van PvdA en VVD in de Tweede Kamer als remedie voor '2002' juist een veel minder open stelsel hebben geëist, uit naam van meer openheid (vgl. bijv. Naar een sterker parlement 2004).

Daar kan men tegenin brengen dat het gebrek aan responsiviteit van het Nederlandse politieke stelsel juist tussen de verkiezingen aan de dag treedt, in de zin dat in de lange periode voorafgaande aan de verkiezingen van 2002 de meeste partijen in de Tweede Kamer zich niet zeer gevoelig toonden voor gevoelens van onvrede over het beleid ten aanzien van veiligheid, immigratie en integratie; gevoelens die de voornaamste motieven vormden van de kiezers die in $2002 \mathrm{op}$ de Lijst Pim Fortuyn stemden (Van der Brug 2003). In de eerste plaats is het nog maar de vraag of deze kritiek treft. Tenslotte kwam in de periode voorafgaand aan de verkiezingen een veel strenger toelatingsbeleid voor vreemdelingen tot stand, nota bene ontwikkeld door de nu vaak als 'soft' in dit opzicht genoemde burgemeester van Amsterdam, toen staatssecretaris. Dat de werking van dit nieuwe beleid pas onder zijn opvolgers en de kabinetten Balkenende zichtbaar werd, wijst meer op de onvermijdelijke tijdspanne tussen besluit en uitvoering dan op een tekort aan responsiviteit van het politieke stelsel als zodanig. 
In de tweede plaats is het geenszins plausibel dat een politiek stelsel zoals nu in verschillende varianten gepropageerd, het in dit opzicht beter zou hebben gedaan. Integendeel: zou, zoals bijvoorbeeld Jozias van Aartsen en Wouter Bos bepleiten - overigens in weerwil van de opinie in hun respectievelijke partijen in Nederland een zogenaamd tweepartijenstelsel naar Brits voorbeeld bestaan, dan was dit gebrek aan responsiviteit hoogstwaarschijnlijk veel groter geweest, tenzij de twee partijen er een electoraal twistpunt van hadden gemaakt. In een meerpartijenstelsel zou het echter meer voor de hand liggen dat een of meer partijen zich op dit strijdpunt zouden profileren. Maar dat hebben Nederlandse partijen net zomin gedaan als Labour en de Tories. Het kiesstelsel is hier kennelijke geen cruciale factor.

Eerder is gesteld dat een representatieve democratie alleen maar ordentelijk kan functioneren wanneer er stabiele intermediaire structuren tussen burger en bestuur bestaan. Dat zijn wellicht niet noodzakelijkerwijs politieke partijen van het huidige type, maar tot nu toe heeft een overtuigend alternatief daarvan zich niet gemanifesteerd. Juist in de democratische variant van representatieve democratie zijn politieke partijen van centraal belang, omdat zij de enige mogelijkheid voor burgers vormen om gekozen vertegenwoordigers te binden aan een politiek mandaat, waarin hun politieke wensen gearticuleerd zijn.

Voor de door mij voorgestane representatieve democratie is het dan ook van centraal belang de vitaliteit van politieke partijen te waarborgen. De oorzaken van hun verzwakking liggen gedeeltelijk in algemene en moeilijk veranderbare maatschappelijke processen, maar zijn gedeeltelijk ook een functie van het optreden van partijen zelf en van de werking van het bestaande politieke stelsel. Zo heeft de verwording van het Amerikaanse partijstelsel alles te maken met de wijze waarop vanaf het begin van de jaren tachtig partijen een van hun kerntaken, de selectie en rekrutering van kandidaten voor vertegenwoordigende lichamen, als gevolg van ondoordachte organisatorische vernieuwingen in eigen kring en eisen van de politiek, hebben verloren (vgl. Polsby 1983). Een van desastreuze gevolgen daarvan is geweest dat het de rol van geldschieters in de politiek vergroot en versterkt heeft, mede door een volkomen tekortschietende overheidsregulering, zulks ten koste van de burgers in een mate dat in alle objectiviteit het Amerikaanse politieke stelsel beschouwd moet worden als een 'beginnende plutocratie' (vgl. Williams 2003).

De degeneratie van Amerikaanse politieke partijen kan daarna niet los worden gezien van het Amerikaanse constitutionele bestel, dat welbewust ingericht is om het functioneren van partijen zo moeilijk mogelijk te maken. Vanzelfsprekend kleven aan elk politiek stelsel voor- en nadelen, dat geldt ook voor de representatieve democratie zoals die in Nederland gestalte heeft gekregen. Bij de discussie over de problemen van de democratie in zijn huidige vorm is het daarom zaak voorstellen tot staatkundige wijziging niet alleen te beoordelen op de veronderstelde voordelen die deze zouden bieden ten opzichte van de bestaande orde, maar daarnaast de maatschappelijke en institutionele context in 
de beschouwing te betrekken. Eendere kiesstelsels kunnen, om een voorbeeld te noemen, in verschillende maatschappelijk-institutionele contexten geheel verschillende effecten opleveren.

Als het gaat om de verbetering van de relatie tussen burger en bestuurder, in de zin dat de laatste meer invloed kan uitoefenen op het optreden van gekozen bestuurders en vertegenwoordigers, dan is een revitalisering van politieke partijen het voornaamste middel om deze tot stand te brengen. De thans in bespreking zijnde voorstellen om het politieke stelsel te wijzigen, zoals een 'gemengd districtenstelsel' en een rechtstreeks gekozen burgemeester, tenderen echter precies in tegengestelde richting: naar een verdere verzwakking van politieke partijen. Zij gaan dan ook in de richting van een meer elitistische en plebiscitaire vorm van democratie, en passen in een richting die al is ingeslagen bij de zogenaamde dualisering van het lokaal bestuur, waarbij de bevoegdheden van de gemeenteraad verminderd werden ten gunste van die van het College van Burgemeester en Wethouders, en het zelfs mogelijk werd gemaakt het laatste ambt te laten vervullen door kandidaten die buiten de kiezers om benoemd worden.

De huidige positie van politieke partijen is al zwak genoeg. Revitalisering is geen eenvoudige opgave. Maar die verzwakking is niet alleen het probleem van partijen. Zij maakt deel uit van een veel groter complex. De afnemende en veranderende politieke participatie is niet tot het relatief dalende aantal leden van de meeste politieke partijen beperkt. Deze vormt in principe een ernstige aantasting van representatieve democratie, die haar bestaansgrond immers vindt in de mogelijkheid die deze alle burgers biedt om minimaal door te stemmen de richting van de politieke besluitvorming te beïnvloeden. Wanneer steeds minder burgers bij verkiezingen opkomen, dan leidt dit niet alleen tot verlies aan legitimiteit van het democratisch stelsel, maar wordt in tendentie ook de effectiviteit ervan ondermijnd, zeker als niet-stemmers in politiek relevant opzicht duidelijk verschillen van degenen die wel opkomen, zoals in de Verenigde Staten in de afgelopen jaren een vaststaand gegeven bij verkiezingen is geworden. Uiteindelijk leidt dit er onvermijdelijk toe dat de belangen van de afwezige kiezers niet meer vertegenwoordigd worden in de politieke besluitvorming.

Afnemende participatie in politieke partijen kan gezien worden als een uiting van een veel algemener proces, waarbij waardegeoriënteerde verbanden steeds meer een instrumenteler karakter aannemen, van universiteiten en kerken tot charitatieve NGO's. Dit proces kan een zichzelf versterkende vorm aannemen, als gevolg waarvan politieke partijen steeds meer alleen nog leden trekken die in de partij een loopbaaninstrument zien, en daarin meer gelijk krijgen naarmate de ledenaantallen dalen tot de omvang van het beschikbare aantal zetels in vertegenwoordigende lichamen. Niet denkbeeldig is een ontwikkeling waarbij de meeste partijen campagnepartijen worden, bestaande uit zichzelf rekruterende beroepspolitici en beroepsadviseurs (uitvoerig hierover Tromp 2003a). 


\subsubsection{VERPLATSING VAN DE POLITIEK}

Een belangrijk actueel thema voor de discussie over problemen van de representatieve democratie is dat van de 'verplaatsing van de politiek' (Bovens et al. 1995). Met dit begrip werd een aantal verschijnselen bedoeld die dit gemeen hebben dat ze politieke ruimte voor democratie op het niveau van de (Nederlandse) staat inperken. Als zodanig zijn aangemerkt: internationalisering, regionalisering, privatisering, verambtelijking, individualisering en juridisering (Bovens 2002: 16-19).

Voor een deel is hier sprake van conceptuele verwarring. De Nederlandse staat is nooit autonoom geweest in zijn beslissingen, intern noch extern. In dit opzicht is de politiek altijd al 'verplaatst' geweest. Niettemin herinnert het thema van 'de verplaatsing van de politiek' eraan dat de idee van democratie, van regering door of op zijn minst namens het volk, gebaseerd is op de vooronderstelling dat regeringsmacht boven de macht van deelbelangen staat, dat politiek het sociaal en economisch leven domineert (vgl. Arblaster 1995: 61). Wanneer de verdeling van leefkansen in de inrichting van de maatschappij niet in de eerste plaats gestructureerd wordt door democratisch gelegitimeerde overheidsmacht maar door krachten die zich aan democratische controle onttrekken, dan tast dit de geloofwaardigheid van de representatieve democratie aan.

Eén implicatie van deze constatering is dat het voor de kwaliteit van de politieke democratie, misschien zelfs wel voor haar overleving, van belang is dat vormen van democratie in een samenleving niet tot de sfeer van de formele politiek beperkt blijven. Vormen van democratische controle dienen ertoe om te beletten dat de invloed van niet-democratische instanties en organisaties op het formele politieke stelsel tot uitholling van de effectiviteit van het laatste leidt. Anderzijds zijn zulke vormen van democratie van belang om het ethos van de democratie tot een integrerend element van het maatschappelijk waardepatroon te maken.

Kortom: voorzover er sprake is van 'verplaatsing van de politiek', dient democratie mee verplaatst te worden, al hoeven dit dan niet per se vormen van representatieve democratie te zijn. Integendeel, in veel gevallen lijken vormen van directe, associatieve of deliberatieve democratie hier beter van toepassing te zijn.

In één opzicht is wel degelijk sprake van een 'verplaatsing van de politiek' als een betrekkelijk nieuw verschijnsel. Dat is enerzijds de proliferatie van transnationale regimes, anderzijds die van het proces van Europese integratie met een voor de afzonderlijke staten verplichtend karakter. Het statenstelsel is nooit een optelsom van geheel autonoom opererende eenheden geweest. Het kent vanaf zijn aanvang specifieke regimes die hun onderlinge omgang reguleren, van het volkenrecht tot de regeling van het internationale postverkeer. Tamelijk recent is echter de opkomst van transnationale regimes die formele bevoegdheden uitoefenen die als 'politiek' kunnen worden opgevat, zoals de Wereldhandelorganisatie (WTO). 'Politiek' in de zin dat zulke regimes niet een louter technisch karakter dragen, zoals die met betrekking tot het post- of luchtverkeer, maar wat betreft hun effec- 
ten uiteenlopende gevolgen hebben voor staten en bevolkingsgroepen, die niet op technische noodzaak teruggevoerd kunnen worden. De EU vormt een speciaal geval, omdat hier op een aantal beleidsterreinen nationale bevoegdheden formeel zijn overgedragen aan de bovennationale Unie.

Het probleem dat hier speelt kan wellicht bekeken worden vanuit het maken van het onderscheid tussen lotsgemeenschap en doelgemeenschap. De staat is een lotsgemeenschap. Hij is er niet voor een specifiek doel, maar vormt het gegeven kader waarbinnen de meeste bewoners hun leven inrichten en waarop ze zich richten als het gaat om hun leefkansen en hun bescherming tegen binnen- en buitenlandse dreiging. In weerwil van allerlei noties van mondialisering, europeanisering en regionalisering is er geen enkel teken dat dit op afzienbare termijn zal veranderen, zeker niet in de kernstaten van het wereldsysteem waar staatsvorming het sterkst is gestabiliseerd. De meeste transnationale regimes zijn doelgemeenschappen, met een formeel duidelijk omschreven doelstelling, die slechts een deel van het bestaan van burgers in staten raakt.

Mogelijke uitzondering is de EU, die pretendeert een lotsgemeenschap in wording te zijn. Maar zij zou dat alleen kunnen worden als de EU tot een werkelijk politieke unie zou evolueren, en daarvan is geen sprake. Aan de andere kant is de werkelijkheid dat het zwaartepunt van de EU, alle andere ontwikkelingen tot nauwere samenwerking tussen de lidstaten ten spijt, nog steeds ligt op het terrein van economische integratie. Deze hybride (en geenszins uitgekristalliseerde) situatie, maakt het vraagstuk van controle en politieke sturing op basis van representatieve democratie buitengewoon gecompliceerd. Aan de ene kant worden nationale democratieën in hun beleidskeuzes beperkt door de informele druk van economische mondialiseringsprocessen, en wordt deze gang van zaken versterkt door de werking van 'negatieve integratie' in de EU, zoals die is vastgelegd door formeel democratisch totstandgekomen verdragen. Aan de andere kant bestaan er op het niveau van de EU geen overeenkomstige democratische mechanismen om hieraan paal en perk te stellen en de negatieve effecten ervan door 'positieve integratie ' te redresseren (vgl. Scharpf 1999: 27-28). Uit het overzicht van Monika Sie Dhian Ho in deze bundel komt naar voren dat de voorstellen tot oplossing van dit 'democratisch deficit' onder andere gezocht worden in het invoeren van instrumenten van representatieve democratie - zoals parlementarisering van de Europese Commissie en rechtstreekse verkiezing van haar voorzitter - die vooral tot doel hebben de Europese besluitvormingsmachinerie meer democratische legitimiteit te verschaffen. In de visie die ik verdedig zou dit passen in het elitistische model van politieke democratie, en niet alleen geen enkele waarborg bieden voor een substantiële democratie (input-legitimiteit zo men wil) op Europees niveau, maar juist de behoefte en noodzaak daaraan maskeren.

Het gevaar dat bestaande politieke praktijken gelegitimeerd worden door formeel-democratische maar substantieel loze mechanismen, dreigt niet alleen bij zulke denkbeelden in het geval van de EU, maar in het algemeen bij de uiteen- 
lopende voorstellen die de laatste jaren circuleren om transnationale regimes institutioneel aan democratische besluitvorming onderhevig te doen zijn. Het komt mij voor dat daarbij te licht wordt gedacht over het feit dat de staat voor de afzienbare tijd toch de primaire politieke gemeenschap blijft; daarnaast dat te gemakkelijk wordt gedacht over wat de noodzakelijke politiek, sociale, economische en culturele voorwaarden zijn voor het functioneren van dergelijke vormen van wat David Held cosmopolitan democracy heeft genoemd (vgl. Held 1996: 335$361)$.

\subsubsection{DE KENNISMAATSCHAPPIJ}

De centrale kwestie zoals hier gedefinieerd is dat 'kennis' een unieke machtsbron is in een democratie, en dat structurele ongelijkheid in kennis daarom de kwaliteit van de democratie aantast. Dit is waar en niet waar. Representatieve democratie berust op het uitgangspunt van de formele gelijkheid van burgers, minimaal gegarandeerd door het feit dat de stem van elke burger evenveel waard is als die van een andere. Dit is tevens een minimale bescherming tegen machtsongelijkheid op basis van de machtsbronnen waarover burgers beschikken, variërend van toegang tot geweldsmiddelen, rijkdom en economische macht, tot overtuigingskracht en deskundigheid (vgl. Tromp. 2002: 151 e.v.). De zogenaamde kennismaatschappij is met andere woorden niet een nieuw fenomeen, maar herinnert eraan dat structurele machtsongelijkheid de werking van representatieve democratie ondermijnt, of deze nu op kennis dan wel op economische macht is gebaseerd. De ongelijkheid in de laatste vormt om een reeks van redenen een veel grotere bedreiging van de werking van representatieve democratie dan ongelijkheid in kennisniveau, daargelaten het feit dat deze twee machtsbronnen in veel gevallen congruent zijn.

Met andere woorden: sociaal-economische ongelijkheid is een veel grotere bedreiging van representatieve democratie dan ongelijkheid in kennis, voorzover die van de eerste onafhankelijk is. De kwestie is hier enerzijds hoe de door Dahl gememoreerde vereisten voor een democratisch proces worden aangetast door sociaal-economische ongelijkheid, anderzijds in hoeverre het mogelijk is op basis van sociaal-economische macht los van het democratische proces invloed uit te oefenen op politieke beslissingen.

De toenemende rol van geld bij verkiezingscampagnes demonstreert dat democratie daar inderdaad door geperverteerd wordt. Daarbij hoeft men niet alleen te denken aan het onverholen plutocratische karakter van de Amerikaanse politiek, onder andere tot uiting komend in het gegeven dat vanaf 1976 de kandidaten voor het presidentschap vaststonden voor er een kiezer aan te pas kon komen: de kandidaat die het meeste geld had verzameld in het jaar vóór de presidentsverkiezingen, is steeds de kandidaat van zijn partij voor het presidentschap geworden (Lewis 2004: 6). Schandalen rond de financiering van verkiezingscampagnes zijn in de afgelopen jaren ook ontstaan in het Verenigd Koninkrijk en Frankrijk; in de Bondsrepubliek is de reputatie van Helmut Kohl er ernstig door aangetast. Noch 
gaat het hier om incidenten. Terwijl Italië geregeerd wordt door zijn rijkste burger, die over een feitelijk monopolie over de Italiaanse televisiezenders beschikt, en alleen dankzij zijn politieke ambt en de meerderheid van de regeringspartijen in de volksvertegenwoordiging niet vervolgd kan worden voor de strafbare feiten waarop zijn fortuin en politieke positie gebaseerd zouden zijn. Maar evenzeer wordt het democratische proces aangetast door de geprivilegieerde positie van economische machten en machthebbers bij politieke besluitvorming (vgl. bijv. het klassieke onderzoek van Crenson 1971). Er bestaat nu eenmaal een inherente spanning tussen kapitalisme en democratie (vgl. bijv. Dahl 1998: 181-183). Maatschappelijk gezien is een volwaardige democratie, zo concludeert Robert Dahl al in 1976, dan ook alleen mogelijk als economische macht aan banden is gelegd (vgl. Lehning 1991: 118-125).

Het thema van de 'kennismaatschappij' kan ook worden opgevat als dat van de toegenomen gecompliceerdheid van politiek en bestuur, en het tekortschieten van mechanismen tot 'reductie van complexiteit' in het politieke systeem (Luhman 1971). Van Doorn ziet vormen van 'verplaatsing van de politiek' als welbewuste pogingen om ingewikkelde politieke beslissingen te vereenvoudigen of uit de weg te gaan. Een alternatieve strategie met hetzelfde doel is in zijn ogen 'de vlucht naar voren': de directe verkiezing van politieke leiders en ambtsdragers (Van Doorn 2002: 50-56). Bij wijze van commentaar twee opmerkingen. De these van de toenemende gecompliceerdheid wordt in het algemeen als een vanzelfsprekendheid geponeerd. Het lijkt mij echter de moeite waard om deze these serieus te nemen en dus na te gaan in hoeverre hiervan werkelijk sprake is in relatie tot een nader te specificeren verleden waar alles veel simpeler en overzichtelijker was. In zo'n analyse zou ook moeten worden betrokken de vraag of de onmiskenbaar toegenomen hoeveelheid kennis en informatie van en over verschijnselen zelf niet een bepalende factor vormt bij het accepteren van de gecompliceerdheidsthese. Om een voorbeeld te noemen: de campagne die uiteindelijk in 1806 tot de slag bij Trafalgar leidde, en ook die slag zelf, was voor admiraal Horatio Nelson aanmerkelijk gecompliceerder dan de Amerikaanse veldtocht tegen Saddam Hoessein in maart 2003 voor de commandant van het aanvalsleger, generaal Tommy Franks.

Aangenomen echter dat de these klopt, dan komt de vraag op - als Van Doorn gelijk heeft met zijn diagnose van de geopperde remedies (en daar is veel voor te zeggen, zie de staatsrechtelijke 'vernieuwingsvoorstellen' die door het tweede kabinet-Balkenende zijn geponeerd) - waarom de oplossing niet gezocht wordt bij de burger. Zijn opleidings- en scholingsniveau is in de tijd immers steeds meer toegenomen, en daarmee, zou men zeggen, ook zijn vermogen om gecompliceerde vraagstukken te doorgronden. Als dat echter niet zo is, bijvoorbeeld omdat de ingewikkeldheid van politieke vraagstukken groter is geworden in verhouding tot de verhoging van het opleidingsniveau, dan zou het ook mogelijk zijn dit te compenseren door te trachten de politieke competentie van burgers te vergroten. Dat zou passen in een streven naar meer substantiële democratie (vgl. Wallerstein 1997). 
De twee oplossingen die Van Doorn signaleert passen allebei in het model van de elitistische opvatting van democratie. Er is echter ook een derde oplossing op het niveau van de politiek die wel recht doet aan de uitgangspunten van een reële representatieve democratie: dat is de 'reductie van complexiteit' in termen van de programma's van politieke partijen. De eerder besproken neergang van politieke partijen komt niet in de laatste plaats naar voren in hun onvermogen of onwil om hun politieke aspiraties duidelijk inzichtelijk en overzichtelijk te maken, hoewel het hier toch een fundamentele kwaliteit in de politiek betreft.

\subsubsection{DE ROL VAN DE MEDIA}

Zoals de naam al zegt vormen de media een intermediair tussen staatsburger en politieke vertegenwoordiging. Meer dan vroeger, hoewel dat ook niet moet worden overdreven. Sinds de opkomst van massamedia als kranten, radio en later televisie zijn zij het belangrijkste instrument dat 'bemiddelt' tussen de grote massa van de kiezers en de gekozenen. Ten dienste van de democratie dienen de media drie functies te vervullen. In de eerste plaats informeren zij de burger over het politieke bedrijf. In de tweede plaats bieden zij een platform waar burgers zich kunnen uiten en met elkaar en politici in debat kunnen treden. In de derde plaats vervullen zij een kritische functie, in het volgen en becommentariëren van het handelen van overheid en politiek.

Ik beperk mij bij het bespreken van het functioneren van de media in het verband van de representatieve democratie tot twee opmerkingen. De eerste begint met te herinneren aan het door Dahl voor een democratie genoemde vereiste van alternatieve informatiebronnen voor de burger. Dat vereiste staat in veel democratische kernstaten op twee manieren onder druk. In de eerste plaats is in verschillende van die staten sprake van een semi-monopolistische configuratie van media, als gevolg van de concentratie van de eigendom van kranten en radio- en televisiezenders. Voorbeelden te over: de invloed van het media-imperium van Rupert Murdoch op onder andere de Britse politiek; Silvio Berlusconi, die nadat hij minister-president werd naast de drie commerciële zenders van Italië die zijn bezit al waren, ook nog de controle ging uitoefenen over de drie publieke netwerken van het land; en de megafusies in de Amerikaanse mediawereld als gevolg van de deregulering van anti-monopoliebepalingen.

Dit proces van oligopolisering en monopolisering van de media gaat, in de tweede plaats, vrijwel steeds gepaard met een commercialisering die ten koste gaat van primaire taken als nieuwsvoorziening (zie bijv. Van Wolferen 2003: 21326 o, voor een bittere beschrijving van dit proces in de Verenigde Staten). Gezien de voortgaande mondiale tendens tot concentratie in de wereld van de media en de neiging in veel landen om onder invloed van een neoliberale ideologie publieke zenders te marginaliseren, dan wel de concurrentie met commerciële zenders op de termen van de laatste aan te gaan, is er geen reden om aan te nemen dat dit proces niet verder zal gaan. Hier ligt een klaarblijkelijke bedreiging van het functioneren van representatieve democratieën. 
Over het functioneren van de media valt meer te zeggen. Maar ik zou tot slot liever enige opmerkingen willen maken over degene die in de meeste beschouwingen over politiek, democratie en media als een gegeven wordt beschouwd: de burger. Alleen in een uiterst naïeve opvatting bestaat de opvatting van representatieve democratie die in dit hoofdstuk wordt verdedigd eruit dat - binnen de grenzen van de rechtsorde, overigens een helemaal niet zo'n onomstreden gegeven meer - de 'voorkeuren' van de burgers vertaald worden in beleid. Die voorkeuren zijn immers niet gegeven. De gedachte dat zij ondubbelzinnig aan het licht kunnen worden gebracht door middel van opinieonderzoek is niet houdbaar (zie bijv. Ellemers 2004, en de door hem aangevoerde literatuur terzake). Die voorkeuren kunnen alleen afgelezen worden uit de keuzen die zij maken voor vertegenwoordigers. Politieke partijen zijn wat dit aangaat niet alleen mechanismen voor de aggregatie van politieke macht, maar ook organen ter reductie van complexiteit. Dit vereist dat de media trouwhartig en betrouwbaar hun informatieve functie vervullen. Anderzijds herinnert deze eis aan de media aan de plicht van de staatsburger om zich grondig te informeren over politiek en politieke alternatieven, althans in die opvatting van politieke democratie die de staatsburger als zodanig serieus neemt. Representatieve democratie stelt ook eisen aan de burgers: zij dienen over een minimaal noodzakelijke kennis van de inrichting en werking van het politieke stelsel te beschikken en over voldoende informatie om tot een rationele stemkeuze te komen. James Madison, een van de auteurs van de Federalist Papers (Madison et al.1987), vaak beschouwd als een protagonist van de 'esthetische' opvatting van representatie, meende niettemin: “( $T$ )o suppose that any form of government will secure liberty or happiness without any virtue in the people is a chimerical idea" (gecit. door Williams 2003: 89), waarmee hij bedoelde dat het politieke stelsel alleen maar kon werken bij de gratie van een betrokken en geïnformeerd electoraat.

De tekortkomingen van de media in Nederland in dit opzicht, met de bekende collusie tussen politieke verslaggeving en vermaak, kleedkamerjournalistiek enzovoorts, vinden hun spiegelbeeld in de informatiebehoefte van de staatsburgers en de wijze waarop zij hun burgerplicht uitoefenen. Hoe kan het ook anders! Een indicatie is het vrijwel ontbreken in het middelbaar onderwijs, van VBMO tot en met vwo, van onderricht op het gebied van kennis van staatsinstellingen en de werking van het politieke stelsel. Kritiek op de wijze waarop de media hun drie taken ten opzichte van de werking van de representatieve democratie ver-vullen kan daarom niet los staan van de wijze waarop de burger de kennis en vaardigheid worden bijgebracht.

\subsection{SLOT}

In dit verkennende essay heb ik op basis van een historische terugblik het onderscheid tussen directe democratie en representatieve democratie uiteengezet, mede om de eerste in bescherming te nemen tegen het misverstand dat in het huidige spraakgebruik als 'directe democratie' wordt aangeduid. Daarop volgde de centrale stelling van dit betoog, dat representatieve democratie de enige vorm 
van democratie is die in omvangrijke politieke gemeenschappen kan functioneren. Deze is echter onmiddellijk van ernstige kanttekeningen voorzien, die vooral de opvattingen betreffen van wat dan wel onder 'representatie' wordt verstaan. Ik heb daarbij niet alleen een duidelijke voorkeur uitgesproken voor die opvatting waarin de burgers niet alleen vertegenwoordigers kiezen, maar waarin deze ook de richting van het politiek handelen van hun vertegenwoordigers bepalen. Dat kan alleen bij de gratie van een intermediaire organisatie, een politieke partij. In de rest van het essay zijn zowel de hedendaagse problemen van politieke partijen kort besproken als een aantal andere tamelijk fundamentele tekorten en bedreigingen van de representatieve democratie. Deze problemen blijken zich vooral voor te doen in de maatschappelijke context van de politiek, niet in de inrichting ervan. Vandaar dat er in dit betoog ook geen reden was om uitgebreid in te gaan op de thans in discussie zijnde voorstellen tot 'politieke vernieuwing' (dat heb ik elders gedaan, zie o.a. Tromp 2004b). Wel voor de summiere slotsom dat deze, vanuit het oogpunt van verbetering van de representatieve democratie in Nederland, precies de verkeerde richting ingaan. 


\section{LITERATUUR}

Ankersmit, F.R. (1987) 'Politieke representatie. Betoog over de esthetische staat', Bijdragen en mededelingen betreffende de geschiedenis der Nederlanden, 3.

Arblaster, A. (1994) Democracy, Buckingham: Open University Press.

Aristotle (1988) The Politics, Cambridge: Cambridge UP.

Becker, F., W. van Hennekeler, M. Sie Dhian Ho en B. Tromp (red.) (2001) De toekomst van de democratie. Het eenentwintigste jaarboek van het democratisch socialisme, Amsterdam: Wiardi Beckman Stichting - De Arbeiderspers.

Becker, F., W. van Hennekeler, M. Sie Dhian Ho en B. Tromp (red.) (2003) Politieke partijen op drift. Het vierentwintigste jaarboek voor het democratisch socialisme, Amsterdam: Wiardi Beckman Stichting - De Arbeiderspers.

Bovens, M., W. Derksen, W. Witteveen, P. Kalma en F. Becker (1995) De verplaatsing van de politiek. Een agenda voor democratische vernieuwing, Amsterdam: Wiardi Beckman Stichting.

Bovens, M. (200) 'De permanente verplaatsing van de politiek', Socialisme \& \& Democratie, 12.

Brink, G. van den (2002) Mondiger of moeilijker? Een studie naar de habitus van hedendaagse burgers, WRR Voorstudies en achtergronden nr. 115, Den Haag: Sdu.

Burg, W. van der (2003) 'How the LFP fuelled Discontent: Empirical tests of explanations of LFP support', Acta Politica, 1.

Carr, E.H. (1961) Michael Bakunin, New York: Vintage.

Crenson, M.A. (1971) The Un-politics of Air Pollution: A Study of Non-Decisionmaking in the Cities, Baltimore: The John Hopkins Press.

Dahl, R.A. (1989) Democracy and its Critics, New Haven: Yale UP.

Dahl, R.A. (1998) On Democracy, New Haven: Yale UP.

Dekker, P. en J. de Hart, (2002) 'Participatie', in Sociaal en cultureel rapport 2002. De kwaliteit van de quartaire sector, De Haag: Sociaal en Cultureel Planbureau.

Diamond, J. (1997) Guns, Germs and Steel. A Short History of Everybody for the Last 13, ooo Years, New York: Vintage.

Doorn, J.A.A. van (2002) 'Democratie in de overgang. Van collectieve beheersing naar geordende vrijheid', in P.G.C. van Schie (red.) Het democratisch tekort: Interpretaties en remedies, Den Haag: Prof.mr. B.M. Teldersstichting.

Downing, B.M. (1992) The Military Revolution and Political Change, Princeton: Princeton UP.

Ellemers, J.E.E. (1976) 'Veel kunnen verklaren of iets kunnen veranderen', Beleid en Maatschappij, 3 .

Ellemers, J.E.E. (2004) 'Het fenomeen Fortuyn. De revolte verklaard', in G. Voerman (red.) Jaarboek 2002. Documentatiecentrum Nederlandse politieke partijen, Groningen: Rijksuniversiteit Groningen.

Hale, J.R. (1986) Florence and the Medici. The Pattern of Control, London: Thames and Hudson.

Held, D. (1996) Models of Democracy, London: Polity Press.

Lehning, P.B. (1991) 'De theorie van het pluralisme', in J.J.A. Thomassen (red.) Hedendaagse democratie, Alphen aan den Rijn: Samsom H.D. Tjeenk Willink. 
Lewis, Ch. en het Center for Public Integrity (2004) The Buying of the President 2004, New York: HarperCollins.

Luhman, N. (1971) Soziologische Aufklärung. Aufsätze zur Theorie sozialer Systeme, Köln: Westdeutscher Verlag.

Lijphart, A. (1999) Patterns of Democracy, Governments Forms and Performance in Thirty-Six Countries, New Haven: Yale UP.

Mackenney, R. (1989) The City-State 1500-1700. Republican Liberty in an Age of Princely Power, Houndmills: MacMillan.

Macpherson, C.B. (1966) The Real World of Democracy, Oxford, Clarendon Press.

Madison, J., A. Hamilton, J. Jay, (1987) The Federalist Papers, Harmondsworth: Penguin.

Mann, M. (1986) The Sources of Social Power, vol 1, A history of power from the beginning to A.D. 1760 , Cambridge: Cambridge UP.

Martines, L. (2003) April Blood. Florence and the Plot against the Medici, London: Pimlico. Ministerie van Binnenlandse Zaken en Koninkrijksrelaties (2003), Naar een sterker parlement. Hoofdlijnennotitie nieuw kiesstelsel, (z.j.) z.p: ministerie BZк.

Mulgan, R.G. (1987) Aristotle's Political Theory, Oxford: Clarendon Press.

Paine, Th. (1984) The Rights of Man, Harmondsworth: Penguin.

Pitkin, H. (1967) The Concept of Representation, Berkeley: University of California Press.

Polsby, N.W. (1983) Consequences of Party Reform, Oxford: Oxford UP.

Rousseau, Jean-Jacques (1988) The Social Contract and Discourses, London: Dent.

Scharpf, Fr.W. (1999) Governing in Europe. Effective and Democratic?, Oxford, Oxford UP.

Schmitt, C. (1985) Die geistesgeschichtliche Lage des heutigen Parlementarismus, Berlin: Duncker \& Humblott.

Schumpeter, J.A. (1966) Capitalism, Socialism and Democracy, London: Unwin.

Stavrianos, L.S. (1992) Lifelines From Our Past. A New World History, New York: M.E. Sharpe.

Tromp, B. (1979) ‘De sociologie van de stad bij Max Weber', in W. Goddijn (red.) Max Weber. Zijn leven, werk en betekenis, Baarn: Ambo.

Tromp, B. (2002a) De wetenschap der politiek. Verkenningen, Amsterdam: Amsterdam UP.

Tromp, B. (2002b) 'Het virus van de plebiscitaire democratie', Socialisme $\mathbb{\&}$ Democratie, 12.

Tromp, B. (2003a) 'De crisis der partijen en enkele voorstellen deze te overwinnen', in Fr. Becker, M. Sie Dhian Ho, W. van Hennekeler en B. Tromp (red.) Politieke partijen op drift. Het vierentwintigste jaarboek voor het democratisch socialisme, Amsterdam: Wiardi Beckman Stichting - De Arbeiderspers.

Tromp, B. (2003b) Neergang van de democratie?, Von Launlezing 2003, Leeuwarden: Rudolf von Laun-instituut.

Tromp, B. (2004a) ‘Democratie of vrijheid?’, Internationale Spectator, 1.

Tromp, B. (2004b) ‘Politieke vernieuwing of politieke verbetering?', Beleid en maatschappij, 2 (te verschijnen).

Voerman, G. (red.) Politiek zonder partijen? Over de horizon van de partijpolitiek, Amsterdam: Het Spinhuis, 1994.

Wallerstein, I. (1974) The Modern World-System. Capitalist Agriculture and the Origins of the European World-Economy in the Sixteenth Century, New York: Academic Press. 
Wallerstein, I. (1997) Liberalism and Democracy: Frères ennemis?, Vierde Daalderlezing, Leiden: Rijks Universiteit Leiden.

Williams, W. (2003) Reaganism and the Death of Representative Democracy, Washington: Georgetown UP.

Wolferen, K. van, (2003) De ondergang van een wereldorde. Amsterdam: Contact.

Zakariah, F. (2003) The Future of Freedom. Illiberal Democracy at Home and Abroad, New York: Norton. 


\section{OVER DE AUTEURS}

Dr. T. Akkerman is Universitair Docent bij de afdeling Politicologie en Bestuurskunde van de Universiteit van Amsterdam.

Dr. B.J.M. Arts is Universitair Hoofddocent bij de Leerstoelgroep Milieu \& Beleid van de Faculteit der Managementwetenschappen van de KU Nijmegen.

Drs. N. Boonstra is als assistent onderzoeker verbonden aan het Verwey-Jonker Instituut en in het kader van het Buurt-project gedetacheerd bij de WRR.

Drs. D.W.J. Broeders is stafmedewerker bij de WRR en als promovendus verbonden aan de Erasmus Universiteit.

Prof. dr. W.B.H.J. van de Donk is raadslid van de WRR en hoogleraar bestuurskunde aan de Universiteit van Tilburg.

Drs. H.O. Dijstelbloem is wetenschappelijk medewerker en projectcoördinator bij de WRR.

Dr.E.R. Engelen is stafmedewerker bij de WRR en onderzoeker bij de afdeling Geografie en Planologie van de Universiteit van Amsterdam.

Dr. C.A. Hazeu is wetenschappelijk medewerker en projectcoördinator bij de WRR.

Ir. M. Jager-Vreugdenhil is stafmedewerker bij de WRR.

Dr. A. Krouwel is Universitair Docent aan de afdeling Politicologie van de Vrije Universiteit.

Prof. dr. P.L. Meurs is raadslid van de WRR en hoogleraar bestuurs- en organisatiewetenschappen aan de Erasmus Universiteit.

Dr. B. Pattyn is Universitair Docent aan de afdeling Wijsbegeerte van de Katholieke Universiteit te Leuven.

Prof. dr. C.F. Sabel is Professor of Law and Social Science bij de Columbia Law School, New York.

Prof. dr. mr. C.J.M. Schuyt is raadslid van de WRR en als hoogleraar algemene sociologie verbonden aan de Universiteit van Amsterdam.

Drs. M. Sie Dhian Ho is wetenschappelijk medewerker en projectcoördinator bij de WRR.

Prof. dr. B. Tromp is bijzonder hoogleraar in de theorie en geschiedenis der internationale betrekkingen aan de Universiteit van Amsterdam. 
Drs. I. Verhoeven is stafmedewerker bij de WRR en als promovendus verbonden aan de Amsterdam School for Social Research van de Universiteit van Amsterdam.

Prof. dr. ir. G.H. de Vries is hoogleraar wetenschapsfilosofie en filosofie van de technologische cultuur aan de Universiteit van Amsterdam.

Prof. dr. P. Winsemius is raadslid van de WRR en hoogleraar management van duurzame ontwikkeling aan de Universiteit van Tilburg. 


\section{RAPPORTEN AAN DE REGERING}

\section{Eerste raadsperiode (1972-1977)}

1 Europese Unie*

2 Structuur van de Nederlandse economie*

3 Energiebeleid

Gebundeld in één publicatie (1974)*

4 Milieubeleid (1974)*

5 Bevolkingsgroei (1974)*

6 De organisatie van het openbaar bestuur (1975)*

7 Buitenlandse invloeden op Nederland: Internationale migratie (1976)*

8 Buitenlandse invloeden op Nederland: Beschikbaarheid van wetenschappelijke en technische kennis (1976)*

9 Commentaar op de Discussienota Sectorraden (1976)*

10 Commentaar op de nota Contouren van een toekomstig onderwijsbestel (1976)*

11 Overzicht externe adviesorganen van de centrale overheid (1976)*

12 Externe adviesorganen van de centrale overheid (1976)*

13 Maken wij er werk van? Verkenningen omtrent de verhouding tussen actieven en niet-actieven (1977)*

14 Interne adviesorganen van de centrale overheid (1977)*

15 De komende vijfentwintig jaar - Een toekomstverkenning voor Nederland (1977)*

16 Over sociale ongelijkheid - Een beleidsgerichte probleemverkenning (1977)*

\section{Tweede raadsperiode (1978-1982)}

17 Etnische minderheden (1979)*

A. Rapport aan de Regering

B. Naar een algemeen etnisch minderhedenbeleid?

18 Plaats en toekomst van de Nederlandse industrie (1980*

19 Beleidsgerichte toekomstverkenning

Deel 1: Een poging tot uitlokking (1980)*

Democratie en geweld. Probleemanalyse naar aanleiding van de gebeurtenissen in Amsterdam op 30 april $1980^{*}$ Vernieuwingen in het arbeidsbestel (1981)* Herwaardering van welzijnsbeleid (1982)*

Onder invloed van Duitsland. Een onderzoek naar gevoeligheid en kwetsbaarheid in de betrekkingen tussen Nederland en de Bondsrepubliek (1982)* 


\section{Derde raadsperiode (1983-1987)}

Beleidsgerichte toekomstverkenning

Deel 2: Een verruiming van perspectief (1983)*

Waarborgen voor zekerheid. Een nieuw stelsel van sociale zekerheid in hoofdlijnen (1985)

27

Basisvorming in het onderwijs (1986)

De onvoltooide Europese integratie (1986)

Ruimte voor groei. Kansen en bedreigingen voor de Nederlandse economie in de komende tien jaar (1987)

Op maat van het midden- en kleinbedrijf (1987)

Deel 1: Rapport aan de Regering;

Deel 2: Pre-adviezen

Cultuur zonder grenzen (1987)*

De financiering van de Europese Gemeenschap. Een interimrapport (1987)

Activerend arbeidsmarktbeleid (1987)

Overheid en toekomstonderzoek. Een inventarisatie (1988)

\section{Vierde raadsperiode (1988-1992)}

Rechtshandhaving (1988)

Allochtonenbeleid (1989)

Van de stad en de rand (1990)

Een werkend perspectief. Arbeidsparticipatie in de jaren '90 (1990)

Technologie en overheid (1990)

De onderwijsverzorging in de toekomst (1991)

Milieubeleid. Strategie, instrumenten en handhaafbaarheid (1992)

Grond voor keuzen. Vier perspectieven voor de landelijke gebieden in de Europese Gemeenschap (1992)

Ouderen voor ouderen. Demografische ontwikkelingen en beleid (1993)

\section{Vijfde raadsperiode (1993-1997)}

Duurzame risico's. Een blijvend gegeven (1994)

Belang en beleid. Naar een verantwoorde uitvoering van de werknemersverzekeringen (1994)

Besluiten over grote projecten (1994)

Hoger onderwijs in fasen (1995)

Orde in het binnenlands bestuur (1995) 
Zesde raadsperiode (1998-2002)

55 Generatiebewust beleid (1999)

56 Het borgen van publiek belang (2000)

57 Doorgroei van arbeidsparticipatie (2000)

58 Ontwikkelingsbeleid en goed bestuur (2001)

$59 \quad$ Naar een Europabrede Unie (2001)

60 Nederland als immigratiesamenleving (2001)

61 Van oude en nieuwe kennis. De gevolgen van ICT voor het kennisbeleid (2002)

62 Duurzame ontwikkeling: bestuurlijke voorwaarden voor een mobiliserend beleid (2002)

63 De toekomst van de nationale rechtsstaat (2002)

64 Beslissen over biotechnologie (2003)

65 Slagvaardigheid in de Europabrede Unie (2003)

66 Nederland handelsland. Het perspectief van de transactiekosten (2003)

67 Naar nieuwe wegen in het milieubeleid (2003)

\section{Zevende raadsperiode (2003-2007)}

68 Waarden, normen en de last van het gedrag (2003)

69 De Europese Unie, Turkije en de islam (2004)

Rapporten aan de Regering nrs $1 \mathrm{t} / \mathrm{m} 67$ en publicaties in de reeks Voorstudies en achtergronden zijn verkrijgbaar in de boekhandel of via Sdu Klantenservice, Binckhorstlaan 403, Postbus 20014, 2500 EA 's-Gravenhage, tel. 070-3789880, fax 070-3789783.

Rapporten aan de Regering nrs 68 en 69 zijn verkrijgbaar in de boekhandel of via Amsterdam University Press, Prinsengracht 747-751, 1017 JX Amsterdam (www.aup.nl). 


\section{VERKENNINGEN}

\section{Zevende raadsperiode (2003-2007)}

1 Jacques Pelkmans, Monika Sie Dhian Ho en Bas Limonard (red.) (2003) Nederland en de Europese grondwet

2 P.T. de Beer en C.J.M. Schuyt (red.) (2004) Bijdragen aan waarden en normen

3 G. van den Brink (2004) Schets van een beschavingsoffensief. Over normen, normaliteit en normalisatie in Nederland

Verkenningen nrs 1 t/m 3 zijn verkrijgbaar in de boekhandel of via Amsterdam University Press, Prinsengracht 747-751, 1017 JX Amsterdam (www.aup.nl). 


\title{
VOORSTUDIES EN ACHTERGRONDEN
}

\author{
Hieronder worden de publicaties uit de WRR-serie Voorstudies en achtergronden opgesomd vanaf de \\ vijfde raadsperiode. Een volledig overzicht van de voorstudies is beschikbaar op de WRR-website \\ (http://www.wrr.nl) of aan te vragen bij het bureau van de WRR (070 - 3564625$)$.
}

\section{Vijfde raadsperiode (1993-1997)}

V82

V83

V84

V85

V86

V87

V88

V89

V90

V91

V92

V93

V94

V95

V96

V97

\section{Zesde raadsperiode (1998-2002)}

V104 arbeid het behoud daarvan

J. Rupnik e.a. (1995) Challenges in the East

oudedagsvoorziening Health Care binnenlands bestuur Nederlandse arbeidsverhoudingen

J.P.H. Donner (1998) Staat in beweging implicaties voor beleid

W.J. Dercksen e.a. (1993) Beroepswijs onderwijs. Ontwikkelingen en dilemma's in de aansluiting van onderwijs en

W.G.M. Salet (1994) Om recht en staat. Een sociologische verkenning van sociale, politieke en rechtsbetrekkingen J.M. Bekkering (1994) Private verzekering van sociale risico's

C. Lambers, D.A. Lubach, M. Scheltema (1994) Versnelling juridische procedures grote projecten СSнОВ (1995) Aspecten van hoger onderwijs. Een internationale inventarisatie

T. van der Meij e.a. (1995) Ontwikkelingen in de natuur. Visies op de levende natuur in de wereld en scenario's voor

L. Hagendoorn e.a. (1995) Etnische verhoudingen in Midden- en Oost-Europa

H.C. Posthumus Meyjes, A. Szász, Christoph Bertram, W.F. van Eekelen (1995) Een gedifferentieerd Europa

J.P.H. Donner (rapporteur) (1995) Europa, wat nu?

R.M.A. Jansweijer (1996) Gouden bergen, diepe dalen: de inkomensgevolgen van een betaalbare

W. Derksen, W.A.M. Salet (red.) (1996) Bouwen aan het binnenlands bestuur

SEO/Intomart (1996) Start-, slaag- en faalkansen van hoger opgeleide startende ondernemers

L.J. Gunning-Schepers, G.J. Kronjee and R.A. Spasoff (eds.) (1996) Fundamental Questions about the Future of

H.B.G. Ganzeboom en W.C. Ultee (red.) (1996) De sociale segmentatie van Nederland in 2015

J.C.I. de Pree (1997) Grenzen aan verandering. De verhouding tussen reorganisatie en structuurprincipes van het

M.F. Gelok en W.M. de Jong (1997) Volatilisering in de economie

A.H. Kleinknecht, R.H. Oostendorp, M.P. Pradhan (1997) Patronen en economische effecten van flexibiliteit in de

W.J. Vermeulen, J.F.M. van der Waal, H. Ernste, P. Glasbergen (1997) Duurzaamheid als uitdaging. De afweging van ecologische en maatschappelijke risico's in confrontatie en dialoog

W. Zonneveld en A. Faludi (1998) Europese integratie en de Nederlandse ruimtelijke ordening

Verslag en evaluatie van de vijfde raadsperiode (1998)

Krijn van Beek (1998) De ondernemende samenleving. Een verkenning van maatschappelijke verandering en

W. Derksen et al. (1999) Over publieke en private verantwoordelijkheden

Henk C. van Latesteijn (1999) Land use in Europe. A methodology for policy-oriented future studies

Aart C. Liefbroer en Pearl A. Dykstra (2000) Levenslopen in verandering. Een studie naar ontwikkelingen in de levenslopen van Nederlanders geboren tussen 1900 en 1970 
V108 Bart Wissink (2000) Ontworpen en ontstaan. Een praktijktheoretische analyse van het debat over het provinciale omgevingsbeleid

V109 H. Mommaas, m.m.v. W. Knulst en M. van den Heuvel (2000) De vrijetijdsindustrie in stad en land. Een studie naar de markt van belevenissen

V110 H. Dijstelbloem en C.J.M. Schuyt, red. (2002) De publieke dimensie van kennis

V111 M.C.E. van Dam-Mieras en W.M. de Jong, red. (2002) Onderwijs voor een kennissamenleving. De rol van ICT nader bekeken

V112 Wendy Asbeek Brusse, Harry van Dalen en Bart Wissink (2002) Stad en Land in een nieuwe geografie. Maatschappelijke veranderingen en ruimtelijke dynamiek

V113 G.A. van der Knaap (2002) Stedelijke bewegingsruimte. Over veranderingen in stad en land.

V114 F.J.P.M. Hoefnagel (2002) Internet en cultuurbeleid. Over de gevolgen van ICT voor het cultuurbeleid van de Nederlandse overheid

V115 Gabriël van den Brink (2002) Mondiger of moeilijker? Een studie naar de politieke habitus van hedendaagse burgers

V116 Willem Witteveen, Bart van Klink, met bijdragen van Wouter de Been en Peter Blok (2002) De sociale rechtsstaat voorbij. Twee ontwerpen voor het huis van de rechtsstaat

V117 Rein de Wilde, Nikki Vermeulen en Mirko Reithler (2003) Bezeten van genen. Een essay over de innovatieoorlog rondom genetisch gemodificeerd voedsel

\section{Overige publicaties}

Voor de eenheid van beleid. Beschouwingen ter gelegenheid van vijftig jaar Ministerie van Algemene Zaken (1987) Eigentijds burgerschap. WRR-publicatie onder leiding van H.R. van Gunsteren (1992)

Mosterd bij de maaltijd. 20/25 jaar WRR (1997)

De vitaliteit van de nationale staat in een internationaliserende wereld (2002) 
WRR VERKENNING 4

\section{De staat van de democratie. Democratie voorbij de staat}

Nederland is nodig toe aan democratische zelfreflectie. Ingrijpende maatschappelijke ontwikkelingen als de verplaatsing van de politiek, mediatisering, Europese integratie, mondialisering, vervreemde burgers en toenemende maatschappelijke complexiteit nopen hiertoe. Maar ook de electorale aardverschuiving van mei 2002 en de recente initiatieven van de minister voor Bestuurlijke Vernieuwing leiden tot veel discussie over de staat van de democratie en 'democratische vernieuwing'. Wat is er aan de hand? En, belangrijker nog, wat is er aan te doen? In deze WRRVerkenning analyseert en beoordeelt een reeks van deskundigen afkomstig uit wetenschap, beleid en veld deze uitdagingen aan de democratie. Vervolgens belicht een viertal democratie-experts wat democratische benaderingen voor oplossingen te bieden hebben. Moet het primaat weer bij de politiek worden gelegd, is het referendum het antwoord, is interactief bestuur het panacee of moeten we juist vertrouwen op het vermogen tot zelfbestuur van maatschappelijke organisaties?

Redactie: dr. E.R. Engelen en drs. M. Sie Dhian Ho Auteurs zijn o.a. dr. T. Akkerman, prof. dr. W.B.H.J. van de Donk, dr. A. Krouwel, dr. B. Pattyn, prof. C.F. Sabel, prof. dr. mr. C.J.M. Schuyt, prof. dr. G.H. de Vries, en prof. dr. B. Tromp.

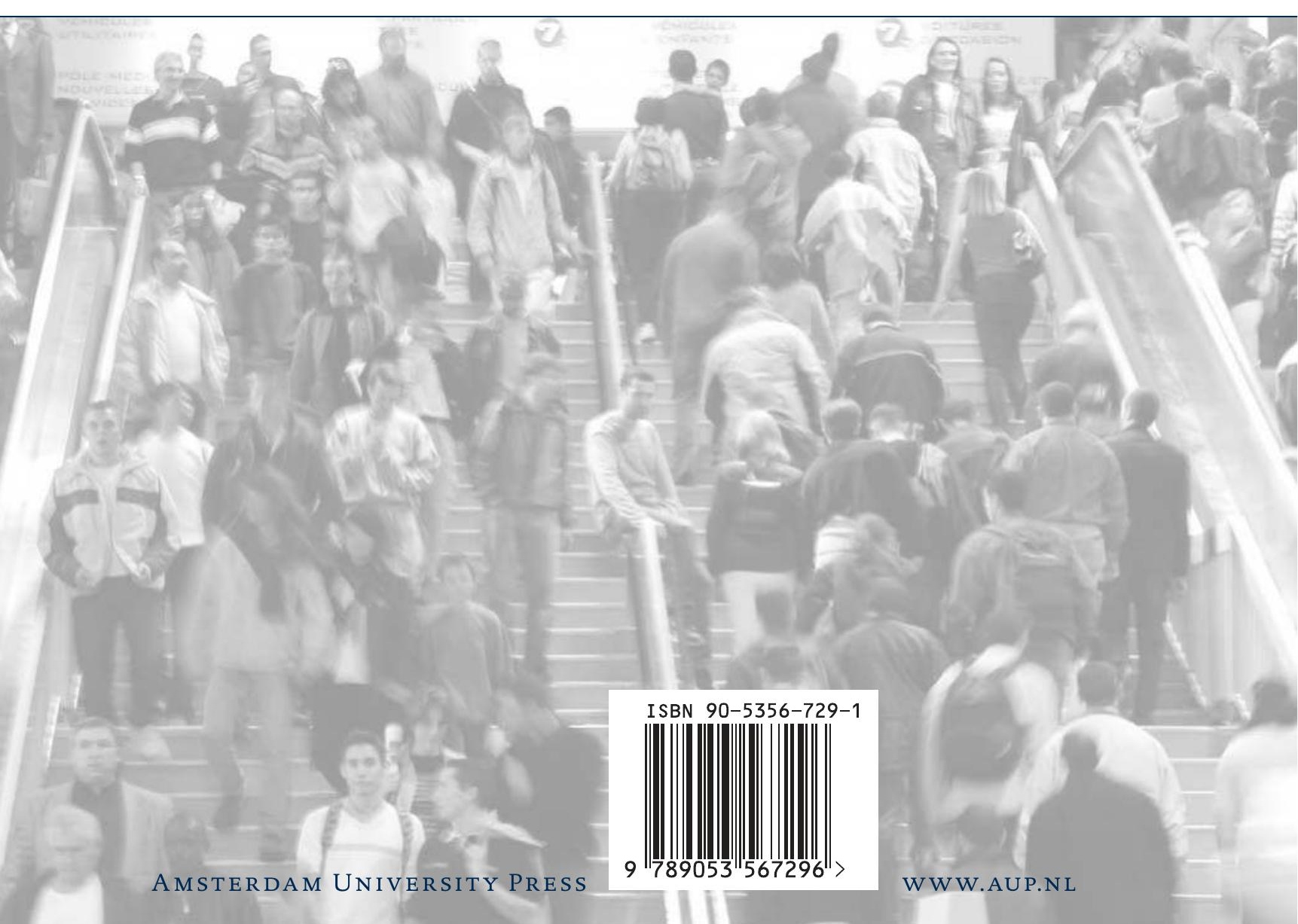

